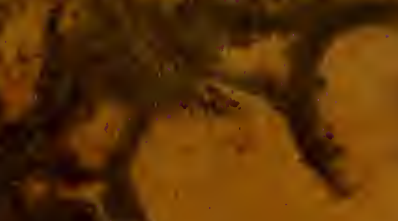

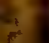

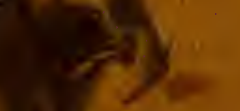

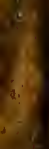

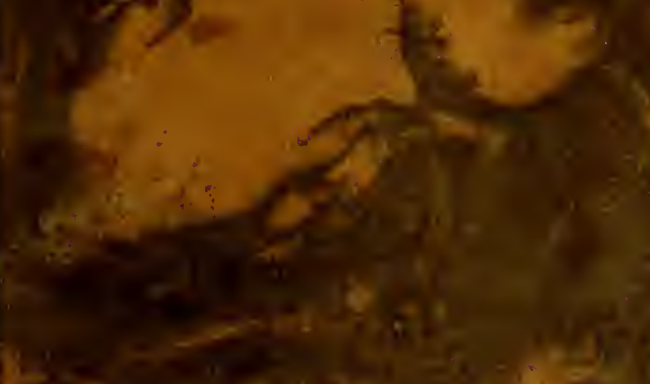

(t)

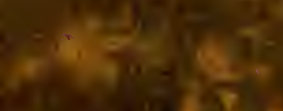

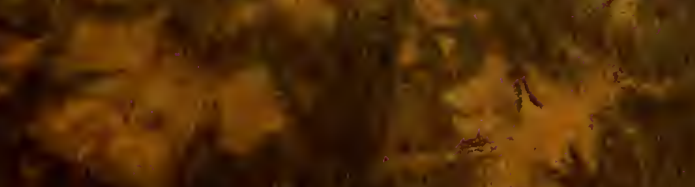

$4 x+3, \cdots$

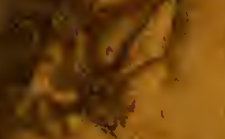

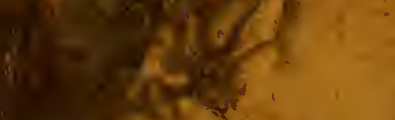
2. 2.

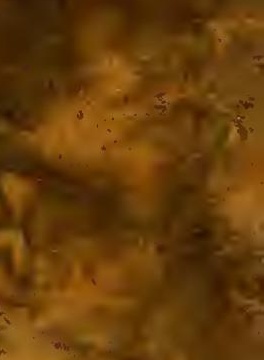
13 ing

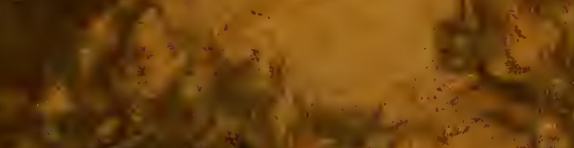

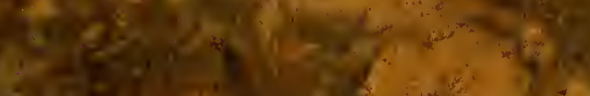
(i) 4.:

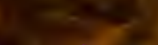
(h) $x=3$ 3. 


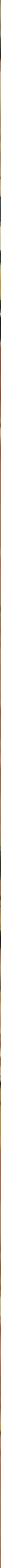




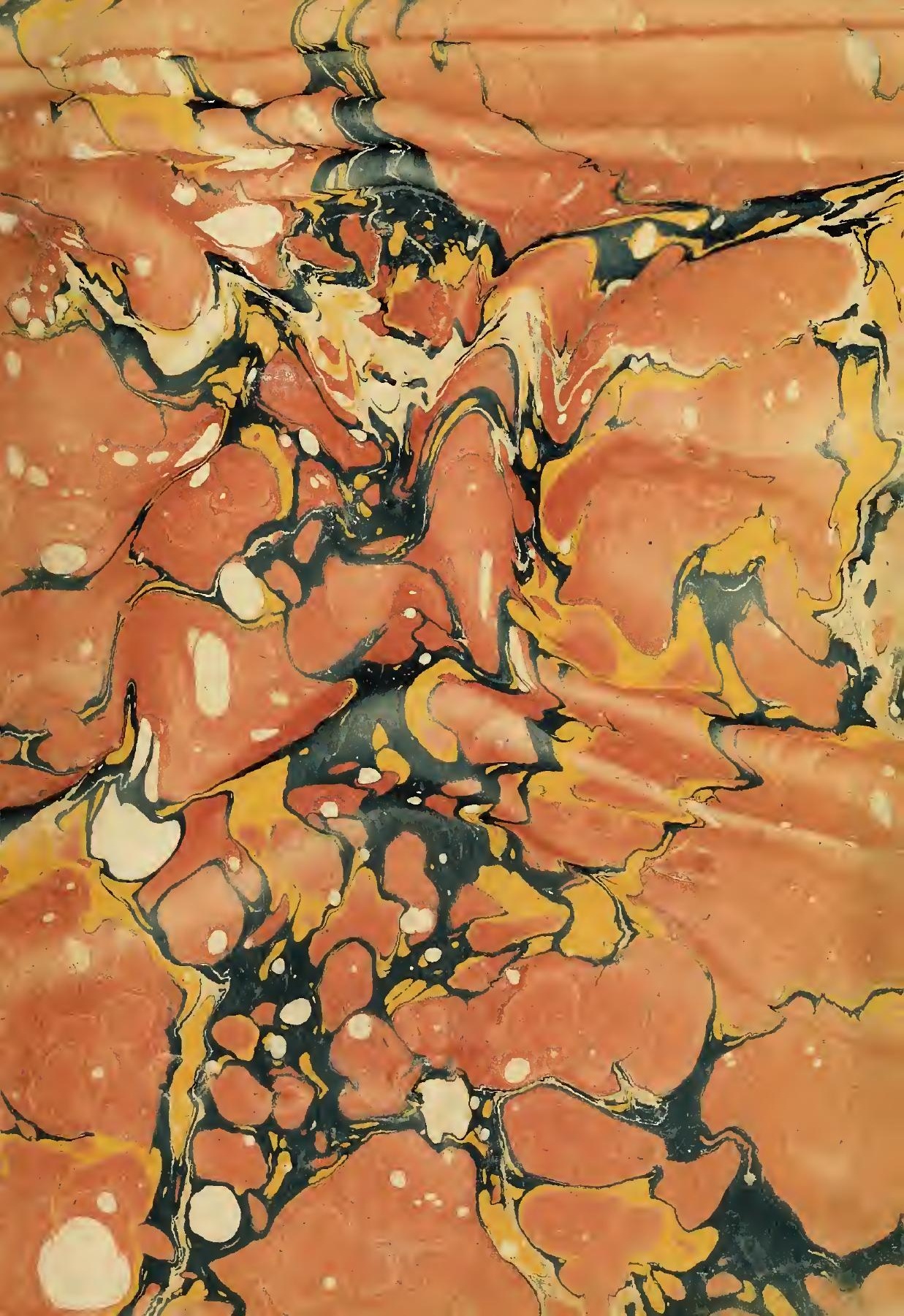



Digitized by the Internet Archive in 2010 with funding from

Open Knowledge Commons and Harvard Medical School 
Boston Medical Library in the Francis A. Countway Library of Medicine Boston 


P R OSPERIALPINI

Marosticensis Pbilosopbi Medicamentorum fimplicium Profefforis ordinarii,

MEDICINA EGYPTIORUM. Accelfit huic editioni ejufdem Auctoris

L I B E R D E
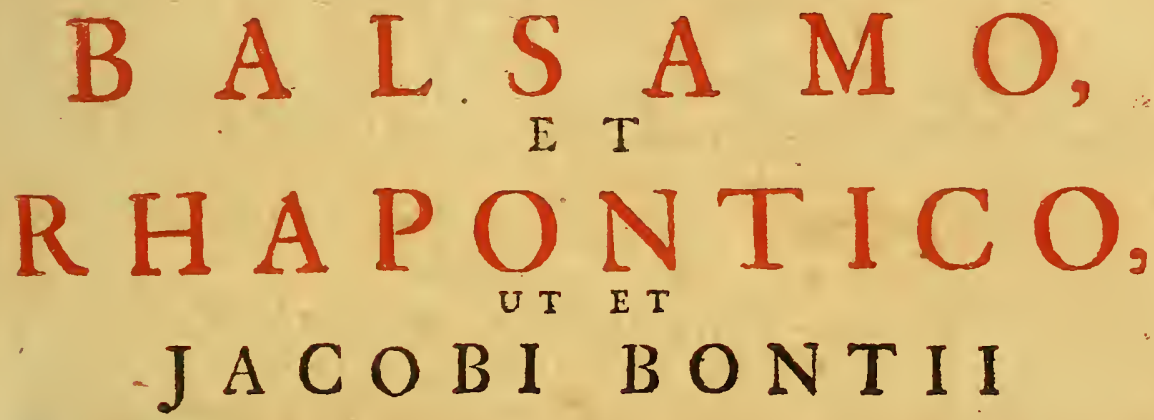

MEDICINA INDORUM. Editio nova.

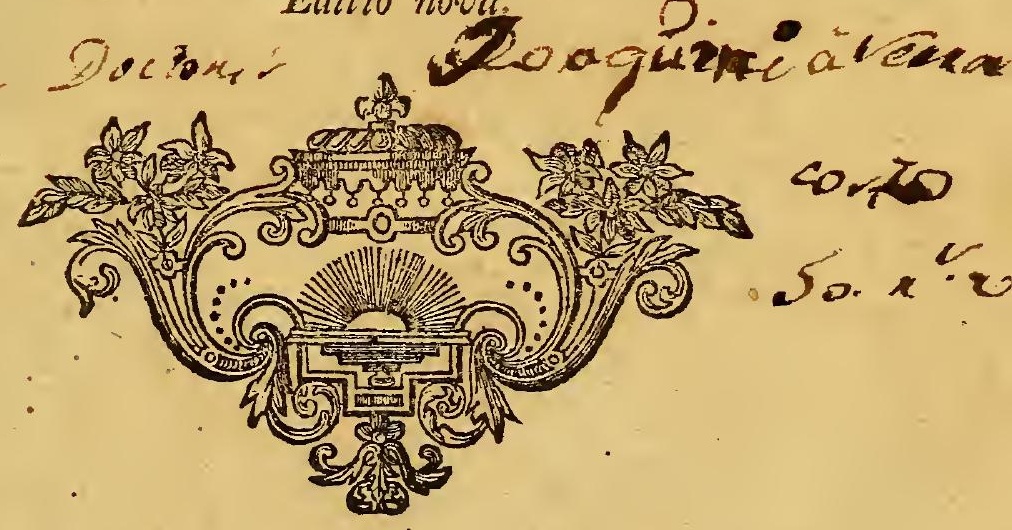

$L U G D U N I \quad B A T A V O R U M I$. Apud GERARDUM POTVLIET, I $455^{\circ}$ 


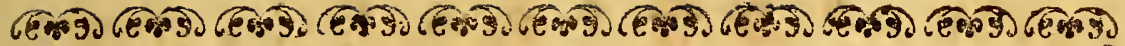

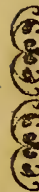

\&

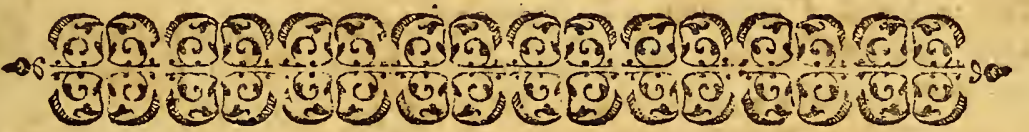

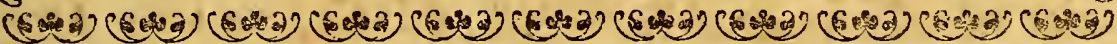

ILLUSTRISSIMO AC SAPIENTISSIMO

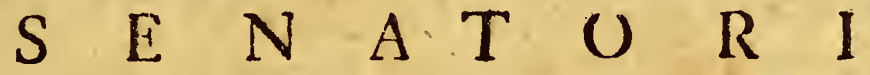

9

\section{ANTONIO MAUROCENO,}

Supremo Reip. Venetæ Confiliario.

PROSPER ALPINUS. S. D.

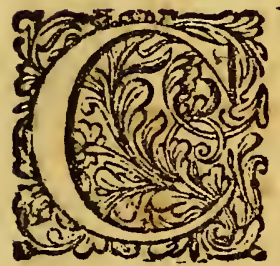

UM multis ab hinc annis (Vir Illuftriffime) medicinæ ftudio, ac fciendi cupiditate ductus, patriis \& ipfe (exemplo preftantiffimorum virorum, qui ad hanc, \& alias difciplinas, perdifcendas, varias regiones peragrarunt, littoribus relictis, in Agyptum profectus effem, quod ipfam medendi artem primas ac verilfimas radices apud illas gentes olim habuiffe intellexerim, quando vel à brutis animalibus ibi medicinam exerceri, aliqui prodiderint, $\mathrm{ex}$ quibus \& vacuandi fanguinis per fectas venas, \& multorum aliorum prefidiorum ufum prodiife, Aigyptionum non paucis perfuafum eft: apud illos populos nonnulios annos moratus, ipforum ufitatam medicinam à me eo tempore obfervatam, \& in quinque Commentarios digeftam, poft meum in patriam reditum eum perficere fummopere optarem, evo- 


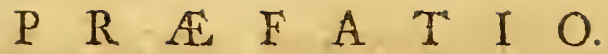

catus interea Genuam ad Joannem Andrream Auriam, Principem ampliflimum, ut apud illum medicinam facerem. alfiduis Aulr curis implicatus, id eo tempore efficere non potui. Cum vero illine reverfis, in perfectiorem cos, quoad potui, ftatum reftituiffem, decrevi fub trio nomine nunc tandem ipfos in lucem proferre. Quos tibi ampliffimo Senatori, milhi jảm ufque à primis meorum ftudiorum annis fautori, adjutori, ac patrono unico jure merito dicare debeo. Tibi enim foli hi primarii meorum fudiorum partus, ac fructus debentur. Quid? non te folo andintore mihi in Aegyptum proficifci, cjurque loca perluftraffe olim conceffum eft? Qui, cum me mex juventutis annos in his locis medicinam facientem exigua fane fudiorum meorum expectatione terere aliquando animadvertiffes, neque parum hanc meam doluiffes vicem, tantum in meis rebus ftudii ac laboris adhibuifti, ut Georgius Hemus $\mathrm{Pa}_{\text {a }}$ tricius Clariflimus, Conful pro Cayro \&gyptı defignatus, me in ea loca medicinæ caufa libenter conduxerit; fcilicct illa peragratione varias hominum perfpectas naturas, morbos, caufas, ac ufus medendi penes varias gentes obfervatos, non parum utiIitatis ac fplendoris meis ftudiis afferre poffe, intelligebas. Taceo innumera alia longe majora ex te in me collata beneficia: quanta enim benerolentia, ac humanitate Francifcum Alpinum, cariffimum Patrem meum, dum viverct (quem medicinæe caufa multos annos cognovifti, ac plurimi fecifti) meque ac alios mex familize femper fueris complexus, dici quidem à me fatis non potelt. Merito itaque non hos modo meos ftuldiorum labores; vcrum me-ipfum quoque cum his tibi devorendum puto. Jam diu enim pluribus de caufis mili fuit in optatis, ut tantorum in me munerum tnorum aliquod tibi grati animi, mexque preftantis in te obfervantix. fignum oftenderem. Ad hac illud etiam accedit, quod has libros de illiufce gen- 


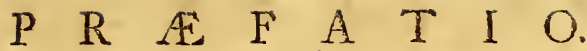

gentis medicina a me (quæ mea eft ingenii tenuitas) confcrip. tos, cum non omni plane culpa carere cognofcerem, tui clarillimi nominis fplendore fultos in lucem prodire volui; quod plurimum illis auctoritatis, \& exiftimationis, te patrono, acceffurum intelligerem. Tu enim is es, qui quidem hac noftra xtate multis virtutibus in hac felicifima Repub. Maurocenorum familiam antiquitate, nobilitate, ac auctoritate claram magis ac magis illuftras, \& ornas. De cujus quidem tux familix, atque de tuis ipfius laudibus mihi nunc agere inftitutum non eft', tum quia ad Oratorem magis hrec tam magna tractare, quan ad medicum pertineat; tum etiam quod adeo omnibus ex note funt, ut nullo, qui eas aliis indicet, indigere videantur. Quis vero hic, aut alibi nunc eft, qui iftis familiæ claritatem, antiquitatem atque auctoritatem ignoret? Quam tot Screniilimi Duces, clafififue maritimæ præfecti excellentillimi, quam Cardinaies ampliffimi, \& Patriarchæe ex ea orti (qui plurimum olim Chriftianain Rempubl. illuftrarunt, ) quam Senatores alii fere innumeri maximis honoribus, ac dignitatibus variis temporibus in hac Civitate decorati, adeo nobilem, amplam, \& Ihultrem effe declarent, ut hoc ad ejus laudes maxime fufficere poffit. Nam ut alios omittam, Hieronymus Maurocenus frater tuls nemini fuperiorum cedens, præclaris virtutibus \& rebus geftis, dum viveret, patriam exornavit. $\mathrm{Cu}-$ jus mortem immituram miltis lacrymis non modo patricii, fed plane omnes, quos tanti viri virtutes non latuere, maxime luserunt. Nec hercle id injuria. In quo enim viro tantam unquam in Deum fidem, pietatem, charitatem ulla reperit antiquitas? Quis etiam in Reipub. magiftratibus obeindis talem ac tantem fapientiam, juftitiam, prudentiam, atque humanitatem oftendit? Teftes funt Veronenfes, qui in ejus prafectura ita fuere tractati, ut \& illius magiftratus, \& rerum ab eo pro- 


\section{$P \quad R \quad A \quad F \quad A \quad T: I$ O.}

clare geftarum nulla unquam fit hominibus oblivio ereptura memoriam. Ex quibus in ea civitate exantlatis tum vigilliis, tum maximis laboribus, ægritudo, qua ille poftea defunctus eft, originem habuit. Is etiam preter alios multos magiftratuum, ac prafecturarum ordines, quibus fua ætate ipfe magnifice ornatus eft, in ampliffino Clariffimorum patrum coetu cooptatus, mulicis annis preclariffimus Senator vixit. Ac tandem Decemvirum capitalinum dignitate fumma cum laude perfunctus eft. Irrec igitur virtutum, \& recte factorum exemplum Iieronymus tuus frater moriens reliquit. Hæc eadem in te poftea hreditario quodam jure, mirifice tranflata fuiffé, teque eodern fiplendore claruiffe, quis ignorat? Nolo enim de te etiam nunc' dicere, quam omnibus Catholicæ religionis verus amator, atque accerrimus defenfor videaris, quamque divini cultus affiduus fis obfervator, quantaque in Deum quoque tua fit fides, in Paulperes pietas, ac charitas. Quod majus pietatis in patriam, claritatis, fortitudinifque exemplum de te proferri poffet, quam quod tu quindecim nunc labentibus annis, hic ingenti illa graffante peltilentia, urbemque hanc atrociffime devaltante, tuis ciribus edidifti? Cum foilicet fextæ partis civitatis pefte infectre, curam à Clarillimis pattibus in tanta calamitate tibi demandatam non modo (quod plerique, fibiipfis plus quam patrix confulentes, tunc faciebant) non recufaveris, fed hihari.potius vultu fumme arduam ac periculofaum illam provinciam fufceperis, non minufque pie, quam fortiter, fapienter, ac feliciter obieris. Neque enim tota civitas hrec infecta pefte in tanta fui neceffitate tunc à te deferi potuit. Omitto pretes rea quanta in multis Reipub. muneribus, à te variis temporibus dignillime expletis, juftitia, probitate, ac prudentia rem. Venetam adminiltraveris. Prefertim ubi te patres confcripti actibus Illuftrilfimorum Procuratorum, atque legum conferva- 


\section{P $R$ A E F A}

tioni præeffe voluerunt. In quibus quidem, atque in Senatu (Senator jam diu ab ipfis creatus) plurimum laudis ac fplendoris es confecutus. Simul \& illud omittam, quam in gravi ifta provincia, qua hoc anno fupremus Reipub. Confiliarius à Clariffimis patribus delectus es, vigilantifime, ac fapientiffime te geras, quantaque folertia, ac benignitate cunctos in eo magiftratu complectaris, ut ea profecto caufa nemo fit, qui te femel noverit, quin ftatim fe tibi addictifimum fateatur. Unum vero illud de te minime tacendum puto; domum etenim tuam fic fapienter, ac prudenter inftituifti, ut merito hac ætate plurimum fit admiranda. In ea quidem talis ac tanta penes omnes, qui ipfam habitant, recte ac honefte vivendi elucet harmonia, ut facer religioforum hominum ceetus jure omnibus videri debeat. In ipfa quidem neminem invenias, qui prater id, quod fumme honeftum eft, quicquam aut facere, aut loqui audeat. In qua talis eft futura filiorum pofteritas, ut fi ex præfentibus ventura prævideri liceat, maxime fperandum fit, fore, ut tharum virtutum claritas aternis feculis in filiis, ac nepotibus tuis refulgeat. Quales Joannes, Petrus, Laurentius, Francifcus, atque Matthæens ; exiftunt, morum profecto integritate, ac virtutum preftantia non parum hoc freculo admirandi. Sic enim à te omnes educati funt, ut inter ipfos nullus fit, qui vera religione; perfectaque in Deum fide non effulgeat, qui plurima tum in te, tum in reliquos fratres obfervantia, obedientia, ac amore eximio non exardeat. Liberalitate vero, modeftia, temperantia, manfuetudine, continentia, aliifque fere innumeris virtutibus nemo certe ex iis, qui vel funt, vel fuere, preferendus ipfis videatur. Sed \& lixc, \& plura quoque hujufmodi omittam, cum hoc meum infitutum non fit, atque plurimum etiam tuam his modeftiam offendi fciam, qui aliorum laudes, quam tuas libentius andire 


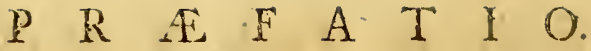

foleas. Etfi tu igitur nunc is Senator fis, cui ampliffima ac divina prope munera debeantur, eft tamen tuæ liberalitatis qua cunctos perbenigne complecteris, ut hos meos libros, quos tibi nunc ego devotilfime confecro, atque voveo, libenter accipias, tenui quidem, \& tenuis hominis munufculum; à fumma tamen obfervantia, ftudio, \& amore in te meo profectum. Id fi tibi non erit ingratum, mihi animum ad graviora medicinæ ftudia plurimum inflammabis. Vale, meque, vit foles, ama.

\section{Tenetiis, Anno Salutis bumana, M. D. XCI. Menfe Martio.}

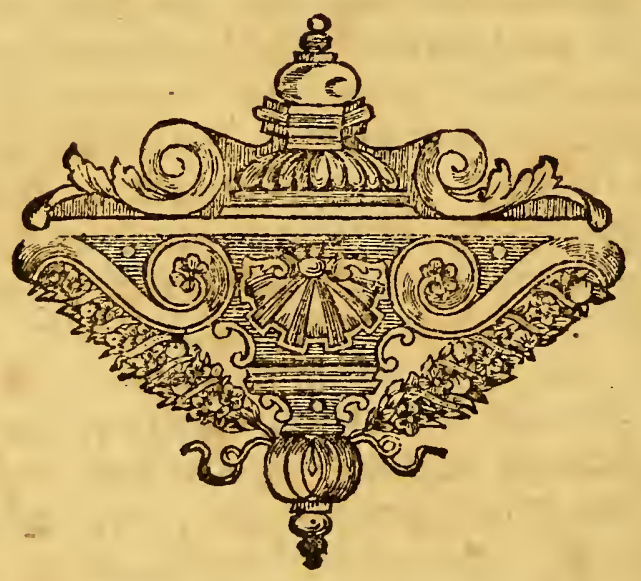




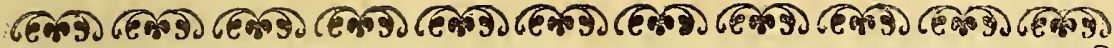

है

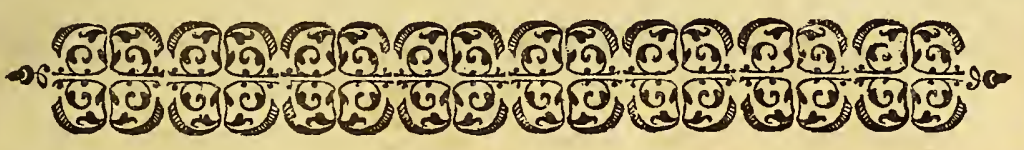

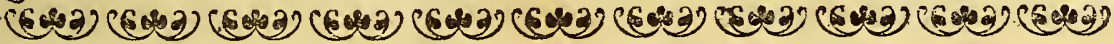
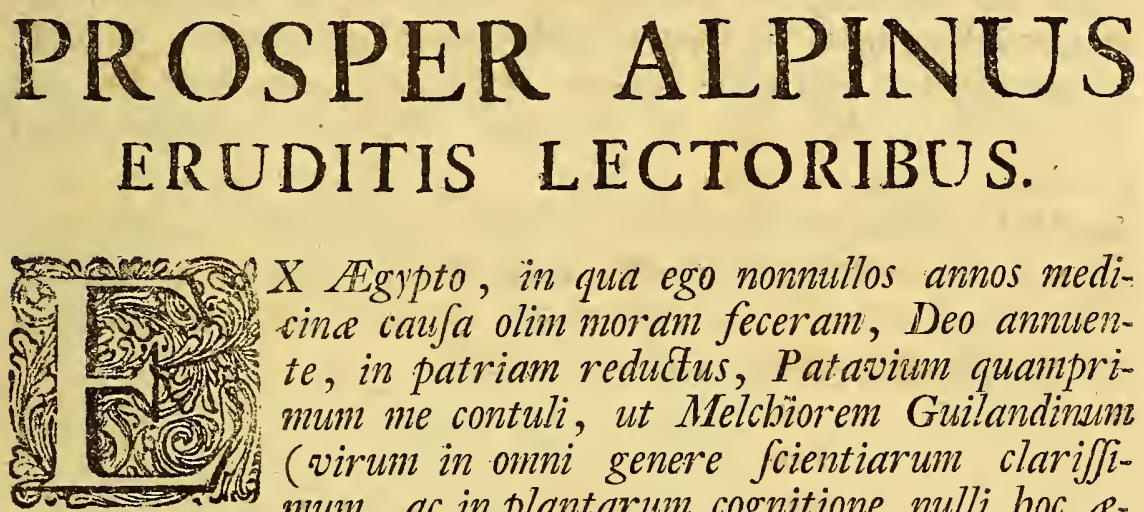

$\mathrm{X}$ Aggyto, in qua ego nonnullos annos medisince caufa olim moram feceram, Deo anmuente, in patriam reductus, Patavium quamprimum me contuli, ut Melchiorem Guilandinum (virum in omni genere fcientiarum clariffimum, ac in plantarum cognitione nulli boc c.wo fecundum, mibique plurima neceffitudine conjunctiffimum) falutationis gratia convenirem: $A$ quo bumaniffime acceptus, aliquot dies apud illum fui, in quibus multa inter nos de Aigypti regione; colo, temperie, $\sigma^{2}$ de illorum corporum habitu, temperamento, locuti fumus, de medicis, ac morbis, quibus illa regio abundat, छे de medicina penes illos populos ufitata, ac denique de plantis, qua illis in locis nafcuntur, fermones aliquos babuimus. Is igitur me poftea, ut illa, que inter nos commentata fuerant, litteris mandarem, obnixe rogavit, Eจ fuafit; fore enim, ut non parum utilitatis, ac voluptatis ex his ad medicine ftudiofos accedat. Cui cum non parere ac oblequi, turpe putarem, quanta cu$r a, 6 \sigma^{\circ}$ Studio potui, eojdem ipfos à nobis per id temporis habitos fermones in quinque libros, divijos, ac digeftos, fub nomine Agyptiorum medicina (quando, de illa tantum agere 米 


\section{PROSPER ALPINUS FRUDITIS LECTORIBUS.}

noftrum pracipum fuerit inftitutum, neque de aliis, nifi itlius gratia) comprehenfos, foriptis tradidi. Quos cum à multis defiderari forte intellexerim, quamplurimis etian id mibi medicis doctiffinis perfuadentibus, proefertimque Hieronymo Mercuriali, ac Alexandro Maffaria bac tempeftate medicis celeberrimis, ne borum voluntatem afpernari, Eo mul. torun utilitati invidiffe widear, ipfos in lucem proferre non fum veritus.. Hos itaque, eruditi, leciores, candido animo accipite, legite, ac bene confulite. Quod fi ego hos vobis gratos fuiffe aliquando intellexero, alia bis graviora, aique utiliora in arte medendi ftudia, à me multo labore, ac vigiliis alias elucubrata, atque informata, vobis medicince anatori. bus comnunicare non. aecujabo.. Valete.

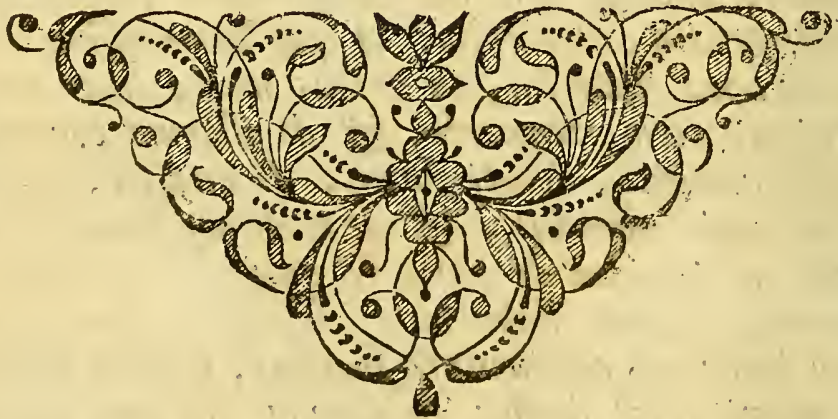




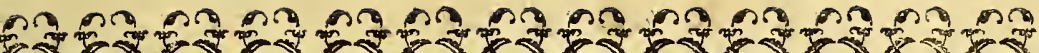

3 .

\section{MELCHIORIS GUILANDINI, \\ D E}

PROSPERO EX $Æ G Y P T O$

AUTHORIS IN PATRIAM REDITU

C O NGR ULA T I O.

In qua obiter multa que in itinere acciderunt, prefa. tionis loco babentur.

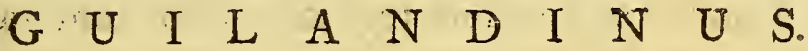

76 ray

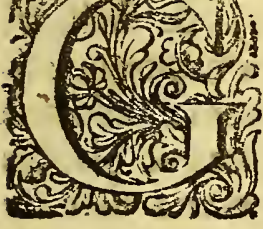
pto tandem incolumem Patavium rediiffe, quandoquidem maximum effe exiftimem, hominem multas, quas longiffima itinera ferunt, moleftias, crebrioraque \& grandiora fimul pericula à varia iliufce gentis barbarie fibi fxpe oblata, fuperaffe, in patriamque falvum omnino reverfum effe. Quem tuum reditum difficilem reddebant variæ Egypti locorum naturæ, cœlique calores, quibus noftra corpora diverfo affueta cœlo, multum alterantur, atque læduntur. Quamobrem galldeo maximopere, atque iterum gaudeo, quod nunc te falvum ad nos denuo contuleris, mihique ita hilarem te nunc obtuleris. Aupin. Atque ego etiam ingenti gaudio perfundor, quod te virum doctiffimum, univerfis literarum profefforibus, \&t principibus multis excellentis tuæ doctrinæ caufa acceptifi- 


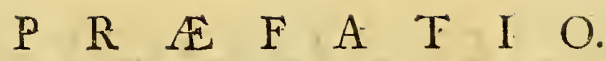

mum, invenerim in hac preclariffima ftudiorum urbe, optinia valetudine tuis ftudiis vivere, pra gaudioque tanti tui boni, \& præ voluptate vix quid loquar fcio. Gratis etiam majores, quas polfum, tibi nunc ago, quod ex meo reditu tantum gaudii, ac voluptatis acceperis, mihique tantum tribueris, quem in tua poteftate effe, quicumque fim, tibi perfuadeas volo. Guilnsp. Tibi non minus multas gratias agere debeo pro tua ifthac humanitate. Iter vero arduum, \& periculis plenum te olim furcepife exiftimo. Sed cur in Aigyptum te conferre volueris tantifque illis te exponere periculis, libenter audirem. Alpis. Ego fere ufque à puleris hujus femper fui fententix, neminem poffe perfectum effe medicum, qui varias regiones, \& loca non peragraverit, diverfofque hominum mores non obfervaverit, atque hoc pace illorum dixerim, qui inftar avium. nunquam nidos fuos deferunt, neque $a b$ his latum unguem recedere audent. Varix etenim regiones varios tum morbos patiiuntur, tum medicinas ferunt ad eos perfanandos accommodatas atque etiam varii medendi ufus in variis obfervantur locis, quorum obfervatione medicus fit prudentior, \& doctior: qua fententia adductus fum, ut fi in arte medica cuperem aliquid proficere, orbis partem aliquam peragrarem, aliofque morbos in aliis familiares locis, \& varias medicinas ac plantas quxe ibi nafcerentur, \& diverfos ufus medendi, penes diverfas rrationes ufitatos obfervarem, atque cognofcerem.: Cum itaque publice medicinam facerem in proximo Oppido C. S. Petri aliquo remotius abeundum exiftimavi, atque, in liac fententia multum perftiti, fed quorfum verfius proficifici præftaret, id vero ignorabam. Quo quidem tempore mihi Deus Opt. Max. optatiffimam occafionem prebuit, ut in. Agyptum proficiferer medicus cum Clariffimo Georgio Hemo, qui illo tempore à Serenilfima feliciffimaque Veneta Republica Conful in ea provincia. fuerat electus. Ad hoc iter etiam me multum 


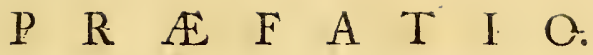

hortatus eft Francifcus Alpinus Medicus paterque meus cariffmus. Tandemque in eam veni fententiam, ut mihi facile foret ex animi fententia illuc proficifci. Itaque accepi conditionem, meque tunc ad iter hilari animo paravi. GuILAND. Quoniam virtus laudata crefcit, non pudebit me hoc vel te præfente dicere, anctum iri vehementer tuorum ftudiorum peritiam ac laudem, ob hanc tui animi non vulgarem nobilitatem, qua hanc peregrinationem fciendi gratia fuffcipere, ita probe in animum induxeris. Sed his omiffis, cuperem tuum nunc iter audire, \& quo tempore ipfum inceperis, quaque forte etiam eo fueris ufus; omnes fiquidem longa itinera conficientes, multos labores patiuntur, \& multa fubeunt pericula, quæ poftea aliis narrent. Acpın. Anno à Virginis beatiffimæ partu M. D. LXXX. Septembri menfe die xxI. eam, quæ Peccatora appellatur, navim confendi una cum Georgio Hemo Confule defignato pro Cayro A Egyti, viro fane pro fua ipfius humanitate, animique integritate Clariffimo: quique in Confulatu ita fe geffit, ut cuique cariffimus fuerit, \& illius difceffum ab Agypto non modo Veneti mercatores, fed vel ipfi Agyptii ægre tuliffe, atque adeo luxiffe vifi fint. Itaque datis velis Zacynthim fecundis ventis paucis diebus pervenimus, portumque ingreffi fumus. Unde digreffis non ita ex voto reliqua. navigatio fucceffit, quandoquidem paulo poft ita validis: procellis tempeftatibufque agitari, turbarique cœepimus, ut facile dixiffes nobis eveniffe, quod Ovidius cecinit:

Navita Sollicitus quoque ventos horret iniquos,

Et prope tam lethum, quam prope cernit aquam::

Quod $f i$ concuffas Triton exafperat undas,

Qui tibi nunc toto eft, nullus in ore color.

Tum focunda voces generofa Jydera Leda

Et felix dicas, quem Jua terra tenet. 


\section{P $\quad$ R}

Copit enim ea nocte, quæ eft ante diem decimum feptimum menfis Octobris, quem diem omnes nautæ ftellarem, ut ita dicam appellant, ventus Hellefpontius ita adverfo impetu tempeftuofe perflare, ut coacti fuerint nautæ proram obvolvere: Qui timentes ab Africis ventis, qui co temporis flare folent, creberrimis, grandioribufque procellis mare verrentes, ne navis in folum ab his abduceretur, naufragiumque fieret, per eofdem Africos ventos iter fuum direxerunt: quo fane ita directo itinere, navis in vaftiflimum mare ab Hellefpontio vento, quem nautarum vulgus Græcum Orientalem appellat, raptim, \& ingenti impetu ferebatur, ita, ut à terra magis magifque ipra elongaretur. Noftrum vero nos judicium fefellit, quod fperabamus eum obortum ventum cito cafurum, ab"eoque rurfum noftrum iter, quod per circium ventum fuerat, brevi tempore nos effe recepturos, fiquidem prior ille ventus non adeo cito ceffavit, quin potius tanta tempeftate ac furore peranctus eft, \& nobis ita freve minari cœpit, ut coacti fuerimus navim velis nudatam mari committere, \& temere ab illorum. infano impetu interitum noftris oculis millies in hora minantium expectare, atque ab his abfque ullo regimine in vaftiffimo pelago alternis undis ad libitum agitari. Atque hæe horrida tempeftas ad diem ufque vigefimum fecundum protendebatur, tanto omnium timore, ut nemo effet, qui de falute fua fperaverit quicquam. noftram aliquantulum demulcebant miferiam illa Lucretii Carmina:

\section{Certa quidem finis vite mortalibus adftat, Nec vitari lethum poteft quin obeamus.}

Placuit tamen mifericordi Deo, ne ab ea tempeftate interire: mus; ut fortaffe ad aliquam rem etiam viveremus: Cui quas poffum majores nunc gratias ago ac perpetuo referam; qui 


\section{$P R$ E A T I O :}

me fua clementia ac pietate cx tanto juiculo incolumem fervaverit. Die vero vigefimo fecundo menfis Octobris, aurora lucefcente, ad Corcyræ locum eum pervenimus, quem Fano appellant, ventis omnino fedatis. Et paulo poft Zephiris placide fpirantibus infulx fretum ingrefli fumus fumma omnium cum voluptate ac gaudio, atque Merleras appellatum portum tenuimus: ab eoque altera die fummo mane alium in portum pervenimus, à primo parum diftantem, atque ab eo Corcyram. In qua per diem moram traximus. Poftridieque Septentrionali exorto vento, ab ejus portu digreffi fumus, quo ceffante non multo poft ad portum, qui eft apud Gomenizzas, acceffimus. adverlis vero neftræ navigationi ventis diu perfeverantibus, \& largiffimis adhuc pluviiis, magnifque imbribus, detenti, quibus quidem Corryræe infule fitus fex quotannis menfibus obruitur, atque aliis fex ficcitate exhauritur, coacti fumus in Corcyræ portum configere, \& faluti noftræ confllere. Ubi ufque ad nativitatem Domini permanfimus, cujus diei feftivitate devote fervata, altera die orto Sole, triremis auxilio noftra navi è portu deducta, velo ventis dedimus, eodèmque die Paxo vidimus. Alteraque die Aparctia vento impetuofe fpirante, fub aurora Zacynthum rurfum vidimus, portumque illum cum magna omnium eam urbem accolentium admiratione, quod accola ceterique omnes ex proxima tempe ftate nos interiiffe fibi firmiter perfuaferint. Zacynthi vero toto Januario menfe commorati fumus. Dieque fequentis menfis tertia $\mathrm{ab}$ eo portu difeeflimus, meliorique fortuna iter noftrum recepimus, ac per diem ante cinerem in portum Sudx, fortiffimum Cretæe infilix propugnaculum, pervenimus, ubi peractis quinque diebus, portum Frafchiam vocatum, qui ab urbe Creta decem millia paffuum diftat, invafimus. Multi ex Cretenfibus, qui pro certa habuerant noftram navin" Octobri proximo menfe mari abforptam fuiffe, fimulque cum ipfa ali- 


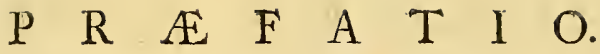

quot Cretentes Caloyerus nubifum navigantes, noftro adverrtu, tanto funt affecti gaudio, ut ipforum lætitiam publiciscampanarum fonis in templis per multos dies publice manifeftarent: ubi vero Cretæ multis diebus moram traximus, inter initia menfis Martii, ut noftro longiflimo itineri finem tandem imponeremus, vela rurfum ventis dedimus, in altumque navim Circio vento, qui leniter fpirabat, advehi permifimus, ceterum tertia die Auftrinis ventis rurfum vehementer exortis, retrogrefli in portum Standiam applicuimus, ab eaque nova procella falvi fuimus, diftat \& hic portus ab urbe decem millia palfum. Ibique tribus peractis diebus, orto Sole, ab eo portu navim folvimus, Agreftique vento, \& Favonio impetuofiffime fpirantibus, mare mediterraneum ingredimur, in ipfoque procellofa navigatione utentes duorum dierum fpatio Alexandriam procul infpeximus, ingentique omnium gaudio iter noftrum tunc finem habiturum fperavimus, neque nos noftra decepiffet fententia, ni ventus ille non modo omnem fubito furorem dimifffet, verum pene omnino filuiffet. Mare etenim quam cito ventis omnibus caruit, adeoque filuit, ut navis ulterius progredi non potuerit, ob maximam ejus tranquillitatem, à qua valde pertimuimus, ne ab ipfa alia nova tempeftas oriretur, noftrique itineris finem, quem oculis profpiciebamus, prohiberet, \& in alia graviora maris pericula nos injiceret. At Dei optimi maximi voluntate factum eft, ut ope triremis Præfecti Alexandriæ, quem Sangiac appellant, in portum navis duceretur, \& die XXI I. menfis Marti finem longiffimæ noftræ navigationi imponeremus. Alexandriæ vero, Cayri ingenti graffante peftilentia, ufque ad Julium menfem manfimus; cujus menfis initio per Nilum flumen navigantes, Cayrum venimus. In qua urbe tribus annis, \& adhuc amplius moram traximus. Tandemque hoc anno MDLXXXIV. Fgyptiis littoribus relictis, navi Balbiana vocata, menfibus Octobri, atque 


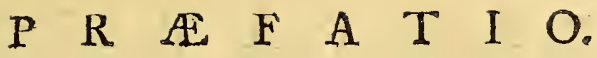

atque Novembri tantum navigantes, Deo fumma pietate patrix redditi fumus. Gulland. Omnia certe maris 'itinera in fummo periculo verfantur, quando navigantium vita, quia proxima eft mari, proxima femper exitio fit dicenda, atque etiam quod fpes profperi itineris in aëris inconftantifimam naturam referatur. Verum ne te pigeat hac atque illa paflum fuiffe, quoniam fortaffe hrec olim te meminife juvabit. Apprime jucundum femper exiftimavi, hominem poffe dicere, hac atque illa fum paffus, fiquidem eorum eveftuum memoria hominem alacriorem ad ferendos fortunæ cafus, prudentioremque efficit. Sed his omilfis age, quafo, quid tu tandiu in $\mathbb{E}$ gyto fecifti, quibufve ftudiis animum toto illo tempore oblectafti? Neque enim eum te effe arbitror, qui non egregium aliquod nobileque ftudium fis ibi profecutus, quando credendum eft, plurimas eafdemque pulcherrimas tibi non defuiffe occafiones, quibus aliquid te ipfo dignum in re medica meditari potuifes AupiN. Quiid facerem ociofus toto illo tempore in Ágypto? nifi apud eam gentem qualis exerceretur medicina, atque quales plantex in eo folo nafcerentur, dignofere operam darem, ne faltem diceretur noctu me Aigyptum adiiffe; per id temporis, quo ibi moram traxi, publice medicinam exercendo, apud illos medendi ufitatum modum difcere ftudui. Et quod temporis etiam ab eo ftudio atque ægrotorum curis mihi fupererat, id ponebam, ut tu ex me quoque audiffi, in opere de prefagio medicorum multis jam ab hinc annis à me incepto. GurLand. Gaudeo te operam Aigyptiorum medicinæ cognofcendx fic dediffe, ut apud illos frequentatum medendi modum, atque ipforum ufitata medicamenta plane, animadverteris, \& didiceris. Qux omnia cum adprime fint digna, qux à noftris medicis cognofcantur, te nunc obnixe rogo, hifce diebus, quibus Petavii commoraberis, ne grave fit tibi, mecum de his, in hoc viridario loqui, præfertim vero de morbis 


\section{P R. A F A T I O.}

illi populo familiaribus, deque ipforum medendi ufu, atque demum de plantis ibi nafcentibus; fic enim in his reftivis caloribus fub gratiflimis hujufce viridarii umbris tempus cum virtute confumere nobis jucundiffimum fore exiftimo. Aupin. Dabo equidem operam libentiffime, ut non in hac re folum, verum in omnibus aliis tuæ obfequar voluntati, quamquam nullam unquam tuorum meritorum partem ego affequi valeam. idque libentius faciam, quod plurimum emolumenti me fperem ex hac noftra collocutione pro tua doctrina, \& humanitate confecuturum. Solem vero cum nunc videam pene in Occafum defcendiffe, fortaffe præeftiterit loquendi principium in proximam diem remittere Gurland. Recte fane, ego vero vix aurora expectata me in viridarium conferam, teque ut quamprimum venias etiam atque etiam oro. Alprn. Perplacet, fed tempus eft, ut abs te nunc abeam, meque à multis meis negotiis nunc expediam, ut mane quam diluculo ad te redire polfim: interea vale. Guiland. Quando apud me effe nolis, ut lubet, ut ante noctem tuis functus negotiis, mane redire pollis, abi felix. 


\section{N D E X C A P I T U M.}

XIV. De morbis Egyptiis familiaribus, deque ipforum carJis.

XV. De pefte, qua Sape loca Esypti invadit, atque atrociflime devaftat.

X V I. Cur peftis contagium ex locis Barbarie Cayrum importatunn diuturnius $\int_{2 t}$, Ë magis exitiofum eo, quod ex aliis locis provenire obfervatur.

XVII. Quo tempore peftis loca ZEgyptia invadere folcat, E quo tempore ipfa definat.

70

XVIII. A qua caufa, Cayri qualifcumque peftilentia Jat, mesSe Funio omnino tollatur.

71

\section{I B R I S E U N D I.}

CAP. I. De uffumittendi fanguinem apud Egyptios medicos frequentato, E cur apud ipfos Janguinis vacuatio fit familiariffinum remedium.

80

11. De ratione variorum corporum temperamenti atquie habitus, deque Egyptiorum vario temperamento, E̋ habitu.

84

III. In quibus morbis AEgyptii fanguinis milfione utantur, at-

IV. Rue in quibus corporibus. evacuationi indulgentes, Ė in pueris mittentes fanguinem.

97

V. Egyptios medicos non errare fi in pueris, qui morbis acutis corripiuntur, aliquando fanguinem mittant.

102

VI. In pinguioribus cnrporibus, Eunuchis, mulieribus, pueris, Senibufque quo modo AEgyptii fanguinem mittant.

- VII. An Egyptii. medici recte Je gerant in ufu miffionis fanguinis in dyfenteria, diarrbea biliofa, exhantematibus, 


\section{IN D E X CA P I T U M:}

tibus, puncticulis appellatis, peftiferifque bubonibus, E parotidibus.

I I 3

VIII. Egyptios medicos à cibo fanguinein mittere, atque als recte faciant etiam illis, quibus fanguinein mittere debent, potum aliquem propinare.

IX. Quot modis AEgytii fanguinem mittere foreant.

$\mathrm{X}$. De venis, que in ufu funt apud Egyptios pro molienda Sanguinis miflone.

126

$\mathrm{XI}$. Aggytios arterias pro Janguinis miffione non Jecus quam venas incidere.

I 33

X1I. De arteriis, quas AEgyptii fecare Solent, atque quonodo illas fecent, E' curent, $\mathcal{E}^{2}$ in quibus etiam morbis ipfarum fectione utartur.

I 36

XIII. De cucurbitulis, quibus in \$Egypto medici utuntur. I 39

XIV. Qualis cucurbitularum apud IEgyptios fit ufus, in quibufque morbis iis ipli utantur.

$\mathrm{XV}$. An folis cucurbitulis corpora recte ac tuto vacuari poffint, $E^{2}$ num in principiis morborum pro vacuatione fint adbibendle.

147

XVI. An errent Aggytii nunquam utentes cucurbitulis pro adjuvanda exhanternatum eruptione.

106

\section{I B I TER T I I.}

CА . I. e variarum Scarificationum frequenti apud medicos Egyptios $2 ! \int u$.

II. De aurium, narium, labiorum, gingivarum fcarificationibus, quas medici Espptii pro evacuatione frequentant.

I 68

III. Malleolornm five crumum fcarificationem ad moliendan evacuationem anxilium effe antiquifflmum, à Grecifque clariflmis medicis valde ufitatum.

$$
\begin{array}{ll}
\text { **** } 3 & \text { I V. Qui }
\end{array}
$$




\section{IN D E X C A.P I T U M.}

IV. Quibus in Italice locis bominibus fanguis crurum fcarificatione fuerit detraitus.

V. Crurum Scarificationem non eam effe, quam noftri applicitis cucurbitulis frequentant.

180

VI. Inter crurun fcarificationem, atque vence fectionem maximam effe convenientian, ac fimilitudinem. $\quad \mathbf{1 8 5}$

VI I. An crurum fcarificatio vicaria fit vence Jectionis. . I88 VIII. Quomodo Aigyptii crurum fcarificationem exerceant, atque adminiftrent. 195

IX. In quibus morbis ufus crumum fcarificationis apud REgyptios frequentetur, atque in quibus corporibus 199

$\mathrm{X}$. An crurum Scarificatio in fura, ut AEgyptii faciunt, vel potius in malleolo, ut Gal. docuit, fit facienda. 203

XI. De uf ul fcarificationis partiun, inflammatione, tumore, puffula, colore non naturali, infigni dolore vexatarum, apud 庭gyptios frequentato. 207

XII. De variis partium inuftionibus, que felectifima fecreta ad varios curandos morbos apud Asyptios babentur.

209

XIII. De feectione, qua in bydropicis \& Juppuratis AEgyptii utuntur.

218

XIV. De lapidis è vefica extractione abfque ulla incifione apud Iegyptios frequentata, Eo de dyfenterice curatione em-. pirica.

223

$\mathrm{XV}$. De uflis balneorum dulcium pro ornatu corporum, atque quid mullieres ad pinguefacienda corpora in ipfis moliantur.

229

XVI. Qua. Esyptice mulieres in balneis factitent, ut ip $\int_{a}$ rum corpora impinguefcant.

XVII. De dulcium balneorum pro Sanitate corporum apud $\mathbb{R}$ :gyptios uf lu. 236

XVIII. De frictionibus, quibus EEgyptiis in balncis utuntur. 240

XIX. De balneorun apud IEgyptios ufu ad varios morbos perSananilos.

244 


\section{N D E X. C A P I T U M.}

\section{I B R I Q U A T I.}

$\mathrm{C}_{\Lambda}$ P. I. D medicamentis alierantibus, que in ufu apud medicos Egyptios exiftunt.

11. De Medicamentis ab Pisyptiis animi gratia ufitatis, $\int p e-$ rantibus $a b$ bis devoratis varia exoptata in infomiis videre.

111. De decoctis, quibus Egyptii, tum in Sanis, tum egro tis corporibus utuntur.

IV. De Jyrupis apud Egytios ufitatis. 268

V. De purgantibus medicamentis dे medicis Egyptiis uf tatis.

VI. Uter nobilitum, vel plebejortum Ayptiorum purgandi ufus fit laudatior, five an purgando medicamentcs leniter purgantia prevalidis magis proftent. $\quad 278$

VII. Apud nonnullos AEgyptios in ufue effe Statim ab affunpto purgante medicamento frigidam aquam multam propinari. 285

VIII. De theriaca, atque aliis compofitis medicamentis, quce in ufu funt apud Agyptios.

IX. Theriace compolitio, quam fingulis annis pro Turcarum Rege componunt, quam tharac faruc appellant. 290

$\mathrm{X}$. In quo \#gyptiorum theriace defcriptio differat ab ea, que $a b$ Andromacho Seniore olim fuit memorice prodita.

294

XI. De aliquibus fimplicitur medicamentis theriace compofitionem ingredientibus confideratio. $\quad 302$

XII. Errores, quos committunt Asgyptii in componenda theriaca, atque de ipforum theriace preftantia. 307 XIII. De quibufdam aliis compofitis medicamentis, quibus Itgyptii etian utuntur. 


\section{N D EX C A P I T U M.}

XIV. De clyfteribus apud 'Agyptios ufitatis. 312 X V. De fecretis auxiliis, quorun ufum ad febres Rgyptio frequentant.

\section{F I N I S.}

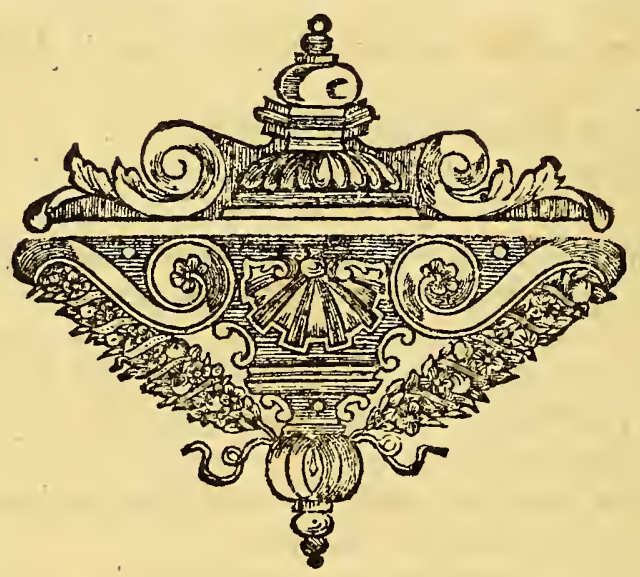




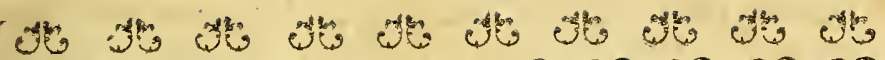

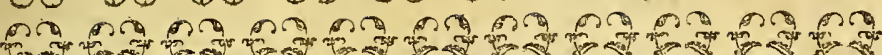

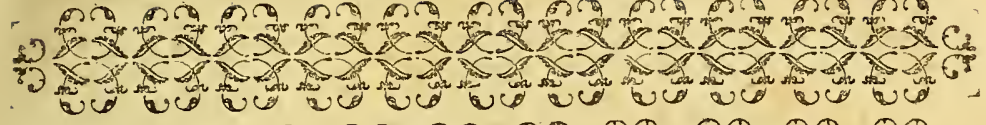

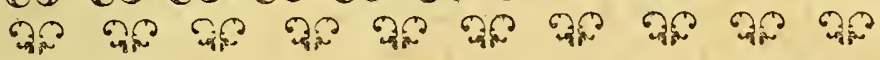

\section{PROSPERI ALRINI}

D $\mathrm{E}$

\section{MEDICINA ÆGYPTIORUM. \\ L I B E R P R I M U S. \\ C A P. I.}

De ftatu Egyptiorum medicorum:

\section{G U I L A N D IN US, A L P I US.}

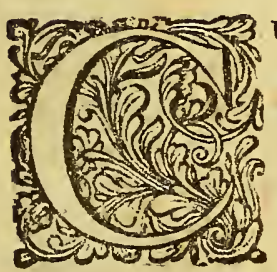

ч $\mathrm{M}$ hæc dies fereniffima jam illuxerit, \& op. portune nos in hoc viridario fimul concefferi. mus, locum fecretioris hujus receffus quietiffimum, opportuniffimamque occafionem naEti, de medicina Egyptiorum jam aliquid commentemur, de qua quidem prius quam agamus, à medicorum, quibus ea regio abundat, narratione principium faciemus. A L P IN. Jamjam è via huc veniendo, eminus te in viridario ambulantem, profundeque cogitantem profpexi, \& haud parum miratus fum, quòd tam diluculo è lectulo furrexeris. Neque tamen abs re credo, in viridarium defcendifti, ut frigidiufcula fcilicet ifthac aura matutina, ac non minus iftius elegantiffmi tui viridarii amonitate aliquantulum te recreares. Sed ne tuum loquendi defide- 
rium amplius oratione mea retardem, ad principium propofiti tui fermonis jamjam defcendo. Sed quid obfecro me de medicis $\mathbb{E g y p t i i s ~ d i c t u r u m ~ a r b i t r a r i s ? ~ a n ~ q u i a ~ m u l t i s ~ p e r f u a f u m ~ e f t ~}$ ibi medicinam primas habuiffe radices, plurimofque illuftres viros tum in medicina, tum in aliis fcientiis olim in Ëgypto floruifie; iifdem etiam hac tempeftate ornari regionem illam ac florere? Guiland. Quid ni omnes iftud ipfum fentiant? quando ufque adeo etiam ibi bruta multa animalia reperiantur, quibus ars infita curandi morbos aliquos exiftimetur? quemadmodum de Hippopotamo equo marino in Nilo flumine degente apud quofdam legitur. Hunc enim equum in quadam medendi parte etiam magiftrum effe aliqui affirmant. Affidua namque ipfe, ut ajunt, ingluvie \& fatietate obefus, exit in littus, recentes indagaturus arundinum cæfuras, atque ubi acutiffimum earum ftipitem cernit, id in corpus adigens, venam quandam fibi in crure vulnerat, atque ita profluvio fanguinis excitato morbidum aliàs corpus exonerat, mox plagam rurfus limo ob: ducit. Quamobrem funt, qui arbitrantur, miffionem fanguinis ab hujufmodi animali homines didicife, veluti etiam à volucre quadam Ibi vocata apud Nilum quoque nafcente clyfteriorum ufum accepiffe. Quod ipfam fæeius fibi alvum exoneraffe roftri aduncitate aqua per anum intromifa fæpe fit obfervatum. Si itaque beftias ipfas in ea orbis parte natura medicinam docuife creditur, quid de hominibus erit ratione ac difcurfu præditis exiftimandum? Atque eo magis cum prifcis iis. feculis Ægyptus plurimis doctiffimis medicis femper floruerit? Alpin. Hippopotamum \& alia bruta animalia, de quibus ea medendi miracula prædicantur, ibi reperiri certum eft : at quod ego de hominibus medicinam profitentibus hife annis obfervarim, in medium nunc tibi proferam, pancifque 'narrabo; qua. ex his fcitu digna mihi fuere vifa, ac primum dico, Cayri aliifque in locis Litgypti plurimos tum viros, tum mulieres reperiri, qui publice per urbem medicinam faciunt, non tamen ullos. exiftere, qui hanc artem aliqua ratione atque Hippocratice faciant. quando ibi nunc non literis, fed armis opera ab his populis detur: neque id quidem mirum, cum Turcarum imperio 
ea gens fubjecta fit. qui nullis fcientiarum ftudiis delectantur: armis tantum, auro argentoque \& veneri indulgentes. de quibus verè videtur Seneca dixiffe:

Turpis librdo dominatur ( $($ cilicet munc) potens venere,

Luxuria vicirix orbis immenfas opes

Gampridem avaris manibus, ut perdat, rapit.

Deeft illis ftudiorum exercitatio, quamquam publicas fcholas, five ftudia ipfi habeant, in quibus varia fcientiarum genera docentur; Cayri ftudii locum Gemelhazar appellant, pro quo tercenta millia aureorum anno quolibet diffipari ajunt. Siquiden ibi totius Academiæ fumptus ad libros, ad victum \& ad reliqua doctoribus \& fcholaribus neceffaria quotannis ære publico fup. peditantur. Ex omnibus vero fcientiis, atque artibus, quæibi docentur, ea fola pars theologica apud ipfos colitur, quæ Pfeudoprophetæ Mahometis leges, inftitutionefque pertractat. Multi fiquidem, propemodumque infiniti funt, qui honoris atque utilitatis gratia in ejufmodi fcientiam incumbunt, quam qui adepti funt, in fummo pretio atque honore apud Turcas, aliofque omnes habentur. Hos Cadi appellant, quafi dixerint, facræ legis doctores, quos Turca illius regionis præfectus fuos quoque judices creat, quibus authoritas concefla eft, ut poffint quacunque de re in jure civili, ac pontificio judicare; ob quam rem ipfi tum in fumma veneratione habentur, tum maximas parant opes. In aliis vero artibus atque fcientiis perpauci funt, qui perfecti fieri ftudeant, omniumque minime in arte medica, quæ cum aliis omnibus ferè in locis fummo dignitatis gradufit, infimum nunc atque vilifimum tum ob gentis barbariem, tum ob eorum, qui per urbem medentur, ignorantiam, locum tenet. quam nifi hinc ex Europa per Venetos Confules conducti medici, curandis ibi Turcarum, Arabum, \& aliarum gentium Optimatibus, \& quamplurimis, quos alii medici defperata fallute reliquerant, ad valetudinem reductis extuliffent, atque illuftraffent, omnium mechanicarum artium ignobiliffima apud Ėgyptum jacuifet; id autem diligentia, ut dixi, noftrorum reparatur. Illi vero cum ab omnibus contemnantur, tum etiam lucrum ipform exigum eft. Guıland. Cum medici illi ita A 2 ne- 


\section{4

negligantur, neque multum lucri faciant, quæ occafio erit, qua ad medicinam valenter perdifcendam illi moveantur. Non eft igitur mirum inter illos parcos perfectos medicos reperiri. Quod cum explicatum à te fit, nune reliquum eft præterea nihil, nifi ut fufceptum de medicina $\mathbb{E g y p t i o r u m ~ f e r m o n e m ~}$ claudas, ac de aliis rebus loquaris. Alpin. Quamobrem? GuILAND. Quoniam ex indoctis medicis, quid boni, ac feitu digni ex te obfervatum audire poffum? Alprn. Intelligo, unde tu in eam deveneris fententiam. Sed hoc fortafle non eft ita exiftimandum, quando feientia atque doctrina ignaros homines, Empirice tamen multa in arte fecreta poffe dignofcere, quis negabit? qualia funt multa medendi fecreta auxilia fummam ob utilitatem nobiliffima, apud Esgyptios prifcos medicos olim inventa, hereditariè potius ab aliis præclariflimis medic:s his relicta, quàm aliqua doctrina ab ipfis acquifita. Quid etcnim, ut tibi de multis aliqua proferam, non ne mirum in $\mathrm{mc}-$ dum laudandus effet ille mittendi fanguinis Fyptiorum ufus ex fectione multarum venarum, quæ noftris medicis minime funt ufitatæ? quales funt jugulares, narium, angulorum oculorum, frontis, poft aures, pollicis atque aliarum multarum corporis partium. Quis etenim medicus is erit, qui nefciat, illarum venarum fectionem ad quamplurimos tollendos morbos effe utiliffimam? Quid dicam de fectione arteriarum, quam ad mittendum in multis morbis fanguinem non minus tutò, quàm in venis ipfi familiariffime ufurpant. Cum Galenus interim iis fectis quafi miraculo multos fævos morbos curatos nobis feriptum pluribus in locis reliquerit. Quid de aurium, colli, occipitis, labiorum, narium, atque malleolorum fearificatione dicemus? Cum ipfi mirabili dexteritate hoc genus auxilii præftent. Et quid de fuarum cucurbitularum ufu $a b$ hoc noftro planè diverfo? Quidque de uftionum ratione, atque de multis aliis ferme infinitis, quibus ipfi medendo utuntur, medicis præfidiis, deque etiam quamplurimis medicamentis fimplicibus, ac compofitis ab his multa cum utilitate frequentatis, erit judicandum? GUILAND. Digna iftæc mihi videntur, ut ab omnibus doctis medicis defiderentur; mirumque omnibus vi- 
deri debet, quo pacto hi indocti homines tot, tantifque nobilibus auxiliis recte uti fciant; nullo ea difcurfu ac medicæ artis ratione cognofcentes. Sed quo ordine his medicis per eam. regionem exercere medicinam permittitur, quando ita artis medicæ dogmatum ignari exiftant? A L I N. Extat Cayri inter cæteros medicos omnes quidam $\mathbb{E}$ Eyptius, quem Achimbafii illi appellant: qui medicorum princeps noftrâ linguâ interpretatur. Hujus officium eft, illos, qui ibi medicinam exercere velint, de illiufce artis peritia fedulo percunctâri, \& examinare, atque eis, qui in medendi examine recte refponderint ac recte fe gefferint, publica fide concedere, ut per eam regionem mederi impunè poffint. Iftud autem in doctorum numero afcifcendi munus non datur multis, ut in multis Europæ locis fieri folet, fed uni foli tantum, illique præfertim, qui plus auri argentive Præfecto Cayri, quem Bafsá appe!lant, hac de caufa folverit. Parum etenim id curat hoc tempore Bafsà, an ille, qui Achimbaffi procreandus eft, fit ad illud munus rectè obeundum probè idoneus, adeo nune apud i!los omnia corrupit avaritia; non hoc, inquam, ille curat, fed an potius aureos multos ipfi offerat. Eodem exemplo \& ipfe Achimbaffi etiam à Præfecto perdoctus eodem avaritiæ vitio fublatus, pretium à cooptandis accipiens, omnes indiltincte cum indoctos, tum doctos mederi per urbem finit. Qua facilitate numerus tum virorum, tum mulierum medentium in ea maxima urbe Cayri eft ferè infinitus, cùm quifque exhibito auro poffit ab Achimbaffi medendi authoritatem obtinere. Horum vero, qui per eam urbem medentur, alii promifcue morbos omnes curare profitentur, alii partis alicujus tantum mala. Veluti funt ocularii, qui omnes morbos ac fymptomata oculos ledentia, fanant. \& dentarii, atque auricularii, tantum malis dentium auriumque medentes. atque alii, qui tantum inteftinorum ægritudines, alii pudendorum, alii veficæ ¿゙ alii uteri curant; in quibus morbis mulieres medicæ viris præferuntur: exiftimant enim ægrotæ mulieres haudquaquám poffe viros fic recte uteri affectus cognofcere, ut mulieres ipfæ. Quare fit ut ægrotæ medicas potius, ut à fuis morbis curentur, quàm 


\section{6 \\ PROSPERI ALPIN I}

medicos adhibeant: funt etiam alii qui tantum febres fanant, quorum alii omnium, \& alii aliquarum tantum curationem profitentur: atque hæc obiter dicta fint de medicis REgytiis

\section{A p. II.}

\section{Egyptii qualem nunc medicinam exerceant.}

\section{G U I L A N D I U S.}

TNTEL LEX I probè omnia, verum id à te fcire cupio, quid 1 eft, quod omnes medici Fìgyptii Empirici exiftant, fectamque Empiricam fequantur. Alpin. Ut per eos annos, quibus Cayri moram traxi, obfervare potui, potius methodicæ fimulque empiricæ ipfos addictos judicavi, quando ad indicandam morborum curationen partium læfarum, caufarum, naturæ, xtatis, virium, habitus cœlique obfervationem efle necefiariam negent, quibufdamque medendo utantur communiffimis propofitionibus, quæ methodicorum fectam referre videntur. Ipfi etenim affirmant omnia morborum genera, vel è caliditate, vel à frigiditate oriri, vel morborum omnium præcipuam caufam in calorem præter naturam, vel frigiditatem referunt: Quoniam vero ipfi arbitrantur eorum omnium, qui Æ̇gyptum incolunt; corpora ratione cœli, fub quo vivunt, valde calidi, ad fummam vergere caloris intemperiem, obid perfrigerantium medicamentorum ufum in omnibus ferè morbis fine difcrimine habent frequentiffimum, illifque temerè \& inconfultò medendo utuntur. Obfervare fedulo fe putantes famofiffimam, vulgatiffimamque in fichola medicorum illam propofitionem, quæe eft, contraria contrariis curari; Hincque credentes ob illiufce coeli fumme calidam temperiem, ibi omnes ferè morbos, vel primo ab ea, quæ praternaturam eft, caliditate procreari, ve faltem femper cum aliis caufis præternaturalem caliditateni concurrere, ob quam caufam ufum refrigerantium medicamentorum maxime affectant, idque prefertim in febribus: in quibus abfque ullo delectu, valde frgidis medicamentis femper utun- 
tur, maximeque in iis, qux ex humorum putredine oboriuntur. Quod fanè contra medicinæ dogmata ab ipfis fieri exiftimo. Nihil enim frigidorum remediorum ufus, quantum ad febrium caufas, quæ fint obftructiones meatuum, venarum, vel aliarum partium, fpectat, aliquid prodeffe, \& multum obefle potelt, cum a frigiditate humorum cruditas, atque obftructio augeantur, maxime vero quando pituitofi fucci funt obftructionis auctores. Tales enim humores ab ufu frigidorum incrudefcunt magis, \& craffi fiunt magis, \& ipforum copia, ventriculo frigidiore atque ad concoquendum ineptiore ab eifdem effecto, peraugetur. quàm vero fint illa refrigerantia medicamenta $a b$ iis frequentata, pofterius fuis locis dicemus. GurLAND. Malus mihi quoque ille in medendis putridis febribus valde refrigerantium ufus effe videtur, quando nemo rationalium medicorum, quorum fectam omnibus præferendam judico, ignorat, obftructiones venarum, aliarumque partium in febrientibus à multis fuccis, vel craflis, vel vif́cidis, fieri, \& à multa frigiditate ipfas adaugeri. Galen. in fynochis putridis febribus, ut apud ipfum in libro nono, meth. medendi legitur, ea laudavit medicamenta, quæ obftructa liberandi vim haberent, abfque multo tamen calore, ne calor febrilis augeatur. ob idque eligenda illa effe, quæ exiguo calore prædita, id tamen præftare poffint. Hincque in tollendis obftructionibus ufum oxymellitis fummopere commendavit. \#gyptii vero fortaflè ita frigidis in iis febribus utuntur medicamentis, quod hæ ex biliofis tenuifimifque humoribus ortum maxime ducunt, qui non attenuandi, fed incraffandi fint, ut Avicennæ affeclæ affirmant, hancque fortaffe ob caufam illi medici frigida medicamenta adhibent, ut ex quibus genita febris fuit, biliofi, tenuiffimique humores craffiores evadant, ad facilioremque excretionem eo modo parentur. Hæc erit igitur ratio quamobrem frigidis adeo medicamentis utantur. ALPIN. Si tu corpora illorum hominum quali temperamento fint, rectè noviffes, in hanc procul dubio fententiam non veniffes; nam, ut fuis locis dicam, omnium ferè illa loca habitantium corpora diverfo conftant temperamento, quòd aliquis cœli illiufce 
ratione, credere poflet, quando pleraque illorum corporum licet ex fui natura fanguinea exiftant, multa tamen pituita, etiam ex victus ratione apud ipfos ufitata, abundare dignofcantur. Quamquam enim Ágyptii in ipfo ortu interna vifcera valde calida fub calidiffimo colo fufceperint, ex potu tamen aquarum, ufuque continuo ciborum tum frigidorum, tum refrigerandi qualitate magna ex parte præditorum, quibus ferè femper utuntur, ab immoderataque venere, atque ab ufu dulcium balneorum, quæ affidue frequentant, temperamentum ilhd calidum paulatim permutant in minus calidum, \& tandem in frigidum; itaque fit, ut qui biliofo nafcuntur temperamento, in fanguineum mutentur, \& qui fanguineo, in pituitofum. Hincque quamplurima fœminarum, mariumque corpora ibi reperiuntur pinguiffima, cum tamen coli calidifimi ratione corpora omnia gracillima effe potius deberent. Ex his igitur omnibus illortim corpora refrigerantur. Quo fit, ut omnes ejus reggionis accolæ ftomachum valde frigidum contraxerint, licet ipfi corporis habitu carnofo, bonique fucci, conftare etiam obferventur. Hujus autem facito ex me conjecturam, qui prius quàm he gyptum adiifem, cum gracillimo corpore fummeque calido effem, ibi ex affiduo aquæ potu, cui ob illos vehementes calores continue indulgendum erat, carnofum effeci corpus \& pingue. quo tempore ftomachus adeo erat ad frigiditatem converfus, ut ejus concoctrix facultas ad concoquendum imbecillior effecta frpe videretur, quam ob caufam frepe acidis cruditatibus vexabar. Quod fi mihi id acciderat, homini medico, \& in temperata regione genito, quid de $\mathbb{E}$ gyptiis ipfis exiftimandum, qui non folum aquam pro potu affectant, fed omnes frigidos cibos, quique immodicæ veneri dant operam ufumque dulcium balneorum frequentant? quæ omnia refrigerandi ficultatem habent; nifi illos crudis multis humoribus abundare? Quod confirmare videntur affidux ventriculi cruditates, in quas ipforum quamplurimi incidunt, frequentifimique articulorum dolores, qui continue fparfim per urbem vagantur, ac mulieres, Eunuchos, \& omnes abfque difcrimine invadunt ac amligunt. Ex his igitur colligo, Cayri rariffimas 
febres ab exquifito humore biliofo gigni, plerafque verò à crudo ac pituitofo excrementorum genere; ideo arbitror ufum refrigerantium mendicamentorum iis febribus non rectè convenire, ob illorum humorum, à quibus generantur, tenuiorem fubftantiam, ut Arabes medici volunt, craffefaciendam, quando eos potius craffiori fubftantia conftare, quàm tenui ex nuper allatis optime pateat: Non erit itaque frigidorum medicamentorum ufus in febribus putridis ibi vagantibus omnino tutus, fed fxpe iis noxius. Illi igitur medici, quod ad febres compefcendas attinet, probandi quidem effent, fcilicet, ut illum febris focium calorem extinguant, peffime vero faciunt, quòd febrium caufas minime auferant. Ac potius ipfos dixerim medicinæ adulatores, quando folum ægrotantium, caloribus, doloribus, fiti, occurrere, fymptomataque folum demulcere ftudeant; perfectam vero curationem, quæ, Galeno docente in lib. 9. meth. med. à caufis exorditur, negligant. Accidit tamen aliquando, ubi febres vehementiores afflgunt, in caloribufque heeticis, ut recte frigidorum medicamentorum ufus adminiftratus videatur. Guiland. Mendofam fatis illos poffidere in medendo artem methodicam, ex his à te narratis intellexi, quam etiam empiricam effe facile perfpicitur, quod ea, quæ in hac arte noverunt, potius hereditarie à majoribus tradita acceperint, atque in ipforum memoria remanferint, quàm ullo difcurfu, vel ratione fuerint ab ipfis cognita.

\section{A P. III.}

\section{Quamobrem boc tempore CEgyptii artem medicam babeant vitiofam.}

\section{A L P I N U S.}

$\mathrm{D}$ IXIMUs, Egyptios medicos noftro hoc ævo non exercere rationalem, vel dogmaticam medendi viam, fed vitiatam, ac multis mendis plenain. Guiland. Quonam modo eft ibi vitium iftud in medicina contractum? Alpin. Scito, hoc 


\section{PROSPERI ALPI N I}

tempore medicos illos finem habere non fanitatem xgrotantium, quem verimedicifemper intuentur fcopum, fed ut gratiam atque obfequium hominum comparent; ita ut nun ibilocum habeat illa fententia:

Terent. Obfequium amicos, veritas odium parit.

in Andr. Hos medicos Gal. adulatores appellat, cum haudquaquảm id Scen. $\mathbf{I}$. Act. I. ipfis fit cordi, quemadmodum ægrotis recte, ac tuto medeatur, fed potius quomodo eorundem deliciis inferviant. Refpicit itaque ipforum medendi methodus ægrotorum gratiam, atque obfequium. \& ob hanc caufam victum ægrotis gratum inftituunt, omnibufque febricitantibus, ac fitientibus permittunt, ut quantum volunt, aquæ potu fe expleant, fructufque in victu quoflibet ab ægrotis expetitos non negant, affirmantes, nihil à natura appetitum poffe ægros offendere, quando naturam ipfam tutius, ac prudentius ad corporis tutelam moveri, quảm medicos, affirmandum fit. proinde multi ægrotis febrientibus non verentur in victu concedere angurias, cuculmeres, cucurbitas," melones, ficus, atque alios, quofcunque ibi habere poffunt, fructus, \& ut uno verbo dicam, omnia concedunt $æ$ grotis, quæ grata illis effe cognofcunt. De medicamentis itidem hoc idem obfervant, ut tantum illa medicamenta ad fanitatem parandam adhibeant, quæ abægris non abhorrentur, eaque tum qualitate, tum copia feligunt, quæ nullo pacto corpora ægrotantium agitare poffint: ob idque maxime in communi funt ufu, ad quofcunque propulfandos morbos, hujufmodi medicamenta, manna fcilicet, caffia , tamarindi, fyrupus de granatis folutivus, atque rofatus, non exceduntque mannæ, caffiæ, tamarindorum unciam, fæpiffimeque ægrotis hæc offerunt, alii fingulis, alii alternis, \& alii pluribus diebus offerentes; pluribus etenim vicibus eam purgationem præftant, quod nos unica vice facere confuefcimus. Ex purgantibus ucuntur, myrobalanis, Rhabarbaro, agarico, fenna, atque aliis hujufce generis multis, quorum dragmam in fingulos hauftus non excedunt; hicque modus purgandi inter plerofque civium ac nobilium exercetur', atque in hoc fe recte gerere videntur', dum cavent à validioribus, Scamoneatifque pharmacis, in iis 
purgandis corporibus. Sunt tamen alii, qui rufticis medentur, cum is vero piævalidioribus purgationibus agunt, fed, ut dixi, non nifi in rufticis. Mirumque non erit, hofce medicos his medicamentis potius lenientibus, quàm purgantibus utentes, tardifiime ægros fanare; id autem ea caufa faciunt, ne purganda corpora nimium $a b$ is agitentur, atque perturbentur; ob quam caufam plerique clyfteribus medentur, potius quàm medicamentis per os affumptis, ut quàm nimine corpora agitent. In materia quoque chirurgica eodem modo ægrotorum obfequia fequuntur, hincque multum fanguinis omnibus detrahunt, quod omnes miffione fanguinis letentur; id vero fape in multis, etiam à cibo, ut miltis obfequantur, qui ajunt, jejuno fto. macho, ægrotis non conducere id auxilium, quod nimium vires abfumat. Et in omnibus denique medicamentis eodem fem: per fpectant, ut quàm maxime ægris obfequantur. GuILAND. Adulatores medicos non folum Egyptus habet, fed non minus multa Italiæ loca, in quibus multi ignari homines eos optimis quibufque medicis ea caufa præferunt, quòd obfequantur fibi, idque tantam vim ad capiendos ægrotorum animos habet, ut plurimi fæpe ab lgnaris atque adulatoribus medicis ufque ferè ad exitium perducti, neque tam grandes illorum in meden. do errores agnofcant, neque, fi etiam agnofcant, ab his difcedere velint. Sed quamobrem medici illi olim præftantiffimi ad medendi modum hunc vitiatum accefferunt? Alpin. Hic cor: ruptus medendi modus non à prifcorum illorum medicorum ignorantia principium duxit, fed, ut ex \&gyptiis hiftoriarum peritis audivi, à barbara prifcorum Kgypto Imperantium tyrannide; tempore enim quo Mamaluchi illiufce regionis obtinebant imperium, omnia ea loca medicis doctiffimis florebant ; qui dogmatice fummaque cum ratione medicinam faciebant, fed tanta erat ea in dominis barbaries, ut optimi illi doctiffimique medici, vel rebus bene geftis fæpe lucri loco ab iis contumeliis afficerentur. Barbara etenim ea progenies, quæ moribus beftiis erat fimillima, quòd originem duxerit è Tartaris rufticifque, rectam ac rationalem medendi methodum non admittebat. Illorum aliquis dolore aliquo correptus non fecùs, quàm 
furens beftia, fubitò ut fanaretur imperabat, quod cum non femper ita citó eveniret, peffime miferos eos medicos tractabat. Idem obfervabatur in illos, qui fitientibus ipfis plurimam crudam aquam in potu negabant, vel à calore febrili valde detentis frigida balnea prohibebant, in quibus immergi volebant, \& iis multum refrigerari. Si tormina ab affumpto aliquo pharmaco fentiebant, vel multum eo purgarentur; vel faftidiofe vomerent, in medicos jurgia, \& contumelias, miferos Egyptios! qui fato quodam femper Tyrannis fubjecti fuerunt. Illi itaque optimi medici recte medicinam exercentes indigne has contumelias ferentes, modum fanè perquàm facilem in medendo invenerunt, quo barbaris is hominibus fatisfacerent, atque perpeflas injuftè objurgationes ac contumelias vindicarent, ac de illorum tyrannide in ipfos exercita hoc modo pœnas fumerent. Guiland. Piget me tantorum medicorum injuriarum, fed mirum non erat, eos ita à barbara ac ferina ea gente contumeliofe pati, quando virtuti vitium, \& fapientix ignorantia opponatur. Ab illorum enim barbaro dominio illis freculis non folum medicinam, fed etiam omnes alias fcientias ab Egypto in alias orbis partes commigraffe exiftimo, atque ideo nunc Turcarum loca ftudiis fcientiarum omnino vacare. Sed perge modum enarrare, quo ad fugiendas \& ulcifcendas illorum contumelias ufi fuerunt. Siquidem haud parum effe judico, homines illos in tanta calamitate pofitos, viam invenifle, qua id periculi effugere potuerint. ALPIN. Tunc hac ratione mederi eis coperunt, hæcque fuit ab his indagata methodus; Namque eis ægroto curando propofito, primò, quo ille morbo, vel miti vel magno vexaretur, atque quibus fymptomatis corriperetur, eaque mitiane an magna effent, fcire operam dabant: quibus rectè perfpectis ac cognitis, omnes curationis indicationes præcipue confiderabant, hinc morbos tantum atque fymptomata refpiciebant, caufis omnino neglectis, vel levifime cognitis. morbo enim, fi fymptomatibus iis vehementibus careret, contrariis mederi omni ratione ftudebant, veluti exempli gratiâ, febre vexato, abfque multis gravioribus fymptomatis, victum primo frigidorum atque humidorum inftituebant, 
quem penitus morbum extirpare, iis ignaris beftiis facile fuadebant, proinde omnes fructus, qui humidi eflent ac frigidi, eis collaudabant, ut funt anguriæ, cucurbitæ, cucumeres, poma, \& ex oleribus beta, malva, bammia, colocafia, lactuca, endivia, funcus atque alia hujufcemodi temperamenti ac facultatis multa. Pro potu frigidifimam quamcunque aquam, largifimeque ad ægrotantium libitum, concedebant. In materia vero chirurgica in quacumque febre, quòd omnes illos barbaros ad largam fanguinis evacuationem inclinatos admodum cognofcerent, multum fanguinis detrahebant. Et ex medicamentis alterantibus ea laudabant, quæ refrigerarent, atque humectarent, atque de purgantibus, evacuationem per epicrafim, lenientibus medicamentis, à quibus nihil Barbarorum corpora turbarentur, moliebantur. Febris vero omnia fymptomata demulcere vel omnino abigere fudebant, calori enim æftuofo interne frigidis aquis, vel fyrupis, vel decoctis, vel fructibus, \& frigidis epithematibus occurrere conabantur ; fitientibus, quantum vellent, ægrotis aquæ permittentes, in appetentiis, quofcunque cibos ab ægrotis expetitos concedentes, vigiliis, valide fomnum provocantibus, qualia funt opiata omnia, obfiftebant, dolores vehementes tollebant, is medicamentis, qux infigni frigiditate partium fenfum adimunt, qualia funt ftupefaciencia à noftris appellata, atque fic in fingulis aliis febrium fymptomatibus facere cœperunt: hicque fuit modus curandi, quo ægrotos blandè curare fe ajebant, eofque medici illi fuo gladio jugulabant, verique inde facti funt medicinæ adulatores, ut illorum tam importunam effugerent tyrannidem, atque miferiam, quando ægroti obfequii vi arbitrarentur rectè à medicis illis tractari. Ortufque eft malus is medendi modus ab Æggpto Imperantium tyrannide, quem poftea omnes alii, qui confequuti funt, medici rectè obfervarunt, mortuifque doetiffimis iis medicis, fimulque cum is hujus artis doctrina, poftea paucifimi reperti fuerunt literarum ftudiis dediti; fiquidem dominorum ob barbariem literarum profefforibus inimicam, academix, ac ftudendi commoditates defecerunt, eaque caufa ftudentium etiam numerus defecit, omnino præfertimque in philofophia $\&$ 


\section{PROSPERI A L P I I}

medicina, indeque Egyptus expers fcientiarum, literarum profefforumque tunc facta eft. Deindeque ille medendi modus, jam multis ætatibus ibifrequentatus, ac per illas urbesreceptus, aliis omnibus medicis, qui pofteà fuere, communicatus fuit, neque difficulter ab iis perdifcebatur, cùm pauca quædam tenenda effent. Hic igitur modus medendi, quem illi homines affecuti ibi optimimedici exiftimantur, tale principium habuif: fe, a multis dicitur. In eo vero ficuti multa corrupta, atque arte Hippocratica indigna obfervantur, fic multa etiam veram præclariffimorum medicorum antiquitatem redolentia reperiuntur, quæ digna funt ob egregiam, quam preftant in medicina utilitatem, ut ab omnibus doctiffimis medicis audiantur, atque perdifcantur. In qua vero parte medicinæ ifthæc eluceant, nuper dictum eft, \& inferius qualia particulatim exiftant, fuis locis dicemus. Sed priufquam ad ea accedamus, multa prius erunt cognofcenda, quæ ad majorem clarioremque dicendorum cognitionem facere videntur, atque in primis, ne tempus fruftra conteramus, confiderandam tibi viro doctiffimo eam propofitionem propono, quam illi medici mordicus obfervare medendo creduntur, quæ eft, contraria contrariis curari. Quam propofitionem vel mulieres ipfemedicinæ \& rerum omnium ignaræ perbelle ibi fe putant obfervare.

$$
\text { C A P. IV. }
$$

Apud CEgyptios medicos medicam illam propofitionem ufurpari, qua eft, contraria contrarus curari, atque an ip li eam rectè objervent.

\section{G U I L A N D I N U S.}

C U M Egyptii in medendo utantur ea propofitione, qux eft, contraria contrariis curari, videntur hac in re non omnino carere rationali medicina, quando ea quoque omnes rationales medici æegrotis medeantur, morbos curantes is medicamentis, quæ eis funt contraria. ut Gal. in lib I $\boldsymbol{1}$. meth. 
cap. 12. teftatum reliquit. Quamobrem \& illos, qui pofito hoc principio medicinam ibi faciunt, ob id inter rationales medicos effe recenfendos, aliquis affereret. Alpin. Huic medicæ. propofitioni non modo ejus loci medicos inniti , fed ipfas etiam mulieres, certum eft; quinimo Cayri fi volueris tertianam no. tham febrem, agrimonio, apio, vel petrofelino, vel chamedrio, vel aliis curare, ut obftructiones, à quibus oritur, atque fovetur ea febris, auferantur, non modo medici, fed mulieres inclamabunt non effe id faciendum, quando febris, qụæ calidiffima eft intemperies, folis refrigerantibus remediis curaridebeat, quibus medicamentis calida intemperie præditis potius febris augeretur, nedum tolli poffet. Hanc igitur ob caufam ea vituperant, atque fufpecta habent, quæ fuperius aperientia narravi: quæ licet morbo fimilia videantur, tamen ejus caufis contraria exiftunt, quibus fublatis febris tollitur, iifdemque perfeverantibus nunquam febres illæ finiuntur, idcirco dicenda funt illa eadem medicamenta per hunc modum morbo contraria. Neque tamen eo, quòd medendo utantur ea, quam dixi, communitate, rationales appellandi funt medici. Tibi enim doctiffimo viro notifimum eft, methodicos tantum appellatos medicos", ufos fuiffe iis communitatibus, qui neque locum patientem ad curationis indicationem aliquid prodeffe autumarunt, neque caufam, neque ætatem, neque tempus, neque colum, neque virium robur, neque ægrotantis habitum, neque temperamentum, fed à folius affectus indicatione remedii indicatione fumpta, ea communitate febrem, exempli gratiâ, nuper in medium propofitam curant. Sed errant in cognofcendis morbo contrariis remediis. Namque putridæ febres, quæ ab obftructionibus genitæ funt \& foventur, ut rectè curentur, debemus uti iis, quæ tum morbo, tum caufis fint contraria, qualia funt, quæ refrigerant, humectant, aperiunt, atque abftergunt, quibus fanè fi obftructiones cedant, febris proculdubio tollitur, iifdem vero ob humorum lentorem \& craffitiem curationi obfi. ftentibus, atque non cedentibus contraria valentiora prioribus requiruntur, fcilicet quæ majorem vim habeant obftructa aperiendi, ut propterea, quod omnia valenter aperientia calida fint, 


\section{I6 PROSPERIALPINI}

ad calida fit deveniendum : ubi vero caufæ febrium putridarum haud admodum curatu funt difficiles, fufficient ea, quæ tantum funt morbo contraria, quæ fimul aperiendi vim habeant, \& ubi caufre non facile cedunt, morbo fimilibus, quoad caliditatem, \& caufis contrariis, quoad aperiendi facultatem uti debemus. At in febribus, quæ caufis conjunctis vacant, ut funt hecticæ ab ephemeris, vel putridis febribus genitæ, medici folis morbo contrariis uti debent: ambobus vero tum caufa tum morbo curationem indicantibus, nos remedia fequimur, quæ ambobus funt oppofita. hineque cichoreacea omnibus putridis febribus convenientia auxilia judicantur, quia tum febri, ea qua prædita funt frigiditate, refiftunt, tum caufæ, ob eam, quam adepta funt obftructa, aperiendi, facultatem. Si vero morbus mitis, ac non vehemens ingruat, iis quæ caufæ contraria funt magis quàm morbo uti oportet, quemadmodum in morbo, tum vehemente, tum magno, medicamenta debent magis morbo effe contraria. Hincque Galenus prudentiffime docuit in lib. meth. med. fi multa fimul curationem indicent, eimedicos attendere oportere, quod magis urget, aliis tamen non neglectis. Egyptii vero fecus in curandis morbis agunt, femper à morbo fumpta curationis indicatione, utuntur iis, quæ morbo contraria effe arbitrantur, morbi caufis omnino neglectis, proindeque in omnibus febribus nullo difcrimine frequentifimum habent medicamentorum valde refrigerantium ufum, quòd ipfa morbo validiffime obfiftere arbitrentur. In putridifque decipiuntur, peffimeque, ut arbitror, fe gerunt, valde frigidis utentes, quia frigiditate intenfà obftructa augentur, \& cruditas humorum crudorum fovetur. Guiland. Mirari nos non decet, fi ii medici etiam ea communitate, quæ eft, contrariorum contraria effe remedi?, peffime, ac vitiofenunc medendo utantur, cum ferè omnia alia, quæ à prifcis doctiffımis illis meticis in ipforum memoria relicta fuere, corruptè ac peffimè nunc etiam fequantur. Neque etiam mirum ipfos ad frigidorum ufum ita præcipites ferri, quoniam omnes ob cœli caliditatem fibi ipfis in animam induxerunt, à calidis effe cavendum, ne calida corpora calidorum ufu obledantur; quod 
$\&$ apud Genuenfes quoque obfervari licet, ii enim biliofa corpora nacti, ita calidorum ufum effugiunt, ut ad contraria potius, ad frigida fcilicet, non fecus quàm \&Egyptii deflectant. fecus veró apud Germanos, Boëmos, Polonos, Anglos, Flan-dros, Gallos, atque alios fub frigido cælo viventes, fieri confuevit; Namque illi tantum à frigidis metuentes, in calidorum ufum nimium labuntur. Aromatum etenim ufu, atque genero. fiffimorum vinorum, calidorumque non minus medicanentorum fibi ipfis hepar, fanguinemque comburunt. AlpiN. Verum profectò dicis, fed de his fatis, nunc ad alia tranfeundum.

\section{A p. V.}

Que prefciri debeant, priufquim ad particularem de medicma EEgytiorum narrationem accedatur.

\section{G U I L A N D I N U S.}

Uenam ifthæc erunt, quæ nunc explicanda ftatuifti, aliquane præcipua \& propria illorum præfidia, quibus ad curandos morbos utuntur? Alpin. Nondum eò pervenimus, ut poffimus de iis nunc agere; etenim multa fuperfunt audienda, priufquam ad illorum narrationem deveniatur. GuIland. Quænam igitur ifthæc, inquam, exiftunt? Alpin. Multa, quippe Rgypti fitus, illius temperies cœli, anni tempora, ipforumque naturæ, \& aëris mutationes ex Nili fluminis incremento, Agyptiorumque corporum habitus, temperamentaque, victus, morbi ibi nafcentes, ipforumque caufa, atque alia, quæ ad medicinam illorum rectè nofcendam facere videntur. Guiland. Quamobrem hæc ? Alpin. Quoniam cum corum, quibus ad curandos humani corporis affectus illiufce regivnis homines utuntur, non fimplicem hiftoriam tibi fim proditurus, fed urià cum ea rerum illarum laudem atque vitium, ut ex horum lectione medicinæ fudiofi is, quæ illi in medicina facienda maxime fequuntur, tuto, \& ex artis præceptis uti fciant, $\&$ ad morborum inftituendam curationem, ab illis qua vitio,

$$
\text { C fe, }
$$


fe, minimeque ex artis ratione funt apud ipfos ufitata præfidia cavere queant. Guiland. Laudo hunc tuum loquendi ordinem, quando præter corum, quibus $\mathbb{E}$ gyptii utuntur in medendo, utilem notitiam, ifta, quæ prius exponenda proponis, non minorem, cognita, nobis afferent, \& voluptatem, \& utilitatem. Perge itaque quod vis enarrare, nulla interpofita mo$\mathrm{ra}$, ne hæc dies fine longa linea nobis abeat. quando multa fuperfunt dicenda, quibus hujus diei reliquum pofe lufficere vix credo.

\section{A P VI.}

De CEgypti fitu atque illius aëris temperie.

\section{A L P I N U S.}

A G Y P I r regio pofita eft inter Ethiopiam, Arabiam, \& Prarmaricam, quæ nunc Barbaria dicitur, atque mare mediterraneum, habet enim à meridie Ǎthiopiam, à Septentrione mare mediterraneum, veluti ab ortu Arabiam, rubrumque mare fpectat atque ab occafu Marmaricám. Cayrus, olim Babylon, vel Babulis, nunc primaria \&Egypti civitas, ab æquatore triginta gradibus diftat, \& longitudo ejus eft, graduum circiter fexaginta. Sex tancum gradibus cum dimidio hane civitatem ad tropicum Cancri accedere Ptolemæus teftatur; maximaque dies ibi eft quatuordecim horarum, \& minima decem. Civitas hæc ad radices montium Arabix Petrex ab Oriente pofita eft, Septentrionalibus omnibus ventis expofita, nullo monte $a b$ ea maris parte contecta, tota meridionalis pars fabulofa eft. à quibus omnibus ejus aër ad frigidum \& calidum alteratur. $\mathrm{Ab}$ Orientalibus vero atque Occidentalibus paruam fufcipit ille aër alterationem. Cum itaque hæc regio prope tropicum fit, mirum non eft, fi Sole multum calefiat, præfertimque æittate, quo tempore Sol radiis ibi terram rectius ferit, copiamque radiorum vel luminis, nnajorem ejus terræ accolis demittit. Quem, calorem ibi multum effe, ac vehementem eos populos quando: 
que perpeti, oftendunt multa ab ipfis refrigerationis caufâ inventa, atque ufitata. Fos enim in primis terrena habitare $æ$ dium loca apud omnes ob calorem noxium manifeftum eft, non minufque in quaque domo frigidarum aquarum in medio æalum pofiti fontes, eos frigiditate: oblectari, fignificant. His etenim aquarum fontibus per totam æefatem ipfum domorum aërem refrigerant, prope etiam illos omnes ferè dormiunt. Amplius, civitas hæe altiffimis eft fabricata ædibus, quæ fupra vias ufque adeo latiffimis expanduntur teguméntis, ut viarum totum pene colum ex fuperiori parte occupent, obftruantque, ne Sol (quando omnibus horis umbræ vias detinent, atque obtegunt') noxam inferat viatoribus. Vaftifimis etiam fiftulis, quæ maximis tubis funt fimiles, intra omnes domos pofitis ad frigidum excipiendum aërem utuntur. Hæ ex mediis domibus meatu decem cubitorum latitudinis ferè exurgunt, per mediumque rectifime furfum feruntur in aërem, perviæque multo latiori ore inftar campanæ expanfo, ad fumma veftigia definunt atque pertingunt, quo ore Septentrionem verfus aperto, frigidam auram fpirantem excipiunt, infernifque ipfum ædium terrenis locis demittunt. \& hoc pacto cujufque ædis inferna, terrenaque loca refrigerantur. Victus frigidorum ciborum, potuumque apud omnes nimium obfervatus eam regionem immodico aëris calore expofitam proculdubio confirmat. GurLAND. Iftæc ceriè omnia fumme calidam aëris illius temperiem coarguunt, nihilominus calorem æftatis tempore ibi talem effe audivi, quem facile quifque perferre poffit. Temperari enim calores illiufce temporis à Nïli fluminis incremento per id temporis celebrato, atque ab affidua Septentrionalium ventorum fpiratione, à multis proditum eft. AlPIN. Ni Deus his duabus caufis ambientis illius aëris æiftivos calores minuiffet, haudquaquam fieri poffet, ut animalia ibi viverent. Tanta eff Dei Optimi Maximi providentia, ut in locis fub coelo calidimmo vi radiorum folis inflammatis, fit aliquid, quo refrigerentur, ficut in frigidifimis regionibus omni ferè calore deftitutis, ut aliquid habeatur, quo ea loca incalefcant. Eaque caufa in locis Septentrionalibus, fub frigidiffimo cœlo pretiofifima ac $\mathrm{C}_{2}$ 
copiofifimæ pelles reperiuntur, \& lignorum comburendorum copia, quibus fe à velıementiffimis illis frigoribus homines deffendant. A ër itaque æftate proximis radiis folaribus rectius terram ferientibus valde accenfus, ab aucta Nili fluminis aqua, Septentrionaliumque ventorum fpiratione affidua obtunditur, ac multum moderatur; ex prædominio vero ipfe eft calidus \& ficcus, inæqualis, valdeque inconitans, fubftantia tenuifimus, maximeque in locis à mari remotis, ut Cayrum, aliæque civitates \& loca fupra ripas Nili pofita. Hic aër hyeme aliquando infigniter frigidus apparet, \& aliquando calidiflimus, ob ficcitatem tmmodicam aëris (ibi etenim rarifime pluit.) quæ ut rerum nature non ignari fciunt, utramque activarum qualitatum acuit, veluti hre ab humiditate hebetantur. Qliam ob caufam ob tenuitaten fubftantix, hyemalis aër frigidior, quàm reuera fit; ab his populis experitur, quoniam is ob partium etiam tenuitatem cornora penitiffime penetrat; frigidamque qualitatem introducit, ledenfque fenfibiles partes, majoris eft caufa fenfus, quám fit ipfa vis frigoris, maximeque ex omnibus corporis partibus caput ab aëris ejus loci frigiditate oblæditur, multoque magis, quòd antea calido aëre calefactum, meatus valde apcrtos habuerit, per quos facilius frigidum aërem fufcipit, a quo poftea facile offenditur. Hincque nullum eft genus morbi ex capitis ditillatione obortum, quod illi populi non patiantur. Dominatur autern aër fumme calidus, ipfius cœeli, ut dictum eft, ratione: quod hee civitas à tropico cancri tantum. fux grafibus diftet. Qua brevi intercapedine, dum Sol ad illum acceclit tropicum, \& illorum Zenith fit propinquior, aër ille valde incalefcit, \& nifi Etefie venti tunc à Septentrione fpirarent, vehementiffimus \& qui vix à noftris perferri poffet, caloris æitus fentiretur. Hyeme etiam nocturnus aër admodum frigidus obfervatur, qui ab orto Sole paulo poft parum incalefcit, in meridicque plurimum; adveniente vero nocte rurfum in frigidum permutatur, ita, ut aër ille valde inxqualis fit dicendus, ab ipfiufque illa inæqualitate plurimi morbi originem ducunt, atque generantur, qui eo temporis per urbem vagantur. Gulland. Cupio etiam ejufdem aëris temperiem pro an- 
ni temporum ratione à te explicari. Quam ob caufam te in primis de anni temporibus, quæ in ufu apud eam nationem exiftunt, atque de ipforum temperie, loqui optimum fore arbitros. ALPIN. Libenter de his nunc fermonem inftituam.

\section{A p. VII.}

\section{De anni temporibus ajud C. Egyptios uflatitis, atque de upjorum teinperie.}

\section{A L P I N U S.}

$\mathrm{D}$ I VIDAM annum apud IEgyptios ufitatum ac obfervatum in quatuor, ut nofri etiam faciunt, partes, fed fecus quàm illi; ac primùn à Vere incipiam. Quod anni tempus ibi duobus menfibus temperatum, obfervatur, Januario quippe \& Februario. Incipitque Orione \& Canicula orientibus, \& definit ad occafum Arcturi, quo tempore æftas incipit, \& definit ufque ad nocturnum Trianguli ortum: Quæ quidem $æ-$ ftas duplex fingulis annis obfervatur, quarum prima eft inæqualiffima ac fummè inconftans vehementiffimo cum caloris æeftu, quæ maxime corpora offendit, præfertimque advenarum ejufce coli qualitati minime affueta: id igitur anni tempus, ut nuper. rime etiam dictum eft, principium facit. Areturo occidente, feilicet in initio menfis Martii, protenditurque ferè ufque ad tropicum cancri, tribus, fcilicet comprehenfum menfibus, quippe Martio, Aprili, Majo. Altera æeftas, quam fecundam partem $x$ ftatis appellamus, priori ftatim fuccedit, nam ipfa incipit Sole fignum cancri ingrediente, terminumque habet prope finem menfis Augufti. Hæcque æftas priori æqualior, conftantior, minufque æeftuofa, atque minus fentitur noxia corporibus. Autumnus habet alios duos menfes, fcilicet Septembrem atque Octobrem. Hyems vero orientibus Pleiadibus, fcilicet incipiente menfe Novembri, incipit, atque ad Januarium menfem ufque protenditur, Hoc itaque modo annum $\mathbb{E g y -}$ ptiorum dividi oportere judico, ut quatuor diverfis aëris natu- 
ris quatuor anni tempora rectè refpondeant. Ver Januario, atque Februario ibi obfervari, non eft mirum, cum ejufce temporis temperamentum mediocre ac temperatum in aëre percipiatur. Id ipfumque etiam tempus veris, inquam, indicant arbores, qua per eos menfes ibi germinant, \& frondefcere incipiunt, terraque illa virentibus herbis, ftirpibus, floribufque amoniffima redditur. His autem exactis menfibus priman $æ$ ftatem, vel primam æftatis partem animantibus valde proejus inconftantia, multumque inæquali caloris, \& frigoris ftatu, noxiam fentiunt. Atque hæc prima æltatis pars inconftanter menfibus Martio, Aprili, Majo, obfervatur. Guiland. A quibufnam caufis hæc prima æftatis pars inconfantifima, $x$. ftuofifima, atque inæqualiffima fit? Memini etenim ego, dum Cayri olim moram facerem, iis utique tribus menfibus me ventos calidiffimos, moleftiffimofque fentiiffe, cum arenarum inflammatarum magna copia, qua aër ita obfcurabatur, ut Sol neutiquam videri poffet. Illoque etiam tempore quamplurimos vagafle epidemicos, atque lethales morbos, maximeque oculorum lippitudines, quas Græci Ophtalmias appellant. Quam ob caufam arbitror hujus prioris æftatis partis caufam effe ventos illos fumme calidos, atque ardentes, à Meridie, locifque arenofis inflammatis perflantes; Hofque ventos Campfim appellabant, quafi dicerent ventos diebus quinquaginta perflantes; id vero tuis proximis verbis adverfatur, qui dixeris iftam æftatis partem non tantum diebus iis, fed tribus perpetuis menfibus durare. Alpin. Euri Auftrique venti, ut tu rectè dixifti, à meridie loca arenofa, fummoque calore inflammata tranfeuntes atque in Fy gyptum firantes, tantum caloris xftus, pulverumque $\&$ inflammatarum arenarum evehunt, ut ignitas flammas, necnon pulveribus obfcuriffimas, nubes eo afportaffe videantur. Pulvis ille, vel arena copiofa ventis tum afportata, tum ex folo Agypti ventis arrepta, atque per aërem agitata, non minus quàm aër fuo calore, corpora lædit, atque offendit, oculofque maxime, quos mordet \& inflammat: Hincque epidemias plurimas \& ophtalmias, qux tunc temporis per illam urbem vagantur, originem habere dicerem. Hi 
renti interrupte ac inconftanter, quandoque tribus, \& quandóque quinque, \& aliquando etiam feptem atque novem diebus (quamquam rarifimo contingat) fpirant. Ipfofque Charonios vocare poffumus, quod quafi à Charonte procedant, fenper plurimos lethales morbos iis populis afportantes. Quo tempore multas peftiferas febres, atque phrenicides, homines non diebus, fed horis paucis perdentes, fævifimafque quamplurimas ophtalmias ibi vagari obfervavi. Corpora omnia ita ab his. languida redduntur, ut ferè cibos abhorrere videantur, inextinguibilique fiti continue ardeant. Pro qua fiti arcenda fillmen Nilum eis Deus largitus eft, cujus aqua præjucundifima omnia refrigerantur, atque humectantur. Advenæ noftri iis perfantibus ventis ad fubterranea loca confugiunt, in quibus morantur, quoufque ille ventorum ardor refederit, atque ceflaverit. Conjunxit hæc incommoda Deus Optimus, cum aliis quibufdam bonis, nam ubi calidiffimi ii venti conticuère, ftatim à Septentrione flare alii incipiunt, qui fubitaneum inflammatis, atque laxatis corporibus folatium preftant. Si enim illi. diu perfeverarent, nemo in ea regione vivere poffet. Quod autem ad primam eftatis partem attinet, quam trium menfum effe affirmarim, \& ad ventos, quos $\mathbb{E}$ gyptii vocent Camplim, quod nomen numerum explicat quinquagenarium, fito circa illius quinquagenarii numeri explicationem multos multa locutos fuifle. Aliqui etenim illos ventos Campfim appellant, quoniam ipfi interruptè diebus quinquaginta fpirare foleant. Atque aliqui eo nomine quinquaginta eos nuncupant, quod illorum ventorum furor ac æftuofa molenia fpacio dierum quinquaginta finiatur. Et alii Camplim ob id cos dicendos affrmant, quod utplurimùm à Pafchate Refurrectionis ufque ad Pafcha Afcenfionis ipfi flare obferventur, quod tempus eft dierum quinquaginta. Quod tamen falfum dognefcitur, quando ego obfervavi fæpius ante Pafcha etiam Refurrectionis illorum ventorum furorem. Alii, \& verius mea quidem fententia, dicunt, hos ventos Campfim vocatos fuiffe ex morte Campfi multarum copiarum ducis, quem immodica arenarum copia, quæ ventis illuc afportata fuerat, cum toto exercitu in Africæ 


\section{PROS PER I ALP I N I}

deferto fuffocauerat, ut in vita Alexandri Magni legitur. Hxc aftatis pars eft corporibus valde noxia, quoniam per id temporis calor interim continuò, \& interim frigus in aëre percipitur. In hoc etiam anni tempore per urbem vagatur ille lethalifímus morbus, quem Demelmuia appellant, qui paucis horis homines perdit. Altera æftatis pars hanc fequitur æqualis \& minus calida: effet tamen \& ipfa calidiffima, nifi Septentrionales venti continuè tunc fpirarent, atçue nifi Nili fluminis fieret incrementum, quibus aëris æftuofa caliditas paululum contemperatur. Hac æftatis parte, quæ à nobis fecunda æetas vocatur, aër eft multum \& ipfe calidus, fed æqualis conftanfque à principio ad finem ufque, non fubito fed paulatim fenfimque caloris adferens mutationes; qui quò Septembri menfi vicinior, eò temperatior redditur. Ideo hoc anni tempus morbis caret, \& falubre eft. Omnes agricolæ tunc vitam otiofam ducunt, quoniam terra ufque ad peraudi fluminis diminutionem culcui eft inepta, inundatione aquæ fupra ipfam non finiente. Atque tunc fpectacula, ludique, augefcente flumine ab his celebrantur. Autumnus Septembri, Octobrique menfibus celebratur, in cujus fine ceffante fluminis inundatione, triticum ferunt, quod Martio menfe maturum ab ipfis evellitur, atque colligitur. Hujus temporis aër eft temperatiffimus, æqualis, morbis carens. Aliis fequentibus duobus menfibus frigidior fit, atque hyemalis. Raro decidunt pluvix; quod fi contingat, tanquam ros eft: Cayri, inquam, quandoquidem Alexandriæ Pelufiique, \& in omnibus locis mari adjacentibus pluit largiffime, \& fape. Novembrique facilius, quam Decembri, id accidit, quòd eo menfe aër fit frigidior: rariffime glacies, neque nix, neque grando ibi vifitur, cum aër careat tanta frigiditate qua hæc gigni queant. Hacque eft temperies aëris locorum, qui à mari longè diftant, per omnia anni tempora obfervata, loca mari proxima aëre utuntur minus calido, \& minus ficco, ibique largiffime, ut dictum eft, plucre folet. Guiland. Tuo de anni in ea regione partibus diligenti habito fermone mirum in modun fum delectatus, fed quoniam dixifti, Sole tropicum cancri ingrediente, aërem ibi ex immoderate calido atque æftuo- 
fo, ad minus calidum ob ventos à Septentrione fpirantes, atque ob incrementum Nili fluminis mutari, id illius cœli naturæ videtur maxime contrarium, quando quis crederet, in calida regione Sole terram ad angulos rectos feriente, aërem à magis calido ad minus calidum mutari poffe. Ideo cupio te de hac eademque aëris mutatione rurfum clarius loqui. A LPIN. Tibi, ut foleo, femper etiam hac eadem in re fatisfaciam.

\section{C ^ r. VIII.}

De aëris mutatione ex ventorum Septentrionalium fpiratione, atque ex augmento fluminis Nili.

\section{A L P I N U S.}

JENTI, quibus ad caloren \& frigus aër Ægypti, præfertimque Cayri permutatur, funt Meridionales atque Septentrionales. Ab his etenim, ut nuper etiam dictum eft, ea loca maxime incalefcunt, veluti à Septentrionalibus refrigerantur. His omnibus tota illa regio eft expofita, fed magis Septentrionalibus, quibus Ægyptus libere ventilatur, a Meridionalibus vero, cum inter ipfum \& meridiem montes quamplurimi fint, præfertimque Lybiæ atque Ethiopiæ, non ita liberè perflatur, rarò etenim ipfi perflant, atque non nifi, ut fuperius dictum eft, in prima æftatis parte. Perflant vero à Septentrione fæpiffimè in anno, fed præcipuè tota æftate. Summa enim Dei fapientia AEyptum coli caufa valde calidum Septentrionalibus magis, quamaliis expofitum effe voluit, ut ipforum refrigeratione aër illiufce regionis fummè calidus multum refrigeraretur. Ab Orientalibus autem parum vel nihil illorum locorum aër alteratur, quoniam \& rariffimi, \& pauciffimi exiftunt, quod tota ea regio montibus ab Oriente fuppofita fit, atque ab his contecta. Et ex his, qui ab occafu fpirant, non multum aër alteratur, cum hi temperati fint. Septentrionales itaque venti, qui menfe Junio flare incipiunt, mirum in modum aërem refrigerant, quoniam longifimos ma- 
ris tractus, priufquam illuc accedant, pertranfeunt, in tam longoque itinere ipfi ab aqua maris refrigerantur. Mirari itaque non debemus, fi hi venti in fecunda æeftate continue frigus per iter fufceptum fpirantes, aërem illorum refrigerant. Quam aëris ad frigus alterationem fovet etian fluminis Nili incrementum, à peraucta fluminis aqua refrigerato five moderato caloris æftu. GUILAND. Quæfo fluminis hujus ortum, incrementum, ejufque caufas, ibi ab iis populis auditas, mihi etiam narrare non pigeat. His etenim probè cognitis, quo pacto Egyptiis refrigerationem conciliet, facile dignofcemus. ALPIN. Qaumquam ego certò fciam tibi viro doctiffimo hujufce fluminis incrementum, \& ejus caufam ex multorum fcriptis effe planè cognitam, nihilominus, cum iftud etiam ex me narrari volueris, operam dabo, ut tibi morem geram. Hoc flumen, omnium, ut audito, longitudine maximum à divina fapientia in arenofa fqualidiorique Africa factum effe creditur, ut illa mundi pars foret habitabilis. Quando fummum admirandumque omnibus videatur miraculum, terram Fsypti, Sayeth, aliarumque multarum Africæ regionum loca efle fœcundifima ob folam hujufce fluminis inundationem, nihil enim terræ, arena excepta, ea loca habent. Deus flumen illud iis populis largitus eft, ut ea arenofa loca pingui limo fluminis aquâ afportato, foecundarentur, atque irrigarentur. Qui accuratius ejus ortum indagarunt, atque noverunt, affirmant nafci proxime brumali tropico ad radices quorundam altifimorum montium, lacum vaftiffimum fexcentûm mille paffuum circuitus, facientes, à quo flumen Gion ab his appellatum directè Septentrionem verfus procedit, tandemque in mare mediterraneum defcendit, ipfunque ingreditur, \& ab ipfo propè rquinoctium magnus rivus procedit, per mediumque totius Africæ tranfit ab Ortu ad Occafum procedens. Quo flumine Nigro à noftris vocato, hi populi perinde ac EEyptii utuntur. Nilus vero, ut adipfum nunc redeam, terram Aigypti arenofam, ac omnino fterilem limo pinguiffimo aquæ larga inundatione obtegit, focundiffimamque ac cultui aptifimam reddit. Deufque etiam, quód eorum locorum corpora fumme calida, 
\& fqualida, præmultoque coli calore admodum fitientia effent, illis hoc flumen largitus eft: cujus aquâ omnium proufit humano optimâ epotâ, corpora ipforum ab his aëris ardoribus defenderentur. Gayri vero, ut hujufce fluminis augmentum nunc dicam, fingulis annis conftantiffime ( cujus veram caufam me ignorare fateor.) menfe Junio, die decima feptima, Oriente Sole, flumen illud augeri incipit, \& nunquam obfervatum eft, ejufdem augmenti principium ab ea die, \& hora confueta deflexiffe; quod certè magnum naturæ arcanum omnibus videtur. Mox magis \& magis perauctum, fingulis aliquando diebus ad octo, vel decem, vel ad pauciorum digitorum altitudinem crefcit : ad fummum quatuor \& viginti cubitis. Aliquando etiam, quod tamen rarifime obfervatum eft, ufque fex \& vio ginti cubitorum altitudine perauctum fuiffe, illorum memoria conftat. Ipfumque decem tantum \& octo cubitis auctum fat eft pro agrorum inundatione facienda. Terminatur vero totum augmentum menfe Augufto, \& plerumque ufque ad medium Septembrem, vel ipfum augmentum ufque ad iftud tempus vigere obfervatur, loquor de aqua extra fluminis ripas aucta, quando intra ripas flumen femper decrefcat ufque ad Majum menfem; \& ex hoc tempore inundatio decrefcere incipit; continuat hoc aquæ decrementum ufque ad medium Octobrem, quo tempore omnis aquæ tumor inundatioque abforpta eft, terræque ob id agricolæ femina committere folent. Decrefcit autem intra ripas Nilus paulatim ac paulatim ad Majum ufque menfem, in quo menfe ejus aqua pauciffima, \& ferè ftagnans cernitur. De hujus aquæ utilitate, atque de magna voluptate pro his mitigandis caloribus, poftea loquemur. Verum à quibus caufis arbitreris tu hujufce fluminis augmentum iftud pendere? GUILAND. Ab Etefiis eo tempore flantibus ventis, ut dicebat Thaletes philofophus, non arbitror quando nihil in eo flumine cernatur, quod prohibeat, quin ipfum omnem aquam evomet in mare. Neque minus puto, ut Ephorus affirmabat, folum Egyptium; quod inftar fpongiæ æftate expreffum, aquam hyeme fufceptam exudando, poffit flumen iftud augere: Minufque etiam, ut Euripides, atque Anaxago- 
ras dixêre, à liquatis Æethiopiæ nivibus id fieri poffe, quod Euripides his verbis expreffit, dicens:

Aqua pulchra deferens.

Fluminis Nili, que ex terra defuit,

Nigrorum bominum, Eo tunc tumefacit undas,

Quum HEtbiopice nives liquantur.

Nives intra tropicos fieri nequaquam exiftimo, cum nufquam in $\mathbb{E}$ gypto, coeli longè minus calidi A Ehiopico, nives, aut pruinæ præ aëris caliditate vifæ fint. Equidem multo veriorem judico fententiam Democriti Abderitæ, Agatarchidis, Diodori Siculi, Plinii atque Hieronymi Fracaftorii, qui dixêre hujufce fluminis augmentum pluviis in Ethiopia cadentibus acceptum referri, quæ ibi Sole cancri fignum ingrediente fiunt largiffimæ ac copiofiffimæ quadraginta ufque diebus perfeverantes. Quam fententiam Fracaftorius his verfibus memoriæ prodidit in libro de vita Jofeph, dicens.

Nam Septem annos qui deinde jequentur.

Infelix fteriles, durofque \&igyptus babebit;

Ip Se intra ripas demilfo fumine Nilus

Curret iners fupraque caput, limumque feracem

Non tollet: Sicca arebunt arva omnia, ficca

Solftitia, Eं nulli defcendent montibus amnes;

Confueti pluviarum amnes fub fidere cancri

Eithiopum populis, nec byems reftiva redibit.

Quod veriffimum effe illius regionis accolæ affirmant, cum fæpe audiant ex multis ab Ethiopiæ variis locis Cayrum profectis diebus quadraginta fingulis annis perpetuoque tempore ibi largiffimos imbres, atque continuas è colo decidere, Cayrim toto ferè augmenti fluminis tempore Etefiæ, ut jam dictum eft, perflantes fingulis fere diebus ab orto Sole, ufque admeridiem multas nubes nigras, craffas, pluviofas in altifimos ufque Lybiæ, Ethiopiæque montes propellunt, atque afportant, in quibus montibus hæ concrefcentes in pluvias vertuntur, quæ $\mathrm{ab}$ his in Nilum cadentes, funt caufæ ipfus augmenti. Obfervatur quotidie Cayri dum flumen hoc augetur, qua die multæe nubes fupra Egyptum verfùs Meridiem à Septentrionalibus 
iis ventis afportatæ tranfierint, multum flumen augeri, atque ex contrario clara apparente die, nullifque nubibus in eo coelo apparentibus, parum crefcere. Et hæc eos nunquam fallitobfervatio. ego igitur fluminis hujus augmentum ab Ethiopicis largis pluviis fieri cum illis doctiffimis viris una exiftimo. ALpIN. Neque immerito, in ipforum fententia te effe, opinor, quando ex ea nubium à te nunc narrata experientia, multis obfervationibus facta, ego etiam animadverterim veriffimum effe affiduas, largilfmafque ibi decidere pluvias, atque imbres, à. quibus flumen crefcit. Imbres nuper dictos in montibus Aithiopiæ fieri à quamplurimis mercatoribus, qui loca Africæ propé Nilum pofita peragrarunt, fæpiffime audivi. Addo majorem pluviarum copiam in montibus illis, à quorum radicibus id flumen nafci ex multorum mente, dictum eft, fieri oportere, quoniam ea loca per id temporis frigidiora exiftunt, Sole $a b$ ipfis quamplurimum elongato, atque excelfos montes habent, quorum juga aërem fervare admodum frigidum credendum eft, quia etiam flumen, quod Nigrum appellant, non falfo à multis creditum effe Nili rivum, aque ut Nilus crefcere obfervetur. 'Pluviæ itaque augmenti fluminis hujus caufæ creduntur. Qulod etfi veriffimum effe arbitror, tamen duo de flumine ifto tibi nunc dicenda effe judico, quorum caufas naturalibus principiis poffe cognofci, nullo modo fieri poffe arbitror. Primumque eft, flumen iftud in Fgypto conftantiffime perpetuo tempore fingulis annis menfe Junio dieque decima feptima, incipere augeri. Secundum eft, obfervatio futuri hujufce incrementi: qua ad quotos cubitus flumen fit perventurum, prænofcunt, nunquamque à fus judicio aberrant, neque falluntur. GurLAND. Quomodo hoc verum effe, \& quo pacto ipfi augmenti hujus magnitudinem præfcire queunt? AlpiN. Nilum incipere augeri perpetuo tempore menfe J unio, dieque feptima decma, omnibus ibi habitantibus notifimum eft, fed qua caufa id fiat, ego prorfus ignoro. Menfe itaque Junio ante folis ad tropicum acceffum, multis diebus Egyptii terram illiufce fluminis toto integro anno adfervatam, \& ficcatam, arefactamque accipiunt, quam lance expendunt,' faciuntque ut pcnderum 
numerus, addendo ac fubtrahendo, dragmis fedulo refpondeat, ut exempli gratia, terra fit trium dragmarum pondere, quam in loco ficco, undique conclufo reponunt, \& confervant, quotidieque librantes, ipfam obfervant nihil auctam, nihilque imminutam pondere effe ufque ad diem decimam feptimam menfis Junii, in qua die auctam ipfo pondere inveniunt, ex cujus qondere multium vel parum aucto, multum vel parum flumen illud auctum iri prænofcunt, à diligentique peraucti illiufce ponderis notitia, quotis etiam cubitibus ipfum fit augendum certò præf́ciunt. Hujus obfervationis, atque veritatis teftes erunt Paulus Marianus Venetus illo tempore pro Gallorum Rege Conful clarifimus, \& ex focietate Jefu Rever. Baptifia Elianus, \& Francifcus Saxus, \& Francif́cus Bonus, Joannefque Varotus Anglus nobiliffimus, qui in multis obfervationibus interfuerunt. Ex qua vero caufa hæc terra pondere augeatur, non eft nunc dicendi locus. Guiland. Hæc certè duo funt multâ admiratione digna, de quibus nifi à fermone de medicina 2 Egyptiorum profequendo, atque abfolvendo nunc aberraremus, quando hoc præcipuum fit nobis inftitutum, ac propofitum, cuperem multo copiofiora, ac altiora loqui. quæ quidem in commodiorem occafionem confideranda remittemus. Sed tempus eft, ut ad alia tranfeamus, proinde optimum fore exiftimo, ut tu nunc de Egyptiorum corporum temperamentis, atque habitu loquaris, poftquam ambientis illiufce aëris temperamentum probè narrafti ; atque omnes, quibus folet mutari, caufas rectè es contemplatus. Expecto itaque ut de his fermonem inftituas.

\section{A p. IX.}

De Egyptiorum corporum temperaturis, atque babita.

\section{A L P I N U S.}

AR operam, ut Egyptiorum corporum temperiem indagemus finitam, five terminatam, nihil fanèaliud erit, quàm 
qnàm tempus fruftra confumere: quod fi tu mihi indicaveris Cayri tantum accolarum temperiem dicendam, non fecus quàm Xanthus ab $\mathbb{E}$ fopo perdoctus, illis, quibus totum mare fe potaturum promiferat, dixerat, ipfum prius à fluminibus fegregari oportere, refponderem itidem, ut Rgyptii a cunctis aliis populis fegregarentur, quod fanè difficilimum eft, quando Cayri habitatores fint AEgyptii, Arabes, Hithiopes, Abifini, Indi, Perfæ, Afyrii, Damafceni, Græci, Armeni, Turcæ, Tartari, Pruffi, Ungari, Sclavi, Mauritani, oinniumque aliarum feré nationum. Semper hæc civitas fuit. publicum ac famofifimum emporium totius orbis terrarum. Hincque apparet difficultas conftituendi, atque defignandi unum aliquod temperamentum, hujufce urbis accolis omnibus commune. G U ILAND. Videtur tamen neceffarium, omnes, qui eam urbein per multos annos habitarunt, ad aliquod reduci temperamentum, eodem tum colo, tum victu ufi, quæ procul dubio nativum temperamentum mutare folent. Nam colum, cibus potus, \& aliæ confervatrices caufæ; corpora neceffariò, (ut dicebat Gal. in lib. artis med.) alterant, atque permutant. Audio vero ibi triplex genus hominum reperiri, Urbanos, fcilicet urbem habitantes, Arabes, qui degunt fub tentoriis, atque demum Agricolas Rufticofve villarum habitatores. Non videtur igitur tam difficile eis temperamentum unum confritui, atque affignari pofle. Alpin. Illorum corpora, quod pofterius etiam, atque ex me accuratius audies, ubi rurfum ipforum, tum temperamenta, tum habitus fumpta ex miffione fanguinis occafione, cum id apud ipfos valde frequens fit, confiderabo, pleraque fanguinea exiftunt. Certò enim affirmare poffumus ipfa coli ratione effe valde calida \& ficca ftatuenda, cum fub calidiffimo \& ficco cœlo habitent, omnium. que maxime rufticorum, \& fecundo loco, Arabum demumque Urbanorum: Quorum caliditatem \& ficcitatem minuunt, \& permutant ufus frequens, \& affiduus potus aquæ, ciborumque refrigerandi facultatem habentium, atque immodicæ veneris. Quæ omnia ita poffunt pro refrigerandis corporibus, ut calidiffima corpora fumme frigida reddere queant. Idque in meipfum 


\section{PROSPERI ALPIN I}

ipfum facto periculo terum effe cognovi. Nufquam gentium memini me vidiffe in tanto numero ita perpingues homines, quales Cayri obfervantur. Ex viris plurimos ufque adeo pingues infpexi, ut mammas haberent longè mulierum maximis mammis majores, craffiores, ac pinguiores. Balneis etiam ibi ex dulci aqua paratis, quibus affiduo utuntur, corpora illorum maxime refrigerantur. Ex his itaque colligo, pleraque illorum corpora fanguineo, vel pituitofo temperamento conftare. profertimque mulierum atque Eunuchorum. Ex corporis paribus præcipuis hepar calidum \& humidum plerique obtinent, atque temperatum, quare mulco fanguine abundant. Stomachum vero frigidum, multaque pituita refertum. atque hoc tum ex cœlo, tum ex victu, nam ab ambiente fumme calido quemadmodum hepar peradmodum incalefcit, ita ftomachus frigefit. dicebat enim non immerito Divinus Hippoc. byeme ventres efAph. xv. Se calidiffinos, E aftate frigidiffimos. Quare ex aëris multa S. I. caliditate, naturali corporis calore, tum extra ad extimascorporis partes evocato, tum exoluto, ftomachus frigidior reddi. tur. ex ufu vero victus refrigerantis quis dubitat corpora ad frigidum mutari? Habitus illorum eft, vel moderate carnofus \& pinguis, vel valde pinguis. loquor de urbanis, quando Arabes habeant corpora graciliora, atque minus pinguia; Omniumque maxime rufticorum, quarum corpora tum gracillima, hirfuta, fqualida, \& ferè combufta à Sole confpiciuntur. GusLAND. Ex colo, cujus nunc qualitatem perfectè ex te percepi, poffum illorum corporum temperamenta, qualia tu conftituifti, confirmare, fed ex victu, quem hactenus non intellexi, nequaquam. Proinde cupio cæteris in aliam occafionem rejectis, ut tu victum illorum mihi enares, quo non folum ea, qux de ipforum corporum temperamentis tu in medium attuli1ti, laudare poffim, fed multo plus etiam quibus morbis ob hane rationem ipfa fint obnoxia, dignofeam. Alpin. Verum dicis: At non minus ex cognito ipforum victu, longævæ illiufce gentis rationem fpeculari poteris, quando pracipuam illorum longavitatis caufam in ipforum viverdi modo confiftere, ego exiftincm. Victum itaque, quem ipf: affectant, tibi detegere operam nunc dabo. 


\section{A 8. X.}

\section{Quali victu CEgypti habitatores nunc utantur. \\ A L P I N I S.}

A- GYPTI tenui, admodumque fobrio viktu utuntur: fæpius tamen quàm noftri, in die comedunt, ter fiquidem quaterve fingulo die cibum fumentes quantitate \& qualitate paucum, unicoque ac fimplici cibo funt contenti, ciborum va* rietatem abhorrentes. neque multum carnium ufu delectantur, atque plerique illorum aquam epotant, lege illis interdicto vino. Sunt tamen etiam multi Chriftianorum, 'Turcarum, atque Hebræorum, qui vinorum potationibus non fecus quàm Ultramontani indulgent. Ufus carnium apud Egyptios eft temperatiffimus, atque non minus fimpliciffimus, omnes ferè arietum caftratorum carnibus vefcuntur. Aliqui ipforum pullis gallinaceis frui nunc cœperunt, à noftris mercatoribus perdocti, tamen in carnium ufu funt parciffmi. GurLand. Qualis igitur eft cibus illis familiaris, quo perpetuo aluntur, cum ipfos carnibus parciffime vefci dixeris? Forfitan leguminum, lacticiniorum, pifcium, fructuumque ufum illos pro cibo frequentare, atque is cibis ali dices. A L P I N. Omnes humido cibo oblectantur, ipfumque affectant, hincque orizam in jure carnis caftratorum paratam, lentefque, pifa, \& albos ciceres, melochiam, malvam, atriplicem, betam, caules, bammiam, cu= cumeres noftrates, \& quos Chatè appellant, colocaffiam, fcilicet ejus radices, melones, angurias, dactilos, mufas, ficus noftrates, \& ficomori, armenica, perfica, uvas, mala aurantia, limonia, citria, granata. Ex carnibus, ut nuper etiam dictum eft, arietum caftratorum, quæ præ cæeteris omnibus ibi in pretio habentur, pullos gallinaceos. multi pauperum . carnes bubulorum, aliquando etiam camelorum efitare confueverunt. Et ex pifcibus, quorum ufus ibi eft aliquanto familiarior, comedunt lupum, cephalum \& multos alios ex Nilo flu- 
mine expifcatos, crocodili etiam carnes non fecus quàm alio. rum pifcium multi mandunt. In locis prope mare politis omnia pifcium genera, in multa copia opcima reperiuntur, quibus omnibus ipfi vefcuntur, falitis quàm maxime ac interim femiputridis, Ex lacte quamplurimos cibos parant, omniaque genera lacticiniorum apud ipfos fant in ufu frequentiffimo, atque hæc de cibis particularibus, qui in ufu apud eos funt, dicta fufficiant, hoc uno tantum cognito, ipfos ciborum varietate non delectari, fed cibo fimplicifimo. Multi enim funt, qui prandium vel conam perficiunt, fola anguria vel pane tritio ceo, quo omnes vefcuntur. ibi etenim nulla alia panis genera cognof́cuntur, quam ex tritico parata. vel folo jufculo ex ra: dicibus colocaffix, vel bammix fructibus, vel melochia, vel oriza, vel lentibus, vel cum alio legumine parato, vel faccha. ri cannis viridibus commanfis, vel folis uvis, vel ficubus, vel cucumeribus, aliifque fimilibus. Gurfand. Suntne apud illos. optima olera atque fructus pifcefque $\&$ carnes, quibus illi vefcuntur? Alpiñ. Omnia olerum genera, illorumque fructus omnes noftris funt longè multò humidiores, atque hinc etiam infipidiores, quando omnia hacc terram non modice irrigatam, at multis diebus inundatam producere, te vidiffe certo fciam. Tạnta eft ejus terræ ficcitas \& ariditas, ut fi ea à terra abigenda fit, terraque ipfa foecundior reddenda, non fat eft ipfanz tantum modice aqua irrigari, fed quamplurimis diebus largiffima copiofimaque aqua inundatam, atque tectam manere. Hincque hortorum viridariorumque diebus fingulis terram fæpins aqua inundare vel demergere folent, ut foccunditati aptiorem reddant; ea item caufa omnia illorum olera, atque herbas effe valde humidas, atque noftris infipidiores arbitror, quibus animalia , quæ pafcuntur, carne fieri valde humida, excrementofa, atque guftui minus fuavia, non eft mirum. Pifces in $\mathrm{Ni}$ lo nafcentes tametfi pingues atque guftui fuaves fint, nihilominus ad fanitatem tuendam peffimi putantur; nam flumen illud faxofum fundum non habet, fed limofum, neque admodum celeri ac velementi motu agitatur, ipfius aqua limofa \& coenofa exiftit. Qua omnia non obfçura effe indicia infalubrium 
pifcim in eo fumine nafeentium Gal. in Iib. de fuccorim bonit. cap. 19. memoriæ prodidit. Pro potu omnes $\mathbb{E}$ gyptii Mahometis affecla fuavifima illinfee fluminis aqua utunttir, quæ aliis omnibus bonitate videtur præferenda. Chriftiani veró atque Hebræi etiam vinis utuntur. Guiland. Hippocrates in lib. de aëre, loc. \& aq. docuit optimam aquam effe quàm pririfimam, cujufvis coloris; atque mali tum faporis, tum odoris expertem. Qualis vero fit puriffima Gal. in lib... de fimp. med. facult. cap. 5. his verbis docuit, inquiens: Aqua, quce eft puriffima, tribus fenflbus judicatur, guftu videlicit, vifu, olfaciu: guftu, fi nullam plane qualitatem pre fe ferat, fed videdfur ab omni qualitate immunis: Vifu, fi pura, fincera, $\varepsilon^{\circ}$ exquifute clara: olfactu, fi cortum nibil elt, qua in aquis vitiofes efje olfactus teftctur, ut aciditas, putredo', acredo, falfedo, aliquodve aliud vitium, quod nomine caret: Docet etiam cognofcere, omnium optima atque peffima aqua quo pacto dignolcatur, in primo de fanit. tuenda. cap. 2. dicens: Quod fi quis eft, qui ex notis potiits vim ejus pranolfe malit, cujus fons è petra fcaturiens contra Septentriones fuit, Solemque aver fum babet, hanc cogrè concoctun iri, tardique tranfitus effe, putandum eft: eadem nimirum calefiet, frigefietque tarde: Contra. cujus ad Orienten Solem fons entumpit, queque per meatum aliquem mundusn, aut puram colatur terram, eademqzie calefit ac refrigeratur ocy fime. hanc omni ætati utilifimam effe exiftimandum eft. Hifque notis peffima ab optima aqua dignofcitur, quibus certi fumus, aquam Nili fluminis probe clarefactam optimam judicari, quando ipfa fit omnium puriffima limpidiffinaque, fubdulci fapore, nulloque malo odore. AlprN. Quis non credet illiufce celeberrimi fluminis aquam omnium ad ufum humanum optimam ac præftantifimam effe, ipfa tum longo itinere (Nilus etenim in locis prope fub tropicum capricorni pofitis nafcitur, ultraque alterum tropicum, fcilicet cancri, in mare ufque mediteraneum labitur) tum quoniam univerfam terræ plagam a Sole exuftam, quam inhabitabilem antiqui effe arbitrati funtob caloris nimium xftum, pertranfit, in longiffimoque itineris tractu ferè à Sole percoquitur, \& è motu vel agitatione, qnæ in tam longi itineris pro- 


\section{PROSPER I ALPINI}

ceffu fit, \& à collapfu five defcenfu à fummis montibus facto, flumine ab excelfis locis ad ima præcipitato probè attenuetur. $\&$ purgetur. Quod vero non faxofum alveum id flumen habeat, fed pinguiffimæ terræ, atque optimæ, ipfam aquarum. omnium minime frigiditate poffe nocere, erit judicandum. Quibus notis Avicenna aquam. illam multis laudibus commendandam literis tradidit. Guicand. Rectè loqueris, fed hoc tempore quo pacto illam, quæ turbidiffima eft, claram efficiunt, ad ufumque idoneam reddunt ?: Galenus etenim in.lib. I. de fimp. med. facult. dixit . Atgyptios olim ipfa per"fictilia vafa percolata ufos fuifie. Arpin. Alium quoque nunc modum apud ipfos adhiberi, ac frequentari vidi, quo aquam illam puram, ac claram eficiunt. Ipfi etenim ftatim camelis in utribus è flumine. domum afportatam aquam in magno fictili vafe. oblongo, alvum latiorem ac rotundam obtinente, binafque aque amphoras continente, reponunt, eaque ibi repofita, \& projecta confertim, quinque dulcibus amygdalis modicè contulis labra vafis inungunt, \& fubito manum cum amygdalis in pugnum obferatum conclufis, fimul cum toto cubito in aquam demergunt, valideque hinc inde per aquam cubitum pugnumque impetuofe. movent, atque agitant, donec ipfa longè multo turbidiorem reddicerint, indeque è vafe detracto brachio, amygdalis intra. aquam relictis, ipfam clarefieri finunt; quæ fpatio trium horarum probè clarefcic. quam è magno illo vafe in parvulis fictilibus rurfum reponunt, in quibus \& clarefcit magis, \& refrigeratur. Plerique incolarum hac aqua ita clarefacta pro pocu, atque cibo utuntur. Alii multi eam pluribus diebus refidere ac. purgari, permittunt, ut purifîmam, atque quàm tenuifimam reddant. quæ proculdubio omnium eft aquarum paxftantiffima. Rectè quidem ipfi, quoad confervandam fanitatem, fe gerunt, illa utentes aqua, quæ ita eft tenuis, ut epota fubito omnes partes corporis penetret, quamplurimi ab epota illa agua, ftatim largiffime fudant. Aliqui mingunt copiofius, atque alii per alvum dejiciunt. eft enim partium tenuifimarum: leviffima, atque à Sole concocta, ita ut ob id mirum non fit. illam immodicè diu noetuque epotam corpora non lædere. 
Quin imo calida corpora ipfa multum juvantur, nam internorum illorum vifcerum calorem, atque incendium contemperat. Hinc quum Cayri Jo. Jacobus Manne Medicus doctiffimus, \& ego de curanda cujufdam Turcæ domini Sangiach renum calida intemperie confuleremus, cum ego pro illo affectu ferum lia. ctis caprini commendarem, ridens ait, eequid fero lactis indigemus, fi Nili aquam habemus? Hoc ego tunc rifu dignum effe judicavi, fed multis poft annis facta de ejus aquæ facultate experientia, non irridendam fententiam doetiffimi Medici, quinimo fummopere laudandam ac commendandam effe, cognovi. Gurcand: Gaudeo tantas laudes aqure Nili fluminis audivife, minufque ob hanc caufam miror, fi ejus regionisaccola fibi infis perfuaferint, aquam illam intra ipforum corpora fifceptam in fanguinem mutari. Siquidem omnes uno ore clamant, ipfam in noftris corporibus non alium humorem, quàm fanguinem generare, \& hocilli à Deo datum fuife, ubi Moy: fi præceperit, ut aquæ in fanguinem mutarentur. Ex quo tenipore creditur, hanc aquam vim fanguinis obtinuiffe. Hanc divites omnes epotant, tum fimplicem, tum faccharo \& fucco limonis miftam. Sed hæc fint fatis de illorum cibo \& potu: perge tu reliqua mihi enarrare. A L PIN. Omnes ejus regionis homines vigiles exiftunt, pauciffmique fomni; Venerem co. piofam exercent. licet enim per legem illis plures, tum uxores tum fervas mancipia habere pro veneris ufu. Hilares exiftunt, otiofam quamplurimi vitam agentes, exceptis Arabibus \& rufticis, qui afperiorem vitam degunt, dulcium balneorum ufum omnes cujufvis fexus \& ætatis ibi frequentant, corporis ornatus gratia, atque refrigerandorum corporum ab itineribus in. flammatorum, non minufque pro demenda corporum illorum. humorum plenitudine.

$$
\text { E }
$$




\section{A P. X I. \\ G U I L A N D I N U S.}

\section{De caujis, cur longavi fint CEgyptii.}

$A$ UD o in IEgyti locis homines vivere longiorem vitam; A quàm alibi, quando ipforum permultiannos plus centum v1vant. Communis ferè omnibus is habitatoribus vita annorum nonaginta folet effe. Caufam igitur vitæ apud ipfos longioris te mihi nunc referre cupio, quando hominis vitam confervare, \& corrumpere ea, quæ vulgus medicorum res non naturales, \& Gal. caufas confervatrices, appellat, quifque noftrum non ignorat. Quæ funt aër, cibus, potus, motus, quies, fomnus, vigilia, excretio, atque retententio, animique pafliones. Ab aliqua igitur harum caufarum, vel à multis fimul conjunctis longiorem illorum hominum vitam pendere arbitror, fed à quibus præfertim id fiat, ex te audire defidero. Alpin. Rigyptios longævos effe, veriffimum eft, atque ex caufis nuper dictis non minus: de his etenim Galenus cap. 35 . lib. art. med. hæc fcripfit: Alteratur igitur corpus à nonnullis quidem necelfario, "à quibusdam vero non necelfario, Dico autem meceffario, quia nulla efl evitandi ration, non neceffario autem reliqua. Nam aërem quidem nos ambientem femper attingere, comedereque, ac bibere, EO vigilare, EO dormire eft necefjarium. Ex bis itaque ea corpora alterantur, ac mutantur, atque confervantur. Quamobrem aërem, cibum, potum, is populis longiorem vitam concedere proculdubio exiftimo. Effectus namque communes à communibuscaufis pendere omnes fciunt, ob id ab aëre, cibis, potuque longam illorum hominum vitam fieri arbitror, quod aëre, cibis, potuque nihil ipfi habeant inter fe communius, fed obfervato ac cognito ipforum aëre calido \& ficco inæquali, fimulque cum cibis, quibus vefcuntur, \& etiam potu, anceps fum, an vitæ apud eos obfervata longitudo ab his pendeat, vel non ab aliis. Teque idcirco rogo, qui tum aë- 
rem illorum locorum, tum victum incolarum nuper natratum audifti, ac novifti, cujus hac de re fis fententix, mihi manifeftare velis. A LPIN. Caufam, ob quam hi populi noftris longiorem vitam degant, in primis efle, judico, fobrium ipforum victum, abfitinentiamque tum à copia, tum varietate carnium, atque ufum optimæ æquæ Nili fluminis in potu, atque in cibis. Si quidem omnes Europai, qui crapulas, atque vina frequentant, brevius vivunt. Germaniæque ob id \& Polonize accolas coelo $\mathbb{E}$ gyptio contrario utentes, quia multis carnibus vef-cuntur, vinorumque ebrietatibus affiduè operam dant, brevio*rem agere vitam non eft mirum: Plerique etenim (ut audio) non excedunt annum fuæ æxatis fexagefimum. Contra Liginres longævi funt, quàm plures enim Genuenfum nonagefimum ufque vel contefimum etiam annum atcingunt, temperatiffime enim vivint, vinifque pauciffimis utuntur, atque ebrietates abhorrent. Ob has igitur caufas homines $\mathbb{E}$ gyptios longævos fieri arbitor. Gurland. Non videntur mihi hæc ufque-quaque veritatem continere, neque ita facile te poffe medicis: perfuadere, arbitror, ufum carnis \& vini effe caufam, ut noftra. corpora (qux illo victu affidue utuntur) fint brevioris vitæ, quam Ėgyptiorum obferventur, quxe pauciflima carne vefcuntur, \& minime vinis indulgent, aquamque in potu frequen tant. Hoc fanè parodoxum ab omnibum judicatum iri fentio: Namque quis credet cibos melius nutrientes, probioremque \& copiofiorem fanguinem gignentes corporibus brevioris vitæ effe caufam, atque alia minus, pejufque nutrientia, \& paucioris fanguinis ad durabilitatem conducere? Hæc certè tibi quoque à veritate aliena efie videbuntur. Quis enim medicorum. dubitat, vel ignorat, ufu optimarum carnium, optimique vini naturalem calorem augeri, atque roborari, mutatumque à fuo naturali ftatu, imminutumque carne \& vino citò revocari, pri-. ftinæque fanitati reftitui? In omnibus etiam morbis præcipuam victus rationem, in qua carnes primum locum fibi vendicant, omnes medici landant, maximeque ubi vires collabuntur, quibus quàm citò probior multufque fanguis gignitur, quo calor naturalis augetur, atçue fovetur. Vinum yero quam citò nul-: 
triat, refolutumque calorem reftituat, peraugeat \& foveat, neminem medicorum ignnorare certò fcio. Quid igitur dicemus, optimarum carnium, vinique ufum caufam effe, quin minus corpora vivant, quando eo victu naturæ vires augeantur, atque conferventur? Hoc profectò qui affirmabunt impoflibile, dicere poffibile videbuntur. Alpin. Litem mecum nunc copifti pergravem, cum me proculdubio multum. aberrafle hac in re exiftimes. At nunc etiam edico tibi, dubii caufa à me propofitum, paradoxum non effe, filicet homines ufui carnium, vinique indulgentes minus vivere, quàm illos, qui $a b$ his abftinent, aliaque in victum affumunt, neutiquam. vini potationibus operam dantes. Porrò ut de hoc nunc mihi certior apud te fit fides, conabor rationibus tibi illud perfuadere. Nam fecus ejus regioni hominibus accidit, ac coli ratione effe deberet: Si quidem calidiorem regionem accolentes citius mori deberent, iis, qui frigidiora loca inhabitant, ratio utique fuaderet, ut hinc non inmeritò Nicolaus Leonicenus in lib. Ariftotelis.de long. \& brevit. Vitæ hæc feripta reliquerit: Afclepiades inter medicos rari nominis memorice prodidifle videtur, Aithiopes quidem trigefnno otatis anno fenefcere, apud Britannos vero multos ad centefimum ufque Eं vigefimum pervenire etatis annum: quoniam Solis calore apud Rtbiopes refolvantur, arefcantque corpora, apud Britannos vero compacta, densaque fiant coli algentioris caufâ, छे exhalationi caloris nullum relinquant locum. Si vivunt igitur AEgytii multis annis in calidiori illo cœlo, non ab aëre, qui multo calore corpora illa refolveret, arefaceretque, fed á victu longævos evadere dicendum erit, præfertimqe à multarum carnium ufu parciffimo, atque $a b$ affiduo \& continuo ufu aquæ illiufe fluminis omnium aquartum optimæ. Quod quidem ex hoc fieri facile feiri poterit. Namque veluti ufus moderatiffimus, quem ipfi fequuntur, optimæ carnis, modicum fanguinem generans, nativum calorem fovet, confumptumque humidum fubftantificum reparat; ita immoderatus frequens, vel afficuus, atque continuus non modo humidum non reparat; caloremque anget, fed eum fæpe fuffocat, corrumpit, atque diffolvit. Guıland. Quonam modo id fieri pot- 


\section{DE MEDICINA EEYPTIORUM. LiB. I.}

terit, cúm multus fanguis genitus humidum fubftantificum de. perditum reftauret caloremque nativum non minus peraugeat? A L P I N. Duobus fanè modis hoc fieri ex me audies; \& primo, quoniam multus carnium ufus multam fanguinis copiam generat, quæ fi reparandæ humiditati fubftantificæ, calorique reftaurando, \& augendo apponatur, tantum abeft, ut humidum caloremque ea alimenti copia augeat, "ut magis fape fuffocet, atque diffipet. Quo fane modo Gal. dixit. in lib. de cauf. morb. parvam flamman multo oles fuffocari Ë extingui. Secundo, quia multa carnis copia in ftomacho fufcepta à calore ipfam alterante, atque in alimentum permutante, ut fiat pro nutriendis partibus alimentum opportunum, omnino vinci, atque mutari non poteft. Ideo illud alimentum non modo calefacit, fed refrigerat. Hincque doctiffime Galenus in libro tertio de temp. docuit, omne nutrimentum, quatenus eft nutrimentum, calorem animalis augere. \& ex hoc fieri, quod ab ipfo calore vincitur, probeque concoquitur, \& mutatur in fubfantiam partium nutriendarum, ut ipfis omninò fimilis fiat, quod ibi ita fcriptum reliquit: Si namque ex nutrientium funt genere, frquidem vincantur, calefaciunt $; \sqrt{l}$ non vincantur, rofrigerant. Et quomodo fiat, in libro de cauf. morb. cap. tertio, ita fubjunxit. Inmodicum alimentum refrigcrare, fi enim ligna univerfim \& multa fupra parvam famman coacervaveris, ob immodice quantitatis exceljum, ipfan extingues. Quibus hæc etiam addidit: $\sqrt{i c}$ optimi cibi, quique plurimum animali afferunt nutrimentum, fupra modum alfumpti morbos frigidos generant. Modica vero fumpta caro probè vincitur à calore naturali, \& ob id nativo humido fimilis facta, ipfum nutrit, fovet, \& auget. eoque aucto vitam quoque foveri, ac confervari, certun eft. Hinc illiufce regionis populi, quoad carnium ufum temperatiffimi, longævi fiunt. Addo etiam plurimos illorum vino non uti pro potu, lege illis interdicto, quod quantum valeat ejus ufus afliduus \& copiofus, ad hominis fanitatem pervertendam, Galenus ibidem is verbis docuit, dicens: Quamquam vinum modice hauftum, ut quod maxime proprium alimentum fit, vativun calorem adaugeat, tamen morbum attonitum, Epilepjian, 


\section{PROSPERI A L P I I}

lefiones motus, fenfufve immodice fursptum ipfum faiere. Ft in fecundo libro de fympt. caufis dixit: tremore corripiuntiur, qui $\int_{e}$ vino meraco amplius impleverunt, vel multis cruditatibus laborarint, vel longo tempore cibis repleti. Et in tercio etiam de temper. ait: Proinde nec vinum ip/um Semper animal calefacit, aque, ut nec oleum flawmam accendit, tametfi aptiffimum ejt ignis nutrimentum, immo, fi inbecille E exiguce flamma confertim multum oleim infundas, Jiffocabis eam, prorfufque extingues potius, quàm augebis, fic igitur \& vinum ubi plus bibitur, quim ut vinci pofjit. tantum abeje, ut animal calefaciat, ut etian frigidiora vitia gignat. Ideo cum illorum locorum accolæ fobrie vivant, lacte, oleribus, fructibufque vefcentes, minimeque in efu carnium, neque in vinorum potationibus delinquant, mirum non eft, fi ipforum corpora multum fanguinem gignentia (quod in plerifque illorum obfervatur) longam agant vitam. Vinorum generofifimorum ufum temperate etiam adhibitum is poffe prodeffe non fatis mihi conftat, quando non calore pleraque ipforum corpora indigeant, fed frigore, ne amplius nativus. calor in biliofis corporibus exolvatur, fed retineatur. Atque ne fanguis biliofior magis etiam fiat. Ufus enim illiufce aqux præitantifimæ multorum illorum corporum fanguinem, cœli occafione calidiffimum, temperationem reddit, atque ipfum cohibet, minufque aptum morbis efficit. Hine Germanix, Poloniæ, Galliæ, Angliæ, Flandriæ, \& aliorum frigidorum locorum quamplurimi, ut etiam dietum eft, ob affiduas ebrietares, quibus afficuè operam dant, pancis annis vivunt. Multi etiam in Italia quotidie à medicis obfervantur, qui ob crapulas, $\&$ ebrietates, tum pauco tempore vivunt, tum vitam miferrimam quamplurimis morbis continuè afficti, tranfigunt. Ipforum alii podagricis doloribus, alii convulfionibus, vel tremoribus, vel vertiginibus, vel aliquo illorum morborum à caloris naturalis imminutione, atque imbecillitate nafcente, ferè per totam vitam vexati. 
DE MEDICINA EGTPTIORUM.LIB.I.

\section{A.P XII.}

Ad vite confervationem aque Nili fuminis ufous, mum vino fit atilior, necne.

\section{A L P I N U S.}

Uam eен м omnia de longæ $/$ Egyptiorum vitæ caufis te rectififime locutum fuife, atque planè de his veritatem attigiffe certo fciam, nihilominus liceat adhuc mihi, de ejufdem aquæ utilitate dubium aliquod tibi refolvendum proponere, quando ex iis, quæ nuper in medium propofuifti aque ufus ad corporum illorum calidorum vitam producendam, ufu vini accomodatior, atque utilior effe videatur. Quod iis contrarium omnino videtur, qua de ufu aqua Hippoc. \& Galenus literis mandarunt. namque aqud eos conftat ab aqux potıl corpora parum juvari. ex Galenoque hæc in libro tertio de rat, vict. in morb. acutis, de ufu aquæ leguntur: Tarde igitur jure optimo meat aqua, difficulter concoquitur, atque agre defcendit, quamquam alioqui E optima $\int i t, \mathcal{E}$ culpa omni vacet. Hic etiam ex Hippoc. mente docet, aquam, quamquam omnium puriffima fit, multo tempore manere in ventriculo, fluctuationefque utplurimum parere, atque in biliofo ventriculo etiam corrumpi, difficulterque in hepar, thoracem, pulmones, renefque diftribui: ob idque ipfam, neque fputum educere, neque urinam, neque fudorem, neque alvum ciere, neque fitim tollere', (quòd ipfa moretur in amplis ventriculi inteftinorumque cavitatibus, nec penitus imas partes permeet, neque eas humectet.) neque alere, neque vires roborare, fed hypochondriis valde effe noxiam, præfertim hepati lienique obftruetis, vel in tumorem elatis. Quamobrem cum hæc de aquæ facultate vera utique fine, quis ille erit, qui non viderit, aut nove. rit, Egyptios falfo ab aquæ etiam illiufce ufu fieri longævos dici poffe, quando, ut jam audivimus, pauciffime iis corporibus conducere ac prodeffe poffit, fed potius fit multum incom- 


\section{4

moda, ac noxia. Quis igitur audebit affirmare, ufum aque in is corporibus in potu frequentatum ufui vinorum præferri utilitate debere? nemo, ut arbitror, in medicina initiatus, id affirmavit, -quia hoc ex Galeno diffinitum eft in libro fexto epidem. comment. 4. text. fecundo, hifce utique verbis: Siquidem vinsm aque prejitat, non folum ad concoetionem, que ventricuto fir adjuraandam, fed etiam ad concoita diftribuenda, ad fanguinem creandim, ad nutriendun, ad lotium citandwn, Ė ad corpora difflanda in reciè valentibus. Valde itaque hinc dubium videtur, quod aqua ad potum affidue ufitata poffit corporum confervacioni conterre, quinimò magis contrarium facere ejus ufum, ut apud Galenum noftrum nunc legimus, aqua vinum præftare. neque immeritò dictum effe, quando aqua neque concoctionem adjuvare poffit, quod frigida ipfa exiftat, atque à calidis omnis coctio fiat; neque concoctorum diftributionem, cum minime tenuiffimarum fit partium, difficulterque ac tarde vifcera permeet: neque fanguinis procreationem cum ipfa fiat à calido, fanguis enim \& ipfe facultate calidus dicitur: neque nutritionem, cum ipfa non alat; neque urinarum, fudorumque excretionem, neque corporum difflationem, quia ut nuperrime etiam dixi, tenuiffima fubftantia non conftat, qua citò facileque corporis partes penetret, atque tranfeat: Atque fi optimam hæc facere aquam verum fit, quid de mala dicendum erit? nonnifi peffime conferre ipfam nobis poffe. Quàm multos enim morbos, feviffimofque ex earum aquarum ufu oriri, in libro de prævidendis morbis a me dictum eft. Sed cum hæe vera exiftant, quæfo, quomodo poterit ufus illiufce aquæ $\mathbb{E}$ gyptiorum longævitati conducere? Cupio itaque hac in re me valde ancipitem tuæ fententix acquiefcere, quam nunc andire expecto. Guiland. Neque omnibus corporibus aquam improbandam, neque laudandam judico, quinimo magis credendum, atque affirmandum exiftimo, aquæ ufum multis proficuum effe, \& multis etiam noxium: Hinc in quibufdam corporibus aquam vino utilitate effe præferendam, \& in quibufelam vinum aquæ. Calidicribus fiquidem corporibus, cui dubium erit magis fore proficuum aquæ, quàm vini ufum. quoniam à vini potius calis 
ditate læderentur, quàm juvarentur. Quam rem non ego, fed Galenus tuus docet cognofci, ac obfervari pro corporum tem. peraturarum, habituumque varietate oportere: quam ob caufam, vinum damnat, tum in pueris, tum in iis, qui funt calidi humidique temperamenti. quibus aquam multum conferre affirmat, ipfamque pro is fumme laudat, ut apud ipfum in primo libro de fanit. tuenda cap. undecimo, legitur: apud divinumque Hippocratem non minus in libro fexto epidem. com: ment. 4. text. 15. his profectò verbis: Percalidos natura refrigeratione potûs æquæ quiéfcere. Ei Galen. in ejus eommentario, dixit Hippocr. eam fententiam fore intelligendam ad fumme calidis corporibus. quod clarius explicavit in libro quinto, de fanit. tuenda cap. 12. cum dixit: Vinum autem frigidis $\sqrt{2}$ ccifque naturis utiliffimum effe, prius dictum e $f$. An vero calidis, onnibus idoneum non fit, fed utilior his aquæ potio fit, ficuti in libro de popularibus morbis, five Epidemion legimus, nuncexiftimandum. Fortaffis enim abfurdum omnino cuipiam videbitur juvenem, qui athleticus vel militaris fit, aut etiam foffor, mefforve, aut arator vel denique, qui robuftum aliquod opus exercet, aqua tantum potione uti: atque in hoc falli Hippocratem, cum calida temperamenta aquæ potionem pofcere, abfolute pronuntiet. Mihi vero Hippocrates non abfolutè id, fed id naturis fumme calidis, qua utique propter intemperiem tales fint, dixife videtur. Et fi quifpiam contradixerit nobis, quòd ei non videatur aquæ potu corpora juvari poffe, quia ipfa quamquam omnium aquarum fit optima, multum in ventriculo moretur, fluctuetque, \& tarde mect per corpus, jecurque atque lienem obftructos vel tumefactos adangeat, inutilifque obfervetur ad omnem corporis evacuationem, fcilicet ad fputorum eduetionem, alvi, urinarum, fudorumque excretionem adjuvandam, atque non minus ad concoctioncm \& diftributionem concoeli alimenti, demum quòd etiam ipfa minime corpora alat: Refpondebitur, hoc planè verum non effe, quoniam aquæ reperiuntur, quæ concoctionem adjuvant, non minufque alimenti diftributionem, citò vifcera permeantes, fanguinifque generationi favent, atque nutritioni, non minus, quæ adjuvant omneras

$$
\text { F } 3
$$

cor- 


\section{6 \\ PROSPERI ALPIN I}

corporis evacuationem. A LPIN. Quo pacto id effe poterit; quando aquæ facultas frigida fit, qux femper concoctionem, fanguinis procreationem, nutritionem, quæ omnia à calore fiunt, impediet, \& fubftantia præterea ejus craffa fit, difficulterque corpus permeet, qua utique evacuationes promovere poffe. non videtur, quando quidem fi hæc præftare debeat, neceffarium fit, ipfam tenuium effe partium, ut anguftos meatus membrorum pervadere queat? Guntand. Aquæ optimæ reperiuntur, quæ neque infigniter frigidæ funt, quæque dulces exiftunt, quales effe coeleftes Hippocr. in lib. de aëre, locis, \& aquis, c. $4^{\cdot}$ memorix prodidit, qui de his ita feripfit: Aquce igitur levifima, Es dulciflime, E temifime, ac jplendidifime junt, Non minufque aquæ nuper dictæ Nili fluminis clarefacta, duls ces, tenuiflimæque, fplendidiffimæ, atque leviffimæ exiftunt. Quæa fanè omnes, praterquam quod ex dulci fapore non valde frigidæ effe creduntur, funt etiam tenuiffimæ, ita, ut celerrime corporis vifcera permeent. Audio etenim (quod olim, cùm Cayri moram facerem, etiam obfervavi) in fingulis ferè corporibus ab ipfis epotis aquis ftatim vel copiofas urinas, vel fudores, vel per alvum dejectiones obfervari, atque in hypochondriis nullam fluctuationem ab ipfis oftendi, loquor de iis, quæ Cayri habentur, \& potantur, quando Alexandriæe aqua conftent fubftantia craffiori, quæ peffimæ exiftunt, tardiffimeque vifcera permeant. Alpin. Confirmo tuam fententiam, atque me in omnibus corporibus obfervaffe, citiffime illas aquas Cayri clarefactas, vel per alvum, vel per urinam, vel fudorem exiiffe, non fecus quam ferum lactis ac aquæ thermalesfacere obfervantur. Omnes advenæ, cìm Cayrum ftatim venerint, in primis diebus temper, ob illiufce aquæ potum, diarrhæam pati foliti funt. Mihi vero aquam illam per urinam, atque fapiffimæ per fudorem exire contingebat. In æftivis caloribus nocte qualibet fæpeffime ob fitim intenfiffimam, qua omnes tunc temporis ex calore ambientis cruciantur, largiffime frepiffimeque ex ea aqua bibebam, à qua femper in copiofifimum fudorem ftatim erumpebam, ita ut quoties ex ea ebiberem, to. ties femper exudarem. Hyeme vero, atque aliis anni temporibus 
ribus non ita calidis, non per fudorem, fed per alvum, atque veficam aquam illan epotam ferè totam excernebam. Non omittam tibi narrare, me hujufce aquæ largifimo potu ufum à dolore renum vehementifímo atque acutiffimo ex calculis orto fanatum fuiffe. Porrò cum interim illo jam dicto renum do lore affictus valde fitirem, multa vafa fictilia frigidæ ac purifimæ illiufce aquæ plena in ferratis meis feneftris aëri expolita profpiciens, uno ipforum avidifime arrepto, item altero, atque mox tertio, totam aquam devoravi, quæ ad minus fex librarum pondere fuerat. à qua affumpta fomno, labore doloris defeffus, capior, quo paulo poft expergefactus minxi, cum multa copia affumptæ illiufce aquæ quinque lapillos phafeolorum magnitudine, quibus excretis ftatim a dolore liber evafi. Guiland. Perplacet exempla, fucceffufque hos audiviffe, quos utique veros effe judico, cum ea aqua fit tenuiffimarum partium, neque multum frigida, fed potius concoctam effe omnes pro certò habere deberent, cum Nilus totam illam mundipartem perneet, quæ omnium orbis terrarum, ut nuper etiam diEtum eft calidilima eft, atque terram habet pinguifimam cljufvis frigoris expertem. Itaque cum hæc vera fint, quifque noftrum poterit affirmare, epotam eam aquam poffe optimi fanguinis procreationem adjuvare, quæ fummum bilioforum illorum corporum hepatis calorem obtemperando, caufa eft, ut non bilis multa, fed multus temperatus fanguis gignatur. Juvabit non minus concocti alimenti diftributionem, ob ejus partium tenuitatem, qua quafcumque partes corporis penetrat; qua etiam fubftantiæ tenuitate minime in ventriculo, aut hypochondriis moratur, neque fluctuationem parit, neque hypochondria lædit, quinimo iecori lienique inflammato auxilio eft. Experientâ didici, potum ejus aquæ valde conferre melancholicis ab hypochondriis effectis. Hac eademque ratione ad omnes excrementorum excretiones utilis eft. An vero nutriat, quando latifima fit apud omnes medicos fententia, ’̀ quam non nutrire, videtur $\&$ ipfa ad nutritionem inutilis cenfenda. Sed $5 y$ gtii affirmant contrarium verum effe, quia hi omnes aquam illam totam in fanguinem in notris corporibus 


\section{$4^{8}$

mutari arbitrantur, ac pro certo habent. Vimque gignendi fanguinem ajunt obtinuife, poftquà, Dei conceflione, $\dot{a}$ Mofe aqua in fanguinem olim fuere mutate. Confirmantque hanc fententiam, quod cernant corpora pleraque illorum inco. larum habitu bene carnofo, copiofi temperatique fanguinis obfervari. Non minufque etian quod ipfa dulcis exiftat. quem. laporem, rem haud planè à nutritione alienam fignificare dicunt. Sed utcunque fit, hoc unum fcimus, ejus aque ufi cor pora illa optime, ac falubriter vivere. \& ob id falfan judico Galeni fententiam, qua omnem aquam noxiam potius, quam. utilem affirmat. fi enim hoc verum effet, quomodo tot infinitarum regionum populi vivere utique poflent, continue aq̨uam potantes. Infiniti propemodum funt populi tum in Africa, tum in Afia aquam folam potantes, qui rectifime valent, corporaque habent boni tum fucci, tum habitus. præfertimque in locis calidis, atque in fumme calidis corporibus aquæ ufus eft faluberrimus. Sed non modo in fanis, at in ægrotis non minus aque ufus adprime opportunus ac utilis óbfervatur. Cum omnibus ferè ægrotis aqua in potu pro vino fubftituatur. Plures exiftunt, qui vini ufu omnino omiffo, aquam frequentantes in potu, à podagra, aliifque multis morbis præfervati funt. Quamobrem, ut ex dictis conclufionem colligam: dico aquam optimam dari, quæ neque admodum frigida eft, \& quæ tenuiffima fubftantia conftat, qurque utiliffma erit corporibus calido temperamento refertis, veluti frigidis naturis eadem ratione incommoda, atque inutilis erit judicanda, in quibus ipfum vinum preferendum abfque dubio erit. At de his fatis. Ad alia enim à te tranfeundum puto, fortaffeque his hactenus auditis non foret inutile, neque noftro ordini averfum, te nunceorum corporum morbos recenfere, quando nunc aëris, ipforumque temperamenta, \& victus rationem omnem audierimus. ALPIN. Rectè fuades, atque nunc tibi morem geram. Quoniam hæc, priufuam præfidia apud eam gentem ufitata tibi narrare incipiam, nos noviffe utile erit. 
DE MEDICINA ELGPTIORUM. LIB. I.

\section{A P. XIII.}

\section{De morbis partriciis, of epidemicis, qui apud CEgyptios objervantur \\ G U I L A N D I N US.}

7 GYPTIORUM corpora haud multis malis effe obnoxia cogito, quodipfa aëre fruantur ficciore, qui pauciorum morborum folet effe canfa. Atque etiam quia eos populos fobrie vivere nuper dictum eft, quem victum corpora ab ægrisudinibus præfervare quifque noftrum non ignorat. A L P I No Aliter evenire audies, quando ad gignendos morbos plures aliæ etiam concurrant caufr, neque omnes ejus regionis habitatores æeque vivere poffunt. Multi enim inopia coacti, quorum numerus ibi fere eft infinitus, peffimis tum cibis, tum turbida ac putrida aqua ali coguntur. Multietiam ibi reperiuntur, qui vine utuntur, non modo ex Chriftianis \& Hebræis, qui omnes vinum ut noftri affectant, fed ex Turcis etiam aliqui, præfertimque milites, etfi lege interdictus apud omnes Mahometi affeclas vini ufus fit, non tamen à vine temperare poffunt, fed longe Germanis, Polonifque magis vino \& ebrietatibus operam dant. Cayri quotidie Turce vino ebrios ab afinis domos fuas portari confpiciuntur. Vinis vero plerique utuntur è Creta infula, Rhodo, Cypro,, afportatis, quæ omnium funt generofiffima: omnia enim alia ex Italia, Corcyro, Zacyntho, advecta, præ nimio cœli calore, acida fiunt. . Quamobrem cum ibi multi malo victu utantur, aërifque inæqualitate, $\&$ c venere immoderata, non erit mirum, eos quoque in multos morbos incidere. Proinde non expers morborum झgyptus erit, fed quamplurimis., diverfifque ac periculofis morbis femper fcatebit., GuILAND. Suntne apud ipfos multi morbi proproprii, vel patrii, quos endemicos Græci appellant? ALPIN. Multi fanè, quales funt oculorum lippitudines, quas Græci ophtalmias appellant, lepræ, Elephantiafes, phrenitides exi- 


\section{PROSPERI ALPINI}

tiofiffimæ, homines paucis horis perdentes, variolæ peftilentes in pueris, articulorum dolores, omniaque genera morborum quæ à capitis defluxu ad inferas partes excitantur, herniæ, renum \& veficæ calculi, phthifes, obftructiones, hepatis lienifque \& ftomachi imbecillitates, febres tertianæ, ardentes, hecticæ \& peftilentes Guiland. Non arbitror patrios iis folum eos morbos dici debere, cùm apud alias quoque nationes ipfi ouferventur, namque in multis aliis locis omnes nuper dicti morbi obferventur. Alpin. Verum eft eofdem morbos aliis non minus populis effe infertos, fed non perpetuo tempore, ut apud REyptios. Apud multos enim populos opthalmias vagari aliquibus temporibus reperiemus, non tamen femper. Semper etiam homines herniofi, leprofi, atque elephantiafi correpti, eaque prefertim, qua pedes fere pedibus elephantum omnino immiles habere cernuntur. Neque exitiofiffimas phrenitides paucis horis ægrotos perdentes ubique reperiri arbitror. quando Gal. in lib. 3. epidem dixerit, nunqquam vidiffe fe phreneticos mortuos ante tertiam diem. nihilominus tribus, quatuorque horis multos periiffe phreneticos vidi, quorum cafus pofterius fuis locis tibi referam; neque fingulis annis, ut alibi fit, bis in anno in pueros peftiferx varioli vagantur, neque continue arthritici quamplurimi homines, quales ibi exiftunt, reperiuntur, neque renun veficæque à calculis larf, neque fingulis annis certo tempore vagantur febres pettilentes exitiofa plurimæ, neque innumera hominum caterva à cruditatibus ftoniachi ubique affligitur, ac vexatur. $\mathrm{Ob}$ quam morborum nuper dictorum familiaritatem, ni $\mathbb{E}$ Eypto proprios vel patrios eos appellare volueris, dices tamen iis populis ipfos effe admodum familiares. Guidand. Vaganturne per eam, urbem Cayri ifti morbi quandoque epidemici? Alpis. Ophtalmiæe, febres peftilentes, nuper dictrque phrenitides, variolæque peftiferæ epidemicæ graflantur. Alii vero morbi fparlim per urbem obfervantur, quos fporades Greci nuncupant, quod fparfim, \& non gregatim homines pervadant. Etfi omnes, quafi endemii etiam fint, five patrii, quia cæteris aliis morbis nuper dietis iis populis fint magis familiarss. GuILAND. Cupio te 
nunc illos rurfum mihi clarius dicere, atque ipforum caufas. Quibus à te narratis, de pefte, quæ fæpe eam gentem infeftat fæviffimeque devaftare folet, te fermonem habiturum cupio, quod illud morbi genus, quo tempore in regione moram traxifti, Cayrum invafife, multumque devaftalfe, audierim: obquam rem te de eo morbo admodum feite ac diftinete loqui poffe judico. De patriis itaque, vel de iis populis familiaribus morbis, qui tum epidemice, tum fparfim graftari per eam urbem folent, nunc fi videtur, ediffere.

\section{A p. XIV.}

\section{De morbis Egyptiis familiaribus, deque ip arume canfis.}

\section{A L P I N U S.}

A LEXANDRIE Autumno graffantur febres peftilentes mulA tæ, lethales, quæ ferè quamplurimos invadunt, cum urinis pulibufque \& colore febrili ufque adeò parum à naturali ftatu mutatis, ut ææpe medicos atque ægrotos decipiant. His vero notis pleræque dignofcuntur: in principio enim vomitus multi biliofi, ac virulenti obfervantur, à quibus cibum affumptum continere nequeunt, affiduifque corporis agitationibus inquietudinibufque vexantur, ftomachique angore anguntur. In plerifque etiam obfervantur multæ fymptomaticæ dejectiones, liquidæ, bilofæ, variæ, admodum ægre olentes, five fœtentes. Plures cibum abhorrent, neque.valde fitiunt, et linguæ ipfis fint ficcæ, afperæ, \& nigræ. Incolæ quàm advenæ difficilius corripiuntur, atque $a b$ his intereunt. De harum febrimm caufis illiufce urbis medicorum variæ fententiæ obfervantur. Si quidem aliqui ipforum ajunt, à ventis nafci, qui à proximo urbis lacu fpirant. Prope ipfam à meridie pofitus eft Mareotis lacus, circuitus ut audio, tercentum mille paffuum. Hi etenim venti vim habent putredines infignes gignendi, quod putres veneficofque è lacu halitus Alexandriæ populis ipfi indu- 


\section{siz

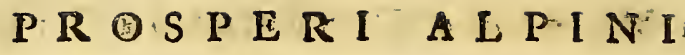

cant. Aliqui earum peftiferarum febrium ortum : referunt po: tius in putridos, veneficofque halitus, qui à fubterraneis urbis locis, cavitatibufve paluftri ac peffima aqua plenis aëri tune permifcentur. Urbs etenim hæc tota fipper columnàs marmo. reas numero fermè infinitas pofita, \& fundata eft, ita, ut fundamenta hæ folum omnium domorum . fint, quæ univerfam omnium ædium bafim fubftentant. Ideo loca urbis omnia fubterranea, inaria, ac pervia exiftunt, ut affirmant aliqui: quod ea caufa factun fuit, ne urbs terræ motibus foret obnoxia: : vel aliis ita putantibus, ut aquam à Nilo flumine per rivum in urbem manantem populus copiofiffimam in fubterraneis illis $\mathrm{ma}$. Snis cavitatibus ad ufum per annum confervaret Singulis âninis peraucti fluminis illius rivus, Caleg vocatus, in ieas urbis cavitates copiofiffimam aquam evomit, quie fequenti æflt:te ferè tota abfumitur, paucilfimaque remanet, quæ cœnofa, paluftrifque reddita, zorrumpitứ, veneficaqne evadit, ex qua tunc multi vapores furfum elevati aërem inficiunt, qui peftiferaram illarum febrium caufa exiftit. Quod neque credendum eft, quia eo tempore ad paucam eam paluftem aquan corrup. tam multa nova ex rivo nuper dicto tune aueti fluminis accedit; atque ei permifcetur, qux utique antique vitium, malamqne qualitatem corrigit. Quamobrem veriorem caufam illarum fe: brium effe autumo, ut multi alii quogue confirmant, ufum ejufdem.nuper dietæantiqux aqux in potul \& cilis. Qux fanè quoufque novæ confluxx aqux, qua ipfi ad cibum dx poiun tunc uti incipiunt, permifta remanet, antiquaque rectè non refidet, neque ab ipfa novo illuc confluxu rectè- expurgatur, femper ufum fuifpectum ad eosfrevos morbos reddit. Ideo antiqua aqua paluftris ac putrefacta novie permita, ad potum \& cibum ufitata infignes parit in corporibus putredines, à quibus eæ perílentes febres facile fiunt. Hyeme oculorum lippitudines ibi miltre vagantur. Plurimafque Cayri eafdemque per om: nia anni tempora homines invadere ob ritrofum pulverem, qui continuè oculos habitantium mordicat, \& calefacit, obfervatur, longè maximeque in æftatis prima parte, quo tempore calor anbientis aëris fummè calidi oculos inflammat, taliumque mor: 
borum numerum auget. Sparfim vero urbem toto anno hæ oculorum inflammationes vagantur; atque epidemicæ plurimæ in prima æltatis parte calidilima, inæqualifimaque ob vehementiffimum Meridionalium ventorum calorem, atque inflammatarum arenarum copiam, quæ ab iifdem ventis afportantur. Eo enim anni tempore è centum hominibus quinquaginta faltèn lippientes obfervantur. Multi præfervantur ad his inflammationibus oculorum fxpius in die algidâ aquâ large oculis lavatis', vel rofacea, vel aliqua ftillatitia, vel Nili fluminis clarefacta. Eodem etiam tempore vagantur ibi epidemica febres piftilentes multæ, atque ille apud eam gentem horrendifinus mo:bus, Dem el muja ab iis appellatus, qui paucifimis hortis hominem perdit: Cujus mori exemplum, quod apud nos novus fit morbus, tibi fubjungere optimum efie puro. Erat enim Gayri Paris Chriftianus omnibus Venctis mercatoribus valde fámiliaris, annos natus quinquaginta, temperamento boliofo $\&$ habitu gracili, qui una die febre ephemera, cum capitis dōlore correptus, fudavit toto corpore multum, excepto capite, quod nihil fudavit, \& febre integrè eft judicatus. Dolor tamen capitis remanfit citra febrem: mane furrexit, folitaque munia obiens illa die, circa finem dolore perfeverante, in angulo dextri oculi rubor cum parvo tumore apparuit fine dolore. No- : ctem præ folito dolore inquietam duxit, rubor tuinorque oculi evanuit, difparuitque; tamen erat immunis omnino à febre, nullifque aliis fymptomatis, quàm à nuper dicts dolore ipfe conflictabatur abfque ullo calore febrili : circa meridiem ab affumpto cibo dolor perauctus eit, copit febrire, fereque continuò vomuit cum cibo multa virulenta, voceque defecit articulata, valde gemebat, non audicbat, non cognofcebat, manum phrenetica gefticulatio, floccos carpebat, feftucafque colligebat. Refpiratio magna, inæqualis, rara per intervallum edita. Pulfus inæqualifimi, duriffimi: Hypochondria in principio mollia, mox valde tenfa. Extrema omnia frigida, minimeque recalefcentia, ftertebat, conuulfus eft, atque fubibitò obiit. Tempus, quo febriit ante exitium, non exceffit duarum horarum fpatium. Plurimi. funt, qui lilariter cœnani G. 3

tes: 


\section{PROSPER I ALPIN I}

tes inftar apoplecticorum moriuntur, phreneticorum etiam notis. Notæ vero humorum cerebrum lædentium miftæ funt ex his, quæ tum pituitam, tum fanguinem, vel bilem fignificant. Omnefque fimul fignificare videntur cerebrum ejufque membranas invafife, tum calidos humores, tum frigidos, effeque ex his factum apoftema. Quam fanè affectionem miftam ex lethargo \& phrenitide judicare poflumus, illamque effe, quam Græci Thiphomaniam appellant. Quod.\& nomen non minus Arabicum, quo hunc morbum nominant, explicare videtur. Nam ipfi hunc morbum appellant Dem el muja. Dem enim Arabica lingua fanguinem denotat, \& muja, aquam, quafi morbum dixerint ex fanguine \& aqua genitum. His humoribus conjungitur infignis putredo ac venefica qualitas, quæ fubitanei atque celerrimi exitii eft caufa. Guiland. Neque mirum videtur mihi in hoc anni tempore, quod eft prima æeftatis pars, fieri hujufmodi cerebri inflammationes, ex illis humoribus pituitofis ac biliofis, vel ex fanguine, atque ipfas fequi etiam exitium quam citifime. Nam cui medico erit dubium, primæ illiufce æftatis partis conftitutionem auftrinam, fummè calidam potuiffe fubvehere à toto corpore in cerebrum maximam com.2. partem humorum, in illis corporibus exuperantium? Quo fanè in text. 73. modo Gal. in lib. 1. epidem, multos phreneticos factos fuiffe narravit ex bile, ab auftrina conftitutione in caput fublata. Proprium effe videtur auftrinorum ventorum fubvehere ad caAphor. 5. put humores, atque ipfum lædere. ut Hippoc. in lib. 3 Aphorifm. docuit, cum inquit: Auftrini flatus caput gravantes, fenfu:fque babetantes, fo reliqua. Cum itaque in illa reftatis parte vigeant hujufmodi venti calidiffimi, mirum non erit, fi capita illorum habitantium quàm maxime læedantur, $a b$ eoque calore inflammentur, multifque ab ipfo calore in caput fublatis vapor ribus, humoribufque à toto corpore in caput à colore, veluti à cucurbitula attractis, atque infigniter putrefactis ab immodica ambientis aëris caliditate. Exitium etiam tam cito illos fequi, non à copia illorum humorum, fed à venefica qualitate, $a b$ intenfifima putredine genita, ut Gal. in phrenetico ab Hippoc. in lib. 3. epidem. defcripto tribus diebus mortuo accidifie, 
memoriæ prodidit. Illiufce vero urbis habitatorum corpora fuccis pituitofis, \& multo fanguine, atque amara bile abundare à te fuperius dictum eft. Sed hæc obiter dicta à me fint; tu vero, ne vacuum tempus demus, perge reliqua mihi enarrare. - Alpin. Rectè fanè dixifti, ex illa primæ æftatis conftitutione auftrina fumme calida, inæuguali, atque ab eorum humorum exuperantia fieri eas cerebri lethaliffimas inflammationes, in quibus fit paucis horis exitium, ob intenfifimam putredinem illorum humorum, cerebrum ejufque membranas peifime oblædentem, ita, ur fubitò virtus animalis extinguatur, atque cum ea vitalis, continuò communicata cordi à cerebro læfione. Singulis annis femel AEgyptii hoc malo conflictantur. Aliquibus annis plus, ubi plus à Campfinis ventis moleftantur, atque ubi minus ii perflant, minus etiam id morbi genus ipfi patiuntur, quo innumeri femper intereunt. Eodem etiain tempore graflantur in pueris plurimæ variolæ peftiferæ, contagiofæ, quæ oriuntur à veneficis vaporibus in aërem tunc à putrida aqua rivi fuminis, $\mathrm{Ca}$ leg vocati, fublatis. Singulis etenim annis aucto eo flumine ad altitudinem decem \& octo cubitorum, aqua ab ipfo in rivum Caleg vocatum ingreffa, perque ipfum tranfiens, totam urbem permeat, fluitque femper per ipfam à tempore, quo Nilam nuper dicta altitudine auctum effe dixi, quoufque flumen ipfum crefcere defit, quæ; finito augmento, fuminis, in alveo Caleg remanet, pauloque poft ftagnans facta, putrefcit, viridifque primo cernitur \& mox nigra, admodumque fœtida apparet. Cujus putredo contracta in ipfa (quando fluminis augmentum. terminetur menfe Octobri, vel ad fummum Novembri, \& Junio rurfum menfe augeri incipiat) adveniente prima æftatis parte, adhuc magis augetur, intenfeque putris reddita, halitus in aërem exhalet corruptos valdeque veneficos, à quibus aër infectus, pueros omnes partem rivo proximam habitantes in peftilentes eos morbos incidere eft caufa. Quam ob caufan omnes civitatis habitatores illam rivi partem habitare timentes, ne ipforum flii ab illo venefico aëre moriantur. alio confugiunt. Hæcque funt mala, qux Cayri epidemice graffari folent. Mul. ta alia exiftunt, quæ fparfim miltos offendunt, quales funt le- 


\section{PROSPERI ALPINI}

præ, elephantiafis, herniæ, arthiritis, catharri malieni ad pulmones, phthifes, in vifcerum obftructiones, inflammationes., \& fcirrhofi tumores, ftomachi cruditates, flatus hypochondriaci, melancholiæ, renum veficæque calculi. Lepra atque Græcorum elephantiafis in multis pauperibus femper cernitur. Qui inopia aquam cœnofam, femiputridamque epotant, atque pro v.etu carnem bubulam, camelorumque \& pilces falitos femiputres, in ftagnifque \& lacubus., captos. cafeumque quendam. immodicè falitum ac femiputrem (eft enim is omnium ciborum pauperibus familiarifimus, tum quia ob infignem falfedinem illorum appetitui fit acceptiffimus, tum etiam, quia ibi viliffimo pretio venditur. Hunc Gibnehalon appellant.) Ex quo victu ipforum corpora multum fanguinis fæculenti, perufræque flavæ bilis, \& pituitæ crafæ., vifcidæ, falfuginofæ gemerare ac coacervare, neceffarium eft. A quibus humoribus, ad cutim protrufis eos excitari morbos cuilibet noftrum manifeftum eft. Vagatur \& altera elephantiafis, ut nuper etiam dictum eft, qua correpti, pedes multis magnis duris tumoribus tumidos, magnos, atque deformes habent, elephantium maxime fimiles, cruribus tumefactis etiam conjunctos; quibus tamen æger nihil doloris fentit, fed ad ambulandum ineptus redditur. Multos vidi ipforum, qui ipfi pedibus calceorum loco ligneis capfulis indutis, incedebant paffu lentifimo ac difficillimo. Hoc morbo correpti multi Cayri cernuntur, ex malo victu, quem affectant, fcilicet ex pifcium Nili, ac multorum lacuum ftagnantium, femiputridarumque aquarum, \& colocaffiæ radicum, bammix, melochiæ olerum ufu, quo multam pituitam craficm. lentamique gignunt, quæ ad pedes defluxa illos fcirrhofos ædæmatofofque tumores pedibus creat. Non minufque multas carnofas hernias parit. Atque ab hac eademque caufa innumeris fieri vifcerum obftructiones, tumorefa. fcirrhofos arbitor. Herniarum omnes fpecies ibi femper vagantur, plurimæque magnæ anguriæ magnitudine cernuntur. Autumant, aquofas oriri ab ufu affiduo illarum anguriarum, quas appellant Batechel muja. Hac auguriarum fpecies intra corticem, non pulpam, ut in aliis vifitur, fed folam aquan 
dulciffimam cum feminibns obtinet: quarum aquam, (cui in illis caloribus omnes libentiffime indulgent, (affidue ebibitam ad teftes defcendere ob partium ipfius tenuitatem, atque fcrotum implere ajunt. Ex flatibus non minus multæ herniæ obfervantur ab imbecillo calore ftamachi, ab ufuque leguminum, radicum, fructuumque, à quibus multi craffiores flatus ortum ha. bent, qui multis hypochondria quoque tendunt, atque alias etiam partes. Ab ufu affiduo aqua in potu, \& crudorum frigidorumque fructuum, olerumque, \& ab immodica venere, ufuque frequenti dulcium balneorum \& ab intenfis cœli caloribus plerifque ftomachus frigidior redditur. Hincque multi illorum affiduas ftomachi cruditates patiuntur, quorum numerus ferè infinitus Cayri confpicitur. Ego enim cum in via (ut apud ipfos confuetudo eft, ut femper cum obviàm alicui medico fiunt, ipfi brachium porrigant, ut pulfus tangat, etfi fani omnino etiam fit, atque ab eo intelligant ipforum ftatum vel fanum vel ægrotum,) mihi aliquando neceffe fuifet cujufpiam 'Turce Domini pulfus tangere, ut ei corporis ftatum detegerem, hac arte fum ufus, ut (quando omnes ferè ejus loci homines opinentur, pulfus obfervatione medicum poffe, ufque etiam annularem, ut ita dicam, digitum manus, dolentem dignofcere.) femper infpecta facie naturalem fuum colorem, habitum, figuram habente, poftquam pulfum rectè tetigiffem, dicerem illum rectè fe habere quoad fanitatem univerfi corporis, fed tantum omnium ipfius corporis partium ftornachum non omnino fanum, fed fæpe à cruditatibus læfum, qui frigidior imbe. cilliorque fit, nequeatque cibos omnes probe concoquere; femperque hac arte ufus plurimum honorem apud ipfos fum confecutus, qui me optimum medicum inde crederent. Arthritici multi ibi exiftunt, ex multis humoribus crudis, quibus ob victum pleraque corpora abundare fuperius dictum eft, \& à multis etiam frigidis ftatibus in articulos decumbentibus, à capitifque deftillationibus creberrime ab inæqualiffimoque aëre caput maxime lædente, excitatis, ad articulos delabentibus. A qua vero caufa multi habeant articulos, debilesatque ad fufcipiendos humores faciles, non eft fcitu difficile, quando illi utuntur imH

mo- 
modica venere, \& frequentiffime dulcibus balneis, quæ quanto articulos debilitent, atque laxent, tu recte nofti. Accedit etiam multa hyemalis aëris frigiditas, quæ ob tenuiftimum, ficcumque, inæqualemque aërem vehementior quàm fit, à corporibus fentitur. Demum confuefcunt etiam multi veftibus iifdem tantum uti hyeme, quibus utebantur per æftatem, \& multi nudis pedibus toto hyeme ambulant; qux omnia articulos lædere fcimus. Renes permulti contraxerunt ex immodica venere valde calidos, ac debiles, in quibus cum multa confluat ea, qua corpora illa featent, cruditatum copia, non erit mirum eos frepifime calculis conflictari, \& ulcera etiam in is pati. Calculorum etiam maxima iis occafio effe folet, aqua non rectè purgata, clarefactaque, quæ quia diuretica eft, facile ad renes permeat, terramque fecum ducit; quæ amplius calore ficcata, in calculos mutatur. Hique morbi omnes exiftunt, qui fparfim per urbem illam femper vagantur. GUILAND. Scio etiam ibi multos melancholicos reperiri, quos fanctos multi effe autumant. AlprN ${ }^{*}$ Innumeri ii propemodum exiftunt, qui vitam agere omnino à peccatis immunem profitentur, fanctitatemque habere exiftimantur, atque vivunt in locis afperis Deo fervientes, moreque Heremitarum. Hique in fummo honore, apud omnes Mahometis affeclas habentur. Divitias fpernunt, \& mundi voluptates ac commoda fugiunt; abhorrentes vitam inhoneftam, colibemque amplexantes. Humanifime cum omnibus cujufvis religionis fe ge. runt, errores omnes acriter accufantes, mundunque homini effe miferiam prædicant. Mofti femper exiftunt; à Deo multa fupplicia ob mortalium flagitia expectantes. Habent corpora nigra, fqualida, gracillima mumiarum arefactis corporibus omnino fimilia. Quæ melancholica exiftunt, confumpto caIore naturali ob immodicum ambientis aëris calorem, \& tenuiffimum victum, affiduas vigilias ac labores multos. Sed his nunc finem imponamus, quando opportunum tempus fit, de pefte illorum locorum nunc loqui, de qua nihil in narrandis morbis Exyptiorum meminimus. Sæpe tamen ipfa ea loca, Cayrimque maxime atrociffime devaftat, ipforumque gentem depafcitur.

CAP. 
DEMEDICINA EGYTIORUM. LiB. I.

\section{A p. XV.}

\section{De pefte, que fape loca EEgyti invadit, atque atrocifime devaftat.}

\section{G U I L A N D I N U S.}

T G YPTIORUM loca fæpiffime à pefte atrociter devaftari $A$ multis notum eft, atque illam ex proximis finitimifque locis tæpe in illa afportari, in ipfifque fponte rariffime nafci, neque multos latet. Sed tu de ipfa verius, $\cdot$-qui ipfam rectè obfervafti, loquere. ALPin. Illiufce gentis peftém aliis omnibus faviorem, atrocioremque effe exiftimo, pro erronea Turcarum Egyptiorumque credulitate, qua omnes pro certo habent, fingulis à Deo præconftitutum effe exitium, exitiique qua: litatem, ita, ut in bello morituros nullo pacto à pefte interimi poffe arbitrentur. Et folum pefte eos mori poffe, qui bus quidem ab ipfa exitium præfixum fit. Qua vana credulitate omnem peftiferum morbum negligunt; atque parvi faciunt, nihilque $\mathrm{ab}$ eo timent, pro certo credentes, fi illis vitam eo morbo finiendam deftinatum fit, quin ab eo moriantur, nullo pacto ipfos poffe effugere, neque in bello, neque in mari, neque alio modo mortem fibi pertimefcendam. Atque hinc pefte Ægyptum depopulante, urbem Cayrum fævifime depafcente, nemo ipforum in ipfa fugam arripit, neque una cum pefte infectis verfari timet, neque veftibus, aliifque laneis, lineifque pannis peftis contagio infectis uti abhorret. Veftes enim, aliaque pefte interemptorum defunctorumque fuppellectilia, fubito in emporiis publice venduntur, quod magis mirum videtur quifque ea emit abfque ullo peftilentis contagii timore. Qux fanè lues nullo pacto $\mathrm{ab}$ - is formidata, cum de ipfius contagio nulla habeatur ratio apud ipfos, fit vehementiffima, frviffimaque per univerfam urbem citiffime expanditur, \& diffeminatur, tantamque tyrannidem in ipfos ac ftragem exercet, ejus contagio ob hominum hac in re negligentiam, in plurimos pros 
pagato, mirumque etiam in modum audto, ut Cayri anno à Virginis Beatifimæ partu 5 80. fex feptemve tantum menifum fpatio quingenta millia hominum, ut audio, pefte perierint. Hoc boni habent ibi pefte infecti, atque ægroti, quod à nulTis deferuntur, quinimo medici omnes pefte correptis libere, non fecus, quam aliis in omnibus morbis, medentur, citraque ullum timorem aftantes ipforum curam habent, non fecus quatm xgrotis ab alio falutari, minimeque contagiofo morbo facerent. GuILAND. Mira loqueris, at fuæ ignorantiæ $\dot{a}$ pefte exitium fubfequens illis pœna fit, ac fupplicium. Quid fultius efie poteft, quàm oculis cernere peftilenti contagio plurimos interemptos efre, atque non credere, vel dubitare faltem fibi ipfis idem contingere pofie, quafi credere nequeant ignem omnia combuftilia comburere poffe? Certe ftultifima ea eft opinio, planeque erronea ac falfa, quam non immeritò apud cam ftuicilimam gentem multorum hominum ftrages, ac ruina fequitur. Quid etenim, nonne naturæ etiam repugnat, dicere quoslibet homines ab excellenti aliqua putredine affici non pofle, quam non æque omnes corripi ab ea poffint, prædeftinatamque cuilibet exitii qualitatem effe, liberaque non efle animalia, at ad particularem moriendi modum prædeftinata? Ceterum hæc omittamus, quando hujus difputationis hîc non fit locus. Nunc ex te audire cupio, illorum locorum peftilentia à qua caufa fiat, atque utrum ab aëris putridi infpiratione exflagnantibus lacubus, vel ab infigni, vehementifímoque calore corpora, ob pravum victum pefimis multis humoribus featentia infigniter putrefcant, vel demum fi peftis aliunde contagio illue potius afportetur. Alpin. Plerumque peftilens contagium in Egytum ex multis locis pefte infectis afportari folet. Rariffimeque ab aëris vitio peftis illa nafcitur. Et hoc nonnifi ubi Nilus immodice ea loca inundat. Aqua etenim longiori tempore terram occupante fit, ut univerfum illud folum lacus invaclit paluftris ac ftagnans, qui accedente primæ æftatis calore auftrino, multo infigniorem recipit putredinem. Vel aër illorum locorum fuapte natura calidus, \& ficcus, fluminis larga Nili inundatione perfeverante, inmodice humidus reddi- 
tur; qnod aëris temperamentum ad gignendam peftilentiam effe valde opportunum ac facile Gal. in I. lib. de temp. memorixe prodidit. Ab halitibus vero putridis ac corruptis paluitrium locorum $\mathbb{E}$ gypti, lacuumque aquarum corruptarum fingulis annis fi multi effent, quales fequi folent immodicas fluminis inundationes aliquando ibi factas, peftis annis fngulis ibi ex aëre fieret. Ex caliditate aëris immodica peftilentiam obortam fuiffe nemo hactenus ibi vidit- Obfervatum vero eft, ab infigni aëris calore potius omne peftiferum contagium extinctum effe, nurquam tamen à calore primæ æeftatis, quòd fua inæqualitate, atque calore fuffocante potius putrefactionis generationi non parum faveat. Plerumque igitur id genas morbi ibi contagio ex aliis locis afportari folet, rarifimeque ab aëris vitio. Neque minus verum eft, per feptennium ibi peftem nafci, vel revivifcere. Ex tribus vero locis pracipue peftis in \$gyptum accedit, fcilicet ex Gracia, Syria, \& Barbaria. Quæ autem ex Græciæ, \& Syriæ locis illuc vehitur, Cayrumque corripit, fatis mitis, \& minus fera pauciores homines interimere obfervatur, brevique tempore tollitur: Sed quæ à Barbaricis locis in eam urbem invehitur, omnium eft perniciofiffima, frevifima, longiffima, plurimos populos defpafcens, atque ftragem multam ipfis inferens. Qualis fuit, quæ Cayrum, ut fuperius etiam dictum eft, anno I580. ex Barbaricis locis menfe Octobri invafit, fæviitque per univerfam eam urbem atrociffime, tantamque ftragem intulit, ut ad Junium ufque menfem (quo tempore peftis contagium, qualecumque fit, definere confuevit) periiffe dicantur ad minus quingenta millia hominum. Guicand. Forfitan id contingere majoris minorifque illorum locorum ab urbe ifta diftantia ratione dicendum erit. Quando Barbarica ea regio Asgypto, tum procontigua fit. Aliaque loca Græciæ \& Syriæ, præter qnod diftant, etiam ipfa ab Kgypto, mari quoque feparata funt. ALpIN. Minime profectò hujufce rei caufa eft, locorum ab urbe Cayro diftantia, quoniam etfi urbs Bizantium, à qua fæpifime peite infecta peftilens contagium afportatur, ab ipfa A£gypto multum diftec, tamen us tu probe nont, Syria nulto propin$\mathrm{H}_{3}$ 
quior eft, quàm Bizantium. Cur itaque contagium peftilens Cayrum ex Barbaricis locis afportatum diu afflictet, miferrimeque urben hanc diruat, \& devaftet, ejufque omnem ferè populum depafcatur, atque ex aliis locis nuper dictis afportatum minus fævire fit obfervatum, breviufque tollatur, \& minorem ftragem pariat, ex te nunc audire defidero, qui altioris in abditis naturæ arcanis contemplationis te noverim. Ideo ifuc ex te difcere expecto.

\section{A p. X V I.}

Cur peftis contagium ex locis Barbarice Carrum importatum, duturnius fit, or magis exitiofim experiatur eo, quod ex alius omnibus locis provenure obfervatur.

\section{G U I L A N D I N US.}

1 $\mathrm{E}$ videar nunc propofitæ dubitationis laborem velle fub1 terfugere, etfil rectius ad te is fermo attineret, qui in is locis longiorem quàm ego moram traxeris, nihilominus non definam tibi fatisfacere, de propofiti dubii caufa meam fententiam in medium proferendo. Caufam itaque cur peftis ex Barbaria illuc profecta, fit diuturnior, fævior \& exitiofior, exiftimo effe præftantiam excellentiamve peftilentis illiufce putredinis, cujus contagium veftibus lineis, laneifque multis pannis (quas merces plurimi ab is locis Cayrum fre advehunt) afportatum, ob eam caufam excellentius effe, atque citius eos invadere, multamque in ipfos tyrannidem exercere, diutiufque vigere poffe ratio expoftulat. Putredine igitur peftis Barbaria locorum exiftente præftantiori, venenofum ipfius contagium afportatum validius fæviufque eos populos invadere, quàm ex locis Græcix Syriæque illue profectum, quodque fiat in his locis peftis, ejufque venenum non ita excellens, non eft mirum. Alpin, Veram fanè nuper propofiti dubii caufam dictam ex 
te fuiffe exiftimo, fed nondum tamen dubium explicatum ac refolutum effe videtur. Quando non demonftraveris quam ob caufam peftis Barbaricx putredo vehementior fit dicenda ac judicanda illâ, quæ in Græciæ, Syriæque locis obfervatur. Multoque magis, quod facile aliquis dicere poffet, Græcia \& Syriæ, peltis putredinem Barbaricâ majorem potius judicandam, quoniam utræque hæ regiones aëre utuntur minus calldo, multoque humidiore. Quem quidem aërem ad excitandam peftilentiam effe aptiffimum \& facillimum Gal. in $\mathrm{r}$. lib. de temp. \& in primo de diff. feb. teftatum reliquit. Hinc Ariftoteles in libro 3. de hift, animal. dixit, corpora fanguinea, quòd aliis fint temperatiora, facilius computrefce. re. \& Hipp. in 3. lib. aphorifm. docuit putredines humidis temporibus \& pluviofis fieri, atque videri. Quas quidem aëris Aphor. qnalitates magis habere Græciam, atque Syriam, quàm Barbariam multi noverunt. Nam fcimus, Barbariæ aërem cœli calidiffimi ratione calidiffimum, atque ficciffimum effe, \& Græciæ, Syriæque illo temperatiorem, atque humidum magis, ob id eorum locorum corpora ad putrefcendum erunt valde apta, \& facilia, atque ipforum non minus putredo illâ erit excellentior, quæ in Barbariæ corporibus excitatur. quia ut etiam nuper dictum eft, ficciora illa funt corpora, minufque ad putrefcendum apta, quinimò magis ut putrefcant valde difficilia. Guiland. Hoc tamen non elt ita facile credendum, quando calidioris ficciorifque corporis putredo longe multo difficilior, mea quidem fententia, ea fit judicanda, quæ in corporibus minus calidis \& humidis, ad putrefcendum facillimis ac aptiflimis excitatur. Quæ res tibi clarior videbitur, fi me altiori magis ftylo ipfam contemplari fiveris A L P I N. Nihil eft, quod ego nunc libentius magis faciam, quàm te de eadem re loquentem, audire. fermo etenim tuus mihi femper non minus pro tua doctrina utilis, quàm gratus effe debet. Guiland. Neminem noftrum effe arbitror, qui ignoret, peftem'five peftilentiam efle corporum ingentem ac fummam putredinem, perniciofiffimi veneni qualicate præditam, quæ fæviffmam fragem in loca ab ipfa infecta inducit. Quam duplicem habere caufam, ex 


\section{$6+4$

qua fit, cognofcitur, fcilicet putrefaciens, atque putrefcibile, five caufam efficientem, \& materiam. Qux efficiens fit caulfa, non eft fcitu admodum difficile, quando omnes medici affirment, ipfam, effe calorem non naturalem, five extraneum, naturali contrarium, planeque inimicum. Naturalis enim calor corpus confervat, \& quicquid in ipfum agit confervationis caufì agit. Extraneus verò, innaturalifque ad corruptionem omnia operatur, atque hic eft, qui putredinem efficit, naturalem calorem corrumpendo ac diffipando, cum ita comparaCap. 14. tum fit, Galeno in 4. lib. de fimp. med. facult. docente, ut res qualibet in propria fervetur natura ex calore proprio, qжo diffipato neceffaria fequitur corruptio, cum humores nequeant

Cap. 8. proprio calore deftituti, imputres manere ac fervari, ut in lib. 2 . de diff. feb. Gal. feripfit, inquiens: Neque enimi fieri poteft, ut aliquis quifpiam ex bumoribus talis permaneat, qualis erat ab initio, nedum qui ita depravatus, ut nature sultum non amplius fitfcipiat, fed alterum omnino Sequitur, ut fcilicet coquatur, apponatur, affiniletur folidis partibus animalis, aut corrumpatur, $\mathcal{E}^{3}$

Cap. 9. putre fiat. Qualis vero fit hic calor, in eodem libro, his verbis fubjunxit paulo poft, inquiens: Nam reḉte fentire videtur Ariffoteles, ab aliena caliditate orivi putredinem. vocat autem alienam, externam non injitam, neque nativam in quocunque genere rerum, nam hac concoquere apta eft, externa autem corrumpere E' putrefacerc. Nofcitur vero hic calor, vel extrinfcece, vel intrinfece; Extrinfece, ab aëre immodice calefacto; ob quam caufam aëre exiftente immodice c.llido etiam putredines propagantur. Hincque fortaffe Gal. in lib. 3. de temp. dixit: At gure corporis noffra naturam putrefaciunt, calida poteftate exiftunt.

Cap. 4. Ex quo quidem aëris calore interdum ortam fuiffe peftilentiam in liune modum in primo lib. de diff. feb. teftatum reliquit, dicens: Conting it autem quandoque pracedere ambientis aëris caliditatem immodicam, quemadmodum in ea peftilentia, qua Athenienfes invafit, ut Thucidides inquit: Sed in tuguriis fuffocantibus eeftatis tempore habitantium corpora corruptione laborant; intrinfece vero calor lise extraneus excitari folet, prohibita caloris naturalis refpiratione. quod fignificant omnes putridæ fe- 
bres, quæ à putredine humorum ab obftuctis vaforum meatibus orta excitari folent. Omnes enim humores, five craffitie five copia obftruentes, aliquo tempore neceffario putrefcunt. Fit etiam à quocumque calore immodico naturalem diffipante, atque corrumpente. Per calorem etiam extraneum nos intelligere debemus, omne illud, quod naturalem calorem difpergit, ac extinguit, ut halitus venenofi, non tantum caliditas aëris immodica, quæ ad putrefcendum concurrit folum in corporibus, quæ multis peffimifque humoribus fcatent, non tamen femper. Hæcque de caufa effectiva putredinis à me obiter dicta fint. De eo verò, quód putrefcit, dicimus, humores omnes, omnefque corporis partes putrefieri poffe, calore ipfarum naturali ab extraneo corrupto \& diffipato, vel eodem ipfo etiam calore partis nativo vincente morbofam caufam; quam putrefactionem noftri fuppurationem \& concoctionem appellant, quarum illa in abfceffibus fuppuratis, \& hæc in febribus putridis obfervatur. Altera vero putrefactio, quæ fit natura velin parte, vel omnino fuperata, ut in vehementiffmis inflammationibus, quæ in gangrænas, fphacelofque, diffipato ac extincto proprio partis calore ab extraneo, permutantur, obfervari folet. Omnes itaque tum partes corporis, tum humores computrefcere poffunt. Alpin. Crediderim ego humida, quæ tantum exiftunt, poffe putrefcere, ac ficca nequaquam, cum putredo ficco potius tanquam contrario tolli obfervetur, ut Gal. in nuperrine abs te recitato libro ita fcripfit: Promptiffime enim putrefcunt, quacuinque calida ac bumida, $\mathcal{E}^{\circ}$ multa funt in calidis locis, nifi diflari, funul ac refrigerari contingat. \& in primo lib. de temp. ait: Deprehendas ex Borea (qui ficcus naturâ Ẽ frigidus ventus eft) omnia quàm diutiffime imputria durare. Contra putrefcere facillime auferino fatu. Fit enim is ventus calidus \& humidus. Idemque affirmavit in primo lib. epidem. his utique verbis; Aufer diffolvere corpora confuevit, bumorefque fundere, comm.x. adeoque putrefacere fimul, ubi cum largioribus fit conjunctus imbri- text. 26. bus. At manifeftiorem hanc rem fecit in lib. 3. epidem. dicens: Et putredo omnis ex materia quidem gignitur bumida, ex $\mathrm{Com} .3$. caufa vero efficiente, extraneo $\mathcal{E}^{*}$ prater naturam calore. Sed quid text. 1 . 


\section{PROSPER I A L P I N I}

Galeni teftimonio egemus, cum omnibus medicis manifeftiffmum, atque apud ipfos obfervatiffimum fit, carentia humiditate non putreicere, quarquam corrumpi queant? Carnes etenim aceto, faleque imputres ob id fervari per multum tempus, quòd minus ob hec humidæ reddantur, cuilibet noftrum notum eft. Hinc colligam folum humida putrefcere poffe, minimeque ficca Gulland. Recte fanè dixiffes, fi actu quæ funthu:iida \& ficca intellexeris, cim fieri nequeat, ut aliquod putrefcat, quod omnino ficcum actu deprehendatur; neceffe enim ei effe aliquam humiditatem, in quam putredo accendatur. Nihilominus poffunt multa putrefere actu humida, quæ ficca etian fint poteftate, veluti vinum putrefcit, flava, atraque bilis, poteftare omnia ficca. Biliofæe enim febres, inflammationefyue erifipelatodes flavam bilem putrefcere fignificant. Humida vero actu., atque poteftate facilius putrefcunt, ut fanguis, lac, \& alia multa. Difficiliufque aliquo modo ficca, \& impoffibile eft actu poteftateque ficca poffe putrefcere. 'Hæcque fufficient de præcipuis caufis ad putrefactionem concurrentibus. Demonftratumque eft putredinis caufam effectricein effe calorem extraneum, \& materialem, \& omnia quæ actu habent humiditatem aliquam, facillimeque putrefcere actu \& poteftate humida, ut fanguis, difficulterque ficca poteftate, \& humida actu, ut bilis, minime vero omnium putrefcere actu, \& poteftate ficca, ut offa. Ab his igitur difcam, putredinem peftis Barbaricæ regionis habitantium effe vehementiorem, intenfioremque ê̂, quæ è Syriæ locis erumpit. Apud me enim conftat, priorum huminum corpora calidi ficcique effe temperamenti, ut indicare fatis aperte videtur habitus ipforum omnium fere corporum fqualidus, gracillimus, durus, ac nigri, exuftique coloris: Grecorum verò atque Syrorum corpora calida \& humida exiftunt, temperata, mulcique fanguinis, \& habitus carnofi moderateque pinguis, floridique non minus coloris. Ideo hac os humiditatem facilima funt, ut putrefcant, \& iila ob ficcitatem ad putrefeendum difficillima. Quæ cum ita intenfe as excellenter putrefcant, putredinis intenfiorem gradum, lapfus à fuo naturali ftatu, certe explicat, qui in is 
maximus eft. Nam ficca omnia corpora non ex quavis caufa facile, ut humida, putrefcunt, fed ex prævalidifima caufa, quâ neceffario prævalidam putredinem illam etiam judicabimus. Hinc hyeme atque in fenibus febres exortas majores iis, quæ in æftate, atque in juvenibus fiunt, affirmamus. quod is magnus lapfus obfervatur, qui illarum effe prævalidas caufas explicet. Barbarica itaque corpora ficca ac qualida, pefte correpta, neceffe eft affirmare, ex magno in ipfis lapfu obfervato, caufas putredinis habuiffe prævalidas: \& confequenter putredinem factam intenfiorem ac excellentiorem illâ, quæ in temperatis corporibus qualia funt Græcorum, \& Syrorum. ) fit; in illis enin ad putredinem ob ficcitatem magnus, $\&$ in his ob humiditatem parvus lapfus obfervatur in quibus parvas ad putrefactionem, $\&$ in illis prævalidas concurriffe caufas dicendum erit, ut in febre æeftatis, \& hyemis. in hac enim ad conciandam febrem prævalida caufa eft neceffaria, veluti æftate quàm facile ex qualibet caufa homines in febres incurrunt. Quam prævalidam caufam putrefacientem corpora Barbarorum præ fqualore ac ficcitate ad putrefcendum valde inepta, neceffario effe calorem extraneum in is corporibus fufceptum exiftimo: fi enim pravo ipfi victu uterentur, fufpicio effet de intenfiffimo ambientis calore, ut ab ipfo ita excellentem fufciperent putredinem, veluti apud Athenienfes olim ortam fuiffe peftilentiam ex Gal. nuper dictum eft. Cæterum cùm vel ab aëre, vel $a b$ aliqua alia caufa hic externus naturali contrarius calor ea corpora putrefaciens, accedat, obfcura non eft caufa, cur illi ita intenfius ab ea putrefcant. Quando jam priori caufæ, (quam ego omnino ignoro.) alia conjungatur, quæ, cur in illis corporibus intenfiores illæ generentur putredines, declarat. Namque omnibus manifeftum eft, humores omnes, partefque corporis proprio calore deftitutas, ab alieno vel extraneo computrefcere. ut Gal. docuit in lib. 4. de fimp. med. facult. atque, ut nuper quoque dictum eft, humores naturali ac proprio fuo calore deftitutos ac privatos; putredinis expertes fervari non poffe, fed neceffario putrefcere. quo fit, ut qui humores magis fuo calore deftituuntur, \& qui minus, majorem, atque minorem ne- 


\section{PROSPERI ALPIN I}

ceffario fubeant putrefactionem. Cur igitur is probè auditis cur Barbarica corpora fub continuo calidiffimo coelo degentia, tam intenfam contrahunt putredinem, admirabimur? quando maximus continufque, quem femper experiuntur, calor abfque aliqua refrigeratione, illorum corporum naturalem calorem difipet, \& diffolvat, ipfaque corpora extraneo ad putrefcendum agenti fubjiciat, atque etiam cum frigore careant, non diffletur, ac refrigeretur. Aër enim fumme calidus, continuè marcefcit, pefímuqque fit, atque corporum calorem innatum corrumpit ac diflolvit. quo diffoluto intenfiffimas fieri putredines non eft mirum, atque $a b$ his peftiferos morbos, qui caloris adjumento, \& latius expanduntur, \& acutiores fæviorefque evadunt, non fecus quàm dicunt medici, venenorum calidiora, magis, \& minus calida, minus ad nocendum effe efficacia. Hincque colligunt multi, in locis fub frigidiori colo pofitis homines mitiorem pettilentiam pati, ut in Boëmia, Germania, Polonia, \& aliis frigidioribus orbis plagis obfervatum eft. ibi etenim peftilentiam mitifimam, ac ipfis admodum domefticam patiuntur. Cum igitur Barbari ex continuo immodicoque cœli calore (fummè enim calida regio eft Barbaria) naturaIi calore imbecilli, ac pauco fruantur, mirum non eft, fi ipforum corpora excellentiffimas fufcipiant putredines; \& Græci \& Syri temperatiori colo utentes, fi multum innatum habentes calorem, non ita intenfas excipiant putrefactiones, quoniam apud ipfos calor extraneus debilis eft, \& infitus multus; veluti apud Barbaros infitus paucus, \& extraneus multus. mirumque ob id non eit, fi Barbarorum corporum pefte infectorum puwedo fit præftantior eâ, quam Græci, Syrique patiuntur. \& ejus non minus contagium apud hos minus excellens fit, adhominefque inficiendos præpotentius apud ilios, excellentius, acutius, prævalidiufque. atque hæc de vehementia peftilentis illorum putredinis, contagii fortitudine, ac imbecillitate, ex efficientis caufr ratione indagata dicere volui. Nunc vero de eadem re ex materix putrefcentis occafione differamus; Nam multa exiftunt, à materia, quæ ibi putrefcit, cognita, quæ cam peftiferi contagii præftantiam majorem \& minorem confir- 


\section{DE MEDICINA EGYTIOR̃U. LIB.I.}

mant. Siquidem corporum humores ibi putrefcentes majori ex parte, coeli utique ratione biliofi, atque exufti exifunt, qui quantò funt ad putref́cendum difficilio:es, eò putrefacti inttenfiorem acutioremque putredinem excipiunt. Quod quidem clariffime fignificant fymptomata, ac morbi ex putiefacta bile, ac atra bile, vel exuftis humoribus orta: quæ omnia acutifima, vehementifima, atque horrendifima exiftunt, ut medicis praxim exercentibus notiffimum eft. In febribus à putredine bilioforum exuftorumque humorum ortis, fæviflima fymptomata, ac horrendifima obfervari, quæ ægrotos male habent, citifimeque aliquando interimunt, cuique planè clarum eft. Acceditquod putredo in ficca materia fufcepta, longe illâ, quæ in humida accenditur, acutior, atque diuturnior exiftit, ut cognofcere poffumus in omnibus formis arte factis, tum in ficca, tum in humida materia receptis, in hac enim qua excepta funt, facile corrumpuntur, atque citò delentur; in illà, maxima difficultate, atque longo tempore. Cui enim ignotum eft, figuram in cera facile imprimi, atque facile corrumpi, ac deleri, in ferro \& lapide quàm difficillime, \& tardifíme? Non videtur itaque à veritate alienum affirmare, contagium peftis Barbariæ in corporum humores ficciores accenfæ acutius, excellentius, diuturnius, Græco ac Syriaco, quod à putredine promanat in corporum humores humidiores, (quando hæc corpora calida \& humida, \& illa calida \& ficca exiftant. ) effe judicandum; ideoque in Egypto ex Barbaria advectum, vehementius incolas pervadere, atque ipfos atrociter depafci, diutiufque quàm alibi vigere atque perfeverare, infignemque ibi hominum ftragem inducere. Hafque puto caufas, cur peftiferum contagium ex Barbaria locis pefte infectis illuc afportatum, citius plurimos homines invadat, quàm ex Græciæ Syriæque locis profectum, atque diutius ibi vivat, atrociufque eam gentem feriat, atque perdat. His auditis, audiendun etiam eft tempus, quo ibi peftis manifeftetur, \& non minus cognofcendum eft, quanto tempore duret, quando audierim, Junio menfe, Sole æetivum tropicum permeante, omnem peftilentiam ibi confumi, atque aboleri. Ideo iftud mihi nune 


\section{0

marrare non te pigeat. ALPrN. Libentiffime à te nunc expetita dicam; atque nunc, ne tempus fruftra conteramus, etiam loqui incipiam.

\section{A P XVII.}

Quo tempore peffis loca Egyptia invadere foleat, of quo tempore ipfa definat.

\section{A L P I N U S.}

Destis Cayri, atque in omnibus locis Fgypti invadere ens populos, folet ineunte Septembri menfe, ufque ad Junium: his enim omnibus menfibus à Septembri ad Junium ufque peftis aliunde per contagium illuc afportata, eam gentem invadere folet. Quæ primis in his menfibus accedit, omnium eft fæviff$\mathrm{ma}$, maximeque fi è barbariæ locis proficifcatur, univerfam etenim ipfa illam urbem afperè depafcitur, multos, propemodumque infinitos mortales perdit. Minus fæva eft, quo tardior illuc acceffit, viderique incipit, ita ut, quò tardiùs venerit, eo mitior ac brevior fit judicanda: quoniam cum anguftum habeat temporis fpatium, quo ferpere per populum poffit, nequit omnes fuas in homines illos vires oftendere. Junio vero menfe, qualifcumque \& quantacumque fit ibi peftilentia, Sole primam Cancri partem ingrediente, omnino tollitur, quod multis planè divinum effe non immerito videtur. Sed quod etiarn valde mirabile creditur, omnia fupellectilia peftifero contagio infecta tunc nullum contagii effectum in eam gentem edunt, ita, ut tunc ea urbs in tutiffimum ac tranquilliffimum ftatum reducatur ex fumme morbofo; atque morbi particulares, fporadici à Græcis vocati, tunc apparere incipiunt, qui nufquam gentium tempore peftis apparebant. GUILAND. Sed nunquid aliis tribus fequentibus menfibus peftis illuc profecta populum illum corripiat, atque quam ob caufam omnis peftilentia menfe Junio abigatur, atque omnino definat, libenter etiam nunc ex te audirem? Alpin.. Junio, Julio \& Augufto menfe numquam, ut Egyp. 


\section{DE MEdicina AYGTíRUM. LiB. T.}

Egyptii affirmant, vifa eft peftis illuc ex infectis locis profecta, quæ eos populos invaferit. Quam vero ob caufam ab $\not E g y p-$ to illo menfe omnis peftilentia, quantacumque \& qualifcumque lit tollatur, nunc venari ac indagare conabor. Arduam fanè ac difficillimam hanc cognitionem effe exiftimo, proinde non ita facile à me excogitata caufa proferenda eft, fed prius ipfam veritati comparare, ac rectè contemplari debeo, \& mox in lucem proferre. Guiland. Sapienter iftuc illo pacto facies, fed quoniam tamdiu ibi cum ea gente verfatus es, non dubito illiufce effectus veram ac certam caufam te ab iis accepiffe, atque didiciffe, vel per te ipfum ratione atque eventibusindagafle. Cupio igitur te nune de his audire.

\section{A p. XVIII.}

Qua caufa Cayri qualifunque pefilentia $\int$ it, mense.
Junio omnino tollatur.

\section{A L P I N U S.}

7 Iнгl eft, neque fit aliquid eo in menfe, fcilicet Junio, quod urbem à peftifero morbo infectam in falubrem ftatum mutare dignofcatur; Nili fluminis excepto augmento, quod ipfum conftantiffime die feptima decima menfis Junii aëris illiufce temporis mutatione ab immodico caloris æftu inæqualiffimo, ab Auftrinis, Eurifque ventis, ut nuper dictum eft, concitato, ad aërem minus calidum, fed æqualem, \& continuum, five ab Auftrina morbofa conftitutione in Septentrionalem falubiem facta. Namque aër tribus fere menfibus ante æftivum Solftitium, quo tempore univerfum peftis contagium abfumitur, interruptè calidifimus, fereque fuffocans animalia, ex Auftrinis Eurifque ventis interruptè, ut fuperius fedulo narratum eft, calidiffimum fpirantibus, obfervatur, inæqualifimufque etiam, quia ii venti non diu perfeverant, fed paucis quibufdam tantum diebus, plerumque tribus fpirare foleant, \& mox definere, à quibus fubitò venti alii perlant, admodum corpora refrigerantes. Atque ab his paucis poft diebus rurfum 


\section{\%:

fumme calidi redeant, aëremque non parum ab aliis refrigeratum ad immodicum calorem confertim mutant. Quamobrem aër calidifimus, æftuofifimus, inæqualiffimus, peffimufque iis tribus menfibus ingruit, \& qui ipfum itidem fequitur, accedente Soliftitio æeftivo, etfi valde \& ipfe calidus fit, eft tamen continue æqualis, uniformis, non confertim, fed fenfim ac fenfim mutationes, quæ cœli ratione fiunt, inferens. Accedit etiam per id tempus Septentrionalium ventorum, quos noftri Etefias appellant, fpiratio. Incipiunt etenim, Sole fignum cancri ingrediente, è Septentrione ii venti fpirare; qui totis Julio, \& Augufto menfibus conftanter, placidifimeque perHant, \& toto fere Junio menfe, Campfinis ventis abforptis, iidem Septentrionales venti orti, conftanter fpirare incipiunt, hique proculdubio exiftunt, quos Gall. aliique Prodromos vocant. Hæcque per id temporis incipiunt obfervari, à quibus fortalfe non immerito caufam extinctionis peftis, morbofique in falubrem ftatum mutationis pendere arbitror, quando nulla alia ex confervatricibus caufis, quas vulgus medicorum res non naturales appellat, ä̈re excepto, ibi eo tempore appareat, in quam morbofi ftatus in falubrem mutationem referre poffimus. Ideo neceffarium erit, hujufce mutationis caufam aëris mutationi acceptam referre: \& quoniam tunc aër mutatur ab $æ$ ftuante calore, inæquali, in minus calidum, \& æqualem, atque continuum, mirum non erit, fi quemadmodum prius aëre à Campfinis ventis, calore fuffocante, atque inæqualifímo, quippè modo calidifímo, modò frigido effecto, ac vigente, morbofus ftatus obfervabatur; ita eodem in minus calidum, atque in æqualem, \& continuum mutato, etiam morbofum ftatum in falubrem mutari, non immerito dicendum erit. Corpora enim in hoc aëris ftatu valde calido, continuo, ac omnino æquali, femper calefaciente, difflantur, aperiuntur, evacuantur atque exficcantur. Nam quifque per id temporis frepiffime per diem largiffime exudat, quo fit, ut peftiferum etiam contagium ab aëris infigni \& affiduo calore exolvi, atque diffipari non injuriâ fit credendum. A Nili fluminis facto augmento, aërem in hunc ftatum mutari poffe aliquibus forfi- 
tan videbitur, quòd eodem tempore, fcilicet Sole Solfticium tenente (cùm annis fingulis flumen crefcere incipiat die decima menfis Junii) conftantiffime obfervetur, hune aëris falubrem ftatum vagari. Quod fanè ita non effe oftendit illo tempore, quo ibi omne peftlens contagium abfumitur. Nili inerementum obfcurifimum, ac pauciffimum efle, ex quo aër non poterit ufque adeo alterari, ac à priori ftatu mutari, qui pòfit morbofum ejus ftatum corrigere, aut omnino tollere. Itaque illiufce fluminis incrementum effe in caufa, ut pertilentia illa definat, non erit credendum, quando alio tempore evanefcit peftis, \& alio flumen fuum fufcipiat augmentum: quod aërem multum alterare queat. Peftis extinćtio nihilominus conicidit cum fluminis augmenti principio, fed quia incrementi initia tenuia fatis funt, atque ita obfcura, ut vix ab omnibus dignofcantur, per id temporis inceptam efle illiufce auctionem ita, ut vel nihil, vel parum aër præfentis ejus temporis, à priori ftatu mutatus fit. Quomodo itaque aër vel nihil, vel parviffime mutatus tantam vim habere potuerit, qui pofit mutareftatum peftilentem in faluberrimum? certè nemo hoc affirmare audebit, nifi dixerit etiam tolli peltilens contagium ab occulta aliqua caufa; veluti principium quoque augmenti fluminis illius per fingulos annos, eodem menfe, die, \& hora conftantifime ac femper obfervatum, ab eadem occulta caufa pendere multi mon immeritò affirmant, quando hujus perpetuo incipientis augmenti caufam poffe naturæ principiis indagari, ac verè cognofci, nullo modo poffe fieri mihi videatur. Hincque ancipites non immeritò fieri, quod Nili aquæ illud augmentum ex pluviis Ethiopum principium habeat, quoniam nullibi pluviæ femper fieri incipiunt eadem tum die, tum hora, ut poffint eadem die femper flumen aliquod augere; quod fi verum effet, utique dubitare omnes poffent, caufam generationis pluviarum, in aëris temperiem inconftantiffimam referri debere. Quare non videtur verum effe, peftis illam diffolutionem tempore eodem, quo flumen augeri incipit, obfervatam, poffe a Nili augmento caufam habere. An vero ipfa referri poffit in Etefiarum fpirationem, quando hi venti tunc fpirare incipiant, 
Jiquatis nivibus, glacieque locorum Septentrionalium, fed Græciæ aliorumque Afiæ minoris, quæ funt Agypto proxima, quæ habent excelfos montes, à quibus nives calore liquatæ halitus Egyptiis locis mandantes, illos profectó ventos efficiunt. Non puto igitur ab re nunc ex te dictum efle, illos ventos incipientes flare in $\mathbb{E}$ gypto, Sole Cancrum ingrediente, \& perdurantes fere toto menfe Augufto, efle Etelias. 'Tu modo perge ad inceptæ reliquum orationis. ALPIN. Ab his igitur ventis aërem alteratum, efle caufam, cur peftis illa diflolvatur, multi illorum affirmant. Quod etiam non videtur penitus a veritate alienum, quando id multis etiam rationibus nobis perfuaderi pofit, in primifque ex contrariorum naturæ ratione: namque nulli dubium eft, auftrinos eos ventos, quos diximus ab iis populis Campfim nuncupari, natura ac qualitate opponi Septentrionalibus Etefiis vocatis: Quod cum verum fit, non erit mirum, diverfum planeque contrarium ftatum, cum Etefii venti dominantur, aërem habere, ab eo, qui Campfinis oppofitis fpirantibus prius obfervabatur. Ideo fi his vigentibus in aëre ftatus aëris fuerat morbofus, procul dubio ipfis abforbtis, Etefiifque oppofitis flare incipientibus, conftanterque flantibus, in oppofitum, qui eft falubris, ipfum mutari debere affirmandum erit. Accedit natura Etefiarum, quæadverfatur peftilentibus conftitutionibus, quemadmodum auftrina putrefactionibus favere, obfervatur. quod Gal. in primo lib. de temp. ita fcriptum reliquit. Deprebendas ex Borea, qui ficcus natura Eै frigidus ventus eft, omnia quàm diutifime imputria dusare, contra putrefcere facillime aufrino flatu. Amplius particulatim Gal. hos ventos aëri falubritatem inducere in multis locis non docuit; in lib. enim 3. epidem. dixit: Si Etefia in ceftate fiant, multa mala probibere, qua iis non flantibus fierent: ideo de peltilenti ftatu inquit. Quo tempore $\sqrt{2}$ Etefice fpiraffent, morboCap. Jum bumani corporis Jtatum omnem abfterfifjent, ALftatem Etefiis carentem admodum morbofam effe pluribus in locis fcriptum reliquit. Et proinde Hipp. æftatem peftilentis naturæ defcribens, ait : IEftas ferena erat $\mathcal{E}^{2}$ calida, magni erant aftus. Etefice parve difperfim fpiraruni. Ex his igitur dicere poffumus I 2

3. Epid. com. 3 . tezt. 75. 


\section{PROSPERI ALPINI}

illiufce peftis abolitionem vel extinctionem ab Etefiis tunc flat re incipientibus, aëremqae in oppofitam temperiem mutantibus, non parvam occalionem, vel caufam habere poffe. Dicunt etiam multi, quod calor æeftatis immoderațus diu durans, abfque quod contrario aliquo frigido vento diffletur, ac ventiletur, non poterit diu fervari, quin corrumpatur vel putrefcat, veneficamque acquirat qualitatem. Non poffe vero peftem illam extingui atque deleri ab Etefiarum fpiratione, hinc etiam. dubitari poteft, quòd peftis in multis locis, quamquam Etefiæ: valde fpirarint, non fuerit extincta: ut in pefte anni. 1575 . Patavii obfervatum eft. Itaque cum ex nuperrime dictis de his: dubius non parum hac eadem de re fim, obfecro, ne te pigeat, de caufis, quibus illam apud Egyptios peftilentiam deleri putas, tuam fententiam proferre. Gulland. Pettilens contagium. totum per illud temporis perpetuò annis fingulis extingui, fcilicet menfe Junio, cum Sol primam cancri partem ingreditur id ex aëris mutatione accidere mili videtur, quando nulla alia-: rum fanitatem confervantium caufarum obfervetur ibi effe, quæa id facere queat. Aërem vero ipfum ex morbofo ftatu.in falubrem mutari tunc temporis ex particulari. temperie fufcepta, alienum effe à veritate non judico. Is etenim, uti ex te-audivi, eo tempore fit priori minus calidus, quamquam valde \&: iple calidus fit, fed continuus, æqualis, eodemque modo perpetuo conftans, qui fi quas fufcipit alterationes ac mutationes, illas non confertim, fed fenfim ac fenfim recipit: Quo. fanè tempore ab ipfo corpora (cum remiferit calor ille æftuofus à Campfinis ventis evectus, fuffocans) melius fe habent, eumque calorem facilius ac melius perferunt: quoniam is tunc. habet calorem à colo, cui illa corpora jam affueta funt, in. ipfoque nata, non autem à ventis, veluti antea fuerat, ad'venam temperiem ipforum aëri inducentibus. Hincque rqualis. $\&$ conftaris fit, quòd à ventis mutationem nullam fufcipiat. Illo itaque aëre tunc multum calefaciente, atque perpetuo eodem. modo.perfeverante, corpora ipforum admodum exudant, aperiuntur, atque ficcantur. quibus tum in ipfis corporibus, tum in veftibus, aliifque omnibus fupellectilibus, omnis excremen- 


\section{DE MEDTCINA FGYTIORUAS. LIB:I.}

titia humiditas diffolvitur, atque confumitur, eaque maxime, in qua peftilens illud contagium fundatur, atque ab ipfa fove: tur. A vehementi aëris caliditate omne contagium diffolvi poffe, vel omnes mulierculæ fciunt, quæ laneos pannos, ceteraque domorum fupellectilia quovis contagio infecta, per multos dies Soli, ut aj his contagii omnem furpicionem abigant, exponunt, neque longa experientia, ut cognitum eft, lua fpe unquam fruftrantur, reddentes hæc omnia ab omni contagio munda, ac libera. Atque hinc mirum utique non eit, fi hi populi infecti peftifero contagio, aëri fumme calido, æqua: li, corpora mulcum difflanti, aperienti, tum per infenfibilem tranfpirationem, tum per copiofum, affiduumque fudorem evacuanti, \& exficcanti expofiti, ab eo liberi fiant. Certum enim eft, ac apud omnes ibi obfervatifimum, omnia corpora per id temporis fumme diffari, fudoribufque affiduis copionifque, ac infenfibili tranfpiratione exficcari. Quæ quantum conducant ad abigendam è corporibus omnem putredinem, neminem medicorum ignorare certò fcio, qui tamen in Gal. fcri- Cap. 4. ptis fit verfatus. Namque is in I. lib. de diff. feb. hos duos effe præcipuos fcopos ad præfervanda corpora à peftilentia dixerat, his verbis: Erat autem eorum. fumma, ut of íendit idem Hip. pocr. ipfa putrefaciio. quod cum nos previdilfemus ftatim ab initio, qucecunque corpora bumida videbamus, omni via exficcare conaba. mur. que vero fisciora, in iis antiquum babitum confervabamus. at in quibus Juperfluitates redundabant, hece purgationibus fanabamus: Objtructiones.autem foraninum aperire, atque abftergere ftudeba. mus. Pauloque poft dixit: una. fiquidem ac prima eft in omnibus communis intentio, quod.corpus quàm maxime fuperfluitatibus vacet, atque optime fpiret. Quam obrem, quod ea aëris temperies admodum corpora exticcet, atque difflet, exiftimo non immeritò fore putandum, inde abfumi eam peftilentiam, ejufque omne contagium, exficcato filicet vel diffoluto ab eo calore aëris humido in pannis, \& omni fupellectili. vefte, qua putredo, ejufque contagium forebatur, atque iis corporibus evacuatis, exficcatifve, atque difflatis.. A L P IN. Hæc veritas videtur non parum obfeura, ac dubia, cum in prima ærtate, K. 3

vel: 


\section{PROSPERI ALPINI}

vel æftatis parte, in qua fummam vigere peftilentiam diximus, oporteret etiam eandem corporum vigere falubritatem, quando aëris tune fumma caliditas queat \& ipfa omnem contagii humiditatem à pannis, cæterifque aliis fupellectibus confumere ac refolvere, non minufque illorum corpora, tum per fudorem copiofum, tum per infenfibilem evacuationem exficcare, atque difflare. GUILAND. Intelligere arbitror ex his, unde tibi orta fit hæc difficultas, refpondeoque, aërem primæ æitatis partis etfi calidifimus fit, ea utique efficere non poffe, tum præ immoderata caliditate ferè animalia fuffocante, tum præ ejus inæqualitate, namque ut dixi, poftquam æifuantiflimi Campfini flârint, fubito oppofiti validiffime ipirare folent, frigidi, quibus neque contagii humiditas confumi poteft, cum calor diu non perfeveret, neque corpora exficcentur, neque difflentur ob eandem caufam. Calor etenim ejus prioris ftatus non eft aptus, ut putredinem deleat, fed potius ipfam concitet, quando ab eo nativus calor fumme labefactetur, ac exolvatur. Nam corpora fuperfluitatibus fcatentia, ad hoc; ut à putredine ipfa vindicari poflint, non folum exficcatione, que fieri poteft ibi præ intenfo calore molita evacuatione vel per fudorem, vel per halitus, opus habent, verum non minus difflatione atque naturalis fpiritus, calorifve reftauratione, aliter calor nativus diffipabitur: in aëre vero immoderatè calido corpora evacuationibus exficcari poffunt, \& difflari, fed non reftaurari vitales fpiritus, qui fola refrigeratione, quæ fit frigidi aëris infpiratione, nutriuntur, foventur, atque reftaurantur. Hincque fecundxe æftatis affiduus calor calidus, continuus, æqualis ac uniformis poterit corpora exficcare, ipforumque meatus aperire, atque Etefiis fimul frigidum temperatum fpirantibus toto illo tempore, corporum etian vitales fpiritus poterunt teftaurari, ac foveri. Nili vero augmentum eodem tempore inceptum poffe huic aëris falubritati conducere, planè ignoro. quod tunc \& obfcurifimum fic, atque etiam, quia potius humiditate, quàm ficcitate aërem refert, atque alterat; qux aëris qualitas omnino inutilis ad tollendam putredinem cognofcitur, quando potius omnem putrefactionem pro caufa, in qua fit, humiditatem 
habere omnes noverint. Hæc idonea judicavi, quæ propofitam dubitationem probè folvere potuerint, quippe Junio menfe omnem peftilentiam, ejufque omne contagium aboleri ex aëris temperie calida, æquali, uniformi, atque continua, Etefiarumque fpiratione, quibus corpora, tum per fudorem, tum per infenfibilem tranfpirationem exficcantur, difflantur, atque refrigerantur. \& hæc de pefte loca $\not E g y p t i$ invadente fufficiant. tuque perge alia enarrare. ALrsn. Omnia jam una die, quire in ipfa dicenda propofueramus, peracta vides, effetque ad alia tranfeundum. Sed quia nos Solem fub horizontem defcendere perfpicimus, in aliam diem aliis de rebus fermonem differamus; ad ipforum autem medicinam mane accedemus. Domum itaque eo, atque huc mane Deo annuente revertar. Quidque tunc præcife fit dicendum, fimul terminabimus. Vale. G U ILAND. Vale \& tu, dum huc etiam veneris. Diluculoque in viridario me conferam, atque te, ufque dum redeas, expeEtabo.

\section{F I N I S P R I M I L I B R I.}

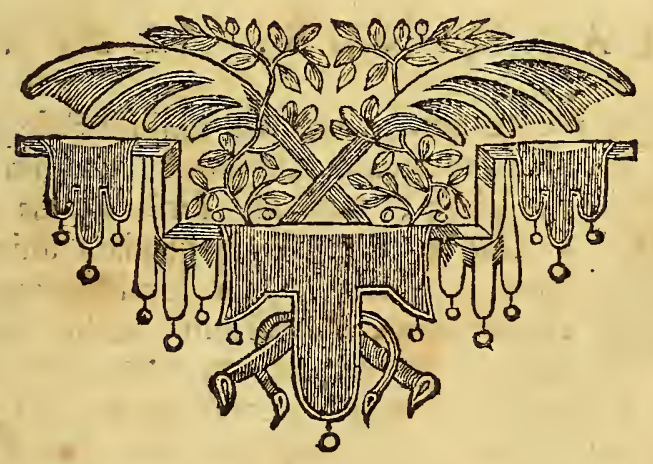


Pag. 80
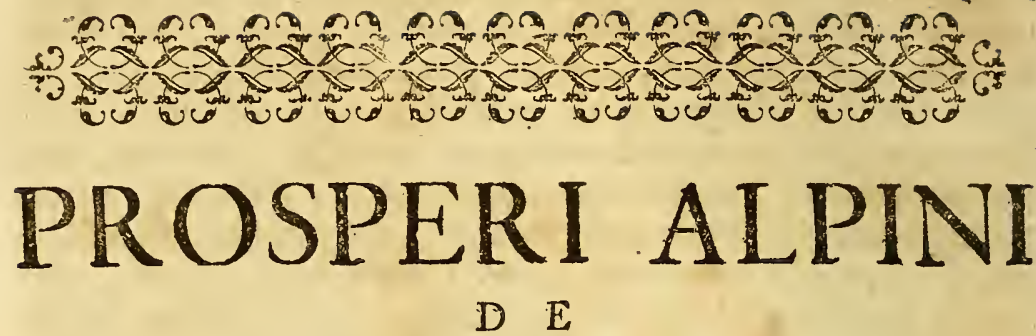

MEDICINA ÆGYPTIORUM.

L I B E R P R I M U S.

C A P. I.

De ufu mittendi Sanguinem, apud CEgyptios Medicos frequentato, ov cur apud ipfos fanguinis vacuatio fit familiarifimum remedium.

G U I L A N D I N S, ALPIN US.

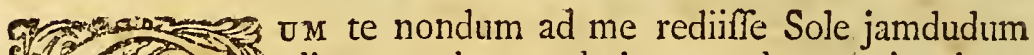
C. 3 diem aperiente admirarer, demum in via te

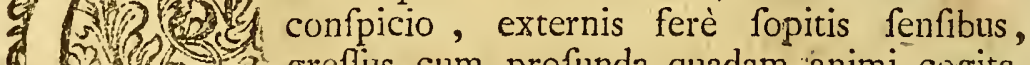
8. 30 greflus cum profunda quadam animi cogita-

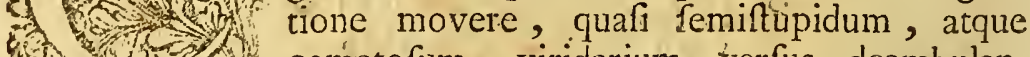
120 comatofum, viridarium terfus deambulantem; à qua tamen non aufus fum te revoca$\mathrm{re}$, ne tuam aliquam voluptatem perturbarem, fed quid iftud eft, quod tu ambulando ita prfundè cogitas, atque ita altius comtemplaris? A trin. Ne fruftra tempus conterem, cundo, atque more Peripateticorum deambulando, varia prefidia, quibus $\mathbb{E}$ gyptii medendo utuntur, in memoriam revocabam, 
materiamque ita paratam mecum ipfe reputabam futuram de ipfa hodierno die tractationem, ne ego, ubi te in viridario conveniffem, in mora interim effem noftris jam cæptis fermonibus. Guiland, Recte fanè fecifti, eam te nunc, ubi in hujufce amoniflimi viridarii fecretiori folito receffu ambo convenimus, referre æquum eft. A LPIN. Tres effe medicinæ curarricis partes, (quas fontes auxiliorum, vel præfidiorum vulgus medicorum appellat.) omnibus manifeftum eft, ea fcilicet, quæ victu; quæ medicamentis, \& quæ manu exercetur. Has vocant noftri direteicam, pharmacenticam, \& chirurgicam. Prima omnem victus rationem continet, quæ rgiotis conducit; fecunda medicamentorum ufum complectitur; tertia ea præfiảia pertractat, quæ manus operâ adhibentur. Cum itaque omnes hæ medicinæ partes juxta illorum populorum ufum. percurrendæ nobis fint, ne quidpiam ad medendum utile omittamus, in primis à poftrema parte exordiri, ab hiftoria quippe auxiliorum, quæ manu exercentur., optimum fore judicavi, præfertimque à mittendi fanguinis ratione, quam illi fequuntur, quòd hæe medicinæ pars apud ipfos in curandis morbis fit ceteris partibus ufitatior, atque familiarior. Præcipua vero hujufce partis capita, de quibus nunc inftituenda eft oratio, eundo \& cogitando, priufquam huc perveniffem, planè firmavi. Quæ omnia nihil aliud decernunt, quàm mittendi fanguinis rationem, atque ufum apud Egyptios frequentatum, tum nonnullas etiam ufus partes variis morbis addictas, inurendi, cauterizandive, atque quafdam etiam præcipuas alias chirurgicas operationes, tum ad fuppuratos, tum ad hydropicos, tum ad illos, qui ex lapidibus in vefica dolent, atque ægro. tant, ad aliafque etiam multas affectiones. Sed quid in his amplius moror? melius eft, ut de his nunc loqui incipiam, ne inceptum hunc diem fine longa linea abire finamus. Guil. Jam his præmifis , tempus eft, ut ad ufum mittendi fanguinem apud ipfos frequentatum, te conferas. Ideo, fi lubet, incipere poteris. A LPIN. Communiffmum eft, admodumque familiare in tota Egypto medicum præfidium, quod fanguinis miffione tractatur. Ita, ut omnes cujufque fexus, atatis, comL. 
plexionis, quocumque anni tempore, in quovis morbo libentiffime largius, fæpiufque variis modis mittere fanguinem confuefcant. Omnefque fanguinis evacuationem libentius, quàm alia medica præfidia admittunt. Quifque etenim huic remedio nimium confidens, ipfum quocumque morbo correptus magna fpe arripit; idque triplicem ob caufam, in primifque, quòd omnibus plane perfuafum fit, ut fuperius dictum eft, quofibet ferè morbos ibi vel à caliditate omnimoda oriri, vel cum aliis caufis caliditatem etiam adeffe. Ex quo quælibet fanguinis evacuatio multum refrigerat, fanguinis miffione ita facile utuntur: Secundo, ibi quifque arbitratur, corpora illa multo fanguine abundare, ob largum aquæ Nili fluminis ufitatum potum, quæ ut illorum eft opinio, tota in fanguinem vertitur, vimque gignendi fanguinem ipfam ex eo tempore putant adeptam ex quo Mofes Dei præcepto aquas in fanguinem mutavit. Demum addunt etiam, ea corpora non effe mali fucci, quæ cachochỵma Græci vocant fed boni multique fanguinis, quæ plethorica plenitudine correpta, dicunt. Guiland. Omnium morborum caufam præcipuam habere, caliditatem, quod ifti autumant, planè falfum, atque à veritate alienum eft; neque hoc ulla egere demonftratione, exiftimo, cum nulla es parte id verum effe poffit: nam fi ex uno homo conftaret elemento, utique, nt dicebat Hippoc. non doleret. Corpora enim variis. pro varietate præcipuorum membrorum, naturis conftant, variifque humoribus redundant, adeo, . ut interim à caliditate, unoque humorum exfuperante laborent, \& interim à frigiditate, ac alio humore, vel aliquando à multis fimul junetis. Et fi corpus aliquod calidis præcife morbis, ob ejus temperiem, obnoxium erit, non tamen omnino. Redundare vero. plurima ipforum multo fanguine utique verum eft; quoniam onnia eorum vifcera quo ad calorem, ut dictum eft, temperamento, omnes cibos in bonum fanguinem mutant; veluticontra, cachochyma corpora mali temperamenti caufâ, quofcunque etiam òtimos cibos in malum fanguinem vertunt. Atque hine ufus mittendi fanguinem ita apud eos invaluiffe dici poteft, quando ex omnibus medicis prafidiis, omnia fere corpo- 
ra, quia fanguine potius, quàm aliis humoribus plerumque offendi foleant, fanguinis evacuatione promptius juventur. ArPIN. Verum dicis, fed de fanguinis evacuatione, idem, quod ex ufu alterantium medicamentorum illis alias eveniffe dictum. eft, contingit. Etenim quia illorum locorum populi, ob ca. li, fub quo degunt, multam caliditatem, putant omnia illorum corpora effe fumme calida, atque à calore fere femper affici, minimeque à frigore, quæ corporum credita temperies omnem calidorum medicamentorum ufum eos abhorrere coëgit; frigidaque complecti, atque frequentare: non fecus quam. etiam frigidorum locorum accole immodice calidis operam dare, à frigidis timere confueverunt, ita Egyptii in miffone fanguinis fe gerunt, putantes corpora omnia, tum à calore ob coeli ftatum pati, tum à copia fanguinis, quòd affidue ipfa multum fanguinem congerere arbitrentur ; \& quia fanguinis evacuatio utrique incommodo prompte, ac tutò fuccurrit, quo. niam tum refrigerat, tum plenitudinem demit, libentifime eam amplectuntur; fanguinemque largius, tum frequentius quàm deceret, atque neceffitas expofcere videretur, in omnibus pueris, juvenibus, viris, fenibus, mulieribus, eunuchis, atque in quocumque cœli ftatu, \& tempore anni atque morborum differentia fæpiffime vacuant. Demum eò redacta res eft, ut tantum evacuationis fanguinis viribus fifi incumberent, ut alia auxilia fpernentes, hoc immoderatè utantur; valdeque in ufu hujus præfidii errare mihi videntur: quando tum largius, tum crebrius quàm deceret, audacter mittant fanguinem, atque adeò in multis, in quibus pluribus de caufis hoc re. medii genus non conveniret. Dictum fiquidem eft, multa ex illis corporibus ad frigidam temperiem inclinare, hincque \& pinguiffima ibi multa, \& pleraque mollia, rarique habitus, \& facile dilolubilis effe; his nulla fanguinis evacuatio familiaris effe poteft, ut Gal. in lib. de curat. per fang. miff. teftatum reliquit. Quamobrem hoc remedium multis opportunum, in omnibus ab ea gente ufurpari non eft laudandum. GUILAND. Non rectè hoc intelligo, fed accuratiorem, atque abfolutiorem illorum corporum temperamentorum cognitionem ex te li- 
benter audirem; fine qua fieri non poffe videtur, ut mittendi fanguinis ratio apud illos nobis innotefeat; proinde itera milhi rurfum ÆEgyptiorum corporum temperamenta. ALpin. Sed ut rectè ea cognofcere poffimus, primo inveniendam effe puto rationem illius, quæ in variis corporibus eft temperies, atque habitus. Quæe recte explicata, facilius illorum hominum naturas, atque habitus varios demonftrabunt. GuiLand. Verum dicis, atque ut commodius videtur, fatagito.

\section{A P. II.}

De ratione variorum corporum temperamenti, atque babitus, deque Egyptiorum vario tempera. mento, \& babitu.

\section{A L P I N U S.}

Cun corporum eorum, qui Kgyptum habitant, temperies atque habitus rurfum accuratius à nobis fit cognofcendus, ut apud ipfos mittendi fanguinis ufus rationem vere confequamur, prius univerfali quadam via ratio varietatis temperamentorum, atque habitus à nobis eft cognofcenda. Siquidem illorum corpora omnia effe fanguinea, fanguineque multo abundare, neque dici poteft, neque utique verum eft. Nufquam enim corpora omnia unico predita temperamento obfervantur. Neceffarium etenim eft, ubique multa ex variis conflata temperamentis reperiri, fcilicet qux fanguinis, quæ pituitæ, quxe bilis, quæ melancholia naturam fint adepta. qux temperamenta fequuntur cordis, hepatifque temperaturam: ab his fiquidem duobus membris univerfum corpus propriam nancifci temperiem Gal. in lib, artis medic. teftatum reliquit, vel etiam ab alterius illorum dominantis temperamento. Qua quidem ratione quale utriufque membri, vel prevalentis temperamentum, atque habitus erit, tale obfervabitur in univerfo corpore. Quo fit, ut fi alicujus cor heparque fimul calidum humidumque tem. 
temperamentum â nativitate obtinnerit, idem in univerfo corpore intueri fit neceffarium, idemque erit totius corporistemperamentum, quod in hepate cordis temperamento prævalente, vel in corde hepatis temperiem vincente, obfervabitur. $\mathrm{Ex}$ quibus dici non immerito poteft, Socrates conftat calido humidoque temperamento, igitur vel utrumque ejus membrum, cor \& hepar, erunt calida \& humida, vel ipforum alterum alteri prævalens, Corporis itaque totius hoc temperamentum prædictorum duorum membrorum, vel alterius altero prævalentis naturam fequi eft neceffarium, veluti calidum \& ficcum, biliofum cordis \& hepatis fimul, vel alterius alteri dominantis caliditatem \& ficcitatem. Et frigidum ficcumque melancholicum, frigiditatem \& ficcitatem, frigidumque \& humidum, pituitofum, frigiditatem, atque humiditatem eorundem vifcerum, vel unius tantum, quod alteri prævalet, naturam fequitur. Hrcque funt omnia compofita corporum temperamenta, quæ à temperamento cordis atque hepatis fimul, vel alterius horum alteri prævalentis, proficifcuntur. Cum igitur univerfum aliquod corpus caliditate $\&$ humiditate conftat, quod temperamentum fanguineum dicimus, illius corporis utrumque fimul cor, atque hepar calidum \& humidum temperate affe, vel alterum illorum non temperate, fed intenfe, ita, ut fi cor fic calidum \& humidum diftemperate, hepatis temperatam frigiditatem ac ficcitatem fuperare neceffarium fit, \& eodem modo hepar, fi hanc ipfum obtinuerit temperiem, ac cor ei obfliterit. Si vero cor \& hepar æque oppofitæ fuerint naturæ, ita, ut cor tantum fit calidum \& humidum, quantum hepar eft calidum ac ficcum, atque è contra. temperiem corporis totius temperatam efficient; quod fi cor caliditate hepar fuperaverit, totum corpus tantum in caliditate excedet, quantus erit caloris cordis exceffus fupra hepatis frigiditatem; quemadmodum fi excefferit hepar frigiditate cordis caliditatem, tantum fieret corpus frigidum, quantus erit exceffus frigiditatis fupra caliditatem cordis. Hæcque funt corporum temperamenta, modo nuper dicto à temperie cordis \& hepatis prodeuntia, ac genita, qua omnia non in une, veluti neque illorum unum tantum tens- 
peramentum, in omnibus hominibus reperitur. Quod quam? obrem fit, id eft cur omnia corpora non uno eodemque temperamento conftent, fed multis ac inter fe variis, ex te nune libenter difcerem. Guiland. Miror cur, cum tu fis adeo aftronomis addictus, hujus rei caufam ab ipforum obfervationibus addifcere nolueris, quando omnes aftronomi corporum naturas à coleftis fchematis in hora nativitatis fupputati obfervatione fpeculentur. Confiderant enim, quæ coeli facies, in ea hora, qua quis natus eft, terris incumbebat; cœlum fiquidem in duodecim partes dividunt, \& in qualibet illarum (quas ipfi domus appellant.) confiderant fignum, quod ex duodecim coeleftibus imaginibus ea hora reperiatur, atque ex erraticis ftellam ibi fimul inventam; ex horumque omnium, fcilicet ex domo, figno, \& ftellis ibi ortus tempore obfervatis, judicium excipiunt, naturafque hominum venantur à prima domo, quæ eft orientalis coeli pars, \& ex figno ac ftellis, quæ in ea domo inventa fuerunt, vel eam domum refpiciunt. Tuam itaque naturam calidam humidamque illi affirmarent, quoniam in tuæ generationis fchemate libra afcendens obfervatur, quam naturam ab eo libre figno manifeftari ajunt calidam humidamque temperatam, hincque etiam hilarem ac muficx non minufque veneri deditum hominem fignificari, à venere libræ domina ; literarumque ftudiis prefertimque aftronomix, philofophix, medicinæque operan te maxima delectatione deditum, Mercurius in nona domo in figno Geminorum clare judicabant; eodemque etiam in nona invento, nuper dictarum fcientiarum caufa te longiffimas peregrinationes, faftidiofiffimaque itinera profecuturum. Sed cur ego de te tanta ex aftronomorum mente loquor, de quo exempli caufa dicendum fufcepi, ut oftenderem. cum aftronomis, hominum temperamenta, ac naturas ex figni natura, atque ftellarum, orientis in prima coeli domo inventarum cognofici. Sed iftis caufis, omiffis alix ad hane rem firmiores ac veriores funt indagandx. Alprs. Gratiffimum mihi fuit ea ex te audivifie, quibus meam ad aftronomorum obfervationem naturam retulifti: quæ cum haud planè verum attingrant, perge modo phyfice magis me docere, cur varii homi- 
nes inter fe variis conftent temperamentis, vel naturis. GurLAND. Qui de natura fcripferunt, in multis hominibus diverforum temperamentorum, vel naturarum caufas, verius, ac manifeftius nobis demonftrarunt. Namque Ariftoteles omnium philofophorum facile primus in lib. 2 : de phyfico auditu affr- Text.26. mavit, Solem atque hominem, hominem fanè generare, ut ipfe doceret, ad animalis generationem duo agentia effe neceffaria, quippe agens proximum, atque remotum : proximum eft homo, qui ut animal ad fui fimilis generationem, agit. Sol vero eft una ex caulis efficientibus remotis; qụæ etiam concurrit ad eandem animalis generationem adjuvandam, \& efficiendam. Agunt vero utraque in materiam bene difpofitam ad agentis formam introducendam. Tria itaque ad noftrorum corporum generationem prima concurrunt principia, quarum primum elt cœlum, utpote caufa efficiens, fub qua omnia cœleftia corpora comprehenduntur. Secundum eft homo, mas fcilicet \& fæmina. Tertium materia, ex qua homo generatur; id vero eft femen humanum. Qualis igitur temperamenti erunt hæc generationis principia in homine gignendo, talis itidem homo genitus erit, quando perpetuo verum fit, generatum generanti effe fimile. Siquidem omne agens vel animatum, vel inanimatum, agit, ut fibi fimile generet, hincque quodlibet generatum erit fimile generanti, \& generans generato. Alprs. Mihi non omnino hæc veritas manifefta videtur, cum -multi homines iis, à quibus geniti funt, haud planè fimiles exiftant. Plures etenim filii patribus ac matribus diffimiles apparent; quod quidem non effet, fi generata omnia, iis, quæ generant effent fimilia, \& generantia generatis. Guiland. Aliam fufcepifti nunc quæftionem folutu non ita facilem, quam: nunc ut diffolvam, neque locus, neque occafio de qua loquimur, expoftulat. Multa tamen funt, quibus efficitur, ut generati hominis patris, ac matris fruftretur fimilitudo. Sæpe enim accidit fotus fimiles produci cuipiam vel viro, vel fæminæ in hora coitus imaginatis. Legitur mulierem fæpe coeundo, Etthiopis nigri pictam figuram intuendo, atque imaginando tandem nigrum filium peperiffe, Hinøque affirmant mul. 
multi adulteras mulieres præ timore, ne à maritis in adulterio comprehendantur, affidua de illis dum coëunt, cogitatione fiJios maritis fimiles parere. Egroti itidem femen vitiatum habentes, fimiles ipfis natos efficiunt. Semina etiam avorum vel aliorum confanguineorum aliquando vim retinuerunt, â quibus juforum fimilitudo in conceptis non rarò efformatur, atque exprimitur. Ceterum tametfi aliqua occafione generatorum à generantibus figura deformetur, tamen natura generatorum (quam philofophi intelligunt) nihil ab iis, quæ generant unquam mutatur. Quales enim erunt caufarum ad generationem concurrentium naturæ, tales quoque erunt eorum confitutiones, quæ ab iis generabuntur. atque in hunc fenfum non errat philofophorum fententia, quæ femper generantis \& generati fimilitudinem docet, ideo generans fimile eft generato, \& generatum generanti naturà, atque fpecie. Præcipuum igitur agens eft colum; fub quo comprehenduntur omnia corpora coeleftia, quod agit (ut Ariftotelici ajunt) in hæc inferiora fublunaria motu \& lumine. In qua igitur orbis parte Sol, qui ex omnibus illis caufis in hæc inferiora efficacius agit, majorem inducet calorem, generata omnia naturâ, vel temperamento calido referentur, atque ubi. parum calefacit, minus etiam calida animantium corpora obfervabuntur. In qua re in primis occurrunt terrarum regiones confiderandæ, locorum fitus, annique tempora. Quicquid igitur temperatis in regionibus, \& locis, ob fitus rationem temperatis, atque ex annitemporibus in vere producetur, temperato procul dubio temperameito conftabit, maximeque, fi natura animalis utriufque generantis, fcilicet maris \& fæminæ, temperata \& ipfa fimul fuerit. Semper enim in temperata regione, \& loco, \& in vere ex anni temporibus, homo à temperato homine proximo generante, genitus erit temperamenti temperati, idcirco ei ex quo ipfe genitus eft, temperamento temperato erit fimilis. Homo enim locum habitans temperatum, fi temperati fit unà temperamenti, \& ex anni temporibus in vere hominem generaverit, ei naturâ, vel temperamento omnino fimilem efficiet. Si vero if hæc omnia agentia inter fe fimul unico non conftabunt 


\section{DE MEDICINA EGYPTIORUM. LIB. II.}

bunt temperamento, fed potius invicem difrepabunt, non omnino generati generantibus caufis fimilitudo refpondebit. Similitudo fiquidem naturæ id quod aliis præftabit abfque dubio fequetur. Ut fi exempli gratiâ, quifpiam ex patre nafcitur temperato, fed in colo minus temperato, naturâ fimilis magis patri quam colo, erit. Siquidem in generatione magis poteft agens proximum, \& particulare, quam remotum \& univerfale: quam ob caufam quando agens proximum, \& agens remotum inter fe differunt. proximum ferè femper fuperabit remotum, ubi præfertim vis agentis remoti non ita fit præpotens, ut polfit vim proximi agentis fuperare, veluti exempli gratia, fi daretur aliquis., qui temperamento natus temperato, in Ethiopia maximis caloribus hominem generaret, abfque dubio hominis illiufce generantis natura vinceretur à vehementiffimo illius regionibus calore, ibique natus ob id homo magis caufæefficienti., videlicet cælo, quàm proximo agenti quippe patri, temperamento fimilis conftituetur. Quando igiwur omnia generationis principia fimul in una natura inter fe conveniunt, efficiunt partus eis omnino fimiles: ac illis inter fe diffidentibus geniti fimilitudo illud fequetur, quod aliorum vires fuperabit. Hinc colligo homines multis variifque conftare temperamentis, ob variam principiorum vel caufarum ad generationem concurrentium vim, atque potentiam: etenim ex patre calidi temperamenti homines orientur, eodem itidem temperamento præditi, nifi cœli prævalida frigiditas patris temperamento calido obftiterit. Nam ea immoderata ob regionem, vel locorum fitum, vel anni tempus hybernum exiftente, homines temperamenti potius calidi, quám frigidi producentur. Atque fi pater \& colum calidi fuerint temperamenti vel frigidi, foboles calidam vel frigidam itidem naturam præ fe feret. Si vero paterno fanguine calidi exiftente temperamenti, cceli obftiterit frigiditas non multa, homines geniti potius calidi, quam frigidi erunt temperamenti. Et è contra, fi homo generans frigidi temperamenti fit, in cxloque moderate calido, generabit boninem quoad temperamentum frigidum. in coloque immoderate calido, calidum efficiet. II Hæc- 
Hæeque erit naturarum temperamentorumve diverforum in hominibus ratio. Alpin. Næ tu omnia, quæ ad temperamentorum varietatem explicandam rationem attinet, doetiffime atque accuratifime comprehendifti. F.t nift materia medica $\mathbb{E}$ gyptiorum nos breviores effe cogeret, cuperem ex te etiam hac eadem de re uberiorem fermonem haberi. De quibus ego in libris de prævidendis morbis Cayri conferiptis multa literis tradidi. Unum tamen hic non effe prætermittendum cogito, quippè corpora in lucem cum prodeunt, vel ftatim enixa, uterumque egreffa, ex ambientis qualitate vel temperamento multum alterari, ita, ut corpora infantium habitus rariffimi, $a b$ aëre alterata facile accedant ad aëris temperamentum. Cum per poros cutis facile ambientis qualitas ad vifcera permeet, jpfaque ad fuum temperamentum alteret. Hoc utique verum efre, id nobis perfuadere poteft, quòd varia anni tempora, cujuflibet ætatis corpora ufque adeo alterant, \& mutant, ut fufcepti ab ipfis temporibus anni temperamenti, varia humorum redundantia clariffimum fit argumentum, hyeme corpora, quòd ab aëre frigido alterentur, \& mutentur, frigidos humores gignere, ac coacervare, \& vero ob aërem temperatum, fanguinem, IEftateque bilem, ob caliditatem, \& Autumno melancholiam, ob frigiditatem \& ficcitatem. Itaque fi perfecta adultorum corpora, denfiffimæ cutis, ufque adeo ab aëris mutationibus alterentur ac mutentur, quid in tenellis corporibusinfantium continuò ex utero, egrefis fieri judicabimus? Ipfa videlicet quamplurimum ab ambientis qualitate alterari, \& mutari. Quod non videtur ufque mulierculis effe ignotum, aliquando dicentibus, homine in hyeme nato à frigoreque facile patiente, mirum non eft, fi hic homo ita à frigore multum ac facile paciatur, quando in lucem proditus hyeme fuerit. Quanobrem exiftimo, corpora ftatim enixa à coelo maxime alterari ac mutari, præfertimque, fub calidiffimo colo nata. Vehementifimus etenim aëris calor, quocumque modo fiat, remediis, quibus moderetur atque contemperetur, omnino vacat. Cujus quidem rei ego in aftivis ÆEgpti caloribus certum periculum feci. Trigido vero aëri multa ubique funt, quæ opponuntur, $a b$ 
ipfoque corpora defendunt. Ob quam rationem in calidiffimo aëre orti, quin à calore multum alterentur, \& mutentur, defendi nequeunt. Quod multò facilius fiet, fi ex homine calidi temperamenti etiam geniti fint. Si vero à frigido mare, atque fæmina gignantur, ambiens calidus aër eos reddet ad temperiem minus frigidam. Et qui ex calido femine, five patre matreque geniti in lucem eduntur fub colo frigido, quum ex calido proximi agentis hominis, \& frigido agentis remoti coli medium quoad temperiem exurgere fit neceffarium, temperatiori natura obfervabuntur. In calido vero cœlo, iidem fient calidiffimi. In aëre vero frigido inopes tantum alterantur ac mutantur, cum divites igne, pellibufque à frigore liberos defendant. A caliditate vero omnes patiuntur, contra quam nullum hactenus validum remedium inventum eft. Ceterum his auditis, de illorum corporum, qui ILgyptum habitant, temperaturis, atque habitus jam loquamur. GuIland. Ex cœliFy gytii ratione, atque ex incremento Nili fluminis, unà cum Septentrionalium ventorum flatu, qui per æftatis calores percipitur, aërem calidum ficcum, inæqualem, tenuiffimumque effe ex te audivi, neque in omnibus locis uniformem: quando aër locorum propè mare pofitorum longe minus fit, valdeque craffus . qui quoad humiditatem \& ficcitatem temperatus eft. In locis verò longe à mari pofitis aër calidior \& ficcior exiftit, fubftantiæque tenuioris. Ex quibus ratione cœeli illorum quidem corpora, ob temperatum calorem, atque humidum, temperata, fanguinea, habitufque moderate carnofi \& pinguis, horum verò calidiora, ficciora, biliofa, graciliorifque habitus effe colligimus. Quod tamen agentis tantum remoti ratione judicatum, nifi proximum quoque concurrat, non erit credendum; proinde de illorum hominum proxino agente, de homine filicet mare atque famina, ibi ad generationem proxime coëuntihus, tempeftivum eft te nune loqui: Alpin. Audita locorum Agypti, quoad temperamentum, diverfitate, atque probè habitantium illorum loci ratione perfpécta, unaque illarum naturarum diverfitate, qua in illos, aëris temperamenti ratione obfervari deberet, quæ tamen á proximo, tum agente, tum à M 2 
potus, ciborum, dulciumque balneorum \& veneris ufu mutata non obfervatur, de Cayrinæ civitatis hominibus agam, (idemque de aliis loca longè à mari pofita, habitantibus, erit intelligendum, quod de iplis nunc à nobis dicetur.) de ipforumque temperamento, atque habitu loquar, quando à cognita ipforum temperie, atque habitu, haud difficile aliorum locorum mari adjacentium hominum, \& temperamenta \& habitus intelligemus. Sunt vero ii populi triplicis differentiæ, ut etiam aliàs dictum eft, fcilicet urbanorum, qui in urbe degunt, Arabum extra urbem fub tentoriis habitantium, atque demum rufticorum, terræ cultui incumbentium. Primi corpora in caliditate, atque humiditate temperata obtinent, multi fanguinis, habiufque bene carnofi \& pinguis. Secundi, fcilicet Arabes, corpora biliofa, gracilia; Demum ruftici fqualidis corpcribus praditi funt, quæ melancholica exifunt, quòd à Solis caloribus exurantur. Quamobrem fingulos hos homines inter fe feminis differentiam habere diverfitati temperamentorum refpondentem, hinc colligi debet. Civium enim femen, quoad - Galiditatem \& humiditatem, temperatum erit: Et Arabum calidius, ficciufque ac biliofius, atque Rufticormm frigidius, ficcius \& melancholicum. Hæcque eft illorum fanguinis diverfitas, quæ tamen nunc ob aliorum populorum permiftionem. haudquaquam perfpicitur. Gurland. Ab advenis fortaffe, qui illuc ex aliis regionibus commigrarunt, illorum fanguis permutatus eft, apud eos facta multiplici Imperii permutatione. Extant advena multi, qui illuc ex quamplurimis locis, cum Ethiopiæ; tum Abiffiæ accefferunt; præfertimque mulieres mancipix, quarum utriufque regionis numerus fermè ibi infinitus exiftit. maximeque ex Abifiæ locis advecta. Hæ frquidem eam habent pulchritudinem \& gratiam, ut longè cariori pretio venundentur, quàm omnes aliarum omnium regio a num. Neque Esyptii eas ad domorum obeunda opera emunt, fed pro veneris ufu. Quam Trgyptii fanguinis mutationis caufam minime fpernendam exiftimo, quod ex te an fit verum melius audire expecto. A L PIN. Veris Agyptiis, (Chriftianis exceptis) nunc tota ea regio ferè penitus caret. Quorum ple- 
rique fanguinis temperamento dignofcuntur. Fuere autem, ut à multis audio, antiquitus temperiei calidioris, atque ficcioris, quippè biliofæe, fed tum aquæ fluminis Nili, tum frigidorum ciborum affiduo ufu corporibus ad frigidum mutatis, tale temperamentum illos accepiffe à multis proditum eft. In aliis vero fanguinis major varietas videtur, quando \& urbani omnes AEgyptii fanguinem permifcuerint mulieribus, Arabibus, Turcis, Syris, Damefcenis, Græcis, Italis, Slavonicis, Ungaricis, Pruffis, Tartaris, Abifinis, Rethiopibus, \& in omnibus Africæ locis Aigypto proximis ortis, in venere ufi. Sunt præterea ibi, ut alias dictum eit, homines etiam plurima. rum nationum, qui cum omnium locorum mulieribus coëeuntes, fanguinem illum evariant. quem neceffariò variusa quoque fequitur temperamentum. Sanguis etenim Rsyptiorum fanguini Turcarum, Armeniorum. Ungarorum, Tartarorum, Sclavorum, Affrriorum, Græcorum, Italorum, aliarum fimilium nationum colo minus frigido utentium permiftus, temperamentum conftituit temperate calidum atque humidum, fanguineum, \& cum Rgyptii, Arabibus, Barbaris, Abifinis, Ethiopibus, atque iis, qui 2 Eypti partem fuperiorem habitant, quam Sahit illi appellant, mifcentur, calidum, ficcumque biliofum, atque aduftum fanguinem reddunt. Duo itaque videntur effe illorum corporum temperamenta, quæ omnibus illis dominantur, fanguineum ficilicet vocatum, atque biliofum. Quæ illorum temperamenta maxime permutat ipforum frequentata victus ratio, ut fæpiffime hactenus à nobis traditum eft. Ufu etenim potus illiufce optimre aquæ, ciborumque vim refrigeratoriam habentium, dulciumque balneorum, corpora fumme biliofa contemperantur, fanguineaque evadunt, \& fanguinea $a b$ his, pituitofa fiunt, calore quippè hepatis refrigerato. Pituitofis vero ea vivendi raticne utentibus, majori facta caloris refrigeratione, valde humidum, atque frigidum temperamentum fuccedit; hincque Mulieres, Eunuchi, \& provectioris ætatis multi, pinguifimi ibi hac ratione facti confpiciuntur. Quamplures ibi reperiuntur naturæ temperatæ, ac multi fanguinis, præterea intempeM 3 


\section{PROSPER I A L P I N I}

ratæ ad frigidum, ex multa pituita. Non paucique ad cali: dum, ex multa bile, ac ad frigidum, per aduftionem fanguinis, in melancholiam vergentes, ut in quamplurimis Ethiopum, Arabum, Rufticorumque vifitur. Atque hæc de univerfá illorum corporum temperie à nobis dićta fint. Addo, ftomachum ferè omnes imbecillum, frigidum ex nuper dicto vivendi modo obtinere, atque ex cœlo fummè calido, quo utuntur, calore aëris calidiore nativum diffolvente, ad extimafque partes evocante.: ut æftate in noftris fieri corporibus obfervamus; atque ab immodico ufu veneris, qui quantùm ftomachum refrigeret, debilitetque, non eft alicui noftrum immanifeftum. Ad has caufas illorum ventriculum labefactantes, acceffit adhuc larga, ac crebra apud eos frequentata fanguinis miffio. Quæ quidem quomodo illis conducat, \& quomodo etiam officiat, pofterius confiderabimus.

\section{A p. II I.}

In quibus morbis CEgytii fanguinis miffone ut an. tur, atque in quibus corporibus.

\section{G U I L A N D I N U S.}

Dostearuam tu illorum corporum temperamenta, atque habitus ita accurate complexus es, nunc opportunum eft, ut ad evacuationem fanguinis apud ipfos confuetam redeas, deque hoc medico præfidio nunc loquaris: quandoquidem ita familiarifimum omnibus auxilium efle dixifti. In primis verò fedulo à te narrari cupio, quibus morbis eo auxilii genere ipfi occurrant; cum enim magnum fit remedium, atque in magnis tantum morbis, ut Hippocr. atque Gal. docuerunt, expetitum, eos in iis tantum curandis illo uti debere arbitror. AxpIN. Uf: que adeo familiaris apud ipfos facta eft fanguinis miflo, ut non modo in omnibus acutis magnifque morbis, verum in parvis qunque non minus eam adhibeant. Cujus inftituti caufa videtur effe, ut nuper ctiam dictum eft, ea, quæ ab illis omnibus corporum omnium fere illorum putatur effe plethora, five fangui- 
guinis redundantia, atque etiam, quoniam ipfi hoc auxilii genus multum refrigerare experiuntur, idcirco omnibus ferè morbis opportuniffmum id remedium arbitrantur, quando certifimum ipfis fit, ibi omnes morbos, ac fymptomata, coli calidioris, corporumque illorum ratione, à calida caufa præcipue pendere. Sed ut particulatim rem colligam ac perftringam, dico eos confugere ad miflonem fanguinis in omnibus puridis febribus, peftilentibus, \& non minus in variolis, puncticulifque peftilentibus, arque in omnibus internis inflammationibus, filicet, phrenitide, atque in ea phrenicidis fpecie, quam Dem el muja illos vocare diximus. fæpiffimeque in lethargo, in Angina, pleuritide, peripneumonia, hepatis, lienis, ventriculi fepti tranfverfi, inteftinorum, tenuium, uterique inflammationibus. In externis non minus copiofat utuntur fanguinis vacuatione, præfertimque in eryfipelate quamcumque corporis partem. occupante, fed præcipue caput. Oculorumque in lippitudinibus, opthalmiifve, gingivarum, colli glandularum, faucium, linguæ, in omnibus inflammationibus, parotidibus, bubonibus, carbunculis, cancris, aliifģue omnibus tumoribus ortuma à calidis humoribus, ducentibus, atque non minus in omnibus. ab iifdem fuccis obortis ulceribus. Idemque etiam præftant in maximis doloribus capitis, oculorum, gulæ, aurium, dentium, pectoris, inteltinorum, renum, crurum, arciculorumque omniam, fi modo non à flatulento fpiritu, vel à frigido humore illi oriantur. Sepe etiam in fanguinis profluvis, alvique dyfentericis fluxionibus. Pariterque in convulfis, epilepticis, vertiginofis, refolutis apoplecticifque, ac in immoderatis vigiliis, \& in omnibus amentiis, in obftructis, hydropicifque in principio multis. Cardiacis, hypochondriacis, leprofis, elephanticifque, atque ferè in omnibus aliis morbis, vel fymptomatis, quæ humana corpora invadere folent, copiofam, frequentemque exercent fanguinis miffionem. In quam plurimis etiam corporibus fanitatis tempore, ad alios morbos præ. cavendos id audent. Quam fanè evacuationem in omnibus corporum temperamentis, habitibus, ætatibus exercent, nullaque præcautione, quam obfervandam in hac evacuatione om- 


\section{g6 PROSPERI ALPINI}

nes docti medici docuerunt. Atque nihil minus ab affumpto cibo fanguinem vacuare moliuntur: Guıand. Nunquid miffronem fanguinis etiam frequentant in gracillimis illis fqualidiflimifque corporibus, quæ femi-tabida videntur, ac in pinguibis, mollibus, maxineque in mulieribus, atque Eunuchis: \& non minus in pueris \& fenibus, abfque debita providentia omnium, quæ obfervanda funt, ut iftud præficilum conferat? Scd qua tandem illi provifione pro milfione ifthac fanguinis utunthir? ALPIN. Cavent multi illorum, cum mittere fanguinem cogitant, ne corpora jejuna fint, atque hic ab affumpto cibo mittere fanguinem plerique folent. Minimeque, ut noltri medici in praxi, qui non immerito animadvertendum cenfent, fanguinem educturi, ne crudi humores in ventriculo, cibufque fit inconccetus; itaque prius lenienti aliquo pharmaco, vel clyftere purgatorio, alvum lenire fæcefque educere nituntur, vel diætam tenuiorem imponunt, ut rectè cruditates concoquantur \& expellantur, ne ab enifio fanguine è ftomacho in venas Cap. 5. rapiantur. Gurland. Galen. in lib. 9: meth. med. ait: Si presiedat ciborun cruditas, tantopere differre renes Sectionem jubebis., quantlim fatisfacere, tum ad corum concostionem, tum, ut excrementa defcendant, videbitur. Atque in multis locis præcepit, ante miffionem clyfterem purgantem præmitti oportere, ut ne evacuato fanguine criditates in ftomacho, atque in primis venis contentæa a venis rapiantur, atque in univerfun corpus excipiantur. Nunquam enim crudo cibo exiftente in ventriculo Cap. 5. mittendum effe fanguinem voluit, quod in lib. 6 . de fanit. tuend. docuit. Quid? illine hæe in molienda fangzinis vacuatione obfervant? ÁLPIN. Paucillimi funt, qui priufquàm mittere fanguinem infituant, velint differre vene fectionem vel fcarificationem, quoufque ftomachi, primarumque venarum cruditates vel concoctre, vel aliguo clyftere, vel medicamento eductæ fint. quinimò (quod porterius audies) à cibo multi fanguinem detrahmnt, ut etiam nune dictum eft. GuiLAND. Illos in ifthac fanguinis evacuatione minime rectè fe gerere, fed potius multum in ipfa cxercenda errare, cogito. Ea ifti fpe in omnibus fere morbis ad miffionem fanguinis confugiunt, ut quam- 
primum ad eam ruant, utentes illa tum copiofius, tum crebrius, tum inordinatius quàm deceret pro morborum curandorum ratione, atque etiam corporum temperamentorum, habituum, atque ætatum ulla habita confideratione. Alpin. Quo patoo exifimas ipfos in hujufce præfidii ufu multum errare, quando pro certo habeant, non modo verum non efle; quinimo magis omnes, qui in mittendo fanguine non eo modo fe gerunt, errorem committere afferant. Si itaque, vir doctifime, quoniodo hac in re errent, demonftraveris, ego illorum partem defendendam, tum difputandi, tum aliquid ex te difcendi caufa recipiam. Mihi non minus utile, quam fumme gratum erit ex te illorum errores, quos in ufu miffionis fanguinis committunt, nunc audire. GUILAND. Operam dabo, ut tibi hac in re omnino fatisfaciam, \& illos, quantum potero, reprehendendo,ipfo= rum errores tibi manifeftos ac planè notos reddam.

\section{A p. I V.}

Egyptios errare, nimmum jrequenti, of copiofe fan. gumis evacuationi indulgentes, \& in puerts mittentes Jangizinem.

\section{$G U I L A N D I N U S$.}

EDICos Egyptios multifariam in frequenti fanguinis 1 largioris evacuatione, plurimum errare, atque à veris medicinæ fundamentis defcifcere, facile demonftrabitur: quando fæpe mittere fanguinem, atque copiofius non nifi cos juvet, qui immoderata fanguinis copia gravati, magnum futurum. morbum expectant. Alia vero corpora omnia, qua neque immodica fanguinis copia redundant, neque ab ejus plenitudine magni alicujus futuri morbi occafionem fubeunt, non modo eâ non juvantur, quinimò valde læduntur, quoniam inde immodice nativus calor diffolvitur, quo refoluto, quis ignorat, omnes totius corporis functiones lædi? Quod apud Galenum in lib. de Cucurb. \& fearif. his profecto verbis legitur: Eodem nam-

Cap. 4. N 
q.0 anno venam frequenter incidere, minime quidem rationi cois. jentanewn arbitramur: quandoquidem.cum larga fanguinis copio vitalis quoque fpiritus emittitur, quo fanè abfumpto, crebrius quidem moles univerfa frigefcit, tum animales functiones omnes deteriores redduntur. Omnia verò illorum populorum corpora non ita multo fanguine abundare (etfi \$Egytii id arbitrantur) ut fæpe in morbofam plenitudinem incidant, manifeftum effe arbitror. Quod cum fit, neceffe eft à crebra copiofaque fanguinis miffione illa offendi. Nec illi accolæ omnes temperamento apto fanguinis evacuationi cernuntur; etfi mul$\mathrm{ti}$, in quibus ampla venæ cernuntur, quique funt modice graciles, neque candidi, neque tenera carne præditi, ibi exiftant, quos copiofæ fanguinis evacuationi ceteris aptiores effe Gal. in lib. de curan. rat. per fang. millf. memorix prodiait. Quibus non ita damnanda fanguinis miffio videtur, tamen plurima corpora etiam ibi exiftunt, ut tu nuper ennarrafi, maxime craffa, \& pinguia, qualia omnium Eunuchorum exiftunt. Præter ellnuchos plurimos ibi, tum mares, tum fæminas reperiri habitu quàm craffiffimo \& pinguiftimo aliàs dictum eft. Sunt etiam nihilominus multa corpora gracillima, nigra, ficca, \& fqualida paucifimi fanguinis, quibus quamcumque fanguinis miffionem nocuain efie quifque noftrum affirmabit. Præterea illud accedit, quod in omnibus fere iis corporibus, quorum temperamentum in multo fanguine fitum eft, caro mollis eft, rarifimæque cutis, ob frequentiam dulcium balneorum, quibus $f æ-$ piffime cos uti diximus. Itaque non poffum ufum mittendi fanguinis apud illos, ita frequentatum planè laudare: fiquidem, ut dixi, in ccelo calido, fub quo degunt, multa ex illis corporibus, præfertim Eunuchorum, aliorumque plurimorum, qui pinguiffimo habitu, molli ac raro præditi funt, minime commode talem evacuationem fufftinere poffe judico; Quare non nifi in magnis morbis illi medici neceffitate coacti, deberent ad fanguinis miffionem accedere, atque etiam ea in palciori quantitate uti. Idemquse in giacillimis nigris, fqualidiosibus multis Fthiopum, Arabum, Ruficorumque corporibus finciendum cenfeo. ALPIN. In plerifque illorum corporum, quise 
tempera!nento funt, vel pituitofo vel melancholico exufto, (quoruin numerus Cayri extat non parvus,) aut habitu pingui, teneraque carne, vel etiam arido \& gracillimo, errare ilios me. dicos, ita copiofe fepius fanguinem mittentes, mini planè obfcurum non eit, quando hæc corpora fanguinis miffioni inepta. fint; at non modo hæc ea languinis miffione juvari non pofle cogito, fed neque alia etiam, quæ multo fanguine redundant. Huncque mittendi fanguinis ufum apud illos frequentatum, abufum voco. Sed quid iu cenfes de ufu mittendi fanguinis vel in pueris, atque non minus in infantibus apud omnes ita frequento? Hanc etenin evacuationem, quamquam Arabes multi præclariffimi medici non omnino abhorruerint, tamen à Galeno aliifque in Græca fchola medicis omnino prohibitum eft, ne in pueris ante annum decimum quartum ullo padto fanguis mittatur. Guiland. Certiffma, atque omnium non modo antiquorum Græcorum, fed noftrorum etiam recentium communiffma fententia, in pueris ante illud tempus non effe fanguinem educendum, quocumque etiam magno, atque acuto morbo correptis. Majorem etenim noxam als emifio in pueris fanguine effe, quam fit utilitas, quæ eam evacuationem confequitur: eo quod corpora illorum fubftantificæ humiditatis; naturalifque caloris refolutioni valde funt obnoxia, cum humidiffima, molliffimaque carne conftent. Quod in lib. 9. meth. med. Gal. his verbis fcriptum reliquit, dicens: Pucrom ergo fubftantia omni:m facillime digeritur, ac difipatur, propterea quod eft ominium humidiflina: nulla vero frigidior. Q:10 minus vacuantis profidiz eget, cum babeat ex fe ipfa, unde naturaliter evactetur. Tanta itaque ab emiffo fanguine in pueris pertimetur futura exolutio virium, ut quàm facillimo negotio à morbo ipfi vincantur. Quam ob caufam Gal. fanguinis mifionem iis, in lib, de ci1. Cap. $13{ }^{\circ}$ randi rat. per fang miff. interdixit, ita dicens: Hac ratione nec pueris venas tundes ufque ad decimun quartum atatis anmun, poft guem $f i$ multus congeltus fanguis appareat. tempujque anni vernum fuerit, regioque natura temperata, $\mathcal{E}^{2}$ pueri naturd bene fanguineâ, fangininem minues; multoque magis, $f_{i}$ aut peripneumonice, aut angince aut pleuritidis, aut alterius acuti gravifque morbi pe- 


\section{-100 PR O S.P.ERI A L P I.N I}

riculum incumbat. Idem fere feripfit in lib. 4. comm. de vies. exx. com. rat. in morb. acut. ita inquiens: At certè pueri quamquam vitali s. facultate valeant, tanch neque bi fanguinis fufinent miffionem. Promptè enim eorum fubftantia, tum propter humidicatem, tum propter temperamenti caliditatem evaporatur. Atque in lib. I I. meth. med. præcepit in juvene annum fuæ ætatis decimum quartum non excedente, etiamfi fynocho invafus fit,

Cap. i4. non efle fanguinem mittendum. Quamobrem ex Galeno colligitur, eos medicos in pueris mittentes fanguinem fatis aperte errare, à veraque medendi ratione deflectere. Alpin. Neque tamen ita ftatim eos accufatos hac de re vellem, quando neque Aigvptii carent rationibus ab experientia, atque ratione defumptis, quibus contraria defenditur illorum fententia. GuIIAND. Forfitan illorum afídua, quam cum ipfis habuifti Cayri, confuetudo, atque familiaritas, ita eos tibi in gratiam reduxit, ut fummos ipforum errores non videris, neque cognoveris. Sed te commoneo, \& hortor, ne tantam medicorum turbam, ita manifeftos illorum errores defendendo, in te concites: vereor enim, ne male contra illos hunc errorem poffis defendere. Siquidem fi nobis ceteræ deeffent rationes, nonne fat efiet authoritatem tanti medici Galeni, quæ illis omnino adverfatur, tibi ante oculos ponere, qui expreffè mifionem fanguinis in.pueris damnaverit? Alpin. Profecto magis adduci debeo, ut Galenum fequar, quàm illius regionis medicos, quibus cum, fi dum in ea regione morarer, familiarem confuetudinem habui, nihilominus à Galeno artem medicam didici, tar men non amicos in fcientiis fector, fed veritatem, cui femper adhereo. At fi potes me pauca dicentem audire, aufculta, quæ Terentius in Adelpho comodia his verbis nos docuerit, dicens: Nunquam ita quifquam bene fubducta ratione ad vitan fuit, quin res, atas, ufus femper aliquid adportet novi, aliquid monzeat, ut illa, que te fcire credas, nefcias, E que tibi putaris prima, in experiundo repudies. Ita nobis fortafe accidere por tuerit, ut multa artis medicæ dogmata vera effe putaverimus, quæ mox falfa, atque $a b$ artis ratione aliena agnita fuerint. Hoc auxilium in pueris totius Arabix, Hthiopix, Abilli, A $\mathrm{Ey}-$ 


\section{DEMEDICINA RE GYTTORUM. LIB.I. IOI}

ptique eft familiarifimum. Quod verum effe conftat ex hominum illorum relatione. Qui ufus in is mittendi fanguinis fi error à noftris judicecur, errare procul dubio fit afirmandun totius \#gypti, Arabiæ, Abifiæ, Fthiopix, quibus hoc remedii genus eft familiarifinum, omnes medicos. INi enim ii aliquid utilitatis ex illo prefidio in pueris tanto tempore cogno. vifient; vel clarius, fi ex ea fanguinis in pueris adhibita mitio-. ne damnum aliquod accidere longa \& antiqua illa experientia ipfi didicifent, tot freculis, atque luftris in omnibus iltarum regiomum locis, ufque in hane diem illam non-frequentafent. Cayri dum eram, \& poftea Baflani, pofquam ex Figypto in patriam me contuli, nultos vidi, quibus meo juflu fanguis miffus fuerat, à quamplurimis acutis morbis curatos. Tandem colligo, atque confirmo, in univerfa Egypto medicos uti in pueris fangumis miffione, idque non parva lemper cun utilitate. Gulland. Cuperem nunc te nuper dictorum elle memorem, quando nuperrime utrique in id convenimus, ut medicos illos valde culpandos cenferemus, qui in ifto mittendi fanguinis ufu ita facile ac frequenter labantur, non in pueris modo, in quibus omnis fanguinis miffo, ob iptorum humidifimam fubftantiam; atque habitum facile evaporabilem, magis deteftab:lis videtur, fed in adultis etiam. Cur igitur nunc fudes mihi fuadere illorum antiqua etiam experientia in pueris, in quibuis major erroris, ac manifeftior creditur effe occafio, non errare, fi mittant fanguinein, cum eofdem in adultis nuperrime errare dixeris? Cefla igitur id amplius afferere, ne ita levi occafione tentes contra te tantam noftrorum medicorum turbam concitare, quam profecto recte nofti non modo non probare hoc auxilium in pueris, fed maxime abhoriere. Quando ad mitten. dum fanguinem etiam in juvenibus fint difficilimi. Quamobrem longè melius confulo, ut de fanguinis in pueris mifione, juxta illiufce populi placita, opinionem, \& conflium, fufceptumque ea de re fermonem dimittas, atque ad alia narranda accedas. Siquidem ego mifereor tui, qui tantos medicos facias inimicos tibi. Alprn. Quinimò fufceptum fermonem, ego profequi cupio, quod non arbicror illos medicos tam grandem er- 
rorem, ut tu atque alii putant, committere, in aliquibus pue. ris acute rgio antibus, ii fanguinem aliquando demant. Quam in his miffionem, exfi Gal.non laudaverit, alis etiam praclariffimis viris in arte medica, ut Rafi, Haly, Avenzoar, Avicennæ, Celfo, fecus perfuafum eft. Gumand. Gaudeo te in hanc effe fententiam, quoniam, ut hoc mihi rectè perfuadeas, fpeso te omnes in medium rationes laturum, quibus mifionem fanguinis in pueris effe faciendam, FEgptii ftatuerint; proinde illas ex te audire nunc defidero. Permagnum erit, quampluximis Erafiftrateis medicis illud te pofle perfuadere, mihi vero, qui cum Egyptiis etiam fentio, quam.facile perfuadebitur.

\section{A p. V.}

\section{Egyptios medicos mon crrare, fi in pueris,
morlis acutus corropuntur, alıquando fan- givem mitiant.}

\section{A L P I N U S.}

7 JMo eft, qui neget, medicum efle naturæ imitatorem, 1.3 atque ipfam ob id medendo femper, quantum fieri poteft, 1equi, atque initari debere. Quod fatis erit pro præfenti re, in noftrorum corporum evacuationibus, atque purgationibus oftendere. Siquidem cum obfervaffent medici naturam fiepiffime, nullo medico auxilio adhibito, multos homines febre vexatos, excernendo humorem, à quo febris illa orta fuerat. per alvum, vel vomitu, vel per urinam, vel per fudorem, vel fanguinis eruptionem ex naribus, aut ab hæmorrhoidibus, aut ab utero, aut ex alvo factam, fanaviffe; ideo \& ipfi à naturæ expulionibus exinde perdocti arte ufi funt, ad educendos humores, à quibus ortæ fuerunt febres. Alii verè, fectis venis, aut cute fearificata cum obfervaffent fxpius naturam, ea ratione xgrotos, vacuata multa copia fanguinis, in priftinam fanicaten: reftituife, fanguinem \& ipfi rittere tentarunt, atque ctiam eaden copia qua fape obfervarunt fanguinem criti- 
de Medicina IEgrptor um, Lib. II. IÓ3

ce à natura excretum fuife. Aliique purgatoriis pharmacis alvum fubducentibus humores, à quibus morbi originem duxe. rant, purgare ftuduerunt. Atque alii medicamento, urinam atque fudorem exficcare. Nonnulli etiam per infenfibilem evacuationem, idem præftant. Exemplum habetur apud Hippocratem in quo feripfit: Lippientem alvi profluvio corripi bomum, Aphos.17. $\&$ Gal. in comm. ait: Eft autem EO boc apud ipfun exemplun unum eorum, que Sponte E utiliter eudacuantur, quod medicun imitari oportet, \& proculdubio fic etian omnes faciunt, in lippitudinibus alvum \& clyfteribus, \& purgationibus fubducentes; omnes verò evacuationes, quas natura critice, ut medici appellant; operatur, bonas efle in dubium non eft revocandum, hincque non minus eafiem arte medica paratas, idem facere. dicendum eft. Nam dicebat Hippoc, in 1. lib. aphor. In per-Aphor. 2. turbationibus ventris, Ev vomitibus $\int$ pontaneis, fitalia purgentur qualia purgari oportet: confert, EO leviter ferunt, fin mimus contra. Omnes enim excretiones à natura non coacta factas optimas effe, ægrotifque falutares, veriffimum eft, eodemque etiam modo arte factas, modo eas, quas natura recte operatur, hæ reetè, \& ex arte imitentur. Quibus pofitis, quis quæfo neget, à natura faetas criticas evacutiones \& purgationes, eandem vim habere in ægrotis pueris, juvenibus, adultis, fenibus, mulieribus, virginibus, nuptis, viduis, atque in qualibet regione, loco, anni tempore atque conftitutione aëris; neque ob ætatis, temperamenti, fexus, cœlique diverfitatem ab ipfis evacuationibus, purgationibuque differentem effe utilitatem dici poterit; quod fi diceretur, à veritate effet alienum. Nam alvi profluvium in omnibus cujufvis ætatis, temperamenti, fexus, coeli, lippientibus bonum erit, quoniam in illis omnibus oculorum inflammationem, opthalmiam vocatam, folvet illa purgatio. Ita Hippocrates in 2. lib. prognoft. docente, iis omnibus acutis, periculofifque pulmoniis correptis, omnes abfceflus in cruribus facti boni erunt judicandi. Atque omnibus etiam acutis febribus afflictis omnes fudores critici utiles exifunt, qui omnes profectè, tum pueros, tum viros, tum fenes; tum freminas ubique rectè judicant, atque ab his febribus liberant, 
quales ab Hippocrate (veluti apud ipfum legitur in libris epldemicis) in Cleonactide Methone, Muliere trimeftri foetu gravidâ, Melidia in Dealcifque horto decumbente, Chrrione, Pericle, Virgineque Abderæ, Anaxione, Muliere Morofa, Virgineque Larifire fuere obfervati. De fanguinis vero evaText. 1o. cuatione, vel eruptione in morbis, Hippoc. in 4. de vict. rat. in morb. acu. ait: Et $\sqrt{i}$ ex naribus fuxierit fanguis, folvitur aIn 3. lib. gritudo. Galenus etiam de Methone loquens dixit: Large de epidem. naribus eruptiones fanguinis liberant ferè, Janè enim videtur à fola fanguinis eruptione, E judicatus, E Servatus, quamquam non Comm. omnino tuta ligna baberet. Et Hippoc. in I. epidem. fcripfit. x. text. Febribus antem ardentibus bec accidebant, quibus rite Eे largiter" fanguis per nares erupit, eadem canfa maxime fervabantur. Nec ullum novi, fi recte ei erupiffet fanguis in boc ftatu, quemquam mortuum. \& in 6. etiam lib. aphorifmorum: In infanientibus $\sqrt{l}$ varices, vel bemorrboides fipervenerint, infania fit folutio. Eodem quoque modo uteri inflammatio ex fanguinis è naribus eruptione liberatur. Quare omnes fanguinis excretiones critice apparentes in omnibus, tum pueris, tum juvenibus, tum viris, tum fenibus, bonæ erunt judicandæ, ægrotifque falutares. Cur itaque aliquis contendat, has quoque arte confectas fanguinis evacuationes, quæ naturam idem rectè molientem imitantur, bonas non efle, ægrotifque tum pueris, tvm juvenibus, tumaliis omnibus alterius xtatis corporibus non conferre? Certò non video, quo, pacto veritati addictus aliquis negare queat. $\&$ fi dicet, in pueris fanguinis eductiones non effe utiles, quia maxime ipforum vires refolvunt, refpondebunt REgptii medici, neque igitur natura poterit unquam pueros febre correptos, larga fanguinis per nares ab ipfa proftita evacuatione fanare. Quod fatfum tamen eft, cum infinitus prope fit puerorum numerus, quos larga fanguinis fponte facta eruptione fanatos quifque verfatus fenex medicus certò comperit, atque cognovit. Neque profecto menfis adhuc eft, cum Baffani puellulam annum fux xtatis oftavum non excedentem, filiam Bonazontæ ralccorum futoris maligna febre affictz $m$, fanguinis fponte facta larga cruptione, plane a febre liberam, atque judicatam, obfer- 
fervavi. Nos igitur, ut Rgyptii, fanguinis miffone vel etiam in ægrotis pueris uti debemus, cum natura ipfa noftrorum corporum affectus edocta, non timeat, emilo in is fanguine, $\dot{a}$ virium refolutione, fed potius eos eo auxilio fanet. Nec putandum huic fententiæ folos illius regionis medicos effe addictos, fed alios quoque multos clarifimos, atque gravifimos, ut de Avenzoare legitur, qui cum fuo filio trimo venam fecuiflet, per eam multo educto fanguine, ipfum à morbi periculo vindicavit. Avicenna etiam poffe medicos, vel in fecundo anno affixis cucurbitulis, fanguinem vacuare, teftatur. Et Haly fen. 5.c. Abbas ait: Quod $\sqrt{ } i$ ad flebotomun puer pellitur, $E^{\circ}$ virtus ejusz2. furrexit, ac poffibile eft paffonis alicujus Janguinece caufa diffuci-_ib. s.c. 2. lis, qualis eft fuffocatio, phrenitis, pleurefis, छo Jimile iis, non tamen preter parentum minuas voluntatem. Sed quid? nonne alii etiam multi reperti funt, qui mittere fanguinem in pueris, fumpta à magnitudine morborum occafione non ita abhorruerunt? Ac dum hæc fcriberem, pro conffrmanda, in pueris fanguinis evacuatione, mihi in memoriam venerunt, quæ aliàs Rafim in li. de flebotomia, ut iifdem interpretis verbis utar, de ventofis \& fanguifugis hæc memoriæ tradita legeram; quæ hæc funt? Dico conficlerare debere in negotio infantium, quoniam forte videmus in iis infantibus effe febrem: deinde erit ex caliditate ejus fluvius fanguinis de naribus fortis: quare fi minutio effet nociva ejus $\mathcal{O}^{\circ}$ diffolutio de eis fieret competens, jam expelleretur bujufmodi febris Eo natura.Hac itaque graviffimi medici ratione duetus, hoc idem à me videtur poffe decerni, fcilicet quia nos fæe vidimus in pueris naturam fanguinem evacuare; eaque evacuatione illos recte fanare, non perdere, etfi multum ipforum fubftantia diffolvatur, ideo eodem modo in is arte facta fanguinis miffio non erit abhorrenda. Idem Rafis paulo poft ex mente Conftantini dixit: Quidam fuftinent minutionem, E quidam non fuftinent, quidam indigent ea vehementer, quidam pereunt per eandem in ipfa ctate: Unde non efl confiderandum in numero annorim, fed in cute corporis E neceffitate. Guiland. Arbitror ex pra:cipuis maximifque auxiliis, ad fanandos pueros à febribus putridis effe fanguinis miffionem, quod nobis facte fuafumet, qua 
nos fiepifimè vidimus pueros larga fanguinis eruptione confertim à natura facta, à putridis febribus continuò judicatos, ex indeque fanatos. Hinc non immeritò Cornelius Celfus in libro 2. de iis, quæ indicant fanguinis miffionem, ait: Intereft enim non que cetas fit, neque quid in corpore intus geratur, fed que vires.

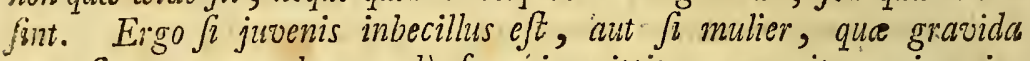
non eft, parum valet, male Sanguis mittitur: emoritur enim vis, quee bis fispererat, EO boc modo erepta eft. At firmus puer, Ev robuftus senex, Ev gravida mulier valens tuto curatur. At quid miremur, eos populos nuuc in pueris ægrotantibus fanguinis miffionem frequentare, cum Amatus quoque Lufitanus medicus Hebræus, non fpernendus, in quamplurimis pnerulis fanguinis Curat. 10.miffione felici cum fucceffu femper ufus fuerit? In prima enim fuarum centuriarum ait, puellam annos femptem natam, à febre liberaffe fanguine ex fecta dextri cubiti vena interna, ad Carat. 96.fex ufque uncias educto. Ibique hanc miffionem fanguinis ex Arabum medicorum mente contra Græcos in pueris faciendam curat. ca confulit. Amplius in fecunda Centuria, itidem à febre continua puerulum octo annorum miffo fanguine per venam fectam fanitati reftitutum narrat: \& in quarta, alium puerum eodem morbo vexatum, eodem auxilio fanatum meminit, atque in Curat. 42. quinta, quinque annorum puerulum pleuriticum; atque in feptima puellam maligna febre correptam fanitati miffione fanguinis. reftitutam fuiffe, teftatur. de qua ipfe ita fcripfit: Puella pulchra, E filia formoja à Saqua nata annos oito, biduo continuo febriebat, E्S.caput dolebat, buic Jecta communi in bracbio vena, fanguis ad uncias quatuor, fuit extractus, tuinc exanthemata veliti culicum morfus crupere, fed poftea perextenfa univer fam ferè cuten occuparunt, \& per nares illi multus fanguis fuebat, ${ }^{O}$ fuxus. ventris quoque ilii Supervenit, Sed rectè gubernata, Eo per intervalla cocbleari ebibito Jyrupo violaceo recenti, libera E' immunis evafit. In fcholiis vero hæc quoque auditu digna memorix, ab eo prodita leguntur: Advertant, qui Galeni preceptis adftricti ante quartum decimum annum fanguinem per vence fectionem extrabere. timent, gurm cx fo natura in bac puella fanguinem copiofum per nares depoficeiti, ut fape aitids in aliis pueris obfervatum eft. Quam 
fanè fanguinis evacuationem Hifpani omnes in pueris frequen tant, præfertimque ut Egypti faciunt, cruribus fcarificatis. Neque defunt alii multi præclariffimi medici noftrorum temporum in pueris etiam laudantes miftionem fanguinis, inter quos eft doctiffimus Fernelius, qui Galenum, cum pueros ineptos fanguinis miffioni dixerit, intellexiffe de pleniori, five copiofiori eductione, qua ufque ferè ad deliquium antiqui utebantur: affirmavit. A L PIN. Sed quænam illorum funt rationes, qui negant, in is hanc fanguinis miffionem effe faciendam, quibus rationibus non decere in pueris evacuari fanguinem affirment; \& quid illis refponderi poteft? GUILAND. Negant eam pueris conferre pofie evacuationem, quoniam ipfi fponte nimis exolvuntur, cum corpora humidiffima, moliffina apertifimaque obtineant, admodumque propenfa vaporationibus, quæ quam citò, detracto fanguine, vel, fupra addita alia evacuatione deficiunt, quando ipfi corpora habeant, quæ continue evacuantur. Quibus evacuatione fanguinis etiam addita vires valde collabuntur', quibus diminutis non poterunt puerorum corpora morbum fuperare. Quam ob caufam Galenum iis miffionem fanguinis prohibuiffe affirmant- Quæ res non videtu omnino veritati confentire, quoniam, etfi corpora puerorum habeant fubftantiam humidiffimam, mollifimam, aperifilmamque, qua continue multum per infenfibilem evaporationem difflantur, ac evacuantur, nihilominus poffunt etiam aliam fanguinis moderatam evacuationem perferre, abfque detrimento. Puerorum fiquidem ætas multo fubfantifico humido abundat, naturalique calore feraciffimo; atque hine non minus viribus multis, ac validioribus puerilis etas eft referta. Namque quia plurimum habent, ut Hippoc. in aphorifmis ait , caloris innati, egent plurimo alimento, eaque caufa omnes pueri funt voracifimi, plurimumque, comedunt: quo fit, ut femper plurimum fanguinem coacervent: eoque abundare puerilem ætatem Gal. docuit in brevi denotatione dogmatum Hippocratis. atque hinc eft, quod in pueris fæpifime finguis multus per nares profluere oblervatur. etfi copia caloris etiam ad idem concurrat; cujus evacuationem ferunt citra aliquan noxan, tum ob ejus copian, 


\section{PROSPER I ALPIN I}

qua ipfi abundant, tum ob vires, quibus funt præditi. Præterea quis ignorat, inter omnia, quæ miffionem fanguinis indicant, virium robur precipuam habere partem in admittendo illo auxilio, quandoquidem corporibus, quæ viribus planè careant, nullus, ni ipfa interimere velit, audebit elicere fanguinem: datis etiam duobus corporibus ejufdem ætatis; temperamenti, eodem morbo correptis, fi alteri tamen languidiores extent, jure nulli dubium, quin in robuftiori fatis audacter fanguinem evacuabimus, in altero vero parum, \& non abfque aliquo timore. Quamobrem cum pueri habeant corpora validioribus viribus munita, multoque fanguine referta, cur aliquo acuto morbo illis infeftis fanguinem in moderata copia non mittemus? quoniam etfi vacuantur continuè per infenfibilem evaporztionem, tamen moderatam quoque ferre poterunt evacuationem, quod nobis certo fuadere debet, pueros obfervari fapiffime ac familiarifime per nares multo fanguine profluxo, abfque noxia vacuatos. Pueritiæ profluvium fanguinis per nares eft familiarifimum, quod ceffat, ubi adultiorem attigerunt xtatem. Quid? An non in pueris etiam lactentibus acuto aliquo morbo correptis obfervatur, eos aliquando inediam multis diebus fine noxa perferre, \& mox quafi mortuos revivifcere? quod illis contingit, quia præterquàm quod viribus conftant robuftioribus, etiam plurimum pituitofi humoris inconcocti habent, quo calor in optimum fanguinem mutato, facile nutritur, atque fovetur. \& proinde quamquam mittatur in iis modicus fanguis, non fit tanta virium jactura. Multa funt præterea, qux non ita valde diffolvi puercrum corpora denotant, in primifque multos illorum febricitantes, eodem tempore poffe fanguinis copiofum fluxum, fudores, alvique copiofas dejectiones fæpe abfque ullo ipforum detrimento etiam perferre, atque posius ab iis fanari, non admodum extenuati vel graciles facti. quinimò fi rectè, tum puerorum, tum aliarum itatum cadavera infpiciantur, procul cubio puerorum femper, fi tum morbi $f_{\text {pecies, }}$ tum tempora, quibus ægrotarunt, inter fe comparentur, minus diffoluta, atque attenuata aliis infpicientur, quod utique haud tante ipforum corporum refolutio- 
nis argumentum etiam effe poteft. Quamobrem probe fatisfacere medicos illos, dicendum eft, qui miffione fanguinis vel in pueris utuntur, neque ut mittant fanguinen, quarcus decimus expectandus eft peractus annus. Ridiculum fanè videtor, annorum numero miffionem fanguinis præfiniri oportere, quando ipfe quoque Gal. dixerit: Itaque non numero jolummodo animun advertes, quod quidam faciunt, fed corporis babitui; nam funt, qui Sexagefimo atatis anno vene fectionem non ferant, cum quidam, qui Jeptuginta nati funt annos, perferant. Minufque ætatis certis annorum numeris poffint à medicis definiri. Gale-Cap. 28. nus idem in lib. de fectis, dixit, non mittendum effe fanguinem in puero admodum parvo. Atque hæc obiter de fanguinis miffione in pueris à me dicta fint. A L P I N. Admodum hoc tuo doctifimo fermone fum delectatus, præfertim cum ex te multa didicerim, quæ in pueris faciendam effe vacuationem fanguinis demonfrant. F Eyptii itaque in pueris hanc evacuationem non fecus, quàm in aliarum ætatum hominibus frequentant, tum venæ, arteriæque fectionem, tum etiam per fcarificationem malleolorum, crurumve, atque aurium. Magis vero per fcarificationem quam per venæ fectionem in ipfis confueverunt id agere. Eodem quoque modo non minus fanguinis evacuatione in fenibus utentur, in is tamen, qui non ad ultimum fenium perducti fint, fed optimi temperamenti \& habitus, quique fatis validis viribus conftent. GUILAND. Cum hactenus dixeris miffionem, vel evacuationem fanguinis illorum locorum, medicos in omnibus iis corporibus exercere, non minufque in Eunuchis, mulieribus, pueris, fenibus, \& pinguioribus hominibus, quibus fatis AEgytus abundat, Cupio etiam ex te audire, an per venæ, vel arteriæ fectionem, vel per fcarificationem alicujus partis corporis, vel per hirudines, vel cucurbitulas, talem vacuationem familiarius præftant, quando his tantum viis quælibet fanguinis mifiio peragatur. Hæcque nunc ex te audire expecto. 


\section{A p. V I.}

In pinguioribus corporibus, Eunuchis, mulieribus; pueris, fenibusque quomodo EEgyptii Jangui-

\section{nem mittant.}

\section{G U I L A N D I N U S.}

Cap. 13. his verbis Gal. in lib. de curat. per fang. miff. docuit; dicens: Deinde confiderandum. qua fit naturalis borminis temperies. Nam quibus ample funt vene, quique modice graciles funt, nec candidi, neque tenera carne prediti, copiofus evacuabis: contrarios autem parcius: quippe qui exigumm babent fanguinis, carnemque facile Cap. 14. tranfpirabilem. Sicque in libro 11. methodi, loquitur: Quod fi corpus decimunn quartum annum excefferit, exiftimandum eft,

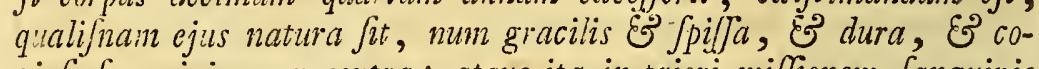
piofi Janguinis, an contra: atque ita in priori miffonem Janguinis adbibebis: in fecunda nequaquan. Quinetiam modus vacuandi fanguinis ex iifdem indicancibus fumetur. Si enim, cui fanguis mitcitur, triginta annos natus fit, fed laxus, \& mollis, \& pinguis, \& albus, \& gracilibus venis, huic planè fanguinem non mittes, aut parum detrahes. Hæc cum in multis hominibus, pueris, Eunuchis, fenibufque fpectentur, Ægyptios non parum in ufitanda fanguinis evacuatione errare dicemus. Namque crebra ac copiofa fanguinis eductio, quæ apud eos onmes eft, eciam ex leviffuma caufa familiaris, iis omnibus valde incommoda ac noxia erit, quando qurlibet nuper dictorum corporum, ex paucifima etiam evacuatione multum refolvantur, atque ipforum moles univerfa inde non parum perfrigefat. Sed quoniam noftrorum medicorum quamplurimi exiftimant, cucurbitulis præ?titam fanguinis evacuationem in his corporibus minorem facere fpirituum refolutionem vel confumptionem, ideò per 
has potius, quàm per fectam venan ipfis fanguinem mitti fuadent, cum per fectam venam fanguis evacuatus multum caloris naturalis abfumat, ut Gal. in lib. de cucurb. hirudinibus feriptum reliquit, itaque nunc quonam illorum modorum mittendi fanguinem illi populi utantur, narres velim, num per venarum, arteriarumque fectionem, an potius per cucurbitulas, vel fimplicem fcarificationem, vel hirudines appofitas venis. ALPIN. In omnibus iis nuper dictis corporibus, fcilicet pinguioribus, albidioribus, molliffima ac tenerrima carne præditis, habituque raro, qualia plurimorum, tum virorum, tum mulierum, fenum, omniumque Eunuchorum, (quorum ibi adeft haud. parvus numerus,) ac puerorum multa cernuntur, quamquam etiam fectis venis fape ab his fanguinem evacuent, nihilominus familiarius cruribus antiquorum more fcarificatis mittere fanguinem confueverunt, omnium maxime in valde pueris, fcilicet infantibus, quibus ibi detrahunt etiam fanguinem? cruribus, vel auribus fcarificatis, ne peracto quidem primo anno. Frovifionis quidem caufa in prima æftatis parte æftuofa, inæquali, in qua multi peffimi morbi, vel etiam puerulos ac infantes invadunt in pluribus eorum fcarificatis auribus mittunt fintguinem; itaque vix inter centenos, tercenos aliquando repcries, quibus aures fcarificatæ non fint. Quamobrem in infantibus, atque pueris omnibus fanguinem fcarificatis auribus, atque cruribus mittunt. In Eunuchis verò, \& mulieribus, pingui, raroque habitu præditis, atque demum in ceteris hominibus, eodem ferme habitu, tum molli, tum raro refertis, per fcarificationem moliuntur fanguinis evacuationem. G U I LA ND. Rectè fane illi in iftis corporibus per cutis fearificationem fanguinem vacuantes, fe gerunt, quando hæc corpora facile tranfpirabilia, ex fanguinis evacuatione per fectas venas confecta valde refolvantur. Quod ex Galeno didicimus, qui de fcarifi- Cap. 4o catione ita fcripfit: Eodem namque anno venam frequenter incidere, minime quidem rationi confentaneum arbitramur : quandoquillem cum larga Sanguinis copia vitalis quoque Jpiritus emittitur: Quo fane abfumpto, crebrius quidem moles univerfa frigefcit, tum animales functiones omnes deteriores redduntur. Quamobrem $a b$ 


\section{PROSPERI ALPIN I}

ignobilioribus membris, utpotè cruribus, educendus eft, fcilicet fcarificatione. Sed talem ufum mittendi fanguinem per fcarificationem optimum effe, atque artis ratione comprobatum, in lib. Cap. Ir. de curat. per fang $m$. docuit his verbis: Porrö que ex mulieribus albidiores fint. Sanguinem acervare tenuem folent: quocirca adbibitis malleolorum fcarificationibus maxime juvantur. At quace nigriores funt, fecta vena curato: craffiorem enim fanguinem, ac magis melancbolicum colligunt, magis vero etiam $f i$ magnas babere venas appareant, quod illis accidit, qua graciliores funt, ac nigrioges: Carnofis verò $E^{2}$ candidis parva infunt vene, quibus malleolos fcarificare, quam venam fecare pireftiterit, quippe cum bee parvas in cruribus venas babcant: itaque etian fi probe fecentur, quod juflum tamen fit, non profluat. Commodior hæc per fcarificatos malleolos fanguinis evacuatio in is corporibus eft, utiliorque non immerito judicanda; commodior, inquam, quoniam corpora pinguia, candida, mollia, exiles parvafque venas, \& fanguinem tenuiorem habent, quarum aliqua rcetè etiam fectx, juftam fanguinis copiam non dabunt: faciliorque fanguinis hæc quantitas fearificata cute crurum five furarum, multis, necitie minimis referta venis. Utilior, quod ex ea fcarificatione celebrata fanguinis miffione, non tanta fpirituum copia refolvitur. Sed quid? ifti hac fcarificatione nonne cucurbitulis affixis fanguinem extrahunt? vel non appofitis, venis aliquibus, ut noftri faciunt, hirudinibus finguinem mittunt? AlpIN. Neque ufum cucurbitularum pro fanguinis evacuatione facienda, reque per hirudines evacuationem nobis cognitam, illi norunt. Mifronem fanguinis per cucurbitulas, ad tollendam plenitudinem, maxime damnant, neque iis unquam fanguinem evacuationis caufa mittunt, fed tantum revulfionis vel diverfionis gratia, piriori loco per fectam venam evacuata copia fanguinis. veluti in ophtalmïs occipiti affixis cucurbitulis uti folent. Neque dorfo, neque lumbis, neque cruribus eas unguam affigunt. Collo tantum, occipiti, ac ejus proximis partibus cucurbitulas apponere confueverunt. Hirudinum ufum prorfus ignorant, dicunt enim veneficam eas habere naturam, illarumque morfum non minus noxium experiri. 


\section{A p. VII.}

An Egyptii Medeci rectè Se gerant in ufu miffionts fangumis in dyfenteria, diarrbaa biliofa, exanthematibus, puncticulis appellatis, peftuferiqque bubonibus, \& parotidibus.

\section{A L P I N I S.}

Dx I illos medicos, cruribus fcarificatis exercere miffionem fanguinis in omnibus pinguioribus, albidioribulque corporibus, Eunuchis, mulieribus, puerulis, in quibus rectè illos ex Galeni fententia facere dices, fed in dyfenteria, biliofadiarthæa, exanthematibufque, à noftris periculis, vel puneticulis vocatis, inque peftiferis tumoribus eos fanguinem mittentes, nefcio, an laudabis, quando multi medici etiam doctiffimi exclament in iis ferè omnibus morbis fummoperè noxiam, ac exitiofam ferè effe illiufce humoris evacuationem. Neque fortaffe citra rationem ipfis id perfuafum eft, quando tum vires admodum ab ea vacuatione collabantur, tum etiam ea plures optimi medici in iis, ufi non fuerint. GUILAND. Cupio audire ex te rationes, quibris illis perfuafum fit, in illis affeetibus inutilem effe fanguinis miffionem. Quibus auditis, meam quoque fententiam in medium poftea proferam. Alfrin. Sigillatin tamen de quolibet affectu hæ dicendæ funt. In primifque recenfebo, quæ in dyfenteria à fanguinis miffione arceant, \& mox de aliis loquar. Sed quæ illi pro ipforum fententia dicunt, hæc fanè funt. In primis Galeni auctoritate fe muniunt, cui omnes medicos addictos effe debere affirmant, atque quod ipfe, dum de dyfenteria loqueretur, miffonis fanguinis nufquam meminife legerint, affirmant idcirco errare onnes pro illo affectu mittentes fanguinem: Multóque magis, qui obfervaverint, tantum medicum manifeftiffime in his fanguinis evacuationem damnaffe. ut in lib. 4. de vict. rat. in morb. acut.'legitur, his profecto com. 118. verbis: Fheente alvo Sanguinem non detrabes. Nam $\sqrt{i}$ poft detra- 
âionem perfeverat fluor, virtutem profternit. Cujus fententiam conftat repetitam fuife in libro $\%$ ad Glauc. quando fcripfit: Sed neque ji fuerit febris cum alvi profluvio, alia eft opus evacuatione. Quicumnque bis plus adimere fore neieffariun putantes, aut fanguinem mittere, aut ventrem movere tentarunt, in graviora pesicula dluxerunt. An in dyfenteria, ac diarrhæa fanguis fit mittendus, utique his verbis explicavit; Quid dubii igitur eft amplius, quin ex ejus fententia in eo affectu fanguinis aliqua eva. cuatio non fit facienda? Quod remedium cum tantus medicus dyfentericis, atque diarrhæâ correptis interdixerit, cur quifque noftrum tanto à præceptore perdoctus, idem faciendum non fuadebit? Quam fententiam multi confirmant dicentes, in dyfenteria admodum vires refolvi, quando tum fanguinis crebra fiat dejectio, interdumque etiam copiofa, \& dolores vehementes ferè affidui, quos etiam vigiliæ fequi folent immodicæ, quæ omnia multum vires labefactare, ac refolvere omnibus eit plane cognitum. Quapropter $f i$ in is medici fanguinis evacuatione utantur, procul dubio erunt in caufa, ut in majores virium lapfus, ac refolutiones incidant ægroti, quibus collapfis natura neceffariò morbo fuccumbet. ltaque hac ratione confirmari poffe Galeni fententiam ftatuunt. Cui libenter ego etiam: fubfcriberem, cum dyfenteria (dico illum affectum, in quo ulcerata inteftina apparent) fiat ex cacochymia, five ex malis humoribus, qui non evacuatione, quo auxilio plethora curatur, fed purgatione, tolluntur. Inteftina etenim abraduntur, \& exulcerantur vel à biliofis acrioribus fuccis, vel à falfa pituita; quæ fanè non fanguinis vacuatione tolluntur, fed ut nune dixi, purgatione. Maximè itaque hic errare medici AEgyptii dicendi funt, utentes fanguinis miffione vel etiam in dyfenteria. GuilnND. Erras (mea quidem fententia) fi id credis, quando in iis affectibus fanguinem evacuare ab artis vera methodo alienum effe, non judicaverim; quinimo in ea re illi multa funt laude digni, atque Hippocratice dyfentericis mederi mihi videntur. Namque fanguinis in is evacuatio dolorem vehementem, quo dyfenterici cruciantur, mitigare poteft, ut ex Galeno colligitur, qui inullum majus remedium in maximis dolori- 


\section{MEDICINA DE AEYTIORUM. LIB. II. IIs}

bus evacuatione atque purgatione fe inveniffe fcriptum reli quit. Nou minufque inteftnorum partium ulceratarum inflammationem, atque febrem imminuit, fluxumque humoris ab inteftinis revellit, fomnumque inducit; itaque in dyfenteria, viribus, ætate ac aliis confentientibus, circa initia revulionis gratiâ, præfertim ubi magna affuerit humorum copia, aut fanguinis impetus valde urgeat, vel maxima inflammatio, aut dolor vehemens obfervetur, vel jecur male affectum fit, à quo acres fucci ad inteftina confluant, adprime utilem fanguinis evacuationem effe exiftimo. Atque illi, qui exordiuntur à fanguinis miffione curationem, eandem rationem fequi videntur, quam medici omnes febres putridas curantes, ab ablatione caufarum curationem incipientes: quis enim ignorat, tria in is curationem indicare, fcilicet morbum, caufam, atque fympto. ma? ut in 9. meth. med. Gal. docuit. veramque ac optimam curationem illam effe, quæ à caufa exorditur? nunquam enim morbus tolletur, non ablata prius ejus caufa. Dyfenteria vero ex Galeno in 4 . lib. aphorifm. \& in 3 . de fympt: cauf. atque in Aph, 24. 6. de loc. affect. alibique in fexcentis aliis locis, ulcus eft inteftinorum ex flava bile, vel atra, Galeno in 4. lib. aphorfm. do. cente, aut I falfa pituita, ut in 3. lib. aphorif. apud ipfum le-A ph. I2: gitur, abradentibus, ortum. Quo pacto igitur quis dyfenteriam, quæ eft ulcus inteftinorum, rectè unquam curabit, nifi caufam prius, à qua ortum ducit, adimere ftudebit? Caufa vero, ut dictum eft, cum fit biliofus fanguis acris, \& mordax ab univerfo corpore vel à jecore ad inteftina demandatus, is proculdubio evacuatione tollitur: nam per fanguinis evacuationem nonne hujus redundantis humoris copia diminuitur? qua diminuta vel nihil, vel minus ad inteftina confluit. Amplis crm biliofus ille fanguis ex calore multo jecoris gignatur, ejufque multa copia fubminiftetur, quis eft, qui ex miffone farguinis jecore refrigerato, minus illius humoris gigni pofle, ignoret? Medici enim omnes, calidorum humorum redundantiam factam, fanguinis miffione prohibere ftudent. Demum cui obfcurum, atque ignotum eft, eorum humorum acrimoniam, qua inteftina mordentur, atque abraduntur, immodico P 2 
jecoris calore fieri? intenfus etenim ac immodicus calor ejufce membri, fanguinem efficit calidiorem, ac acutiorem : quis, inquam, ille erit ita artis medicæ ignarus, qui nefciat, jecore præ multo calore gignente fanguinem biliofum, acremque, eo evacuatione fanguinis refrigerato, minus acutum atque acrem producturum effe fanguinem? Cum igitur fanguinis miflio copiam biliofi fanguinis diminuat, ejufque acrimoniam obtundat, talemque fanguinis curfum ab inteftinis avertat, id nihil aliud erit, quàm caufam, qua ulcera fiunt in inteftinis, planè adimeve, qua fublata facile facta ulcera fanabuntur. Quæfo, quis ille eft (fanguifugariis enim ufque eft manifertiffimum) cui homo aliquis ob ulcus in quacumque extrinfeca corporis parte, ex biliofo humore confuente ortum, lanandus occurrerit, qui ut illum hominem rectè curet, priufquam medicamentis exficean: tibus utatur, non in id incumbat, ut corpus prius, tum evacuetur per fanguinis miffionem, tum aliquo medicamento purgetur? fanguinis enim evacuationes prohibent, quin minus illiufce calidi humoris amplius gignatur, purgationes vero genitam ejufce humoris copiam diminuunt; hæc enim magnorum ulcerum, localibus remediis non cedentium rationalis, ac vera curatio exiftit, quam cur non eandem fieri oportere in iifdem ulceribus internam quampiam partem occupantibus, præfer: timque inteftina, omnes velint aut nolint facere cogentur? fi dicerent hanc evacuationem, quamquam ipfa opportuna. fit, non conducere dyfentericis, quia eft in caufa, ut vires multum refolvantur, atque collabantur, qua poftea imbecillita: te non poffent alvi profluvium firmare, refpondebitur naturam non ita pati ex. modica fanguinis exacuatione, ut ea valde viribus deftituatur, ad morbum pervincendum: quod fi $æ-$ que à milfione fanguinis in omnibus læaís ulceratifque partibus corporis natura debilitari exiftimanda fit, cur inteftinis læfis tantum patietur, fi mittetur fanguis? ex aliis vero corporis p.rtibus nequaquam? fi dicent, quia ulcerata inteftina ex fan$\mathrm{g}$ linis evacuatione diminutis viribus, minus, poterunt firmari \& 1utti, \& ita profluvium ægrotos perdet; nos dicemus, fi non mittatur fanguis, atque eo modo ftatim in principiodivertatur 
DE MEDICINA IEGYPTIORUM. LHB. II. II

fluxus ab inteftinis, multo fanè majorem fanguinis copiam per alvum, perfeverante illo affectu, emanaturam, quæ longè plus, quàm arte facta, vires refolvet. Optimum itaque effe remedium dyfentericis, modicam fanguinis evacuationem exiftimo. Cujus fententiæ fuere Alexander Trallianus, Aëtius, atque alii multi graviffimi medici: ex recentioribus verò Donatus Antonius ab Altomari paucis his verbis optimum efle auxilium miffionem fanguinis in veris dyfentericis fcriptum reliquit, dicens: At $\int i$ male admodum affecto jecinore favö bili admixtus fanguis $a b$ co ad inteftina deferatur, ita, ut frigmenta quoque inteftinorum dejiciantur, fumma inteftinorum tunica bumoris acrimonia derafa, quifnan verebitur internam in dextro cubito venam Jecare? nedun. revulfonis gratia, verum etiam ipjuffmet jecinoris alterationis. Cur plerique medici in boc cafu, qui folam inteffinorun cxulcerationem, neglecto jecinore curare confueverunt, in caufa funt, ut cegri moriantur ex Galeni fententia lib. 4. de articulis com.4. Ruifus ubi vebementiffinus infeftaverit dolor propter rodentium bumorum acrimoniam, ad inteflina is totn, feu ab aliqua corporis parte confluentium, Es propterea verenda fit phlegmonis generatio, aut virium defectus, cui abfonum videbitur venam fecari debere? Cum \& idem Gal. in maximis doloribus nullun majus invenerit remedinn, quàn uf gue ad deliquium animi fanguinem mittere, aut purgare, ut patet aphor. 23. lib. I. Quamquam venam Secandam dicimus, ubi - cuncta ea admiferint, nec usque ad animi deliquium, fed paulatim, ac fenfim, ne vires imbecilliores reddant, ipfam probamus, prout Aëtius \& Alexander probarunt. Atque hæc Altimarus medicus fua tempeftate clarifimus, qui omnibus dyfentericis feliciori femper eventu fanguinem fecta vena mittebat; cujus rei excellens Afcanius Curacciolus à dyfenteria fola fanguinis miffione abfque aliis auxilis fanatus, atque alter filiorum Joan. Ferdinan. di Rocchi dyfentericus eo auxilio fervatus; teftes fuere. Cum eodem etiam tempore codem morbo alter frater correptus, cui fanguis non fuerat miffus, mortem obierit. Amatus Lufitanus medicus non fpernendus Chiam mulierem dyfentericam miffo 1anguine, atque alios multos curavit, ut in ejus centuriis memoriæ traditum eft. Muli alii medici doctifimi ufi funt hoc 


\section{8 \\ PROSPERI \\ A L P I N I}

auxilio in curandis dyfentericis, quos omnes hic recenfere nimis moleftum foret. ALpin. Confpicuam hanc veritatem mihi nune planè ita reddidifti, ut deinceps maxime mihi conftitutum fit, miffionem fanguinis pro curanda dyfenteria opportuniffimum fore anxilium, atque abfque eo maxima cum difficultate homines à dyfenteria fanari pofle. At optimum etiam erit, ut adverfariorum nuper allatis rationibus, quibus hoc auxilium in hoc affectu damnant, nunc etiam fatisfacias. Guiland. Ad ea, qux apud Galenum feripta leguntur, præfertimque in lib. $\mathrm{I}$, ad Glauc. qux illorum opinioni magis favere creduntur, refpondendum eft, ibi Gal. locutum fuifle de alvi profuvio, quod febris fymptoma exiftit, febremque fequitur, ut accidens, quòd ejus morem fignificare videtur. Nos vero, cum de dyfenteria loquimur, prout morbus eft, cui fit febris conjuncta, ejus eft fyniptoma; itaque verba Galeni nihil nobis obfunt, dum loquimur de dyfenteria, quæ morbus eft à febre diftinctus. Quòd Text.com. fi alibi, ut dictum eft, in 4 . lib. de vict. rat. in motb. acut. dii16. xit, Fluente alvo fanguinzom non deirabes. Nam fo fluor poft detraztionem perfeveret, vires profternit, ego, ut recte hanc rem intelligam, ita rurfus diftinguo, alvi profluvium fieri læfis inteftinis primario affectu; aut ftomacho, vel illis communicata læfione ab univerfo corpore, aut ab aliqua parte, præfertimque à jecinore, quo fane modo pleræque diarrhææ biliofæ, \& dyfenteriæ gigni folent. Ubi igitur profluvium fit lælis inteflinis, vel ventriculo, primario affectu, tunc fanguinis miffio, atque purgatio videtur damnanda, quandoquidem ex illa evacuatione partes illæ pauco calore nativo refertæ plus aliis debilitentur, \& idcirco hoc auxilii genere non juvantur, fed potius læduntur. Orta vero fluxione biliofa, qux abraferit inteftina, idque vel univerfi corporis, vel hepatis vitio, quo vifere læfo pleræque fieri folent; proculdubio fanguinis evacuatio utilis erit, que non intertina labefactabit, etenim ab ipfis divertendo biliofum fanguinem inteftina ulcerantem, ipfis potius non parum roboris adjiciet. Hinc vero fit, ut omnes ulcera tantummodo inteftinorum curantes, \& non hepar, tanquam caulfam, exs qua id mali creatur inteftinis, peffime curent, ut di- 
ce'sat Gll. in lib. de artic. his verbis: Interdum enim quam com. 40. propter dejectiones acres, principio quidem pinguedo, procelfu temporis quedain ftrigmenta, quce ab inteftinis deradantur, uná excernantur, plerique medici neglecto jecinore; ulceri duntaxat inteftinorum medentur, atque idcirco agrotantes precipitant; hoc igitur modo refponfum fit ad eorum adductas rationes. Supereft, ut Egyptios in biliofis dyfenteriis, atque diarrhæis, quæ non inteftinorum, fed vel totius corporis, vel hepatis vitio obortæ funt. fanguinem mittentes laudemus. Alpin. Idem faciunt in omnibus peftilentibus morbis, maximeque in omnibus exanthematibus, non minufque periculis vocatis, atque parotidibus, carbunculis, atque bubonibus. In is enim in principio, viribus confiftentibus, largè fanguinem mittere folent; in omnibufque corporibus cujufvis ætatis, vel temperamenti. Multis vero, puerifque maxime fcarificatis cruribus, atque multis fecta vena fanguinem evacuant: \& hæc de miffione languinis a. me dicta fint. Quibus ita cognitis, antequam mihi è memoria effluat, aliud tibi narrare cupio, id vero eft, illorum multos à cibo mittere fanguinem. Quod fortaffè tibi doctifino medico, non parum rationiadverfari videbitur, hoc unum feio, multos ufum hunc in mittendo fanguine fectari; fed an optimus fit is ufus, \& à nobis recipiendus, ex te libenter audirem.

\section{A P VIII.}

EEgyptios medicos à cubo Janguinem mittere, atque an rectè faciant etram, illis, quibus Sanguinem mittere debent, potum aliquem propinare.

\section{A L P I N U S.}

U ulgus Égyptiorum medicorum à cibo confuefcere mittemo. Sapirffime etenim, qui jejuno ftomacho fieri miffionen fanguinis alicui ægroto præceperim, ab Egyptiis accufabar, me corpora ægrota alimento vacus tum evacuare velle, atque ipfo. 
ipforum tum vires, tum functiones labefactare. Sxpius rogabam, ut mihi clarius hane rem explicarent, vel docerent, qui in ipforum fententiam ducere conabantur, dicebant, omnibus optimis medicis notum effe, fanguinis evacuatione corpora valde labefactari, facta plurima innati caloris ab emifio fanguine refolutione. Ideo fi id fiat ante cibum jejuno ftomacho pertimefcendum fore abfque dubio à multa virium refolutione. Addunt non minus corporum amaram bilem ab evacuato fanguine fieri acutiorem, multofque in fyncopen ftomachi jam vocatam inducere. Guiland. Sed quæfo, num tu rationibus illos falfos effe demonftrabas, an potius ab illis gratiam inire cupiebas, ipfos verè aut fietè laudando magis, ut cum iis lites detrectares? Atrin. Non ego unquam fui tam vili animo, ut eos mihi contradicentes pertimuerim, quinimo magis fæpe medicas difficultates coram nonnullis 'Turcis dominis perfequi ftudebam, ut illi cognofcerent, quantó plus Kegyptiis noftri faperent medici. Negabamque illis ab onini fanguinis miffone ægrotantium corpora debilitari, ac refolvi; veluti iis, qui ex multa plenitudine vel fanguinis, vel aliorum humorum gravati, ab emiffo multo fanguine, vel pharmaco quopiam in humoris copia exhibito exonerati, vires acquirant, fæpe fieri obfervatur, idque exemplo alicujus humeris multum pondus geftantis, qui vel omnino ab onere, vel aliqua in parte fubtractus, collapfas ferè à:labore vires recipit, illis perfuadere conabar. Quos exiam redarguebam, qni in mittendo fanguine poft affimptum cibum, eum ufum non modo ipforum multi fectarentur, verum etiam artis medice rationi illum confentire affirmarent. Hunc igitur vacuandi fanguinis peffimum effe ufum mordicus affirmabam, veluti neque alterum illum eorum ufun laudabam, qui apud om. nes eft frequentifimus in miffione fanguinis, ut ægrotis priufguam fecent venam, potum aliquem frigidum propinent. Gulland. Fortafé cibum afiumendi ante fanguinis evacuationem ufum ex Arabum clariffimorum medicorum mente illi Cap. 22. defendere poterant, quando Avicenna lib. I. fen. 4. hace ad unguem fcripta reliquerit, dicens. Subtilitatem vero fenfus babenti, ED debilitatem, bucellce mundi panis in rob acetofo bonum $b a \cdot$ 


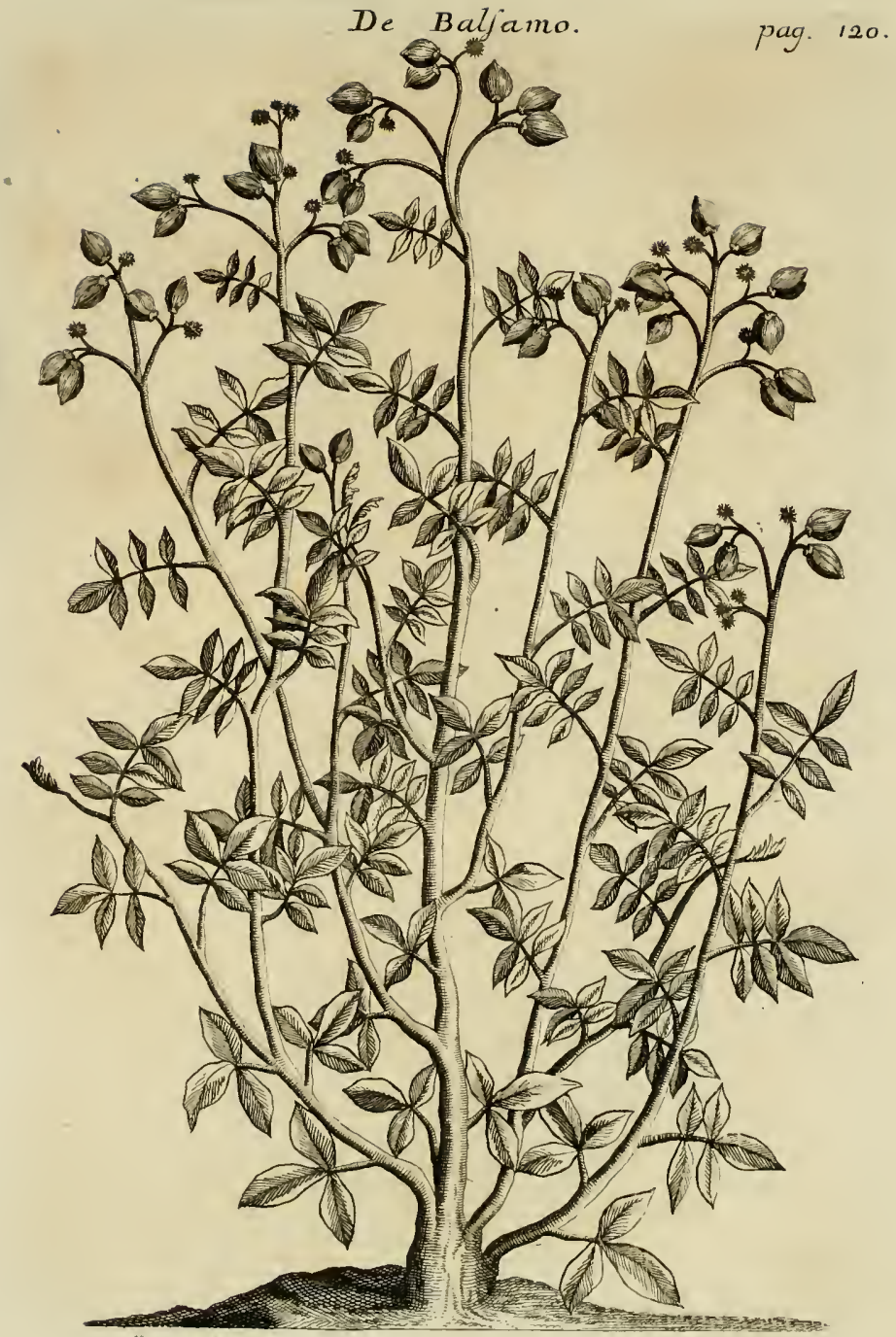





\section{DE MEDICINA EGYPTIORUM. LIB. I. ILI}

babenti odorem infufa funt dande. Et fi fuerit dibilitas comple. xionis frigide, fent intinite in aliquo, quod fit ficut aqua cum zuccharo cum Alefniati, aut in fyrupo mente mujcato, aut in myva inufcata, poftea minuatur fanguis. Optimum igitur efle, priufquàm fanguis evacuetur, eos aliquid cibi capere, qui ftomachum debilem, vel fenfus acutioris obtinent, cum Avicenna dici poterit. Cujus fententiæ Rafim non minus gravifimum medicum effe, legitur in libro de phlebotomia, Vent. \& Sang. ex mente Conftantini, cum dixit: Cholerici debent primo comedere, E p pltea minui: tamen de cibo tenui ad modum gallicelli, aut carnis bredine, aut de pane iufufo in vino, aut Jucco granatorum. Sed ip $f$, quorum corpora funt rara, condenfentur, $E^{2}$ poftec minuatur. Cum itaque hi præclariffimi medici in biliofis ftomachis, in ventriculo debilioris oris, vel acutioris fenfus laudaverint priùs aliquid cibi fore ab ægrotis capiendum, quàm fanguis mitteretur, mirum non fuit, fi \& Egyptii, cum obfervaffent pleraque illorum corporum habere ftomachum debilem, ac biliofum, idem fore $a b$ ipfis obfervandum, ne animolinquerentur, fibi ipfis perfuafum fit. Quod tamen minime aliquem Græcorum medicorum præcepiffe legitur; quin potius contra in miffione fanguinis eos memoriæ prodidife compertum eft. Gal. in lib. meth. med. dixit. Nam $\sqrt{2}$ precedat ciborum cruditas, tanto tempore differre vence fectionem jubebis, quantum fatisfacere, tum ad corum concoctionem, tum ut excrementa defcendant, videbitur; hoc idem in pluribus aliis locis docuit, præfertimque in lib. de cur. rat. per fang: mifr. atque in tertio epidem. Cui non modo omnes Græci planè affentiunt; verum etiam Arabes præcipui. Quod ex Rafe in nuper citato libro hiș verbis legitur: Quoties in fomacho cibarium fuerit, nulla fiat minutio, dum non fuerit digefum, 'E' egredietur Jubftantia de, inteftinis, qui nifi emitti poterit, emittatur cum clyftere, deinde minutio fuat: \& paulo poftidem iis verbis clarius patuit, qua funt. Horribilis eft minutio ante digeftionem cibi, qui eft in ftomacho, E? meeraïca, quoniam faita mimutione attrabitur aliquid de eo. quod in venis E' ftomacho eft ad bepar, Eं meatus ejus, refpectu vacuitatis Sunt fricti, E incongrum eft, quod attrabat: crudum, we fiat in 


\section{2

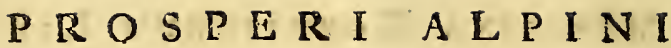

venis bunor crudus nocivus, E' eis non digeretur, fed putrefcet $E^{3}$ augebit febrem, aut infert ci aliquid pejus; idco expectanda efl mimutio fi opportuna fuerit, donec integre fiat digeftio. Cujus fignum habebitur per urinam croceam, \& alieviationem corporis, fufcitato pauco appetitu cibi. Quid igitur dicemus, quando ita periculum fit (his gravifimis medicis docentibus) poft cibum mittere fanguinem, ut multos Algyptiorum facere, dictum eft? reprehendemufne illos hac in re, an potius eos recte facere affirmabimus? Hactenus tu, quid fit pro utraque parte fentiendum, refpondendumque, rectè intellexifti. ALPIN. At ego ex te hoc dubii explicari velim. GuILAND. Hæc in refponfione funt prænofcenda. In primifque in fanguinis miffione primam operationem effe, ejufdem evacuationem, quam duo álii effectus fequuntur, fcilicer venarum inanitio, \& fpiritus calorifve diminutio, quam fequitur univerfi corporis refrigeratio, veluti inanitionem venarum omnium fucceffiva partium attractio. Atque à modica fanguinis facta in venis inanitione, paucá, \& ab immodica multa fiet fanguinis attractio, quemadmodum etiam immodicam fanguinis vacuationem fequitur immodica caloris naturalis refolutio, vel diminutio, atque hanc omnium coporis partium refrigeratio, qua omnes functiones in deterius abeunt. Ab hac poftrema fpirituum immodica refolutione, fyncope; vel animi deliquium, fit, quæ plerumque fit refolutis viribus à plurima fanguinis evacuatione. Excitatur etiam fæpiffme is affectus, ftomacho vảlde imbecillo effecto, cujus vires facile à modica etiam fanguinis vacuatione refolvuntur, vel ejus ore valde fenfibili exiftente, vel biliofis humoribus acrioribufque oppleto. In iis itaque ventriculo aliquo trium nunc dictorum modorum læfo, atque ægroto, non effet mit-

Cap. 5. tendus fanguis. Quando Gal. lib. 9. meth. med. eos ventriculi nimium fenfibile, aut imbecillum, vel amara bile redundans, dixerit, prohibere fanguinis miffionem, quam dum moliri cogimur, acutorum morborum urgente aliqua occafione, Arabes multi volunt os ventriculi pauxillo cibi muniendum effe, ac roborandum, ne in fyncopen ægroti labantur, malumque augetfcat bile amariore facta, à ventriculoque intra venas rapta. Qua mem. 
DE MEdICINA Egytionus. LiE. T. I23

membri roboratione ac defenfione à fyncope, ut jam dixi, multi ægrotis evacuandis pauxillam cibi offerunt, atque multi vice cibi exhibent aliquem frigidum potum, cum aliquo fyrupo robur ventriculi refpiciente: atque hic ufus potandi ante miffionem fanguinis, vel ftatim ab emiffo, vel dum educicur, eft ferè apud omnes fatis frequens, qui etiam ut alter cibandi in malum eft apud ipfos deductus ufum, fed de potu paulo poft dicemus. De cibo vero ante miffionem fanguinis, ægrotis concedendo, fum hujufce fententiæ, illud inftitutum inutile effe, neque citra periculum exerceri. In corporibus enim ftomachum, neque imbecillum, neque nimium fenfile ejus os, neque cum multa amara bile obtinentibus, cui dubium, fummum errorem effe, à cibo mitti fanguinem? Nihil enim ipfa ab emiffo fanguine patientur, neque vires admodum refolventur. Cibus vero multi mali caufa fieri poterit, namque incoctus intra venas attraheretur, quo venæ obftruerentur, quibus obftructis putredo \& febris neceffario augeretur. Quare in is non erit exercenda fanguinis miffio ftatim a cibo. In aliis vero ægrotis, habentibus, ut fupra dictum eft, ventriculum vel imbecillum, vel acutioris fenfus, vel amara bile redundantem, nunquam, fi fieri poteft, ad miffionem fanguinis eft veniendum: quod fi a magno morbo cogamur id facere, poffumus præcepto AEgyptiorum uti, ut detur aliquid cibi vel potus. Mihi tamen magis potus, quàm cibus arridet; proinde illos magis laudo, qui aliquo potu utuntur, quo acutum oris ventriculi fenfum, vel bilis calorem, atque acrimoniam obtundant, atque attemperent. A LPIN. Quibus fanguinem mittere volunt, ne in fyncopen incidant, aquam fimplicem crudam faccharo commixtam cum modico fucci limonum, exhibent: quam potionem, ut poftea dicemus, ipfi per excellentiam, farbet, appellant, atque ipfam vel ftillatitiam calaf, vel de nenuphare, vel de foncho, vel endivia cum aliquo fyrupo refrigerante, veluti eft violatus, nenupharinus, rofatus, de fucco limonum, vel de acetofitate citri. Alii eandem cum vino granatorum, atque faccharo, atque alii exhibent aquam infufionis, florum calaf, vel berberorum, vel tamarindorum cum faccharo. Atque alii. 


\section{4

etiam offerunt potionen, de quibus poftea loquemur. Quæ omnia videntur idonea auxilia ex calida temperie imbecillo ventriculo, vel acutioris fenfus, atque biliofo five picrocolo, $a b$ eo enim potu, exeunte fanguine, non facile in deliquium animi ægroti concidunt. Quid mirum enim eft, frigidæ aquæ potu a fyncope ægrotos defendi poffe, cum ea tantum in facie projecta, jam ortum deliquium animi mitefcere compertum fit? Guiland. Aquæ illiufce potus ufum iis, quibus fanguis ftatim mittitur, noxium potius, quàm utilem apud eos judico, quando, ut ex te audivi, non modicò, fed larga frigidam aquam illis propinent, qua etfi videantur tunc juvari, qui rectè perferant fanguinis miffionem, tamen paulo poft nimium refrigerato ventriculo, aliquam noxam fentient; maximequé etiain, quia $a b$. ipfa intra venas rapta ægrotos in hydropem incidere poffe Avicenna teftatum reliquit. Quod ejus verba ita explicant: In eo, qui phlebotomatur, fuper potum aque plurime timetur hydrnpifis, propter expulfionem aque attraEte cum fanguine ad profunda membrorum: Quare oportet, ut fit occupatus in provocanda urina., E? $e a$, qua Sequuntur. . Neque rectè utilitatem aquæ in facie projectæ calorem intus protrudentis, qui tunc vividior in ventriculo, aliifque internis membris fit, ei utilitati effe comparandam judico, quæ per os potu aquæ in ftomachum affumitur, quando hæc non modo calorem non vivificet, fed potius imminuat, atque extinguat, \& illa foveat, atque roboret, ab extrinfecis partibus manduntur, $\&$ potantur, in miffione fanguinis: utilius nunc erit, ut ad modos, pro quibus illi fanguinem mittunt exponendos, accedas. Ne tempus in his amplius conteramus. 
DE MEDICINA EgYPTORUM. Lib. II.

\section{A P. IX.}

\section{Quot modis E Egytii Janguinem mittere foleant. \\ G U I L A N D I N U S.}

บот modis medici illi fanguinem mittere nane confueve rint, ex te audire defidero, ex quo fermone non parum ego voluptatis accipiam, quando apud illos medicos cogitem, præter eam rationem, qua noftri medici in mittendo fanguine utuntur, aliquos alios in ufu effe mittendi fanguinis modos, quos noftris non minus pro varietate præfidiorum, quàm utilitate multa, maxime gratos fore exiftimo. Igitur, fi placet, de his fermonem inftituas. Alpin. Tribus modis eos mittere fanguinem ibi obfervavi, ac cognovi, quippe per venarum, \&t per arteriarum fectionem, atque tertio per facrificationem cutis. Venarum enim fectione, non fecus quàm roftri, nacti ab acutis, atque magnis morbis occafionem, fanguinem mittunt. fed à plurimis venis, quæ apud noftros medicos non funt in ufu, miffionem fanguinis exercent, veluti funt venæ temporum, frontis, aurium, angulorum oculorum, nafi, labiorum, gu-læ, atque aliarum partium aliæ, quas paulò poft recenfebinus. - Arteriarum pro miffione fanguinis etiam fectionem, apud ipfos effe non minus in ufu, quam venarum ad multos chronicos morbos profligandos, omnes, qui ea loca habitarunt, teftes exiftunt. Et ego hifce oculis fæpe vidi frontis, aurium, manufque arterias fectas, quæ non fecus quàm vena brevi tempore coaluerunt.' Harum ufum pro mittendo fanguine, Egyptiorum, Arabumque proprium effe exiftimo, quando alibi nufquam gentium, neque viderim, neque audierim obfervari talem miffionem fanguinis, quæ etfi multis ad multos morbos idonea, ac multum utilis videretur, non tamen arteriatum feEtionem tutam, atque fine magno periculo exerceri poffe quifquam affirmabit, magna fiquidem cum difficultate, \& non fine multo yitæ difcrimine fectæ arteriæ coalefcere poffunt, ut \&

$$
\text { - Q } 3 \text { apud }
$$




\section{$x=6$

apud Galenum \& alios præclarifimos medicos planè conftitutum eft. Sed de his fuis locis loquemur accuratius, atque uberius. Cute etiam fcarificata, frequentiffime, atque familiarifiime, mittunt fanguinem, in pueris, mulieribus, atque Eunuchis. Scarificant autem ad mittendum fanguinem, cru$\mathrm{ra}$, aures, nares, labia, \& ab his partibus fearificatis abfque ulla cucurbitula fanguinem evacuant. Advertant medici-noftri temporis illos nunquam ab illis facrificatis partibus pro eductione fanguinis ullo cucurbitularum genere uti, fed earum vice dulcis aqua calido balneo, nec unquam pro univerfali corporis evacuatione cucurbitulis fanguinem educunt, fed folum pro partis alicujus evacuatione molienda, præfertimque capitis, neque præterea partibus corporis cucurbitulas affigere folent pro mittendo fanguine, occipite atque collo exceptis, à quibus in oculorum morbis, multifque aliis calidis morbis capitis, femper facta univerfali corporis evacuatione, fcarificatione cucurbitulis appofitis fanguinem mittunt. Cucurbitulæ etiam, quibus illi medici utuntur, $a b$ is, quæ apud noftris in ufu exiftunt planè diverfæ fpectantur, illique diverfo modo iis utuntur, Quando eas non igne, vel aqua, ut noftri faciunt, fed fpiritus attractione cuti affigunt. Sanguinis miffionem per hirudines prorfus negligunt, quòd ibi hæ fortaffe non nafcantur, neque reperiantur. Hique modi exiftunt, quibus illi medici fanguinem mittunt. Nunc vero de omnibus venis, quarum fectionem pro fanguinis miffione frequentant, loquendum eft.

\section{A p. X.}

\section{De venis, que in ufu funt apud Egyptios} pro molienda fanguinis mifrone

\section{A L P I N U S.}

$A$ PUD Medicos Rgyptios pro mifione fanguinis facienda $A$ omnes utique venæ in ufu exiftunt, fed quæ magisfami- 
liares apud ipfos habentur, fæpiufque frequentantur, funt temporum, frontis, magnorum angulorum oculorum, aurium, nafi, narium, labiorum, præfertimque inferioris labii, linguæ, occipitis, colli, atque jugulares, cubiti, manus, poplitis, furarum, atque tali. Ufus vero venarum capitis apud illos frequentiffimus, atque familiarifimus eft, quòd fæpe ingens ipforum caterva oculorum lippitudinibus corripiantur, atque afflictentur. Quibus occurrunt, fanguinis in primis facta evacuatione, ex cephalica cubiti directè partis affectæ, vel magis Jæfæ refpicientis, \& mox fecta vena frontis, deincepfque non definente morbo, magnorum angulorum oculorum. Multi priufquàm ad venam frontis accedant, miffionem fanguinis ex occipite, atque partibus proximis poft aures pofitis, cum farificatione appofitis cucurbitulis procurant, atque mox non fublata oculi inflammatione, ad alias nuper dictas fecandas defcendunt. Guiland. Rectè in iis fecandis fe gerere videntur, quando, Gal. in lib. de conftit. art. med. docuit, fanguinis Cap. $17:$ evacuationem affecte parti per vicinarum partium venas fieri oportere, veluti his verbis apud ipfum legitur: His ergo docentibus, qui in coxendicem fluxus decubuere, per poplitum ac malleolorum evacuabimus venas, uti fanè, Eे que in uteris barefcunt: que in thorace ac pulmone babentur, per venam cubiti internam: Quce in capite E' in collo ex buneraria. Proximarum enim, omniumque affecte particula venarum evacuatio optima eft ac facillima. Providere itaque oculorum inflammationibus per has fectas venas rectè videntur. Sed quonam modo ipfi parvas, vixque apparentes multarum partium venas fecare queunt? ALPIN. Certè Chirurgi Rgyptii, five operarii in fcindendis venis, longè noftris accommodatiores, ae peritiores obfervantur; tenuiffimas fiquidem ac multum obfcuras venas commodè ac tutò fecant. Quod etfi tutò faciant, nihilominus in multis partibus, hæ minimæ venæ vixque confpicuæ cernuntur, fearificatione utuntur, pro evacuando fanguine, veluti faciunt $a b$ auribus fanguinem mittere volentes, venis intra extraque ipfas fcarificatis. (Quamquam Gal. in epidem. Hippcoratem reprehenderit, dicentem. Cedemata curantur $\int c a r i f i c a t i s$ venis 


\section{:28 PROSPERI ALPINI}

qlie intra aures funt.) Idemque in labiis, gingivis, naribus, collo, cruribufquee facere obfervantur; à quibus partibus fearificatis non æquè copiam fanguinis evacuant; namque $a b$ auribus, labiis, gingivis, collo, paucus emanat fanguis, cujus pauca quantitate ex auribus infantium detracta; (hæc enim aurium fcarificatio propria ferè puerorum ibi exiftit.) atque etiam a labiis, gingivifque eductum fanguinem etiam in adultis præcedente univerfali evacuatione, mederi poffe malis illarum partium arbitrantur. GuILAND. Expecto etiam, ut dicas, quibus malis occurrant ex fectis is fingulis nuper dictis venis, pro fanguinis evacuatione facienda. De cujufque igitur fectionis; qua hi utuntur pro miffione fanguinis, utilitate, nunc te verba facere cupin. Alpin. Dico igitur à vena frontis facto principio, eam Egyptios fecare, atque ab ea fanguinem mittere; in maximis capitis doloribus, ac inflammationibus: quibus malis fanguinis evacuationem ex ifta vena celebratam verèconduAphor.68. cere Hippocr. lib. 5. Aphor. \& Gal. tum in lib. de curandi rat. Cap. 19. per fang. miff. tum in 13 . meth. nos docuerunt. Itidemque veCep. I1. nas temporum, magnorumque angulorum oculorum ipfi in iifdem affectibus fecant, quibus ab iis feetis venis miffionem fanguinis convenire, Gal. in lib. de Anatomia vivorum, fcriptum reiiquit; quippè in capitis doloribus, præfertimque, hemicraniis, atque in antiquis opthalmiis, \& lacrymis, panno, fcabie, palpebrarum. nyctalope. Venas vero poft aures, atque intra aures fecant in pueris aliquo acuto morbo vexatis, præfertimque in calidioribus capicis morbis. Nariumque \& nafi venas in. cidunt in antiquis doloribus capitis, atque in oculorum etiam paffionibus, facieique ruboribus, \& inflammationibus, proximas nafo particulas lædentibus, ut eft gutta rofacea. GuiLand. Hunc venarum ufum, atque utilitatem fortaffe eos à Galeno accepiffe, dicendum erit, qui in lib. 1. de comp. med. fecundum loc. hac eadem à te narrata ad unguem his verbis fcripferit, dicens: Oulod fi affectio (ut potd clolor capitis) perfeveret, vona fectione î nafo, aut fronte, aut cucurbitis affixis utitor, fanguinis a locis affectis detractiones In affectionibus inveteratis convenire omnes medici fatentur. Alpin. Et labiorum, gin- 
givarumque venas fecant, vel potius fcarificant, in faucium, gutturis, oris, gingivarumque inflammationibus, atque in dentium doloribus, à dentium gingivarumque morbis, atque labiorum fiffuris fcarificatione gingivarum, ad dentium radices ter quaterque in menfe facta, felongo tempore præfervant, eas vero fcarificant acutifimo ftilo argenteo, vel aureo. Mittunt etiam fanguinem fectis fub lingua venis in gutturis, afperæ arteriæ, faucium, \& tonfillarum inflammatione, non fecus, quàm noftri faciunt. Collum vero atque mentum fcarificant, in gutturis maximis inflammationibus, ab iifque fanguinem mittunt, appofitis cucurbitulis. Quod ex Galeno faciendum, in iis morbis in 6 . de compon. med. fecundum locos, his verbis docemur. Si vero nibil tale appanuerit, augefcat tamen malum, ita, ut cogrè transglutire poffint egri, ut filffocationis principium fit nobis fufpe- Cap. 3 . Etum, alvus forti clyftere, aut glande Jubducenda eft, Eं vena cubiti fecanda cucurbiteque cum fcarificatione collo ac mento affigendce. GuILand. Quafi ifthæc omnia Gal. confirmat de miflione fanguinis à venis capitis, quiæ tu nunc dixifti, in lib. de curat. Cap. Ig. per fanguinis miff. ita dicens: Quo circa quie in gutture Eo-arteria gravi torquentur inflammatione, in principio quidem fecta in cubito vona, poft principium autem in ipfa lingua magnifice prodeft, incifis videlicet venis, que in ea funt, ambabus. Sic indurate phlegmonis in oculis reliquice, Jecta, quice ad magnum decurrit angulun, vena, mirifice juvantur: Sicut capitis gravitas, $E^{2}$ inveteratos in eo ex plenitudine dolores levare, manifefte folet tufa in fronte vena: ac incipientes, aut etiam vigentes per cucurbitam in cervice procurata retractio, interin quidem folam, interim cum fcarificatione. Sed tu perge reliqua enarrare. Alpin. Jugulares venas non minus fecant in maximis, tum gutturis, tum ceterarum partium refpirationi fubfervientium inflammationibus, atque tumoribus, maximeque in angina fuffocante. Multo etenim fanguine ex altera jugularium ferta vena, evacuato, multos ferè planè fuffocatos ad vitam rediifle, à multis illorum, atque à me obfervatum eft. Neque mirum, quando \& Auctor lib. de Anat. vivorum hæc fcripta reliquerit: Et ex iffis funt suce jugulares, Eo mimuntur in principio lepre, EO fortis angince, 


\section{PROSPER I A L P I N I}

E angufia anbelitus, $E^{2}$ in aftbmate acuto, Eे in raucedine vocis, $\mathcal{G}^{-}$in apoftemate pulmonis, $\xi^{\circ}$ in spirandi difficultate, que exi multo fanguine fit calido, E' egritudinibus Jplenis, E' laterum. De aliarum vero venarum utilitate nihil amplius dicam, quando fatis omnia, quoad illorum ritum hactenus dixerimus. De crurum vero auriumque fcarificatione, à quibus partibus per fearificationem abfque cucurbitulis mittunt fanguinem, aliàs fuis locis loquemur. Atque hic eft illarum omnium venarum apud REgytios frequentatus ufus, \& utilitas. Quæ omnia non diffentire videntur à Galeni doctrina. In lib. enim nuper dicto, fi tamen ejus eft, de venarum temporum, jugularium, magnorumque angulorum oculorum, atque omnium aliarum ufu atque utilitate eadem planè leguntur, \& illarum, quæ in Cap. 2. naribus exiftunt, fronte, lingua, in lib. 2. \& 6 . de comp. Cap. 3. med. fecundum loc. non minufque ufus cucurbitularum in collo $\&$ mento, atque poft aures, in lib. de oculis, atque in 6 . epiComm.5. dem. GuILAND. Priufquàm ulterius progrediaris, lubet alitext. 22. qua adverfus ea, quæ de ufu venarum, quæ funt in magnis oculorum angulis atque poft aures pofita, ex ⿸厂犬gyptiorum inftituto dixifti, nunc in medium afferre. Nam author lib. de Anat. vivorum dixit: Et duce vence temporum, que flexunfe inscedunt: Eे duce vence, qua funt in angulis oculorun lacrimalibus, non apparent multum, nifi propter conflicictionem fuffocantem, Es in ipfis non eft profundandus pblebotonnus, quoniann fortè firrent fiftulce, \& non egreditur fangitis nif $\sqrt{\imath}$ paucus. Ex his igitur apparet ufum venarum, magnorum angulorum oculorum neque tutum, neque multum utilem effe, quando ab iis fectis venis, \& fiftularum impendeat periculum, ex parte fubjacente ad fufcipiendas fiftulas facillima; atque cum parum etian fanguinis per earum venarum feetionem evacuetur, parum utilitatis effe poffunt. Eas vero, quæ intra, extraque aures cernuntur, quas tu fecare illos affirmafti, certum eft Galenum, Hippocratem in o. cpid. reprehendiffe, qui dixerit, Cedemata curari fcarificaEap. i. tis quxe intra aures funt. 'De' venis autem poft aures pofitis Hippoc. hrec in lib. de aëre, loc. \& aquis memoriæ prodidit: $A$ principio morbi utranque venan retro aures incidunt, quo facto 
fanguine mulio promanante fommus cos corripit pre imbecillitate, ficque obdormifcunt, quorum quidem aliqui depulfo Jomno fani exirigunt, aliqui vero minime. Atque mibi Sane videntur ea medicatione Jeipjos perdere: vence enim retrò aures funt, quas $\sqrt{i}$ quis $\int e$ cet, fterilitatem inferet bis, quibus fecantur: Quamobren ex is apparet, primo magnorum angulorum venas parvæ effe utilitatis, quòd per ipfarum fectionem paucus fanguis educatur, \& fecundo, aurium nuper dictas fectas venas fterilitatis, atque exitiofi fomni aliquando effe caufam; ideo illarum ufum haud à nofris medicis arripiendum puto. AlPin. De venis magnorum angulorum in oculis Galenum dixiffe, paucum fanguinem vacuari, atque impendere periculum ex ipfarum fectione futuræ fiftulæ, veriffimum eft, fi tamen is ejus eft liber, quando in alio libro de curat. per fang. miff. de iis venis, hæc etiam fcripferit: Sic indurate pblegmonum in oculis reliquice, Jecta, que ad magnum decurrit angulum vena, mirifice juvatur. Ego vero femper quantum volui fanguinis copiam, ab his fectis venis in multis corporibus detraxi. Francifco enim Rigono, Georgii Hemi; eo tempore ibi pro Sereniffima, fimulque feliciffima Veneta Republica, Confulis clariffimi, Oeconomo, difficili oculorum lippitudine afflicto, vena, quæ dextri oculi magnum perreptat angulum, diffecta, fanguis ad librarum pondus frepe detractus eft. Nullifque, etfi in pluribus iftius venæ fectionem obfervaverim, exinde fiftulam obortam fuiffe obfervavi. De venis verò, quæ tum intra tum extra aures exiftunt, quas omnes fcarificatione fecant, quamquam in illarum fectione Gal. Hippocratem reprehenderit, nos pofterius, ubi de fcarificatione aurium fermonem habuerimus, quid fentiendum fit, dicemus. Quod verò apud Hippocratem legitur in lib. de aëre, loc. \& aquis de venarum poft aures pofitarum fectione, atque ab illa evacuato copiofo fanguine, cum fterilitatem induci, tum immoderatos fomnos, partim verum, partim falfum eft. Etenim ex larga fanguinis per illas venas diffectas evacuatione homines in profundiffimos, longifimofque fomnos, prolabi, non eft mirum: multa exinde cerebri facta refrigeratione, ab imminuto calore nativo, ob multam cum fanguine fimul firi$R_{2}$

tuum 


\section{PROSPERI ALPIN I}

tuum factam diffolutionem. Minime tamen obfervatum eft; aliquam ab ea fterilem evafiffe. Memini juvenem Chriftianum natione Cophtum, annos natum fupra viginti, Aois appellatum, Cayri ab appofitis cum facrificatione cucurbitulis poft aures, ob oculorum difficilem opthalmiam, illifque venis profunda, more illorum, fcarificatione facta, incifis, ac plurimo vacuato fanguine, in profundiffimum fomnum incidiffe, ex quo multi mortuum ipfum funt arbitrati, qui tamen poft très dies expergefactus, convaluit, paucofque poft menfes puellam pro uxore duxit, cum qua filium habuit; hæcque à me obiter de his dieta fint. Guiland. Venas capitis multas quippè temporum, angulorum oculorum, nafi, frontis, \& alias non nifi propter conftrietionem fuffocantem apparere, ut commodo fecari poffint, Author libri de anatom. vivorum docuit. Proptera nefcio, an \&gyptii illas ita parent, ut intumefcant, more noftrorum, linteo quàm foriter collo devincto, vel alio utantur, ut idem præftent, artificio. Amplius duo etiam alia fcire ex te cupio, quorum alterum eft, quo pacto jugularem venam apparere faciant, quaque in parte rectè appareat: non minufque quomodo ab iis fecetur. Demum idem de ea, quæ in poplite fcinditur, à te dicendum puto. Alprn. Eodem modo, quo noftri facere obfervantur, Egyptii utuntur in fecandis omnibus capitis venis, ligantes collum linteo quàm fortiter, vel etiam frontem pro fcindenda vena frontis: In fecanda vero altera jugularium, in primis collo eodem modo fortiter linteo devineto, ægrotum caput flectere; atque inclinare ad oppofitam partem jubent, venamque per rectitudinem tundunt, ac vacuato fanguine, caput preter quod ad oppofitum inclinantes diftendunt, obliquè flectunt, ut venæ fectio obtegatur, faciliufque coalefcat. Secant itidem fub poplite venam, facta ligatura fub genu, interimque etiam fupra genu. Sed fepe non apparet, maximèque in iis, quorum corpora venis exiguis referta funt. Sed tempus eft, ut ad arteriarum fectionem, qua $\mathbb{E g y -}$ ptii non fecus quam in venis utuntur, tranfeamus. 
DE MEDICINA EGYPTIORUM. LIB. II. T3

\section{A p. XI.}

Egyptios arterias pro Janguinis mifione non fecus quàm venas fecare.

\section{A L P I N U S.}

F GYptris fanguinis vacuatio per fectas arterias non minus quám per venas, familiariffima eft, $\&$ abfque ullo timore eas lecant ad quamplurimos curandos morbos. Ufumque fanguinis vacuationis per ipfas fectas frequentiffimum habent, ac pro tutiffimo auxilio, divinoque fecreto, ad diuturnas oculorum opthalmias, aque inveteratas, nec-non ad capitis, vifcerumque multorum antiquos, diuturnofque dolores. In hifque malis audaciffime illi non fecus quàm venas, arterias fecant, atque $a b$ ipfis fanguinem mittunt. Gurland. Mirabile nunc ex te de arteriis audio, quòd ipfas pro mittendo fanguine illi medici fecare audeant, atque ita familiariter \& tutò, perinde ac in venis facerent: hoc certè non poffum non multum admirari, maximeque cum nemo noftrum hanc provinciam aggredi hactenus aufus fuerit. Harum fiquidem fectarum arteriarum ufum pro miffione fanguinis, non modo omnibus medicis recentioribus, verum etiam antiquis maxime fufpectum fuife, multorum teftimoniis planè conftat. Neque immeritò Gal. in lib. decur. rat. per fang. miff. hæc loquente; Quin छ̇ interiiffe quofdam novi $a b$ arteria interiori in cubito, vena fubjecta, nonnullos quidem potius ob vinculum circunpofitum, volentibus medicis fiftere fanguinis eruptionem, in gangrcenam incidentes: alios poftea in aneurifonate manu curando defunctos. Quo timore non injuria in animos, tum antiquorum, tum recentiorum medicorum injecto; exinde omnes abhorruere fanguinis miffionem per arteriarum fectionem faciendam, tantique remedii ufum hinc parvi fecerunt, atque neglexerunt. Quid itaque ais, tantùm illis medicis Ægyptiis nunc ineffe audaciæ, ut omni abjecto timore, magnifque neglectis periculis, arterias, ufque ad mittendum fanguinem fe$\mathrm{R}_{3}$

cent? 


\section{PROSPERI ALP I N I}

cent? Alpin. An non tibi videntur medici tutò poffe arterias fecare, quia fortaffe fectxe arteriæ nequeant coalefcere, atque hinc aneurifmatis periculum impendere, tandemque exitii?

Cap. 6. Fortaffe nunc eorum tibi non venit in mentem, quæ Gal. .hac de re fcripferit in libro 5. methodi, quæ funt hujufmodi. De arteria autem vulnerata jam dictum eft, nonnullis mediconum videgi non poffe fieri, ut coeat. Atque afferunt aliqui quidem fola experientia Se contentos profeffi: Alii vcro etiam ratione usi ejufinodi, fiquidem duram effe ac cartilagineam ajunt alteram arterice tunicain, talium vero nibil polfe in unum coire, cum fit mollium tantum corportim in unum coeundi babilitas: ut tum in externis, vidielicet nullo nec lapide cum lapide, nec tefta cum tefta unquam coeunte: tum vero in nobis ipfis, quando nec cartilago cum cartilagine, nee os cum offe coalefcat. Non enim fracta offa per unionem cobserent, Sed per callum eum, quen Graci poron wocant, cen glutine junguntur: Suquidem arterie natura difficultatem quidem durior is tunice fuce glutinande, prorfus indicat, non tamen ejufmodi, que evinci omnino nequeat, neque ita eft ficca $\mathcal{E}^{2}$ dura, ut os vel cartilago, immo longe bis mollior, ac magis carnofa. Quo utique mimus de unienda fectione ejus eft defperandum, ubi tum ipfa fit parva. tum bominis corpus natura molle. Videtur autem experientia quoque ipsa rationi fubfcribere: cum $\mathcal{E}^{W}$ in pueris $\mathcal{E}^{*}$ in mulieribus propter corporum bumidiatem, $8 \mathrm{~g}$ mollition, eam viderim glutinari, Eं in uno juvene, cui (ut dictum efl, ) exigue erat incifa. Cum vero fanatu difficilior fit arteria, quàm vena, non tamen eft medicamentorum admodum diverfus in utraque ufus, immo fpecie planè idem majoris minorifque ratione evarians. Quippe tanto ficcioribus medicamentis eget arteria, quim vena, quod $f i$ carnem circa gigni eft opus, eadem amba requirunt: atque hæc Gal. Ex quibus cum conftet arterias fectas poffe coalefcere, quamquam ita non facile id fit, cur \& nos non fatebimur, tuto polfe earum aliquas pro mittendo fanguine fecari? nee ab ipfarum fectione, femper aneurifmatis pendere periculum? Mihi quidem hoc videtur, verum ratione in primis, quod arterix fectx poffint coalefcere, atque mox experientia Eyptiorum omnium, quos fepiffime viderim multas in multis agrotis fecuife, abfque uilo difcrimi- 
ne vel timore, nullumque à fecta aliqua arteria obiiffe vidi; quinimo multos exinde fanatos fuifle, Galenus etiam vifus eft hoc non modó non rejeciffe remedium, verum tutò medicos uti. que arterias fecare poffe confirmaffe, atque eafdem coalefcere poffe. Etenim ipfe in lib. de curat. per lang. miff. circa finem dixit: poftquam per infommia monituis arteriam fecui, quee eft inter pollicen E⿺ indicem, E Sanguinem ea lecta mifi, beneque fucceflit, atque vidi etian magiftrum quendam Pergami artcria cubiti fecta, à lateris dolore liberatum abfque ullo aneurifmate; atque hæc etiam fubjungens, ait: Hec itaque mibi perfuctferunt, ut fubinde in fummis artubus, immo $\mathcal{O}^{2}$ in capite arterias Jecarem in omnibus doloribus, qui à calida, fpirituofaque fubfeantia nafci videbantur, Eे maxime in membranis: quarum dolor punctioni fimilis eft, ac Jenflun expanditur, pungente quidem jenfu una in parte, tanquam in affecti loci centro infixo. GuILAND. IVon differt mea hac in re à tua fententia, quinimo eidem addictus fum, exiftimoque non effe defperatam arteriarum fectarum unionem, atque coalefcentiam; duo tamen exiftunt, qux mihi hujus rei veritatem non parum ancipitem reddunt, quorum alterum eft, pulfus in arteriis motus, qui videtur valde efficax ad vitandam arteriæ unionem, ulcerifque fanationem. Gal. enim pulmonum ulcera fanari non poffe ob continuam pulmonum motionem, non inmeritò docuit, cum ex motu vulnera, qne coaluerunt, facile denuo rumpantur, atque aperiantur. Cogito itaque motum continuum arteriarum ipfis, quominus coalefcant, atque fanentur, effe multo impedimento, quæ difficultas augetur a duriori fubftantia arteriarum, qua fectæ arteriæ multo difficilius venis fanari poffunt. A L P I N. Galenus ait, arterias dura fanè fubftantia præditas effe, non tamen ea, quæ nullam recipiat coalefcentiam, atque unionem. Illi vero arteriarum prævalido motui facillimo ac tutifimo remedio occurrunt. Sectioni enim arteriæ, probe in primis unitæ digitis fruftum æris planum, rotundum, \& craffum fuperponunt, ipfumque valide, ei annectunt, \& fortiter ligant, ut valide arteriam comprimat, atque ejus pulfui valide obfiftat, ne rurfum. vulnus aperiatur. Gurand. Hæc fufficere mihi videntur, ad des 


\section{PROSPERI AL PIN I}

demonfrandum rectum in arteriarum fectione ufum, \& hac ratione tutò illos medicos operari pofle exiftimo. Nunc te, quas illi fecant arterias, narrare decet, atque quonam modo, tum illas fecent, tum fectas fanent, ab aneurifmateque defendant, \& in quibus malis earum fectione pro mittendo fangui: ne, illi utantur.

\section{A p. XII.}

De arteriis, quas CEgytii fecare folent, atque quo* modo illas fecent, of curent, \& in quibus etiam morbis ipfarum Jectione utantur.

\section{A L P I N U S.}

H $\mathrm{J}$ u s regionis medici omnium arteriarum, qux in capite cernuntur, fectionem pro fanguinis vacuatione aggredi folent. In antiquis enim capitis doloribus, maximeque cum pulfu affligentibus, in omnibufque etiam capitis inflammationibus, arteriam frontis, temporum, atque eam, quæ poft aures eft pofita, fecare folent; idque feliciter ipfis accidit, ex his vero omnibus eam, quæ in fronte exiftit, frequentius ad illius affectus fcindere folent, præfertimque in antiquatis ophtalmiis. Multos, qui vel antiquum capitis dolorem pertulerunt, vel oculos longo tempore habuerunt lippientes, per fectam frontis arteriam fanguine evacuato fubito, quafi præftigio quodam fanatos fuiffe Cayri vidi. Harum itidem earundem arteriarum ufum Galeno fuiffe plane cognitum, verba ab co in lib. 14. meth. tradita probè manifeftant, quæ hæc exiftunt: Oportet autem derafo capite curiofe tangere, tum quce retro, tum quce fecundum utramque aurem fint, arterias: preterea, que in fronte, $E^{2}$ que in temporibus fint. Quarum quce calidiores aliis apparebunt, ac majorem exhibentes pulfum, be funt incidende. Qulecumque vero E̊ parsa E⿺ propè cutein refident, barum vel fi partem aliquam excideris, veluti facere in crurum varicibus folemus, aptius erit. Quod \& apud illos frequens eft; neque immeritò, quando ar. 
teriæ; quæ calidiores atque grandiores apparent, multum fanguinem excalfactum, vel aliquo flatu permiftum contineant; eoque repletæ diftendantur; qui per eas fectas, tum evacuatur; unà cum halitu, tum refrigeratur. GuILAND. Quæfo ne te narrare pigeat, an apad illos medicos videris nuper dictarum arteriarum aliquam fectam, ut venæ $\dot{a}$ noftris fecari folent, fimulque extractam, vel exuftam fuiffe. Quando in lib. de Anat. vivorum hæc de his legantur: Ex arteriis veró, que funt in capite, eft arteria temporis, qua quandoque aduritur, Eं boc. fit, ut rbeumatifini fubtiles conftringantur, qui ad. oculos defcendunt; Es duce arterice, que funt poft aures, que pblebotomantus" propter Species opbtalmia, E principium aqua, nycialopes, E' antiquum dolorem bepatis, in earum tamen pblebotomia femper exiftit timor, E Eardatur confolidatio. AlpIN. Nunquam illos medicos vidi arteriam aliquam totam fecuiffe, vel extraxiffe, fapiffime tamen phlebotomatam nọ fecus quam venam fuife in multis oculatim vidi... Sæpiffime ad prohibendos catarrhales fluxus in oculos; temporum arterias exurunt: In omnibus fanè $\not$ Egypti locis quamplurimos exuftis temporibus, ob eam caufam cernes: is vero arterias illas, atque alias exurendi ufus ab Athiopia illuc delatus eft. Nam \#thiopum, Abifionorumque plurimi eum modum exurendi affectant. Nunquam. vidi aliquem ufum fuife fectione arteriarum, poft aures pofitarum, pro lippientibus, atque iis, qui hepatis dolorem, patiuntur; hepate enim affecto illam fecare folent arteriam, quæ inter pollicem digitum, \& indicem manus pulfat. Quod Cap. 13. à Galeno quoque comprobatum fuiffe legitur in lib: de curat. per fang. miff. Audivi ab illis-medicis etiam jugulares arterias in fuffocantibus affectibus fecari, quod ego nufquam in illis locis vidi. Secant in manu, ut dictum eft, pofitam inter pollicem \& indicem digitum, ab eaque mittere fanguinem folent ad omnes internorum vifcerum dolores, atque inflammationes. Hrque funt arteriæ, quas eos ad fanguinem detrahendum, fecare per id temporis obfervare potui. GuILAtid. Illos mihi in multain gratiam reduxifi, qui non modo omnes Græcos, Arabefque antiquos medicos longè in hoc fliperarint, cum nun- 


\section{$13^{8}$

guam ipforum aliquem fuife legatur, qui fectione arteriarum ita familiariter, \&r tutò ufus fuerit, fed fortaffe multis fecretis auxiliis vel medicamentis fectas illas arterias, magis tutò conglutinant, \& ipfarum vulnus fanant. Alpis. Duo nune tibi narro, quorum primum eft, quomodo illi fecent arterias; fecundum, fectas quo pacto facile fanent. Operarius in primis partem, in qua arteria feindenda exiftit, fafcia linea, non fecus quam in venarun fectione fieri folet, ligat, arteriamque fanguine impleri, atque tumidam fieri, finit, quam tune acutifimo phlebotomo, five fcalpro oblique fecat (phlebotomis regyptii ad fectionem arteriarum longè noftris acutiores utuntur, ) in fectioneque etiam illarum femper minimam effciunt fectionem, quia ianguis tenuifimus eft, atque etiam quòd magnum vulnus difficilius coalefcit. Seeta itaque arteria finit fanguinis tantum effluere, quanto opus habet: cujus quantitatis regula à multis obfervatur, quando ex femetipfo fanguis definit efifluere. Sanguineque vacuato, non fecus quàm noftri in feEtis venis ad unionem digitis labia deducunt, ita fectam arteriam unit, ejufque vulneri modicum goffypii fuperponit, fupra quem æneum magnum denarium ibi ufitatum, (quem illi Follara appellant, eftque ipfe latitudinis conmunis veneti aurei, \& crafitie argentei aurei) fortiter alligat, permittitque hoc modo arteriam ligatam, \& adftrictam tribus diebus manere, quibus finitis, ligaturam detrahit, nullo ad ipfius curam auxilio $a b$ is ufitato; nullumque ex plurimis, vidi, cui fectæ arteriæ fuerunt, qui detracto æneo denario, ligatura poft très cxactos dies, aliquo alio auxilio opus lrabuerit, fed integrè fanatos omnes obfervavi. Sunt vero aliqui, qui priufquàm liggent arteriam, goffypiumque ei fuperponant, parum thuris accenfie candelæ flammâ calefacti apponunt, eoque arteriæ vulnus reetè digitis uniunt, \& mox goffypium, \& tandem follara fiuperponunt, atque alii lentium nigrarum pulverem arteriæ vulnus afpergunt, \& mox goffypium \& follaram apponunt; atque hæc de fectione arteriarum apud illos ufita fufficiunt, ex quibus colligitur duo in fectione illa obfervari, feilicet in is affeetum minimun vuhns, peroblique acutiffimoque phlebo- 


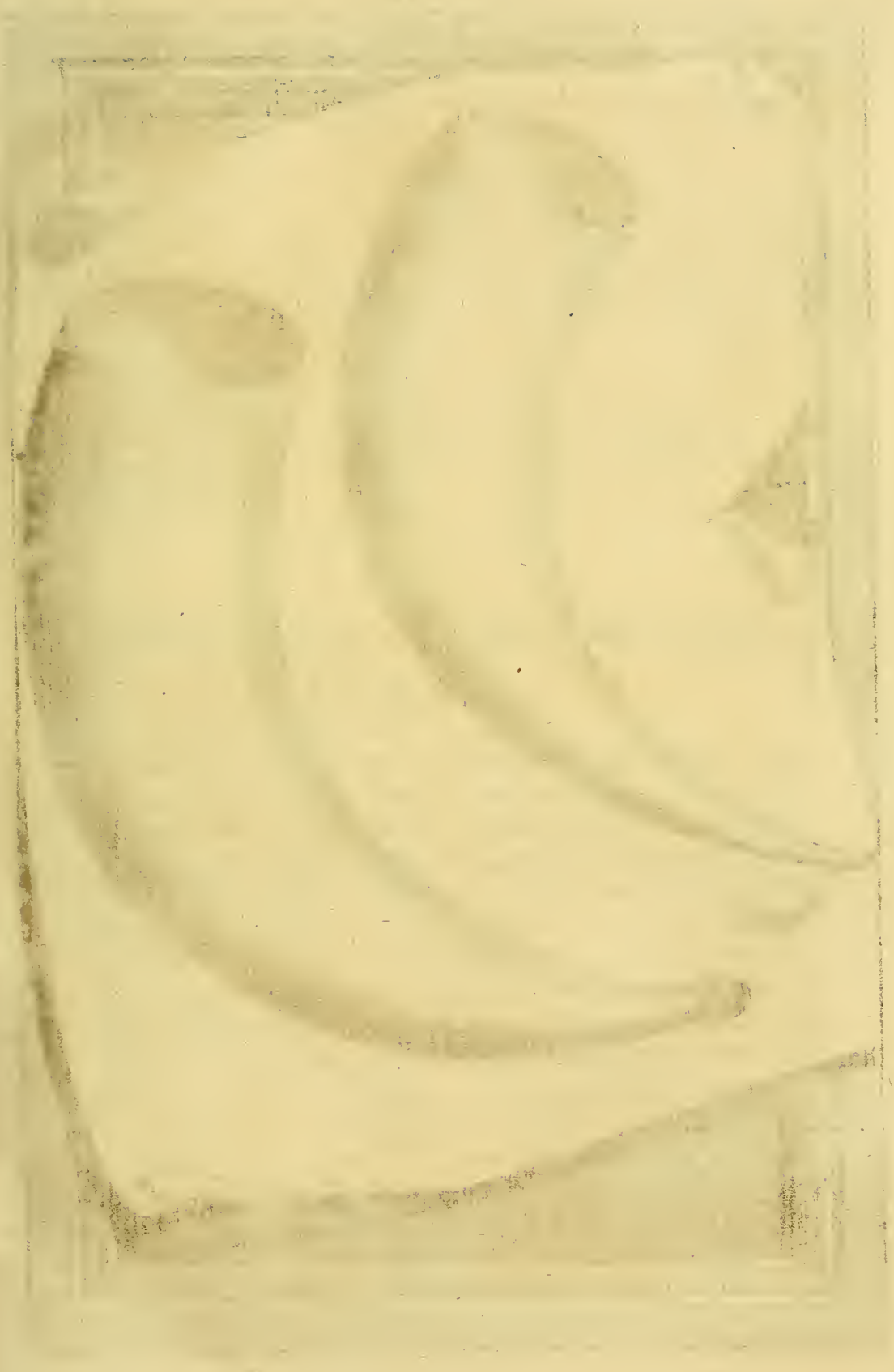




\section{Med. Egypt.}

Pag. 59.

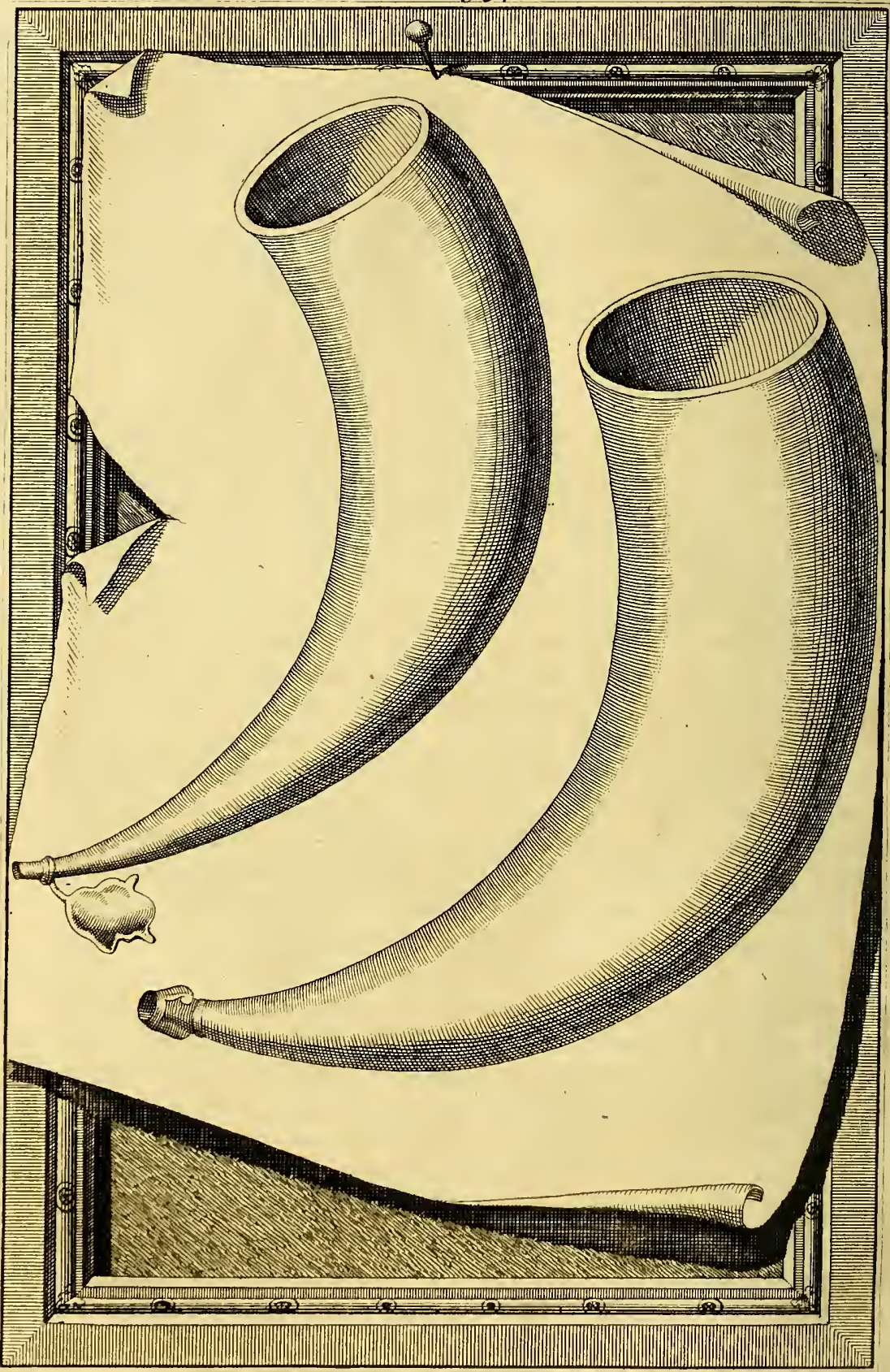


tomo adactum, \& applicationem ænei denarii fupra arteriæ vulnus. Quo \& frigiditate, \& duritie pulfus arteriæ motus cohibetur, atque ne valide arteria pulfu vulnus percutiat, atque ne. vehemens ille motus fiat, quo poffit arteriæ vulnus rurfum dilatari, atque obftare, quin arteria fecta rectè coalefcat, prohibetur. GuILAND. Hactenus ufum fectionis arteriarum probè narrafti, atque modum, præterea tuto eas, tum fecandi, tum fectionem fanandi, quare omnes facile noftri medici audacter ipfum ufum aggredi, atque experiri poffunt. Quum poffe multis ægrotis prodeffe, ubi tutò adminiftrari queat, nemo noftrum contendat. Sed de his fatis. Nunc operæ pretium effe exiftimo, ut etiam de cucurbitulis, quibus illi medici utuntur, aliquid differas.

\section{A p: X III.}

De cucurbitulis, quibus in CEgypto medici ntumtur.

\section{A L $\mathbb{I} I N \cup S$.}

o o cucurbitularum genera illorum locorum medici ufurpant, unum quippè vitreum, corneum alterum. Utrumque tamen genus fimul convenit, quòd fpiritus five oris attractione, five ore attracta, vel retracta refpiratione apponuntur. Omnes ii medici hoc fcilicet modo illas pertractant. Igne enim, vel calenti aquà ipfas cuti affigere nemo illorum novit. Sed ore: tantum attracta refpiratione moliuntur opus, \& fic cuti anigunt. Qui modus admovendi cucurbitulas planè ei fimilis videtur, guem Hero Alexandrinus in lib. Spiritualium nobis prodidit. Corneæ, taurorum parvæ, perpolitæ \& perforatæ exiftunt, quibus utraque extremitas, latifima quippe $\&$ angufififima, five acutiffima, meatu pervio confat. Earum formam fubjectæ figuræ demonftrant. Cornu anguftior extremitas eft perforata, ut operator ore eam excipiendo, per ipfum fpirationem intro attractann, cucurbitulam altero ore expanfo latiori, affigere cuti poffit: ea vero cuti eo modo affixa, anguftioris: 
extremi acuti meatus, vel foramen continuo ex ore detractum fruftulo pellis ovilis faliva medefacta, \& emollita clauditur, cuteque exinde in aliquem tumorem ducta, cucurbitulæ parvum foramen pelle obductum, \& claufum detegitur, atque aperitur, quo aperto continuò cucurbitula à cute excidit, atque Chirurgo rurfum eam cuti apponere volente, rurfum os latum magnum cuti applicitum, extremi cornu parvum foramen ore excipit, rurfumque fpiritum-intro trahit, quoufque probè affixam illam cuti adhærere viderit, quo vifo continuo extremum pellicula nuper dicta lingua revoluta claudit, ne flatus exinde refpirare queat. Hoc idem illi faciunt, volentes unà fanguinem mittere eadem cute fcarificata. namque eodem modo cucurbitulam cuti annectunt, vel affigunt. atque extremi cornu parvum foramen ore excipiunt, fpiritumque in fe trahentes fanguinem foras trahunt. quem etiam valenter trahit fola cucurbitula cuti eo modo affixa: quam non trahere, ut volunt fanguinem, cum viderint, opem ferunt fpiritum ore valenter per parvum extremi cornu foramen trahentes. Hincque iis cucurbitulis eo modo ufi, quam noftris copiofior fanguis evacuatur. Talium cucurbitularum igitur apud illos medicos eft ufus. Ceterum hæ'ræpius chirurgis ore fanguinem, ut dictum eft, trahentibus in cucurbitulam affixam, illud incommoditatis afferunt, ut fanguis fæpius in trahentium chirurgorum ora trahatur, quando ipfum roltrum vel cornu acutum extremum, cujus per foramen fit attractio, non altius multum emineat à corpore cucurbitulæ; neque corpus eft ita magnum, ut multum fanguinem contineat, quod fanguinem eduetum fufeipit, atque retinet. Hincque ufum inftituerunt vitrearum, quæ majoricorpore rotundiore ventre conftarent, $\&$ in medium ventris ab eminentiori parte roftrum longiffimum pervium five cavum, haberent. cujus minus foret, ut per ipfius foramen five roftri extremi os in ore chirurgi exceptum, cucurbiculæ cuti applicarentur, atque fanguinis miffionem commodiorem molirentur, qua fanguis eductus per roftrum ad os trahentis non duceretur, fed totus intra corpus cucurbitulæ retineretur, minimeque ad attrahentis os efflueret, cum roftri extremitas à corpo- 


$$
\begin{gathered}
5 \\
5 \\
53
\end{gathered}
$$


Med. Aqupt.

P.1. 1.11.

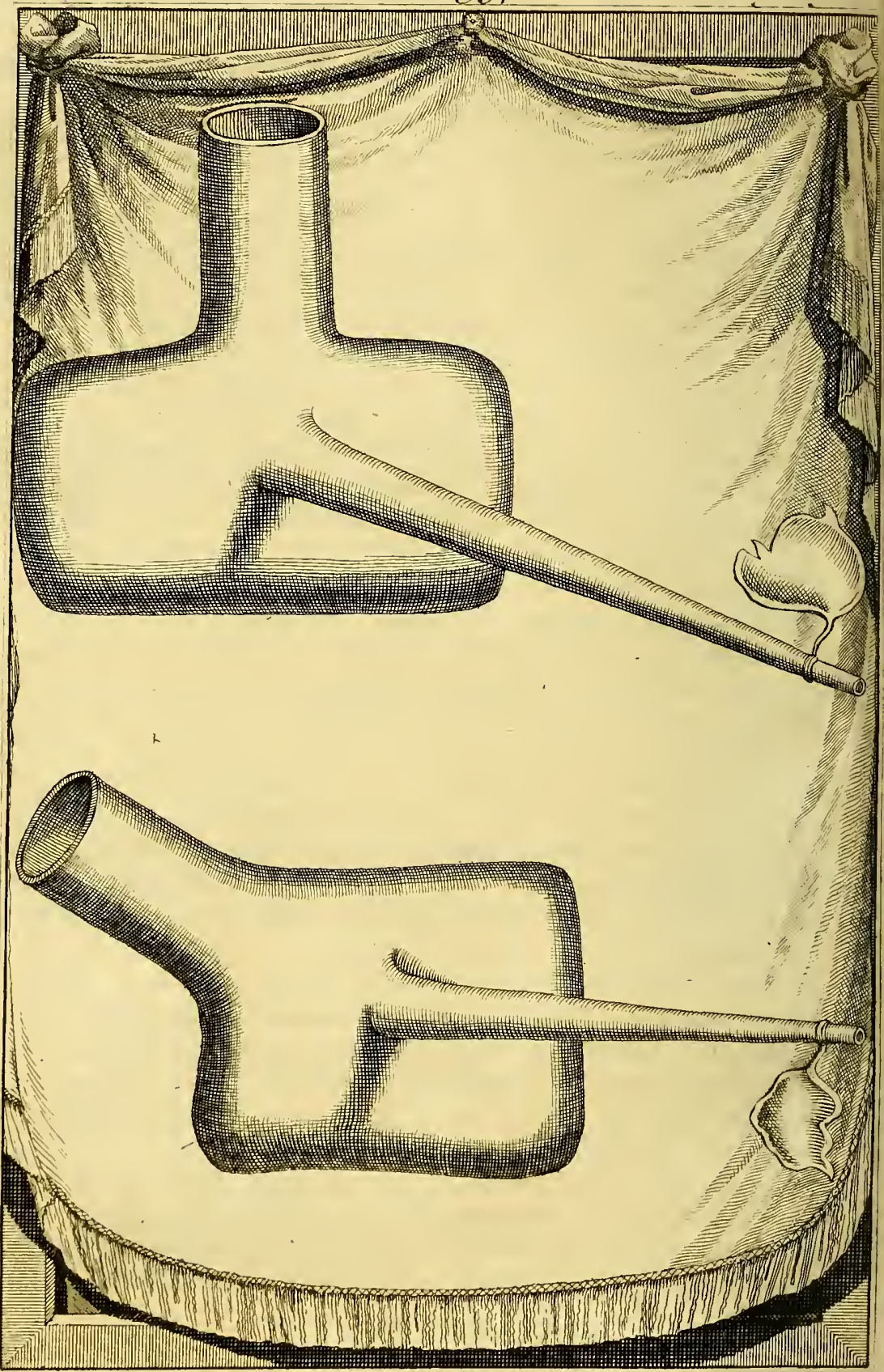





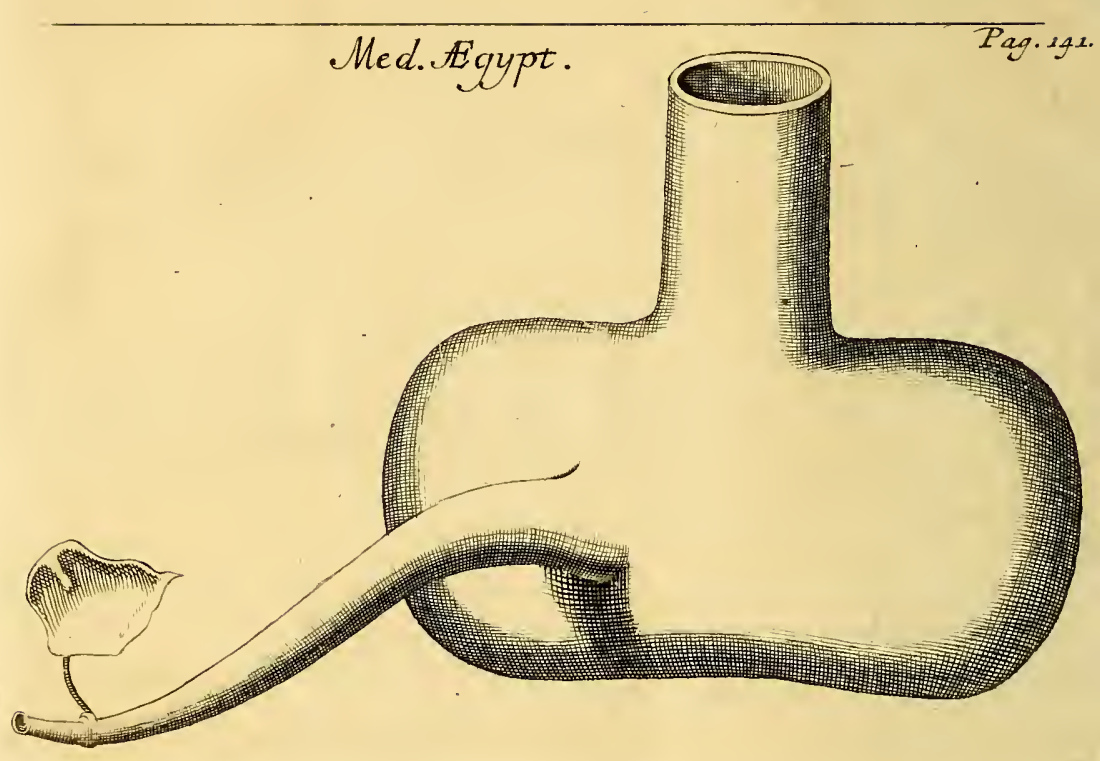


re eminentifima, ac remotiffma fit, roftrum enim longifimum exiftit. Ufus vero omnium nuper dictarum cucurbitularum unus, atque idem eft, tum cornearum, tum vitrearum, fingulæque eodem modo ab iis adhibentur. Vifus eft etiam Corne-Cap. Iө. tius Celfus hæc novife, cum lib. 2. hæc fcripfit: Cucurbitularum aneam E corneam. Fnea altera patet, altera clau!a eft. Cornea altera parte eque patens, altera foramen babet exiguum. In Eneam linteamentum ardens conjicitur, ac fic os ejus corpori aptatur; imprimiturque donec inbereat. Cornea per fe corpori imponitur; deinde ubi ea parte, qua exigunm foramen eft, ore fpiritus adductus -eft, - Juperque cera cavun id claifum eft, ceque inberefcit, Verum in Fypto cavum facilius, atque non minus tutò pelle, five membrana faliva emollita, linguæ opera claudunt. \& non cera, qua foramini ita citò aptare, atque abigere; ut opus eft, non pofiumus. tener apud illos in ufu non 'funt: fed illarum loco vitreis utuntur, quæ hac figura, five effigie exornantur, \& cernuntur. Nullæ aliæ ab his, quas diximus, atque delineavimus, cucurbitulæ apud ipfos in ufu exi. -ftunt, fed jam de ufu \& ope-illarum loquamur.

\section{A P. XIV.}

\section{Qualis cucurbitularum apud CEyptios fit ufus, in quibufque morbis iis ipfi. utantur.$$
\text { G U I L A N D I N U S. }
$$

Cu P o modo illarum cucurbitularum ufum audire, quando apuid noftros medicos cucurbitularum ad plures morbos fa nandos celeberrimum fit remedium: neque id immeritò, cum hoc præfidii genus tantopere à multis præclariffimis medicis, ferè ad omnes morbos laudatum fit: quandoquidem ex antiquioribus medicis, Herodotus celeberrimus iis feculis medicus Lib. $\tau^{\text {* }}$ hæc de is (Oribafio referente:) fcripferit: Cucurbitula mate Cap. $1 \%$ riam, qua in capite eft, evacuare poteft, itemque dolorem folvere, inflammationem-mimere, inflationes difcutere, appetitum revocas $S_{3} 3$ 
re: imbecillun exolutumque ftomacbum roborare, animi defectiones anovere: que in profundo funt, ad fuperficiem traducere: fuxiones ficcare, fanguinis eruptiones cobibere, menftruas purgationes provocare, facultates corruptionis effectrices attrabere, rigores fedare, circuitus folvere, à propenfrone in fomnum excitare, fonnum conciliare, gravitaies levare, atque bac quidem, quceque bis fimilia funt, preftare cucurbitularem ufus poteft: Quæ eadem apud Galenum in lib. de Hirudin. revulf. cucurb. \& fcarif. fcriptaleguntur: \& Cornelius Celfus ufum illarum in febribus quovis tempore utiliffimum, atque tutiffmum prædicavit. idcirco hunc ipfarum ufum apud eam gentem, ex te nunc audire cupio. Alpin. . Dixi illos cucurbitulis abfque miffione fanguinis wariffime uti, fed in corporum evacuationibus eas frequentare. Guiland. Pro univerfaline five totius corporis evacuatione, an pro alicujus tantum partis, ipfas adhibere confueverunt? ALPIN. Neminem illorum vidi, qui cucurbitulis aliquando pro univerfali facienda vacuatione ex toto corpore ufus fuerit, fed alicujus tantum partis gratià, præcedente tamen univerfali. Hincque illarum frequentiffimus eft ufus, prius facta univerfali fanguinis vacuatione ex fectis in cubito venis, in capitis doloribus, \& inflammationibus: præfertimque in phrenitide, amentiis, morbo Dem el muja vocato, oculorum, auriumque doloribus, ac inflammationibus applicant unam occipiti, atque duas partibus circumpofitis, vel in collo. Cuti verò pro qualibet cucurbitulla tres, vel ad plus quinque fcarificationes infligunt, longas tamen atque profundas: roftrumque cucurbitulæ cavum ore excipientes, ac fpiritum fortiter trahentes quantum fanguinis volunt evacuant. Frequentiffimus cucurbitularum eft ufus, cum fearificatione occipitis, atque partiun circum ipfum poft aures pofitarum, atque colli: emiffo ex is partibus fanguine: qui multis officit, ipfrfque maxime, qui non admodum. calido conftant capite, quemadmodum in calidiffimis capitis. morbis fanguinis multa evacuatio, eo modo ab iis fcarificatis partibus ope cucurbitularum; furnmopere femper prodeft, $\mathrm{Ni}$ hil eft præftantius ad excitandum fomnum, quàm copiofa ab is partibus fcarificatis fanguinis evacuatio.. Sed hæc admodum 


\section{DEMEDICINA EGYPTIORUM. LIB, IT. IA}

cautè eft adminiftranda etiam in calidifimis capitis affectionibus, quando multos acutè febrientes ob continuas vigilias ifthac ufos immoderata fanguinis vacuatione, in veternofos, lethalefoue fomnos incidifle, obfervaverim. Hinc fortafie non immerito ab Hippoc. in lib. de aër. loc. \& aq. proditum eft, Scythas ufos hac immoderata vacuatione, vel in fomnos lethales incidiffe, vel inde viros impotentes factos, quippè immodice univerfo corpore exinde refrigerato. In capitis verá doloribus, gravitatibus inflammationibus, oculorumque lippitudinibus, \& aliis calidis omnium capitis partium affeetibus ex plenitudine obortis, fummo femper adjumento erit ifta moderata cucurbitulis procurata vacuatio: quod Gal. lib. de Hirud. revulf. cucurb. his verbis planè etiam confirmatum reliquit, dicens: Incipientes, aut vigentes capitis gravitates dolores à pleni. tudine per cucurbitulam in occipite pofitam, vel folam, ve! cum fiarrificarionibus juvat: verum totum corpus antea vacuatum effe oportet : idemque in lib. de cur. per lang. miff. apud ipfum, legitur. Egyptii medici in nuper dictis affectibus primo fecta cubiti vena cephalica vel communi, occipiti applicant cucurbitulas., mox, cum morbus illis vacuationibus non cefferit, vel ad fiontis, vel anglorum magnorum, vel narium, vel temporum venam fecandam confugiunt: eafdem etiam pro iffdem malis ad vacuandum fanguinem fupra occiput, in averfa capitis parte applicantes. Certumque eft, ab his partibus, ita fcarrificatis, quantum fanguinis volunt copiam vacuare. Cavent tamen hac uti vacuatione in is, qui caput frigidum, humidum molle, rarique habitus obtinent, quod eorum ab hoc auxilio immodice cerebrum refrigeretur. Quo ita refrigerato, necefiarium fit, mox rgerrime fuas functiones obire poffe. Siquidem hoc membrum fuapte natura frigidum, haud facile fanguinis miffione refrigeratum, recalefcere poteft. In occipite etiam \& collo cum fcarrificatione cucurbitulas adminiftrant ad gutturis inflammationes, felici cum fucceffu: nam preter quod à parte affecta evacuant, etiam naturam excitant, ut per eam viam noxium humorem expellat. Quafi conentur cucurbitularum ad eam partem facta attractione, naturæ motum ad exteras illas 


\section{4 \\ PROSPERI A L P INI}

partes imitari. Siquidem ad eas partes humorum decubitum Aph. 24. fæpiffime naturam critice facere, ex Hippoc. lib. 6. aphorifm. colligi poteft; Quum ipfe dixerit: Ei, qui ab angina corripitur, $\sqrt{3}$.tumor factus fuerit in collo, bonum eft; atque etiam in Aph. 12. lib. 7, aphorifm. Ei, qui ab angina corripitur, $\sqrt{2}$ tzimor E? rubor. in pectore Jupervenit, bonim, extra enim vertitur agritudo. A dorfo, lumbis, fcapulis, pectore, auribus, atque cruribus nufquam in Esypto aliquem vidi, qui fanguinem per cucurbitulas, eduxerit. GUILAND: Nonne evacuant plenitudinem totius, aliquando cucurbitulis? An non, ut noftri, præter- occiput polteriorefque capitis partes, fcapulis etiam dorfo, lumbis cruribus, atque aliis corporis partibus eas applicant, atque. fanguinis per eas vacuationem procurant? nonne etiam utuntur in peftiferis febribus ad juvandam exanthematum eruptionem, iifdem fcarrificatis, atque etiam fine fcarrificatione, quas noftri. appellant leves cucurbitulas, vel ficcas? Quales verò facere illi. fcarrificationes confuefcant, libenter ex teaudirem. Alpin. Illi.rarò, vel nunquam utuntur cucurbitulis fine fcarrificatione, neque præter nuper dictas capitis partes, occiput, fcilicet., omnemque averfam partem, atque poft aures inter occiput, \& collum, alias ab his pro vacuando fanguine ufquam fcarrificatas., potui obfervare: idcirco neque dorfo, lumbis, natibus, coxendicibus, ..cruribufque applicant cucurbitulas pro adjuvandaque exanthematum apparitione multo minus is utuntur:-quiinimò potius adverfus noftros omnes, qui pro juvandis variolis, morbillis, vel puncticulis malignis ufum illarum in nuper dietis partibus confectantur, multa.(me audiente) dixerunt, quibus earum ufum in peftiferîs iis febribus cum ex anthematibus $\mathrm{ab}$ animis noftris penitus eruerent. Demum nullis cucurbitulis tollere pofle plenitudinem vel univerfalem etiam, vel particularem affirmant, atque hinc nemo ipforum ufum cucurbitularum aggreditur, nifi poftquàm univerfum corpus probè fuerit vacuatum. Pro qualibet cucurbitula applicanda quatuor, aut ad fummum quinque infligit fcarrificationes ea longitudine, qua eft indicis latitudo profundè adacto fcalpello, non epidermidem tantum, ut peffime noftrorum medicorum. multos par- 


\section{DE MEDICINA. EEGYTIORUM. LIB. II. 145}

Nas, ac tantum in fuperficie cuti fcarificationes infligentes, facere dicunt, fedmulto profundius fecundam cutem, atque adeò carnem vulnerantes, atque fcindentes. Guiland. Mihi haud mirum eft, ufum cucurbitularum in occipite, ejufque proximis partibus apud Fgyptios ita effe frequentifimum, \& familiarifimum, quando - etiam veterum clariffmorum medicorum non pauci eundem morem fecuti fint, præfertimque Hippoc. atque Galenus; ab occipite enim ejufque proximis partibus ad capitis dolores, gravitates, atque longe magis ad lippitudines oculorum, fanguinis mifione cucurbitulis, nuper dictis partibus applicatis ufos fuiffe, hæc in libr. aphorifm. à Galeno memoriæ mandata explicant: In doloribus itaque partis capitis pofterioris, cum averfione evacuatio ex fronte fiet: ficut anterioris ex occipite. Sic itaque diuturne oculorum fluxiones fepius fanate funt, ex partibus Secundum occiput fanguine miffo unà cum cucurbitula uf $f u$; atque in lib. I 3 . meth. med. hæc habentur: Praterea cu- Cap. Iq. curbitc in occipite defixa efficax eft remedium ad oculorum fluxiones: $\&$ in lib. de curat. per fang. miff. ipfe eadem, quæ fuperius in ejufdem de Hirud. libro fcripfle, annotavimus, fcripta reliquit, ita dicens: Sicuti capitis gravitates EO inveteratos in eo ex Cap. I. plenitudine dolores levare manife fte folet tufa in fronte vona. At incipientes, aut etian vigentes per cuiurbitain in cervice procurat retractio; interion quidem folam; interin cum farificatione. Ceterum prevacuatum effe corpus univerfum oportet: \& Hippoc. in lib. de paffionibus, ubi agit de faucium inflammationis auxiliis., dixit: Si vero ex his gracilis non fiat, retro rafo capiti cucurbitce duce adbibentur, E Sanguinis plurimum detrabatur, E pituitce fluxus retrò revellatur. \& Gal. in lib. de medicamentis facile parabilibus de oculorum vitiis fermonem habens, fcripfit: Quod fo vebemens fuerit capitis gravitas, auferenda erit, ac occipitio cucurbitula affigenda, concifa prius cute $\int_{\text {calpello, copiofufque inde }}$ fanguis detrabendus. Quare cum apud Hippocratem \& Galenum medicos præclariffimos ufus cucurbitularum in occipite, $\&$ circum ipfum fuerit frequentiffimus, non eft mirum, eodem modo Rigyptios eandem retinere confuetudinem; ita neque in his folum, fed in aliis partibus Græcos illos imitantur. HipT 


\section{I46 PROSPER I A L P I N I}

pocrates enim in libro de loc. in homine (fi tamen ejus eft liber.) prope aurem ad alterius auris dolorem apponendam effe cucurbitulam memoriæ prodidit, non minufque etiam in coxendico dolore coxendici, ad foras trahendum humorem. Ejufdemque coxendici applicatæ ufum ad procidentiam vulvæ in lib. de Aph. 50. natura humana laudavit. \& in lib. 5. aphorif. de iifdem ad mammas adminiftrandis, \& utendis ait: Mulieri, $\sqrt{2}$ velis menftura cobibere, cucurbitulam qudun maximam ad mammas appone. \& Gal. idem in lib. I3. meth. med. fcriptum reliquit, atque de. Cap. x. earundem ad præcordia etiam ufu. Sic namque ad mammillas cucurbitam imponimus, cum Sanguis exi utero profluit, defixo maximo in ipjis communibus pectoris, Ev uteri vafis ejus ore: Jic fi ex naribus fangziis, profunditur, precordiis maximas cucurbitas affigimus. Cap. ult. \& Gal. in I. lib. ad Glauc. docuit: ad firmandum fanguinis fluxum ex liene prodeuntem, hypochondrio finiftro, \& ex hepate dextro cucurbitam effe affigendam: idemque omnino in lib. de curandi rat. per fang. mifl. affirmavit: eademque umbilico pofitam cum multa flamma incantamenti modo dolorem ventris a flatulento fpiritu ortum fanare, in lib. 12. meth. med. fcriptum reliquit. Meminitque etiam cucurbitæ ufum ad lapidem renum, in lib. de ren. aff. digno \& med. Cordi, thoracique etiam ad derivandam humorum ad pulmones fluxionem, Gap. 4. adhibendam cucurbitulam effe in lib. I 1. meth. med. docuit. Ceterum non folum Hippoc. \& Gal. ufi fuere cucurbitulis in occipite, ejufque partibus \& collo, verum, ut ex jam in medium allatis patet, quamplurimis etiam in aliis corporis par-

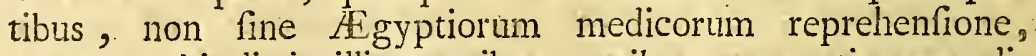
quos cucurbitulis in illis omnibus partibus, raro uti nuper dixifti. Maxime vero, ipfi videntur etiam damnandi, quòd rariffime ficcis, five abfque fcarificatione illis utantur: neque dorfo, fcapulis, lumbis, cruribufque affigere, in febribus peTtiferis cas confuefcant, in quibus fanè partibus, tum corporum evacuationis gratiâ, tum in malignis febribus, ad foras trahendam improbitatem veneni noftri ferè omnes eas apponunt. ALPIN. Nefcio, an noftri illis de ufu cucurbitularum plus errent. Zigyptii enim planè contendunt, nunquam affigendas fore cu- 


\section{RHAPONTICUM THRACICUM.}

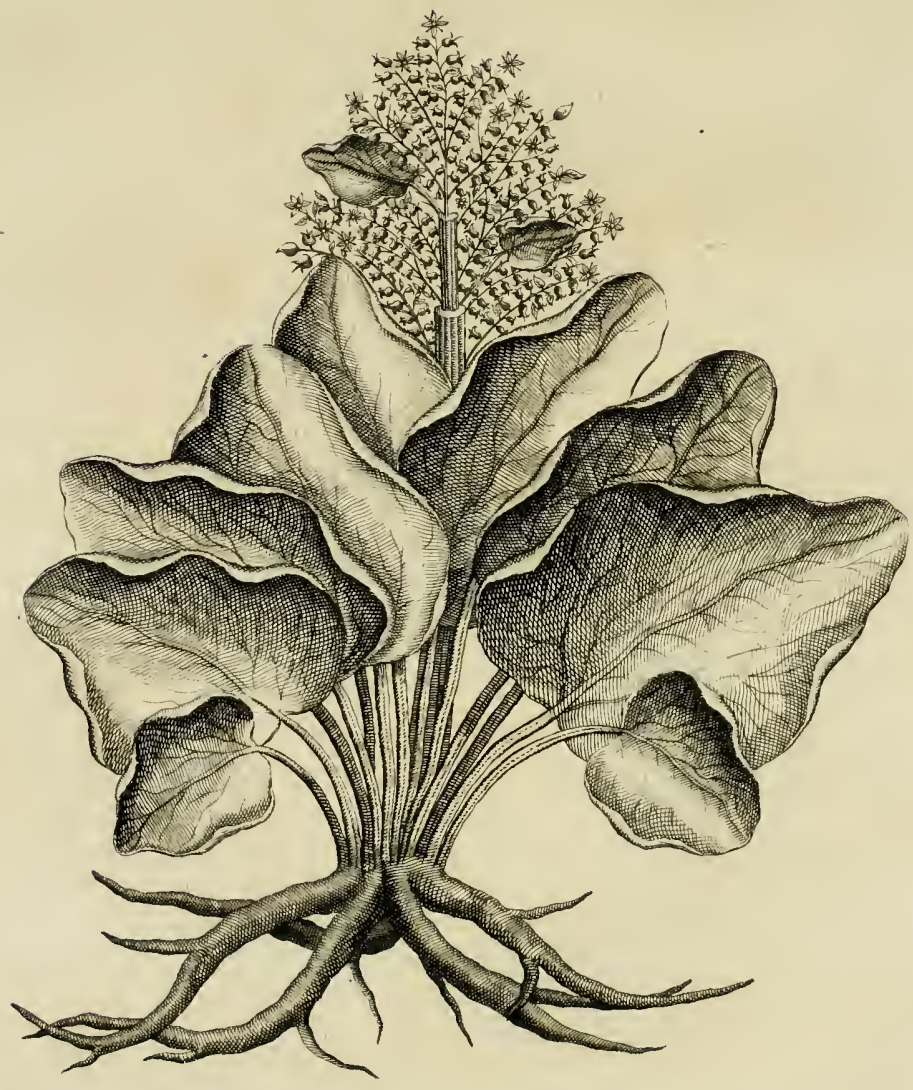



curbitulas, ni prius univerfalis vacuatio præcefferit. Proindeque negant, folis cucurbitulis plena corpora poffe vacuari. Demum fummopere adverfus noftros damnant ufum illarum in febribus, fcapulis, dorfo, lumbifque, maximeque in peltiferis, ad extrahendum veneno imbutum humorem. Guiland. Quibus rationibus corporum plenitudinem non poffe folis cucurbitulis vacuari, contendunt, in principiifque morborum haud facta prius univerfali vacuatione per venæfectionem, cucurbitulas ufum non habere, atque non minus, cur eafdem in peftiferis febribus ad humorem extrahendum damnent, ex te nunc libenter fcire cupio; nam polliceor tibi, me deinceps in medium laturum etiam meam fententiam.

\section{A p. XV.}

An folis cucurbitulis corpora rectè, ac tutò vacuari pojsint, \& wm in principiis morborum pro vacuatione fint adbibenda.

\section{A L P I N U S.}

TN primis de ufu cucurbitularum pro fanguinis vacuatione lo1 quemur, atque poftea de earundem ufu pro attractione humoris venefici ex alto, five ex penitioribus partibus corporis ad cutim. Veriffimum itaque eft, Egyptios damnare ufum fcarificatarum cucurbitularum, pro tollenda corporum plenitudine, quam ajunt non cucurbitulis illis recte ac tuto tolli poffe, fed folum vel fecta vena, vel fearificatione crurum, malleolorumve præftita. Quam fane fcarificationem folam vicariam venæ fectionis., affirmant, nequaquam vero cucurbitulas, de qua re pofterius nos deliberatius agemus, ubi de ea fcarificatione fermonem habebimus. Non debere igitur, neque rectè ac tutò plethorica corpora folis cucurbitulis vacuari : poffe affirmant, iifque rationibus ipfis hoc perfuafum eft, quoniam arbitrantur, fola fectione magnæ alicujus venæ, communem 


\section{$\mathrm{I}^{8} 8$

corporis plenitudinem vacuari poffe, vel etiam cruribus (ut jam dictum eft) fcarificatis, atque ab appofitis cum fcarificatione cucurbitulis fcapulis. dorfo, atque lumbis, folam fieri particularem evacuationem, quando fecta magna vena, à qua plurimæ venæ ramificatæ, per plures partes corporis expanduntnr, abfque dubio in univerfo corpore fiat inanitio, \& fectis cutaneis venis nuper dictarum dorfi partium, non poffint, nifi eæ partes vacuari, quæ iis- venis refertæ funt. Quare $a b$ iis fcarificatis non poffe à toto corpore fieri vacuationem aflerunt. GUILAND. Cur magis à fcarificata cute crurum volunt univerfum corpus poffe vacuari, minimeque fcapularum dorfique cute eodem modo fcarrificata? quod tamen adverfari veritati judico, quoniam dorfi cutis venæ funt fanguinis fonti propinquiores, quàm crurum, qua vicinitate cui dubium, quod à cava magna vena illis proxima citius attrahent, atque in majori etiąm quantitate fanguinem? Alpin. Refpondent, quod etfi venæ dorfi, ac lumborum venæ cavæ propiores, quàm crurum ven $x$ fint, nihilominus, quia ad dorfi partes nón ita rectè à vena cava vęnæ illæ accedunt, vel admodum etiam exiles exiftunt, ineptiores effe ad evacuandum fanguinem, quàm crurum venæ, quæ iis longe grandiores, cum maximis venis, à vena cava rectius ad crura procedentes in firras fparguntur.

Cap. 8. Quod docuit Gal. in lib. de diffectione venarum \& arteriarum, dicens: Hinc reliqua magna vena in crus ipfum dividitur, primam juxta inguen emittens propaginem, que cum parva arteria in anteriores mufculos fpargitur, fecundum utrimque unam, que ex internis partibus ad genu ufgue Jubter cutem diffipatur; ac alias non paucas ad profundiores femorum partes: Ceterun paulo allius quàn femur, cunn tibia articulo jungitur, in tres partes dividitur: quarum media, que maxima ejt, per ipfan deorfum ad poplitem fertur, atque inde per profundum pofterioris tibie partis, quan furam dicunt, pracedens, non modicam in mufculos cjus ramorum fobolem jpargit. Sed his dictis jam redeo ad ea, quæ adverfus cucurbi'tularum nuper dictum ufum afferunt.' Ajunt 'fiquidem non fólum, quia cucurbitulx dorf partibus cum fearificatione applicatæ particularem', \& minime totius vacuationem præftare poffunt; 
funt; idcirco illis tantum poft univerfalem factam fanguinis vacuationem, pro particulari capitis facienda evacuatione, in occipite, atque nuper dictis capitis partibus-uti non immeritò confueverunt, fed quod etiam cucurbitulæ fanguinem tenuiorem tantum evacuant, craffumque relinquunt, qui obftructa fovet, atque exinde putredinem concitat, atque ortam adauget. Tenuiorem verò fanguinem cucurbitulas evacuare cum Avicennæ, multorumque aliorum Arabum graviffimorum medicorum auctoritate, tum non minus ratione verum effe arbitrantur. Avicenna etenim, quem præcipue in artemedica obfervant, hæc in lib. 4. fuæ medicinæ fcripta reliquit, dicens: Ventoja cutis partem magis mundificant, quàm pblebotomia, Es. plus extrabunt fanguinem fubtilem, quàm grolfum. Et ipfarum Fen. 4 . Cap. zr. quidem juvamentum in corporibus groffis $\varepsilon^{2}$ cralfis, babentibus grofJum Sanguinem, eft parvum; quoniam ex iftis non extrabunt Janguinem, neque extrabunt ficut opoitet, immo qui ex eo vebementer eft fubtilis, E cum difficultate, E' in membro ventofato debilitstein efficiunt. . Et hoc, ut dixi, ratione confirmare conantur, dicentes venas, quas pro cucurbitularum ufu operarii fcarifi: cant, efle tenuiflimas, atque ferè capillares, per quas craffus fanguis exire non poteft: proindeque ab iis fcarificatis non nif tenuiorem fanguinem educi poffe. Tertio fubcutaneum etiam folum earum fcarificatione eduei affirmant, quando tantun contentus in capillaribus iis venis per fearificationem fectis evacuetur, minimeque ille, quem aliæ penitiores, grandiorefque venæ continent, cum præ ipfius craffiori fubftantia, exiles illas cutaneas venas ingredi nequeat: quem violenta fua attractione ipfæ moventes, trahentefques $\&$ non vacuantes, multas in iis venis obftructiones, fanguine craffiore in ipfis multo attracto, atque inculcato, efficiunt. Quamobrem ipfas fanguinem multum violenta fua attractione commovere, parumque vacuare, eumque folum, qui tenuior exiftit, quique commode cutaneas illas venas fectas tranfire poteft, affirmant; hineque multas in corporibus concitari obftructiones, maximeque in is corporibus, quæ à nativitate venis, atque arteriis parvis effecta funt. Demum addunt, partes fcarificatas debilitari, quod \& AviT 3 cens- 
cen. in loco nuper audito memoriæ prodiderat. Ceterum quia bifariàm folent cucurbitulæ à noftris cuti applicari, quando ipform alii applicent eas, fcarificatis folis venis minimis epidermidis, cuticulam enim hi quàm leviffime fcarificant. Aliique profundiùs non epidermidem tantum, verum cutem etiam, atque carnem fcindentes utuntur fcarificatis cucurbitulis. Priores in omnia nuper recitata incommoda, ex cucurbitularum applicatione incurrunt: \& ifti etfi non folum cutaneum fanguinem evacuent, fed ctiam ex profundo internarum magnarum venarum, \& multum, tamen \& ipfe tenuiorem educunt, $\&$ obftructiones pariunt, fcarificatafque partes labefactantes refrigerant, denfant, atque obftruunt. Guiland. Sed quo pacto has cucurbitulas profundioribus farrificationibus cuti defixis, quæ copiofiorem, quantus defideratur, fanguinem evacuant, ifta omnia incommoda corporibus facere perfuadebunt, cum proxime accedat fanguinis per ipfas facta vacuatio adeam, quæ per fectam venam molimur? A L PIN. Obftructiones in venis fæpius eas cucurbitulas facere, non eo quòd multum fanguinis folum ab ultimis venis evacuant, fed quòd id valde violenter trahunt ad ipfas, ut evacuent. Guiland. Multum quoque fanguinem vena fecta evacuat, non tamen obftructionem parit, licet aliquando fiat, ubi in ftomacho \& hypochondriis plurims cruditates exiftunt. Gal. in lib. de fanit. tuenda ait, quod fi illis, qui cruditatibus in ftomacho, \& hypochondriis exuberant, fanguis dematur, vel frictiones, ac balnea moliantur, procul dubio omnes cruditates illæ in univerfo corpore à venis rapientur, atque iis obftructiones, putredines, febrefque contingere. ALPIN. Cucurbitulas, cum magnis profundioribufque fcarificationibus adjectas, plurimum fanguinem exhaurientes, obftructionum multarum fxpe effe caufam, eorum locorum medici ex hoc demonftrant, quòd neceffariò ex copiofa per ipfas facta fanguinis vacuatione, tota maffa fanguinis in venis contenta per corpus ad cutaneas capillarefque venas cutis trahatur, cujus craffior pars, vel fanguis craffior tranfiens per anguftiores venas, eas fape obftruit. hincque in corporibus craffiori fanguine exuberantibus, fimulque 
venis a natura minoribus, refertis, qualia funt melancholicorum multorum corpora, valde fufpecta iftæc per cucurbitulas fanguinis vacuatio non immerito efle folet. Cur vero itidem venæ fectione facta, fanguinis copiofa evacuatio non ita, ut cucurbitulis operata facile obftruet, dictu (ajunt) non eft valde difficile, quoniam vena fecta, multoque fanguine inanita, non folum è radicibus venarum, in quibus pars fanguinis crudior craffiorque refidet, fed multo plus à venis omnibus ab ea procedentibus, ufque ad cutem, quæ multò minores ipfa exiftunt, quæque fanguinem continent puriorem, atque tenuiorem trahit; hincque probè à medicorum vulgo creditur, venæ fectionem trahere à circumferentia ad centrum, quoniam is fanguine in amplioribus prioribus venis contento, Iongè purior \& tenuior exiftit, ut in fubftantia illarum nutriendarum ab. ipfo corporis partium quám facile mutari poffit, à quo fanè fanguine non ita facile, veluti à primis venis prodeunte, venæ illæ obftrui poffunt. GuILAND. Vulgaris tamen medicorum opinio eft, quod cucurbitulæ à centro venarum ad circumferentiam trahant, quod tamen fi verum Agyptii dicerent, contrarium verum effe nos fateri oporteret, fcilicet non folum cucurbitulas à centro ad circumferentiam, fed contra potius circumferentia ad centrum fanguinem trahere, quod nulli haetenus ex noftris animadverterunt: tamen veriffimum etiam hoc effe judico, quando verum fit, atque planè expertum, venas fanguine inanitas, vacui ratione, ut repleantur, trahereà ve. nis proximis, \& proximas à proximis ufque ad ultimas venas, quæ venarum radices, chylum à ventriculo inteftinifque exugentes vocantur: Venarumque itaque centrum æquæ in medio radicum venarum, quæ in mefenterio ortum habent, meferaïcæque dicuntur, atque capillarium, cutanearumve pofitum eft atque miferaïæ \& cutaneæ' extrema, per quæ fiet circumferentia: fit enim venæ meferaïcæ, vel venarum principium $A$, \& ipfarum centrum $B$, atque cutanearum venarum finis fit $C$, Quantum igitur venæ $C$, cucurbitulis trahent à $B$, tantundem $B$, trahet ab A. Quamobrem veriffimum erit, quod cucurbitulæ multum fanguinem vacuantes, trahent fanguinem contentum 
in venarum centro, \& venæ centri à primordiis ufque ipfarum venarum. Qua ratione apparet manifeftiflimum, cucurbitulas a centro trahlentes puriorem fanguinem, atque tenuiorem in iis yenis contentum ac cutem trahere, \& evacuare, $\&$ ad centrum inanitum trahi impuriorem, crudioremque \& craffiorem, qui à primis venis chylum à ftomacho exugentibus ad magnas renas trahitur, atque aliis in alias. A L P I N. Ad unguem illorum mentem confpicuam effecifti, qua via, purum tenuemque fanguinem, venas cutis per cucurbiculas ad fe ab internis, \& crudum craffumque internas iecoris venas à meferaïcis trahere planè cognofcitur, atque ab hac ultima venarum attractione obftructiones fiere poffe. Quod eafdem facere cucurbitulas trahentes per venas fanguinem, violentia, \& non fenfim ac fenfim, ac in venæfectionis, \& crurum fcarificationis vacuatione fit, etiam ftatuunt, quando earum violentâ attractione, craffi crudique humores indif́criminatim per venas trahantur, à quibus multa facile obftruuntur. Hifque de caufis 2 Eyptii nunquam plenitudinem corporum cucurbitulis tollere audent, iifque tantum utuntur pro partis alterius vacuationé, poft univerfalem vacuationem molienda. Gurl. Rectè fanè mihi videntur illi ufum. cucurbitularum pro evacuatione complecti, atque affectare, fecuriufque corpora vacuare, quàm noftri medici ferè omnes faciant, qui ferè in omnibus corporibus ftatim nulla effęta totius evacuatione, ad affigendas fine difcrimine cucurbitulas fe conferunt fapeque non citra.ægrotantium noxam, \& ipforum non parvo cum dedecore: purgatis etenim corporibus eas tantum ufum habere Gal. multis in locis docuit; in libro enim de curat. per fang. mifr. de his ita feripfit: Cucurbitule purgatis prius corporibus utiles quidem, fed in repletis (que pletborica Greci vocant.) pretermittendae funt: in lib. 11. meth, cap. 17. ait: Quippe foras trabere potius, quim reprimere in eo debemus: itâque etiam cucurbitula utiliter iis, qui fic laborant, $\sqrt{2}$ prius fint vacuati, applicabitur: $f i$ vero abundantia fuccorum, quam vocant pletheram, in bis fit, non magis ex pulmone in pectus aliquid excrementitransfert, quiam ex toto corpore attrabet in utrumque: \& cap. 18 . dizit: In pbleginonis cerebri, membranarumque initio cucurbitulis 
uti medici non debent, fed finita fluxione, Eं pritis toto corpore vacuato: \& in lib. 13. cap. 19. dixit: Veruan utendum cucirivite in ipja parte, qua pblegmone urgetior, inter initia non eft, immo pofteaquam totum corpus vacuaveris, ac neceffarium fit eorum, qua in inflammata parte continentur, aliquod educas, atque cruas, aut etian foras ver/us attrabas. AlpIN. Multi reipondent Galenum locutum ibi fuiffe de cucurbitulis citra farrificationem affixis, quas vulgus medicorum ficcas appellat: quarum ufum præcedere debere ajunt totius corporis univerfalem vacuationer, quod in fcarificatis non eft neceftarium, quum hi poflint abunde corpus vacuare. Guicand. Gal. in lib. de cucurbitulis explicat, utrifque vacuationem præire debere, his profectòverbis: Incipientes autem $\mathcal{E}^{*}$ vigentes capitis gravitates, ac dolores $\dot{a}$ p'cnitudine revulfio per cucurbitulam in occipite pofatam, vel fola, vel cum fcarrificationibus juvat, verum totum corpus antea vacuatum effe oportet: idemque iifdem omnino verbis in lib. de curat. per fang. miff. planè confirmavit, ibi enim jubet omnino totum corpus vacuari priufquam cucurbitula applicentur, vel id fiat cum fearificatione vel fine fcarificatione. Non defunt medici graviffimi, qui Egyptiorum ufum laudare nituntur, præfertimque in febribus peftilentibus, in quibus folent exanthemata, vel maculæ in cute apparere, quibus plerique his ctcurbitulis vacuantes fanguinem, medentur, cum videant naturam per cutim excernere: atque Hippo. in apho. præceperit medicos fequi debere motus naturæ, atque per viam qua ducere natura humores tentat, ipfos vacuare humores debere: Dicebat olim quidam medicus clariffimus; aliqui ajunt, evacuare nolumus nifi per cutim, guia qud natura vergit, $f i$ per convenientia loca, è ducere oportet, $\mathcal{E}^{2}$ cum cut is fit conveniens regio, quoniam inter membra, qua naturaliter fifcipiunt excrementa, cutis eft talis, ideo per eam evacuare potcritis. Cum fcarificationibus etiam? rejpondebitis, quod fi materia erit pauca, nec multa in venis, nec multum cralfa, ita quod repletio pauca fit, poteft tunc natura adjuvari: Sed in febre peftilenti, ubi materia eft multa, fi cumn illis malediatis cucurbitulis exterius trabere velletis, nibil effei deterius, quia jubtile traberetis, Ev remaneret craffinn : Calorem minutere- 


\section{$15+$ PROSPER I A L P I N I}

tis, छَ putredinem augeretis: ideo vel cum phlebotomia, vel cum medicinis evacuantibus. Addunt Asyptii, quod ufus cucurbicularum in feb. peftilentiuus pro vacuatione molienda non eft utilis judicandus, tum ob ea multa, qua ab is eveniunt incommoda, tum prafertim, quia ha coxpora non vacuant, ut facit natura rectè operans; vel, ut docuic Gal. in lib de diff. feb. qui dixit, febrium peftilentium curationem duobus comprehendi, atque adminiftrari, fcilicet ficcatione, atq tia, ut curentur, debent exíccari à copia humorum, tum obftructi fovente, atque tranfpirabilia fieri: fecus autem facere cucurbitulas in iplis corporibus fatuunt, cum ipfæ evacuando exficcandòque, obfructiones multas pariant, modo nuperrime juxta ipfortim fententiam explicato. Non defunt multi medici etiam illuftriffimi contrariam fententiam veram affirmantes, qui ufum cucurbitularum in vacuandis corporibus idoneun, ac utilifimum efie ftatuunt, præftantifimumque auxilium, venæ fectionis verè vicarium, \& in corporibus virium caufà non ferentibus vacuationem fanguinis per venam fectam, adprimè tutum, ut ex Avicenna (a quo fortafiè aliquis cucurbitularum ufus originem duxit.) lib. 1. legitur, qui dixit, cucurbitulas in multis corporis partibus fanguinis vacuationem rectè præftare, fed prafertim cruribus applicatas, proximas efle ei, quæ venæ fectione fit: ipfe enim ibi fcripfit de his in hune modum: It ventofe quidem, qua cruribus fuperponuntur, funt minutioni propinqua, E mandificant fangumen, छ

Cap. 1o. Hoc vero clarius á Carnelio Celfo, is utique verbis nobis etiam perfuafum eft: in fecundo enim libro hæc fcripta reliquit. In acutis quoque quibufdam $\int \mathbb{E} \sigma^{*}$ levari corpus debet, $\sigma^{\circ}$ ex vena Jangumen mitit, vires non patiuntur, idque anxilium, ut minus vebomens, ita magis tutum. Neque unquam periculum eft, etiamf in medio febris impetu, etiam incruditate adbibetur. Ideoque ubi fanguinem mitti opus eft: $l i$ incifa vena praceps periculum eft, cut $j i$ in parte corporis etiam vitium, eft, buc potius confugiendum. eft. Non minus apud Antyllum fuiffe in ufu fcarificatas cucirbitulas pro oppletis partibus, cx Oribafii libro feptimo, ma- 


\section{de Medicina Mgytorum. Lib. I. 159}

nifefte conftat. Nec minus pauci ex recentioribus medicis exiftunt, qui ipfarum ufum pro corporibus vacuandis fummopere commendant, neque difficile eft, medicorum noftratium ferè ommibus id perfuaderi, quando hic evacuandi per cucurbitulas modus fit familiarifimus, plebique admodum receptus.- Patroni cucurbitularum, nuper ab $\mathbb{E}$ gyptiis allatis rationibus aliis medicis, adverfus cucurbitarum affeclas excogitatis, atque objectis, refpondent, cucurbitulas copiofiflimam fanguinis vacuationem, magnis factis fearificationibus, nec-non eas, etiam qux fuperficiariis moliuntur epidernidis incifionibus in multo numero applicatas variis corporis partibus effcere poffe, qua detracta per partem poft partem, cuidubium, partibus multis ab ipfa vacuatione inanitis a toto corpore trahentibus, fieri totius corporis vacuationem? Nequeunt tamen iis fanguinem tenuiorem tantum vacuari, atque craffio- li 4 . fer. 4. rem xgerrime, non fateri, cum Avicen. hoc idem admo- Cap. Ix. dum aperte confirmaverit, literifque tradiderit, in corporibus craffiori fanguine conftantibus per cucurbitulas fanguinis vacuationem parvæ effe utilitatis, quoniam in ipfis hæ non extrahunt, ut par eflet, fanguinem, \& id ipfum cum difficultate. Neque recta ratione negare poffunt, per tenuiffimas cutis renas craflum fanguinem non facile tranfire poffe. Sed aliqui in medicina etiam viri graviffimi non omnino abeunt fine ratione, dicentes, ut huic dubio fatisfaciant, antiquos ob id medicos doctiflimos monuife, ut applicationes cucurbitularum, frictiones fotufque calidi pracedere debeant, ut fanguis fic attenuetur, pareturque ad excretionem. Quod tamen non videtur omnino credendum, quando, priufquam applicentur cucurbitulæ cute vel fricata, vel fotu aliquo vel balneo laxata, fanguinem in univerfo corpore contentum pofle attenuari non fit dicendum: is fiquidem tantum attenuabitur, qui fub cute erit, ad quem facultas frictionum vel fotuum pervenerit. Cucurbitulæ vero juxta ipfos vacuant non à partibus fubcutaneis, verum etian ab omnibus venis corporis, ad hoc ut per ipfas facta evacuatio, totius \& non alicujus partis, vel particularis, fed univerfalis fic dicenda. Oporteret verò, ut æquè 


\section{PROSPER I A L P I N I}

rectè omnium corporis venarum craflus fangliis attenuaretur, univerfum vel corpus fricari, vel in balneo per multum fpatium temporis morari, ut Avicenna in lib. I. his verbis teftatus eft. Et oportet quidem, ut à ventofis fibi quilibet caveat poft balneum, nifi cujus fanguis fuerit grolfus, quonian ipfe je prius balneari debet, E una bora morari, E poftea ventofas apponere. Sed quàm tutum fit in plethoricis corporibus, non præcedente vacuatione totius, prafertimque in principio febrium putridarum, balneum vel frictiones, quæ omnia fequi debent corporis probam evacuationem, adminiftrare, illis-relinquo judicandum : etenim notilimum eft omnibus in Galeni doctrina verfatis, nunquam febricitantes balneis uti polfe ante humorum concoctionem, qua morborum principia omnino carent. Negant etiam ift cucurbitulas fcarificatas à primordiis ufque venarum incoctum fanguinem trahere, multoque minus obftruere venas, quod tamen, fi hæ copiofam vacuationem præftiterint, neceffe eft fieri debere, cum nequeat educi copiofus fanguis à cutaneis venis, nifi eædem à proximis attrahentes, \& proxime à proximis ufque ad ipfarum radices pervenientes repleantur. Quod non eveniet, fi paucus fanguis his extrahatur, quoniam priufquam attractio ad primas venas perveniat, fanguinis in renis cutaneis inanitis repletio, five reditio fiet. Neque etiam neceffariò, etfi fiat ufque à prioribus venis ad ultimas attractio, venas obftrui erit affirmandum, cum corpora ita latioribus venis prædita fint; ut fanguis etiam craffiffimus, non ita difficile ipfas permeare ac tranfire queat : veluti tenuioribus venis referta corpora ad obftructionem ea via non erunt inepta. Paucum etiam fánguinem ducentes, vel nullum, multumque attrahentes \& modicum vacuantes; cui dubium quod, quàm facile ex multo in illis venis vi attracto, \& conculcato, obftruendi occafionem dabunt? Ajunt vero utroque modo applicatis, cutem, cui funt applicatæ, debilitari, ex contentique in ipfa fanguinis vacuatione primo refrigerari, \& mox ejus omnes meatus conftipari, atque obftrui. Quod febricitantibus inutile \& noxium erit; cum una indicationum curativarum lit corporum obftructa liberare, ipfaque corpora 
tranfpirabilia reddere. Quibus fi refponderent, cutis eun dem calorem amiflum ex vacuatione fanguinis, ex novo attracto fanguine reftaurari, verum haud planè erit, cum tunc temporis nequaquam pars queat reftitui in priftinum ftatum, ob fufcepta vulnufcula, minufque folita copia fanguinis repleri, quantâ cutis per cucurbitulas fuerat privata. Negant non minus dorfo appofitas cucurbitulas probam fanguinis vacuationem facientes, poffe ad cordis regionem, multum fanguinem trahere; \& fi etiam intra aliquod vifcus aliqua fuerit inflammatio, eam poffe magis augeri. Cum tamen Gal. contra illos apertifime fentiat, qui in lib. I 1 . meth. ita fcripfit: Quippe foras trabere potius, quam reprimere in eo debemus: ItaCap. 37 que etian cucurbitula utiliter iis, qui fic laborant, fi prius fint vacuati, applicabitur. Si vero abuindantia fuccorum, quain vocant pletboram, in bis fit, non magis ex pulmone in pectus aliquid excrementi, transfèret, quam ex toto corpore attrabet in utrumgue. Sed ex me hæc obiter dicta de his fint. Alpin. Verum cum tu, Guilandine doetiflime, utrorumque de ufu cucurbitularum pro vacuatione corporum rationes animadverteris, eafque fueris contemplatus, quæio, tuam profer fententiam hac de re, ita ancipiti, qua ego vere poffim de illarum ufu atque utilitate ftatuere, quando hactenus pro ifto negotio hujufmodi ufum non parum pertimuerim, ac fere abhorruerim. GUILAND. Non parvam occafionem fuife arbitror, ut medici non modo doctiffimi, verum etiam graviffimi exiftimaverint, cucurbitulis poffe corpora etiam plethorica recte vacuari, quod ipfi tum apud Gal. tum apud alios celebres medicos legerint, crurum fcarificationem poffe idem præftare, quod venæ fectio, unumque atque idem putantes effe hanc fcarificationem, \& cucurbitulas fcarificatas. Quam ob caufam non eft mirum, fi ufum cucurbitularum tantum pro vacuandis corporibus, ubi vel vires non prævalidæ, vel ætas, vel aliquod aliud non ferat miffionem fanguinis per venam fectam, laudaverint: fed quanto in errore ifti verfentur, pofterius, ubi de nuper dicta fcarificatione fermonem habebimus, ex te recte audire fpero. Diverfiffimam vero rem effe nuper dictam fcariftationem à cucurbitulis, ex 


\section{$15^{3}$ PROSPERI ALPINI}

Galeni, Oribafique teftimonio planè conftare videtur; ipfi enim Apollonius \& Antyllus feparatim de utroque auxilio fcripfere. Quan vericatem medici aliqui etian hujus temporis priclarifimı rectè noverunt. Cum itaque plerique idem auxilium cucurbitulas atque fcarificationem illam affere pro certo haberent, mirum non eft, fi legentes apiid Galenum in 2. lib. Aph. 17 Aphor. eam effe proximam venæ fection, atque in lib. de faCap. 4. nit. tuend. tantundem valere, quod vene fétio valet, \& inCap. 5. lib. 13. meth. corpus plethoricum vacuari aut vena fectione, aut fearificatis malleolis, ufum cucurbitularum vicarium effe ftatuerint. Sed an nos tuto uti pofiimus in plethoricis corporibus tali vacuatione, vel in febribus putridis etiam vacuationis gratia, nunc dicam, quid de hac re fentiam: primilque cen¿éo nullo pacto medicos moliri debere fanguinis vacuationem in plethoricis corporibus per cucurbitulis, ubi nihil fit, quod venx fectionem vel crurum fcarificationem prohibuerit; nam fum hujus firmiffimæ fententiæ, quod cucurbitule fint auxilia partis, quæ fequi debeant totius corporis vacuationem : quod In lib. de ex Galeno fuperius cognitum eft, qui dixit cucurbitulas occicurat. per lang. min: piti applicandas vel cum fcarificatione, vel fine, fequi debere totius corporis vacuationem, atque in hoc non poffum non nifi multum \&.gytios hoc modo illis utentes poft univerfalem vacuationem, fummopere laudare, minimeque tutum auxilium in corporibus plethoricis cucurbitulas effe exiftimo: multoque magis, fi ea corpora craflioribus fuccis abundarint, in quo cafu eas omnino abhorrerem, ne ab ipfarum tractione, fanguine illa multo in venas attracto multæ obftructiones fierent. Hincque Galénum in lib. de curat. per fang. mifi. in corporibus gracillioribus, nigrioribus, fcariticationi crurum præuliffe venæ fectionem non immerito judicavi, quia ea corpora conftant fanguine crafiori, qui neutiquam per venas cutis parvas facile vacuari poteft. Quare fi is, ait, eam non convenire fearificationem, qux fit, majoribus illis crurum venis profundius fearificatis, quanto magis putandum erit cucurbitulas fcarificatas non convenire, tum ob periculum obftruendi ex crafo illo fanguine violentî̀ attractione per ren's moto, tum ob parvas cu- 
tis venas, non etiam profundius fcarificatas, quas ob crafitiem commode tranfire nequit? Itaque neque in iifdem corporibus putrida febre correptis per ea molienda erit evacuatio, præfertimque in quibus copiam crudorum crafforumque humorum adeffe fignificatur, in iis enim fumme exitiofus creditur ufus cucurbitularum, quoniam purior, tenuiorque fanguis vacuatur, craffior \& crudus remanet, atque nativus calor diminuitur. Talium vero crafiorum humorum crudorumque copiam atteftantur, urinæ crafæe, vel cum craffis contentis albis pituitofis obfervatæ, quales ego Cayri, Genuæ, Baffani in epidemica peftiferarum febrium confitutione, fere in fingulis obfervavi. Sudorefque frigidi, vel multi noctu apparentes non ex multo cibo orti, atque alia hujufcemodi generis multa, quæ brevitatis caufa hic taceo. In interna etiam vifceris alicujus inflammatione dori partibus applicata cucurbitæ fumme erunt perniciofe, quoniam in partem affectam fanguinem multum trahentes, augebunt neceftario putredinem. Non convenient etiam in febribus putridis iifdem partibus appofita, quia cutem, fanguine multo ab ipfa vacuato, refrigerant, atque conftipant. Ubi vero fanguine neque multo, neque craffo abundarint, pro moderata fanguinis vacuatione facienda, neceffitate coactusaliquando mitti fanguinem etiam tuto pofie is affirmarim, multoque magis cruribus applicatis: fed confulo tamen omnibus medicis, ut vice harum, libentius utantur furarum fearificatione more $\mathbb{E g y p t i o r u m ~ a b f o l u t a ; ~ a t q u e ~ h æ c ~ e f t ~ m e a ~ f e n t e n t i a ~ c i r - ~}$ ca ufum cucurbitularum pro vacuatione corporum, cum $f$ carrificatione applicandarum. Alpun. Rectifinam atque verifimam efle tuam iftam fententian judico, meque ei libenter totus fubferibam: quare lubet mihi nunc nonnulla exempla, huic veritati plane conducentia, narrare. Cayri enim dum morarer, duofque juvenes Gallos maligna febre correptos in æde Pauli Mariani Veneti pro Galliarum Rege Confulis clariffimi, præ manibus haberem, non tamen eodem utrumque tempore, obfervavi ab applicatis dorfo cucurbitulis, paulo poft in lethalem pulfus intermiffionem deveniffe. Idemque Baffani in Minerva Forcatura matrona honeftifima eadem febre laborante à 
me obfervatum eft. Quo in loco binos etiam homines evacuationis gratià Vaftaniam villam profectos, atque in æltuariis, à mulcis applicatis univerfo corpori cucurbitulis in acutas febres incidiffe, quorum alter, qui Baffanum habitabat, qui meæ curæ commendatus fuit, vix fervatus fuit: alter ruri degens inopia medicorum non recte curatus, obiit. Venetiis etiam filius Bartholomæi Falgherii juvenis eodem modo à cucurbitulis in æftuario in acutam febrem incidit, qua tamen liber evafit. Ex his ergo videre poffumus atque plane etiam cognofcere, cucurbitulas \& obftruere, \& ad initimas partes corporis trahere, nam quis non fatebitur, binos illos viros Baffanenfes, atque nunc falgherium à cucurbitulis in venarum magnarum obftructionem craffis, crudifque vi cucurbitularum intus deductis primo, atque non minus in meatuum cutis conftipationem, \& inde accenfa putredine in febrem putridam incidife? ut \& Gallos illos \& Forcaturam, pariter in pulfus intermifionem, ex multo fanguine crualo in regione cordis vi ipfarum attracto, quo fuffocati perire, ut ex Gal. in 3 . lib. de præfag. ex pul. proditum eft. Sed his auditis, melius erit, ad alterum propofitorum diffolvendum pertranfire.

\section{$C_{\text {A p. }} \quad \mathrm{XVI}$.}

\section{An errent. Egyptii medicu nunquam utentes cucurbitu-. lis pro adjuvanda exanthematum eruptione. \\ $\Lambda$ L P I N U S.}

LTERUM caput reliquum erat explicandum de ufu cucurA bitularum propofitum, quippe Aigyptios in fe'bribus malignis ad apparitionem exanthematum, nullis uti cucurbitulis, quod miltis ex noftratibus medicis auxilium felectiffimum effe folet. Nam hi in iftis febribus applicant ad decem ufque \& plures cucurbitulas univerfo corpori., interdum fearificatas, atque interdım citra fcarificationem, ut ex alto à partibus nobilibus ad cutim venenum avellant. Quem ufum omnino illiufce 
DE MEdicina Egytiorum. LiB. II. IGi

regionis medici omnes formidant, atque abhorrent, præfertimque fi eæ dorfo applicentur, eumque multis de caufis damnare folent, præcipueque quod omnibus ferè corporibus à peftilenti febre vexatis communiffima res fit, copia multa crafforum crudorumque humorum, quod arguere fudores frigidos vel multos in ipfarum febrium principiis, vifos, vomitufque craffos, ac vifcidos, \& urinas craffas, vel ipfarum craffa, multa, pituitofaque contenta, atque alia hujufce generis multa, affirmant. Neque abfque ratione in his febribus adeffe multi in venis humores craffi, \& vifcidi dici poffe videntur, quando in illis corporibus non defit copia caloris febrilis, humorum ichorem confumentis, qua via illi tum craffefcunt, tum lentorem accipiunt. Qua humorum iftorum copia in iis corporibus exiftente, applicare cucurbitulas valde timent, ne ex attractis craffis iis, vifidifque per venas fuccis, multas concitent obftructiones. Non fearificatas, inquiunt, plurimum trahere, \& parum vacuare; ex quo multo attracto facile partes hæ obftruuntur. Scarificatas, etiamfi aliquid educant fanguinis, puriorem tamen, \& tenuiorem vacuare, craffioremque relinquere, \& violenta attraEtione inæqualiter omnium humorum copiam attrahere. Præterea nullo pacto ajunt, ut fupra dictum eft, dorfi partibusapplicatas poffe iis febribus effe alicujus utilitatis, cuni hæ primo in venas proximas cordi trahant noxios fuccos, atque vacuato etiam fanguine, cutem refrigerent, denfent, atque ejus meatus obftruant, \& calorem naturalem imminuant, vacuato multo iis fanguine puriori, \& tenuiori. Præterea addunt, eruptiones exanthematum effe adjuvandas trahentibus ex alto ad cutem veneficos humores, fenfim ac fenfim fine violentia, ut natura facere fæpe folet, quæ fæpe incipit expellere puncticulas ad cutem quarta die, \& paulatim fingulis diebus paululum expellendo, ufque ad feptem, \& plures etiam dies quandoque expellere definit, quoniam per tenuifimas venas non eft ita facile noxios totos humores poffe femel deducere, atque expellere: \& ob id paulatim, \& non fine magno judicio pluribus diebus expulfionem perficit fcilicet modicum coquendo, \& illud módicum vacuando: nam cum fuccos veneficos habeat inequaliter con- 


\section{PROSPERI ALPIN I}

coctos, quod illorum paratum eft ad expulfionem, ftatim expellit, mox crudum atque ineptum digerit, \& parat, cujus cum modicum percoxerit, atque devicerit: ftatim (nequit enim. ipfum ob ejus improbam, \& venenofam naturam intra venas continere, ne alios corrumpat, vel ad nobile vifcus deferatur.) expellit, atque ita totam expulfionem perficit, paulatim, ut dixi coquendo, \& paulatim etiam expellendo. Sed cucurbitule ftatim ad partem, cui affxw funt, attrahunt mulcum tum concocti, tum crudi humoris intra venas exiftentis, neque folum expulfioni per concoctionem paratum humorem trahunt, fed. incoctum etiam, qui cum nequeat per parvas illas venas egredi, proculdubio obftruit, putredinemque auget, \& febrem, \& malignitatem. Proinde medicus attrahens per cucurbitulas, natura motum non initatur, quia natura tantum preparatum humorem expellit, at cucurbitulæ fimul etiam crudum, hæc. que adverfus cucurbitulas in febribus peftilentibus applican. das illi objiciunt. Guiland. Hæc eadem multi alii ex noftris medicis dixere, fed multi tamen funt Clariffimi medici oppofitæ Egyptiorum féntentix addicti, qui fummum effe auxilium cucurbitulas in peftilentibus febribus perfuadent, ajuntque quocumque modo a nobilibus partibus longius venenum detrudatur, five cucurbitulis id fiat, five alia ratione, fummum femper inde fequuturum auxilium, naturæque plurimum adjumenti, quoniam ubi à membris nobilibus longe aberit venenum, natura erit fortior, agetque in reliquum humoris commodius, \&: robuftius. Quod fi humor venenofus, naturæ ex toto genere inimicus prope præcipua membra in venis magnis relinquatur, naturam neceffario labefactabit, five, ut ita loquar, coarctabit, vel in anguftum rediget, quæ nihil ant parum roboris preftare poterit ad concoguendos, \& expeliendos noxios fuccos, qui facile in precipua vifcera recurrentes exitium inferent. Quare tutiffimus erit ufus cucurbitularum, qux ex alto ad cutim venenum pertrahant, neque cutis partes, quibus applicitre fuere cucurbitula, 'etfi vacuato fanguine modicum refrigerentur, \& conftipentur, debemus ullo pacto ab iis prohibere, corpore tamen toto prius, tum vacuato, tum purgato; quo- 
niam quam levi negotio nuper dictis partibus proprius calor reflituetur, atque meatus etiam cutis aperientur, vel aliqua friEtione levi, vel calida ilinitione, qualis eit, quæ ex Ruffi mente paratur oleo aliquo laxativo, \& nitro; \& fi dicant, ab iis fieri obftructiones, à quibus augetur putredo, ejufque gradus, alii refpondent neutiquam poffe fieri obftuctiones, quando præceflerit illis totius exquifita vacuatio: quoniam cum iis vel nullus, vel pauciffimus fanguis vacuatur, tollitur occafio trahendi à radicibus venarum fanguinem crudiorem, quod illucufque attractionis motus nequeat pervenire; \& fi obftructiones aliquæ in parvis, fub cute exiftentibus venis accident, cum totus fanguis attractus illic remaneat, eæ \& minoris funt mo: menti, atque etiam non difficili negotio tollentur, aliqua leni frictione, vel illinitione illo attenuato fanguine, atque refoluto: parum etiam naturalis caloris diffipari poteft, cum vel nullus (ut jam dictum eft, ) vel pauciffimus fanguis in iis vacuetur. Quod etiam non fit timenda attractio in cordis regionem, apparet ex Galeno, qui, ut jam fuperius vifum eft, in lib. I1. Cap. II? meth. in pulmonum inflammatione cucurbitulam pectori tuto effe applicandam ftatuit: verba ejus hæc exiftunt: Ac longe quidem magis in pulmonis phlegmone abftinendum al adftringentibus eft: quando in eo ipfis quoque reluxantibus adnifcendum aliquid acrium quodammodo, Eे evidenter calfacientium eft: quippe foras trabere potius quam reprimere, in eo debemus. Itaque etian cucurbitula utiliter iis, qui fic laborant, $\sqrt{i}$ prius fint vacuati, applicabitur. Ad id vero, quod de inæquali cucurbitularum attractione objiciunt, eas filicet, inæqualiter coctum crudumque humorem abfque difcrimine attrahere, neque naturæ excretionem criticam imitari paulatim coquendo, \& paulatim expellendo, fatentur verum effe, fed hoc nihil tamen effe detrimenti, quod utilius fit venenum a corde longius diftrahi, quam crudum humorem in parvis is venis vi attrahi, atque ipfo fic attracto aliquas fieri obftructiones, quas mox poffumus attenuato humore rurfum aperire, fed non ita facile venenum intra venas contentum, \& in vifcera recurrens prohibere poffumus, quo in venis magnis retento, natura ita læditur, labefactaturque, ut nihil, vel parum contra, tum ipfum humorem jam vehementer pu- 


\section{I64 PROSPERIALPI I}

trefactum, tum illum, qui in via ad putredinem eft, agere poffic: quare fatius erit ipfum cucurbitulis à magnis venis amoliri. A L P IN. Itaque ex his errare thypcios videris affirmare, cum a cucurbitulis illis omnino abtineant, neque immerito ufus illarum laudabitur, cum foras ad trahendum venenum cucurbitula ceteris præfidiis præftet. Gur. Neque dicam ipfos omnino errare, neque recte fe gerere, cucurbitularum ufum non fequentes in febribus illis, earum loco quibufdam illinitionibus, ac frictionibus idem potius præftantes. In corporibus fiquidem craffis multis fuccis fcatentibus, eas eo modo applicatas haudquaquam laudare poffum, cum er certo certius obftructiones multas pariant, à quibus putrefactus humor majorem putredinis gradum necelfario adipifcitur, neque etiam in aliis corporibus, ubi nondum apparet ad vifcera noxios humores venenofos inclinare, quod facile oftendunt, ægrotos non omnino effe inquietos, recteque refpirare, nuilloque dolore, vel angore ipforum cor angi, recteque dormire, beneque mente valere: veluti contraria accidentia fi extent, contra arguent, proindeque urgente occafione tantum applicationem cucurbitularum laudarem, quibus venenum longe à principalibus membris avelleretur. Quibus vero partibus tutius utiliufque fit eas affigere, ego dorfo magis, quam cruribus affigendas fore cenfeo, nifi vacuationis gratia is applicarentur; quo cafu vacuatio multo fanguine procuratur: poft univerfalem vero factam vacuationem, venenofos humores divertendi à vifceribus, gratia, non videtur idonea larga fanguinis miffio, qua neceflario vires collaberentur, fed ipfis cucurbitulis diverfionis gratia applicatis, paucum fanguinis mittitur, qui fi à cruribus iis mitteretur., vim non haberet a corde venenum attrahendi ad ignobiles partes, quoniam fanguinis illa modica vacuatio, attractionem in venas concitabit, quæ vel non perveniet ad cor, vel fi pervenerit, admodum, debilis atque inefficax erit ad trahendum venenum ad partes, quibus applicitæ funt. Quod inutiles non fint cucurbitulæ in febribus peftilentibus, præfertimque in apparitione exanthematum, experientia quotidiana confirmat. In elapfa enim peftilentia fæpiffime expertum eft vel ad tumores, bubonefque maxime, \& parotides promovendas vel ortas, quin re- 
trocedant, retinendas, vel quæ evanuerint vel retroceflerint rurfum evocandas, nihil cucurbitulis præftantius. Multis enim fcio eo tempore cucurbitulas fumme contulife ad magnificandos tumores, atque ad intus abfconditos revocandos. Exemplum digniffimum habeo, quod maxime faciet ad illuftrandam hanc veritatem. Georgius Selaccus Chirurgiam Venetiis exercens, in ea peftilentia uxore ejus pefte correpta cum tumore in inguine, narrat, fe cum vidiffet tumorem illum infignem (quam facile frpilfime imminutum, \& evanefcentem) vel imminui, atque intus recurrere, quod continuo mulier delira evadebat, quo ftatim cucurbitula frepe inguini cum igne appofita, iterum ad folitam magnitudinem tumore illo revocato, atque peraucto, ftatim fana mente reddebatur, fæpifimeque dum ipfa ægrotaret hoc obfervavit, coactufque idcirco fuit fæpiffime cucurbitulis diminutum ac fere evanefcentem tumorem foras trahere, quod fane femper fuccedebat. Quo facto femper ejus uxor ad fanam mentem redibat, atque ubi rurfum aliquo pacto bubo minueretur, delirium ipfam rurfum invadebat. Teftaturque mulierem, quo tempore ab appofita tumori cucurbitula afflgebatur, femper mente fanam extitifle, qua fubito excidebat, tumore intus recurrente, fanaque rurfum eo cucurbitula foras attracto. Quod fane exemplum confpicue fatis oftendit, quantæ utilitatis fit judicanda cucurbitula ad avellendos venenofos humores à membris præcipuis, atque adjuvandas omnes naturæ excretiones, vel fymptomaticas vel criticas illas vocemus, atque hæc arbitror fufficere ncbis pofie in hac die, quando fermonem noftrum longius ncs profequi nunc nox, quæ jam noftris oculis tenebras obducere incepit, prohibeat; proinde finem hodierno fermoni demus. Alpin. Recte fuades, nam totum quod de miffione fanguinis apud Egyptios ufitata, nos loqui propofueramus, vix toto fequenti die abfolvere poterimus, nam de variis pro fanguinis evacuatione fcarificationibus, quibus illi utuntur, etiam fupereft loquendum, quibus peractis, fi aliquid temporis eo die fupererit, nos multa alia ad partem chirurgicam pertinentia, valde \& ipfa tcitu digna profequemur.

$$
\text { F I I I L I BR I SEC U N D I. }
$$


Pag. 166
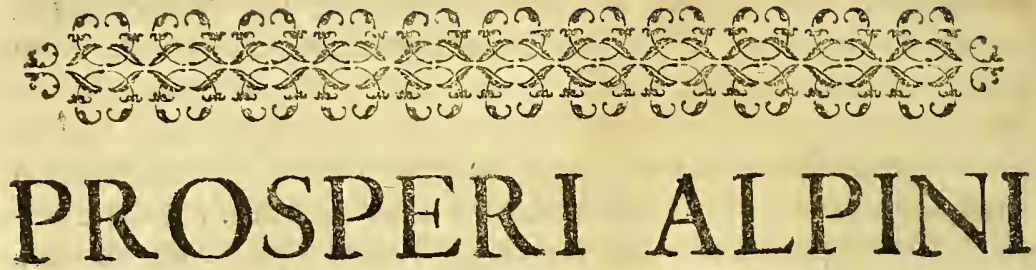

D E

MEDICINA EGYPTIORUM.

L I B E R T E R T I U S.

$C \wedge$ P. I.

De variarum frarificaiconum frequenti apud Medicos CAgytios ufu.

\section{GUILANDINUS; ALPINUS.}

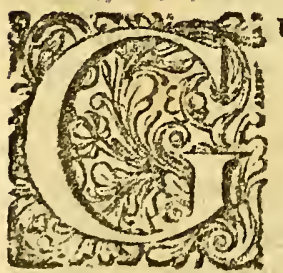

3 UI I ANDINE, acifum nunc tibi, fed tumulto tardius quàm heri in viridiarium defcendifti, Salve. Guiland. Iit tu quoque, nefcio quáa de caufa tardius huc te contulifti. Sol enim fupra horizontem ita fe extulit, \& aërem ita inflammavit, ut nos fub hujus latiffimæ Platani umbra confedere, nunc optimum fit. Alpin. Rectè fuades, fed ubi hîc confedimus, præftiterit de medicina $\mathbb{E}$ gyptiorum inchoatum fermonem recipere, \& abfolvere. GUILAND. Cur te igitur ad rem ipfam accingere cunctaris? Nihil mihi jucundius efle poteft, quàm te hîc de IEgyptiorum medicina loquentem audire, ac multa ad medendi artem fpectantia ex te cognofcere. Supererat, opinor, de 
DE MEDICINA EGYPIORUM. LIB. III. I6

variis fcarificationibus, quibus illi medici ad vacuaridum fanguinem familiarifime utuntur, agendum. Ideo tuum nune erit eas narrare, atque docere, teque ut id facias etiam atque etiam rogo; fpero fiquidem hunc fermonem mihi non minori fore utilitati, quàm cetera de variis mittendi fanguinem modis fuperius explicata. Alpin. Omnibus in Rigypto verfantibus variarum cutis fearificationum pro mittendo, vacuandoque fanguine vice fectarum venarum, ufus eft notifimus. Quis etenim certis anni temporibus, atque in primis in aftatis prima parte, innumeris infantibus aures fcarificatas ibi non vidit? eo fiquidem tempore è centenis quibufque pueris quadraginta vix ibi reperias, quorum aures ob fcarificationem gollipia non geftent: nec minus frequens eft crurum farificationis pro fanguinis vacuatione ufus in omnibus $\mathbb{E}_{g y p t i}$ locis, præfertinque in pueris, Eunuchis, mulieribus, atque omnibus corporibus molli carne præditis. Hoc etenim vacuandi prefidium ab illis uno affenfu venæ fectionis, ut paulo pont dicam, vieariun credicur; proque tali auxilio, in iis, qui pre virium inbecillitate fanguinis vacuationem per venam fectam non ferunt, hoc fcarificationis genus apud eos medicos præito effe folet. In pluribus etiam fæpe nafum, vel potius nares ab is fcarificari, atque labia ac gingivas non minus obfervatur. Ex his igitur colligo, partes quas illi pro fanguinis vacuatione fcarificare folent, effe aures, nares, labia, gingivas, loquor de iis', à quibus circa applicatas cucurbitulas fanguis educitur, mam adhitis cucurbitulis plures alias partes fearificant. Amplius quafcumque partes etiam corporis extrinfecas, aut aliqua inflammatione antiqua, admodumque difficili, vexatas, vel gangræna ob malignitatem, vel ob copiam humoris naturali illarum partium fuffocato vel extincto calore, vel aliqua puftula, vel tu more, vel quacumque re preter natuwam detentas, $:$ fcarificatione fanant: in hydrope, atque fuppuratis hoc prafidio ad vacuandum utuntur, ut de his fuis locis nos loquemur. Sed ad eas fearificationes, quibus ad vacuandum fanguinem $\mathbb{E} g y$ : ptii uti confueverunt redeamus, quarum duæ præcipuæi vel primarix in puerorum vacuandis corporibus ab ipfis adhibentur 


\section{8

aurium quippè una, atque crurum altera. Reliquarum verò ulitatior, atque utilior eft, quæ intra nares adminiftratur. Præfentaneum etenim remedium apud eos habetur in omnibus acutis febribus, in capitis cum doloribus, tum inflammationibus venas intra nares fcarificari, atque $a b$ iis tepido dulcis aquæ balneo fanguinem educi. Guiland.. Dignæ funt hæ apud illos populos ufitatæ fcarificationes, ob ipfarum multam utilitatem; ut locupletiori fermone, atque pleniore ftilo à te rurfum confideren. tur, præfertimque cum harum pleræque noftris medicis ignotæ fint; is enim, qui hactenus de ipfis à te fermo eft habitus me admodum delectavit, fed quæfo eadem clarius mihi atque accuratius exprime: $a b$ illis fi lubet, quas auribus infligunt, deducto principio.

\section{A p. II.}

De aurium, narium, labiorum, gingivarum, fcarrificationibus, quas medici Asgytii pro evacuatione frequentant.

\section{A L P I N U S.}

Drima ejus regionis ineunte æftate, Campfinis ibi fpirantibus ventis calidifimis, plerumque adverfus infantes tonfillarum epidemicæ inflammationes vagantur, febrefque acutæ, atque circa pudendorum partes inflammationes, \& ulcera. Quibus malis, atque aliis etiam omnibus ex calore ortum ducentibus, fuccurrunt aurium fcarificatione intus vel extra præftita, fanguinis vacuationem molientes: ut vero hanc fcarificationem operentur, in primis collo infantium lineo panniculo vincto, atque paululum ea ligatura anguftiori reddito, tumidiores aures fieri ftudent, quas eodem tempore frmul itidem manibus multum contrectant, atque perfricant, aqua calenti dulci eafdem fxpius irrigantes, \& abluentes, vel fpongiam calenti aqua plenam auribus fcarificandis applicant. Qua- 
rum exinde magnitudine aucta, atque ruborem infignem adepta, tribus, vel quinque incifionibus oblongis recte per lacitudinem, cutem ante vel retro cultro fcarificant, à quibus fcarificationibus parum fanguinis calido aquæ balneo fæpe illas abluentes, educunt, atque fere nullam infantuls tamen lamentationem ploratu aliquo edentibus, ita fine molentia hec fanguinis vacuatio conficitur: eflluxo deinceps fanguine, fcarificationibus probe lineo panno deterfis, atque ficcatis, goflypium adaptant, quod tribus ad fummum diebus in auribus $f$ carificatis geftant, atque mox ab ipfis recte conglutinatis, illud abigunt. In omnibus vero acutis febribus, atque omnibus inflanmationibus oculorum, aurium atque ceterarum capitis partium, cutim ante vel intra aures poficam fcarificant, atque in iifdem partes infernas occupantibus, retro vel extra aures pofitam. Guiland. Hoc remedii genus non omnino fore fpernendum ac negligendum videtur, nec penitus antiquis medicis ignotum fuife, quando apud Hippocratem in 5. epidem. hæe ad unguem legantur. Cum adfunt cederizata, vene in auribus poCimm. S. tent. $2:$. feriores fcindende funt. Sed Galenum aurium iftam fcarificationem minime novife hine fufpicari poteft, ex quo ipfe in commentario Hippocratem reprehendendo hæc dixerit: In bis quidem verbis locutio impropria, Ev vitiofa ef , ip $\int 0$ fcribente, venas in auribus: neque enim venas in auribus, fed circum aures dicere cportebat: Siquidem vence quedam poft aures grandiores funt,

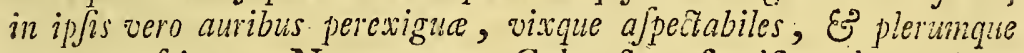
neque perfpicuse. Non noverat Gal. ufum fearificandarum aurium eo modo, quo Hippocrates fenex fapientifimus cognoviffe legitur. Sed tamen hunc ufum aures fearificandi andio multis Saracenorum admodum familiarem extivife. Quod \& Doetiffimus lranc. Valefius probe confirmare videtur, qui in comm. fexti lib. epidem, Hippoc hæc fcripfit: Id quod didici à Saracenorum filits, quos numper Pbilippus dominus meus deviEta rebelirone, it Granatce funibus in interiorem Hifpaniam Secedere imperavit: illi utebantur aurium fcarificatione, quan pefit quifpiam in bunc Hippoc. locum referre. Non eft itaque diffcile credere nune Egyptios etian hac aurium fearificatione uti. . Neque hine Y 


\section{0

Hippoc. orationem impropriam, ut Gal. voluerat, efle certo cognofcitur, fed potius haic Galeno fuife ignotam puiaverim. Alpiv. Veruntanen id aut nulius, aut parvi adjuneñti (cum aurium hæ partes, quæ fcarificantur, excarnes ac exangues fint, venifque vix apectabilibus refertæ) effe quis exiftimabit, quod ab harum fectione paucifimus fanguis educatur, qui aut nullum, aut obfcurifimum auxilium is præftare poieft. Valefius ut Iippocratem à calumnia fervaret, qui aurium fcarificationes ad coxendicum affectum (ut dictum eft) laudavit, ait iis, quibus ex capite fluente humore ad femora, in eos affectus inciderunt, cauterio aurium partibus, vel ante vel retro politis inu. ftis vel diflectis, poffe conferre. Sed quia negare non poterat, hanc fcarificationem apud multos Saracenos in ufu effe, id. circo fubjunxit, etiam Saracenos hac uti fearificatione, quia funt timidiffimi à miffione fanguinis; neutrum jure videtur $\mathrm{cre}_{\text {: }}$ dendum, quando Hippoc. manifentifime non de aurium cauterizacione vel inuftione, fed de fcarificatione locutus fit. Neque Saracenos ita fanguinis vacuationem formidare, hominum relatione certo conftat. Regyptii vero atque Arakes, quibus copiofa fanguinis eductio eft familiariffima, aurium (ut nuper dixi) utuntur etiam fcarificationibus ad evacuandum fanguinem. GuIland. Puto timorem miflionis fanguinis in pueris non aliunde venire, quam ex ipforum fumme calido atque humido temperamento, habituque maxime aperto ac molli, facillimeque diffolubili: ex qua copiofa fanguinis vacuatione corpora illorum nimium exolverentur: quare $\mathbb{E}$ gyptii pueris quam parciffimam imperant vacuationem, cum fua corpora habeant ex temperamento, atque habitu, unde evacuentur promptiffma. Hincque in pueris aurium fearificatione fanguinis vacuationem moliuntur, quod ipfa pauciffima, tum is fufficere, tum minime multum vires diffo'vere, queat. Alpin. Non folum aures, fed \& nares ad multa mala non in pueris modo, verum in omnium ætatum hominibus, Esgyptii fcarificare folent: venas enim intra nares maxima dexteritate fcarificant, \& ut ipfis lubet fanguinem interim copiofiffmum exinde evacuant. Idque naturam imitati in febribus acutis, in quibus præfertim 
caput, vel doloribus vel aliqua inflammatione lefum obfervatur, atque in phreneticis, aliifque ex calidis fuccis delirantibuspræcipueque ex fanguine. Arcanum etenim quoddam apud illos copiofa fanguinis à naribus intus fcarificatis mifio creditur. In omnibus doloribus, ac inflammationibus capitis partes occupantibus, non minufque in iifdem affectibus oculos infeftanti, bus, in continuis putridis febribus, ubi ruborem in facie, vel affiduas vigilas, vel deliria ægros vexare confpexerint, ftatim ad hanc fanguinis vacuationem confugiunt, maximeque in diebus criticis, in quibus crifis aliqua per fanguinis eruptionem fperatur. In phreneticis, atque acute febrientibus, quibus in aliquo criticorum dierum ftillæ ex naribus illabentes obfervatæ fuerint, minimeque exinde fperantes fanguinem poftca large fluxurum, intus nares phlebotomo fcarificantes, eruptionem per ftillas inceptam adjuvant, atque perficiunt. Nova hæc apud noftros medicos, pro molienda fanguinis miffione fearificatio erit, neque puto quempiam ipfus rationem, atque ufum habuifle. Multi enim intra nares appofitis hirudinibus fanguinis vacuationem pertentarunt. Amatus Lufitanus Medicus Hebræus non fpernendus, fe rectum ufum à naribus educendi fanguinem reperiffe in tertia fuarum centuriarum memoriæ prodidit, qui tamen folis hirudinibus illam vacuationem moliri oportere, putabat. Guliand. Gal. vifus eft his verbis hunc vacuationis modum noviffe ac docuiffe in 2 . lib. de compor. medicam fecundum loc. qui dixit: Quod $\sqrt{2}$ amplius fanguis redundare videatur, etiam ex naribus aperta vena, Eo quantum fufficere videtur fanguis vacuetur. Hinc intelligi poteft Galeni temporibus ufum mittendi fanguinem à naribus fuife probe cognitum, atque frequentatum. Sunt aliqui, qui exiftimant fieri hanc vacuationem, fecto nafi mediaftino, quam multi laudant in faciei, nafique ruboribus, atque in aliqua inflammatione. Alpns. Errant illi certiffime id credentes, quoniam apud Egyptios omnes, narium fcarificatio, atque mediaftini, una, eademque non eft, neque ad eadem mala utrifque his utuntur. Narium enim fcarificatione multum fanguinem evacuant, qua vacuacione omnibus capitis inflammationibus cum internis, tum exI 2

ten:- 


\section{I\%2 PROSPERI AL PIN I}

ternis, \& in febribus fæpe utuntur: à Mediaftino vero fcarificato paucifïmus fanguis exit, qui tantum faciei nafique ruboribus adjumento effe folet. Guiland. Sed quomodo nares fcarrificant, atque nafi mediaftinuin? Alpin. Nafo in primis, pofiquam collum fafcia devinctum eft, ut venæ craffefcant, tum multum perfricato, tum aqua calida multa dulci afperfo, atque tumefacro cutem narium ambarum, vel unius, per longum tribus, vel ad fummum quinque fcarificationibus fecant, a quibus fanguinem calido aqux dulcis balneo educunt. Mediaftinus vero \& ipfe eodem modo una fcarificatione fecatur, guttæque tantum fanguinis ex ejus fectione promanant. Utuntur etiam illi populi labiorum, præfertimque inferioris fearificatio: ne pro oris, gulx, inflammationibus, fed longe maxime ubi fifturis labia fuerinc obnoxia, gingivafque fcarificant, ex confluxo fanguine dolentes, vel aliqua inflammatione vexatas. Sed his omiffis, utilius erit, nos tandem accedere ad celeberrimam crurum, maileolorumve fcarificationem: qui enim habebitur fermo de tanto prefidio, non poterit non nifi multum medicis adjumenti afferre, quando hæc fcarificatio venæ fectionis vicaria, mea quidem fententia fit, de qua nunc prolixius tecum loqui cupio ; fperoque hujus fermonem majori, quam ceteros nobis voluptati fore, nec minori utilitati, quem totum in hae die vix credo à nobis poffe abfolvi. Guiland. Quæfo, quæ in fermone hujus fcarificationis, quæ à noftris etiam iis partibus applicatis cucurbitulis communiter in quibufdam malis ita facile molitur, tam copiofam orationem accerfunt? Vellem igitur hac de caufa, ut quamprimum ad illam te converteres. ALpin. Faciam ut lubet, fed vereor, ne tu in communi multorum errore verferis, qui celebrem hanc malleolorum farificationem, a's antiquifque medicis præclariffimis pro venæ fectionis vicario anxilio receptam, atque ufitatam, in cucurbitularum cum fcarrificatione applicatarum ufum commutarunt. Verum fi quid de illa Gal. \& Oribafius in multis locis, ex quamplurimum celebratorum medicorum fententia, nobis prodiderint, nunc meminiffes, fortaffe ita hic fermo te delectaffet, ut longiorem hac de re explicationem à me peteres. Guiland. Nihilominus ego 
fortaffe, avidius quam tu fermonem, qui de hujufmodi præfdio accurate habeatur, expecto. Sed antea fcire ex te volo, an eodem modo 1 gyptii mentum fcarificare foleant, \& krachia, quando horum fearificationem apud Hifpanos confici aliqui prodicierint: atque \& menti fcarificationis Gal. in 6. lib. de compofit. med. fecundum loc. ad multa mala meminerit. AlpiN. Etfi utrumque fieri meo quidem judicio poffet, tum brachiis, cruribus, quoad venarum ordinem fere omnino refpondentibus; tum etiam quia menti fcarificatio, \& commode adminiftrari poffet, \& multis affectionibus effet utilis. $\mathrm{Cu}$ jus utilitatem anciquitas medicorum nos recte perdocuit. Sed tempus eft, ut ad propofitam fcarificationem redeamus.

\section{A P. III.}

Malleolorum, five crurum farificationem ad mo. liendam evacuationem auxiluum efse antiguisfimum, à Gracifque clarifomis medicis valde frequicntatum.

\section{A L P I N U S.}

monum maxime crurum, furarum, vel malleolorum fcarificationem pro fanguinis molienda evacuatione in pueris, Eunuchis, mulieribus, atque carnofis vel pinguibus onnibus hominibus ufurpant, tutiffinumque apud eos creditur vacuatorium remedium: quo quifque multorum morborum occafione ingenti falutis fpe utitur ad vacuandum fanguinem, præfertimque viribus vacuationem per venam fectam præ imbecillitate non ferentibus. Scarificant enim, ut inferius propriis locis dicam, in utroque crure furam, five partem cruris craffam, quæ malleolo contermina eft, multis adactis profundis, ac longis fcarificationibus, à quibus free tepida aqua clurci ablutis, quantum volunt farguinis fine multa corporis commotione, educunt. Ad hoc auxilium illi in omnibus morbis, $\mathrm{ab}$ humoribus calidioribus ortum habentibus, veluti ad facram. 


\section{4

anchoram confugiunt, neque id immeritò, cun tot, \& tantas habere ad fanitatem virès fæpiffime fint fcarificationem experti. Mirorque idcirco, Guilandine doctiffime, noftrates medicos nolle tam utile. atque a multis doctifimis Græcis medicis antiquis, ad morbos profligandos, hominefque $a b$ his præcavendos, adeò laudatum auxilium agnofcere, atque in ufuni revocare. Et quamquam eos medicos non omnino latdem, qui ita promptè in quovis ferè morbó fanguinem per venam fectam mittant, rectiùs tamen eos agere putamus, quàm qui eandem vacuationem fanguinis per cucurbitulas dorfi partibus cum fearificatione applicatas moliri confueverunt. GurLAND. Pribres illos medicos eo auxilii genere, quippe venæ fectione poffe morbos eos profligare tutius ac certius judico, quàm alios cucurbitularum ufui. Quod miffio fanguinis per venx fectionem procurata, magnum utique fit remedium, atque ob id magnis meritò occurrat morbis. Ab ufu verò cucurbituIarum tantum abeft, ut magnos morbos à plenitudine humorum ortum ducentes, profligari poffe credam, ut potiùs iis applicatis, eos in deterius fuccedere poffe autumem. Quod à nobis heri diligentiùs difputatum, atque conftitutum fuit. Sed cur ego te tamdiu interpello, teque ab incepto tuo fermone his verbis amplius diftraho; perge igitur reliquum hac de re fermonem abfolvere. ALPin. Pro tollenda corporum plenitudine Gal. nullum cucurbitularum verbun fecit, ut noftrorum, multi cogitant, fed folum venæ fectionis, atque crurum fcariAphor.17. ficationis meminit. Quod ab ipfufmet verbis in 2. Aph. Hippocr. commentario proditis colligitur, quæ hæc exiftunt: Evacuatio omnium bumorum aqualiter, que quidem exquifitifima eft, fit per vence fectionem; proxima autem buic illa eft, qua fit per malleolorum fcarificationem. In libro etiam de hirud. cucurb. fearif. dixit: Cucurbitulas in plethoricis corporibus non modo effe inutiles, fed etiam noxias. Atque in lib. de curat. per fang. miff. docuit, ante cucurbitularum adminiftrationem totum corpus evacuatum effe oportere, illifque vel cum fcarificatione vel fine ea applicatis. Ex quibus noftri medici perdocti, nefcio cur, in magnis morbis, viribus fanguinis eductio- 


\section{DE MEDICINA. EEGTTTORUM. LIB. III. 175}

nem per venæ fcctionem non ferentibus, ad hane, relictis illis cucurbitulis, faltem crurum fcarificationem non accedant vel confugiant, cum hæc tutiffimum fit auxilium, vacuationeque (yt ait $\mathrm{Gal}$.) venæ fectioni proximum. Hocque etiam venæ fectioni utilitate præferendum Gal. in eodem lib. de hirud. cucurb. aliis verbis meminit: Eodem namque anro renam frequenter incidere, minime quidem rotioni confentaneum arbitramur: Quandoquidem cum larga Sanguinis copia, vitalis quoque fpiritus emittitur, quo fane abfumptn, crebriu's quidem moles univerfa frigefcet, tum animales functiones omnes deteriores redduntur. Quamolren ab ignobilioribus membris, ut potè d̀ cruribus Janguis edncendus eft. Atque in libro de curat. per fang. miffio. in quibufdam corporibus crurum præfert fcarificationem venæ fectioni, ut ipfe hune in modum prodidit, dicens: Porro que ex mulieribus albidiores funt; fanguinem aceroare tenuem folent. Quocirca adbibitis malleolorum fcarificationibus maxime juvantur. Et paulo poft ait: Carnofis vero Ë candidis parve infunt vene, quibus malleolos fcarificare, quan venam fecare praftiterit: quippe cum bee parvas in cruribus venas babeant. Eft \& Appollonius ille atque Antyllus, medici olim graviffimi, ut apud Oribafium le- Lib. $\%_{0}$ gitur, qui hujus fearificationis clariffima monumenta pofteri- Cap. $20_{0}$ tati reliquerunt. Oribafius vero hæc de ipfa crurum fcarificatione fcripfit: Et fane dim peftilentia velsemens Afiam deprehendiffer, multofque perdidifjet, meque ctiam morbus attigiffet, fe= cunda morbi die remiffone febris faita, crus fcarificavi, duafque tere Sauguinis libras detraxi, bacque de caufa periculum vitavi. Plerique igitur etam alii boc prefidio ufi fuperftites evafernist: erant enim plenitudinis Jigna. Crurum itaque fcarificationis ufum Galeno, Apollonio, Antyllo, Oribafio, plerifque etiam aliis ex antiquis clarifimis medicis \& cognitum, \& valde apud eos frequentatum exinde plane conftat. Guil. Vera fane prædicas: fed quid mireris multos etiam doctiffimos hoc ita ab op. timis medicis laudatum auxilium minime velle agnofcere, ac in priftinum ufum revocare, quando multorum infanabilem in defendendis erroribus pervicaciam tu rectè noveris? Quid mireris, inquam, cum ipfi aliquid habeant; quo culpa cärere 


\section{PROS PER I AL P I N I}

aliquo pacto videntur? Namquis unquam ab Ægypto huc profectus eft, qui ejus fearificationis verum modum nobis manifeftarit? Cerie nemo nos eam edocuit: ego magis mirandum effe puto, hactenus multis in Italiæ urbibus, præiertimque Venetiis perinde ac Erafiftratei faciebant, medicorum multos fan guninis miffionem per venam fectam ita abhorruiffe, ut maximum timorem id genus auxilii plerifque incuteret. Qua in re non parva gratia Alexandro Maffarix medico clariffimo eft habenda, qui cum urbem illam olim ingreflus ita à fanguinis miffione abhorrentem, ac timentem invenerit, medicæ artis Hippocraticis principiis veritatem illis fepe fuadendo ac demonftrando, errorem in medicina fummum, è mentibus doctiffimorun multorum medicorum eripuit. Tamen caterva medicorum (ita morbus invaluit) fuperfuit, adhuc antiquis erroribus plane addicta: qui affirmant, non effe conficiendam fanguinis vacuationem per venæ fectionem, ob plurimi caloris refolutionem, fed tantum cuti dorfi aliifque partibus applicitis cum fcarificatione cucurbitulis. Hineque earum ufus eo gratix devenit, ut nunc frequentiffimus apud multos, ac familiariffimus factus fit. Hacque de caufa multi audent affirmare cucurbitulas fcarificatas venæ feetionis vicarium effe auxilium, Quorum opinio quàm erronea, \& à veritate aliena fit, præter ea quæ Cap. 5. dicta funt, patet etiam ex Galeno, qui \& in 2. lib.' Aphorifim. $\&$ in 4 . de fanit. tuenda, atque in lib. meth. med. aliifque multis in locis dixit apertifimeque, fecundum locun, à fectione venæ, crurum fearificationem obtinere: nam in 2. lib. Aphorifm. ait: hane fearificationem venæe fectioni effe proximam: atque in lib. 4. de fanit. tuend. afferit, tantundem ac venæ feEtio valere maleolorum fcarificationem; \& in lib. 13. meth. med. feripfit: Si corpus fuerit pletboricum, fanguinem mittendum effe, aut vena incifa, aut cruribus fcarificatis. Alpin. Recte fane dixifti, fed hactenus excufari poterant noftri hi medici, quod nemo ipforum hanc fcarificationem, quo pacto arlminiftraretur $\mathrm{ab}$ aliquo didicerit. Nunc vero quifque fumme redarguendus erit, nifi voluerit hoc gentus prefidii utiliffimum ¿̀ nobis faltem accipere, \& in antiquum ufum revocare. Maxi- 
meque cum audierit, hujus fcarificationis ufum cum in tota Figypto, tim in tota etiam Hifpania apud omnes familiarifime frequentari in omnibus pueris, Eunuchis, mulieribus, pinguibufque corporibus, felici femper cum fucceffu. GurLAND. Amatus Lufitanus medicus non fpernendus hoc remedium maximi femper fecit, atque fæpiffime eo pro vacuatione fanguinis ufus eft: ut paulò pòft fufus etiam narrabitur. Eademque, qux tu, Joan. Jacob. Manni pofteritati tradidtt. Quam ob rem crurum fcarificationem mulcis \& antiquis, \& recentioribus medicis fuife cognitam, \& ab eis adhíbitam manifeftiffimum eft. Quod ut apertius omnes cognofeant, ac ne ab hoc vacuationis ufu, ideo fe abftinere dicant, quod ignari fint, an eodem modo hæc fcarificatio, tum in Fypto, tum in Italia hominibus conducat; ideo fi polequam tu in patriam redieris, in aliquibus ipfa fueris ufus, ac quali etiam falutis fucceffu vel fetici, vel infelici, intelligere ex te nunc cupio.

\section{A P. I V.}

2uibus in Italice locis bominibus fanguis crurum $\int c a-$ rificatione fuerit detractus.

\section{A L P I N U S.}

B Egypto ego in patriam reverfus, Baffanum oppidum A loci amænitate pulcherrimum, meorum ftudiorum gratiâ, me contuli, ibique medicinam publice faciendo multos fcio æegrotos crurum fcarificatione, fanguinis fæpe evacuatione more $\mathbb{E g y p t i o r u m ~ p r o c u r a t a , ~ f a n i c a t i ~ r e f t i t u t o s . ~ S c i s ~ e t e n i m ~}$ poftquam in Italiam ex illis locis pervenerim, me perpetuo optima If gyptiorum veftigia in medendo fequi voluife, præfertimque in fanguinis vacuatione molienda, maximeque in ufu crurum fcarificationis, pro qua exercenda diligenti, atque experto invento hujus operis miniftro, in multis fanguinem mittere more Regyptiorum pertentavi. Quod mihi feliciori cum fucceffu femper evenit. Primufque, cui eo modo fanguis fuerit Z 


\section{5

vacuatus, puer fuit annos decem natus, quem in humanarum literarum cultu Francifcus Lanzarinus Baffanenfis in ejus fchola a Caftro franco exercendum fufceperat. Qui duplici tertiuna correptus, cruribus ambobus fcarificatis, \& educto fanguine conviduit. Huic enim propinato prius pharmaco, quo ejus corpus noxiis paulifper expurgaretur humoribus, iilque maxime, qui in ftomacho \& venis meferaicis continebantur, quarta die ambobus cruribus vel furis more Rgyptiorum fcarificatis, fanguinis fere libram commodiffime eduximus, à qua præftita vacuatione febris imminuta, alia tantum acceffione defiit. Paucos ab hinc menfes ab hujus pueri morbo mulier fere fexagenaria, Bona vocata, quæ, apud Baflanos famofifimos pictores habitabat, hepatis peffima inflammatione correpta continue cum dolore, \& tenfione dextri hypochondrii, affiduis vigiliis atque difficillima refpiratione, ingentique fiti, lingua nigra admodumque fqualida febricitabat. In qua urinæ tenues, colorätiores, cum contentis crudis fpectabantur, diefque duodecimus ab ægritudinis principio agebatur, quando accerfitus illam inveni eo modo ægrotantem, cujus morbo, caufis, ac fymptomatis reete perfpectis ac cognitis, atque chirurgo accerfito, internam dextri cubiti venam fecari juffi, à qua nullo fanguine, muliere in fyncopim collapfa, vacuato, ne mifera ceteris negleetis remediis moreretur, ex ejus corporis habitu bene carnofo, pingui atque albo, Galeno in libro de curand. rat. per fang: miff. docente, malleolorum five crurum fcarificationem magis quam venæ fectionem, præftare ei poffe: probe cruribus fcarificatis, fanguis ad libre pondus commode eductus eft, à quo ftatim melius fe habuit, nocteque fubfecuta fomnum cœpit, melius refpiravit, atque adeo febris minui exinde copit; die quarta-decima fere libera fuit, at decima-feptima in univerfo corpore critica exorta fcabie, prorfus convaluit. Poft hane aliam eoflem annos natam, habitu admodum pingui, ac valde carnofo præditam, villam Angaranum habitantem, febre continua, acuta, correptam cum intenfiffimo capitis dolore, affiduifque viziliis, delirio, atque multa inquietudine curandam pric manibus habui, cui dis tertia præmifo clyftere, ambobus 


\section{DE MEDICINA EGYTiORUM. Lib. III. 199}

itidem profundis incifionibus cruribus fearificatis, fanguinis libra \& plus fuit elucta, à qua mulier melius ftatim fe habuit: dieque feptima omnino à febre libera evafit. Puer etiam duodecim annorum Citıdellenfis in domo Jofeph Caratelli pharmacopolie, cum febre furdus omnino factus, ejus à fcarificatis cruribus, plurimo fanguine eracuato, ftatim audivit, atque paucis diebus etiam à febre convaluit. Duæ itidem eodem tempore puellie virgines in Valle Stagna decumbentes, in peftilentem febrem collapfa à fuppreffis menftruis, ea fcarificatione adjuvate fanitatem cito receperunt. Cito enim ambabus is copiofi menfes denuo fluxerunt feptima die cum judicic. Criticeque ambæ judicatæ in eadem die fuerunt. Audifti ex me igitur, quos vacuatione fanguinis, furaium fcarificatione præ: ftita, Deo annuente, Baffani fex fere menfium fpatio fanitati reftituerim. In principio dum ea uti cœperim, propter multas magnafque ac profundas fcarificationes fere omnes hoc auxilium formidabant. Deinceps vero multi fuere, tum viri, tum mulieres, quæ ab utilitate perfuafi hoc genus remedii facile complexi funt. Guiland. Gaudeo te tantum de hujufce fcarrificationis utilitate periculum feciffe: cui facile omnes acquiefcere poffent. Ego vero, ut idem confirmem, puto non inutile fore, fi tuis experientiis alias ab Amato Lufitano memorix traditas fubjungam. Alpin. Gratam rem facies, fi eas mihi etiam indicaveris. Guiland. Is in prima fuarum centuriarum Curat. is. hæc litteris tradidit: Paucis interpoftis diebus bujus didti frater, duos annos natus in eafdem oris ulcerationes incidit, qui jurarum Sive tibiarum ventrim fcarificatione, Ev topicis adbibitis enumeratis medicamentis fanitati illico fuit refitutus. Et in fcholia, poftquam tum omnes medicos prater Hifpanos, quod hos foIum crederet, hujufce fcarificationis peritiam obtinere, reprehenderat, fubjunxit alcerius pueri hiftoriam, his verbis; $D_{0}$. minicus Maria à Bala mercator Binonienfis cum filinlum graviter rgrotantem baberet, ut illum inviferem me rogat, ad quem accerfirus jubeo protinus crura fcarificari, prius ea per fpongiam fovens aqua calida, $\mathrm{g}^{2}$ ad poplites ligatura ac al furas evocato farguine, eas fape barundine fufa percutiendo, fed invita matre pueruli na$Z_{2}$ 


\section{0

tione Greca, patria Bizantina, quce quun intra dhos dies pucrum fanum confpexerit, ad me poftea, tanquam ad Jacram anchoran, quum pueri fui vel amicorum agrotarent, confluebat, ut illam illis juberem evasuationem facerc, tantum videlicet buic evacuationi tribuens: nec fane inmerito, quia prater multa, qua Jecum adfort commoda crurun fcarificatio, materiam in corpora exundantem minuit , E caput à dolore E. malis affectionibus liberat. In fecunda Curat. 58. centuriarum pueri hanc fubtexit hiftoriam dicens: Filius Barbofii natus annos novem cum febri continua corriperetur, E' inter medicos confultum effet pro cjus falute de fanguinis mifjone, primo is furarum Scarificatione captum fuit; qua vel tantum illico famus eft factus. Hæc extant monumenta illiufce doctifimi medici de milifione fanguinis per crurum fcarificationem pofterorum memoriis prodita.

\section{A p. V.}

Crurum fcarificationem non cam effe, quam noftri applicatis cucurbitulis frequentant.

\section{G U I L A N D I U S.}

Lib.r.fen.

Jon video hoc auxiljum Arabibus medicis notum fuife: Quamquam nunc ipforum ferè proprium illud effe dixeris, quando nemo illorum de eo aliquid friptum reliquerit. Avi4. c. 2. cenna enim hanc fearrificationem à cucurbitulis feparatam minime cognovit, quod ex ejus his verbis facile perfpicitur: Et vento $\int_{s e}$ quidem, quae cruribus fuperponuntur, funt minutioni propinquae, E' mundificant fanguinem, E' provocant menftrua. Quod apud alios quoque Arabes medicos multos ufitatum, ac creditum eft. Nam neque Averroes, neque Rhafis, neque Haly Abb. neque alii multi de fearificatione crurum, ut quid diftinctum a cucurbitulis fcripfere. Itaque apud hos vacuatio per crurum fcarrificationem procurata nihil aliud erit, quàm communiter noftris cucurbitulis, cum fearificatione applicatis fanguinis facta eductio. Cui opinioni id favere videtur, quòd 
DE MEDICINA $R$ GYPTIORUM. I, IB. III. I 8 I

alios multos præclarifimos medicos, ne verbum quidem de hac diftinctia à cucurbitulis fcarificatione feciffe videam. Nulla fiquidem apud Hippocratem ipfius extat memoria, neque apud Celfum fecundum, ut multi ajunt, Hippocratem, neque apud alios multos. Hincque multi etiam doctilimi medici nullam differentiam inter hanc \& cucurbitulas fcarificatas fecerunt, ut Hieronymus Cardanus in lib. 2. controv. med. qui hæc Galeni verba de fcarificatione ita interpretatus elt: Sunt autem que equivalent fectioni vence retentarum bemorrboidum apertio, vel menfiun fupprefforum, vel in quibus nibil eft tale, malleolorum cum cuburbitula fcarificatio. Quæ tamen, in: terpretatio (pace tanti medici dixerim) longè à veritate eft aliena, cum Gal. per malleolorum fcarificationem diftinctillime eam abfque cucurbitulis intellexerit. Nam in libro de hirudinibus diftinctè duo capita fcripfit, alterum de fcarificatione, atque alterum de cucurbitulis. Qui fi idem intellexerit fcarificationem, \& fcarificatas cucurbitulas effe, proculdubio cucurbitularum ufum nufquan meminifet. Nam in libro nuper citato dixit: At incipientes aut etiam vigentes (fupple capicis dolores) per cucurbitam in cervice procurata retračio interin quidem folain, interin cum fcarificatione. Quod prorfus confirmavit in Aphorif. lib. atque in lib. de curat. per fang. miff. Cur igitur ibi Gal, meminit cucurbitularum cum fcarificatione, fi nomine fcarificationis femper cucurbitulam fubintelligat? Certe ex Galeni feitentia, utrumque effe unum \& idem, falfiffimum eft. Alpiv. Cui dubium id eft, variis utramque operationem moliendi modis perfpectis, atque utriufque auxilii facultatibus? Nam modus vacuandi applicatis cucurbitulis plane eft diverfus ab eo, qui in ufu fcarificationis adhibetur. Cucurbitulam fiquidem linamento ardefcente, vel igne vel aquæ calidæ halitu, cuti primo applicant, quæ valide intra fe cutim attrahit, á qua cutem in ruborem atque tumorem elatam fcarificant, eique ftatim rurfum cucurbitulam affigentes ea fanguinem à fcarrificationibus extrahunt. Secus vero in molienda fearificatio. ne obfervatur, nam qui volunt crura fearificare pro vacuando fanguine, primo aretè crus fub poplite ligant, \& mox totum

$$
z_{3}
$$

crus 


\section{I82 PROSPERI ALPIN I}

crus in primis multum perfricatum, in dulcis aquæ calidum balneum immergunt, fæpeque ablutint furam, ac ac arundine ipfam percutiunt, ut totum crus intumefcat, multumque ertbefcat, atque obtorpefcat, ne incifionum acutum dolorem ægroti fentire queant. Quibus omnibus peractis crus ordinatis longis, ac profundis incifionibus fcarificant, à quibus quantum volunt fanguinis, aqua calida vulnera fæpe irrotantes, vel totum crus in aquam obruentes, evacuant. Quis igitur fcarificationem à cucurbitulis diverfum quippiam efle non fateatur, ex modorum omnino variorum, quibus adminiftrantur, obfervatione? Quæ etiam inter fe ex utriufque facultatum dignotione diverfa utique effe, facile fuadebitur. Differunt quidem hæc in ea quam præftant, evacuatione, quantitate fanguinis qui evacuatur, nec minus attrahendi modo. Etenim cruribus fcarificatis libræ fanguinis facile non fecus quam per venæ $\mathrm{fe}$ ctionem educi poffunt. Quod fæpiffme experientia verum effe didicimus. Oribafufque in libro de cucur. fcarif. hirud. fibi cum pefte ipfe vexaretur, altero crure fcarificato binas ferè fanguinis libras extraxifie teftatus eft. Addo, per crurum fearificationem tantum fanguinis vactiari, quantum per venæe feEtionem evacuari poteft. Quæ fanguinis copia uon ita facile cucurbitulis exhauriri poterit. GuILAND. Neque citra rationem aliquam hoc fieri arbitror, namque fanguis à fcarificatis cruribus abfque cucurbitulis calidx dulcis aqux balneo continue educitur., ex qua caliditate fanguinem attenuante, movente, atque attrahere, humiditateque incifiones venafque plurimum laxante, facile fanguis effluit. In ejus vero eductione, que cucurbitularum attractione fit, aliæe caufe exiftunt, \& rales quidem, ex quibus potius fanguinis fluxio cohiberi, quàm adjuvari poffit: namque non adeft caliditas, quæ fluxurum fanguinem attenuet, neque adeft quod relaxet cutem fed magis cutis ex vacuato fanguine frigefcens, denfatur, \& fanguis extra venas egreflus in trombos concrefecns, fluxionem potius coercere poffunt. Hine mirum non eft cucurbitulis non poffe tantam fanguinis copiam vacuari, quanta per nuper dictam Scarificationem educi poteft. $\Lambda$ L I IN. Difierunt etiam fangui- 
DE MEDicina EGYTiORUM. Lib. HI. I8

nis vacuationes cucurbitulis factra ab iis, quas hac fcarificatione molimur, quod illæ violenta attractione, atque hæ fine ulla violentia procurantur, fed fenfim ac fenfim fine multa agitatione. Galen. enim in lib. 13. dixit: Cucurbitulam ad hoc effe inventam, ftrenuumque plane ad id effe auxilium, ut foras evocentur, quæ funt in alto, atque ut eximantur \& eruantur, quæ jam in firrhum abeunt: neque cucurbitæ attractionem violentam effe noftrum cuipiam ignotum effe cogito. Scarificatione vero fanguinem dulcis aquæ calido balneo fenfim ac fenfim citra commotionem multam corporis educi, fenfui patet: ut Appollonius non minus antiquus quam gravis medicus his verbis fcriptum reliquit. Quæ apud Oribafium leguntur ex illiufee medici graviffimi mente de hac fearificatione, hæc exiftunt: plethoram autem commoderatam, que aliquid mali factura fit, ac Orib. lib. de cuc. fcarif. cap. $g$. jam everfronem in morbofum ftatum attingat, tibia que fourifica. tionibus vexata fuerit, innoxiamque totam quam volumus fanguinis illigationem reddiderit, citra validan totius molis commotionem folvit. Amplius Gal. atque alii Græci medici multi dixere, fearificationem hanc tollere plenitudinem, quod in plerifque locis legitur: præfertimque in lib. nuper citato de Hirud. revulf. cucurb. cum dixit: Si qua exuperans materia in corpore Cap. 4 minuenda eft, atque ob potiffimum exuperantia ea oriatur, quod materia ipfa, qua emitti folet, fupprimatur, fcarificatione utimur. Cucurbitulis vero fcarificatis vel line fcarificatione antequam corpus totum vacuatum fit, nunquam medicos uti debere, Gal. pluribus in locis, quos fupra adnotavimus, memoriæ prodidit. Guland. Differentia evacuationis, hac fearificatione facta, atque ejus quæ cucurbitulis celebratur, in alio confiftere non videtur, quam in attractione, quæ in his calido balneo, in illis vero cucurbitulis perficitur. Una eademque fcarificatio cutis utraque erit, fed ab una fanguis calida aqua evocatur, \& $\mathrm{ab}$ altera cucurbitula ex alto ad cutem trahente. Alpin. Neque hæc duo exiftunt vacuationis inftrumenta, tametfi utraque in fearificationem cutis fundentur, etenim in utrifque non eadem fit fcarificatio. Nam ad ufum cucurbitularum cutem multis incifionikus, longis, neque pro- 


\section{PROSEER I ALPIN I}

fúndis, neque ordinitis fearificant. Qux omnia in hac fea rificatione $\mathscr{L}$ gyptii ad unguem obfervant. Qnod etiam Oribafius ex Antyllo in lib. de cucurb. fcarif. faciendum præcepit. Quare multis differentiis crurum fearificatio, \& cucurbitulæ fcarificatæ diftinguuntur, unumque \& idem non præftatur ab utrifque auxilium, nec iifdem utraque viribus eft referta, diverfamque inter fe ambo promunt operationem. GurLAND. Non poffum idcirco non multum Avicennam ceterofque alios Arabes medicos præclariflimos admirari, qui de fanguinis vacuatione agentes hanc fearificationem minimeà cucurbitulis diftinctam cognoverint. Alrin. Quid igitur de his diceres? tantos medicos tantum auxilium ignoraffe? multi nobis non credent. GuILAND. Hoc auxilii genus proprium fere fuit \&ygptiorum, atque Arabum: quæ loca cum neque Avicenna, neque Rafis, Averroes, Haly , atque alii habitarint, nof $c i$ ab his eam fcarificationem non potuiffe putandum eft. Quod an verum fit, nemo noftrum certus eft: hoc unum tamen fcio, quod cum hoc remedium apud Galeni fcripta, Apolloniique, Antylli, Oribafii inveniatut, \& apud illos Grecos medicos nulla extet de eo memoria, iftorum fcripta male verfa in Arabicam linguam habuifie certo certius judicari poteft, atque hinc eos nos potuiffe hoc auxilii genus probe didiciffe. Quod quidem apud Avicennam manifertiffime comprehenditur ita fuiffe. Cum quæ Gal. loquebatur de fcarificatione citra cucurbitularum applicationem, ipfe in cucurbitulas fcarificatas tranferipferit. Galen. fiquidem in lib. de curat.

Cap. Ir. per fang. miff. de fearificatione hac, ita feripfit: Porro quce ex mullieribus albidiores funt, fanguinem tenuem acervare Solcnt, quo circa adbibitis malleolorunn fcarificationibus maxime vacuantur, atque que nigriores funt, feita vena curato. Craffiorem enim fansgrainen, ac magis melancholicum colligunt, magis vero etiamfi maynas babere venas appareant, quod illis accidit, que sraciliores funt, ac nigriores. Carnofis vero ac candidis parve infunt vence, quibus malleolos fcarificare, quam venan fecare profliterit, quippe cum bo parvas in crutibus renas babeant: itaque etianfil recle fecontur, azuod juftumb tamen fit non profituat: à quibus fane ver- 
DE MEDICINA GYTIORUM. L.IB. III. 18;

bis de fcarificatione, \& non de cucurbitulis á Galeno prodi. tis, male in aliam linguam verfis Avicenna eadem hæc ad unguem tranfcribens, de cucurbiculis fcarificatis, \& non de fcarificatione intelligens, dixit: Et ei quidem, quce ex mulieribus alba exifitit, ac laxa, fanguinem babens fubtilem, ventofe in crur $i$ bus pofitce funt meliores quam phlebotomia, quce fit in fapbena. Sed hæc fatis fuife exiftimo, ad demonftrandam differentiam, quæ eft inter fcarificationem, \& cucurbitulas fcarificatas. Quibus ita explicatis non inutile foret, fi quæ inter malleolorum hanc fcarificationem, \& venæ fectionem fit convenientia ac fimilitudo, nos aperiemus. Alpin. Jure quidem hoc dixti, neque puto, facile nos hujus fearificationis utilitates perfequi poffe, nifi harum fimilitudinem fedulo prius cognoverimus.

\section{A p. VI.}

Inter crurum fcarificationem, ataque vence fectio. nem maximam effe convenientiam, ac fimilitudinem.

\section{A L P I N U S.}

ANGUINIs vacuationem per crurum fiarificationem factam, $\int$ ei, quæ venæ fectione fit, admodum fimilem effe cognofcitur. Quantitas enim fanguinis per hujufmodi farificationem educta vel eadem omnino eft cum ea, quæ vena aliqua fecta educitur, vel faltem ei proxima: libras fanguinis ifta fcarificatione vacuari à nobis nuper dictum eft, non minufque Oribafium in feipfum ex feipfo eam fanguinis copiam crure fcarificato eduxife: Galenumque exinde in comm. 2. Aphorifm. dixiffe Aph. 14. vacuationem per malleolorum five crurum fcarificationem præftitam, proximam ei effe, quæ fit per verix fectionem. Simili etiam modo \& fanguinis quantitas per eam fcarificationem, non fecusquam ex vena fecta fenfim ac fenfim fanguis effluit, lente \& abfque ulla violentia benigne balnei ex dulci aqua 


\section{PROSPERI A L I NI}

calefacta parati adjumento educitur. Quomodo naturam fae piffime critice, ut verbis utar medicorum, fanguinem excernere cernimus: atque hinc fanguinis vacuationem, tum quæ per venam fectam fit, tum qua nuper dicta hac fcarificatione perhibecur, proficuam ægrotis efle, quod prorfus à natura factam imitetur, exiftimo. Quemadmodum etiam ex purgationibus eas ægrotis effe valde proficuas dicimus, quæ naturæ optimas excretiones imitantes nulla violentia vel corporis molefta com: motione lædentis humoris redundantiam ejiciunt. Cujus rei fignum effe ægrotos purgationes leviter perferre, Hippocrates in 1. lib. aphorif. nobis prodiderat. GuIL a D. Dubia hæc veritas haud parum multis vifa eft, neque immerito de ea quantitate fanguinis, quæ educitur crurum farificatione: etenim quæ ratio eft, quamobrem à cute crurum fcarrificata plus quam ex aliarum partium fcarificatione fanguinis copia major educi ac vacuari debeat? Certe nulla, quando dorfi cutis multis venis referta eandem copiam fearificata exhibere queat; ut hinc fapularum venas fcarificatas iecorariæ venæ vicarias Arabes. dixerint:-ex quibus non videtur crurum fearificatio quantitate fanguinis venæ fectioni proxima, vel faltem aliæ etiam partes corporis fcarificatæ eandem copiam fanguinis exhibentes venæ fectioni itidem proximæ erunt. A LPIN. Memini alias de hac eadem quæitione nos verba feciffe, remque plane fic abfolviffe quia furæ ceteris aliis cutaneis partibus, tum numerofiores venarum ramos, tum grandiores obtinent: ex quibus fcarificationibus multis venis diffectis copiofior, quam ab aliis corpoxis partibus feariffeatis fanguis exit. G UILAND. Verum dicis, neque immerito; cum Gal. crurum hanc fearificationem femper venæ fectioni facultate vel utilitate proximam tradiderit; ait cnim plenitudinem corporum ipfam fere, ut venæ fectio, tollere... Cujus loca nunc, in quibus hoc nos docuit, audire non erit inutile: ex quibus clare cognofeemus, quanta apud $\mathrm{Ga}-$ lenum fuerit inter fcarificationem hanc \& venæ feetionem fimilitudo ac in juvando affinitas. A L P I N. Exopto illorum locorum auctoritate, veritatem hane ex te confirmari. Gu IAph. 17. LAND. In lib. 2. Aphorif. Hippoc. ut alias etiam eft, liæc ad 
unguem verba fcripta reliquit, dicens: Evacuatio omnium bumorum cqualiter, que quidem exquifitiffima eft, fit per vene feEtionem, proxima autem huic illa eft, quce fit per malleolorum $\int c a$ rificationem. Quod non minus clare etiam in libro 4. de fanit. tuenda confirmavit iis provecto verbis ita pofterorun memoriæ traditis: Nan virium robore conftante fi lafjutudo adbuc infeftat, exiftimandum eft, cum fanguinifne copia, an cum crudis ac minime coctis bumoribus, an per fe folus confiftat vitiofus bumor, qui laffitudinem creet: Nam fi cum fanguinis copia, aut vena incidenda, aut aliquid, quod tantundem valet, agendum. Sane tantundem poffunt bee, quibus bemorrboides funt retente fi bas aperueris, $\sqrt{i}$ mulieri menferua confuetudo ceffavit, hanc, $\sqrt{i}$ provoces: $\sqrt{b}$ borum nibil eft, mialleolos fcalpello incidas. Et in lib. 13. meth. med. Cogimur ergo alias Sanguinem mittere, idque aut vena incifa aut membris iis, que lafa non funt, fcarificatis, manu enim laborante fcarificabis crura: altero crurinn male babente, reliqumn. Has namque evacuationes indicat ipfa copia, fucuti etian fuccorum vitium redundantis fucci purgationem. Idemque etiam in lib. de Hirud. revulf. fi tamen is Galeni liber exiltit, proditum eft, atque hifce verbis. Si qua exuperans materia in corpore minuenda eft, atque ob id exupcrantia illa oriatur, qiod materia ip $\int a$, que emitti folet, fuppritnatur, forrificatione utimur. Hæc eadem fere apud Oribafium ex Apollonio, Antyllo, \& à femetip. fo leguntur: quæ cum alias, tum relata fint, tum quia quifque apud Oribafium ea legere poterit, repetere nolumus, exceptis iis, quæ Oribafius de feipfo memoriæ prodidit, quæ ita inftituto noftro quadrare videntur, ut nos ea audire fas effet. Quæ funt hujfmodi: Et Sane dum peftilentio vebemens Afiam deprebendiffet, multofque perdidiffet, meque etiam morbus attigifSet, Jecunda morbi die remiffione febris facta, crus fcarificavi, duafque fere fanguinis libras detraxi, bacque de canfas periculum vitavi. Plerique igitur etiam alii boc prefidio ufifuperftites evaSere: erant enim plenitudinis figna, illique precipue falvabantun, qui fanguinem copiofum exbauriebant. A LP IN. Hæc fufficiunt ex Galeno, Apollonio, Antyllo, Oribafio, pro demontranda hujufce fearificationis malleolorum cum venæ fectione conA 2

In lib.de cucurb. Cap. Io. 
venientia, hactenus demonftrata. Ix quibus omnibus confpicuum fit, hane fcarificationem vicariam effe venæ fectionis, quando fi quod eft, quod ex præfidiis vacuatoriis, ad venæ feĖionem prope accedat, hoc unum fcarificatio malleolorum eft, cum nullum aliud ex vacuatoriis prafidiis ad fit, quod ea proximius ad venæ fectionem accedere queat. Guiland. Res confpicua videtur ex Galeni aliorumque Græcorum medicorum monumentis, fed difficillimum eft, multis pro vicario auxilio cucurbitulas, cum fcarificatione applicatas fubftituentibus, iftud poffe fuaderi: quæ res nobis non levem anfam præbuit altius eorum fententiam fpectandi ac judicandi, ne tam grandis error, tam alte in multorum medullas defixus, non. fine aliqua ægrotantium jactura ulterius progrediatur...

\section{A p. V: II.}

\section{An crurum Jcarificatio vicarna fit vena fectionis.}

\section{A. L P I N U S.}

ALLEOLORUM fcarificatio an non venæ fectionis vicaria erit affirmanda? cum nullum evacuans præfidium \& proximius ex Galeni aliorumque prifcorum medicorum monumentis, effe hactenus cognitum fit: equidem non video, cur in hac affertione nos jure quis reprehendat, etfi plures etiam graviffimi medici fuerint, quibus alia præfidia pro fectione venæ fubftituenda magis placitum eft: Quorum alii fcarificatas cucurbitulas pro tali vacuanti auxilio fubftituere, atque alii hirudines non modo hæmorrhoidibus, verum etiam aliarum partium venis appofitas, quemadmodum fæpe in pueris, quibus; ex eorum fententia cum merito, ut fuperius à nobis dictumeft, miffio fanguinis alia via prohibita fit, fanguinem hirudinibus. alicui venæ appofitis mittere non difplicet. Scarificatas cucurbitulas pro fectione venæ fubftituentes: quibus rationibus, atque auctoritatilus moveantur alias à nobis proditum eft. Quas. etiam præfentis occafionis caufa itidem repetere non gravabor, 
ex quibus hujus propofiti ratio clarius innotefcet. Ajunt fiquidem cucurbitulas, medifs fcarificationibus adminiftratas, non fecus quam venæ fectio, vel faltem proxime, ad venæ fectionem accedere, ut fanguinis optatam copiam evacuent, præfertimque feapulis applicatas: quas venas ab Avicenna edocti, je. corariæ venæ vicem gerere affirmant: fanguinis multam copiam evacuari nobis dubium non eft, atque ab ea etiam totum corpus inaniri, ex quo dubium cui erit, ipfas vicem gerere venarum fectionis poffe? certe nemini latet, omnes Arabes clarifimos medicos huic opinioni fuiffe addictos, præfertimuue Avicennam, qui dixit, cucurbitas cruribus appofitas minutioni effe proximas; \& ex Latinis Celfus magni nominis medicus manifeftiflime poft venam fectam ufum cucurbitularum celebravit; ex Græcis vero Paulus Simia Galeni appellatus, nufquam fcarificationis crurum meminit, vacuationem vero laudare videtur, quæ applicatis cucurbitulis cum fearificatione procuratur. Quid igitur? à prædictis rationibus, atque à graviffmis illis medicis diffentiemus? Guiland. Præterea ex Galeno etiam crurum huic fcarificationi objicientes, per eam fieri poffe totius corporis perfectam evacuationem, negant: quando non quamlibet humorum redundantiam ea tollat, neque cujuslibet humoris: neque in quolibet habitu fieri debeat, \& ut paucis dicam, tantummodo, ubi cum vacuatione ad partes inferas trahendum fit, utilem iftam crurum fcarificationem cenfent. Gal. enim in lib. de hirud. revul. cucurb. de ea agens, inquit: Cor-Cap. 4: poris partes fcarificande funt, que pblégmone vel duritie urgentur, que vel tenje fuerint, vel dolore aliquo affliguntur: quceque fluxionibus vexantur, ubi ece ipjea fluxiones deflerint: aut cum acrem. materiam fubelfe viderimus, feu vis aliqua venenofa cxtrinfecus illata fuerit: preterea $f \mathfrak{b} a b$ altera ad alteram partem deducere materiam volumnus ficuti fcarificatis cruribus, affecio capiti medemnur: Sique exfuperans materia in corpore minuenda eft, atque ob id potifinmm exfuperantia illa oriatur, quod materia ip $\int a$, que emitti folet, fupprimatur, fcarificatione utimur. Atque in lib. de Cap. Ir: curan. rat. per fang. miff. Gal. dixit crurum fearificationem folis albidioribus corporibus, exilioribus venis, atque tenuiori A $a 3^{\circ}$ 
fanguine preditis conducere, minimeque nigriores latiores venas ac fanguinem craffiorem præ fe ferentibus. Ibidemque non omnem fanguinem fcarificationem hanc vacuare, fed folummodo tenuiorem. Hæcque ei fearificationi ifti objiciunt. ALpiN. Ab Esgyptiis igitur nos diffentire, atque abfcedere hæc hortantur: Quod tamen faciendum non puto, quando ipforum veriorem fententiam putaverim. Neque ipfi carent rationibus, quibus fearificationem hanc probe tueantur, atque ab illorum machinis variis oppugnatam defendant. Superius à nobis demonftratum eft fcarificationem hanc majorem fanguinis copiam vacuare, quam cucurbitulas, neque immerito, cum illa fanguis calenti aqua dulci educatur, quæ cutem laxat, fanguinem attenuat, atque attrahit: \& cucurbitule neque fanguinem attenuent, neque cutin ac venas relaxent, quinimo magis $\mathrm{ex}$ fanguine educto, in ipfifque contento ac paulo poft coagulato, cutim ftipandi, fanguinifque fluxum fiftendi non parva occafio datur. Talfumque etiam hoc effe experientia à quoque in utriufque remedii ufu exercitato, comperitur: quando plurime fanguinis libre ifthac præftita fearificatione facile, ut volimus, educantur, quod non ita certo de cucurbitulis afirmari poteft. Divineque hinc Galenum docuiffe in 2. lib. aphorifm. pro vacuanda corporum plenitudine, crurum fcarificationem proximam effe venæ fectioni, vel melius fanguinis vacuationem illa effectam fearificatione proximam ei effe, qux fit per venæ fectionem, quippe copia, vel quantitate fanguinis, qux vacuatur, funt admodunn fimiles, 'ut paulo fuperius dictum eft. Qua caufa Gal. cum Apollonio, Antyllo Oribafio, fcarificationem hane humorum exuperantiam tollere nobis prodidit, cucurbitulafque non nifi prius toto corpore vacuato; $\cdot$ minimeque ante totius vacuationem medicos his uti debere: in lib.

Cap. 5. enim I 3 . meth. med. de illa ita feripfit: Cogimur ergo alias fainguinem mittere, idque aui vena incifa: aut mombris iis, que lasas noin funt, fcarificatis: manu crim laborante, fcarificabis crura: altero crumlin male babente, reliqunm. Has namque vacuationes indicat ipfa copia, ficuti etiann fuccornm vitiunn, redundantis fucci purgationem. Atque in 4. de fanit. tuendo, idem docuiffe vifus eft, 


\section{DE MEDICINA $R$ EYPTIORUM, LID. IIT. I9I}

eft, tantundem valere fcarificationem hanc, ut venæ fectio. Atque Orib. in lib. 7. hoc identidem meminit. Cucurbitulis vero Gal. fcarificatis aliter fentit in lib. enim de curan. rat. per fang. miff. tradidit, eas non efle accerfendas, nifi prius totum corpus probe vacuatum fit. Quamobrem vero iftud? nifi quia hæ debitam ac exoptatam fanguinis copiam, ut ea facit fcarificatio, non evucuant? Præterea violentia etiam ipfe fanguinem attrahunt ab univerfo corpore, ut fuperius dictum eft. Quo motu non videntur fectionem venæ in molienda evacuatio. ne recte imitari, quæ non violentia, fed paulatim, fenfimque ac lenfim fit. Quo fane modo eam crurum fcarificationem vacuare fanguinem dulcis aquæ calentis balnei adjumento, paulo ante à nobis proditum eft. Sed ad ea, quæ huic illi objiciunt refpondere confentaneum eft, atque ad id, quod in primis afferunt, quippe illan non cujufeumque humoris, vel fanguinis exuperantiam tollere poffe, fed tantum fanguinis tenuioris, idque ex Galeno in lib. de curan. rat. ubi dixit, in corporibus Cap. is: craffiori fanguine exuperantibus magis præftare venæ fectionem, quam crurum fcarificationem. At hi, qui ex hoc loco oppugnationem aggrefi funt, non recte videntur Galeni mentem affecuti, quando ipfe non negarit, per hanc fcarificationem non poffe in mulieribus, quibus menftruæ purgationes fupprefiæ fint, etiam craffum fanguinem vacuari, quod fieri utique poffe non videtur à ratione remotum, quando calido balneo fanguis craflus utique attenuari queat, quod ab Avicenna etiam in lib. I. proditum eft. Séd affirmarit in hujufce fanguinis redundantia, vacuationem commodius fieri per venæ fectionem poffe, quam fen. 4 . Cap. 25 per fcarificationem, atque idcirco illam fcarificationi praftare; veluti neque negat ibidem venæe fectione poffe utique te. nuiorem fanguinem vacuari, fed commodius quam per venæ fectionem fcarificatione vacuari poffe; dixit enim: Porro que ex mulieribus albidiores funt, fanguinem acervare tenuem folent: quocirca adbibitis malleolom fcarificationibus maxime juvantur. At que nigriores funt, fecta vena curato: \& paulo poft: Camois vero Gं $^{2}$ candidis parve infunt vene; quibus malleolos foarifi. sare quam venam fecare prefliterit, quippe cum be parvas in cru. 
ribus venas babeant: itaque etiam $\sqrt{2}$ probe fecentur, quod jufurum tamen fit, non profluat. Hic enim Gal. fibi propofuerat tollendam effe fanguinis plenitudinem, ex fupprefils menfibus in mulieribus ortam, pro qua miffionem fanguinis copiofam utilem fupponens, atque ideo fore moliendam à venis crurum folummodo, ut fimul \& femel plenitudinem vacuando menfibus naturalem etiam motum reddat: confiderabat, an fcarificatis à cruribus, vel a crurum perfectis venis melius effet eam moliri, ita ut ea vacuanda fanguinis copia commodius vel uno, vel altero modo educeretur; proinde in cruribus amplioribus venis refertis, atque in craffiori fanguine redundantibus etiam tuto per aliquam crurum fectam venam, facileque educi poffe, \& in iis, quibus venæ crurum funt parvæ, fanguifque eft tenuior, non nifi fcarificatis cruribus, quoniam \& diffcillime hæ cum parvæ fint, fecari poffunt,; atque ab una etiam exfecta: minime poftulata fanguinis copia vacuatur. Idcirco plurimas in cruribus farificandas jure cenfuit. Qua in re interim venam fectam præfert fcarificationi, atque interim hanc venæ fectioni. Neque ex his colligi potef, fcarificationem hanc non poffe fanguinem craffiorem vacuare, quoniam furarum venæ non ita parvæ exiftunt, ut in aliis partibus corporis cernuntur, fed ea fcarificatione profundius facta, venarum craffiores rami fecantur, calidoque aquæ dulcis balneo craffities fanguinis abfque dubio artenuatur, ipfaque fluxilis redditur: \& afferentibus fcarificationem hanc non efle idoneum inftrumentum ad vacuandum craffiorem fanguinem, è contra dicenilus, nos quoque eodem modo fe habere venam fectam ad tenuiorem fanguinem, in exilibus venis contentum ducendum; nam ut dicebat Gal. etiam ab ea recte fecta ejus jufta copia non diffluet: mirumque hinc non eft, fi Galenus in albidioribus, corporibus fectioni venæ fcarificationem præferat, atque in nigrioribus, amplioribufque venis à natura donatis venæ fectionem. Ex fuppreffione vero menfrum exortæ plenitudini hanc fearificationem maxime conducere certum eft, ut à viro excellentiffimo ex multorum fententia proditum eft; atque etiam non minus id Galenum in lib. de Hirud. revulf. fcarif. nos docuifle; fed quod ob id plenitudinem. 


\section{DE MEDICINA. RGYPTIORUM. LiB. IM. 19;}

tantum, à nuper dicta fuppreffione menftruarum purgationum ipfa tollat, minimeque alıam ab aliis caufis ortam, falfum plane ex Galeni mente exiftit: etenim ipfe non abfolute in fupradicto ejus libro trudidit, hac tolli plenitudine:n ex fupprelitis purgationibus uteri ortam, fed plenitudini præcipue conducere, quod ex ejus verbis plane manifeltum videtur. Neque id injuria, cum hæc fearificatio præterquam quod evacuat, etiam revocare interceptos menfes foleat: quinimo in lib. de curand. rat. per fang. miff. ad revocandos menfes præfentaneam efle fearificationem illam ftatuit. Verum fiquidem eft, hane præter vacuationem fanguinis, quam præftat, etiam ad inferas partes fanguinem trahere: quod ex Galeni fupra recitatis verbis plane conftat; quæ hæc exiltunt: Neque enin proferio prorogainda in bis vacuatio eft, non tamen necelje eft illis renam fcindere. Quippe cum malleolorum fcarificationes fiperflitiati, quandoque evacuande fatis effe queant, qua $\mathrm{F}^{2}$ alioqui boc etiam babent, quod menfurum racuationem ciere polfunt, ficiti etiam in matleolis ac poplitibus incife vence. Quamobrem ex Galeni fententia poteft ifthxc malleolorum farificatio non modo nuper dictam humoris redundantiam tollere, fed quafcumque alias, quas venæ fectionem abigere fcimus. Quod quidem ex verbis ejufdem Galeni in 4. lib. de tuenda fanitate alias etiam recitatis Cap. 4. cognofcitur; Nam ipfe fcripfit: Nam $\sqrt{l}$ cum fanguinis copia, aut vena incidenda, aut aliquid, quod tantundem valet, agendum. Sane tantunden polfunt bac, quibus bumoirboildes funt retente, $f i$ bas aperueris, $f i$ mulieri menftria confuetudo celfavit: banc $\sqrt{i}$ provoces: $\sqrt{ } i$ borum nibil eft, malleolos fcalpello incidas. Quam fcarificationem plenitudinem quocumque modo obortam tollere poffe Gal. ut nuper dictum eft, multis prodidic in locis, quæ jam à nobis antea commonftrata funt, in quibus ait, hanc ad minuendam fanguinis exuperantiam proxime accedere ad venæ fectionem; neque ut de cucurbitulis fæpe ab ipfo dictum eft', ipfam egere alia vacuatione, vel poft totius corporis factam evacuationem effe adminiftrandam voluit: ex quibus, quanto in errore verfentur cucurbitulas ferrificatas venæ fectionis vicarias facientes, fatis cuique manifeftum erit 


\section{9t PROSPERI A LPINI}

cum has femper poft vacuationem totius locum habere ipfe in lib. de cur. rai per fang. miff. aperte prodiderit. Gulland. Ita probe adverfus farificationis calumniatores rationibus te erexifti, ut non difficile fit, me in tuam veniffe fententiam. Hoc tamen verum eft, perpetuo hujus fcarificationis proprium effe, fimul vacuando ad crura etiam attrailere, quod certe ab ea feparari non poteft; nequit enim hec fcarifcatio fanguinem vacuare, \& adinferas partes è fupernis exinde evocatum etiam non attrahere; non femper vero illa attractione eft opus, atque, ut pancis rem nunc colligam, malleolorum hanc appellatam furificationem evacuans eft, revulforium, atque etiam fimplex revullorium, ubi feilicet non multis eâ fanguis vacuatur; vacuatorium atque revulforium fimul, ubi plurimus. A LPIN. Verum prædicas, fed quid, quæfo, mali eft, fcarificatione hac evacuando, etiam à nobilioribus partibus ad ignobiliores humorem avellere, præfertinque in febribus putridis, malignis, peftilentibus, in quibus plerumque fuperiora membra noxis fuccis infeftantur, caputque potifimum, vigiliis afficuis, diuturnis fomnis, deliris , \& dolorihus, quibus quanti adjumenti atixilium futurum fit, quod plenitudinem vacuando finul ad crura partes ignobiles etiam attrahat veneficos fuccos, alis judicandum libenter relinquo? Quinimo tanta effe in his morbis tollendis, utilitatis judico, it omnium ad præfandium celeberrimnm fit remedium, quando ipfum cum evactet exuperantiam humorum, tum à fupernis nobilibufque partibus ad infernas ignobilefque noxios humore attrahat. Hinc admirari Oribafum tantum medicum non debemus, qui ex feipfo ea adhibita fcarificatione, ut à pefte, qua vexabatur, periculum eritaret, fanguinis vacuationem pertentaffe, hocque auxilio multos alios è pefte vexatos liberaffe, cum illo plenitudinem dempliffet atque ad crura veneficum humorem attrahendo fine corpris mulca commotione, vifcera ac infeftatione humoris liberare. Rextifimeque hac ratione arbitror tunc Egiptios fe gerere, gui ad eorum, qui pefte infeeti funt curationem, à farificitis cruribus plurimum fanginem mitere confueverint. Sed tempus eft, ut picifquam ad alia trunfeamus, in hac fcar- 
DE MEdicina EGYPTIORUM. LIE: III. I 195

rificatione conftituenda, modum prius obfervemus, quo cruma Aigyptii fcarificant, acque quomodo fanguinem demunt. Quod nihil aliud erit, quam modum ab is crura fcarificandi difere. Gulland. Probe: idque ut facias, tempus jplum fuadet.

\section{A p. VIII.}

Quomodo CEgytii crurum fcarificationem exerceant, atque adminiftrent.

\section{A L P I N I S.}

$\pi$ Gyptii à cruribus fearificatis fanguinem mittere volentes, in primis furas muitum perfricant, paululumque retractant, \& mox in vas aqua dulci calida plenum collocant, eaf-
que multum ac fæpius calenti ea aqua irrorantes, manibus, atque arundine modice percutiunt, quas perfricatas pertractatafque, ac ita verberatas, calidaque aqua incalefactas fub poplite arcte zonula coriacea ligant, atque à ligitura etiam calida aqua fxpe eas calefacientes, manibufque ac arundinis fruftro rurfum fxpe ac valide totam furam verberantes, eam tandem fummo rubore afficiunt, quo valde adaucto, partem non parum exinde obftupefaciunt, ne ex fearificationibus ægroti prævalidum dolorem tunc fentiant. Alterius cruris itaque primo furam rubore multo fuffufam ac affectam, non minufque cum magnitudinem adeptam, tum fere obftupefactam ufque ad medietatem a malleolo incipiendo fummam ufque eminentiam, vel craffitiem multis longis ac profundis incifionibus, æqualibus interftitiis ordinatim per mufculorum longitudinem non $x \propto \tau \alpha \dot{\alpha} \pi \lambda y_{y} y^{\prime}$, id eft, per percuffiones, fed xatá suppòv, id eft, per tractum cultro factis, fcarificant. ab illifque fcarificationibus finunt fanguinem exire aquæ calentis, qua creberrime furæ irrorantur, \& afperguntur, adjumento; cum vero voluerint fcarificare furam, inferne trahentes, valide diftendunt, ut cutis commodius fcarificari queat, aliquando etiam difficulter ac in modica quantitate manantem fanguinem adjuvant manibus, arun- 


\section{P ROSPERI ALPIN I}

dineque frpe eas verberantes, fanguinifque copiam metiuntur expenduntve, obfervata filicet aqua cruentatæ copia, ut noftri etiam in feetionibus venarum pedis facere folent, vel accuratius æqualibus temporis intervallis dorfo cultri egreflum, atque concretum fanguinem abftergentes à fura fcarificata: itaque fingulis vicibus abftergere unciam fanguinis obfervant. Qua quidem ratione copiam educti fanguinis rectiffime ipfi conjiciunt. Interea alii ambas furas fearificant, atque ab iis fanguinem mittunt, \& alii ex uno tantum crure, ubi partem quampiam particularem refpiciunt, ubi vero fimpliciter pro facienda fanguinis vacuatione, abfque alicujus vifceris læfi, revellendi caufa, refpectu, femper ex utroque crure fcarificato fanguinis vacúationem comparant, ubi vero vel ex jecore, vẹl ex alia parte inflammata, aut, quopiam dolore cruciata, vacuando fimul revellere volunt, $a b$ uno crure folum fanguinem ducere ftudent. Numerus vero fcarificationum, atque magnitudo apud varics medicos varia etian conftituitur: fiquidem alii ufque quadragenas faciunt, alii riginti, alii plures aliique pauciores- Plerique vero in viris atatem perfectam agentibus circiter triginta infligunt, atque in pucris circiter viginti. Qui plures faciunt, eas minores, \& qui paucas, majores infligere folent: funt vero qui in pefte infligunt tres, aut ad fummum quinque in furis non dicam fcarificationes, fed magna tulnera, quæ faltem quatuor digitorum latitudine per furam extenduntur, eanque ab evacuata fanguinis defiderata copia, apertam, ufque dum a febribus immures evaferint, adverfant, illifque quotidie medicamentis attrahentibus medentes, fuc$\cos$ veneficos exinde vacuare conantur. Auxilium in is morbis fummæ efficaciæ, fed admocum barbarum exceptum eft. Incipiunt vero fearificationem ab inferiori parte, ubi tendones mufculorum defierint, quippe in principio malleoli fe extendentes, ufque ad cruris majorem crafitiem, quæ patlo fupra furarum medictatem terminat. Incifionefque, ut etiam dixi, ordinatas, requalibus fpatiis interfinctas, atque culrri tractu, furæ infligunt. Hicque eft modus, quo crurum furarum fcarifacation Egyptii noliuntur. G U IL $\Lambda N D$. 
LAND. Habeo tibi multam gratiam, qui ita clare me modum, quo crura Fisyptii ad miftionem fanguinis fcarificant ? edocueris: is autem non videtur diverfus ab eo, quo prifci medici olim utebantur. Quod ex Antyllo facile conjici poteft (qui ita referente Oribaio, de hac fcarificatione olim feribebat;) Et fane pars, que Scarificari debet, prius, fi fieri poteft, lavanda eft: Jin minus, aqua tepida, quoufque rubefuat, eft perfundenda, aut Jpongiis fovenda, aut foli ignive exponenda, ac pojtea fcarificanda: \& paulo poft: Magnitudine porro inter feje Jint cequales incifiones, E qua inter eas funt intervalia, inter jeje equalia fint: Scarificationifaue initiam ab infernis partibus jumatiar: ita enim fanguis ad fuperficiarias partes decurrens, eam, que $\int c a-$ rificari deinceps debebit, non obfcilrabit. Incifionian fitu per aqua-

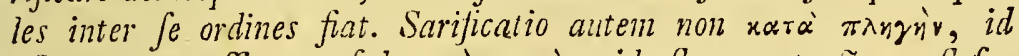
eft, per percuffiones, fed x x+č ovguòv, id eft, per tractum eft $f a-$ cienda: boc enim pacto citra dolorem fiet. Numerum, magnitudinem, fcarificationum, atque ligaturam, ut quod cuique fuis temporibus fit notilfimum, omiferunt: de vapulatione vero vel percullione furæ fcarificandie, quæ apud illos populos arundine fit, quod \& apud Hifpanos pro hac facienda fearificatione ad unguem obfervari Amatus Lufitanus in fuis Centuriis tradidit, nhil meminerunt, quam cum ad trahendum fanguinem, tum ad ftuporem parti fcarificandæ obúucendum, inventam Ægyptios fateri audio: de magnitudine vero illarum fcarificationum quod ex te relatum eft verifimum judico: quippe eas effe longas, ac profundas, longas quidem digiti craltitie, \& profundas ufque quo etiam carnem attingant, ac ferianc: parvæ enim, quæ communiter apud plerofque medicorum in epidermidem vel ad fummam cutem, quam nec perforant, quidem, perveniunt, pauciffimam evacuationem preftant. Quod ex Galeno confirmari videtur, in lib. 2. ad Glauc. itafcribente: Cap. 7. Tentavi autem fapius plurimas, E valde tenues in fuperficie farrificationes: contrario autcm bis modo alias profundiores magnas: Eे tertias, quie medium tenebant in longitudine, ac profunditate. Quxe igitur in fiperficie fiebant, debile auxilium afferebant; que vero lunge erant, ac profunda, phirimum guidem Janguinis exbaurieB b 3 bant, 


\section{I98 PROSPERI A L PIN I}

bant, adeo, ut fere animi defeidim afferrent: Rurfus vero ipfee proprian curationem veliti vuinera exigebant. Hincque mirari non debemus, fi illi medici cruribus eo modo fearificatis quantum volunt fanguinis detrahunt, cum ipfi longis, ac profundis utantur fearificationibus. ALpIN. Longas ac profundas crurum effe fearificationes, quas ipfis pro vacuatione infligere folent, verifimum eft. Vacuato fanguine, atque recte cruribus abfterlis, manuum volis oleo fefamino, vel febo inunetis per longun, valide fupra fcarificationes inferne manum trahendo comprimunt, ut vulnerum labra probe uniantur, mox gofypio undique aptato, arcte linea fafcia totum fearificatum crus ligant, indeque poft tres dies ligaturam folvunt, omniaque abigunt. Guiland. Infigni dolore dum fearificantur homines affligi debent, cum hæc fearificatio non nifi multis ac profundis incifionibus conficiatur. Durum atque perdifficillimum erit, hic ob doloris timorem iftud auxilium in ufum revocari. Alpin. Suras, dum eæ fcarrificantur, dolere dubium non eft, fed prevalido dolore, ut putas, atrociter vexari nequaquam verum eft. Nam dolor multus effe non poteft, tum, ut dixerat Antyllus, quia fearrificatio tractu fit, tum maxime quod priufquam crura fcarificentur, \& aquæ calidæ perfufionibus, \& crebris factis in illam vapulationibus, ac arundine percufionibus, ftupefcit, fenfuque illo infigni deftituitur. Teftes multi mihi effe poterunt, multos pueros, quibus fanguinem eo modo vacuare curavinus, dum fearificarentur, ullos vel parvos ploratus edidiffe. Hoc unum priufquam hinc abeam, monere volui, quippe crura fearificata aretilisme, ac omni fedulitate devincienda effe, ut incifiones ftatim rectè coalefcant, \& fanentur. Aliter enim ni fumma digilgentia fimul unientur factæ fcarificationes, periculun effet, ne rgrotus, cui per hunc modum miffus fuerit fanguis, citius à morbo fanetur, quam ex fcarificationes coalefcant, atque priftinæ unioni reftituantur. 
Médutigupt.

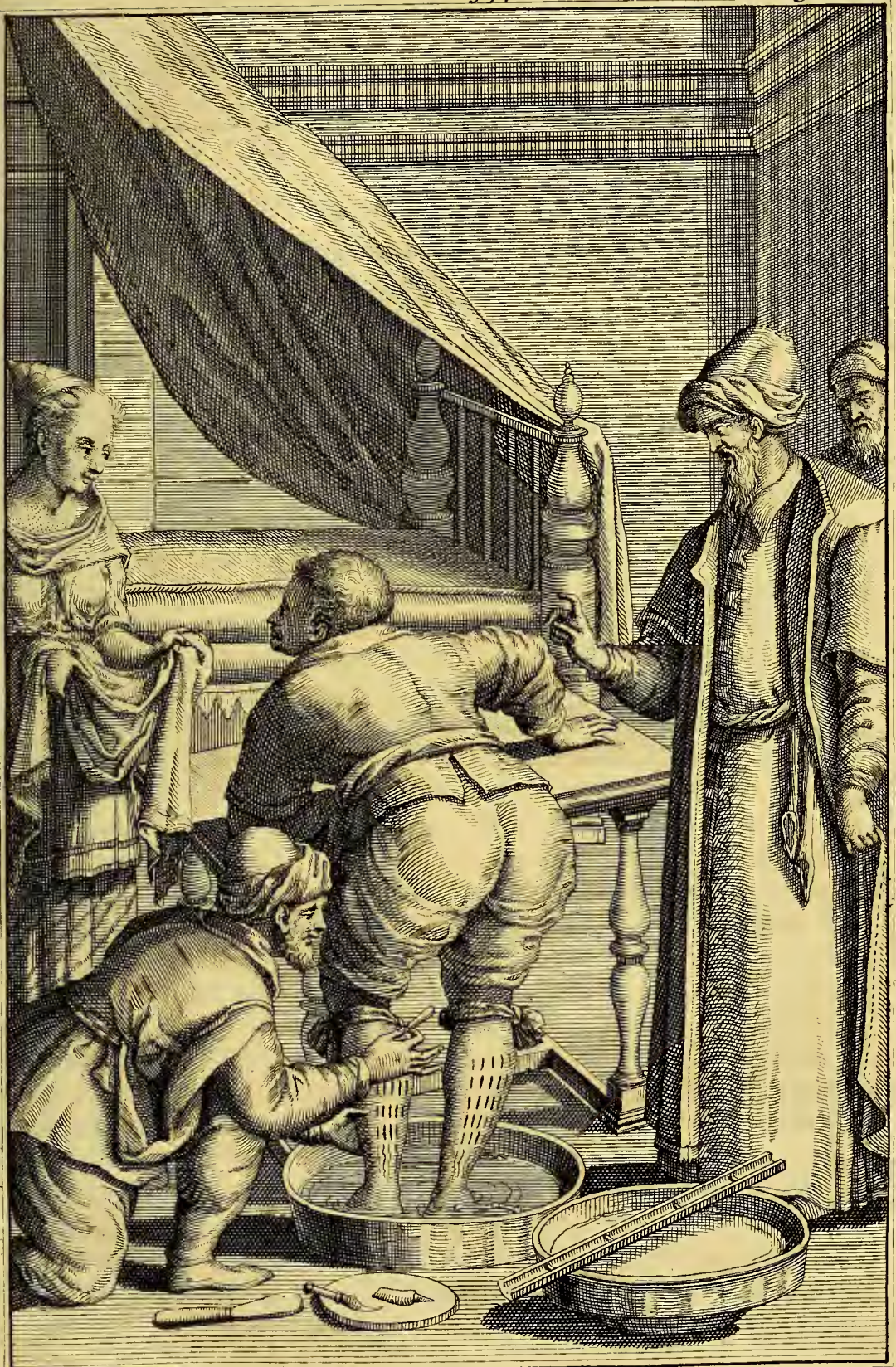




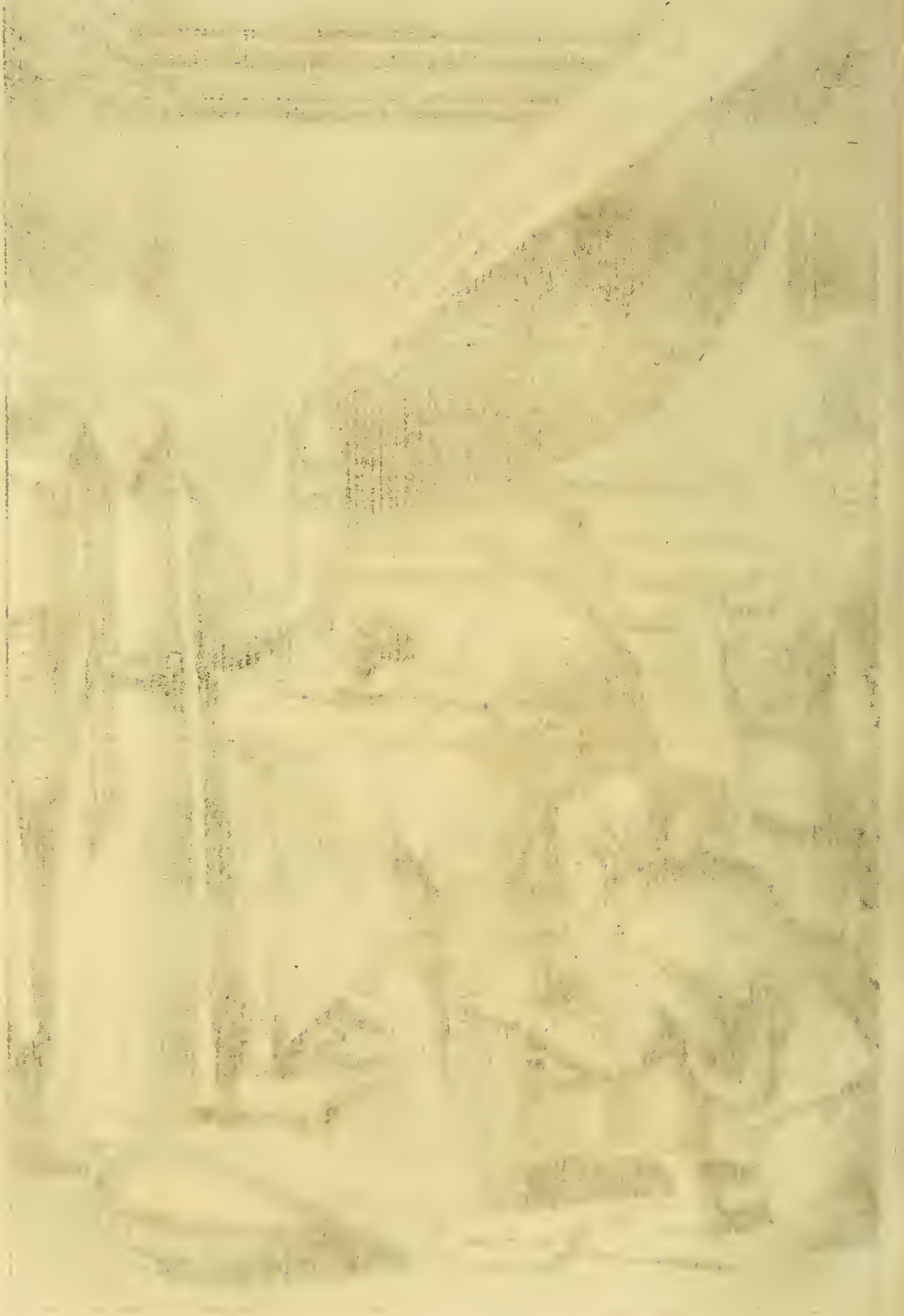


de Medicina Egyptiorum Lib. III.

\section{A p. I X.}

\section{In quibus morbis ufus crurum fcarificationis, apud Egyptios frequentetar, alque in qubus corporibus.}

\section{G U I L A N D I N U S.}

A $\mathrm{g}$ yptos ad hanc fearificationem pro tollenda fanguinis plenitudine, veluti ad facrum quoddam auxilium recurrere ex te audio, præfertimque in ægrotis pueris, eunuchis, atque in aliis pinguioribus hominibus. Precipuos vero morbos, qui illa vacuatione juvantur, te mihi referri cupio, expectoque nunc, ut de his loquaris. Alpin. In omnibus febribus putridis in principiis uberiorem fanguinem hac via demunt. In puerifque nullum remedium apud eos eft, eo ufitatius, atque magis expertum, ut paulo poft dicam, Hujus itaque prefidii ufus frequentifîmus eft, ad omnes purridas febres, quibus fanguinis per venain fectam conveniffet evacuatio, quandoquidem vires præ debilitate minime patiuntur, potifimumque in continuis, acutis, malignis, atque peftiferis. Hoc enim auxilium parum vires labefactando maximam æegrotis adfert utilitatem, quoniam fimul evacuando, plenitudinem à nobilibus partibus, ad ignobiles noxos humores avellit, capurque ex hac fearrifcatione maxime juvatur, ita, ut non facile fit vel vehemente's, affiduofque dolores, vel diuturnas vigilias, vel deliria, vel phrenitides, vel in alia fymptomata ab hujufmodi vacuatione ipfum incidere, neque eo modo vacuatis, ita facile hypochondria tenduntnr ac inflammantur, neque ita funt obnoxii inquietudinibus, cordifque angoribus, refpirandi difficultatibus, aliifque vifcerum lafionibus, quæ in febribus acutis, malignis, peftiferifque. Mirifice igitur in his febribus id auxilii prodeft, quando liberet internas partes, noxios ficcos ad crura trahendo. Quid quæris? noxium humorum à nobilibus partibus, ad ignobiles protrudere, motus eft fimilis ei, quem fæpe naturam cri- 
tice facere obfervamus, dum à vifeeribus detrudit humores ad partes ignobiles; perpetuo etenim ipfa non poteft humores vel confumere refolvendo per halitus, vel foras rejicere: interim fat ei eft, humorem à vifceribus ad quafdam ignobiles partes detrudere, veluti iis contingit, quibus poft longas febres tumores in cute fiunt. In omnibus vero internis inflammationibus frequentifima ac tutifima ifthæc fearificatio eft. Certis anni temporibus puerorum multitudo epidemice glanc'ularum fauciumque inflammationibus vexatur: pro quo expellendo malo in ommibus pueris, infantibufque etiam iftud auxilii genus exercent: etfi infantibus multi hujus vice aures, ut fuperius dictum eft, ficarificent. In pefte ad hane fanguinis vacuationem tanquam ad facrum, \& divinum auxilium confugiunt, neque immerito, cum, ut nuperrime dictum eft, hac fcarificatione tum plenitudo minuatur, tum ad ignobiles partes à nobilibus noxii humoresattrahantur. Quare quid dicam, de frequentif, fimo ufu hujus fearificationis, quæ tribus vel ad fummum quinque farificationibus, longis tamen ac profundis, fpeciem vulnerum præ fe ferentibus in pefte adminiftratur, quæque non folum in principio copiam fanguinis tollit, fed toto morbitempore, cum hæ aperta referventur, perpetuo noxios fuccos ad eam partem accerfit, atque vacuat, quod in curanda pefte nihil utilius, defiderabiliufque effe putarim? Guiland. Remedium præ dolore barbarum, atque fortaffe hine abhorrendum; neque injuriâ, tamem in pefte ipfum laudandum cenfeo, quando ipfo venenum à vifceribus evocetur ad ignobiles partes, atque per eas perpetuo evacuetur. Quemadmodum illi, qui in péte, peftiferifque febribus, veficantibus uti confuefcunt, ut excrementa per eas partes ulceratas effluant, ita non effe improbanda illarum fcarificationum vel melius vulnerum evacuatio. Sed perge dicere in quibus corporibus utantur hac crurum fcarificatione. Alpin. Ufum hujufce fcarificationis evariant corporum xtas, fexus, habitus, atque temperies. Aitas enim huje auxilio accommodata eft infantia, pueritia, juventus, atque ætas fenilis. Infantes vix annum nati ad hoc auxilium ab iis admittuntur: ufque adeo pueris familiaris eft, crurum fcarifi- 


\section{DE MEDICINA EEgPTIORUM. LIB, III. 26!}

catio, ut mulieres, pueros à ploratu firmare volentes, eos deterreant, dicentes fe velle accerfire fcarificatorem, quem illi Mezaim appellant. Quo audito pueri fubito filent. Eo autem auxilio medici non nifi in pueris magno morbo correptis uti deberent, quia eorum præmollia, humida, ac fumme calida corpora non funt ita temere vacuanda, quando ipfa fuapte natura five ex fe continuè vacuentur. Quæ noxam etfi non cito, tamen poft longum tempus fentiunt. Hinc plerofque illiufce gentis crura ac pedes habere imbecillos exifimo, in plerifque enim crura edematofa, ac male affecta fpectantur: non immerito, cum Egyptii ex quacumque caufa, minimeque fempe: ex magnorum morborum occafione in pueris per hanc confuetam fcarificationem largius fanguinem mittere confuefcant. In juvenibus etiam atque fenibus fcarificationem hanc exercere cernuntur: jure id quidem, cum in illis corporibus ob redundantiam fanguinis tenuiores, atque ob virium debilitatem ex Gal. hic modus evacuationis fit opportuniffimus : in lib. enim de cur. rat. per fang. mifl. ait corporibus tenuiori fanguine redundantibus magis præftare hanc fcarificationem, quam fectionem venæ, quæ tenuioris fanguinis redundantia, tum in pueris juvenibus, tum fenibus obfervatur, etfi horum fanguis frigidior fit, atque illorum calidior. In his etiam fingulis $æ$ tatibus virium lapfus pertimefcitur, in pueris, \& juvenibus ex multa, quæ in is fponte fit, vacuatione, cum Gal. in lib. 9. meth. med. docente, eorum corporum fubftantia omnium facillime digeratur, atque refolvatur, qux eft omnium humidiffima. In fenibus vero vires per fe imbecillas effe nemo ignorat. Quamobrem in ipfis merito fcarificatione hac potius quam venæ fectione utuntur, qua corpora admodum refolvi, \& debilitari Gal. in lib. de hirud. revulf. teftatum reliquit. Promptam etiam habent hanc fearificationem in variis temperamentis, in calidis fcilicet, atque humidis, in frigidis \& humidis. In ficcis vero eam abhorrent. Eodem modo pro ea feligunt corpora pinguia, mollia \& laxa, mulierefque atque eunuchos exinde ea firificatione vacuare folent. G U ILAND. Recte fane; cum omnia hæc corpora fanguine tenuiori fca- 
de MEdicina Egytorum. LiB. III. 203

\section{C ^ Р. X.}

An crurum scarificatio in Jura, ut Egyptii faciunt; vel potius in malleolo, ut Gal. docuit,

fit facienda.

\section{G U I L A N D I N U S.}

Uinimo ex Galeno hæc dubii occafio ortum habere vide. tur, quando ipfe crurum fearificationem particulatim dicat, malleolorum, effe, five in malleolis fieri. Et 'Egytii in fura parte cruris carnofiori, Gaftrocnœmia Græcis, ut Ruffus Ephefius tradidt, appellata, eam moliantur. Ex quibus illam crurum à Galeno celebratam fcarificationem, ab ea, quam medici illi frequentant, plane diverfam efle non immerito à multis videri poteft. Quando fura atque malleolus pars eadem cruris non fit: fura etenim, quamquam etiam de offe dicatur, cruris, pofteriore, eft venter cruris five carnofa pars inter poplitem atque malleolum media: malleolus vero, ut Gal. habet in lib. de fect. venarum, eft imus proceffus tibiarum, a talo incipiens in furamque definens. Crurifque hæ partes exiftunt, quarum ex fitu, atque divifione facile furæ atque malleoli differentia manifefta eft. Ex Galeno cruris fcarificationem in malleolo faciendam effe probe ex ipfius verbis, variis multifque in locis manifeftum fit. In lib. etenim 2. Apho- Aph. 17. rifm. dixit venæ fectionem præftitæ vacuationi proximam effe, quæ fit per malleolorum fcarificationem: idemque in lib. de curandi rat. per fang. miff. \& in 4 . de fanit. tuenda teftatum reliquic. Quare hinc jure dubitare poffumus crurum ab $\mathbb{E g y p}$ tiis frequentatam fearificationem, non effe illam, qua antiqui præclariffimi illi medici utebantur. Neque aliquis in malam Galeni verborum verfionem caufam referre poterit, cum ipfe partem cruris fcarificandam nomine hoc quippe $\sigma \phi$ ig $_{\text {c figni- }}$ caverit. Quod ex Græca lectione commentarii lib.-2. Apl. qui omnium locorum precipuus eft, patebit; ibi etenim hune $\mathrm{C} C 2$ 


\section{4 \\ PROSPER I ALPIN I}

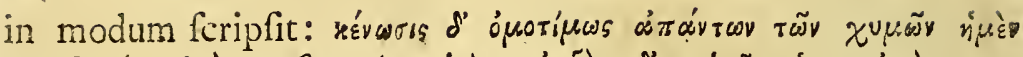

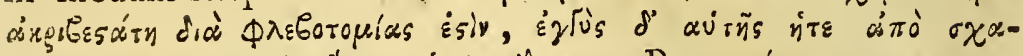

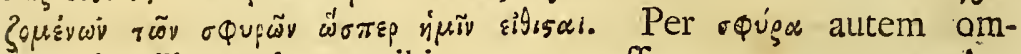
nem intelligunt imum tibiarum proceffum: quam partem Latini malleolum vocavere. AlpiN. Docta fane ac diligens dubitatio videtur, non tamen quæ polfit, aut debeat aliquo pacto ufum fcarificationis apud $\mathbb{E g y p t i o s}$ ufitatæ dirimere, vel damnare. Quod fane fi etiam elfet, ego potius cum Galeno errare vellem, quam cum Egyptiis fi alia cruris in parte a fura Ahl. 17. diverfa, fcarificationem faciendam intelligerem. Ille enim in comm. 2. lib. Aphorif. ait vacuationem malleolorum fcarificatione factam proximam ei effe, quæ fit per venæ fectionem: \& in 4. de fanit. tuen. hanc in vacuanda plenitudine tantundem Cap. 4. valere, ut venæ fectio: Atque in libro de curat. per fang. miff. Cap. I r. eandem pro venæ fectione ad minuendam plenitudinem in muCap. 19. lierum corporibus adbidioribus laudat. Qua res quo pacto vera erit, fi malleoli fcarificabuntur? cum ab iis fanguinis paucifima quantitas educi poffit, etiamfi profundius incifiones infligerentur, cum ea pars excarnis, atque exanguis fit, nervis ac tendonibus tantum referta, ex quo illiufce partis fearificatio cum fumme dolorofa erit tum periculo fcarificata minime carebit. Quamobrem hujufce partis fcarificatio ad revellendum præettans erit remedium; ad evacuationem vero nequaquam, cum ex ea pauciffimus fanguis mitti, vel educi pofitit. Quo pacto igitur vacuationi per venæ fectionem abfolute, qua copiofus fanguis promanare poteft, proxima erit? Dixit evacuationum omnium eam effe exquifitifimam, quæ fit per venæ fectionem, huicque proximam effe, quæ per malleolorum operatur, fcarificationem, quomodo autem erit proxima, fi illà fanguis pauciffimus promanat, \& vacuatio omnis quantitatem fanguinis refpicit, veluti purgatio qualitatem? Nullo profecto pacto effe poterit proxima, cum non habeat, quod in vacuatione obfervatur fcilicet copiam fanguinis, qux vacuatur cum vena fecta copiofiffima, atque malleolo fcarificato paucifima, Certe nullo pacto verum effe poteft, Galenum per malleolum intellexife extremam cruris partem offibus, tenda- 


\section{DEMEDICINA ESGPTIORUM. LIB. III. 205}

nibus, nervifque tantum refertam, omninoque excarnem. Namque ejus mentem fuiffe arbitror, vacuationem ex cruribus faciendam, poftquam meminit, ipfum velle medicos debere partem cruris ad vacuationem aptam feligere, ex qua queant defideratam copiam fanguimis educere, qur utique neque poples, neque malleolus erit. cum hæ partes tendinofæ ac fere exangues fint, \& ad fcarificandum ridiculofa: neceflario igitur erit afferere ipfim furam, five ventrem cruris, carnofam, ac multis venis repletam, intellexiffe. Quod verifimile videtur, cum plerifque in locis à cruribus fearificatis fore moliendam fanguinis vacuationem docuerit: neque immerito, cum crus ex triplici parte conftet, fcilicet, poplite, fura, \& malleolo, non extremis, fed potius medio fignificetur: nam fi cuipiam crus oftendere voluerimus, non poplitem, vel malleolum, quæ funt ejus extrema ei detegemus, fed magis furam. Crura vero fore fcarificanda pro molienda univerfi corporis vacuatione, ex Galeni locis plerifque conftare facile hinc cognofcemus. Is fiquidem in lib. 13. meth. ait: Manu enim laborante fcarificabis crura. Et in lib. de Hirudinibus: Quemadmodum fanguinis perfulionibus Juppreffis (quas hemorrboidas Greci vocant) Cap. 5.capit. de farificatione. crura ip fa lota quidem prius, vel fpongia calido fomento adbibito fcarificantur: \& paulo poft: is cruribus utpote fanguis ducendus: in pluribus etiam aliis locis licet legere apud ipfum crurum fcarificationem. Cui féntentiæ addicti quoque vifi funt, Antyllus, Oribafius, qui omnes crurum fcarificationem nominarunt. Cap. rg: Apollonius vero rem apertius fignificaffe videtur, cum hæc fcripferit: Pletboram autem commoderatam, que aliquid malefactura fit, ac jam everfionem in morbolum. Jtatum attingat, tibia, fcarificationibus vexata, innoxiamque totam quam volumus fanguinis illigationem reddiderit, citra validam totius molis commotionem, folvit. Guiland. Tuæ fententix me quoque addictum habes: fed cur aliquando $\mathrm{Gal}$ - partem fcarificandam particulatim edocens, dixerit, effe malleolum? ut ex Græco etiam nomine rqugà plane cognitum eft. Alprn. Aliqui ex REgyptïs refpondent, Galenum fcarificandam partem vocafle malleolum, quoniam ea pars, quam noftri furam appellant, proprio 


\section{P R O P ER I A L P I N I}

nomine ufitato carebat, licet aliqui eam appellarint yasgorvy$\mu_{i}^{\prime} \alpha v$, apud omnes tamen illud nomen non erat ufitatum vel cognitum; ob idque nomine malleoli, quæ eft fcarificandæ parti pars proximior, partem fcarificationibus, vexandam indicavit. Suræ vero nomen ei non proprie convenire ajunt, cum proprie illo nomine os cruris pofterias, \& non mufculum illum ventrem etiam à quibufdam cruris nuncupatum. Alii vero melius refpondere putantes, fcindunt, vel dividunt crus in tres partes, fcilicet in malleolum, furam, \& poplitem. Malleolumque cruris partem effe ajunt à pede incipientem, quæ ad cruris partem craffiorem, carnofioremque, elevatioremve definit. Suramque effe craffiorem partem cruris, atque ab ipfa declinare incipiente poplitem accedere, qui ad genu ufque terminatur- Ex qua divifione clarifime apparet, Egyptios malleolum, \& non furam fcarificare, non craffiorem, atque elevatiorem, fed quam eâ minus effe craflam, \& carnofam fuperius dictum fit. Incipiunt enim fcarificationem parum fupra claviculam, fere ad cruris elevatiorem craffioremque partem eam continuantes. Quare juxta iftorum fententiam vere malleolum fcarificant, minimeque furam, vel partem malleoli, \& furæ. Qui vero hanc cruris divifionem minime laudant, faltem fateri debent, Galenum vocaffe malleolum, quoniam vult furæ tantum medietatem malleolo contiguam fcarificari, ad differentiam illius, quæ ad poplitem pervenit; vel demum vocavit malleolum, quoniam fcarificationem deorfum incipientes, ab ipfo malleolo omnes illam exordiuntur. GuILAND. Rem hanc perdocte, atque diligenter hactenus es perfecutus, atque ita, ut hinc dubitare amplius de cruris parte fcarificanda non liceat. Sed tempus eft, ut ad alios ufus fearificationis narrandos te transferas, ut quæ fuperfunt de hac materia dicen$\mathrm{da}$, hac die abfolvere poffinus. 
Med.Agypt. Pag.zos:

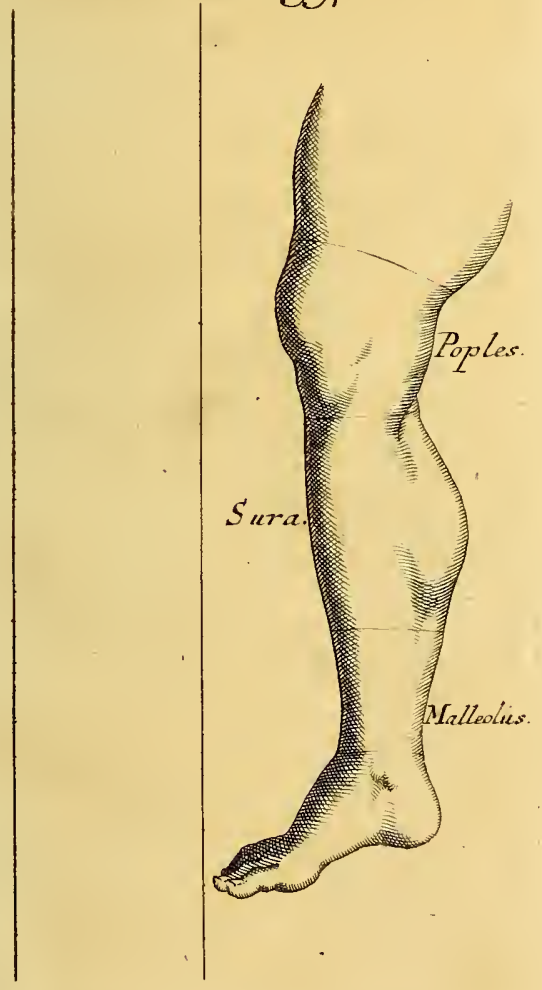



DE MEdicina Egyptorum. Lib. III, $20 \%$

\section{A p. X I.}

De farificatione partium, inflammatione, tumores. puftula, calore non naturali, infigni dolore. vexatarum apud Egyptios frequentata.

\section{G U I L A N D I N U S.}

A non illi alias partes pro aliis ufibus fcarificant, quando A prifci medici eam ad multa alia fcarificationem commendarint? Alpin. Itidem \& ipfi pluribus aliis affectibus cutem vexatam fcarificare folent. In vehementiffimis enim doloribus potiffimum vel ex copia, vel venefica qualitate fenfibiles partes lædente in fluxione paululum firmata, præmiffa univerfali, tum purgatione, tum vacuatione, partes dolore afflictas, vel proximas illis alte fcarificant, multumque fanguinis emanare finunt. In fingulis enim inflammationibus diu perfeverantibus folent, partem inflammatam alte fcarificare, veluti in pleuritide latus dolens, atque in peripneumonia pectus, dextrumque hypochondrium jecore inflammationem patiente, atque liene finiftrum, atque fic de aliis inflammatis partibus facere folent, præfertimque in magnis eryfipelatis, vel aliqua alia inflammata parte, ubi pertimetur, ne in gangrænam degeneret, vel in fcirrhum abeat. In ufu frequentiffimo habent in podagricis doloribus ex fanguinis defluxu obortis poft univerfalem vacuationem, tumefactos digtos dolentes fcarificare: ea enim fcarificatione modico deflexu fanguinis vacuato, mirifice eis conducit. Eodem itidem modo, tum in tumoribus, tum in ulceribus ad citatricem non venientibus, fcarificatione utuntur. Ad omnes etiam cutis defoedationes, maculas, puftulafque, idem præftare folent, Non minufque etiam partem à fcorpione fauciatam, vel ab aliqua alia fere demorfam alte fcarificant, multumque eo modo fanguinis ab ea parte detrahunt. Ad hæc igitur Ætgyptios etiam partis fearificatione uti obfervavi; quem ufum plane à noftris laudatum etiam intelligo. Sed te 


\section{PROSPER I A L P I I}

de ipfo aliquid loqui decet, ut fciamus, an ille fcarificandi afflictas partes ufus ex artis ratione laudari queat. Guiland. Cur non hic ufus etiam fcarificationis laudandus erit, quando refpiciat partis moliendam vacuationem? Cui etenim dubium eft, in omnibus vel inflammationibus, vel fluxionibus humorum ex plenitudine obortis, binas indicare vacuationes, alteram totius, univerfalem appellatam, atque alteram partis, in quam humor decubuit? Qua vacuationis diftinctione in his affectionibus, quemadmodum in primis neceffaria eft totius corporis univerfalis vacuatio, fic poftea inflammatæ partis particularis: illa enim caufam refpicit abigendam, atque hæc affectum ip. fum. Noftri vero medici multi hunc ufum, partis fcilicet inflammatæ fcarificandi tuto frequentari poffe negant, co majorem defluxi fanguinis copiam in partem affectam ferriafferentes, ex quo non poffe juvari ægrotos autumant. Quod tamen

Lib. 13. vanum effe exiftimo, corpore prius probe vacuato. Quinimo meth. in is etiam cucurbitularum ufum Galenum laudaffe certum eft, quibus facilius ex prævalida, quam præftant, attractione, ad læfam partem humorem copiofiorem deduci poffe, atque exinde inflammationem, vel fluxionem peraugeri fufpicandum effet. Sed de fearificationibus fatis, Ad ufumque variarum partium inuftionis, quam maxime eam gentem affectare audio, tranfeundum eft. Quam te fedulo apud illos obfervaffe, certo fcio: de ipfo igitur cupio modo te fermo. nem facere, vel ipfum ufum probe, ut reliqua fecifti narrare, quem mihi non minus utilem, quam reliqua ex te audita fore fpero. 
De Medicina AEgtiorum. Lib. III. 209

C A p. XII.

De variis partium inufionibus, que felectifines Secreta ad varios curandos morbos apud Eggptios babentur.

\section{G U I L A N D I U S.}

UDIO igitur apud eos populos variarum partium inuftio1 nem, non fecus quam olim apud antiquos medicos in ufu fuerat, adhiberi tanquam præftantifimum auxiliun ad multos morbos fanandos: quod remedii genus, veluti prifcis feculis notiffimum ac ufitatiffimum femper fuic, ita nunc apud noftros fere omnino obfolevit, atque non fine aliquo artis medicæ dedecore, ac etiam non levi ægrotantium jactura, cum hoc præfidio multis ægrotis defperata fanitas miraculo quafi refituta fuerit. De hoc igitur præfidio aliqua ex ufu Egyptiorum nunc ex te fcire defidero. Alpin. Homines ibi quali infinitos licet fpectare, quibus ex cicatricibus multas partes inuftas fuiffe certo conjicitur. Siquidem permultis capitis partes, prefertimque finciput, occiput, aliafque pericranei, non minus tem. pora, poft aures, collum, pectus, latera, hypochondria fub umbilicum, fpinam dorfi, articulofque brachiorum, vel manuum, vel crurum, vel pedurn inuftos fuife, ignis relictæ cicatrices facile, ac certo fignificant. Et, ut uno verbo dicam, omnes ejus regionis incolæ, inuftionem ad multos morbos aliis remediis non cedentes pro fecreto habent auxilio. Guicand. In primis inurendi modum mihi narrato, atque an ipfi inurant ferro, vel auro, vel medicamento igneam facultatem obtinente, \& ad quos morbos inuftionis ille ufus apud illos ita familiaris evaferit. Alpin. Non ferro, non auro, neque alio metallo ignito ad inurendas partes illi utuntur, neque ut aliqui utebantur, buxeis lignis, fed goffypio, \& lineo panno ignito inuftionem moliri. confueverint. Volentefque inurere' aliquam partem corporis, fumunt lineam petiam, cubici longitudine, $\mathrm{D} d$ 


\section{PROSPERI ALPIN I}

latitudineque trium digitorum, atque goffypii juftam quantitatem, quod totum linea prædicta petia involunt, ac filo ferico ligant ad formam pyramidis, ipfiufque latiorem extremitatem urendæ parti applicant, probeque cuti adhærere ftudent, alterumque caput vel extremum fuccendunt, comburique permittunt, quoufque fafciculus ille ex linea petia, atque goffypio omnino crematus fit, continue dum cutis uritur, carnem circum circaferro tangentes, ne ex eo calore oboriatur interea aliqua inflammatio; obfervant etiam dum involucrum illud parant, ut in ejus medio fit foramen, vel meatus, per quem. fiat aliqua refpiratio, atque eventatio. Pof inuftionem in par: te exuna utuntur offium medulla, quoad efchara cadat. Hicque eft inurendi modus apud eam gentem obfervatus, ac frequentatus. Efque non modo REgytiis familiaris, fed multo magis Arabibus equitibus fub tentoriis degentibus, atque aliis omnibus loca diferta habitantibus, qui cum aliis careant loci inopia auxiliis, inufione multos morbos fanant. Pauciffima etenim ipforum corpora invenies ab igneis cicatricibus non defcedata. Ufus hujus remedii ibi eft frequentifimus, ob multos genuum, aliorumque articulorum atque partium aliarum dolores antiquos, ex frigidiorumque humorum defluxu obortos, aut à fimplici frigida intemperie, vel à flatulento fpiritu aliunde elato, vel in ipfa parte-genito. Doloribus igitur, iifque antiquis hac inuftione occurrunt, qua partium omnem imbecillitatem corrigunt, contentos humores, vel flatus refolvunt, articulofque calefaciunt, \& valide ficcando roborant. Hincque mirum non eft, fi profpere hoc remedium in omnibus articulorum doloribus curatu difficilioribus, experiuntur, potiffimoque in coxendico dolore multas uftiones non modo fupra articulum, fed etiam fupra femur facientes. Et non minus in podagra \& chiragra, priufquam pedes vel manus tophi invaferint, yel geniti fint. Exurunt: enim articulos, atque illis fuperpofitas venas in podagra, ex qua dolor occupat. nodum pollicis. exurunt fupra ipfum; inquam, nodum inter pollicem, 2 indicen. Qua facta ipfarum partium uftione, per quas humor ad clebiles articulos fluit, viæ angu. 
ftiores redduntur, neque ita facile poft humor ad árticulos fluet; ex quo, neque ita facile in podagram incidunt. Gal. fiquidem in 6. lib. Aphorifm. dicebat, duplicem effe caufam podagricorum dolorum, alteram humoris redundantis fuxionem ad articulum, atque alteram articuli imbecilitatem, qua articulus defluxioni fuccumbit. Altera vero harum deficiente non poffe homines fimili malo corripi, à Galeno ibi proditum eft. Itaque REgptii inulitione, articulorum laxitatem vel debilitatem corrigunt, roburque ipfis conciliant, quo ab humoribus illuc decurrentibus defendantur, minimeque ipfis fuccumbant. Probatiffimum igitur eft remedium ad quafcumque partes ab humorum defluxione vexatas. Verum non tancum partes fluxione vexatas inurunt, fed illas quoque, qua ipfis humores demandant. Atque ea ratione caput multis uftionibus afficere folent. Ad omnem ctenim fluxionem vel difillationem à capite ad pectus, aut pulmones, urunt fynciput; verticem, occiput, ac quod eft poft utramque aurem, quod etam faciunt in antiquis lippitudinibus, atque aliis diuturnis oculorum malis. In epilepticis non minus, paralyticis, apoplecticis, vertiginofis, amentibus, patientibulque in capite gravitatem, ftuporem, ftoliditatem, atque fomnos immoderatos. In vehementibus doloribus ex capitis diftillatione effectis, oculorum, aurium, atque dentium, tempora inurunt. Periodicos dentium dolores, commotiones atque putrefectiones gingivarum, ipforumque dentium, peruftione fanant. Quamobrem inuftione partibus, tum humores mandantibus, tum iis, quæ ipfos præimbecillitate recipiunt, obfiftunt. Qua de caufa utiliter inurunt fufpiriofis à frigidis craffifque, ac lentis humoribus pulmones ac afperam arteriam invadentibus, vel obfidentibus, pectus: \& vexatis malignis ex capite ad thoracem diftillationibus fanguinemque etiam expuentibus, $a b$ iifdem humoribus aliqua vena erofa, caput \& pectus. Phtyficis, \& fuppuratis, empyis vocatis, pectoris tantum partes exurunt. Dominicus è Rege quadraginta annorum Cayri multos annos ab afthmate difficillimo vexatus. à nullo ex inumeris ab ipfo expertis auxiliis juvatus, $\mathrm{Dd}: 2$ de- 
demum ad peetoris uftionem \&gyptiorum modo præftandam, ad ultiman falutis fpem, quafi totus confumptus ac fere tabidus, fibi pectus triplici uftione inufit, ulceraque diu aperta fervavit: quo auxilio fanatus eft. Habentibus quoque ftomachum frigidum humidumque, \& ab humorum defluxu, à flatibufque multis vexatum, eo auxilio fuccurrunt. Hepar etiam ac lienem induratum, refrigeratumque multa cum utilitate inurunt. Et in liydrope fub umbilico, fub hypochondrio finiftro. In doloribus dorfi, lumborum, colli, articulorumque omnium. hoc auxilium frequentant, in fpina dorfi, lumbis, collo, \& aliis partibus dolore cruciatis uftionem adhibentes. In tumoribus ä crudis pituitofifque humoribis obortis inuftione utuntur pro fecreto. Demumque hoc auxilium, quod cito multa mala fanet, inopum proprium effe affrrmant. Hoc igitur eft illorum propofitum auxilium, quod multis aliis utilitate in morbis antiquis præferunt, de ipfoque illi populi non parum iactantur. GUILAND. Gloriam hane aliis concedant, fatifque eis fit tanii remedii commodo, ac beneficio uti poffe. Ubi ex te nunc modum audivi, quo id genus remedii factitant, fere præ tanta illorum doctrina obftupui. Etenim quod fortaffe alii parvi faciendum fore putarint, quippe ipfos involucrum ex linea petia cum gofyyio pyramidali forma paratum, acutiore altero ejus extremo ignito, alteroque latiore parti urendæ applicato, ac aptato, finentes cutim inuri, non fine multa ratione ab iis fieri exifimo. INam eos non uti fero ignito, vel aliquo alio netallo, fed involucro ex goffypio, \& linea petia parato, accenfo, quod ignis, cum fit in materia rariori, clementius agat, alteret, ac refolvat, mitiufque dolorem ac inflammationem cu$\dot{i}$, dum uritur, inferat; ex quo hic inurendi ufus non eft apud ipfos ita horribilis; qualis noftras. Ignito enim quovis metallo, intenfifimus, ac intolerabiilis dolor excitatur, qui ægrozos mifcere dilacerat, ob quem dolorem hoc genus remediinofrri non immerito abhorrent. Materiam hane uftionis creditur novifle Polybus in lib. de affectionibus, quando in coxendico dolore, ac podagra feripierit, uftionem elfe faciendám 


\section{DE MEDICINA EGYTIORUM. LIB, III. 2I}

lino crudo. Cenfeo igitur illos rectius agere, quam noftros, qui ferro ignito utuntur, dum gofypio, atque lino ignito utentes, ut mitius in refolutione le gerant, neque ita partem urendo inflamment, præfertimque ubi nervi, tendinefque reperiuntur, periculum fiquidem eft ex prævalido igne, ne multum ledantur, Sed majus artificium ex urendi modo detego, ap: tantes cuti urendæ alterum involucri extrêmum non ignitum vel fuccenfum, atque alterum, quod femicubiti longitudine à cute diftat, in primis fuccendentes igniunt: quo fane modo primo illos urendam partem, non ignire apparet, ut noftri ferro cauterizantes facere folent, peffimeque mea quidem fenten: tia, quando fubitaneas mutationes natura recte non ferat, vel etiam ab iis non modice lædátur. Atque fenfim ac fenfin partem à fuccenfo involucro extremo ad calorem difponi, atque ita calefieri, ut toto involucro cremato, ignëquie ad cutem deduEto cutis prius calfacta, fereque ftuporem ex eo adepta, ignis incendium non omnino totum fentiat, neque ab eo admodum doleat, quod etiam ignis incendium rarioris involucri fubftan. tiæ ratione, neque immodicum fit. Duo igitur ex hujus præfidii operatione fcitu digna animadvertuntur, quippe partem ab igne clementius inuri, atque ab ea haud immoderatum, qualis ex igniti ferri uftione fentitur," percipi dolorem, prinum ab accenfæ atque ignitæ raræ fubfantiæ ; fcilicet goffypii, \& lini ratione fit, atque fecundum, præccepto calore ex totius involucri combutione, qux fenfim ac fenfim procedit, cute calorem ftuporemque, adepta, non ita acute fentiente." Ex his hoc auxilii genus facifius ægroti admittent, neque præ intenfifimo dolore, qualem ferro factæ inuftiones indicere folent, ipfum abhorrebunt. Alpin. Hac ratione xgroti. facilius admittent uftionem non ferro, vel aliquo alio metallo, vel fupradicto involucro, fed medicanento ignea vi prædito, clam uftionem fáciente præftitam, quandó hoc nullo, vel faltem levifimo dolore uftionem proftet, quo etiam remedio multi fonticulos apud noftros ufitatos factitare folent." GuILA id." Noftri appellant hæc medicamenta cauftie poteftate, veluti inuftiones

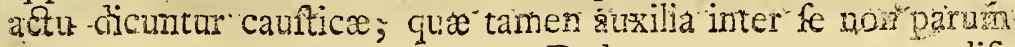
D d 3 
differe, medici omnes cognofcunt, quando ea minime urendo, roborent partes ob ipforum veneficam naturam, calorem. naturalem partis exolventia: \& hæc ipfum vivificantia, humidumque excrementitium refolventia, multum uftas partas roborent. Alprn. Poffunt itaque EEgyptiis medici merito tanti auxilii cognicione non parum gloriari, lætarique fe his feculis folos auxilii hujus ufum, atque utilitatem præftare poffe. GurLAND. Neque hoc verum erit, quando neutiquam hujus remedii inventores fuerint, vel ipfo foli ufi fint. Antiquis etenim ipfum probe fuife cognitum multorum teftimoniis conftat. Namque Hippoc. de capitis uftionibus in lib. 2. de morbis, in capite humoribus repleto poft totius præflitam purgationem, ait: Cruffas octo capiti imurito, duas circa aures, duas in occipitio binc atque ad cervicis nervum, duas in nafo circa angulos oculorum. Vence autem circa aures wrende funt, donec pulfare definant. Ferramentis vero cuneoli forma paratis, obliquas venas! perurito: \& in lib, delloc. in homine eafdem eapitis uftiones laudat, pro Aph. 44. capitis dolore tollendo. Et Gal. in iis, qui morbo laterali ægrotant, de hoc auxilio in 7. comm. Aphor. ita dixit: Quos urere confuetos effe veteres difeere licet ex his, quæ dixit Plato Comicus de Cinefia, hifce verbis; Poft bac Evagorce filius Cinefias è morbo laterali aridus, puris expers, calamacea gerens crura, tabis nuncius, pluribus efcbaris corpus inufus, in concionem prodiit: Hippoc. etiam in præcitato libro de morb. laudat, iis, quibus pulmones funt inflammati, ut pectus, \& dorfum inurant. Ibidemque non minus in fputo fanguinis, priufquam ad puris fputum deventum fit, urendum effe pectus, atque dorfum ex utroque latere memoriæ prodidit. In fuppuratis vero utilem quoque effe uftionem in 7 . lib. Aph. docuit. necnon in lib. de internis affecibus idem confirmavit, quod etiam in 3 . lib de morb. apud ipfum legitur: præfertimque uftiones ad eos morbos curandos prope feptum tranfverfum fieri oportere meminit. In hepate vero indurato, vel inflammato, ita in lib. de inter. affect. fcriptum reliquit, dicens: Si vero neque fic definat, urere oportet, qunn maximum factum fuerit, EF maxime cminuerit. Urito autem per buxeos fusos in oleum fervens tinctos. Apponito 
autem donec tibi bene babere, E' ufionem factam effe vifum ficrit, aut per fungos octo criftas inurito. Ibidemque in liene tumefacto faciendum effe docuit, his verbis: Si vero ab bis non melius habeat, fplenem fungis urito decen magnis cruftis inufis, cumb maximus fuerit $\int p l e n$, E maxime elevatus. Idemque in eodem libro pluries confirmat, atque docet. Ad articulos vero, qui ob multam humiditatem vel dolent, vel luxantur, uftionem fummopere conducere fcribit. Quod manifeftiffime apparet ex his, quæ apud ipfum leguntur in lib. de aëre loc. \& aq. in hunc modum: Magnum autem argumentum bumiditat is corporum Scytbarum boc exibibeo. Multos enim ipforum, precipue quil Nomades funt, reperies exuftos bumeros ac bracbia babentes, manumnque juncturas, pectora, coxas, Eo lumbos, nullan fane alian ob caufam, nifi ob bumoris, Eo mollitiei naturce detractionemi. Nam neque arcus intendere, neque telum torquere polfunt, pre impotentia bumiditatis bumorum. Quum autem uruntur, bumor ip se à juncturis exolvitur, funtque corpora ipformm validiora, melius mutritutur, E. magis redduntur articulorum ufu potentia. Particulatim vero in coxendico dolore in lib. 7. Aphor. ait: Quibufcumque à coxendico dolore moleftatis diuturno excidit coxa, iis crus tabefcit, E claudicant, fi non uraniutr. In hifque malis utilitatem ex uftione Gal. in comm. hifee verbis comprehendit, di- Aph. 60 . cens: Cum ipfe fuadoat aduri coxam, ficut in lib. de artic. docebat, ut $E^{2} i d$, quod mucofum eft abfumatur, EO laxitis cutis, ad quann articulus lubricat, magis ex aduftione contracta, aretet, ac pro. bibeat articulum tranfponi. Et in lib. de internis affeet. Hippoc. ait, in coxendico dolore cfe crus urendum multis; atque profundis inuftionibus. Atque in lib. de affect. quem Polybi Gal. effe autumat, 'legitur crus effe inzurendum lino crudo. Hoc idem ex Græ- Cap. "77o" cis Paulus in lib. 3. confirmat his utique verbis: Quare cum vititm longius fe prorogat, articulum tribus, quaturve locis urere oportet, ut in cbirurgia diceiur, ac complufculis diebus ulcera adapertc, fine cicatrice fervare; quod clarius docet etiam in fexto libro. Cornelius Celius ex Latinis in lib. 4. fur medicina fcribens de coxendico dolore ait: Ultimum eft, Ein veteribus quoque morbis afficcaciffinum, tribus aut gutatuor locis fuper coxam cls- 


\section{6

tein candentibus ferramentis exulcerare, E genumm inveteratos doe lores vix citra uffionem finiri. In podagra vero venas paulo fupra pollicis digiti articulum, vel nodum inuri oportere lino crudo Auctor lib. de affect. nobis prodidit. Quod Aetius in lib. Cap. 25. 12. ubi fcribit de articulorum morbis, plane confirmat. Quem locum hie non inutiliter referendum effe duxi, quia ad omnium articolorum dolentium curationem mirifice faciat. Ibi itaque ab ipfo literis tradita, hec exifunt. Cruftas igitur inurere oportet aliquas quidem paulo altius loco fluore infeftuto, aliquas vero propius, atque id cauteriis facere preflat, ant $j i$ id oger ferre recuefer, cunin medicamenis, longe autem preftantior ejt cauteriorum af fus, nam E citius, Es ficcius perurunt. In univerfum vero pedibus ex funu infeftatis, loci circa utrmngive tolum forinjecus, Ev intrinfecus inurendi funt, cauteriis juxta magnas ibidein fulas venas admotis, paulo altius fupra talorim locuni. Inurendus item locus inter magnum pedis digitun, Eे eum, qui ei proximus eft, inedius, ubi fane vone magis tumefacte con/piciuntur, prefertinn ex eis maxinne. Quibufdam autem छे articulos ipfos excurere expedit, quum fubomucidi valde conspiciuntur, privequan durities ad modum toforum in eis generetur. Sciendum tamen, inquit Ruffus, quod in articulorum fubmucidorum peruficione ulcera egre curabilia oboriuntur, verum ubi cicatrices coaluerint, maximum ro= - bur ip $\int$ ss articulis prcebent, ut non amplius ad Jufcipiendunn influentia excrementa fint apti. Hæcque ac multa alia multi antiqui medici de uftionum utilitate, \& ufu fcripfere: omitto multos alios ex Arabum fchola, velut Haly Abb. atque alios, quos hec eadem cognovifie ex ipforum fcriptis conftat. Non tamen modum inurendi, qualem $\mathbb{E}$ gyptii frequentant, ullum antiquorum, vel juniorum medicorum cognoviffe comperi. Nifi dixeris Auctorem lib. de affectio. tali experientia aliquando ufum fuife, cum ad coxendicum dolorem, \& ad podagram, inufionen lino crudo faciendam tradiderit. At ifti non lino crudo, fed cocto, atque goffypio id præfidii genus exercent. Audio etiam Barbaros multos urere folis petiis lineis coct is fimul. glomeratis, \& inuftis. Alpin. Fortafie hoc auxilium non yidetur omnino tutum, quando apud Hippoc. lib. 5. epidemio- 
ram legatur, Eupolemum coxendico morbo afflictum, ex multis magnis inuftionibus fupra coxam factis interiiffe. GuILAND. Refpondet ejus libri Auctor, \& recte fane, Eupolêmum mortuum fuife, à magnitudine, \& mulitudine ulcerum, atque ex virium imbecillitate: quæ morbo admodum imbecillæ redditæ, tam grande remedium ferre non potuerunt. Sed his nune finem imponamus. Alpin. Quin huic de uftione fermoni paulifper adhuc immoremur, fiquidem ea gens hoc præfidio familiariffime ad empyos, hydropicos, herniofos, atque ad omnes frigidos tumores utitur. GUILAND. Age igitur aliquid hac de re, fi quid habes, afferas. A L P I N. Ultione utuntur in fuppuratis, quos Empyos Græci vocant, hydropicis, herniofis, atque in frigidis omnibus tumoribus. Qui pectus, ac dorfum inurere folent, tribus vel quinque uftionibus inflictis, modo antea narrato, eo auxilio multi fuppurati fanitati fuere reftituti, nam per factas inuftiones pus continuo refudabat, quoufque totum vacuatum fuerat. Hic modus non admodum periculofus eft, quoniam modicum fic puris fenfim, ac fenfim tranfmittitur, \& vacuatur. Recteque Hippocratem hi fequuntur in copia puris educenda, qui in lib. 6. Aphor. fcripfit Quicunque Juppurati, aut aquam inter cutem patientes uruntur, aut fecantur: $\sqrt{6}$ pus, aut aqua univerfim effluxerit, omnes moriuntur, In peccoris, pulmonumque inflammationibus, atque in tumoribus frigidis, \& non minus in anhelofis ex frigida temperie, frigidoque humore, vftione utuntur, quem ufum in is morbis Hippoc. in libro de morbis , \& de internis affec. docuit. Urunt hydropicos aqua affectos, multis in locis, quorum alii fub umbilico in tribus locis, aperta ulcera fervantes, ut per ea aqua exfudare queat, alii in fromacho, liene, hepate, atque fub umbilico inuftiones infligentes, utuntur in plerifque uftione prænarrata, atque in multis etiam medicamento poteftate urendi prædito, alii fub claviculis pedum, atque alii fupra genu intus extraque inurentes, ulcera aliquandiu aperta fervantes. Alii etiam tibias eo modo inurunt, vel veficant, veficifque ex iftis ulcera eodem modo faciunt, per qux paulatim aquam univerfam vacuanto His omnibus inuftionibus hydropem afcitem fanant: itidemque Ec

her- 
hernias aquofas, atque etiam carnofas, de aquofis mirum non eft finuftione ea, qux cum actu eft, tum potentia exficcans, fanentur, quando aqua eo auxilio abfumatur, fed carnofas etiam eo auxilio curatas in multis fuiffe hernias vidi, quemadmodum \& tumores omnes frigidos Oedematofos, atque fcirrhofos. GuIIAND. Quid de cancrofis obfervafti? Alpin. Paucos eo auxilio curari, nifi in principio, ubi neque occulti, neque magni tumores fint. Scirrhos vero ex phlegmate craffo obortos eo auxilio tolli, certum eft. Sed de uftionibus jam fatis, etenim de iis multa locuti fumus, eaque attulimus, qua etiam apud Hippocratem, Galenuin, Avicennam, atque alios gravifimos medicos paffim leguntur. Ad nonnullas alias adminiftrationes chirurgicas jam tranfeamus, in primifque ne hydropicorum, empyorum, hernioforumque aliis remediis defparata falus, fectione aliquando multis inftituta in oblivionem abeat, de ea $\mathrm{fe}-$ ctione aliquid prodam, ac interea de nobiliffimo modo, quo illi lapides è vefica fine ulla incifione educunt, deque ridiculo experimento, quo dyfentericos fluxus fanare, autumant. GUT: LAND. Multam tibi gratiam habeo, qui hæc etiam proferre in medium velis, non inutilem fore mihi hunc tuum fermonem. fpero, quamobrem expecto, quid loquaris.

\section{A p. X III. \\ De fectione, qua in hydropicis, of fuppuratis AEgyptii utuntur$$
\text { A L P I N U S. }
$$

Curant etiam non raro hydropicos, fectione aquam educentes, quorum varii varias fectiones ad id celebrant : alii fiquidem fub umbilico per tres digitos verfus partem, à qua lyydrops ortum duxit, terna vulnera infligunt. Atque alii parvis fcarificationibus ventrem tumidum fcarificant, per quas aqua paulatim exit. Alii vero tutius fupra, vel infra pedum claviculam intus extraque binas adigunt fectiones, per quas 

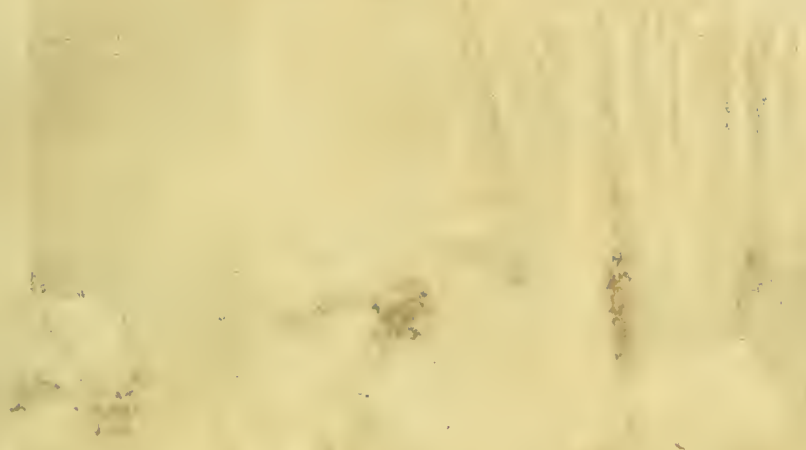

is

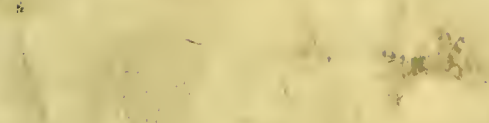

㗼, -
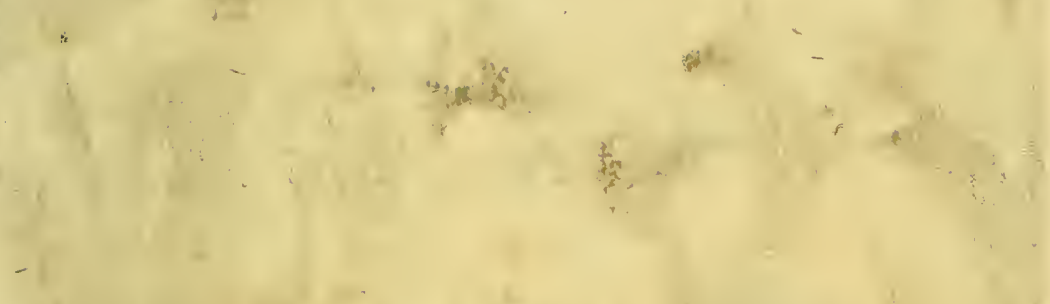
Med.Agypt.

Pag. $21 S$.

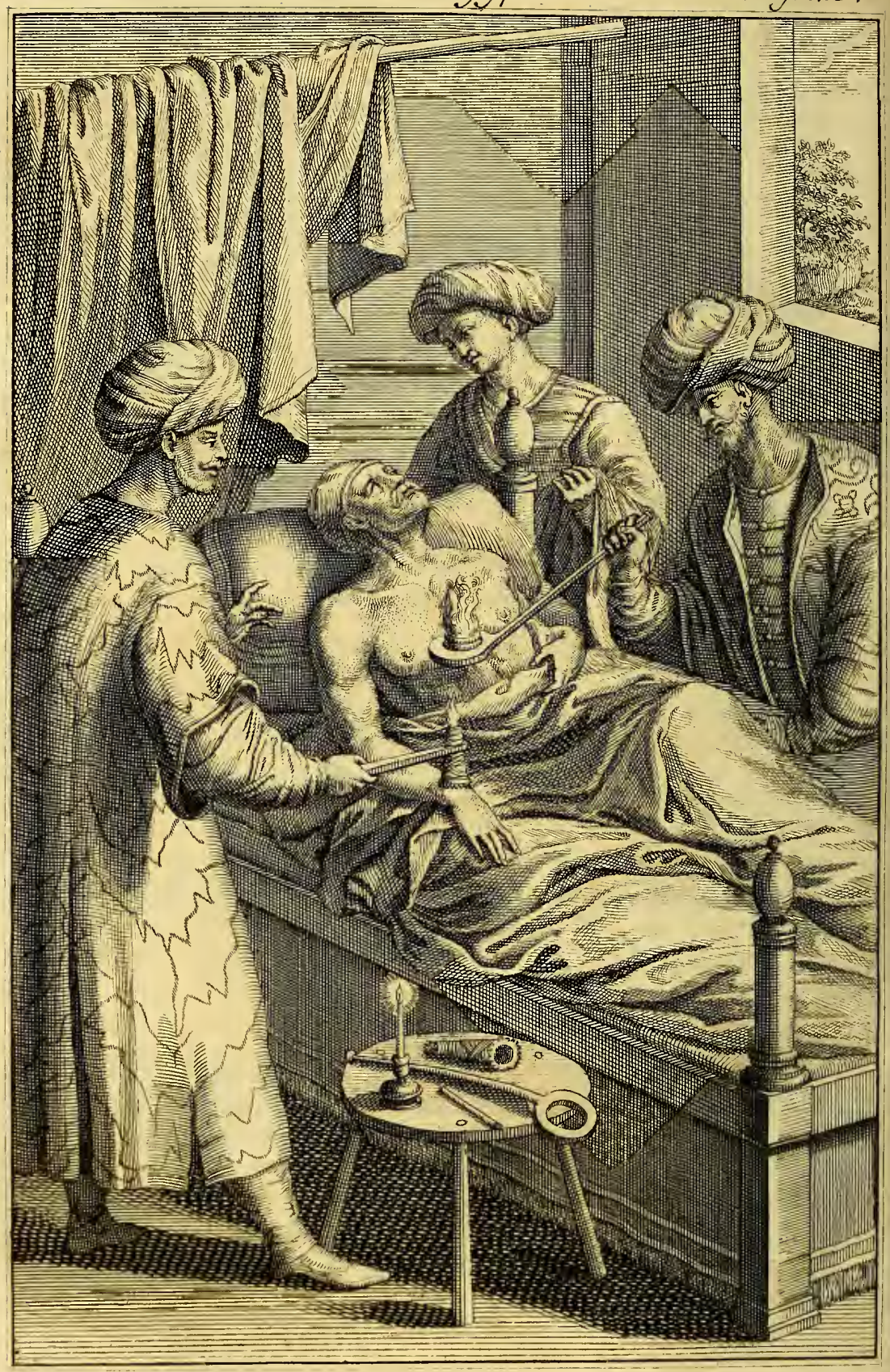




\section{DE MEDICINA EgYPTIORUM. Lib. III. $2: 9$}

commodo, fenfimque ac fenfim aqua educitur. Quo fane modo fectionis aliquos ab hydrope effatu digno fanatos obfervavi. Sed periculum tamen eft, ne à longo aquæ ad easfectiones defluxu illiufce partis, tum ulcera aperta, tum ceteræ aliæ partes mortuo fere calore in gangrenas mutentur. Mulierem etenim Venetiis vidi, iis fectionibus omnino ab hydrope fanatam, \& paulo poft ulcera illa in gangrenas degenerafle, à quibus gracillima mortua eft. Guiland. Novum illud remedium non eft, quando omnibus antiquis medicis, junioribuifue non minus probe notum fuiffe, multorum fcriptis plane conftet. Hippocrati enim id notum, Aphorifmus vigefimus fexti libri certe explicat, Cujus verba hæc funt: Quicumque fuppurati, aut aquan inter cutem patientes uruntur, aut fecantur, $\sqrt{l}$ pus, aut aqua universem effluxerit, omnes moriuntur. Et in lib. de loc. in homine hæc leguntur. Ceterum in puero bydropen fic curare oportet. Partes tumida, Es aqua plene aperiende Junt fcalpello Eे frequenter, ac parum educendum eft. - Educendum autem eft $\dot{a}$ Jingulis corporis partibus, EO fomentis utendum, Ev Jemper locum apertum, unde eduxeris calfactorio medicamento illines. In lib. vero de affeet. ubi curationem hydropis recenfet, idem confirmavit, dicens: Si igitur à pharmacis, Ẽ alia victus ratione eger utilitatem percipiat Eo venter ip. fus evacuetur, bene eft: fin minus, Sectione facta aquam emittat: Secatur autem vel juxta umbilicun vel retro juxta lumbos. Gal. etiam de hoc auxilio multis in locis meminit, fed clare fatis in comm. 6 . Aphorifm. cum dixit: In iis autem, qui aquam inter cutem patiuntur, ille, que $\dot{a}^{-}$Grecis paracentefes; id eft, punctiones nominantur: magis quam uftiones, medicis funt confuetc. In lib. vero compof. medicam. fecundum loc. 9. hæc ita etiam fcripta de hydropicorum curatione, ex Archigene reliquit: Siarificatis item ipforum talis, E vulnusculis impactis ipfos in ferculo, aut lectica geftato, ac circumvebito: multus enim bumor boc indo ip fis profuere folet. Quam curationem ad unguem fere meminit Celfus in lib. 3. ubi fcripfit: incidendum quoque fuper taluin quatuor fere digitis ex parte interiore, qua per aliquot dies frequens bumor feratur. Et Paulus, \& - Aetius prolixe fatis hujufce remedii ufum ac adminiftrationem

Lib. $\sigma$.

Cap. 50.

Lib. 10.

Cap. 20. 
prodiderunt, præfertimque Aetius; ex quo quifque noftrum poterit fectionis in hydrope rationem habere. Arabes etians omnes eodem modo fxpe hydropem afcitem, atque leucophlegmatiam curandam effe nobis tradiderunt, ut apud Avicennam, Albucafim, Haly, atque Rafim legere poffumus. Antiquis igitur medicis id auxilii genus notiffimum fuit, \& non modo ad duas hydropis differencias, quippe ad afcitem, \& anafarcam, vel leucophlegmatiam, verum etiam ad hernias aquofas, \& ad omnes aqueos tumores. Herniæ aquofe tutifime hac fectione ab omnibus curantur. Quod autem cognofcatur hoc remedium pro hydropis curatione etiam ab omnibus junioribus, atque præfentis temporis medicis, id ut manifeftum omitto. Non elt itaque remedium hoc tantum Ægyptiorum, fed omnium fere aliarum nationum, ad id mali inventum. Non eft tamen admodum in frequenti ufu, tam quia, ut recte monent optimi medici, poft alia omnia auxilia tentandum eft, tum etiam quia raro eo hydropici juvantur. ALPIN. In Ægypto eft fatis familiaris fectio hæc apud plerofque prope talum , fupra claviculas adminiftrata, tum in afcite, tum leucophlegmatia: in utraque enim diu apertis vulnufculis adfervatis, humor omnis vacuatur, atque ex ea vacuatione humoris non minus fublata caufa, à qua hydrops originem duxit, aliquot fanatas vidi; nullum vero fecto ventre, quamquam ibi audierim à multis per eam feetionem aliquot fanatos fuiffe. Plerique vero tutiorem effe fcarificationem malleoli affrmant, atque fub talo, in parte enim interiore duas fcarificationes alte infligunt, atque unam in exteriore, per quas qualecumque tumidifimum corpus cammode exficcari, certuim eft, non femelque ego infpexi. Hac vero fectione plerofque fanari arbitror, fi in principio, vel non longe $a b$ eo fecentur. Quo tempore vires validæ exiftunt, commodeque talem aquæ vacuationem ægroti ferunt. Quod recte Hippocratem in 6. epidem. nos commonuiffe Palladius in ejus Commentario prodidit: fiquidem Hippo. ait: Aqua fuffufos celeriter fecare oportet: tabefcentes ftatim urere. Noftri vero fectione uti folent, jam deftitutis coorotis omni $\int p e$ Jalutis, quo tempore vires tale remedium non patiun- 
tur. Unum ex illorum obfervatione addo, quippe multos infigni ventris tumore eo modo omnino curatos, ulceribus tamen ac pedibus ipfis in grangrenam verfis obiiffe; quod non aliunde illis accidiffe arbitror, quam, quod ulcera illa atque partes item proximæ ex larga aquæ fluxione diu eas partes lædente, atque refrigerante, calore multum diminuto, facile in gangrenam labuntur: eaque caufa doctiffime Hippocratem vel auctorem lib. de locis in homine, poft fectionem, aquæque eductionem hæc etiam addidiffe exiftimo, $\delta^{2}$ femper locum apertum, uncle eduxeris, calfactorio medicamento illines. Quo calido medicamento non alia ratione ulcera fovenda effe ftatuit, nifi ut calor naturalis confervetur, neque à fluxione frigida ullo pacto extinguatur. Quod Fyyptii non animadvertentes, fæpe infelicis fucceflus caufæ exiftunt, eorumque auxilio hydrope homines fanati, fape alterius morbi caufa moriuntur: fed jam tempus eft, ut ad fuppuratorum curationem, quam itidem fectione non raro adminiftrant, fermonem convertamus, de hydrope fatis fuperque locuti. Guiland. Recte putas, quando, ut audio, homines fuppuratos non minus fecare, quàm urere ipfi foleant. Operatio fane valde celebris, quæ magno etiam periculo non vacat. Alpin. Cum illi viderint pleuriticum, vel peripneumonicum, multum, ut par effet, non expuere, doloremque cum febre perfeverare, atque cetera alia fymptomata, pus fieri arbitrantur: neque immerito, cum in is morbis fi tuffi non purgantur, contenti in pulmonibus humores fuppurentur. Quod Hippoc. his verbis docuife vifus eft. Quicumque morbo laterali laborantes, in quatuordecim diebus non repurgantur, ii ad fuppurationem vertuntur. Ex pondere in latere percepto, E' fuctuatione obfervata, mitiorique dolore effecto, cun difficili refpiratione fuppurationem certam intelligunt. Quam ftatim tollere fectione conantur, neque dant ad id perficiendum induducias; fecant vero plerumque latus finiftrum inter coftas fpurias, prope feptum tranfverfum; plerique tamen inter fecundam ac tertiam coftam phlebotomo perforant, atque per intromiffam in vulnere cannulam argenteam modicum puris educunt, eamque quantitatem, quam fuppurati vires commode E e:3 
patiuntur, omnique pure educto, vulnus exficcantibus fananit. Qui inter fecundam \& tertiam coftam perforant, rectitis ac tutius rem tranfigere putant, ut totum pus, qtiod ad feptum tranfverfum gravitate refidet, commode vacuetur. Ceterum alii ipforum feptum tranfverfum lædi phlebotomo formidantes partem ab eo magis diftantem, feligunt, quare ex ipís omnes fecant inter tertiam \& quartam coftam. Atque hic eft ufus fecandi empyos, vel fuppuratos, quo Ægyptii multos fanatos fuife prædicant. GuILand. Ufus hic, ex fententia etiam prifcorum, medicorum, qui fumme hunc modum empyos perforandi commendarunt, non eft fpernendus. Hippocrates enim in lib. de morbo ipfum clariffimis verbis hunc in modum docuit: Hunc ubi decimuls quintus ab eruptione dies adefi, multa calida lotum in fella firma collocato, E' alius quidem manus ipjus teneat: tu vero bumernin concutito, ut audias in utrunn latus affectio Jtrepitum edat. Optandum autem in Jiniftrum. Hunc ipfuns igitur locum feces, minuls enim letbalis eft- Si vero crafitudine, ac copia ftrepitum non edat, quo ipfum cognofccre pofis (nam boc aliquando contigit) utrum latus tumuerit, ac magis doluerit, boc infimo Secato retro tumorem magis, quan ante ipfinn, quo puris exitus facilem fuxionem babeat. Secato autem inter coftas per novaculam primum cutem, deinde Scalpello acuto, quod panniculo fit obligatam, ita, ut Jumma ipfuns pars ad unguis magni digiti menfuram expedite reftet, quam intromittas, poftea emiffo pure quantum vifum fuerit, vulnus linamento ex lino crudo alligato, foras propendente filo, concludito, Ẽ quotidie femel pus educito: poftquam autem decimus affuerit dies, omni pure emifo linamentum ex linteo indito. Apud multos etiam alios graviffimos medicos tale præfidium ad fuppuratos, quibus nulla fpes falutis reliqua erat, laudatum atque celebratum reperias. Veruntamen empyos tultius magis uftione curari pofle Gal. tradidit, hifque proprius uftionem convenire, veluti hydropicis fectionem. Raro etenim in curandis fuppuratis fectionis meminit, fed magis uftio-

P.ph. 77. nis. Quod etian ex traditis in comm. 6. Aphorif. Hippoc. facile confirmatur, ibi enim fcripfit: UJfione igitur indigent, qui plurimum babent pus, adeo, ut defperent per fpuitiones pofse expurgari. 
gari. Nos vero ipfos $f$ difficultas anhelitus vehementer infeftat exi loci anguftia, que etiam nos cogit, ut cos uramus: in comm. etian 7. Apl. veteres urere fuppuratos confuevife, prodidito Hippocratefque in 6 . epid. dixit: tabefcentes ftatim urere oportere. Quare in iis tutiorem effe uftionis, quam fectionis ufum putaverim, quamquam me non lateat apud Hippoc. prefertim, utraque auxilia pro illo affectu ufitata fuiffe: ut ex 6 . lib. Aph. atque ex 7.. apparet, atque adeo, in pluribus aliis locis. Arabibus quoque multis hoc remedii genus cognitum fane fuito A I P I N. Ubi pueris multum non eft, uftio accommodatior videtur, qux revera, ut illi affirmant, eos tuto magis quam feEtio fanat. Sed puris immoderata copia thoracem obfidente, uftionem recte fanare raro obfervatum eft, quos fi curare velint, feetione uti debent, qua totum pus vacuatur. Utrumque tamen remedium pro eodem affectu apud eos familiare eft, fectioneque, uftio faniliarior. Nam formidant \& ipforum multi fectionem, de qua fatis locuti fumus, proinde ad alia orationem noftram traducamus.

\section{A p. XIV.}

De lapidis è vifica extractione ablque ulla incifione apud Asgptios frequentata, do de dyjenterice curatione empirica.

\section{G U I L A N D I N U S.}

PTAREM priufquam de aliis fermonem haberes, ut mo: dum, quo audio, Egyptios lapides è vefica abfque ulla incifione extrahere, nunc mihi explicares: fummæ enim utilitati hujus actionis cognitionem noftratibus medicis fore exiftimo: avide igitur id, quoniam modo fe habeat, andire expe¿to. Alpin. Certe hic modus extrahendi lapides è vefica valde utilis eft, eo quod nulla incifione operetur. Extrahunt lapides è vefica colem in primis vento replentes, atque cum eo os etiam veficæ dilatantes; atque laxamtes, ut per os vefica lapis: 


\section{P R O S P E R I A L P I N I}

facile meare poffit, colifque dilatatum $\&$ ampliatum meatum , ex quo ipfos lapides vento fubreptos foras extrahunt, ipfo continuo toto violenter evocato. Guiland. Haud probe intellexi quin dixeris, ufque adeo obfcura oratione ufus es. Duo tamen mihi videris dixiffe, quorum alterum eft, illiufce regionis medicos, lapides è vefica extrahere volentes, in primis colis veficæque meatum vento laxare ac dilatare, per quem commode lapides exire poffunt, atque eofdem lapides vento eodem foras educi, an non hæc dixti? A L P N. Plane eadem, fed quid te dubii cæpit? Gulland. Quoniam vix credere poffum os veficæ, colifque meatum tantum dilatari ac ampliari poffe, ut magni lapides in vefica contenti, qui magnæ nucis inftar fæpe cernuntur, commode exire queant: ex quo dubiat fit apud me ea lapidum eductio, quonam pacto ita poffit adminiftrari, maxime, cum ut etiam affirmaveris, eos vento fubrepi, forafque educi, quod mihi haud fieri poffe videtur. AL pIN. Utrumque verum effe cognofces, neque omnino à veritate id alienum putabis, os veficæ, colemque eo modo dilatari poffe, quando nervofa, ac pelliculofa fubftantia illi meatus conftet. Admirandum magis exiftimare debemus. Uteri os in mulieribus nervofum durum, atque ita angufum, tempore partus tantum ampliari augeri, ut fotus per ipfum exeat, atque foras propellatur. Unum hoc fcio, me colis meatum ita dilatatum infpexiffe, ut per eum facile magna avellana tranfiiffet. At utilius erit, ut nunc modum oftendam, quo ad extrahendum lapidem ii uti foleant. GUILAND. Hac eadem de caufa apertis auribus tuum hunc fermonem expecto. Al P I N. Eo tempore, quo ego in $\not$ Egypto moram faciebam, Arabs quidam Haly vocatus ad extrahendos lapides fine incifione celeberrimus erat, quem ego fane cuidam duci Turcarum, Horam Bei vocato, multos lapides extraxiffe vidi. Quo in opere abfolvendo ille ligneam cannulam accipebat, longitudine octo digitorum, \& latitudine digiti pollicis. Quam colis canali admovebat, fortiterque infufflabat, atque ne flatus ad interiora perveniret, al tera manu extremum pudenidi perftringebat, foramen deinde cannula claudebat, ut virge canalis intumeferet, \& latior 
DE MEDICINA FETPTIORUN. LIB. III. 225

fieret, ac appareret. Quo facto minifer digito in ano pofito, lapidem paulatim ad canalem virgæ: atque in ejus extreñn deducebat. Qui, ubi preputio lapidem appropinquafle fentiebat, cannulam à virge canali fortiter impetuque amovebat, ut magna dexteritate lapis ad nuclei olivæ magnitudinem fuerit extractus; \& ego interfui huic duci Turcarum, \& poftea duobus item Judæis, quorum alter puer erat, cui octo lapillos extraxit, \& alter adulitus, cui extraxit lapidem ad magnæ olivæ magnitudinem. Hicque eft extrahendi lapidem è vefica modus, quo utebatur ille medicus Arabs. Audivi tamen alios etiam ibi effe, qui alio etiam modo lapidem extrahebant, quem mo: dum nunquam ab aliquo, quamdiu Cayrum habitaverim, potui cognofeere. Cum vero GENU $\mathrm{E}$ pro Illuftriff. ac Excellentif:. Joan. Andrea Auria Melphorum Principe, atque Philippi Hifpaniarum Regis, maritimæ Clafis præfecto medicinam facerem, atque hæc mea fcripta reviderem, Octavius Roveretus Medicus doetifimus, mecum multo amore conjunctus, quique poft me in Figypto pro natione Veneta, medicinam multa cum laude faciebat, extrahendi lapiden hunc modum à priori fatis diverfum mihi literis fignificavit, his verbis. Aliud etian fatis fcitu dignum tua Excell. narrare non omittan, eflque modus aliquis è vefica lapidem extrabendi fine incifione, bic à quodam $A$ rabe viro Cbriftiano Sajetico ad quendam Chriftianum Coptotum vocatum, ab binc nomullos menfes operaius. Alque is eft bujufmodi. Hic babet quafdan cannulas, unam majorem altera, in modum mufici inftrumenti Syringe appellaii, è Jubftantia Cartilagi nea, que facile dilataiur. Harumque graciliorem in virge canalem intromittit, figitque quofque ad vefican pervenerit, moxquse ore infufflando ipfam inflat quantum plus potefe, pofreaque bac majorem, vel craffiorem introducit, infufllandoque inflat coden modo, Es poft tertiam, vel etiam quartan omnium maximam. Et cunn $\sqrt{i c}$ iis virgam dilataverit, ut putet viam canalis fuiffe fufficienter dilatatam, per eamque lapidem exire pofje, Etgroto in primis comnmode collocato, digitoque in ano pofito, lapidem ad collum vefice subi majoris cannule extremitas pervenit, deducit; in cannulan lapidem conducere conatur. Quo facto aliero cannule meatu ore exFf

cepto 


\section{PROSPERI A L I N I}

cepto conatur fpiritum ad fe trabendo, lapidem fimul trabere, qui fo nimis craffus fit, fepe rumpitur, atque ir frufia attrabitur. veluti contigit fupra dieto viro Coplsto. Cui frultum, Eo reliquum lapidis admodum craljum, Go dimum, intus remanjit, non educium. Hic modus fcitu eft facilis; atque ab alio fortafjis medico exercitaiori, EF acutioni mulio plus facilitari poterit, ac in melionem atque utiliorem ufism reduci. quod multorm ab eo malo bominum infortunatorum auxilio fumme eflagiandum ac expedandum efjet. Hactenus Roveretus. Ix his igitur cogito te recte audiviffe binos hos modos, quibus Aigyptii ad extrahendos lapides è vefica utuntur. Addo aliam operationem, quam pro fecreto in dyfentericis conficiunt; qua res cum ratione, ut arbitror, demonftrari non poffit, tibi, qui omnia ex fuis caufis fpectare fo. les, haud facile fuadebicul: fed cum ego una cum aliis frpe viderim ex illa operatione empirica fluxus dyfentericos interdum curatos fuife, non finam te hinc aures ad alia retrahere, priufquam hanc quoque audieris. Illi fiquidem empirici hoc pacto fluxus dyfentericos fanant, illofque præfertim, qui diuturnires facti funt, minimeque aliis remediis cefferunt. Quod ut efficiant, primo hypochondria manibus molliter fricant, atque mox fefamino oleo, vel anygdalino dulci ea inungunt, digitoque poftea intra umbilicum pofito, ipfum pluries circumvertunt, terque mane jejunis ea re repetita, aliquos dyfentericos lanitati fuiffe reftitutos memini; hocque genus remedii familiariffimum apud multos exiftit, qui variis remediis ad dyfenteriam inutiliter tentatis, ad hoc veluti ad facrum confugiunt. Pauci tamen exiftunt, qui recte hanc moliri circumvolutionem umbilici fciant. Gurland. Secretum, teque una ridendum cenfeo, qui ipfum non modo verum credideris, verumetiam aliis confirmes. Cafu fiquidem arbitror ( $\mathrm{i}$ aliquis tamen unquam. eo modo fit fanatus) accidifle, ut inde aliquis à dyfenteria funatus fuerit; veluti accidit, ut Socrate ambulante tonaret; hocque experimentum ex is eft, qux cum nullam in fe rationem habeant, nullo pacto funt credenda. Ni dixeris, eos defendendo, frictione hypochondriorum, atque inunctione juvari hepar, vel aliquod aliud membrum fub ipfo locatum, quod bilio- 
fim humorum tenuifimum atque acrem, acrimonia, vel falfedine inteftina abradentem, vel exedentem, fluxum gigneret, ad inteftinaque ipfa demandaret, vel humorem illum tenuiffimum ea frictione, \& inunctione digeftum refolvi, vel ejus fluxionem ad inteftina diverti, vel umbilici illa præftita digito circumvolutione motioneve, inteitina mota. in meliorem fitum mutari, ex quo non fint fluxioni ita obnoxia. Sed de aliis loquamur. AlpiN. Melicerides, Stheatomata, Atheromataque vocatos tumores, atque etian ftrumas optime fecant, radicem avellentes. Carnem etiam, quæ palpebris adnaf́citur, maxima elegantia abigunt, palpebras in primis fecando, \& poftea feEtionem confuentes, \& conglutinantes. Sed poftquam de his à nobis fatis dictum eft, de dulcium balneorum ufu, quo non fecus quam prifcis feculis, utuntur, atque de frictionibus, \& vomitibus, qui in balneis funt, dicendum eft. Guiland. De his quoque libentifime nunc te audiam, horumque fermo mihi erit gratifimus, neque minorem nobis afferre poffe utilitatem arbitror, quod hoc genus remedii apud nos minime nunc fit in ufu, atque etiam quia ipfo pluribus morbis mederi ab antiquis proditum fit: proinde, ut de eo loquaris, nunc à te vehementer peto.

\section{A P. XVI.}

\section{De ufu dulcium apud Egyptios balneorum.}

\section{A L P I US GUILANDINUS.}

CEMADMODUM populi frigidarum regionum multa habent, quibus ad caloren conciliandum familiarifime, uti folent, ita calidarum, ad refrigeranda corpora multis itidem utuntur. Ex quibus Egyptii inter multa ad id excogitata, qualia funt fontes multi, domorum tubæ fuperius recitatæ, ad ipfarum refrigerationem inventæ, terienæque habitationes, balnea quoque ex dulci aqua parata, in ufu habent frequentifimo, tum ad refrigeranda corpora, tum ad varium illorum orFf 2 


\section{P ROS PER I A L P I N I}

natum. Guizand. Arte illa ibi parari exiftimo, quando ÆEgyptus (ut atidio) foonte natis balneis nunc plane careat. Proinde fi ita eft, ea mili fedulo narrato. Atque an ex aqua fimplici, qualia prifcis antiquis medicis in ufu fuerant, an potius medicata illa parentur. ALPIN. Arte fane ab illis parantur, ex dulciqne aqua Nili fluminis clarefacta, eaque fimplici, minimieque mecicamentis alterata. Sed in primis balneorum loca tibl in memoriam revocanda cenfeo, fiquidem te olim Cayri, ac Alexandriæ, cum tu ea loca invifffes, multas, fereque innumeras ædes magnifice pro balneorum ufu conftructas, infpexiffe intellexerim. Dican præterea quot, ac qualibus cameris. five cellis ex conftent, atque aërem in fingulis quomodo illi calefaciant, qualifque calor eo in aëre fentiatur. GuILAND. Domus eæ balneorum, fi recte memini, multis cellis inter fe difinctis conftuctæ erant, in quibus homines fudabant, fricabantur, atque lavabantur. Permagnaque in ipfarum medio tanquam in ciomus centro cella extabat, in qua homines lavandi nudabantur, veftefque omnes reponebant: quam fpoliarium vél Apodyterium noftri appellant. Aliæ vero cellæ omnes ea caufa conftructæ erant, ut in iis lavarentur: fpoliariique aër temperate calidus eft, atque humidus, ipfeque aliarum cellarum calidor ita, ut variæ cameræ varium aërem quoad calorem haberent. Alpin. Recte meminifti, innimeras permagnas ædes. ibi pro balneis paratas fpectari, multis variifque cameris inter fe diftinctis, præditas, ecdemque modo, ut tu dixifti, conftructas atque ordinatas, ut in qualibet camera idoneus, quoad caliditatem, aër effet pro variorum corporum ufu vario paratus. Namque varia hypocaufta, five camera varium, quoad caliditatem, aërem habent, ut variis corporum temperamentis auxilio fint. Nam facta funt pavimencis marmoreis, emblemate conftructis; duoque labra marmorea, quilibet illorum locorum. obtinet, in quæ aqua ex alto decidit. Tectum five culmen il: la habent orbiculari forma, ex vitreis luminibus perbelle labo. ratum, undique conclufum, ne aër aliquis ingrediatur. Hypocaufta illa calfaciunt calentis aquæ vapore in fingularum labra elabentis. Non cnim, ut noftri, igne illorum balneorum: 
aërem calfaciunt, fed humicis calidifque aquæ calidæ vaporibus loca illa complentibus. Guiland. Cum varia corpora variis indigeant balneis, quippe ipforum alia multum calidis, \& alia moderate, aliaque tepidis, atque demum alia etian frigidis, qualia hecticorum effe Gal. in iib. 7. meth. med. fcriptum reliquit, quæfo an non illa omnes has partes obtinent, quippe ut corpora variis illis modis alterare queant? AlpIs. Balnea illa calida, tepida, frigidaque quolibet tempore, quando quis velit, ibi reperiet. Sed plerumque ea balnea funt temperate calida, quandoquidem pracipuus ufus fit, apud plerofque ad refrigeranda, humectanda, evacuanda atque munda corpora. GUILAND. Recta fane ratione calidarum regionum incolas tepida balnea ex dulci aqua parata cupere dicendum eft, quando ob aëris ambientis infignem caliditatem corpora inflammentur, arefcantque, quæ utique dulci aqua irrigata, ac humectata refrigerantur, \& humectantur, cutifque eorundem corporum meatus relaxantur, denfatique aperiuntur, exindeque naturalis calor per eos diffatur, refrigeriumquie capit. Sed his obiter dictis, cupio ex te audire omnes illorum balneorum ufus apud eos populos frequentatos. Alprn. Balneis illis ea gens utitur ad corporis ornatum, atque ad multos morbos ex plenitudine humorum prohibendos, demumque ad multos variofque obortos etiam morbos abigendos. Hos vero omnes ufus tibi ordine libenter narrabo, ab eorundem ufu ornatus gratia comparato, exordiens. Guiland. Atque ego libentifime hac de re te dicentem audiam.

\section{A p. XV.}

De un balneorum dulcium pro ornatu corporum atque quid mulieres, ad pinguefacienda. corpora in ip/is moliantur.

\section{A L P I N U S.}

PULVRraus, qui . Egyptiis fere toto anno, vento. $\mathrm{I} \in \mathrm{3}$, 


\section{0

exiftunt, atque $a b$ affiduis fudoribus, quibus cœli calore omnia corpora continue abundant, illuvieque quadam immunda redduntur, atque fœtentia, ex quo pleraque ipforum, \& fœtere \& pediculis abundare folent, Balneis omnes hi populi utuntur familiarifime, pro corporum abfterfione, maximeque mulieres, quibus curæ magis eft corpora ipfarum, pulchriora facere ipforum illuviem, \& fætorem corrigentes, ut cariores fint fuis viris. Eæ etenim fepiffime corpora in is lavant, \& mundant ab illuvie, perlotaque variis ornant odoribus, ut recte unguentis oleant. Ac veluti Italiæ mulieres, atque aliarum mularum etiam nationum ad capillorum, facieique cultum omne adhibent fudium; ita IEgyptix capillorum cultum negligunt, ex confuetudine omnes capillos in burfam ferico panno paratam concludentes, ac ad pudendorum, abditarumque corporis partium ornatum omnem diligentiam adhibent, Pudendis igitur tota cura in balneis ab iis adhibetur. Ea fiquidem in primis lavant, pilíque nudant, locaque pudendorum perpetuo glabra geftant, turpeque ibi eft mulierem pilis obfitam vulvain habere. Demum lotas eas partes, glabrafque effectas variis unguentis etiam exornant, Mufco, fcilicet, Ambra, Aloë, Zebet, fumptum ferre potentes; aliæque aliis unguentis recte olentibus, quæ ibi viliori pretio ubique venduntur. Copia unguentorum fere incredibilis in vulvæ ornatu., ejufque corrigendo foctore, ac ad coëuntibus voluptatem conciliandam, ibi continue diflipatur. GuILand. Quæque regio fuos mores habet, ibique omnes nimis libere Venere utuntur. Sed quid? nonne aliud in balneis iis preter ornatum moliuntur? ALpIN. Nultæ etiam pinguedinem in is procurant: gracilefque præfertim ita ibi carnis vitium hominum medullas invafit, quando mulieres, quo camofiores, \& pinguiores fint, eo libentius à viris expeti putent. Tx quo ibi plurimas pinguiffimas reperies: quid turpius corporum obefitate ob fceleftiffmum carnis vitium, effrenemque libidinem defiderari poteft? Quod vitium ita ibi frequntatur, ut illarum plurimæ perinde ac fues cernantur pinguifinn humi recumbentes, maximeque Hebrex, quibus iftud vitii aliis familiarius obfervatur. Quod ut obtineant, 
multis diebus, dulcibus tepidis balneis indulgent, in iifque diumorantes, comedunt, potant, clyfteribufque ibi ex variis pinguedinibus ac adipibus paratis utuntur, multaque etiam medicamenta per os affumunt. GUILND. Recte lane videntur pro pinguefaciendis corporibus, ufum illorum balneorum, à cibo, allervare, Quod Gal. in lib. I4. meth. med. his verbis Cap. I4. docuit. Ceterum quibus totum corpus exteruatum; is lavari quoque poft cibum eft idoneum. Quod fane etiam nobis ratio perfuadet, quando dulci illo balneo à cibo adhibito, ad cutim plurimum alimenti trahatur, atque deducatur, ut Hippoc. \& Gal. in lib. de Salub. diæta prodidere. Alpin. Verum iftud effe fæText.com. 14. pe experientia didici: plures etenim mulieres illorum balneorum multis diebus à cibo ufu frequentato, pingues evafifie vidi. Atque in hæc balnea præcipuam ego caufam confero, qua illiufce calidioris cæli corpora pleraque habitum pinguem obtineant. Cum tamen cæli ratione gracilia potius, quam pinguia effe debuiffent. Hincque Galen. in libro 7. de Compend. med. fecundum loc. dixiffe, dulcium balnearum ufu corpora reddi. effominata. At dubium eft, quomodo gracilia corpora eorum ufu balneorum poffint pinguefieri, cum potius contrarium arbitrari quifpiam merito poffet, quippe ab illis balneis plurimis largioribufque vacuatis fudoribus potius corpora vacuata gracilefcere, quam craflefcere deberent. Pinguia enim à plurima. aliqua vacuatione contabefcere, certum eft. GuILAND. Balnea, quibus mulieres ex pro impinguefaciendis corporibus, utuntur, tepida exifunt: quando calida in triplici fint caloris differentia, etenim illorum quædam multum, \& quædam parum calida funt, hæc tepida, atque illa calida medici appellant. Tertio funt alia medio modo fe habentia, quæ fcilicet temperate calida exiftunt. Quorum omnium balneorum Galen. in libro. 3. de fanitate tuend. facultates ac vires his profecto verbis Cap. s. prodidit: Dulcium calfaitarum aquarum $\sqrt{l}$ media temperie fint, wis calida, Eं bumida eft: Sin tepidiores fint. bumida E frigida; quod $\int i$ jufto calidiores fiant, calida quidem, $\int e d$ non perinde bumida. Ex quibus dixerim, eos, qui pinguefieri volunt, balneo dulci tepido uti oportere, quali ex te audio mulieres illas uti. 
Cetera enim fua caliditate vim habente refolutoriam, vel vacuatoriam, potius ad gracilitatem, quam craffitiem comparandam corporibus conducint. A L P I N. An non præcipua caufa eft, quain naturales proximam appellant, \& materialem, ex qua corpora crafefcunt ac pinguefiunt, copia multa humiditatis? Gurcand. Facile cognofcitur, cum mulieres viris fine dubio humidiores, etiam iplis corpora pinguiora obtineant, \& crapulis, ocioque indulgentes aliis fint pinguiores. Qui enim multum comedunt, atq'e potant, quod multum pinguedinis alimentum affidue fuppetat, ceteris pinguiores merito fiunt. Sed qualis fit hæc humiditas, ex qua corpora pingueicunt atque quomodo ipfa in corpore concrefcat, Gal. in z. lib. de temp. hifce verbis prodidit, dicens: Q E' temue eft, id in calidioribus corporibus alimenitum quodcm calido fit, in frigidioribus fervatur, cunnque id vence extra fe tranfmiferint, ubi in frigidas particulas incidit, quod genus membrana funt, circum eas concrefcit; in partibis vero natura calidioribus, cujufmodi carnofe funt, à calore ipfo abfunitur, ac digeritur, nifi jic ubi frigiditati temperamenti etiam vita indulgentior accedens ipfis carnofis particulis aliquid adipis allinat. Caufas, quibus corpora pinguia fiunt, probe Gal. attulife, cenfeo: etenim ad gignendam pinguedinem, ac adipem, concurrere debent alimentum pingue, leve, \& tenue, atque calor remiffus, vel frigiditas partium, in quibus adeps ac pinguedo concrefcunt. $H$ æc, inquam, duo, alimentum, atque partium frigiditas, ad impinguefcenda corpora funt neceffaria. Citra pingue alimentum nulla pinguedo fieri poteft, ideo ipfum ad id efficiendum neceflario, ut materia concurrit, A dininuto vero calore, quod frigus vocare poffumus, id alimentum in adipem ac pinguedinem concrefcere, docent corpora frigidiora, quæ facilius calidis impinguefcere folent. Ex quo Gal. dixit, corpora latioribus majoribufque venis prædita difficilius pinguefieri, quod ea valde calida fint, frigida fiquidem parvis venis gaudent, atque $a b$ eo calore, pinguedinis, adipifque alimentum abfumitur, Et parvarum, anguftarumque venarum corpora ob oppofitum temperanentum, quippe frigidum, impinguefcere quan facillime, 
DE MEDicina Egytiorum. Lib. III. 233

quoniam in his multum ejufce adeft alimenti (quando parum ex eo confumatur) quod ob frigus non diffolvitur, faciliufque concrefcit. Alpin. Cui mirum, mulierum Egyptiarum corpora alimento craffo ac pingui referta, balneorum tepidorum ufu refrigerata, in balneis ad cutim deducto, \& coagulato alimento, carnem ac adipem acquirere? Guiland. Quæfo, omnia, quæ illæ in balneis, ut pinguefiant, moliuntur, mihinunc paucis narrare non te pigeat. Ea fiquidem etiam audiviffe fumme jucundum erit.

\section{A p. X V I.}

Qua CEgyptice mulieres in balneis factitent, ut ipfarum corpora pinguefcant.

\section{A L P I N U S.}

ulieres $\$$ Egytiæ multa factitant in balneis, ut pingues evadant, quæ omnia utramque nuper dictam pinguedinis caufam refpiciunt, eamque præfertim, quæ pinguedinis alimentum fuppetit: Multa fiquidem agunt, è quibus multum humorem pinguem generent, ex quo multa fiat pinguedo, balneique calida vi ad cutim deducere ipfum ftudent, in qua tepido balneo refrigerata concrefcat. Potant itaque ob eam caufam jura multa variis ex adipibus, \& pinguedinibus parata. Bammia melochia, \& Culcaffia alterata; nam his vifcofiora redduntur, ex quo facile partibuls adhærent. In ufu familiariffimo apud multas eft jus gallinarum pinguium, Maluph ab iis appellatarum, vel nigrarum arte pinguefactarum. Ipfum etenim totum ex unica gallina confectum unaquæque mulier potat, totamque gallinam in balneo comedit. Multæ ex pauperculis frcem olei fefamini, quam thaine vocant, vel oleum ex Indicis nucibus expreffum, vel chinæ radicis decoctum, carne nuper dictarum gallinarum fimul cum Indica nuce percoctam epotant, vel oleum fefaminum, in quo fit diffoluta nux Indica, vel expreffum ex pifis, fructibufque terebinthi, \& amygdalis G $\mathrm{g}$ dul- 
dulcibus, nucibus avellanis, \& piftachiis. Comedunt etiam adhuc multa, gallinas quippe arte pingues factas: nucemque Indicam in jure diffolutan, ac in maffam redactam. Sed ex omnibus pro fecreto habent fingulo die, dum eunt dormitum, ad decem vulgares bulbos, pro hermodactilis à noftris pharma. copæis receptos, quos aliqui potius Colchicum effe autumant, contoftos mandere, eofque pluribus diebus, quidecim fcilicet \& viginti ad ufque, frequentant. Ex quorum ufu, quod noftris mirum videbitur, nihil vel per alvum, vel vomitum evacuantes, minufque aliqua moleftia mulieres vexantur. GuILAND. Hinc noftros falfis uti hermodactilis, cognofcitur, dubiumque etiam fit, eos effe Diofcoridis Colchicum, cum per os fumpti nullam noxam inferant, minimeque ftrangulent. Nif loci diverfitate illi collecti aliam à noftris facultatem obtineant, minimeque venenofam. Sed hæc omittamus, atque tu reliqua dicito. Alpin. Nulla alia funt à te hac de re audienda, quam quæ à doctiffima medica Aigyptia, publice per urbem Cayri mulieres olim artem pinguefaciendi profitente, audivi. Ex quibus omnibus aliqua fortafle ex artis medicæ principiis ad hoc negotium defumpta cognofces. GUILAND. Gratum erit hæc ex te etiam audire, ALPIN. Aliquæ in balneo hoc oleum epotant. Accipiunt farcocollæ, olei fefamini an. libram mediam Mirabolanorum chebul. XIII. Citronorum XII. omniaque probe contufa cum oleo mifcent, finuntque fic permanere, quoufque in ea maffa niger color cernitur, moxque colant, \& reliqua ficcari finunt, oleum hoc totum in balneo unica vice calidum bibunt, reliquaque in pulverem tenuifimum redacta cum vino dum eunt dormitum, affumenda pluribus diebus exhibent. Aliud, quod eodem modo factitant. Accipiunt pifa, amygdalarum dulcium, pulpæ nucum avellanarum, piftachiorum an. dra. 6. fructuum terebinthi, pulpæ nucis Indicæ an. dra. 3. omnia fimul contundunt, ab ipfifque oleum exprimunt. Quod quatuor vicibus in balneo bibunt, \& quæ remanent $a b$ expreffione, quatuor iiflem diebus euntes dormitum devorant. Aliud. Accipunt gallinam nigram probe pinguem ac carnofam, in cujus ventrem injiciunt avellanarum contufa- 
DEMEDICINA IEGYTIORUM. LI B. III. 235

rum, amygdal. dulc. piftachiorum pineollorum, ipforum an. dra. 3. quam hoc pacto paratam in aqua concoquunt, ipfamque percoctam unica die in balneo mulier una totam comedic, ejuique jus, in quo etiam farcocolla ebullivit, abforbet, pluribufque diebus hoc mulier pinguefienda factitat. Eodem fere modo aliam concoctam gallinam eandem comedunt, \& ejus jus bibunt. Sed prius tritici mundi in aqua cum driafmagarb uncia una decocti libram unam comedendam, exhibent. Quod dum ipfa comederit, ab ipfis decapitatur, \& coquitur, totaque in balneo comeditur, \& jus totum bibitur. Idem facticant aliæ, fed alio modo gallinam coquendam præparant, nam pifa, \& triticum ad libram femis in aqua decoctum gallinæ comedendum exhibent, quod ubi totum comederit, decapitatam decoquunt, folamque comedunt, ejufque jus bibunt in illa die, quinquiefque, hoc illæ factitare folent. Aliæ is non contentæ, addunt ufum variorum clyfteriorum, quibus in balneo non bis unica die, fed ter quaterque utuntur: quos aliæ fola pinguetudine urfi præparant, aliæ hoc clyftere uti folent. Accipientes pinguedinis urfi dra. 3 . olei firis. id eft, fefamini dra. 3 . furfurum triticearum man. I I. quos furfures in aqua calida per aliquod tempus infundunt, à quibus mucilago exprimitur, qua adipi oleoque permifta clyfterem faciunt. Ex his, quibus extra balneum utuntur, hæc à multis factitari folent. Siquidem ante prandium exhibent quafdam pilullas ita paratas. Accipe mirabol. Indorum pulverizatorúm dra. I. jujubarum ab offibus mundatarum, dra. 3. ex quibus una commiftis fiunt pillullæ. Aliæ confuefcunt fingulis diebus per plures dies, ubi eunt dormitum, devorare quinque mirabolanos Indos, ad ufque etiam fep: tem. Vel aliæ eorundem prius intra pulpam unius batech, per noctem maceratorum, unciam fingulis diebus ante prandium devorant. Aliæ etiam dum eunt dormitum fingula die fumunt mirabol. citrinorum pulverizatorum unciam, miltam cum fæce olei fefamini atque faccharo candido. Aliæ fumunt gummi draganthi unciam femis; quod infundunt in modico aquæ per horas duodecim, cui admifcent facch. candidi tantundem, atque ubi dormitum eunt, devorant, pluribufque diebus factitant. Aliquæ Gg 2 


\section{PROSPERI ALPIN I}

armonicaco utuntur pluribus dicbus, ejus drag. femis afiumentes, Demum aliquæ in balneo novem diebus fumunt fellis vaccini chirat in aqua calaf diffoluti. Nonnullæ ex nobilibus utuntur in balneo, decocto radicis chinæ, nucis Indica, atque colocaffiæ radice alterato, viginti diebus, \& plus; ex quo auxilii genere plures vidi emaciatas mulieres pingues evafife præfertimque parato in pingui gallinarum jure. Paupercule multis diebus fimplicem aquam, in qua per noctem infufa fuerit feminum fonu Græci, atque zizib Cretici femuncia, cum eunt dormitum potant, prius fænu Græcum, \& zizib comedentes. Hæc ex HEyptia medica illa muliere, quæ pinguefaciendi artem publice per urbem profitebatur olim audieram.

\section{A P. X VII.}

\section{De dilcium balneorum pro fanitate corporum apud CEgyptios ufu.}

\section{G U I L A N D I N U S.}

IT A B E O tibi gratiam, qui ad pinguefacienda mulierum corpora fecreta mihi etiam communicare volueris, quæ neque prorlus nobis fore inutilia fpero; nam multa materiam ex qua pinguedo fit, refpiciunt, \& dulcium balıeorum tepidorum ufus adjuvat attractionem illiufce alimenti pinguis ad cutim, in qua refrigerata facile toto illo pingui alimento concrefcente, pinguedo fit. At tempus eft, ut tu eorundem balneorum ufum non ad corporum ornatum, fed magis ad fanitatem apud eas gentes utilem etiam narres. Scio etenim illos populos plurimum illorum balneorum habere ufum, tum ad ipforum tuendam, tum ad vitiatam corrigendam, atque denuo reftituendam fanitatem: proinde de ufu illo te in primis loqui, quo fea morbis præfervant, defidero. A LPIN. Ufus illorum balneorum maximus ibi fervatur ad eos, quiex itinere inflammantur, ipforumque cutis arefcit, ac confipantur meatus: his fiquidem utentes, refrigerantur, atque humectantur. Quando talis fit illo: 
illorum temperies, Galeno in tertio, de fanit. tuend. docente, ut refrigerent ac humectent, corporaque illorum difflantur; iis etenim ita affectis mirum in modum ea balnea conducunt. Quod in multis fepiffime cernitur, qui ab itineribus calidorum locorum, arenoforumque, in quibus nihil eft, quo ab urente Sole illi deffendantur, inflammati atque exutitillis tepidis balneis utuntur. At.non folum ab externa caufa inflammatis exuftifque corporibus ufus illorum balneorum magnopere conducit, led omnibus quoque ex jecore immodice calido ita affectis. Qua de canfa frepifime corpora immodice calida, ac exufta ea ingrediuntur, atque ipfis lavantur. Omnes etiam, qui ex quacumque caufa in meatuum cutis obftructionem inciderunt, libere iis utuntur, calidis; qui ex frigiditate; tepidis, qui ex uftione, \& ficcitate id paffi funt. Multi vero iis balneis utuntur vacuationis gratia, quando ipforum corpora plurimo fan: guine redundant, ita ut ab ea plenitudine morbus aliquis oriri poffit. 'Irifariam itaque illi plenitudini ipforum corporum providere balneorum ufu affolent, fiquidem alii in iis fudando, alii vomendo, aliique perfrictionibus ad univerfas corporis partes adhibitis plenitudinem tollere conantur, \& alii etiam omnibus is tribus modis vacuantur. Horum plerique femel in menfe iis vacuationibus utuntur, aliique non pauci bis faltem. Sunt qui fingula hebdomada id facere ftudeant. Guiland. Quam tuto illi has omnes vacuationes in balneo exercere queant, non intelligo: quamquam recte noverim, quam utilis fit vomitio multis facile vomentibus, maximeque biliofis atque per æftatem, quando hac vacuatione ftomachus ab excrementis multis mundecur. Mulcos etenim novi à podagra, renumque calculis vexatos, vomituum crebro ufu magnopere juvatos, eodemque modo, \& exudatione atque frictione vario tempore uftatis idem multis contigife. Sed quam, inquam, tuto eoden tempore fimul halitus refolutionem, exudationemque, atque vomitum quifpiam poffit perferre, non recte intelligo. Etenim naturam a multiplici illi vacuatione haud leven jacturam fubire, ftomachique præfertim calorem nativum, ejufque omnes functiones in deterius abire poffe dubitarim. Stomachi naturalis calor in 


\section{PROSPER I A L P I N I}

ambiente calidiore multum exolvi ex Hipp. colliginur, qui dixit in Aphorifmis: Hyeme ventres effe calidiffimos, \& æftate frigidifilinos. Neque immerito, cunn multus ambientis calor naturalern calorem diffipet ac refolvat. Corporaque in fumme calido colo degentia continuis vacuationibus fubjiciuntur, ex quo mirum haud eft, fi multis, atque magnis non egeant vacuationibus, vel potius eas non recte perferant. Hincque doctiffimus fenex Hippocrat. fub canem, $\&$ ante canem fugiendas à medicis vacuationes infignes prodidit, hac eademgue ratione, quod puerorum corpora pre multo calore habent unde vacuentur; magniis vacuationibus inepta effe Gal. pluribus in locis ftatuit. Cui igitur dubium erit, ftomachum in balneo ab illis multis vacuationibus lædi oportere, atque exinde admodum imbecillum ad concoquendum evadere, ejufque calorem tum à calore balnei ipfun foras evocante, tum ab halitus refolutione, exudatione, vomitione, admodum pati? ex qua illiufce membri labefactatione quamplurimos $\mathbb{A}$ gyptiorum iis vacuationibus fape indulgentibus, ad concoquendum ventriculum ineptum habuiffe, atque crebrius, familiariufque ejufce membri cruditatibus acidis vexari minime miror, etfi non hanc folam caufam illiufce membri fufceptæ imbecillitatis efle certo fciam, fiquidem à venere immoderata, ciborumque refrigerantium atque aquæe crudx in potu ufu, etiam ftomachum multis lædi ex te ipfo audierim. A L PI N. Vomere nihilominus in balneo humido homines facilins poffe, cum id ftomachum relaxet, ad motumque accommodatiorem reddat, nemo fane contendet. Hacque vomitione homines à multis morbis defendi, vel præcaveri poffe itidem fæepius à multis comprobatum eft. Illo vero crebrius frequentato homines ventriculo imbecillitatem aliquam comparare veriffimum eft, quando hujuffemodi membrum ex validioribus crebrioribufque his motionibus, fieri non poteft, ne modo aliquo laxetur debiliteturque. Poffe vero aliquando eodem tempore fimul hominem in balneo multiplices illas innoxie ferre vacuationes, experientie repugnare non videtur. Quando, \& naturam id frepe in multis xgrotis feciffe obfervatum fit, ex quo non videtur omnino à ratione alienum, medi- 
DE MEDicina RGgPtorum. Lib. IIT. 239

cum, qui ommimodo naturam femper imitari debet, quique hinc ejus imitator à Galeno in Aphorifmorum Hipp. Cornm. vocatus eft, itidem in homine aliquando multiplici fimul eodem tempore uti pofle vacuatione. GUILAND. Verum dicis, nam \& Hipp. in multis agrotis id plane fe obfervafte in libris epidemicis memoriæ prodidit. Etenim in primo lib. de Com. 3 . Metone, fcripfit, ipfum quarta die fanguine è naribus atquie fudore decretorie vacuatum fuifle. Et mulierem trimeftri foetu ægrotam decumbentem \& qui in Deulcis horto, exudatione, alvique pituitofa excretione. Virginefque Abderæ, \& Lariflæ fanguinis fudorifque eruptione. Si itaque agroti poffunt Com. 3. innoxie multas aliquando ferre eodem tempore vacuationes, cur non multo tutius recte valentes, præcavendi à morbis caufa? Quinimo hoc neceffarium videtur pro molienda alicujus corporis univerfali vacuatione, medicis effe, quando varii purgandi humores varios vacuationis modos expofcant, tenues etenim ichorofi humores per urinam, infenfibilem tranfpirationem, exudationemque facilius, præfertimque in univerfo venarum ambitu contenti, vacuabuntur, quemadmodum pituitofi ac melancholici per alvum, \& per vomitum biliofi. Alpin. Dico itaque non male $\mathbb{E}$ gyptios aliquos aliquando tollenda univerfali plethora fimul uti vomitione, fudatione, atque frictione. Non omnes vero iis omnibus fimul utuntur, aliquibus fola vomitione ac exudatione contentis, \& aliquibus fola exudatione, \& frictione totius corporis. Plerique vero, quibus non eft difficile vomere priufquam fudent, \& fricentur, copiofa excitata vomitione, in primis ftomachum à cruditatibus multis, atque etiam aliis humoribus vexatum exonerant. Ut vero quifque vomat, ad decem ufque libras aquæ, in qua glycirizæ radix, feminaque foniculi fint percocta, epotat, cum qua evomit multa, \& quam facile. Sed illi tamen ea multum juvantur, quique, \& facile vomunt, atque ftomachum multis excrementis repletum habent. Difficulter vero vomentibus, quibufque ftomachus minime copia excrementorum redundat, neque tutus eft, neque utilis, flọuidem qui difficulter vomunt, non mediocre periculum fubeunt, ne vena aliqua pectoris rumtext. 3 . 
patur, \& vifus oblædatur, non minufque fauces, columella, \& gula inflammentur. Qui etiam duro ftomacho conftant, minmeque excrementis multis redundante, vomitus ipfum laxiorem facit, labefactat, aptumque facit ad recipiendam excrementorum quancumque redundantiam. Neminem fiquidem latet, partes imbecilliores factas facilius fibi ipfis mandata excrementa à robuftioribus partibus fufcipere, neque fluxionibus obfiftere pofiunt. Quamobrem iis neque tutum; neque utilem effe vomitun puto. Guiland. Omnia veris medicinæ principiis plane refpondere videntur, at de exudatione, \& frictione, qua ipfi ita familiariter in balneis is vacuationis, atque partium roborationis caufa utuntur, velim aliquantulum agas. AlpiN. De exudatione hand multa funt dicenda, cum nullis ii medicamentis fudores provocare foleant, fed folo calido talnei aëre. Quo quifque utens, large, \& facile fudat. De frictionum autem ufu prolixior fermo futurus eft, tum quoniam illi in iis peragendis magno ftudio utuntur, tum quod funt omnibus admodum familiares; proinde de iis nunc prolixius loquar, quando de exudatione apud eos frequentata illud tantum dixiffe fat erit, quod illi poftquam vomuerint, exudant: tempus autem exudationis, apud varios varie obfervatur, etenim aliqui horæ fpatio, \& alii binis atque ternis etiam horis fudare folent; nunc vero de frictionibus fermonem facere incipio. Guiland. Recte facies.

\section{A p. ' XVIII.}

De frictionibus, quibus $\mathbb{E g}$ gptii in balneis utuntur.

\section{A L P I N U S.}

Tus frictionum in balneis apud $\mathbb{E}$ gyptios ita eft familiaris, ut nemo ex balneo non fricatus abeat. Eas vero exercentes, hominem in primis horam fere in calido balneo commoratum, quo vomuerit, vel faltem extidaverit, in folio federe jubent, ac fedentis omnes partes corporis manibus variis mo. 


\section{DE MEDICINA E GYPTIORUM. LIB. IIT. 24 E}

dis pertractant, atque exercent. In primifque à pedibus incipientes, eos antrorfum, retrorfum, iniftrorfumque movent; \& mox crura, \& coxendices undequaque ter quaterque: poftea ad manus exercendas pertranfeunt, quas itidem eodem modo moventes, ac manibus flectentes exercent, figillatim vero fingulos manuum digitos, \& mox cubitos, atque ab his humeros, $\&$ fcapulas, ab hifque collum primo, caput fecundo, tertioque pectus atque dorfum, ut undequaque flectatur, ftudent. Qua fingularum partium motione finita, qua fingulis ter, \& quater fieri, contendunt, hominem fupinum humi decumbere, atque hic diftendi fupra pavimentum (quod omnes cameræ habent ex lapillis marmoreis perbelle paratum) jubent, corpufque univerfum molliter fricare deorfum verfus a pedibus incipiunt, inprimis anteriorem univerfi corporis faciem, nioliter per fingulas partes perfricantes. In hac vero univerfali frictione tribus frictionum generibus utuntur. Prima etenim, quam moliuntur eft mollis, mediocris. Secunda mediocris ac multa. Tertia eft dura, \& mediocris. In perfricanda vero tota anteriori corporis facie, à pedibus, ut dictum eft, exordiuntur, ipforumque omnes mufculos per rectum, five per ipforum longitudinem, manibus fuperne deorfum dimotis, ab articulo ad articulum pertractant, quod illi tanta concinnitate, \& peritia perficiunt, ut non fricatum nullum articulum relinquant. In primis itaque anterioris faciei pedum omnes mufculos mediocriter, ac molliter volis manum fricant, fimulque etiam omnes articulos, \& poftea mufculos, malleolorum, tibiaruin, poplitum, ac coxendicum, molliter, ac mediocriter fricant, \& mox manuum, cubitorum, humerorum, \& fcapularum, \& poft hos, vultus, colli, pectoris, ventrifque interioris idem per omnes mufculos præftant. Finita hac in poftica corporis parte frictione, corpus in oppofitum, vel contrarium mutant, ut pofterior pars recte fricetur, quam non fecus, quam anteriorem perfricant. Atque hæc prima eft frictionum differentia, quam primo in toto corpore exercent, quæ ut dictum eft, eft mollis, \& mediocris, quam volis manum plerique operantur, \& nonnulis inunctis oleo fefamino. Poft hanc, paulo $\mathrm{Hh}$ poft 


\section{PROSPERI ALPIN I}

poft fecundam factitant, qux inter mollem, \& duram media, atque multa exintit, nam fit in nuper dictis omnibus corporis partibus prolixius, \& durius, quam panno lineo crudo omnes exercere folent. Tertia, quæ poftremo fit, afpera, præduraque ent, arque mediocris, hancque panno afpero ex caprina lana parato præetant. His tribus frictionum differentiis abfolutis, corpus univerfum à planta pedis ufque ad verticem capitis communi fapone illi emplaftrant, \& deinde calido dulci balneo cutim lavant, atque $a b$ ea immuniditias abftergunt. A lotioneque pudenda pilis nudant, emplaftro cafum illorum fubitaneum præftante. Demum pedes per horam emplaftrant maffa quadam ex pulvere archenda, \& aqua communi parata. Pulvis hic fit ex foliis liguftri $\mathbb{E}$ gyptii, Alcanna, \& Elhanna ab iis vocati. Hæc pafta mire humidis, \& fortentibus pedibus juvat, nam valenter ficcat, adftringit, ac roborat, ita multo adjumento fit iis, qui pedes imbecillos habent. Colore etiam aureo eos exornat. Populares etenim mulieres confuetudine fibi manuum, pedumque ungues eo colore tingunt. Guiland. Ufus harum frictionum in illis balneis optimis medicinæ confervatricis principiis recte refpondere cognofcitur, quando \& Gal. in 2. lib. de fanitate tuenda dixerit: Frictio vim babet folvendi, ligandi, carnem augendi, minuendi. Nempe dura ligandi, mollis folvendi, multa minuendi, mediocris carnem augendi. Atque ut audio pleraque Egyptiorum corpora, multo fanguine exuperant, quibus tum balnea, tum frictiones illas poffe conducere arbitror, quod iis ipforum plenitudo tollatur, exindeque corporis oborta gravitas, laffitudinefque non minus, ipfifque interim ceperdita appetentia, roburque quam facile comparetur, Etenim in balneo primo calido, \& humido corpora per infenfibilem tranfpirationem, atque fudorem tenuioribus fuccis vacuantur, moxque contentos in mufculis, articulifque motione, \& frictionibus mollibus humores refolvunt. Prima vero, quam in balneo tentant, frictio, qux mollis eft, cutem aperit, atque laxat, in qua multus fanguis ex univerfo corpore trahitur, ex qua frictione mediocriter ufa is parum refolvitur, caroque ab eo gignitur. Ufufque ob id hujus frictionis apud mulieres, 


\section{DE MEDICINA E GYPTIORUM. LIB. III. 243}

nt impinguefcant, ibi eft affectatifimus, ca fiquidem decaufa à cibo molli frictione hæ utuntur; ut ex ea attractum alimentum non diffolvatur, fed in carnem, vel adipem vertatur. Secunda frictio, quæ mollis eft mediocriter, atque multa, multum attracti fanguinis refolvit, \& evacuat, cutaneofque multo plus meatus aperit, \& laxat, ex qua corpore multum tum vacuato, tum laxato, tertiam frictionem, duram, mediocriter ad fiftendam refolutionem ac vacuationem, atque ad cutim denfandem atque firmandam. Duro etenim afperoque panno ex caprina lana contexto, cutem parum vel mediocriter omnium corporis partium fricant. Apparet itaque illarum frictionum ufum non effe pro vacuandis corporibus omnino fpernendum. Ceterum hinc non levis oriri difficultas videbitur, quando non æque illas frictiones omnibus corporibus, pro qua libet tollenda humorum plenitudine, conducere poffe non immerito fit fufpicandum: Siquidem humores calidi atque tenues, fuapte natura, \& quam facile per cutim vacuari queunt, frigidi vero ac craffi nequaquam: quod Gal. in lib. 3. epid. his verbis docuit, dicens: Sepe cnim dictum jam eft, ut bumores corporis calidiores tenuiorefque paratiffini fint ad excretionem: Crudis vero $\Xi^{2}$ craffis, aut per abfcelfum aut per fympepfim, id eft, concoctionem natura medeatur. Er quibus frigidis humoribus atque craffis corporibus exuperantibus peffime has frictiones pofle conducere arbitror, quando ob craffitiem per tenues corporis meatus illis permeatio non fit commoda, veluti iis, quæ tenuioribus calidioribufque abundant, multi fore adjumenti has affirmare poffumus. ALPIN. Qamquam eam ob caufam multi craffis, frigidifque hümoribus exuperantes mirum in modum. $\mathrm{ab}$ iis frictionibus ledantur, multofque ego hac caufa in diffciles vifcerum obftructiones incidife obfervaverim, \& alios' in putridas febres, nihilominus vomitibus copiofioribus, ut $\mathbb{E}$ gyptii priufquam fricentur, facere confuefcunt, ftomacho à cruditatibus probe purgato, illos innoxie ac tuto fricari eo modo poffe dicerem. Guiland. Cum, te afirmante, pleraque illorum corpora, ftomachum ex fuperius a nobis cognitis caitis imbecillum atque infirmum obtineant, crebrioribufque, crit- 


\section{PROSPER I A L P I N I}

ditatibus vexantur, non minufque exinde continue ea corpora hypochondria habent aliquibus cruditatibus, ac flatibus repleta, non video, eos tuto fricari poffe, etiamfi copiofius in bal. neo prius vomant: unica etenim die in multis multa redundantia excrementa, poffe vomitu expelli non cogito, quamobrem cogito illas multarum obftructionum occafionem effe poffe, ut ex Gal. lib. 4. defanit. tuend. \& 8. meth. med. proditum eft. Averrhoefque acriter Galenum, in lib. de fanit. tuend. docentem febres ex cruditatibus ortas frictionibus curari debere, damnat, minime effugere poffint. Caute itaque ufus ille vacuandi corpora per frictiones tractandus erit. Sed nunc tempus eft, ut ad quos morbos tollendos iis utantur balneis, narres, quando jam fatis fuperque de his frictionibus à nobis dictum fit: non defunt rationes multæ utrique parti faventes, quibus earum ufus fuaderi, \& diffuaderi poterit, quod noftrum non eft in præfentia comtemplari. Sequere itaque reliqua de ufu balneorum in curatione multorum morborum enara rare.

\section{A p. XIX. \\ De balneorum apud E Egpiios ufu ad varios morbos perfanandos.}

\section{A. L P I N U S.}

Rar neis illis ex aqua dulci paratis, non fecus quam antiqui 13 utebantur, Egyptii noftri temporis ad varios tollendos morbos uti folent : nam iis interim humorum minuentes eo modo, quo dictum eft, plenitudinem, corpora à multis morbis ex plenitudine ortis fublevant: interim, cutis meatus adfrictos, atque ex calore, vel frigore, vel ficcitate conniventes aperientes, multas febres exinde genitas fanant. Multis etiam morbis ex fola ficca \& calida temperie, vel ex fanguine, vel bili acutiori, vel ab exufto humore obortis, opem præftant. Multafque 
tafque tum internas, tum externas inflammationes perfolvunt. Etenim balnea illa, ubi volunt, vacuant humortm exuperantiam, cutis meatus laxant, aperiuntque, \& inflammatas paries aliquando refrigerant, ac ficcatas humeetant, carnemque non minus à cibo utentes generant, atque ob id gracilioribus utiles exiftunt. G UILAND. Pro quibus autem particularibus morbis, is $\mathbb{E}$ gyptii uti foleant, feire cupio. AlP!N. Ufum illorum exercent ad febres ephemeras omnes ex caliditate, frigoreque, nec minus ex ficcitate obortas, atque etiam ad putridas quæ ex copia fanguinis, bilis amaræ, atque exuftæ oriuntur, ad hecticas quoque, \& ad omnes inflammationes, melanchcicas, variafque cutis defoedationes, \& ad luem venerean, ad fuppreffafque menftruas purgationes, atque etiam ad earundem immoderatos fluxus, ad opthalmias, hemorrhoidum dolores, \& urinæ fuppreffionem. Gulland. Mirum non eft, fi balneorum ille ufus, vel illorum morborum caufis, vel ipfis morbis, dum recte omnia comparentur, eos prodere poffit effectus; in febribus fere omnibus balnea ex dulci aqua parata ufum ufque in antiquis temporibus apud omnes præcipuos medicos, habuere, neque immerito, cum ea tali fint temperie ac facultate prædita, qua calfaciunt, humectant, refrigerant, ficcant, evacuantes per poros cutis, Gal. enim in 3, lib de fanit. tuend. de is dixit: Dulcium calfactarum aquarum, $f i$ media temperie fint, vis calida, E bumida eft: fin tepidinres fint, bumiada $E^{\circ}$ frigida: quod $\sqrt{3}$ jufto calidiores fiant, calida quidem, fed non perinde bumida. Ex quibus dignofcitur illorum balneorum ufum febribus, atque inflammationibus etiam effe utiliffimum. Siquidem omnes febres in hoc conveniunt, quod in calore \& ficcitate confiftunt, five ipfarum effentia ignea exiftit, quam corrigere ac delere pollunt tepida dulcia balnea, quippe quæ refrigerant atque humectant, ex quo omnibus febribus caufis conjunctis carentibus ipfa valde conducere videntur, atque etiam aliis fimul caufas habentibus, quales putridæ exiftunt, quæ pro caufis, exuperantiam variorum humorum putridorum, atque vaforum obftructiones habent. In is etenim etfi febrium ratione balnea conveniant, non tamen in principiis ipfarum, Ith 3

quan 
quando prius febrium caufe fint auferendæ, quæ fere contrariis medicamentis auferuntur. In Ephemeris vero febribus caufis carentibus ftatim in principiis homines in balnea tepida dicunt, veluti eos quibus una cum febre quæpiam ctiam caufa adeft, qualis obftructio cutis meatuum exiftit, vel meatus iidem ex ficcitate conftipati, in eadem balnea moderate calida in primis ducunt, \& mox in tepida, illis etenim conveniunt calida, quia aperiunt obftructiones, quibus fublatis, mox tepida conveniunt, $\&$ is quibus cutis ex ficcitate conftipata re manfit tepida maxime conveniunt, quæ refrigerando atque humectando tum caufam, tum morbum refpiciant. Quod Gal. in lib. 8. meth. cap. 3. docuit, iis verbis: Quippe in prima accelfione inclinante ducendi in balneo omnes funt: tum pinguiter fimul ac molliter fricandi, ii quidem qui ex aliquo, quod cutim adftrinxit, laborant, ficut dictum eft. Qui vero ex ficcitate, fricandi quidem \& ipfi, fed parcius, lavandi autem uberius. Qualia vero illa fint, quæad hecticas febres atque ad putridas, ex te nunc fcire cupio. A I P I N. Ufus corum balneorum apud eos non unus obfervatur, fed multiplex, quando alii balneo utantur tepido, \& alii frigido; eo profecto modo, quo Gal. hecticos lavandos docere in lib. Io. meth. med. videtur, attamen illis non valde frigidis utuntur. Tepidum balneum, quo utuntur, alterant lactuca, violis, loto $\mathbb{Z}$ gyptio fcilicet nenuphare, endivia, funco, hordeo, coriandro, folatro, malva, foliis vitium, papavere, aliifque refrigerandi, \& humectandi facultate praditis. Hi vero obfervantes ex his frebrilem calorem hecticorum nihil diminui, ad frigidum balneum accedunt, fenfim ac fenfin ad frigiditatem per tepiditatis gradus afcendentes; à tepido" fiquidem ad minus tepidúm, \& ab eo ad frigidum, \& poftea ad magis frigidum afcendentes, corporaque tandem tota fubito in aquam frigidam injiciunt, ut æque fimul omnes partes corporis alterentur. In putridis etian febribus, apudillos ufus balneorum eft frequentiffimus; co etenim in omnibus tum continuis, exceptis peftilentibus, tum intermittentibus familiarifime utuntur, non tamen in principiis, fed quando febres ftatun adepta fint, vel declinare coperint. 
DE MEDICINA EGYPTORUM. LiB. 111. 247 .

In his etenim calidis balneis fingulis diebus ante cibum ægrotos immergunt, eofque ibi per horam morari jubent. GuILAND. Corpora cruditatibus fcatentia balneis uti non debere, Gal. pluribus in locis docuit, præfertimque in lib. Io. meth. med. quando ex balneo cruditates funduntur, ac liquantur, atque facile in vifcera fluere poftunt, præfertimque is aliqua fint imbecilla. Gal. etenim in balneis tria fore obfervanda præcepit, nempe ne, qui balneantur, aliquo pacto horreant, fecundo, ne ullum vifcus imbecillum habeant; demumque, ne multitudo crudorum humorum in primis venis adfit: Quæ ab ipfo in lib. 2. meth. med. hifce verbis docentur: Tribus enim bis in balneo, quod in quacunque febre adbibebis, intentus fis oportet: uni quad citra borrorem fit adminiftratumn: Secundo, quod mullun prince note vifcus fit imbecillum: Tertio, quod multitudo crudonlinn bumon un in primis venis non contineatur. Horror namque (ut prius dictum eft) non folum intendere eam prefentem febrem poteft, fed cunn non fuit, ean interin excitare: Partes vero imbecille, liquatos jain bumores magis recipiunt, quan antequan liquarentur: Crudorinn vero bunorum copia in totum. corpus digeritur. Horum fi nibil obftet, ex balneis duo bae agro compendia accedant, Ë quod redundantice bumorum aliquid oucuabitur, E quod multum febrilis calor tranjpirabit. Quamobrem ex his colligitur, quomodo febrictantes balneis uti debeant, ut ipfis ucilitatem afferant; ex quibus non video, quamobrem $\mathbb{E}$ gyptiis corporibus, tantopere balneo conducere queant, quando alias ex te audierim illorum corpora fere continuo in primis venis multas cruditates habere. Alpin. Verum eft, at quis eft putrida febre correptus, cujus nunquam ad vigorem vel decrementum etiam febris, venæ mefenterii cruditatibus minime repletæ fint? idcirco illo tempore balnea neutiquam tuta efle, aflero: fed ubi ill cruditates confumptæ funt; qua ratione neque in principio acceffionis, neque in incremento, quando neque cutis meatus pervii facti funt, neque excrementa digefta, Gal. ægrotantes balneis uti debere meminit in lib. 2. meth. ita dicens: Quo rationabilius nec in febrilis fognificationis principio, nec incremento quifo guam egrotantem lavit: quippe denfata eft boc tempore, coatica- 


\section{8

que Ė cutis ipfa, Eq quae Jub bac babetur, carnea fubftantia. At in febris inclinatione incipente, aut jam progrefja, E nos Jape, EO alii medici nomnulli multos Sapenumero agrotos lavantes, non parnm bis contulimus. Quare cum $\mathbb{E}$ gyptiis quoque ægrotantibus in primis duobus morbi temporibus, quippe in principio, $\&$ augumento, primarum venarúm cruditates, quibus \& ipfi exuperant, plane digerantur, meatufque cutis, \& carnis fubftantix aperiantur, balnea importuna, \& noxia effe videntur; in aliis vero temporibus ipfa utiliffima exiftunt, præfertimque corporibus calidioribus, calidioribufque febribus correptis, quibus ufus illorum balneorum familiarior, ac magis peculiaris ibi obfervatur. Etenim quamquam his balneis omnes indifcriminatim febricitantes utantur, tamen corpora biliofa, atque adufta, quæ acrioribus excrementis abundant, igneis febribus correpta magis in familiari ufu illa habent. Neque id injuriâ, cum fi ea temperata adhibeantur, non modo fuliginoforum excrementorum acrimoniam, verum etiam totius maffæ fanguinis, hepatifque præfertim fervorem ac acutiem compefcant, evacuent, \& humeetent ' cutimque laxant. Quare in biliofis febribus, atque aluftis illorum balneorum ibi jure merito eft frequentifimus ufus. Corporaque illa in primis in aërem temperate calidum paululum verfari finunt, in quo exudant, atque cutanei meatus laxantur, mox oleo violaceo vel nenupharino $a b$ eis inunguntur: \& tertio in aquam tepefactam merguntur finuntque ibi tantifper morari, quoufque aqua balnei omnem calorem amiferit, frigidamque redditam ægri amplins innoxie ferre non poffunt: qui e balneo educti linteis abfterguntvi:, atque exficcantur, in lectuloque pofiti aliquantifper dormiunt, mox cibo reficiuntur: in intermittentibus febribus, diebus tantum, quibus æǵri febre non tentantur, in balneum ducuntur, fpeciatimque in febribus amphimerinis, duplicibufque fpuriis tertianis; quartanis; in iis etenim tempore acceffionum à balneis abftinent, in tertianis vero exquifitis, vel multum ad ipfarum naturam accedentibus, quotidie balneo utuntur, atque aliquando bis \& ter, in corporibus graciliori ac fqualidiori habitu, temperamentoque exufto præditis, quotidie fre- 
frequentant: neque mirum, cum Gal. de his in primo libro ad Cap. ${ }^{-}$; Glauc. tertianarum febrium curationem docens, dixerit: Balnea vero calida ex aqua potabili profunt, tum quia aliquid bilis educunt, tum etiam, quia fua qualitate plurimum juvant: nam hujufmodi omnia balnea bumeitant, ac potentia refrigerant: atque hæe obiter de ufu balneorum in putridis febribus diximus, quibus illi nil minus familiariter utuntur ad plures alios morbos, nempe ad oculorum inflammationes: nec ad oculos modo ipfos, fed ad univerfum corpus, ut corpora exficcent, atque contemperent. Sunt aliqui, qui pluribus diebus in balneis illis exudantes, atque hepatis flammeam qualitatem iis contemperantes, à Gallica lue fanari arbitrantur, qui quanto in errore fint, poftea cegnofcunt, qui intermiffa victus fobrietate, \& ufu bảneorum, quibus ipforum corpora inaniebantur, ac ficcabantur, rurfum eodem morbo ægrotant, iifdemque fymptomatis Gallicis conflictantur. Sed quid dicemus de melancholicis, qui his tepidis balneis tum in univerfum corpus, tum præcipue fupra capitis futuram coronalem ftillantibus perfecte fanantur? de his fatis. Ac fi placet hoc tandem fermone-diem claudamus. Craftina die polliceor me tibi viro doctiffimo omnia tum fimplicia, tum compofita medicamenta, quæ apud eos in frequenti ufu exiftunt, narraturum. Quorum hiftoriam non minus, quám cetera hucufque à nobis tradita, utilitati, \& voluptati fore judico: finem igitur hodierno fermoni imponamus. Guizandinus. Satis loquendo ambo defeffi fumus, ut nunc confultius fit, paululum quiefcere. Libentifime te cras mane expectabo, ut medicamenta, ab ea gente ufitata ex te etiam audire queam. Vale.

\section{F I N I S L I B R I TER T I I.}


Pag. 250

s.?

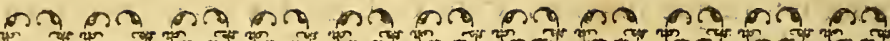

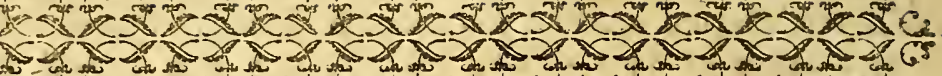

U. एu

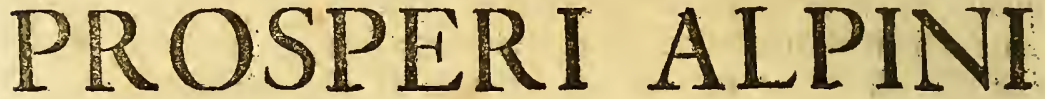

D E

\section{MEDICINA ÆGYPTIORUM.}

\section{I B E R QU A R T U S.}

$\mathbb{C}_{\text {A P. I. }}$ I.

De medicamentis alterantibus, quorum ef apud: Egyptios ufus.

\section{G U I L A N D I N U S:}

Ro $\mathrm{RTO}$ Sole, quando jam in locum noftris fer

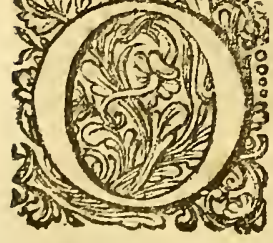
monibus conftitutum oportune venimus, ne tempus fruftra conteramus, cum multa hodie: de medicamentis ab Ægyptiis ufitatis nobis dicenda fuperfint, jam de his ipfis fermonem aggrediare. In primis vero illa medicamenta, qua pro alterandis corporibus, \& mox purgandis ea gens fequitur, mihi prius narrato: fpero enim il-. los medicos aliqua ex illis in ufum hakere, quorum notitiam, \& novitate rei, \& eximia utilitate, mirum in modum nobis profuturam, voluptatique futuram arbitror. Expecto itaque. de his nunc, ut loquaris. Alpin. Quamquam nihil fere habeam, ex his, quod tuis auribus dignum effe judicem, nihilominus, 
minus, ne laborem fubterfugere videar, quæ per hos annosibi medendo obfervavi, tibi dicere non recufabo: Quæ qualiave fint, tu quoque facilius conjectura affequi potes. Situs enim locorum, hominumque loco habitantium perfpectæ ac cognitæe naturæ, ufum familiarium medicamentorum communi quadam ratione medicis fignificare videntur. Siquidem coli frigidiores plagas habitantes, quod corpora exinde habeant frigidiora, calida medicamenta frequentare obfervamus. Contra, qui fub calidiori cælo degunt, quia calidioribus corporibus præditi funt, frigida appetunt, ac pro tuenda ipforum valetudine refrigerantium medicamentorum ufus apud illos eft frequentiffimus. G U I LND. Vera loqueris : Hincque Germani, Boemi, Poloni, Angli, Flandri, atque alii frigidarum regionum populi, ufque adeo aromatum ufu delectantur, ut maxima piperis, zinziberis, Gariophyllorum, nucum; aliorumque omnium aromatum apud illas nationes copia abfumatur, itidem arbitror, ut hi calefacientia medicamenta fequuntur, ita calidarum regionum incolas frigidis oblectari ac gaudere, atque exinde ufum refrigerantium medicamentorum ipfis effe familiariffimum, præértim vero Ficgytios, ut ex te alias audivi, ea de caufa plus æquo refrigerantibus indulgere. Ex quo etiam malos ibi cum vivendi, tum medendi ufus, vel potius abufus originem duxiffe recte arbitrari poffumus. Quandoquidem incolæ frigidorum locorum ab ufu refrigerantium plufquam opus effet, timentes, ufque adeo à refrigerantibus tum cibis, tum medicamentis cavere, \& abftinere folent, ufque adeoque ufum calidorum amplecti, ut refrigerantia plane negligant, non tantumque inutilia, verum etiam fibi valde noxia effe autument: exindeque refrigerantia omnia medicamenta abhorreant, ac fugiant, adeoque vulgo ob eam caufam calfacientium ufus receptus eft, ut illum immodice fequentes, in caufa fit, ut plurimi populares morbi, per ea loca fere affidue graffentur. Plures enim Germani, Poloni, atque alii frigidarum regionum populi ob eam caufam a frigidis caventes, vinis generofis, aromatibufque nimium indulgentes, hepar immodice calfaciunt; atque exurunt, ex qua temperie qualia oriri foleant mala, noIi 2 


\section{PROSPERI AL PI NI}

bis obfcurum non eft $;$ \& cum ab his tamen: abftinere nolint, cos breviorem vitam vivere, mirum non eft. Eodem quoque modo alias me dixife memini, ex frigidorum frequenti, \& continuo ufu, Egyptios in multos morbos incurrere: atque hanc effe ex præcipuis caufis unam exiftimo, qua terra $\mathbb{E}$ gypti calidori colo utens, corpora pleraque fanguinea, ac pituitofa gignat, quod magis admirandum nobis videatur, ea loca populares morbos frigidos plerofque pati, ab hifque plufquam à calidis incolas vexari. Sed cur mihi cupienti ex te cibos, atque medicamenta, quibus illi utuntur, audire, egomet impedimento fum? AlPIN. Ne ab incepto fermone difcedamus, dico in primis Agyptios ob multum ambientes calorem, victum, medicamentaque vi refrigerandi atque humectandi prædita præcipue confectari. Plerique enim pro victu omnia eduliorum genera, quæ ex lacte parantur, ufurpant, maximeque lac acetofum, quo omnes ibi libentiffime, atque familiariffime vefcuntur. Plebsque paupercula lac comedit, cucurbitæ, cucumeri., lactucæ, endivæ, portulacæ, . vel aliis oleribus refrigerandi vi præditis minutiffime incifis, miftum. Oleraque, quibus eos vefci confuetudo eft, funt Melochia, bam* miæ, fructus, lactuca, endivia, foncus, coriandrum, portulaca, culcafliæque radices, quas quifque ibi familiariffime variis modis paratas comedit. Atque ex fructibus, cucurbitæ, cucumeres, mala infana, Melones, anguriæ, Mufæ fructus, ficus noftrates, \& ficomori, qui funt noftris latiores, breviores, atque longe infipidiores, limonia, atque aurantia, da¿lili, fabæ, ciceres, atque ipfa viridia. Ex radicibus, ut nuper dictum eft, culcaffiæ eft frequentifimus ufus. Arundinum quoque viridium, ex quibus faccharum ibi exprimitur, in cibo apud eos ufus eft familiariffimus. Pro potu-plerique fluminis Nili aqua perpetuo utuntur; fiquidem illis vinum lege interdictum eft. De medicamentis itidem dicendum eft: illa ete: nim fequuntur, quæ refrigerandi, atque humectandi facultate funt prædita, qualia exiftunt Nymphea, papavera, ipforum fuccus ab ipfis affion, à Græcis meconium, \& à latinis opium vQcatus. Pfyllium, coriandrum viride, quod etiam in fercu- 


\section{DE MEDICINA EGYPTIOXUM: LIB: IV. 25}

lis : in frequentiffimo eft ufu. Endivia, foncus, cichoreum, lactuca, plantago, Melochia, malva, rofa, fandala, limo. nia, cytria, atque acacia. Interim etiam ex calidis utuntur, meliloto, fœnu-græco, amaraco, menta, camomelo, anetho, liquiritia, foniculo, anifo, atque aliis multis. Berberis fructus in medicinæ ufu valde frequentant, quos putant cor multum roborare, virefque-reficere, ac perfrigerare, frimque extinguere, in febribufque ardentibus, atque peftilentibus iis paratis uti folent. Horum fiquidem libram in vafe magno aqua pleno, vel duodecim etiam aquæ libras continente, mittunt cum nonnullis feminibus foniculi, vel frufto panis, atque per noctem, vel diem fic manere volunt, deincepque de frigi da hac expreffione, per colum transfufa, cum faccharo multo rofaceo, vel fimplici, vel fyrupo ex acido citri large ægrotis propinant, qua potione calorem febrilem fitimque extinguunt, virefque reficiunt, atque etiam putredini prævalide obfiftunt. Præftantifímum auxilium ad alvi fluxiones apud eam gentem fua adifrictione, habeturi, eoque potu ego olim ibi peftifera febre correptus . cum immoderata diarrhæa biliofa, libentiffime felici cum fucceffu, Egyptiorum medicorum confilio fum ufus. Cum autem volunt, hos fructus non modo roborare, fed etiam alvum folvere, tamarindosipfis mifcent, aut mannam, aut terrengibil. Chinæ radices ex proximis Indiis delatæ ufus apud eos eft familiariffimus, non tantum ad Gallicam lucem, fed ad multos alios innumeros morbos curandos, præfertimque pro emacitatis, atque gracilioribus corporibus. Hujufce radicis recentis ex jure gallinarum nigrarum pinguium decoctum per multos dies propinantes, corpora carne replent, pinguiaque reddunt. Id etenim, præterquam, quod corpora pinguia reddit, cutem etiam faciei fic pulchram efficit, ut fi illiufce vires noftræ mulieres recte aliquando experientia didiciffent, hujufmodi chinæ radix apud nos cariori pretio, fine dubio vendere tur. Raro ligno Indo, vel falfaperilla ii utuntur, ejus regianis merito calorem timentes. Niulieres pauperculæ fumptum pro aliis ferre nequeuntes, vulgares hermodactilos, quitus communiter noftri pharmacopolæ utuntur, modice contoftos, I. 3 ; 


\section{P R O S P ER I A L P I N I}

æque atque nos caftaneas edimus; multos unica vice, ad im. pinguefcendum, devorant, ex quibus neque alvus aliquo pacto turbatur, neque aliud quippiam mali accidit. Hinc noftri pharmacopola fcire poflunt, quantum illis, pro vero hermodaetilo utentes, hactenus erraverint. Egoque hos non parum admiratus fum g çando 2 gyptix mulieres earum radicum (quas fine dubio, modo Diofcoridi credendum fit, Cholchici effe quifque herbarum materiæ peritus fatebitur) per multos dies ad decem, \& plurés etiam euntes dormitum fumpfffe, inftarque caftanearum comediffe, fine ulla noxa ibi frepius compererim. Eft etian illis in ufu frequentifimo femen illud bon abipfis appellatum, ex quo illud decoetum parant, de quo pofterius loquemur. Huic omnes non fecus quam noftri in publicis tabernis, vinorum potationibus, operam dant. De eoque fingulis dicbus fæpe admodum calenti interdiu, fed niaxime mane jejuno ftomacho large bibere confueverunt. Siquidem ipfo ventriculum calefieri, roborarique apud eos compertum fit, non minufque etiam vifcercm obftructiones tolli, quotidie experiantur: Mulieribus ad evocandos menfes præfentaneum eit remedium, apud eafque in ufu eft frequentifimo, quibus diminute fluentibus, ejus decoei probe calentis multum epotant, paulatim modicum forbitantes. Sic enim in ufu eft apud omnes, ut paulatim ipfum deglutiant. In ufu etiam fatis frequenti funt femina lactuce, Altheæ, malvæ, cucumeris, melonis, abdellavi vocati, papaverifque utriufque. Albi quidem femina fanitatis tempore libentifime, largifimequecomedunt. Utuntur etiam fruticis cujufpiam floribus, falicem æmulantis, quem alii ban, alii calaf appellant, ad multos morbos, præfertimque ubi cor patitur; nam ajunt, cor is maxime roborariexpertum effe, fatifque valenter excellentiori putredini obfiftere, febrefque delere. Hincque eis ad peftiferas febres utuntur frequentiffime. Flores etiam alterius fruticis elhanne dicti, qui eft Alcanna Avicennæ, maxime frequentant, ad dolores, caput ex frigida caufa infeftantes. Et quos præterea ex cafiiæ arbore colligunt, pro omnibus leniendis doloribus, maximeque in podagra habent itidem in ufu. Utuntur frequentifime \& feminibus 
pfyllii, maximeque in febribus ardentibus, quorum infufum, feu mucilaginem, in his febribus tutiflime propinant ægrotis. Ex quo profpicitur errare cum Diofcoride omnes, qui pfyllium. venenum effe fcribunt; quando ibi tutilfime nemine ab eo unquam læfo, pfyllium aflumatur. Opobalfami quoque, quod illuc ex felici Arabia legitimum, ac fincerum defertur, ad multa mala ufus apud eos eft familiarifimus, præcipuufque ad mulieres ex uteri frigiditate, atque humiditate teriles, per cly-fterem intra uterum injecti. Expertum eft fæpiffime, ipfum ad id magnum auxilium effe, quibus imbecillus, laxus quippe, ac frigidus eft ventriculus, id per os fumptum maximi effe adjumenti. Ejus fiquidem calorem valde fovet, auget, ac roborat: ex quo ad juvandam concoctionem ceteris omnibus fine dubio præftat. Opii, quod ii affion nuncupant, utuntur hi frequentifime, cui longo tempore fic illi affuefcunt, ut mox, vel trium etiam drachmarum pondus aliqui tuto per os affumere audeant, eo homines duarum horarum intervallo hilares fieri arbitrantur, promptiorefque in obeundis ipforum muneribus, maximeque ad bellum, atque venerem. Ibique vulgus faubulatur, milites in bello, qui eum fuccum fumpferunt, omnes bel. li timorem deponere, ficque ferociores ad fubeundam pugnam fieri, ut quælibet belli incommoda fortiffime ac ftrenuifime deinde ferant. Non pauci etiam funt, qui eum affumentes, opinantur, fe per fomnum varia pulcherrima, amœniftimaque viridaria, atque amatas puellas vifuros, feque cum iis oblecta : turos. Guiland. Nefcio unde affirmes, eam gentem opio, Græcis meconio, atque ab ipfis affion dicto, tuto vel innoxie. uti, quando tu ipfe in libris de prævidendis morbis, à te olim conferiptis, plurima fæviffimaque fymptomata ex ufu hujus fucci concitari feriptum reliqueris : atque ab omnibus tun Græ. cis, tum Arabibus medicis meconium, feu opium, feu affion in numero frigidorum medicamentorum recenfeatur: ALPIN. Haud effe abfurdum, ut homines aliquorum venenorum ufui affuefcant, tibi plane notum eft, præfertim, fi quifpiam eo uti à minima quantitate incipiens, paulatim ac gradatim ad majorem quotidie afcendat, Quod Amus Atbenien $\sqrt{s}$, Galeno bis: 


\section{PROSPER I A L PINI}

verbis in lib. 3. de alimen. facul. docente, cujus percelebris memoria eft; fecilfe dicitur, etenim ea à minima cicutce portione aufpicata, nullo detrimento ad permagnam progreffa eft copiam: principio enim paycim exiguitate ipfa devictum eft, at confuetudo naturale addidit. Multi \&gyptiorum in ifta erronea opinione adeo permanent, ut ab aflumpto opio multa fe per fomnium fpectare imaginentui, atque pro certo habeant omnes opium per os fumentes multa optata viridaria, puellas, \& alia id genus effe fpectaturos. Quot deliramenta læfa imaginatio aliquando in homine pariat, neminem medicorum latere arbitror. Mirumque idcirco haud erit, illos ea imaginatione, quod omnes ufu opii multa videant, dedıctos, eo devorato, fomno graviori captos, quippiam rerum defideratarum ipforum inaginationi objectarum, fomniare. An vero vere quicquam eis opii ufus conducere poffit, non eft, quod tibi perfuadeam, quando te non lateat, ipfum prævalidum venenum effe, ac nullo pacto juvare, \& omnino homini nocere. Negandum tamen non eft, quamplures Egyptios opium quotidie fumentes, nullam noxam fentire, eo longa fcilicet confuetudine à natura fuperato, $\&$ in alimentum quoquo modo verfo. Hincque fieri puto, eos qui ipfum quotidie devorare confueverint, aliqua die intermittentes, hora, in qua affumebant, in graviffima fymptomata incurrere. Animi fiquidem deliquio faftidiofiffimo ipfi tentantur, nulloque auxilio fic tuto liberantur, quam rurfus opium devorantes. Multos ab hac fervitute liberatos vidi, fi in hora, qua foliti funt ipfum capere, largius ex vino cretico, pipere, atque aliis aromatibus alterato potent. Verum etfi ii affirment eo ufu recte fe valere, minimeque lædi, tamen eorum corpora valde frigida redduntur, function efque deteriores fiunt, ebriique, atque torpidi fere perpetuo apparent. Singula, quæ funt à me vifa, ex opii ufu fymptomata, in libris de prævidendis morbis in Ngypto monoriæ proditis, extant, ad quos, qui hac de re plura fcire volunt, nos remittimus. Sed ad rem modo redeo, reliquaque medicamenta ab illis ufitata perfequor. Habent fiquidem alia multa compofita medicamenta, quibus animi gratia utuntur, veluti de opio nune dictum eft. A qui- 
bus per os fumptis inquiunt fe multa per fomnium videre, de quibus, nifi nunc multa decocta, quæ medicinæ caufa ufurpant, expofiturus effem, longiorem fane fermonem tibi fecif fem, cui tamen finis jam eft imponendus. GUILAND. Haud inutile, neque injucundum fore exiftimo, fi antequam ad illo. rum decus te conferas, illa eadem medicamenta, quæ animi gratia ab ea gente affumuntur, edifferas. In memoria fane habeo, dum per ÆEgypti loca olim diverfarer, multos ejufmodi medicamentis veluti ebrios, ac amentes factos, multa capite, oculifque præfertim deliramenta facientes infpexiffe, de quibus aliqui ex Turcis, qui mihi tum ad fecuritatem aftabant interrogati, refponderunt, illos effe, qui herbam animi gratia co. medere affolent, quique etiam confirmabant illos tunc in fomniis multa lætiffima viridaria, amatafque puellas videre. Multaque alia de iis dixere, quæ mihi rifu valde digna videbantur. Itaque de his etiam aliquid aliud te loqui, defidero

$$
\text { C A P. II. }
$$

De medicamentis ab Egyptiis animi gratia ufitatis, quibus sperant, bus devoratis, varia exoptata in fomniis fe vifuros.

\section{A L P I N U S.}

RIUsquam tibi ea medicamenta recenfeam, quibus devoratis multi Esyptiorum fopore capti, varia optata objecta fe videre opinantur, atque iis admodum delectantur: præftiterit, an iftud verum effe queat, nunc ex te in primis addifcere, quando ipforum alii affirment, fi per os affion vel affis, vel bofa, vel bernavi, vel denique bers acceperint, fe plurima pulcherrima viridaria, atque formofiffimas lafcivientefque puellas, quafi fomniantes videre: Atque alii fe illa tantum fomniare ac videre, quæ ipfos valde delectant ita, ut viridariorum vifione gaudentes, eadem in fomniis videant, $\&$ amantes, defideratas puellas, \& milites bella. Hrcque opinio fic ipfos invalit, at$\mathrm{Kk}$ 


\section{8

que ibi tandiu invaluit, ut nunc quamplurimos femper ibi fpečtare poffis illis medicamentis indulgentes. Nec tantum lic ufus in plebe, verum etiam in primatibus, nobilibufque 2 Ėgyptiis retinetur, ibique antiqua confuetudine fit, ut aliquis ad rem aliquam vocatus, volens ejus laborem fubterfugere, neget fe id poffe, quod ea die, atque hora herbam comedere confueverit. Guizand. Cur tu de his loquens, qui ad movendas illas vifiones iis medicamentis utuntur, dixti, herbam eos comedere, proverbio dici, quando ex te quædam electuaria potius, quam herbam illos devorare, nuper audierim? Alpin. Non me latet HEgyptios ad illas concitandas vifiones, pluribus medicamentis compofitis uti, ut eft electuarium bernavi vocatum ex proximis Indiis delatum, Bers, Bofa: fed ad id fimplex herba cannabis ceteris apud illos eft familiarior, quam ea gens affis appellat; quo nomine nihil aliud quam herba fignificatur, quafi: cannabem hinc herbam per excellantiam vocent. Quia vero (ut audivi) prima experientia eas movendi vifiones ex hujus herbæ ufu prodita eft, atque originem traxit, vel quod ipfa promovendis his vifionibus ceteris aliis medicamentis præftet, adagium illud herbam fumendi venit. Sed hæc miffa faciamus, quando ex te nunc audire cupiam, an id verum effe queat, Rgyptios quippe iis devoratis medicamentis poffe in infomniis eas vifiones cernere; an potius hæc ipfis falfa, læfaque ferat imaginatio. Quamobrem tuum nunc erit, quæfita diluere. Guiland. Quid? an non hanc effe fatis jucundam fpeculationem, ipfamque etiam uberiorem fermonem defiderare, quam præfens hoc tempus nobis concedat? verumtamen non finam te omni refponfione carentem abire, qui mihi tantopere confidens, facillime poffe me hanc veritatem cognofcere, arbitraris; fed quicquid eft, quod ego in hac re fentiam, nunc paucis ex me audies. Quod igitur ibi famofiffimum fit, omnes qui ea medicamenta affumunt, multa, ac varia, quibus deleEtantur, objecta fopore captos videre, certiffimam dictorum vifionem quifque fperet, facile erit, ut fibi ipfis omnia fe. vifuros fuadeant, qux famofe illo modo ab omnibus fpectari àffirmantur. Neque immerito, cum à devoratis medicamentis 


\section{DE MEDICINA RGYPIORUM. Lib. IV. 259}

vapores multi concitati, \& in caput delati, ipfum variis modis feriant, ejufque fenfus valde perturbent, ex quibus, iis præfertim, qui vifui audituique deferviunt, fic turbatis, varia, ac multa objecta ex confuetis rebus, communi fenfui, cujus munus eft fibi oblata objecta contemplari, diftinguere, ac judicare, offeruntur. Quæ non modo dormientibus, fed etiam vigilantibus apparere poffunt. Hominibus itaque ab hujufmodi ufu medicamentorum variis modis capite læfo, atque ejus fenfibus exinde turbatis, illis certo multa objecta offerri videntur, quæ vulgus illorum medicamentorum ufu per infomnia fe videre arbitratur, qui tametfi nihil vere videant, tamen ea cernere imaginantur. Vel dicendum erit (quod facilius fortaffe nobis fuadebitur) ufu illorum medicamentorum vitiatam effe ipforum imaginationem, nen fecus quam accidit in melancholicis. Homines fiquidem eo morbi genere correptos, melancholico humore, vel halitu cerebrum invadente læfa imaginatione, varia deliramenta opinari medicis notiffimum eft. Duo in melancholicis obfervantur, quippe primo humor, vel halitus, qui cerebri partem, in qua refidet, imaginatio, obfidet, atquæ lædit, qua parte læfa, functiones imaginatricis facultatis continuo vitiantur, atque exinde homines haud recte imaginantur. Secundo eft illiufce, vel humoris, vel vaporis ater color, quo, ut Gal. docet (quanquam Averrhoes aliter fentiat) fingula illa deliramenta cum timore, \& mærore omnia fiunt. Quæ duo melancholicæ amentix, Hippocrate affirmante, verum charaEterem explicant, quo ab aliis amentiis vere diftinguitur. Hinc igitur à ratione non erit alienum, vapores, vel halitus ex de. voratis illis medicamentis in caput delatos, cerebri membranas ferientes ac lædentes, varia per id temporis objecta, ac phantafmata ad imaginationem deferre pofie, ex qua vitiata imaginatione homines plura variaque deliramenta, veluti melancholici faciunt, videre opinantur. In dormientibus iftud haud obfcure licsbit obfervari: etenim quis ille erit medicus, qui plura variaque fomnia feu vifiones fere fingulis noctibus à variis efitatis cibis, in quam pluribus hominibus fieri, non audiveric? Braffeam percoctam in cibo fumptam, paftinacam, præfertim ca$\mathrm{Kk} 2$ 


\section{0

rote, vocatam, porra, erucam, phafeolos, multaque alia fẹre infinita, varia turbulentaque fomnia facere noftrum latet neminem. Diofcoridefque de hortenfi finilaci hæc fecundo libro memoriæ prodidit, dicens: Siliqua cocta cum femine in oleribus a/paragi modo eftur, urinam ciet, Ë tumultuofa fomnia facit. Unum: vero fupereft intelligendum, filicet quod Egyptii fabulantur, an fieri poffit, ut $a b$ iis devoratis medicamentis ea utique dor:mientes, quæ ipfis valde accepta exiftunt, quæque valde amant, \& defiderant, videre queant; quando omnia vel folia, vel femina, vel radices, fomnia moventia, illa tumultuofa ac melancholica. plerumque faciant, quod fingula hæc fuccum halitumque gignant melancholicum. Quomodo itaque prædictorum ufus amata, atque defiderata objecta illis offerre poterit? Alpin. Hinc proficici putaverim, quia halituum commotione, vel agitatione in cerebrum facta, ea frequentius objecta facultati imaginatrici repræfentantur, quæ aptiora funt, ut ad ipfam facilius. moveantur, ac ferantur, qualia funt hominibus plus accepta, \& cara, quæque ab ipfis plus coluntur atque defiderantur. Hæc fiquidem frequentius memoriam ac imaginationem occupant, ex quo amantes frequenti fomno amatas, ac defideratas puellas. videre, bellaque milites videntur fomniare, atque nautæ naves, maria ac ventos, amata fiquidem \& multum defiderata objecta fere continuo à memoria ad imaginationem moventur, atque ab. hac, adillam, \& rationem. Ad imaginationem ea citius moventur ex motu, quem amor, defiderium, delectatio, ac appetitus hos fequens concitant, hxcque ceteris aliis objectis citius, frequentius, \& facilius internos fenfos movent ac exercent, ex quo aliis objectis familiarius ac frequentius non tantum dormientium verum quoque vigilantibus ipfa imaginationi offeruntur; hine à quiburvis fumptis medicamentis fomnia excitandi vim habentibus amata plufque defiderata objecta ceteris aliis facilius ad imagsinationem moventur. Quam ob caufam ii illis devoratis medicamentis plus amata ac defiderata objecta frequentius in fomniis, atque etiam levifimo, perinde ac ipfi vigilarent, fopore capti videre certo affrmant. GulLand. Satis nos ration nem illarum vifonum, is medicamentis movendo ea medica- 
de Medicina Egytiorum. Lib. IV. 261

mentis movendarum, nunc confideravimus, videmurque de ignotis loqui quando ea medicamenta haud hactenus agnoverimus; proinde præftat, ut nunc de his loquaris. ALPIN. Diximus tamen illa his nominibus apud eam fentem appellari, fcilicet affion, affis, bofa, bernaui ac bers. De affion, quod eft Græcorum meconium, atque noftrorum opium, feu fuccus è nigri papaveris capitibus expreffus, referunt homines, eo devorato, paulo poft hilares admodum evadere, multaque ac varia loqui, fortiorefque ad quæque obeunda munera fibi videri, præterea fubdormientes, hortos etiam \& viridaria multa arboribus, herbis, ac floribus variis perbelle ornata fpectare. Horum vifiones omnibus Mahometis affecis funt acceptiffmæ. Tiunt nihilominus, opium fumentes comatofi, veternof, fereque ftupidi, atque apud omnes inconftantes habentur; modo etenim ajunt, modo negant, cum ipfifque tractare omnes cavent. Joann. Jacob. Manne medicus fane in Aigypto multum verfatus, quique ante me medicinam pro Illuftr. Veneta Natione, magna cum lande ibi fecerat, tres cafus de iis, qui opio uti confuevere, mihi narravit; dixitque cuidam viro, opii ufui aflueto, per Nilum flumen Alexandriam verfus naviganti, cum opium deeffet, ille ftatim egreflus navi, adeo celerem curfum Cayrum verfus tenuife, ut nunquam quifquam noftrum ipfum confequi potuiffet, idque ne in hora folita fumendi opium præterita, in faftidiofa fymptomata laberetur. Secundus fuit Nauta, qui dum fua navi multos Alexandriam veheret, in medio itineris, opio carens in frvifima incidit fymptomata, præfertim in fyncopim moleftiffimam, quibus à viatoribus opio oblato illico fanatus eft. Iterque illud incolumis profecutus eft. Demum alius fuit, qui codem modo opio deficiente, in exitiofiffima fymptomata lapfus, fere mortuus eft, vixque revixit, atque non nifi longiffimo tempore fanus evafit. Hunc fuccum, quo omnes utuntur, ex locis Sajeth, ubi olim 'Thebarum urbs erat præclariffima, deferunt; ubi etenim nigra papavera copiofiffime proveniunt, ceterifque omnibus facultate præftant, ex quorum capitibus fuccum exprimunt, quem fole ficcant, atque ad ufum fervant. Affis nihil quidem aliud eft, ut fuperius quoque $\mathrm{K} \mathrm{k} 3$

di. 


\section{PROSPERIALPINI}

dißum eft, quam pulvis ex cannabis foliis paratus, quem cum aqua dulci miftum in maffam redigunt, cujus bolos quinque caftaneæ magnitudinis, vel plures devorant, à quibus per horam poft homines, qui eos fumpfere, quafi ebrii facti, fuas amentias produnt, atque in ecftafi diu manentes, fuis delideratis vifionibus oblectantur: hocque medicanti genus plebs frequentat, quia viliori pretio ibi venditur. Tibi mirum haud erit, ex cannabis ufu hoc fieri, quando is caput vaporibus replere, atque ferire multum valeat, Galeno in primo libro de alim. facult. docente. Qua mira ejus facultate ifta herba apud ipfos nomen, ut jam dictum eft, affis affecuta eft; quod per excellentiam harbam dicit. Bofa idem, \& plus quam afiis præftare, dicunt, quam ex farina loliacea, \& feminibus cannabis, \& aqua componunt, nihilque aliud quam mafia ex his confecta exiftit. Alii ex his cremorem parant, ut in potu abforbeant. Bernavi electuarium in proximæ Indiæ locis paratur, in Aigyptumque copiofa defertur, cujus Aisyptii compolitionem plane ignorant; ejus tamen operationes videntur admirabiles, tuifque auribus non indignæ; fiquidem ab aftumpta uncia hujus electuarii, homines primo hilares fieri incipiunt, multaque loquụntur, \& canunt amatoria, multumque rident, aliaque deliramenta læta produnt, quæ amentia fere per horæ fpatium, in his perdurat; a qua ftatim iracundi funt, in iramque præcipitantur, effrenefque redduntur, in qua parum perfiftunt; demum iidem fic triftari incipiunt, tantoque moerore atque triftitia, \& timore angi, ut continue plorent, \& lamententur, quæ paulo poft, ab his deliramentis multum feffi fomno correpti, digerunt, ac finiunt redeuntes ad priftinam fanitatem. Hæc in conviviis ab Hiftrionibus ut convivantibus folatio fint, fepiffme fieri confueverunt. Ad mihi hæc narranti, mulier quædam Aisyptia in memoriam venit, quæ à pott. largiori vini cretici cbria, omnia fere prenarrata varia deliramenta faciebat. Frimo enim immodice hilaris fiebat, atque fic tunc amore lafciviebat, ut quencumque virum fibi obvium continuo complecteretur, ac ofcularetur, mox è rifu cantuque ad iram, \& furias fic tranfiliebat, ut cum omnibus rixam habere vellet; ficque lites, \& contentiones fequebatur, ut om- 
nes qui in eadem cum ipfa domo erant, ab ipfa non parum timentes præcaverent. Demum ab his tota in meftitiam ferebatur illo moftifimo, ut confuetudo eft, aftidue deplorabat, cantu illo moeftifimo, ut confuetudo eft, afidue deplorabat, quoufque fomno caperetur, quo ebrietatem plane digerebat. G UILAND. Neque immerito illa fymptomata in illa muliere ex largiore vini generofi potione fiebant. Sanguine fiquidem primo ex vino calfacto, \& multum humectato, qui fortaffe biliofus, vel exuftus effe debebat, nec non adaucto vividioreque reddito, hilaris fummopere mulier oftendebatur, ex quo etiam ubi vini caliditas eximia immodice in illiufce fanguinem egit, multumque ipfum calfaciens, biliofum, atque acutum, fecit, vapores illico acuti mordentes membranas cerebri biliofos ilios effectus concitabant, rixas fcilicet, contentiones, atque furias. Sanguine vero eodem à vini calore fere exufto, admodumque exficcato non ab re in mœftitiam mulier, facta exinde melancholica labebatur. Quam hepar valde calidum ac exuftum habuifie cogito, cujus quidem fanguis exufus, quamprimum à vino copiofo humidior fieret, ftatim ea perinde ac fanguinea evafiffet, hilaris reddebatur, quo poftea à vini calore potente calidiori reddito, ut biliofa, bilis accidentia fentiebat, $\&$ denique intenfiori in fanguinem facta aduftione, melancholica fiebat. Sed cur hæc amplius repeto, teque moror, quominus reliqua jam abfolvas? A L P I N. Bers quoque eft electuarium, quo Fgyptii ad illa deliramenta utuntur, cujus compofito hæc eft. Accipiunt piperis albi, feminum hyofciami albi, an. dra. $\mathrm{xx} \cdot$ opii, dra. x. fpicæ Indæ euphorbii, piretri, an. mitchal. croci. fcr. $\mathrm{xv}$. Contundunt omnia in mortario marmoreo, \& mox cum mellis partibus tribus mifcent, quo utuntur tantum poft fex menfes. Bers uero nomenclatura fanitatem. una hora tantum durantem fonat. Utuntur illi etiam aliis compofitionibus, veluti eft diamufcus, philofopha, Theriaca Andromachi Senioris, \& aliis. Nunc vero is auditis utilius erit, ut ego ad decocta accedam, quæ parantur, tum ad corporum tuendam, tum perditam recuperandam fanitatem, ab illis populis ufitata, à quibus deinceps de fyrupis fermo à nobis etiam? 


\section{PROSPER I A L P I N I}

erit habendus, ut demum de ipforum Theriaca quoque loqui poflimus aliqua ; quam illi ita egregie fe componere arbitrantur, ut ipforum compofitionem aliis omnibus præferendam putent. GuiLand. Recte dicis, \& fpero etiam Solem non occifurum priufquam omnia, quæ fuperfunt dicenda, plane abfolveris, proinde ne fruftra tempus conteramus, nunc perge de propofitis decoctis fermonem habere.

\section{A P. II I. \\ -De decortis, quibus Egyptii tum in Sanis, tum agrotis corporibus utuntur.}

\section{A L P I N U S.}

Dauca funt decocta, qux frequentare illos medicos novi; attamen qualiacunque ea fint, tibi etiam exponere minime gravabor. In frequentiffimo ufu ibi eft decoctum, chaova appellatum, quod ex quibufdam feminibus nigris, fabas imitantibus parare confueverunt. Duobufque modis ab ipfis parari folet; eorum enim alii decoctum faciunt ex feminum nuper dictorum tunicis, feu folliculis, \& alii ex eorundem feminum fubftantia, quod ex folliculis paratur, efficacius quam ex feminum fubftantia elaboratum prædicant. Semen hoc bon vocant, arboremque ipfum ferentem vidi in quodam Turce Bei viridario ex Arabia delatum, quæ evonomo maxime fimilis erat. Illiufce decoctifacultas eft frigida \& ficca, quoad primas qualitates temperata, cui etiam mifta eft caliditas, quando illa femina ex duplici fubftantia conftent, altera craffa \& \& terrea, qua cogunt, \& roborant; altera calida in tenui fubftantia fundata, frigidaque modice prævalenti, qua calfaciunt, abftergunt, obftructaque aperiunt. Horum decoçum cichorei decocto guftu proximum eft, quod tamen ipfo valentius obftructa liberat. Cum ego animadvertiffem mulieres, quibus cœperint fluere menfes, ad eos adjuvandos de eo calidiori femper paulatin multum forbillare, apud illafque omnes adjuvandam eam vacuationem in ufu effe frequentiffimo, cœpi, 


\section{DE MEdicina Eegptiorum. Lib. IV. 269}

illa perdoctus experientia, in omnibus, illo uti, quibus aliquam ob caufam eorum purgatio menftrua deftitifet; quod quidem feliciffme multis eveniffe vidi, exindeque didici hoc genus remedii pro evocandis menttruis ab uteri obftructis venis, effe præftantifimum: Polt univerfalem tamem corporis vacuationem, mane jejuno ftomacho iftud decoctum affumptum efficacifime menfes provocat, temporeque, quo multis cum vehementibus doloribus minutæ difficulter exeunt, eis præfentaneo eft auxilio. Parant autem illi hoc decoctum, fumentes nucleorum illorum feminum, à folliculis mundatorum libram unam \& mediam, eaque parum igne torrefaciunt, contortaque bulliunt in aquæ lib. viginti; aliis finentibus nucleos prædictos torrefactos, ac minutim confractos per diem infuíos in aqua manere; atque alii nulla præcedente infufione eos bulliunt ad confumptionem medietatis; percolatumque decostum ad ufum fervant in fictilibus vafis undique claufis. Eodem itidem modo parant decoctum ex feminum folliculis, in minori tamen quantitate fumptis: Pro quo parando accipiunt alii prædiEtorum folliculorum fex uncias, atque alii novem, in librifque viginti aquæ fontis ad confumptionem medietatis ipfum co quentes. Hoc decoctum ftomacho fummopere conducit; id ii valde calidum, \& effervefcens, jejuno ftomacho paulatim forbentes, potant ad ciathi menfuram, \& eo amplius. Ut autem vino in œnopoliis five tabernis noftrorum multi ebrietatibus dediti indulgere obfervantur, fic illi chaova decocto delectantur, eique indulgent. Aliud decoctum apud illos ufitatum obfervatur, maglub, appellatum. Multæ ibi medicæ officinæ exiftunt, quæ in ea urbe nihil quidem aliud, quam ipfum vendunt, ejus quotidie mane jejuno fromacho femilibram propinant, quod ftomachum maxime juvare ajunt, ipfum calefaciendo, concoctionem adjuvando, flatus diffipando, atque obftructa aperiendo. Ipfum parare volentes, accipiunt feminum fœniculorum, radicum glycirrhizæ contufarum, an. unc. ij. s. cucumerum. s. Altheæ, an. dra. 1. jujubas nu. quatuor, aquæ fontis lib. 3 . bulliuntque omnia fimul ad confumptionem medietatis, \& colatum cum faccharo exhibent. Habent quogue 


\section{PROSPERI A L P I I}

ii nonnullas forbitiones, quæ refrigerant, nutriunt, obftruaetiones tollunt, ac roborant. Harunque omnium hæc eft illis familiariflima, quam maftahaleb vocant, quæ quidem in febribus omnibus præftantifimum eft remedium, maxime vero ad. fitim extinguendam, caloremque febrilem minuendum, atque non minus ad urinam provocandam. Hanc potionem in lateris inflammatoriis doloribus maxime frequentant, quam fic parant, fumentes feminum melonis, abdellavi vocati, unc. 40. hæc etenim ceteris omnibus plus refrigerare creduntur, femin: anguriarum, cucurbitarum, cathe cucumeris, an. unc. I. liquiritiæ mundatæ radicis, facchari candidi, an. unc. I. f. femin. foniculorum, vel aniforum, dra. 3 . contundunt in mortario minutifime omnia, quæ petia linea ligant, ex qua aqua rofacea irrorata lac exprimunt, quod ægrotis propinant. Hoc. genus potionis fic communiter omnes parant, cujus facultaten. variant, variis additis medicamentis, prout variorum morborum, \& caufarum ufus pofcere videtur. Siquidem in ardentibus febribus, in quibus major refrigeratio defideratur, prædiEtis addunt femina endiviæ, lactucæ, pfyllii, portulacæ, al-. borumque papaverum; atque ubi etiam fimul flatus diffolvere: cupiunt, addunt, coriandri, dauci, foniculi, \& anifi femina, atque alia etiam, quibus flatus-diffolvere datum eft. I cidemque dolores mitigare volentes, maftahaleb cum feminibus. etiam altheæ, malvarum meliloti, fcenu-græci, lini, fefami, melochiæ, bammiæ, parant. Ad eofdem quoque dolores mitigandos decoeto ex camomeli, meliloti, ban, caffiæ fiftulæ, atque aliorum floribus parato utuntur. Meftahaleb etiam faciunt fepifime, priori addentes micam panis, vellac amygdalarum dulcium ex Gaza advectarum, quia eas quam aliorum. locorum amygdalas minus calfacere opinantur, vocantque ipfa laux Gazavi; quam potionem in acutis morbis pro cibo multi frequentant. Aliam parant, quæ nutrit, ac refrigerat, fumen:tes furfuris tritici pug. 3. quam ter aqua abluunt, eamque abjicunt, rurfum in nova aqua ipfa eodem modo lota, aquam cum modico facchari candidi, ac aqua rofacea parum bulliunt quam fic paratam calidam febricitantibus bis in die pro prandio, 
\& cona exhibent : alii addunt lac variorum feminum refrigerantium, prout ufus expoltulat. Alii eam in aurora modo ferapiorum fumunt; hæc alit, refrigerat, abltergit, aperit, fitimque extinguit. Ef alia Taluina ab is vocaca, quam parant capientes fermenti opiimi ex farina triticea femunciam, atque aquæ rofacex libran, quam addito faccharo candido, aut lacte amygdal. vel feminum frigidoram, parum ebullientes, parant. Ef etiam favich. apud omnes familiarifima potio pro alendis febricitantibus; quam etiam hoc modo parant, accipientes modicam farinam hordei torrefact, quam cum aqua rofacea difiolutan multum bulliunt, cui poltea faccharum candidum permifeent. Non pauci in victu utuntur farina, amygdalarum dulcium cum aqua rofacea bullita. Superius quoque dictum eft illos in febribus fequi berberorum decoctum, vel infufum, cui interim addunt pulpam tamarindorum, aliaque fe. mina, prout varius in is medendi ufus expoftulare videtur: Non minus etiam in ardentibus febribus feminum pfyllii, atque cidoniorum mucilagine uti folent. pro potu vero non in xgrotis modo, verum multo magis in fanis corporibus hanc po tionem frequentant, quæ fitientibus eft jucundiffima, quam farbet quafi potum per excellentiam vocant: illud etenim nomen, potum, fimpliciter explicat: ipfam parant, in aqua multa faccharum diffolventes, eique admifcentes tantum limonum fucci recentis, quantum modice aquam acidam reddere queat. Hanc aquam in æftivis caloribus omnes libentiffime potant, tum ad fitim exinguendam, tum ad refrigerandum. Nobiles सEyptii; \& Turcæ addunt modicum mofchi, vel ambre. Pro ægrotis febricitantibus, in aqua interim rofacea, ubi febres non carent malignitate, interimque in aqua endiviæ febribus ardentibus obfervatis hunc potum parant. Antiqua confuetudine ibi nobiles $\mathbb{E}$ gyptii, ac Turce fuis in domibus advenas honorare volentes, perinde ac noftri Lombardi vina optima, fic ipfi jam dictum potum propinant. Ibi etiam in uft frequentifimo funt anguriæ vel navi, vel batech elmuja vocatæ; quæ nihil præter aquam, \& femina continent. Domini, vel primates magnam, ac optimam anguriam accipunt, in ipI. 12 


\section{${ }_{26 \delta ึ}$ PROS PERI A L P I N T}

faque foramen faciunt, per quod mufchum, ambram, cum modico rofaceæ aquæ diffolutam intus injiciunt, aquæque anguriæ permifcent. Hæc aqua miræ voluptatis eft omnibus fi: tientibus, febricitantibufque jucundiffima, atque utilifima, quia refrigerat, humectat, aperit, urinamque valenter movet. Hac in renum, jecinorifque caloribus omnes utuntur. Hoc tamen mali iis, qui eam frequentant, facere obfervatur; quippe aquofas maximas hernias parit. Decoctum; quod ex chine radicibus paratum $A$ gyptios fequi dictum eft, tum ad luem gallicam, cujus non minus quàm Itali ac alii, ÆEgytii divites funt, pellendam, tum ad hepatis fanguinifque calores corrigendos, tum maxime in longis tertianis, atque in corrigenda corporum gracilitate. Eft etiam in ufu non minus ad firmandos quofcumque fluxus ex utero; alterata tamen acacia, licio, dactilis immaturis. Atque hæc fuere decocta à me ib i apud eam gentem obfervata. Tranfeo jam ad fyruporum ufum; atque ad medicamenta quibus purgandi gratia utuntur.

\section{A.. P. IV: \\ D. Jyrupis apud Egyptios ufiatis: \\ A L P I N U S ..}

GRUPIS non fecus quam noftri, Egyptii, fani, atque ægro:3 ti utuntur; divites omnes varios fyrupos domi paratos ha bent, quos aqua diflolutos in æftivis caloribus devorant. Uf 1 : tatiores vero apudeosfunt violatus, acetofus, oxymel, rofatus. ex fimplici infufione, vel ex decocto paratus, nenupharinus de pomis, de citro, de limonibus, de omach, quod eft medium inter citrum, \& limonem, de moris acidis, de mirtho, de fándaló, de ligno aloe, atque de dactilis immaturis. Quos omnes tum in folida forma, tum liquida parare ii folent. GurLAND: Memini alias ex te intelléxifle, illos medicos fyrupos ægrotis exhibere, non ut noftri faciunt in aurora, fed ad xgrotantium, afficlentiumque libitum, omnibus, fi libeat; 


\section{DE MEDICINA ËGYTIOROM. LIB. IV. 269}

horis, parum fyrupi miftum aquæ exhikentes. Qui quidem ufus quantum fit laudandus, vel non; alias aperuimus. Omnes fere hos fyrupos fcio noftros etiam mecicos fequi, præter fyrupum, de fandalis, de ligno aloe, atque de dactilis, quibus nos plane caremus, proinde hos mihi tantum narrato. Alpin. Parant fyrupum ex fandalis hoc modo, capientes fandalorum alborum modice flavorum -drach. Io. contundunt craffo modo, \& duotus diebus, in unc. vj. aquæ rofaceæ infundunt, pofteaque colant, \& colatam aquam fervant. Deirceps idipfum fandalum in tantundem aquæ rofaceæ bulliunt ad medietatis confumptionem, miftaque fimul aqua infufio: nis cum aqua decoctionis in ipfa diffolvunt facchari optim libram, atque coquunt dum confiftentiam fyrupi adipifcatur. Parant vero ex ligno alce, accipientes illiufce ligni opti$\mathrm{mi}$, feminum balfami a folliculis mundatorum, an. dra. 2. fpi cæ Indæ, gariophyllorum, nucis mufchate., maftiches, anz dra. I. omnia craffiori modo contundunt, in tenuifimoque lineo panno albo obvolvunt, ligant, atque infundunt in libram aquæ rofaceæ, mox docoquunt ufque ad tertiæ partis confumptionem, atque in colatura diffolvunt facchari optimi libram rurfumque quod fatis eft coquentes, fyrupum conficiunt, cur poftea addunt mufchi orientalis chirat. Hic fyrupus facit ad on nia membra, præfertimque ftomachum; \&:cerebrum, eaque, \& cor valde roborat; ftomachus ad concoquendum eo robuftior fit: ex quo etiam haud immerito experiuntur, laxiori fa: Eto fummopere conducere, atque non minus cordis palpitatio. ni, refolutis, convulfis, afthmaticis, atque aliis morbis itidens maxime fubvenit: Ex dactilis vero faciunt fumentes fucci dactilorum immaturorum lib. ij. s. fueci granatorum acidorum lib. s. facchari optimi, lib. quinque, ex quibus fecundum artem: faciunt fyrupum, quo frequentius utuntur ad ventriculi inteft: norumque relaxationem, arque ad fanguinis fuxum, maximeque ad cruentas expuitiones. Hæcque de Fyptiorun fyrü pis erant dicenda, tompufque elt, ut de purgantibus medica? mentis., quibus ii uti confuefcunt, nunc etiam loquamur. 


\section{$270^{\circ}$ PROSPERI ALPINI}

\section{A P. V.

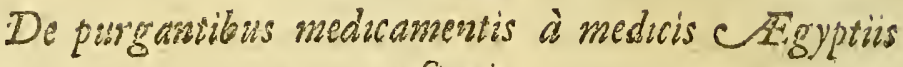 ufitatis.}

\section{G U I L A N D I N U S.}

Trentissime purgantium medicamentorum, quibus ibi ii medici utuntur, ufum ex te audiam. Etenim illos plura ex his familiaria habere, nobis fortaffe incognita, ac nova, quæe noftris quoque medicis valde accepta erunt, tuque, atque alii multi in Occidentalibus Indiis noverunt plura medicamenta, ex REgyto quoque quodpiam novum purgans medicamentum ex te cognitum nobis afportatum erit ALrin. Neque multa ibi purgantia medicamenta novi, quæ ob aliquam fingularem facultatem, atque præftantiam digna tuis auribus putem. Egyptii fiquidem medici, ut alias etiam à nobis dictum eft, medicinæ haud perfecte incumbunt, quod ea apud illam gentem in viliori pretio eft, proinde in is locis plerique medici empirici exiftunt, qui fi quid boni in medendo habent, hereditate potius à prifcis medicis ipfis relictum, quam fcientia acquiftum poffident; ex quo non miraberis in is locis medicamenta plura nova non fuife inventa. Dicam tamen, quæ ibi hifee annis ean gentem pro moliendis corporum purgationibus exercere ac affectare cognoverim. IMedici vero ii, quoad purgantium ufum, Cayri duplici fecta interftincti funt, fiquidem plerique illorum, quique medicinam in nobiles exercent, fic in purgando fe gerunt, ut ab omnibus folventibus fortibus abtineant, timentes in regione fumme calida, corpora à valide fo'ventibus nimis calfieri, vacuari, refolvi, atque labefactari: quare abtinent ab ufu fcamonii, turbith, ellebori utriufque, cataputix, mezerei, efulæ, cucumeris afinini, brioniæ, cyclaminis, colocynthidis, atque aliorum hujufmodi. GuILAND. Horum ufu certe ea cöpora. valde incalefcerent, purgarentur, \& refulverentur, prefertimque quod ex te audivi, ibi pleraque 


\section{DE MEDICINA IEGYTIORUM, LiB. IV. $27 T^{\prime}$}

corpora effe temperata, habitufque moderate carnofi, pinguis, \& mollis, quæ quam facile, \& multum refolvi Gal. in lib. Io. atque etiam II. meth. med. memoriæ prodidit, quod facile humidum per latiores poros cutis diffluat, ac refolvatur. Addo plerofque illorum ftomacho languidiori confare, tum $a b$ ufu frigidorum ciborum, tum à potu aquæ, venerifque $a b$ ufu immoderato. Itaque recte faciunt medici illi abftinentes $a b$ ufu valido folventium, quia omnia valide folventia calidiffima funt, multumque caloris nativi refolventia, ut Gal. in lib. de purg. med. facul. teftatum reliquit. Sed quid clarius Hippocrate? qui fcripfit: Sub cane, Eे ante canem molefta funt purgantia medicamenta. Aftatis vero ambientis caliditatem idem atque calidæ regionis calidam temperiem pollere, nemo ignorat. ALpIN. Non confirmaverim tamen utique id verum effe, cum magis cre: diderim illos haud parum errare, in nobiles omnes ufum lenientium potius quam purgantium medicamentorum exercentes. Guiland. Quid, inquies, illos in regione fumme calida abftinentes in purgandis corporibus à valide folventibus medicamentis errare? vide, ne tu quoque hac de re fis accufandus, atque in majorem errorem labaris. A L P I N. Si potes parumper pati, ut quod fentio loquar, id forfitan haud ita certe affirmabis, atque nos ejufdem fententiæ effe cognofces. Itaque dico non in hoc ftare medicorum $2 \mathrm{Eg}$ gtiorum errorem, quod ibi abftineant $a b$ his fortibus folventibus: hoc enim nunquam aufus effem affirmare, fed quod ii non modo à fortibus abftineant, fed $\mathrm{ab}$ omnibus folventibus. GuILAND. Quid rurfum affirmabis, an nonne folent illi ibi corpora aliquando purgare? qui fi id faciunt an non medicamentis folventibus id præftant? ALPIN. Purgantur quidem in Egypto pleraque corpora madicamentis fic debilibus tum qualitate, tum quancitate, ut humores noxii ä ftomacho, vel primis venis debiliter moveri queant, quæ profecto lenientia magis quam purgantia vocanda funt. Ea vero hujufmodi effe folent, quippe caffia Ksyptia, quæ ibi copiofa provenit, manna, Tamarindi, fyrupus ex granatis dulcibusfolvens; de manna, hre funt is in purgando maxime faaniliaria, atque in ufu frequentifimo, Rarifime folventibus 


\section{$27.2 \quad$ PROSPERI A L P I N I}

utuntur, atque $\ln$ modica, $f$ is utantur, quantitate, qualia funt rhabarbarum, mirabolani, fenna Mechina, Agaricus, \& alia. His aliquando utuntur, fed in exigua adeo quantitate, ut potius humores movere, quam educere queant. Nemo, quidem rhabarbari drachmam unam cum dimidia tranfcendit, vel drachim. agarici, quibus tamen rarifime utuntur, quia tormina concitant, interim, quod rarilime contingit prædictorum, aut fennæ, aut mirabolanorum drachmam cum unicia mannæ, mifcent; vel cum tantundem fyrupi ex manna parati, rel fyrupi ex granatis dulcibus folutivi. His medicamentis loco ralide purgantium utuntur, putantque fic fe purgare polle humoris exuperantis copiam, quod tamen non affequuntur, quia pierique utuntur nuper dictis lenientibus abfque ullo folvente, rarimique funt, qui utrifque commintis, uti velint. Quibus quidem exuperantes humores plurimum movent, parumque vacuant, qui non vacuati tum in venas exiles in motione inculcati, ipfas obftruere poffunt, tum, quod pejus eft, ad nobilia vifcera decurrere poffunt. Sed hic quoque plures medicos $\AA$ gyptios reperiri certo fcio, qui hoc modo purgantes humores interim prævalido pharmaco purgandos, lenitorio moventes, modicumque ex his ducentes fæpius in caufa fuere, ut multi putridis febribus correpti obftructionibus ex humore vi medicamenti per venas attracto, \& non vacuato, adauctis, aut aliis è novo exinde concitatis, perierint. AEgyptii itaque, ut ad rem noftram nunc redeamus, quamquam corpus ipfis fit purgandum, quod vel articulorum doloribus vexetur, vel afthmate, vel vertigine, vel alio morbo, validiori purgatione indigente, unciam mannæ, vel caffiæ cum faccharo, vel fyrupi è munna, aut ex granatis dulcibus, binas vel tres unicias exhibent, qui tamen pluribus vicibus purgant, quotidie, alii, \& alii alternis faltem diebus, alii vero horum vice, quod tamen rariffme faciunt, \& multo cum timore, vel rhabarbari, vel agarici, vel funne, vel mirabol. drachm. offerunt. Multos ego ibi novi febricitantes in eodem morbo pluribus vicibus mannæ, au cuffix, vel libras fumpfife, minime tamen fanatos, qui mox femel tantum prevalide purganti medicamento plurimum pur- 


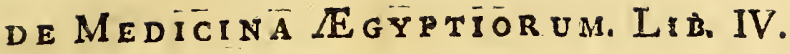

purgati ftatim fani evaferere. Sed his omiffis, tempus eft, ut figillatim de prædictis medicamentis, quibus ad purgandum co modo illi utuntur, fermonem habeamus, eaque primum narremus, quia multa ab his fuperfunt difputanda de illorum purgandi ufu. Guiland. Recte putas, atque à Caffiæ Fgyp. tiæ narratione exordire. Alpin. Caflia fructus eft omnibus notiffimus, de quo copiofius in alio libro dicemus: ipfius duæ obfervantur differentiæ, quarum alterata ex loco, in quo nafcitur , colligitur, quando catfæa aliæ Cayri, aliæ Damiatæ , \& aliæ Alexandriæ proveniant, ex quibus locis variis aliquam etiam bonitatis differentiam præ fe ferunt. Quæ Cayri proveniunt atque Alexandriæ, omnium funt optimæ, duplicique differentia obfervantur, fiquidem aliæ colore nigro rubefcente, qualis in Abiffinis vifitur, atque aliæ nigræ cernuntur: illæ his meliores exiftunt, abifinæque ex colore gentis, vocantur. Utræque funt in frequenti ufu, corticeque conftant tenuiore. Quæ vero Pelufii, nunc Damiatæ, colliguntur, omnium minime utiles creduntur, quia funt corticis craffioris, modicumque pulpæ habent, atque etiam minus ad folvendum efficaces reperiuntur. Quare ex caffiis Abiffina ceteris omnibus merito magnitudine, tenuiori cortice, multaque fubftantia, atque afficaciori folvendi vi præfertur; hac nigra Cayrina inferior eft bonitate, \& omnium minime Damiatina, quæ parva, craffiori cortice, nigriorique colore cernitur. E filiquis extracta pulpa ibi omnes libentiffime utuntur in omnibus mọrbis, ac fymptomatis à flava, atque exufta bile obortis. Etenim ipfam per os fumptam fanguinem, calidofque, ac exuftos humores educendo atque obtundendo, refrigerare, purioremque fanguinem facere opinantur; ftomachum etiam à quibufvis excrementis ipfa exonerari multiplici experientia apud eos compertum eft. In calidis diftillationibus ad pulmones, vel thoracem prolabentibus fumma cum utilitate eam frequentant, interim folam, interim mannæ, ac faccharo candido, vel oleo amygdalarum dulcium miftam, quam fic paratam, atque fimplicem renes, \& veficam fummopere juvare experiuntur. Mannæ vero, qua illi utuntur, quatuor ibi obfervantur differentiæ, 


\section{$27+$

quarum prima eft fimilis grano maftiches, quam noftri maftichinam appellant: Secunda eft adulterata ex amido, faccharo, $\&$ modico mannæ maftichinæ, eqque exiftit, quam noftri vocant bambacinam. Has duas mannæ fpecies Regyptii, atque Arabes Siracoft nuncupant. 'Tertia (terreniabim ab iis dicta) eft rubra, granellofa ex Armenia afportata. Quarta eft quidam liquor, ut mel, qui interdum condenfatur, colligiturque fupra arbores montis Synai in Arabia deferta à Reverendis monachis Calojeribus, eum montem habitantibus eamque confulibus, Cayri degentibus illi offerunt, quid magnum ipfis donare opinantes. Hanc vocant terrengibil. Ufus cujufvis dietarum fpecierum non differt à noftrorum medicorum ufu. Apud illos maxime commendatur maftichina, quæ ad purgandos omnes humores in ufu frequentiori habetur, præfertimque in affectibus pectoris à calida caufa concitatis, \& in fiticulofis. Namque ipfam inflammationes mitigare, febriumque calorem, atque fitim extinguere, atque alvum mediocriter fubducere teftantur: Ejus vero quantitatem idoneam fic metiuntur, ut pro fingulo anno drachmam exhibeant, afcendunt vero in totum ufque ad binas, vel ad plus ad tres unicas in adultis. Tamarindi non minus apud ipfos in ufu exiftunt, quam fit caffia, \& manna. Quorum duplex genus ibi obfervatur, alterum, quod ex regione Sahit defertur, atque alterum ex India; hoc alteri bonitate præfertur. Indofque tamarindos bazzi appellant. His ÆEgyptii utuntur frequentiffime in morbis calidis, ficcifque à flava bile ortum ducentibus. Siquidem hunc humorem commode ac jucunde vacuant, fitimque omnium maxime extinguunt. Ipfis vero utuntur infufis ; infundunt enim ipfos in aqua fimplici fluminis Nili, vel ftillatitia cichorei, vel endiviæ, vel fonci, vel alterius hujufmodo qualitatis per feptem horarum fpatium, aquamque percolatam cum faccharo, febricitantibus fiticulofis propinant. Non defunt, qui fubito infufis tamarindis exemptis, aquam cum faccharo epotant. Pauciffimi funt, qui cos bulliunt, verum non nifi binis, vel tribus ebullitionibus: ibi quoque tamarindi non fecus quam nuces mufchatæ, aliaque aromata, condiuntur, faccharo conditos aflumere confueve- 


\section{DE MEDICINA LEGPTIORUM. I.IB. IV. $275^{\circ}$}

runt, qui funt etiam guftui jucundifimi, commodeque biliofos humores purgant. Sic conditos plures fecum in longis itineribus deferre folent, præfertimque per defertæ Arabiæ loca iter facturi, quando iter facientium corpora ex longo itinere, folis calore inflammata, ufu tamarindorum juventur, quoniam ipfis non modo fufceptum calorem comtemperant, verum etiam, quod non fic facile eft iter facientes per ea loca arenofa, ac à Sole inflammata homines à fiti non cruriari, fitim extinguunt. Sæpe etiam tamarindis fructus berberis addunt, ubi præfertim roborare, ac adftringere volunt, quæ duo fejunctim in aqua infundunt, moxque utriufque fimul miftum infufum propinant, ei fæpe addentes mannam maftichinam, vel terrengibil, in petia ligatam, hæcque potio jucunde alvum fubducit, à biliofifque humoribus exonerat. Frequentant non minus fyrupum folutivum ex granatis dulcibus paratum, quorum fuccum ibi habent dulciffimum. Parant vero fyrupum iftum, capientes ejus fucci dulciflimi libram unam ac mediam, quem bulliunt ad confumptionem tertiæ partis, cui alii mannam, alii amidum, alii penidia, aliique julep addentes, fyrupum conficiunt. Utplurimum vero parant, accipientes fucci illiufce ebulliti libram, mannæ maftichinæ libram femiffem, julep violati, unc. 4. Quæ mifcentes fyrupum conficiunt. Hunc dicunt alvum lenire, biliofos humores vacuare, atque fanguinem refrigerare. Utuntur etiam fyrupo folvente ex manna parato, quem parant ex mannæ drachmis centum, aquæ drachmis quinquaginta, mellis defpumati drachmis decem, parumque fimul bullientes, fyrupum conficiunt. Prædictorum fyruporum exhibent adultis ufque ad tres uncias. Hæc igitur funt medicamenta, quæ ad purganda nobilium corpora in ufu frequentiffimo apud eos, qui fe primates medici profitentur, atque vera purgandi methodo uti opinantur, exiftunt. Dicunt enim is fe corpora blandiffime purgare, adprimeque hunc purgandi modum is corporibus conducere, nihilque noxæ inferre. Ubi volunt infignem aliquam moliri purgationem, unciæ mannæ addunt binos fcrupulos, vel ad plus drachmam rhabarbari, vel agarici; vel fennæ, vel mirabolanorum. Interim vero prædictorum pur$\mathrm{Mm}_{2}$ 


\section{PROSPERI ALPIN I}

gantium medicamentorum drachmam cum faccharo rofaceo Iniftam exhibent. Hos medicos iis blandioribus medicamentis corpora nobilium purgantes, veram medendi artem callere cives omnes, ac nobiles exiftimant, hofque prædicant, atque ufque ad fydera ipforum præftantiam tollunt. GuILand.. In memoria habeo, jejuno, ut ita loquar, purgandi modo, prifcos illos, doctiffimofque medicos cœpiffe uti, non ut illum ex arte optimum crederent, fed ut multas contumelias vitarent, quibus recte medentes fæpe, ut ufus requirebat, illorum corpora purgantes valioribus medicamentis, ab illa barbara gente afficiebantur. Nam infignes purgationes illi damnabant, quæ $f i$ aliquando quibufdam torminibus iis medicamentis operantur, veh miferis illis medicis, quorum aliqui verbera etiam in mercedem accipiebant. Hincque blandis illis uti medicamentis ipfi coperunt. Hocque non ex te tantum, fed ex pluribus aliis, dum Cayri olim moram facerem, audieram. Alpin. Hic jejunus purgandi corpora ufus, apud primates medicos, ut jam dictum etiam eft, qui nobilibus tantum medentur, in ufu eft frequentiffimo, quem ii omnes libenter fequuntur. Alii vero, \& non pauci in urbe Cayri exiftunt, qui oppofito modo corpora purgant: hi etenim corpora non nifi prævalidiffimis purgantibus vacuant, qualia funt fcammonium, colocynthis, multaque femina validiffime purgantia, quæ apud eos in maximofunt ufu. Qux medicamenta in magna etiam dofi audacifime: plebeis, rufticifque concedunt. In ufu apud aliquos fimiles empiricos, \& audaces medicos quædam femina exiftunt, qux immodice per vomitum, \& per feceffum purgant, funtque his omnibus ufitatoria, quædam minutiffima caulium feminibus proxima; ex his enim unciam, qux eft communis adultorum dofis, craffo modo contundunt, ex quibus cum aqua miftis. maffam conficiunt, quam ægrotis devorandan offerunt; hoc enim inopum remedium eft, quod non fecus quam antimonium valide purgat. Cuidam mulieri Turce publicæ per eam urbem. pro mulieribus hyftericis medicinam facienti, hæc funt famihariffạma, quibus dicitur multas divicias fibi ipfa paraviffe, apud omnefque creditur doctifima. Fateturque fe morbos mu- 
lierum omnes recte fanare poffe, virofque minus illorum morborum cognitionem habere polle, quod non liceat ipfos oculatim pudendorum partes omnes mulierum fedulo obfervare, ex quo ignorant ææpifime multorum uterinorum affectuum caufas. Hanc mulierem, medicam ipfe novi, mihique fuit valde familiaris, pulchraque atque perliberalis vifa eft, noftrifque fatis perbenigna ac faceta. Aliqui femine utuntur abdelmeluch vocato, quod præftantius quam catapotia purgat, \& aliqui feminibus abdeleherua appellatis, quæ funt ricini Arabici femina, alii fcammonium exhibent ufque ad drachman, alii utroque helleboro præfertimque nigro, colocynthide, turbith, \& aliis hujufmodi generis, quæ validiffime purgant. Sed jam hoc empiricorum ufu, prævalide purgantium, fermonem claudamus. Ex quo animus cupidus effectus eft, dignofcendi ex te, an in curandis morbis longis, contumacibufque laudabilior fit ufus leniter ac benigne purgantium, quam eorum, quæ prævalide purgant. Quando fapientiores medici leniter purgantium, qua medicamenta benedicta appellant, ufum libentius fequantur, quam valide purgantium, dicantque corpora nunc non fic, ut olim effe robufta, quæ valida medicamenta ferre queant: atque è contra antiquiores ac eruditiores, ut Hippoc. Gal, Avicenna, atque alii valididorum medicamentorum ufum femper fecutos fuiffe, ipforum monumentis plane conftet, non minufque hoc tempore fre ignara muliercula, quem nunquam plures doctifiimi medici medicamentis benedictis fanare quiverunt, unico nuper dictorum prævalidorum medicamentorum medicamento, curarit. Qua in re valde ancipiti tuæ opinioni acquiefcere volo, quam nunc audire, \& cognofcere ex te fummopere expecto. 
${ }_{278}$ PROSPER I ALP I N I

\section{A p. VI.}

Uter nobilium, vel plebejorum Egyptiorum purgandi ufus fit laudatior, five an purgando medicamenta leniter vacuantia pre validioribus preftent. G U I L A N D I N U S.

T Trumeue purgandi ufum $\mathbb{E}$ gyptiorum inutilem judicandum cenfeo, quando neque lenientibus, benedictifque appellatis illis medicamentis corpora omnia recte purgari poffint, neque minus imbecillium, mollium, pinguium, rarique habitus corpora valide purgantibus tuto vacuentur; facile fiquidem ipfa ab his nimium refolvuntur. Exindeque neuter illorum purgandi ufus mihi laudandus plane videtur. AlPIN. Hinc nobis data occafione, libenter ex te intelligerem, cum tu apudantiquos celeberrimos medicos medicamenta in ufu fuiffe ad morbos curandos validiffime purgantia, cognoveris, qualis fuit uterque helleborus, fcamonium, colocynthis, peplium, atque alia hujufmodi, nunc vero non modo in $\$$ Eypto, fed in toto terrarum orbe plerique medici ufum leniter purgantium libenter frequentant, utrum valide purgantium medicamentorum ufus, leniter purgantium ufui in morborum curatione præftet. GuILAND. Mirabar ni mihi tam arduam inter medicos litem refolvendam nunc indicaffes, quafi meos humeros, quidvis ponderis geftare poffe arbitreris. Nolo tamem hunc laborem fubterfugere, quo te tantopere meo judicio delectari nunc fciam. Itaque mea hac de re hæc erit jententia, quam non audies, nifi prius aliqua clarioris cognitionis gratia tibi prædixero. ALpin. Recte fane, nam fine aliqua diftinctione non poffe refolvi quæfitum puto. Guiland. Id ipfum arbitror prænofcendum: etenim jam novimus prævalida medicamenta robuftis corporibus convenire, minimeque imbecillioribus, quanquam eosipfa morbi quoque magnitudo poftularit, eodem itidem modo leniter purgantia robufta corpora parum juvare affirmandum erit: vidi enim multos ab affumptis leniter purgantibus, nihil aut parum 
purgatos fuiffe, \& aliquos etiana ex purganti pharmaco non invalido parum dejeciffe. Quamobrem non omnibus corporibus eadem purgantia convenient, fed variis utique varia, ut $\mathrm{Gal}$. in 4 . de rat. vict. in morb. acut. teftatum reliquit, quandoqiidem corporum habitus, temperamentum, fexus, ætas, victus, cœlum, anni, tempus, varia purgantia admittunt. Cui etenim dubium, corpora habitu pingui, ac carnofo, difficilius purgari, quam gracilia: \& frigidi temperamenti exiftentia, quam calidi, \& denfi habitus, quam rari, \& duri quam mollis, \& rarioris molliorifque qualia funt puerorum, valde à medicamentis refolvi, \& quæ frigido conftant temperamento, quam calido facilius ferre ea medicamenta? proinde validiora pharmaca requirere, \& calida corpora præterquam, quod citius refolvuntur, magis etiam ab his refolvuntur. Zarotus medicus doctiffimus, mihi olim affirmavit, cum in Tranfylvaniæ locis aliquot annis diverfaretur, quamplurimos non nifi à prævalidiffimis medicamentis vacuatos obfervaviffe, ex quo ipfe non nifi prævalida purgantia ibi in omnibus eorum locorum accolis medendo exercuifle dixit. Eodem quoque modo mulieres molles, ac rari habitus, plufquam viri à purgantibus medicamentis labefaetantur. Atque ex ætatibus pueritia, \& fenectus difficilius purgationes ferunt. Itidemque crapulis indulgentes, diff. culter purgantur. In cœlo itidem calidiori omnibus corporibus purgationes difficillimæ exiftunt. Hippocratefque hinc dixit, fub cane, \& ante canem moleftas effe purgationes. His itaque præauditis, rem propofitam facilius refolvemus. Omnibus igitur corporibus, ex quacunque caufa facile refolubilibus, præfertim in calido coelo degentibus, medicamenta leniter, \& non valide purgantia conducent, ex quo, illos $\mathbb{E g y p - ~}$ tios, qui purgando nuper dictorum feminum, \& aliorum validorum purgantium ufum frequentant, errare cognofcimus. ALpin. ligitur ufus purgandi olim prifcis medicis familiaris (utebantur enim ii ad purgandum fammonio, colocynthide, helleboro, peplio, atque aliis validiffimis purgantibus) illo, quem noftri nunc medicamentis benedictis appellatis exercent, minus utilis cenfendus erit; Guiland. Apud Hippocratem hellebo- 


\section{PROSPERI A L P I N I}

rum album fuife purgans familiariffimum cuilibet noftrum no. Text 27. tum eft, quod in 2. lib. de fracturis, \& quarto Aphorfm. maAph. 13. nifertiffime legitur. In lib. etiam 2. de rat. vict. in morb. acut. 14.15. 16. in pleuritide, ubi dolor aliquando ad hypochondria defcende-
Text 2. comm. 3. rit, ufum nigri hellebori, ac peplii commendavit; \& Gal. in Texc. 29. quartana febre album helleborum in lib. 1 . ad Glauc. utilem effe docuit, etfi ipfe in 6 : lib. epidem. affirmaverit, ipfum effe violentiffimum purgans, Familiari Galeno medicamenta purgantia, utpote quæ apud ipfum in ufu fuerant, funt catapocia ex aloë, colocynthide, fcammonio, ab ipfo olim parata, quæ de-

Cap. 8. voranda dedit homini habenti linguam prætumidam, ut in lib. 14. meth. med. legitur: atque etiam confecta ex aloë, colocynthide, fcammonio, agarico, bedellio, \& gummi Arabico. Quorum ufum in tuffientibus a falfuginof humoris diftillatione ex capite ad pulmones, lib. 5. meth. fummopere commenda-

Cap. 14. vit. Quæ quidem Catapocia, in libro de remediis facile parabilibus, ad pfydracia, atque alopeciam laudavit: hæcque compofuit, ut in 3 . lib. de remed. facile parabil. colligitur, ex aloës unciis fex, maftiches, unciis duabus, totidemque abfynthii fucci: colocynthidis unciis quatuor, hocque medicamentum appellat catapocia ex aloë, \& paratum ex aloë, colocynthide, feammonio, agarico, atque aliis, vocat hyeram diá no $\delta$ s. Hæc enim medicamenta validiffime purgantia in ufu fuerant apud Hippocratem, \& Galenum medicorum omnium facile principes. Hinc à nobis fciri poteft, apud ipfos non medicamenta leniter purgantia, fed valide purgantia ad vacuanda corpora in ufu fuiffe. Alpin. Vera loqueris, fed ii benedictis appellatis medicamentis à nobis cognitis carentes, cogebantur illis uti, quæ validiffime purgant. Guiland. Hoc verum nunc concedatur, nilhilominus in temperatis corporibus, quæ non ex multa copia, neque admodum ex tenacibus ac craffis humoribus ægrotant, validiffime purgantia, fimul cum humoribus carnem liquantia, bonæ humiditatis non parum educent, veluti in Cacochymis, malorumve fuccorum, ubi multi impacti, infarctique funt, tenaces ac craffi fucci in vifcerum meatibus, leniter purgantia nunquam poterunt radicitus univerfam purga- 


\section{DE MEDICINA EGYPTIORUM. LIB. IV. 23I}

re humorum copiam. Fruftraque volentes multos in vifceribus infarctos fuccos tenaces ac craffos educere, tentant illos lenicer purgantibus vacuare, vel aliis à noftris medicis ufitatis, quibus raro, vel nunquam morbum à multis, \& tenacibus illis fuccis ortum, perfecte fanant: Quod videre poffumus in multis diuturnis febribus, quotidianis, tertianis, \& quartanis. In iftis fæius obfervavi humores noxios ab affumpto leniter purganti, potius moveri, quam vacuari, plurefque fic agrotantes his leniter purgantibus fæpe in eodem morbo devoratis, potius faftiditos, quam curatos vidi, quos fæpe quæpiam indocta muliercula unico pharmaco validilimo, non fine doctiffimorum medicorum dedecore, perfecte fanavit. A L I I . Non omittam hoc loco hiftoriam plane tua dicta confirmantem. Cayri erat Helena Chriftiana Cophta, annos nata triginta, cui à fuppreffis menftruis purgationibus caput fæviffimis doloribus lædebatur, eoque ipfa moleftiffime cruciabatur, vigiliifque affiduis cum aflidua tuffi, atque orthopnæa mifera etiam detenta, quæ vix recta cervice refpirare poterat, perdoctaque ab amica muliercula, ac plane fuafa, antimonii præparati grana quinque devoravit, à quo medicamento in primis vomitu multa cruda, pituitofa, craffa, ac vifcida excrementa rejecit, \& mox biliofa, viridia, \& tandem æruginofa, atque atra multa, eadem per alvum dejecit, ex qua vacuatione ftatim fic bene fe habuit, ut nocte tota infecuta dormierit. atque quieverit, è tuffi, orthopnæa, capitifque dolore plane fanata. Plurefque alios vidi ibi hujufmodi valentibus purgationibus à morbis fere incurabilibus fuiffe fanatos. GuILAND. Atque his malis nos non fic ex arte medemur, ut antiqui faciebant, utentes prævalidiffimis purgantibus: volentes potius noxiorum humorum copiam vacuare, etfi non fine ægrotorum moleftia, infignes hæ vacuationes operarentur, quam ab ea naturam devinci, \& non tentata valiela purgatione, finere exitium fequi. Multi ex medicis reperiuntur, qui ægrota corpora præ manibus habentes, ’̀ craffis, tenacibufque multis fuccis in vifcerum meatus, cavitatefve infarctis, curanda, dubitantes poffe omnes illos humores wacuari, naturamque ægrotantium, vel vires non recte præva$\mathrm{Nn}$ lidum 


\section{PROSPERI ALPINI}

lidum purgans perferre, prius finunt naturam copia humorum vinci, quam purgationem tentare, vel experiri velint, quod tamen poftea fæpe viribus morbo imparibus factis, non fine maximo ægrotantium detrimento facere coguntur. ALPIN. Fortafle hine non femper abhorrendas prevalidas purgationes, colligitur; quinimo magis illas quandoque ægrotis multum conAphor.13. ferre; Quod Hippoc. in primo lib. Aphorifin. docuife vifus eft, cum dixerit: Dejectiones non multitudine funt exiftimande, fed fi talia dejiciuntur, qualia conveniunt, $E^{2}$ cegri facile tolerant, atque ubi ufque ad animi defectionem expedit ducere, faciendum". fil eger poffit tolerare, Ë multo magis; cum ejufdem omnino fententia Gal. in Commento fuerit, dum dixerit; in maximis etian: inflammationibus, Eo vebementiffimis doloribus mullun majus novi remediunn, quam ufque ad animi defectionem evacuare, adbibitcs diftinctione an mittere fanguinem; an purgare oporteat ufque ad amimi defecitonem: Gumband. Multos jutvalfe infignes, ac etram immoderatas validiffmis purgantibus præftitas vacuationes, nor raro multis obfervatun eft. Plures inveniuntur, qui vel fti-: bium præparatum, vel reris infufum fumpfere, ut ab antiquis hepatis, lienifque obftructionibus fanarentur, quibus per vomi$\mathrm{tum}$, \& alvum copiofiori facta vacuatione, priftina fanitas reftituta fuit, qui nunquam pottiere alits uf medicamentis leviter purgantibus fanari. Ex quo forfitan fufpicandum eft, apud Hippocratem, aliofque ejus temporis medicos doctiflimos, vesatrum aibum fniffe in ufu familiariffimo, quod morbos brevi tempore, ac perfecte humorum noxiortm multitudinem, vifceribus, atque alis internis partibus tenaciter adhærentium Aphor.23. Ar ta Hippocratis Galenique preceptum in primo lib, ÁphoIfin. menoriæ proditum in nedium quoque attulifti, qui ambo docnerunt, corpora aliqua interdum etiam ad animi ufque defectionem purgari pofle. Quorum fententia fic omnes fere noftros medicos diftorfit, ac turbarit, plerique ipforim nune contendant, illiufce Aphorifini proceptum Hippocrate dignum non effe, quoniam in ea non funt fententia, ue imnoxie purfint corpora unquam ad animi defeclionem pargari, neque 
DE MEDICINA ERYTIORUH. Lib. IV. 283.

id ex arte medicos facere nullo pacto debere affirmant ${ }_{y}$ neque $\mathrm{fi}$ fiat tutum effe: Qui tamen, ut tantorum medicorum fententiam fervarent, plurima commenti funt, alii fiquidem dicentes, communi quadam ratione, \& non proprie ab his dictum. fuiffe, vacuationem aliquando ad animi ufque defectionem moliri polle, \& alii verborum feriem pervertentes, negant hæc yerba, ad animi defectionem, in antiquis Codicibus reperiri, atque alii Hippocratis Aphorifmum corruptum fuife affirmant. Quem fic quoque Galenum interpretatum fuiffe, cujus mos elt, fic ut jacent, Hippoc. textus ac verba commentari. Nonnulli etiam opinantur, licere aliquando corpora purgari ad animi defectionem, at per defectionem, non exquifitam fyncopim, quæ refolutis fpiritibus fit, fed levem quidem animi defectionem, quæ frepiffime affumptorum purgantium qualitate, vel ab humore acri, ore ftomachi læfo, vel etiam in inteftinis, dum mucofi acrefque humores ab ipfis evelluntur, atque tranfeunt, torminibus quibufdam concitatis, vel etiam à quapiam levi re. folutione vacuationem infignem fecuta, excitatur; qualem quifque noftrum in praxi in multis purgationibus aliquantulum majoribus, quam par foret, vel à medicamenti., vel ab humorum qualitate infefta, in ftomacho, vel inteftinis angorem, vel tormina concitante, fæpiflime obfervavit. Plures fiquidem ab his caufis etiam à non prævalido purgante in fyncopim fæpelabuntur. Hincque fit, quod omne prævalidum purgans aliquam defectionem pariat, aliqua fpirituum refolutione facta, aut ab ejus infefta qualitate; uti in helleboro, fcammonio, ftibio præparato, aliifque fimilibus medicamentis obfervatur. Ufum prævalidi purgantis, ubi ajunt, ad animi ufque defectionem purgandum efle, Hippocratem atque Galenum intellexiffe, quale veratrum erat Hippocratis tempore, quo omnes femper cum vacuarentur, lipothymia aliqua corripiebantur. Omnefque medici ftibium, æris infufum, fambucum, camelæam, fcammonium, aut aliquod ejufmodi validiffimum purgans exhibentes, præmonent ægrotos purgandos, fore à medicamenti vi prævalida, atque ab ejus infefta qualitate ftomachi angoribus, tormiribus, atque aliquando animi defectionibus medicamento coo- 


\section{PROSPERI A L P I N I}

perante, tentandos. Itaque per purgationem ad animi defectionem faciendam infignem, ac copiofam, quæ fit prevalidiflimo purganti, Hippoc. Galenumque intellexifie multis hinc perfuafum eft. Quæ dum fit, multi levi lipothimia corripiuntur. Neque alienum à ratione, \& experientia effe puto, quoftam copiofis ac infignioribus his purgationibus juvari poffe, præfertinx robuftos, eas tolerantes, maximeque à vehementiffmis inflammationibus, ve! doloribus ex copia humorum exortis cruciatos, quippe copia moleftantis humoris prorfus vacuata, dolores tolluntur, atque inflammationes fanantur. Et quamquam non æque facile, perinde ac fanguinis mifio, purgatio fifti firmarive poffit, nihilominus, non eft ex his, quæ fieri nequeunt, etfi quandoque valde difficile, fluentem alvum firmare, ac fiftere. Quapropter, ut tandem quafitum dubium refolvam, in omnibus antiquis morbis, qui à tenacibus multis fuccis, obftructionibufque vifcerum pertinacibus, oriuntar; in tumoribus, fufpiriolis, afthmaticis, in antiquis doloribus, præfertimque articulorum, in chronicifque febribus, atque in alins fimilibus morbis contumacibus, dummodo robur corporum admittat, prævalidorum purgantium ufus, leniter purgantium ufui præferendus videtur.: In debilioribus vero corporibus prævalidas vacuationes ferre nequeuntibus res ex oppofito creditur : fiquidem his leniter purgantia magis conferent, etiamfi morbi caufre validum purgans expofeerent. non fecus quam in mittendo fanguine nos fape obfervamus, in is, quibus morbi ratione plurimuin fanguimis effet vacuandum, viribus, vel ætate, vel alio renuente, farguinem mittimus in pauciori tamen quantita. te, qui tantum commodi iltis affert, quantum nuper dictis debilibus corporibus leniter purgantia; fi enim maximan ferre poEurfent vacuationem, majus quoque eis commodum accederets proinde juvane, quæ non inopportuna quancitate fint vacuationes, quantum jurare pofunt. Alpin. Verum dicis, nan que, ut alias tu quoque narrafti, ego etiam multos vidi à diturumsis ex capite in pumones difillationibas languidos, ac pene tabidos effectos, ac redditos, ut vix eorum falus amplins fpezari potuerit nihil per longum empus a benedictis ullis woeatis 
DE MEDICINA EGPTIORUM: LIB. IV. 28;

purgantibus juvatos, femel à devorato fcammonio, vel ftibio, vel colocynthide largiffime purgatos, continuo fanos evafiffe: Ceterum hæc medicamenta requirunt medicum non minus doEtum, quam prudentem, ut quid opus fit, fcice, ac prudenter videat: fed nunc fatis de his locuti furnus, tempurque eft, ut ad alia tranfeamus: fed quid de aquæ potu poft devoratuni purgans, à quibufdam recepto, judicabis?" Gulland. De eo nunc etiam quæpiam à nobis dicenda erủnt, fed clarius antea tunc mihi ufum manifeltes, ut rem apertius tractemus.

$$
\text { C A P. VII. }
$$

Apud nonnullos cEgytios in ufu effe ab affumpto pur: ganti medicamento, frigidam multain propinari.

\section{A: L P I N U S}

1 IDrculos fane hic ufus ac valde-barbarus tibi videbitur: quippe medicos illos non paucos ab affumpto ftatim purganti medicamento, ægrotis multam frigidam aquam bibendam propinare. Ego unum hoc ex ea fepias obfervavi, levif: fimo medicamento, infignem per alvum vacuationen fieri: Multi illoram confuefcunt ex omnibus niedicamentis purgantibus, caffiam, mannam, terrengibil, fyrupum de granatis fo: futivum, atque ex manna paratum cum aqua exhibere: in primis quidem caffiam, vel mannan, vel aliua nuper dictorün' medicamentorum ægrotis offerunt, paulo poft aquam propirantes frigidan, alii ejus binas, vel tres libras, atque alji quantun ægrot bibere queunt, concedentes a." ex qua fæpe ego, etfr $a b$ ea alvus turbate multa dejecerit, tamen multos pene inortuos, toto corpore ea "cafa inmodice tumefacto, veTiementiffimifque doloribus lacerato, confpexi. Malis quo que rưfus poft affumptam mannam ad hinds líbras perhau fia, alvum abfoue multa moleftia fundurtam dejeciffe, atque contulffe vids. Quod fortafe accidebat, quia aqua Nif fib

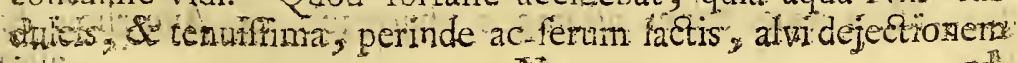


adjuvabat. Guiland. Barbarus, ac fumme periculofus ufus mihi videtur, à nulloque imitandus, quinimo ab omnibus abhorrendus, neque etfi aliquos commode, ac utiliter eo purgatos fuifle dixeris, aliquid boni habere putaverim, quod cafu. eos fic purgatos fuifie certus fim, aqua fiquidem omnis quamquam optima fit, omnique culpa vacet, ut Gal. in 3. de vict. rat. in morb. acut. docebat, tarde meat, difficile concoquitur atque xgre defcendit: quonam itaque modo aqua poterit vim purgantem medicamenti fovere, atque augere? atque fi ex ipfa aliquando commode quofpiam purgatos compertum fit, in caufa fuiffe, vel ab ea cruditas concitata, vel natura ex multitudiné aquæ excitata intempeftive ad expellendum. A LPIN. Nihilominus ego fum hujus fententiæ, quod ipfa, quæ eft omnium aquarum, ut alias demonftratum eft, \& tenuiffima, \& maxime concoeta, modice fumpta poffit commodam alvi dejectionem adjuvare, multoque magis, quod omnes aquæ $\mathbb{E g y p -}$ ti aliquid nitri fapiant: tota etenim $\mathscr{E}$ Eypti terra nitrofa, ac falfuginofa eft, proinde aqua quoque illiufce fluminis fupra terram, nitrofam tranfiens, aliquantulum in fe nitri naturæ retinere potuit, quamobrem aqua illa fubducendi, vel abftergendi quapiam facultate prædita fit, cujus rei fortaffe non fpernendum hoc erit argumentum, quod omnes advenæ, cum primum Cayrum acceflerint, eaque aqua in potu ufi fint, per multos dies diarrhæam copiofam patiuntur; hincque etiam ipfam fortafle, præterquam quod probe in tam longo itinere $\dot{z}$ Solis calore concocta eft, etiam aliquantulum nitri habens, ventriculi calorem non fic labefactet, neque fit ita ipfi ftomacho molefta, ut alibi, percipitur. Averrhoes etiam in lib. 7 . collig. dixit: Et quantitas, quam dare debes, ex rheubarbaro, eft $\dot{a}$ duabus dracbmis ufque ad tres, miscendo ei fyrupum julcb, छे Squinzibim an. minica una, cum quinque partibus aqua frigida. Atque hoc fortaffe idem invenietur apud Avicennam, Haly, atque Rhafim, \& alios, qui interim aquam poft purgans medicamentum frigidam dare præcipiunt. Guiland. Poflet quidem aquæ Nili fluminis ineffe talis vis, fed tu hac non contentus, ufum aqua etiam affumptis pharmacis ex Averrhois \& 


\section{DE MEDICINA AGTPTIORUM. LIB. IV. 287}

aliorum Arabum præclarifimorum medicorum tertimonio pro: bare videris: quod fi ita eft; animadvertas velim, Averrhoem, atque alios Arabes medicos, aquam frigidam dandam illis tantum confuevife, quibus præ caliditate itomachi periculum eft; ne vel vomant medicamentum, vel in fyncopim ferantur, ut manifeftifime cuique fedulo prædictorum fcripta aninadvertenti, \& ipforum mentem percipienti, notum erit, fed ce hoc ufu hæc dixiffe nobis fufficiat, atque ad varia compofita medicamenta, quibus ea gens utitur, accedamus.

$$
\text { C A pi VIII. }
$$

\section{De theriaca, atque aliis compofitis medicamentis,} qua in uf funt apud Egyptios.

\section{GUILA D I N U.S.}

Tonne etiam Rgytil medicl compofitis aliguibus medica 1 mentis utuntur? quæfo, qua funt, ea mihi narres, $A t_{\text {. }}$ MN. Panciffima compofita illos in medendo exercere obfervavi, nullaque ad purgandim, neque catapotia, reque electiaria feitu digna. GuILAND. Ea tamen qualia fint, narrare quoque non te pigeat. Alpin Quæe ex medieamentis compofitis apud éos in ufu fuife tune temporis ab is didicerant, hxe plare exfture, quippe theriaca, bernavi, bers phenonie, philofopha, atcize Diarnefch. Hee enim fititigna eos in medenido fre. quentare animadverti, fed omnium maxime theriacam fndromach Senioris, quam julit Turcartum Regis ipf famma cun diligentia componunt in aliss vero, qux dix medicamentis \$on eandem adhibent ill diligentan cum pro arbitrior ómines dom componere pofint: quifque enim medicinæ etian plañe igtiarus, ue lubet, ea pro ufu fibi parat, ac componito De theriata vero res aliter fe habet, fiquidem non licet al icu ipfam: privarini componere, fed publice coram onmibus medicis, in problico loco qued pro pfortu rege componatur y cujus juffu ommis sura: ac chilgentia ab inlis adhibetur ot perfectifimat ac 
abfolutiflima perficiatur. Atque hine Egyptii, apud quos nunc optima medicina obfolevit, theriacam ceteris aliis medicamentis accuratius componunt, ejufque compofitioni maxime incumbunt, qui fciant hac ratione fe fuo regi obfequi, cui tale medicamentum gratiffimum effe intelligant. Accedit etiam, quod id medicamentum apud omnes $\mathbb{E}$ gyptios in trequentifimo eft ufu, quando fere ad omnes morbos ea gens theriaca utatur. Locus, in quo eam componunt, eft templum, urbis Cayri præclariffimum, Moreftan vocatum. In eo omnes medici juffu præfeeti, cum archiatro medicorum, five principe, quem Achim-Baffi appellant, fimul conveniunt, mene Majo fere femper, ut de hac præclariffima compofitione paranda confilium apud ipfos habeatur: ibi tum is quicompofitioni faciendæ defignatur, qui eft pharmacopola exercitatiffimus in ea compolitione, folamque theriacam componit; coram omnibus paltillos omnes conficit, cum quibus poftea totam compofitionem accuratiffime abfolvit.' Is autem qui eo tempore, quo Cayri ego medicinam faciebam ; compofitionem hanc moliebatur, fuit Mahemet ebne Haly, vir quidem quamvis Mahemetis affecla, morum tamen integritate non fpernendus, quique advenas plurimi facere præ fe fert; fingit tamen ingenti fpe lucri, ex multa theriaca, quam advenis continue vendit. Nunquam tamen ego, etfi mihi admodum domefticus, ac familiaris effet, theriacæ compofitionem, quam illi fervant, ex eo difcere potui, nunquam voluit me ipfo etiam præfente legere. Timent enim, fi nos ipforum compofitionem, quam ceteris abfolutiorem ac præftantiorem effe opinantur, ab ipfis didiciffemus, multi lueri, quod cum advenis plurimis Italis, Germanis, Polonis, Anglis, Gallis, Flandris, aliarumque multarum nationum hominibus frpiffime in Kgyptum. navigantibus continue faciunt, fe non parum jacturam ac damnum paffuros. Vel etiam quia illis lege interdictum eft, Chriftianos homines eam compofitionem pofle docere. Hincque nemo advena poteft ullo pretio abillis eam compofitionem intelligere Guiland. Hoc jam diu fciveram, fed tu quanam arte ufus fuili, ut cam ab illis intelligeres? auro fortaffe phar- 
macopolæ illius timorem, atque legis interdictum te expugnaffe puto. Alprn. Nullo meo confilio id accidit, fed cafu atque $a b$ alio Mahomete mihi valde familiari, rei herbariæ longe omnium Egyptiorum doctifímo, cui quotidie ex Arabiæ, atque Aithiopiæ, Indiæque locis aliqua nova medicamenta ab amicis mittebantur, theriacæ, quam Egyptii componunt, integram ac veram habui defcriptionem: paucis enim diebus antequam ab Asypto difcederem, Deo volente, mihi contigit, ne citra fic defideratam illorum theriaca compofitionis cognitionem, exinde malo animo abirem, idque nec aurum, nec aliud munus, nifi multa ejus viri erga me humanitas confecit. Apud ipfum enim cum difcederem, vidi librum permagnum, \& mirabilem, qui à doetiffimo Ægyptio, olim Sultani cujufpiam AEgyto Imperantis mandato, qui omnes Ægypti, Arabiæ, Ethiopiæque locorum plantas diligentiffime obfervaverat, de omnium illorum locorum plantis confcriptus fuerat. Quem fi recte latinitate donatum noltri haberent, de multis medicamentis peregrinis lites omnes abfolverentur. Forte fortuna igitur, ut ad rem nunc redeam, diebus pauculis, antequam illine difcederem, cum quorundam fimplicium medicamentorum occafione, dictum Mahemetem herbariæ profeflorem conveniffem in ejus apotheca feligentem, parantemque fimplicia pro theriaca F gyptiorum, ab omnibus medicis illo tempore indicta, ut illa in Moreftan mitteret Mahemeti theriacæ compofitori. Nam Mahemet ille, qui jam multos annos theriacam componebat, folitus erat omnia medicamenta, quibus theriaca paratur, ab eo accipere; is rogatus à me, quid nunc negotii haberet? cum refpondiffet herbas, fuccos, gummata, radices, femina, atque alia medicamenta fimplicia pro componenda theriaca feligere, quæ in Moreftan ad Mahemetem compofitorem miffurus erat, fchedulam, in qua theriacæ compofitio Archiatri medici AEgyptii litteris defcripta legebatur, ejufdem medici, quoque figillo fubmunitam, rogatus, mihi fe præfente legendam paululum conceffit, atque poftea etiam permifit, ut cotam eam diem illam commodius perlegere poffem, ac contemplari. Cujus fcripturæ principium cum $\mathbb{E}$ gyptio medico $\mathrm{O} O$ IIe- 
Hebræo Italicam æque ac Arabicam linguam callente, cum legiffem, theriacæe effe compofitionem, quam per eum annum. medici IEgytii componere pro Turcarum Rege conftituerant, quamprimum agnovi. In qua, ut jam dictum eft, aderat Achim baffi fubferiptio. Illam continuo domi cum dicto $\mathrm{He}$ bræo medico, præfente etiam Oetavio Rovereto Tridentino medico excellenti, qui cum Franc. Delphino, ibi pro SerenifDominio Veneto Confule Clarifimo, in AEgyptum, medicinam exercendi caufa venerat, ex Arabico idiomate in latinam linguam verti, quam quidem ne amplius tuum defiderium remorer, hoc modo fcriptis traditam nunc ex me audies. Verum nomina medicamentorum fcribere primo Arabice, \& mox. Latine clarioris cognitionis gratia volui.

\section{A p. IX.}

Theriace compofitio, quam fingulis annis CAgyptii pro Turcarum Rege componunt, quam Tharachfaruc appellant.

\section{A L P I N U S.}

T T Theriacam igitur componant, accipiunt.

Acras haufel, id eft, paftillorum Scyllinorum, dra. 864 . Acras Affa, id eft, paftillorum ex ferpentum Thayr vocatorum carnibus paratorum, dra. 432 .

Acras Alindaracoron, id eft, paftil. Hedicroorum, dra 432. Darfelfel, id ent, piperis longi, dra 432.

Affium Rumi, id ent, opii Thebaïci, dra. 432.

Zaraverd, id eft, florum rofarum, dra. 216 .

Haffelefuflan, id eft, radicis iridis, dra. 216.

Scordium, id eft, fcordii, dra. 216.

Garicum, id eft, agarici, dra. 216.

Dehenbalafian, id eft, opobalfami, dra. II 6 .

Darfini, id eft, cinnamomi, dra. 216.

Rohobfus, id eft, fucci Glycirizæ, dra. 216. 
DE MEDICINA EEYPTIORUM. LIB. IV. $29 \mathrm{~T}$

Bezer Saglian, id eft, feminum bunii, dra. 216.

Mur amar, id eft, Myrrhæ coloratæ, dra. 108.

Zaffaran, id eft, croci, dra. Io8.

Cheft mur, id eft, cofti amari, dra. I08.

Archer, id eft, floris fquinanthi, dra. I॰8.

Selica feuda, id eft, calfiæ nigræ, dra. 108.

Sombulendi, id eft, nardi Indici, dra. 108.

Condor Abiat, id eft, Thuris albi, dra. I08.

Felfel abiat. id eft, piperis albi, dra. 108.

Felfel affuet, id eft, piperis nigri, dra. I08.

Zenzibil, id eft, zimziberis, dra. 108.

Stecadus, id eft, fticados, dra. 108.

Elchelimbat, id eft, therebenti, dra. Io8.

Faudeneg, id eft, calamenti montani, dra. 108.

Rhavend feni, id eft, rhabarbari, dra. 108.

Mafchatramaffie, id eft, Dictami, dra. I08.

Fraffium, id eft, praffii, dra. Io8.

Pentaphilum, id eft, pentaphyli, dra. 108.

Petrofelium, id eft, petrofelini, dra. 108.

Chamefitos, id eft, camepytheos. dra. 72 .

Giahade, id eft, polii dra. 72 .

Phu, id eft, Valerianæ. dra. 72 .

Amama, id eft, amomi, dra. 72 .

Tinmactum, id eft, terræ figillatæ, dra. 72 .

Sombul Rumi, id eft, fpicæ Græcæ, dra. 72.

Colochtar, id eft, vitrioli, dra. 72 .

Mea feile, id eft, ftyracis liquidæ, dra. 72 .

Ab balaffan, id eft, carpobalfami, dra. 72 .

Henud, id eft, acori, dra. 72 .

Rafianeg famar, id eft, feminum foniculorum, dra. 72 .

Gentiana, id eft, gentiana, dra. $?^{2}$.

Sang Arabi, id eft, gummi Arabici, dra. 72.

Gardemani, id eft, cardamomi, dra. 72.

Rohob Chachia, id eft. fucci Acatiæ, dra. 72.

Nanachue Endi, id eft; ameos Indi, dra. 72 .

Bezer carafs, id eft, feminum apii, dra. $7^{2}$. 
Anifum helb, id eft, aniforum dulcium, dra. 72.

Chemadrios, id eft, chamedrios, dra, 72 .

Sefelios, id eft, fefelios, dra. 72 .

$\mathrm{Mu}$, id eft, mei, dra. 72 .

Horf, id eft, nafturtii, dra. 72 .

Hafart leget, teteis, id eft, fucci hypociftidis, dra. 72\%

Secbines, id eft, ferapini, dra. 72 .

Hyufaricum, id eft, Hyperici, dra. 72.

Gindubaleftar, id eft, caftorei, dra. 72 .

Zaravend tavil, id eft, Ariftolochiæ longx, dra. 72 :

Daucum, id eft, Dauci, drá. 72 .

Vini granatorum, aut vini antiqui quantum fufficit. Mellis. optimi partes tres. Guicand. Theriacæ huic defcriptioni addenda quoque à te eft paftillorum in primis; qui ex fcylla conficiuntur, mox etiam aliorum, compofitio. Alpin Paftillos Scyllinos parantes, accipiunt fcyllam albam mediocris magnitudinis, quam triticea pafta contectam, ac conclufam in ignem. ponunt, urique finunt, quoufque pafta circa Scyllam pofita, perfecte affata videatur, ac cruftam contoftam concraxerit, quam continuo eximunt, atque extrahunt, quodque intus cœpæ fcyllæ eft molle accipientes, ei farina orobi permifta, in ea portione, ut refpondeat duabus fcyllæ partibus una farinæ, $\&$ plus etiam farinæ admifcent, fi fcylla multam habuerit acredinem: ficque in mifcenda farina fcyllæ fe gerunt, ut ex multo, vel pauco fcyllæa acri fapore farinæ quantitatem expendant: fcyllis acriori fapore prædit is farinæ plus, \& minus his, qui obfeuriorem habent acrimoniam permifcentes. Utrumque quippe percoctam fcyllam, atque orobi farinam manibus conterunt, atque poftea fimul mifta in mortario contundentes, maffam efficiunt, ex qua orbiculos parvos faciunt, digitis prius oleo rofaceo inunctis: hofque permittunt per multos dies fub umbra. ficcari. Viperinos vero eodem certe modo, ut Gal. in lib. primo, de antidotis docet, ipfi parant; uno hoc excepto, quod ex viperarum carne, ex quibus noftri fuos faciunt paftillos, eos non parant, fed ex quibufdam ferpentibus viperis tamen omnino corporis colore, magnitudine, figura, atque habitu pro. 
ximis, capite excepto, quod in viperis noftris depreffius eft, cornibufque caret; frquidem ferpentum illorum capita, uno, vel duobus cornibus prædita funt, duo fœminæ, unum: mares habent, quæ cornua funt veluti acutiffimæ acus, quibus mulieres ad fuendum utuntur, atque in hoc noftræ viperæ $a b \mathbb{E}$ gyptiis differre cernuntur. Sed de his pofterius copiofius loquemur. Paftillos vero alindaracorum, quos noftri hedicroos vocant, parant, accipientes.

Darfifchan, id eft, corticis rad. afpalathi, dra. 108.

Caffabelderira, id eft, calami, aromatici, dra: 108.

Idam balaffan, id eft, xilobalfami, dra. 108.

Cheft mur, id eft, cofti amari, dra. 108.

Affarum, id eft, afari, dra. I08.

Mu, vel Meu, id eft, mei, dra. I08.

Achaovan, id eft, mari, dra. 108.

Maftiche, id eft, maftiches, dra. 108.

Fecahatcher, id eft, floris fquinanthi, dra. 360 .

Ravends, id eft, rhabarbari, dra. 300.

Selica, id eft, caffiæ, dra. 360.

Darfini, id eft, Cinamomi, dra. 360.

Sambul endi, id eft, fpicæ. Indæ, dra. 288.

Sadegendi, id eft, folii Indi, dra. 288.

Mur, id eft, myrrhæ, dra. 432 .

Zaffaran, id eft, croci, dra. 216.

Omnia hæc terrunt tenuiffime, atque cum vino granatorum mifcentes, digitis opobalfamo inunctis ex ea maffa orbes fa;ciunt, quos in umbra. ficcant. 
204 PROSPER I ALPIN I

\section{A p. X.}

In quo CEgyptiorum theriace difcriptio differat ab ea, que ab Andromabo Seniore olim momorice fuit prodita.

\section{G U I L A N D I N U S.}

7 A C theriacæ defcriptionem, quam $\mathbb{E} g y p t i i$ fequuntur, longe ab ea, quam Andromachus Senior docuit, differre pater: Primum quidem numero ingredientium medicamentorum ab ea differens eft, quando in hoc ingredientia medicamenta fint novem, \& quinquaginta, in Anaromachi vero unum, \& fexaginta: Deeft Kisyptiz afphaltus, five bitumen Judaïcum, Centaurea, galbana, malabatrum, opponax, neque in ea perfectus ingredientium fimplicium numerus obfervatur. Andromachi etenim theriacam fimplicia omnia ingrecientia fex numeris comprehenduntur, quorum primus eft quadraginta octo, fecundus vinginti quatuor, tertius duodecim, quartus fex, quintus, quatuor, atque ultimus duorum. . $\mathbb{E}$ gyptiorum theriacæ defcriptioni deeft fextus numerus, quæ tamen ceteris aliis numeris fimilis eft, fuofque habet Andromachi diferiptionis numeris plane refpondentes, quanquam in majori quantitate illi ipfarn una vice componant. Primum enim ingredientium ordinem faciunt octingentorum cum fexaginta quatuor, qui fane magnus numerus ingredientium, defcriptionis Andromachi primum numerum decies, \& octo plus comprehendit, cum Asyptii decies, \& octo plus theriace una vice componant, quam fit Andromachi defcriptio. Primus igitur ordo ingredientium fimplicium, \& fecundus, \& tertius, \& quartus, primo, \& fecundo, \& tertio, \& quarto Andromachi ordinibus recte convenit. In quinto vero partim convenit, \& partim differt; convenit, quod ex quatuor cum viginti fimplicibus medicamentis, omnia, exceptis duobus, habet, qriando folum malabatrum, atque thlapfi ei deeft. Differt etiam, quia alia habet, quæ in Andromachi defcriptione 
non leguntur, qualia funt, acorus, apium, \& nafurtium, habetque reliqua, quibus ab Andromacho fextus ordo datur, qualia funt, caftoreum, ariftolochia longa, atque daucus. Alia defunt, non enim Kyyptii in fua compofitione ponunt, afphaltum, opopanacem, \& centaureum: ex his itaque nobis perfuafum eft, illorum defcriptionem fcatere miltis erroribus. Sed cupio, ut de omnibus rurfum ingredientibus commodius loquamur, eaque altius fpeculemur, a paftillorum præparatione facto principio. Alpin. An non omnium paftillorum intheriacam ingredientium compofitionem ex dictis didicimus? GUILAND. Quxpiam de ingredientibus in paftillorum compofitionem, fore à nobis clarius cognofcenda exiftimo; atque in primis quia tu dixint, paftillos ex viperarum carnibus parandos, ibi ex ferpentibus thayr vocatis parari, velim, ut ferpentem illum ex quorum carnibus paftillos, vel trochifcos illos conficiunt, mihi fedulo defcriberes, ut clarius ipfum cognofcere poffim. Arpin. Tahyr ferpens eft longitudine duorum ad fummum cubitorum, corporis magnitudine, colore, figura, ut nuper etiam dictum eft, viperis à noftris vocatis, proximis, hoc excepto, quod caput habent magis latum ac depreflum, atque in eo cornua alba geftant, mas unum, \& fomina duo, in fincipite, non fecus quam acus acutiflimas; ex quibus aliqui judicarunt, illum ferpentem veram effe ceraftem: quod fi Arabum ceraftis defcriptione acquiefcendum effet, fine dubio ceraftis ille ferpens non erit putandus, quando in hac fera five ferpente, non reperiantur cartilagines fpinarum loco, fed eadem fpina, quibus viperarum corpora prædita funt, neque, ut ajunt, plura quam duo cornua geftant, quæ recta, minimeque obliqua cernuntur; Neque dignofcitur in his feris, quod Aetius in lib. 13. fcriptum reliquit, his profecto verbis dicens: Ceraftes magnitudine cubitalis eft, longiffimus cubitorum eft duorum, corpore vero arenofus eft, Eं juxta caudan defquammatus: eminentias babet in capite duas, cornuun finnilitudine. Audivi in commorfis ab his ferpentibus thayr vocatis eadem plane fymptomata obfervari, quæ à viperarum noftrarum morfibus prodeunt, hocque unum certo fcio, non effe illorum 


\section{PROSPERI ALPIN I}

morfum ufque adeo exitiofum, ut de ceraftis morfu a multis proditum eit. Teftis erit Antonius Palmerius presbyter admodum reverendus, qui multos annos Cayri, multis Venetis Confulibus facra miniftravit, fuitque Cancellarius; is mecum una vidit, Mahemetem theriacæ compofitorem, duos thayr vocatos ferpentes, dum ut nobis aliquando oftendere vellet, manibus contrectaret, $a b$ altero ipforum commorfum, fola theriaca foris intufque adhibita fanatum fuife, in quo cum omnia fymptomata viperarum apparuerint, fine dubio affirmare poterimus, thayr viperam cornutam effe, cum folis cornibus à vipera noftrorum differat. Ex horum carnibus paftillos illi, ut jam etiam dictum eft, non diffimili, qui noftri parant modo. Hedicroos vero, quos alindaracorum appellant, diverfiffime ab is, qui tum à magno, quos Galeno in lib. de theriaca ad Pifo. docuit, tum ex Andromacho ab eodem Galeno, in lib. primo de antid. litteris proditi fuere, componunt. Quod tibi ex ipforum narrata deferiptione manifeftiffimum effe puto Gurland. Admodum certe diffimilis eft hedicroorum hæc paftillorum defcriptio, ab ca, qua in illis componendis, ufus fuit Galenus ex Andromachi mente; attamen illos veris, ac legitimis plerifque ingredentibus ut exiftimo, quod in his locis non fit difficile multa medicamenta fimplicia haberi, cum AEgypto Arabia, Ethiopia, India, Græcia, fint conterminæ, in quibus præclara multa fimplicia, quæ nobis defiderantur, fponte nafcantur, atque facillime illuc convehantur. ALP I N. De his omnibus, dicam libere, quid ab his didicerim, atque quid fentiam. Et ut à Darfifahan, qui eft afpalathus Diofcoridis, principium faciamus, dico, illos in hane hedicroorum compofitionem veram radicem afpalathi conjicere, quam ex Creta, vel Rhodo ipfi fe habere ajunt, quæ eft valde craffa, longa, dura, coloreque flavo rubefcente, admodum odorata. Eam 'Dominicus à Rege', qui pharmacopolam Cayri agebat pro Georgio Hemo Confulatum tune gerente, in Cretx loco pro pe portum Frafchia dictum meo juffu plures radices excerpfit, \& Cayrum pro ufu fecum tulit. Arbuftus eft afpalathus ramulis denfis, fpinis albis durifque horridus, foliis rutæ proxi- 
mis, atque floribus aureis, raris, fparthii florum æmulis, fumme odoratis; ego eam plantam jucunditate eximia odoris, ex ejus floribus, ubi Cretæ loca aliquando diverfarer, ad nares elata cognovi. Alii funt; qui eo carentes, quandam herbam fubftituunt, quam falfo aliqui dirfifahan vocant: hanc ego hyperici fpeciem ex ejus figura, \& feminibus nigris fubrubefcentibus, in parvis folliculis, qui picis redolent odorem, judico. De Caffab, elderica rectius, quam noftri, cum vero ac legitimo mea fententia utantur calamo aromatico, \& non acori radicibus, quæ nunc apud multos herbarum materiæ ignaros medicos, pro calamo aromatico in ufu familiariffimo exiftunt, qui quam bene hoc intelligant, tu melius in herbarum materia exercitatior explicabis. Guiland. Quid? non omnibus manifeftiffmum eft, calamum aromaticum effe non radicem, fed cannam, vel calamum? quod ex Diofcoridis verbis plane verum effe conftat, dixit enim: Calamus odoratus in India nafcitur, melior eft fulvus denfe geniculatus, Eे qui affulose frangitur, plena araneorum fiftula, albicans, lentus in mandendo, $\delta^{2}$ adftringens, ac cum aliquanta acrimonia amarus. Et Plinius quoque cannam effe calamum aromaticum affirmare videtur; cum dixit: Ineft fiftule araneum, quod vocant forem. Ac Serapio, EO Canna ejus eft plena cujufdam rei fimilis texturce aranece, cujus color eft albus, ES cft vi $\int c \rho j a$. Ex quo aperte cognofcitur, falfam effe eorum fententiam, qui acori radices verum calmum aromaticum efle affirmant, quando neque calamus acori radices exiftant, neque concavitatem habeant plenam ejus medullari fubftantia, quam florem ipfi appellant, neque affulofe frangantur. Atque tu illum fæpe mihi oftendifti verum, ac legitimum, quem ex ÆEgypto tecum afportafti, qui quidem certiffimus calamus aromaticus antiquorum eft, calamus enim in primis eft, coloreque fub fulvo fpectatur, eft fiftulofus, concavus, odoratus, amarus cum aliqua acrimonia, affulofeque frangitur, id eft, in fruftula multa -inæqualia, . inque fiftularem. meatum araneum florem vocatum habet. Hoc fi A Fyptii in componenda non modo theriaca, fed in omnibus aliis medicamentis, utantur, rectius certe quam noftri agunt. Caflab el* 
derira Arabum verus proculdubio eft calamas aromaticus. Hinc: rogatos vellem omnes tum medicos, tum pharmacopæos, ut: illum afpernari nolint tanta cum componendorum medicamentorum jactura. Cujus copia, modo ipfum in ufu recipere voluerint, ex Fypto, atque Syria eis non deerit. Alpin. Gratulor te hanc veritatem cognoviffe. Sed nunc age de xilobalfamo; de quo non minus etiam multi ex noftris hæfitant, guanquam nonnullos ramulos, tenues, rectos, fubrubefcen-: tes, odorem ac faporem non obfcure veri opobalfami redolentes, in fuis officinis habeant, quos eo nomine etiam appellant, qui certifime veri ramuli plantæ balfami exiftunt, id quod ego finfibus verum effe cognovi : nam non modo Cayri afportatas ex Arabia recentes virgas vidi, verum etiam Venetiis in Arbufculo veri balfami, quem domi meæ viventem plures viderunt, atque quod magis mirum multis videbitur, etiam ex.itlius parvuli balfami arbufti ftipite, ubi alia quæpiam foliorum ab eo abfcindebantur, verum opobalfamum ftillaffe nulti fpeetarunt, quod e guftu, atque odoratu omnes qui alias afportatum ex. 2 Eypto verum opobalfamum viderunt, verum effe fáfif funt. Hoc vidit Jacobus Contarenus, Senator Clariffimus, plantarumque materia doctiffimus, atque ftadiofiffimus, Nobilifimufque Joannes Vuthus Anglus, fimul cum nobilififmo Fererio Gallo, quamplurefque alii tum Angli, tum Germani; atque Marcus Phenarius Venetus pharmacopola præclarus fimpliciumque medicamentorum cognitionis non ignarus, ac alii multi, quos, ne te virum doctifimum majori tædio, quan liceat afficiam, omitto. Hanc vero balfami, carpobalfami, \&. xilobalfami veritatem in dialogo de balfamo olim Cayri confcripto fufius manifeftavi, de qua etiam inferius non pauca erunt fuis locis rurfum memoria mandanda.. Multas recentes. virgas balfami ex.Arabia Cayrum valde cito convectas infpexi; quæ eximium odorem opobalfami fpirabant, qui tamen adeo:) cito exolvebatur, ut paucos poft dies obfcurifime fentiretur. Guiland: Atque hinc eft, quod hæ virgæ, huc afportatæ; in tam longo itinere: odore mulcum refoluto, obfeniffimun: tom. faporem, tum odorem referunt.: Quamobrem laudarem. 


\section{DE MEDICINA EGYPTIORUM. LIB. IV. 299}

ego, ut pro illis interim carpobalfamum odoratum fubftitue. rent. Sed per Achaovam, quid intelligunt? ALPIN. Per Achaovam herbam aliqui accipiunt camomello valde fimilem, quam achaoen, vel uchoven, vel alachuan etiam appellant. Crefcit hæc herba copiofiffima in Egypto, præfertimque Cayri, in loco Sbechie vocato, altitudine paulo minore ipfius camomelli, floribufque ei maxime proxima, ac foliis matricariæ five parthenio, fimilis; ipfamque ego fæpiffme virentem decerpfi, quæ obfcuriflimum tum faporem, tum odorem, atque etiam ingratum edebat. Aliqui vero fequentes fortafie Avicennam, dicentem achaovam effe acuti faporis, atque odoris, aliam herbam albam odoratam, atque cum acri fapore origani fere æmulam intelligunt: ex quo non adeo erraffe Avicennam conftat, qui dixit, achaovam habere flores odore atque fapore maro proximos, jam dictam herbam acuti odoris, faporifque intelligent, ac vero ipfa verum marum fit, adhuc ignoro. Per darfini optimam cannellam intelligunt, five cinnamomum, quod nulla in re a cannella differt, quam gracilitate, odorifque, an faporis præftantia; Fafces multos confpexi veri, ut arbitror, cinnamomi, qui cortices erant cannellæ colore, contorti, vel obvoluti, cannellis multo tenuiores, graciliores, \& breviores, craffitiem veri calami odorati, habentes: quo etiam tenuiores exiftunt, qui vetuftate omni fere, tum fapore, tun odore carebant. Et fi aliquibus odor aliquis, vel fapor aderat, fatis obfcurus, atque non nifi cannellæ proximus fentiebatur. Quam fpeciem cannellæ tenuem, brevem, obtortam, darfini Arabes appellant. Quæ maxime cum difficultate in Ægypto invenitur. Quam noftri cannellam communiter dicunt, Arabes cherfe nuncupant, \& caffiam ligneam felica. In qua multi etiam Cayri decipiuntur, non tamen in theriace compofitione ipfam ponunt, quando veram caffiam illi femper in ipfa adpofuerint, opinantes felica non effe caffiam ligneam, fed corticem ex Barbariæ locis afportatum, craffum, ac fubrubrum, qui cortex, me judice, eft verus ac legitimus macer Diofcoridis: hunc corticem felica feuda vocant. Ibi vero multæ felieæ circumferuntur, quarum in una aureus eft cortex, amarus, cume Pp 2 


\section{0

quadam adftrictione, cujus decoctum, \& infufum in aqua fimplici frequentant inftar fomenti, ad oculorum lippitudines, quibus mirifice prodeft, quem corticem vocant felica umra. Alter eft cortex fubflavus, vèl fubruber, vel fubniger, fapore fubdulci, ftipticoque, ac omnis odoris expers, quem aliquir veræ caffiæ ignari, caffiam effe opinantur; hincque aliqui ipfum appellant, quod caftia nigra fit, felica feuda, quod idem eft, ac fi dixerint, corticem nigrum. Hunc corticem verum effe Diofcoridis macerem ego fine dubio ex notis à Diofcoride proditis, affirmarim. Eit \& terti us cortex, quem felica per excellentiam appellant, quafi dixeris, cortex, omnium præftantiffimus, .. qui fane caffia eft vera, , quam noftri ad differentiam fiftulæ folutivæ, quam etiam cafliam vocant, ligneam cafiram dicunt. Per rhavend fevi, rhabarbarum accipiunt, \& per fadeg endi cinnamomi folia, lauri foliis proxima, fed multo majora, quibus noftri pro vero folio utuntur. Per cheft; utuntur quadam radice alsa odorata, fapore modice amaro, cum multa acrimonia linguam feriente, quam ex Syria convehunt; . qux radix fi acutifimum odorem, quo caput feriretur, haberet, fine dubio verus coftus. Arabicus effet. Neque opinor multum falli illos, qui pro vero Arabico cofto ea utuntur: GuLAND. Id ego quoque verum effe coftum Arabicum puto, recteque idairco facere Aisyptios medicos eo utentes. Neque obftat, quod caput codore acutiori non'feriat, cum Diofcorides dixerit, Syriacum tantum caput odore ferire; non tamen Arabicum, quem potius fuavioris, ac jucundi efle odoris fcriptum reliquit; unum eft in eo præciputm; fcilicet fapor valde mordens, cum pauco amarore. Sed, quæfo, quid per amomum ipfi intelligune, de quo inter noftros hactenus maxima lis fuit: quoque pro eo in medicinæe ufu illi utantur, audire cupio, atque num femina, an lignum ab iis credatur. A LPIN. Ipfi non feminibus, fed ligno quodam odorato pro amomo utuntur., quod amama appellant. Eft itaque ipforum amama ramulus brevis, gracilis, multis obliquitatibus, atque parvis denfis obortis ramis præditus, vereque racemo uvarum figura fimilis. , Eft tamen lignofus, durus, frangibilis, colore 


\section{DE MEDICINA EGYPTIORUM. LIB. IV. 30 I}

corticis quidem nigro, fubrubefcente, ligno vero, vel albo, vel flavo, præditus, valde jucundum atque aromaticum odorem refpirans: nullius tamen eft faporis: hocque ligno pro amomo merito utuntur, cum, mea quidem fententia, Diofcorides, qui verius de eo fcripfit, potius de ligno intellexerit ". quam de feminibus, non ab reque dixeris amomum racemofum, quafi lignum uvarum racemis figura fimilem. Guiland. Multi ajunt lignum hoc, pro quo amomo Ægypti utuntur, effe plantærofæ Hierici vocatæ, quod tamen falfum effe comprehenditur, ex hoc præfertim, quod hujus ftirpis caules, vel ramuli lignofi non exifunt, neque frangibiles, neque odorati, quales funt, quibus pro amomo. ii utuntur, qui duram lignofam fubftantiam habent, facillimeque digitis franguntur, odoremque fuaviffimum refpirant, \& quia flores parvos albos violarum floribus primos proximos habent, fortafle non immerito eos pro vero amomo habent: Nam \& ipfe Diofcorides dixit: Amomum eft arbuftum, quod e ligno racemi modo in Seipfum convolvitur, florem babens parvum, album, violis proximum, atque folia brionice. Melius ex Armenia portatur, asreo colore, cujus lignum fubrubrum, atque odoratum exiftit. Ex quibus ZEgypios magis, quam noftros probarem, qui ligno utantur pro amomo, \& non feminibus, ut noftri faciunt, prorfus fapore atque odore carentibus. Res tamen eft perdifficilis, quippe ut hæc veritas antiquorum monumentis demonftretur, cum apud varios fcriptores, amomi hiftoria plane varia inveniatur, ex qua nihil, vel parum certi elici poteft. Sed de myrrha etiam loquamur, quam illi vocant Mur. Alpin. Per mur myrrham om-a nes intelligunt, fed tamen optima Trogloditica carent, cujus loco illa utuntur, qnam Diofcorides ergafimam appellat, qua \& Venetos pharmacopæos uti quoque fcio. Hæc enim colore, atque afpectu gummieft proxima, odere gravi, guftu modice amaro. Alia : fimplicia medicamenta, quibus utuntur ad dictorum paftillorum compofitionem, eadem exiftunt, quæ apud noftros quoque in ufu exiftunt. Hæcque de hujufce compofitionis ratione à nobis dicta fint. Nunc per opportunum erit, ut ex. medicamentis in theriace, compofitionem ingredien-j P. 3 . 


\section{8 \\ PROSPERI ALPIN I}

tibus, quæ cum apud noftros ufitatis conveniant, \& quæ differant, loguamur. GUILAND. Ut lubet; fed non de omnibus, fed tantum de neceffariis brevitatis caufa fermo habeatur. ac tantum de his, quorum ufus non omnibus adeo patet, \& in quibus multi dubitare videntur.

\section{A p. XI.}

De aliquibus fimplicibus medicamentis in theriace compofitionem ingredentibus, confideratio.

\section{G U I L A N D I N U S.}

$Q^{\circ}$

U I D itaque intelligunt per denbelaffam, velim in primis mihi narres, atque mox de fingulis aliis, quorum ufus noftris haud omnino clarus eft, erit dicendum. Alpin. Per denbalaffam fuccum balfami arboris, per idanbalaffam, lignum, \& abbalaflan fructus, illi intelligunt, quæ omnia vera habent, atque recentiffima, quibus ad componendam theriacam atque alia medicamenta, utuntur. Noftri hæc ex Græcis appellavere, opobalfamum, xilobalfamum, atque carpobalfamum. Omnia hæc apud me vera ex 1 Egypto comportata vidifti, faffufque tunc fuifti fine dubio legitima ac vera effe. Quoniam autem de his pofterius, ubi de balfami planta loquemur, copiofius agemus, propterea alia de his in præfentia dicenda non funt. De cinnamomoque \& caffia nihil aliud, quam quod de ipfis jam dictum eft nos dicere oportet. Guiland. Quoniam autem ubi de cinnamomo, \& caffia fermonem habuift, non recte percepi, ideo rurfum exploratius à te eadem audierim, tu enim dixifti, Egyptios pro cinnamomo, \& caffia, iis tribus nominibus uti, quippe darfini, cherfe, \& felica, quibus fane nominibus intelligunt cinnamomum, cannellam, atque caffiam, fcilicet per darfini corticem cannellæ fimilem, fed eo tenuiorem, longe breviorem ac graciliorem, in feipfum inverfum, convolutum. Per cherfe noftram ufitatam cannellam, \& per Selica, Caffiam, quam ligneam nofri appellant. ALPIN. Cayri vidi non. 
DEMEDICINA EEgPTIORUM. Lib. IV. 3?3? nonnullos fafces veri cinnamomi, præ antiquitate toto fere odo. re ac fapore refoluto, idque apud Joannem de Leonarcis, Venetum, mercatorem integerrimum. Erat enim illud cinnamomum cortices tenuiffimi in feipfos cannellæ modo involuti, craffitie tamen communium arcutum cordas non excedebant, vel calamis aromaticis proximi, longeque erant cannellæ breviores, quæ palmi longitudinem non excedebant. Ipforumque odor, ac fapor, quamquan obfcuriffime ex vetuftate fentiretur, nibil differebat, ab eo, quem communis cannella fpirat, atque fapit. Cannella igitur, quam, ut jam dictum eft, cherfe appellant, neque odore, neque fapore, neque colore $\dot{a}$ vero cinnamomo differens eft, \& folum corticis craffitie, \& longitudine interftinguitur. Verum cinnamomum, ut ex multis audivi, canellæ lapore atque odore præfertur, quia cinnamomi:odor fuavior, atque validior, faporque dulcior, atque mordacior fentitur. Hincque puto Theophraltum fcripfifie, cortices tenuiores è furculis, vel farmentis tenuioribus eximi, cinnamomumque, quod ex tenuibus fit præftantius, atque caffram ex crafforibus, minus efficacem; ex quo dicendum eft, cinnamomum nihil aliud effe, quam furculorum, vel ramulo. rum tenuiffimorum cortices, \& cannella, majorum, atque craffiorum, atque adhuc craffiorum juxta Theophraftam, caffia. Qui an verum attigerit, valde dubius fum, quem tu, qui ifthæe omnia accuratius cognoris, facile illuftrare poteris, atque hujus veritarem mihi aperire. Gurland. Quid? caffiam à cinnamomo, \& cannella differt craffitie, ac odoris, faporifque preftantia? hoc plane falfum effe fcio, fiquidem has obfervari differentias in variis cannellis, atque cannamomis puto, ex quo differunt cinnamoma atque cannellæ inter fe corticum magnitudine, ac odoris faporifque præftantia. Namque cinnamonorum alia funt tenuioris corticis, odorifque ac faporis validioris, \& alia craffioris, \& odoris, faporifque obfcurioris, velut etiam ex cannellis aliquæ funt craffiores, majores præftantiorefque : quoad odorem faporemque atque aliæ mirores; atque o. doris faporifque humilioris Ex his colligo cinnamomam quod $^{2}$ da fini Arabes vocant, mhil alid efle, quam corticem tenuif- 


\section{4

fimorum furculorum, qui funt odoratiores, ac validioris fapo. ris, \& cannellam, quam cherfe appellant, effe corticem craffiorem, omniumque craffifitimum, qui à craffioribus ramis ac truncis aufertur, eamque cannellam quoque effe, minimeque cafliam, ut voluit Theophraftus, cum eundem odorem fpiret, atque eundem plane fervet faporem, qui in cannellis obfervatur, etfi longe obfcuriorem. Caffiam vero, quam felica $\mathbb{E}$ gyptii dicunt, alterius efle arboris corticem cenfeo, cum diverfiffima tum odore, tum fapore à cannella clariffime cognofcatur: odores fiquidem faporefque cannellæ, ab odore, faporeque caffiæ fpecie lane differunt; fapor cannellæ eft fubdulcis, cum multa mordacitate; at caffix aliquantulum amarus. Igitur cum caffia differentiffimum à cinnamomo, cannellaque, qui funt unius ejufdemque arboris cortices, odorem faporemque edat, quid diverfum a cinnamomo, \& cannella neceffario erit judicandum ; ex caffire etenim corticis gracilitatis, tenuitatifque, \& craffitiei differentia, variæ ejufdem profecto caffiæ præftantioris, \& minus præftantis differentiæ exurgunt. Cayri plurimos cortices caffiæ craffiffimos vidi, ufui prorfus fere inutiles, cum vix aliquid odoris, atque faporis haberent. Non immerito igitur सEyptios ego laudaverim, qui illis tribus nominibus cinnamomum, cannellam, atque caffiam comprehendunt. Quod autem cinnamomum nunc reperiatur, apud plures medicos eruditos dubium non eft, nihilque à canella differre, nifi, quod ipfa præftantius fit: fi enim cannellæ corti-ces tenuiffimi, \& gracillimi, ex furculis extracti recentes haberentur, veluti paulo craffiores, quos cannellas, \& cinnamoma confufim noftri appellant, habentur, fine dubio effent ad ufum præftantiores, veraque cinnamoma dicerentur. Verum quia odor, faporque corticum tenuiffimorum furculorum in humido facile refolubili fundantur, facile priufquam in ÆEgyptum, vel Syriam convehantur, in tam longo itinere odor, faporque evanefcit, ac minuitur, ea ratione fit, ut mercatores, quod fic cito cinnammoma fua preftantia deficiant, atque inutiliora reddantur, non convehant ea, tum quia difficilius à furculis eximi poffunt, tum quia odore faporeque in tam longo itinere 
DE MEDICINA Egyptiorum. Lib. IV. jog

itinere deftituta, viliori pretio \& difficilius à mercatoribus ven. duntur. Cannellam vero, quod certe craffior eft, non fic facile è quacumque caufa patitur, odore faporeque, namque non deficit: ob id ex Arabia mercatores convehunt, quia diutius odorem, atque faporem confervat, facileque ab omnibus coëmitur. Sed hæc de his dicta fufficiant. Per Elchenlimbat, ut nuper etiam dictum eft, in ufum habent refinam terebinthinam, ficcam, duram, lucidam, foris albam, \& intus flavam, odoratam, quæ linguam ápero fubdulci fapore ferit, dentibufque commanfa in ore, ac cera mollefcit, ficque in ore, fubftantia, mollitie, faporeque ceræ videtur proxima. Per tinmactum ve. ro bolum orientalem ex terra, in Chia infula certa quadam die mandato Turcæ maris præfecti fingulo anno effofta, paratum. Juffu enim hujufce præfecti Baffa vacati, cui Turcarum Rex eam terram dono dedit, "fngulo anno certa ac fatuta die ifta terra effoffa Byzantium fub figillo mittitur, ibique recte purgata in varios orbes formatur, quæ his coloribus fpectatur, quippe cineritio, vel fubrubro, vel fubflavo, faporeque fubdulci, adftringenti, lenta, vifcofave, atque pingui fubftantia obfervatur. Hanc terram pro compofitione theriacæ habent præftantiffimam, e Byzantio fub figillo Cayrum conductam. Per fang Arabi gummam in compofitione recipiunt, quam noftri Arabicam appellant, ex arboribus acatiæ in Arabia petrea nafcentibus collectam. Magnam quidem hujus gummi copiam eas arbores in $\Varangle y$ gypto gignere te fcire certo fcio: ex quo illos plane errare cognofitur, qui communem gummam ex IEgypto advectam veram effe Arabicam negant, fed illam tantum Arabicam fatentur, falfo à Diofcoride perdocti, quæ vermicularis cernitur atque alba; Quod fane falfiffimum eft, quando omnia gummata, non tantum alba, lucida, vermicularia, fed etiam gummis noftratibus colore, \& figura proxima, exinde afportata, vere Arabica fint, atque ex fpinæ $\mathbb{A}$ gyptiæ, vel acatiæ arboribus colligantur. Nullæ fiquidem in $\mathbb{E}$ gypto, vel Arabia deferta arbores, excepta acatia inveniuntur, vel ibi vivunt, quæ gummata gignant : omnia quæecumque illine afportantur in arboribus prædictis, \& non in aliis colliguntur; ea enim lo. 


\section{6- PROSPERI AL PI N I}

ca omnia, cerafis, prunis, pomis, pyris, atque aliis arboribus gummatorum feracibus carent: fola acatia ibi eft, quæ gummata gignat: fed de his etiam, ubi de Acatia arbore loquemur. Per Rhob. cachiæ, fuccum ab immaturis filiquis illiufee arboris expreffum intelligunt, eoque in hac compofitione utuntur. Miror quidem aliquos excellentifimos medicos, lacrymam ex Acatia arbore collectam, \& non ejus fuccum fore ad compo. nendam theriacam in ufum recipiendum, quando in /Egypto nemo viderit ab hac arbore ftillantem lacrymam, colligi, vel illiufe aliquem unquam fuiffe ufum, cum nulla $a b$ ea ftillet lacryma. Neque mirari nos debemus Galenum, atque poft ipfum Aetium dixiffe, liquidum fuccum, qui talis femper eft, ubi non multum coquitur, ex quo etiam peraffatur, nam remanet liquidus modo $a b$ his ( ut nunc omnes nefcio qua negligentia fa. ciunt) à nimio calore non peraffetur, atque ficcetur. Ibi enim liquidus, mollis, acatiæ fuccus, reperitur, atque ficcus, \& durus; ficci vero major eft ufus apud Coriarios, pro tingendis coriis, ficcus optimus eft recens, nigro colore fubrubefcente, atque fapore fubdulci atque adftringenti obfervatus. Ameo, quem Nanachue endi vocant, utuntur optime ac finceriffimo ex India delato. Pro Gardemani utuntur iifdem feminibus aromaticis, à noftris pro cardamomo receptis. Daucum ex Cre-. ta perquirunt optimum, quo utuntur - pro Hehud, id eft, acoro vero utuntur, feilicet illis radicibus, quibus noftri pro calamo aromatico utuntur, quæ vere radices acori exiftunt. In ufu aliorum ingredientium à noftris Æ̇gytii non differunt, $\ddot{i} f$, dem ac noftri implicibus medicamentis recipientes in ufum ad componendam theriacam. Guiland. Video etiam Egyptios multos errores committere in componenda theriaca, proinde merito fufpicandum à nobis videtur, tot laudes, ei à multis datas fortaffe non convenire, vel neque iis morbis, atque venenis, quibus fic præftantiffime fuccurrere dictum eft, ita præfentaneum, atque tutum effe auxilium; eos ego tibi errores diftinctius explicabo, tu vero quid fentias expectabo. 
DE MEDICINA EGTTIORUM. LIB. IV. $30 \%$

\section{A P. XII.}

\section{Errores, guos EAgytit committunt in componenda theriaca, atque de ipforum theriace praftantia. \\ G U I L A N D I N U S.}

Uurs dubium, quin Kggyptii in componenda theriaca mutitos errores committant: in primis ipforum compofitio ab ea , quam Andromachus docuit, multum differt numero ingredientium: cum ex Andromachi Senioris defrriptione conftet, ingredientia theriacam effe numero unum ac fexaginta, \& . . gyptiorum defcriptio fit tantum quinquaginta novem, eique etiam deerit afphaltum, five bitumen, centaurea, Galbana, malabatrum, opopanax, \& thlafpi, qux omnia habet Andromachi defrripto. Esyptia vero quedam habet, quibus illa caret, acorum, apium, atque nafturtium, Preterea Andromachi defreriptio ingredientia medicamenta fex numerorum ordines complexa eft, quorum primus conftat, quadraginta-octo, fecundus, viginti-quatuor, tertius duodecim, quartus fex, quintus, quatuor, fextufque \& ultimus duobus. In Eggyptiorum vero deferiptione, quinque tantum ingredientium numerorum ordines leguntur. Mellifque etiam in compofitione triplam addunt proportionem, cujus Andromachus nullam præfcripfit quantitatem: praterea trochifchorum, vel paftillorum alindaracorum defcriptio apud ipfos diverfa plane ab ea, quam Gal. laudavit. Paftillos quoque ex carnibus cornutorum ferpentium parant, quos omnes noftri medici damnant, multo magis, quod in arenofis locis illi capiuntur, quos Gal. fummopere in lib. de theriaca, ad Pifon. damnavit. Quid itaque dicemus de preftantia theriacæe Egytix tot fummis laudibus à multis celebratx? ALPrN. Diverfam fane effe compofitionem ab ea, quam Andromachus frriptam reliquit, eaque caufa etiam non nihil à fua antiqua preftantia ipfam defeciffe, credendum profecto eft. Quod peccatum commune etiam eft nofris theriacis, qux à noftris pharmacopolis ita parantur, ut multa defiderentur in- 
gredientia, multaque male fubftituantur, non fine artis dedecore, veluti eft acorus verus, calamus aromaticus, amomum, terra lemnia, opobalfamum, xilobalfamum, \& carpobalfamum, atque alia, quibus noftra theriaca caret, quanquam illa fimplicia levinimo negotio haberi poffent, fi modo illi ipfa agnofcere vellent. Rgyptiorum vero theriaca hæc omnia cum habeat, etif aliis erroribus in compofitione commiffis, theriaca Andromachi Senioris non fit dicenda, eft tamen affrmandum, antidotum efle infigne, multis viribus preditum. Aliquos ab afpidibus, cornutifque $/$ Egyptiis viperis, atque à fcorpionibus, qui ibi funt perniciofifimi, quales Diofcorides defcriplit, demorfos, vel fuuciatos, illiufee tantum theriace ufu probe, ac fere continuo fanatos vidi:- omnes affirmant theriacam illam vim efficacifimam habere adverfus omnia venena, atque ferarum virus, plurimos vero morbos hoc antidotum juvare polle, non eft longa oratione perfuadendum, cum ex ingredientium fimplicium viribus facile pateat, ego mulierem viduam, multis annis ab uteri gravioribus doloribus vexatam, nec non ab aflidua cruditate, ventriculum languidius adeptam, eam crudorum humorum gignere copiam, ut quotidie ingentem aquofe pituitæ molem vomere cogeretur; hæe, inquam, mulier ufii theriace AEgyiptix probe fanata fuit: fileo brevitatis caufa alia commoda in paralyticis, vertiginofis, fufpiriofis, ac confumptis, atque in aliis fere innumeris malis ex thariacx uft obfervata. Neque id injuria, cum ea valde perficiatur vero calamo, acoro, amomo, opobalfamo, carpobalfamo, xilobalfamo, \& multis aliis præclarifimis medicamentis, qux humani generis faluti magnopere conducunt, quæ quidem in noftra theriaca defiderantur, Sunt qui affirment, illius theriacx præftantiam, ex cornutorum ferpentium carné augeri, fiquidén ajunt, carnes tyrorum, quas aliqui ceraftes dixere, effe noftrarum viperarum carnibus calidiores, venenofiorefque. Quod non parum efficaciæ ipforum theriacæ addere colligunt; quando antidotum promptius ad cor deducatur ex ferpentis facultate, cujus venenofam qualitatem cum homine inimicitiæ caufa, fubito ad cor precipuum hominis propugnaculum fuapte natu- 
ra duci ac invadere onnes fciant. " Ex quo, ut dicunt, caro illorum ferpentium longe multo noftrarum viperarum carne eit venenofior. Igitur antidotum reddet promptius, ut cor fubeat, illique opem ferat. Præterea, ob animalis fpeciem, \& ob ca-? lidum, fub quo nafcitur \& alitur, coelum, \& quod in locis af-i peris arenofis vivat, ratio fuadet, ex ipforum carne confectos: paftillos effe calidioris facultatis, idque antidoti motum ac operationem fine dubio juvare. Quamobrem has non indignas laudes de Figyptiorum theriaca prædicere videntur. GuIland. Hoc antidotum, etfi Andromachi theriaca non dici queat, cum adeo diverfo modo componatur, tamen quod ex. multis nobiliffimis venenis atque medicamentis fit compofitum, quæ multis aliis morbis valide occurrere poflunt, non indignum ac inutile anditotum dicetur; affirmoque \& ega, ipfum poffe multis malis præfentaneun effe auxilium; verum illius fumma facultas, ab illius forma refultans, \&. tum experientia ab Andromacho, ut puto inventa, tum ab ingredientium medica. mentorum natura, ab ipforum fic ordinato pondere probata vitiato portea ingredientium pondere, atque multis defideratis ingredientibus, aliifque pefime: admiffis, interiit. Sed ne plus temporis in hoc antidoto conteramus, cum aliqua præterea fuerint à te de illius ufu dicta, finem faciemus.. Alprin. $U$ fus theriace apud Egyptios ef frequentilimus, præfertim in venenatis, atque $\mathrm{ab}$ omnibus ferpentibus demorfis, a fcorpionibufque ictis, qui ibi, ut dixi, exitiofifimi, quales Diofcorides prodidit, habentur; noftris etenim feorpionibus longe majores exiftunt, colore viridi, claro; nullique nigri ibi exiftunt. Multi igitur thericam diu frequentant ita, ut aliqui per totuin annum, \& aliqui per pluresiea utantur, putantes illum natura, lem calorem fovere atque augere, juventutemque diu çonfer, vare, \& vitam longiorem readdere Ejus vero utilitatem in iis, qui ftomachi languores patiuntur, \& à diminuto calore concoquere nequeunt, nemo, eft, qui ibi ignoret, ita familiaris eft pro ftomachi calore: angendo, vel confervando; ne; que immerito, cum plerique debilem ftomachum, ac langui dum obtineant, quod omnes vefcantur cibis refrigerantibus, 


\section{P R O P ER I A L P I N I}

aquamque ebibant, \& dulcibus balneis immoderate ac inordinate, utantur: venerique maxime indulgeant. Quifque etenim ibi uxores multas ducere poteft, atque non minus mancipia, quot alere fuis fumptibus poteft, pro veneris delectatione, nec tamen ipforum turpiffima libido vincitur; ex his itaque caufis multi ventriculi debilitate laborantes, ufum theriacæ feliciffime frequentant. Multos vidi fere tabe confumptos non concoquente ventriculo, ufu illiufce antidoti vitam redemiffe. In antiquis opthalmiis, furditatibus vertiginofis, refolutis, epilepticis, convulfis, atque aliis omnibus tum morbis, tum fymptomatis à frigiditate nafcentibus, omnes theriaca utuntur,'non minufque in omnibus peftiferis febribus, $\&$ in pefte nihil habent, in quo magis confidant, quam theriaca. In puerulis etiam ejus ufum exercentes, quid verbis longius rem produco, ipfi fere ad omnes morbos, ac fymptomata therica utuntur: atque hæc de ipfa dicta fufficiant. Guiland. Compofita alia, quibus illos uti nuper narrafti, te quoque fubjungere æquum eft, proinde expecto ea quoque ex te audire.

\section{A p. XIII.}

De quibufdam aliis compofitis medicamentis, quibus etzam CEgytii utuntur.

\section{A L P I N U S.}

Tabent illi aliam theriacam ad fcorpionum ictus, qua fre1 quentiffime utantur, quam tarach elacrap appellant, quem componunt accipientes, piperis nigri, dra. x. piperis longi, dra. v. cyperi, dra. ij. ariftolochiæ longæ, radicum paftina$c æ$, quam cariotam noftri appellant, ex quibus pulverizatis, \& melli dulcium filiquarum commiftis electuarium parant. Hujus femunciam exhibent ictis à fcorpionibus, quibus validiffime etiam adverfari cenfent, pulveris ariftolochiæ rotundæ, \& corticum radicum capparorum femidrachmam cum vino aromatico datam. 'Aliud antidotum, quod el philofopha appellant', in 


\section{DE MEDICINA EGYPTORUM. LIB. IV. 3i}

ufu apud ipfos eft etiam frequentiffimo, ad firmandum catarrhum, quod fpiritus corporis roborat, appetentiam concitat, concoetionem juvat, memoriam, bonofque mores augere quoque ajunt, à frigore defendit, ftillicidio urinæ confert, \& doloribus veficæ ex flatu concitatis, femen genitale auget, dolorem itidem à dorfo levat, membraque principalia roborat, dentes in gingivis firmat; hæque dotes atque aliæ leguntur in libro ebnag el ducan vocato, in quo omnia compofita, quibus illi utuntur, fcripta funt. Parant vero hoc electuarium, accipientes, piperis nigri, piperis longi, zinziberis, cinnamo$\mathrm{mi}$, mirabolanorum emblicorum, fumi terræ, ariftolochiæ rotundæ, florum calaminthæ; granorum pinearum, nucis Indæ, curcumæ, \& alli etiam addunt, nafturtii', teftium lupi, an. unciam, paffularum à feminibus mundatarum, id eft; pulpæ drachmas triginta, mellis partes tres: omniaque fimul mifcent, pulverizatifque pulverizandis electuarium faciunt. Alii hoc fic componunt, fumentes piperis nigri, piperis longi, zinziberis recentifimi, cinnamomi, mirabol. emblicorum, bellericorum, fumi terræ, ariftoloch. rotundæ, curcunæ, florum calaminthæ, granorum pinearum magnarum, nucis Indæ partem unam, mellis defpumati partes tres, fingula feparatim pulverizant, per cribrumque denfum deducunt, mifcent, \& faciunt electuarium fecundum artem! Aliud etian parant, eftque philonium perficum Avicennæ, quo utuntur; componuni vero ipfum accipientes piperis albi, feminum hyofciami albi, an, dra. xx. opii, terræ ligillatæ, an dra.x. croci, dra. v. euphorbii, fpicæ nardi, peretri, an. dra. ij. caftorii, camphoræ, an. 1c. xv. contundantur omnia, quoad pulverizentur, per fetaceumque trajiciantur, quæ fimul mifce, \& rurfum fac, it per fetaceum exeant, ex quibus cum mellis defpumati idonea quantitate miftis, fiat electuarium, quod per menfem in claufo vitreato vafe ad ufum fervetur. Cujus apud illos ufus eft familiarifimus ad immoderatum fanguinis, vel alterius humoris fluxum, profertimque ad menftrua profluvia firmanda, atque ad gonorrhæam. Aliud etiam quod bers nominant, penes omnes ef ufitatiffimum, ipfumque parant ex piperis albi femi- 


\section{$312 \quad$ PROSPERIALPINI}

num hyofciami albi, an. dra. xx. opii, dra. x. croci, dra. $T$. (Alii crocum ad quinque tantum chirat in hac compofitione ponunt) fpicæ Indx, euphorbii, piretri. an dra. j. Omniaque in tenuiffimum pulverem redigunt, ex quo cum melle defpumato electuarium conficiunt. Videturque hæc compofitio parum diffimilis, vel differens à Philonio Romano, ex Avicenna litteris prodito: iifdem enim viribus effe Egyptii experiuntur. Demum ii non minus Dirmufch, electuarium, quod Diamefch vocant, in ufu habent frequentiffimo, ad hilaritatem animi conciliandam, \& ad augendam venerem, cujus gratia dictum eft, medicamentorum, phenoniæ, bers, atque Diamufch ufum eos maxime exercere. Hæcque illa exiftunt medicamenta, quæ penes illas gentes tum componi, tum frequentari obfervavi. Supereft modo, ut nonnullos clyfteres etiam narremus, quibus ad varios morbos atque fymptomata ii quoque familiariffime utuntur. GUILAND. Neque id nobis inutile erit. Quo auxilii genere eos populos maxime delectari olim intellexi. Itaque ne hos quoque mihi narrare pigeat.

\section{A R. XIV.}

De nonnullis clyfteribus apud EEgytios ustatis.

\section{A L P I N U S.}

IN febribus, inflammationibufque internis, \& in aliis omnibus morbis a calida caufa concitatis, clyfteres iifrequentare folent paratos ex decocto feminum endiviæ, lactucæ, malvæ, altheæ, bammix, melochiæ, fonci, oxylapathi, abdellavi, melonis, chate cucumeris, cucurbitæ, ac oleo fefamino (dehenfiris apud ipfos appellato) melleque carnubus ex filiquis quippe dulcibus expreffo, quo ii familiariffime in clyfteribus ab fubducendam alvum, utuntur. Sunt aliqui, qui ad fupra dictum conficiendum decoctum pro clyftere parando, addunt etiam pruna damafcena, febeftena, atque fructus paliuri, quos nabca 
DE MEDICINA 死GYPTIORUM. LiB. IV. 3i

nabca nuncupant, caffiam folutivam, vel tamarindos. In is vero, quibus ex calore febrili atque ficcitate, vel à calidis, mordentibufque halitibus vigiliæ, deliriaque contingunt, clyfteres conficiunt, decocto ex feminibus pfylii, papaveris albi, interdum etiam nigri, hyofciami alibi, aliquando etiam rubri, nenupharis, portulacæ, malvarum, betæ, parato; atque oleo nenupharino; in quibus ubi etiam ab iifdem caufis fitim concitatan lenire volunt, addunt fubftantiam tamarindorum, $\&$ acidorum ceraforum, necnon berberis fructus, quando etiam adftrictione aliqua alvus opus habet. Et in ficcitatibus ventris, cum ipfum laxare folummodo ftudent, clyftere utuntur, ex feminibus malvarum, melochiæ, bammiæ, betæ, pfyllii, hordei, fœnugræci, meliloti, lini, altheæ, cytoniorum, papaverum alborum, paffulis à feminibus mundatis, prunis damafcenis, febeftinis, dactilis maturis, ficubus fycomori, mufarum fructibus, atque jujubis parato, cum melleque carnub, vel caffia folutiva, \& oleo fefamino, quibus ubi etiam purgare alvum defiderant, addunt aliquando fcammonium ufque ad binos fcrupulos, vel agarici binas drachmas, vel tantundem pulpæ colocynthidis, vel feminum minimorum, validiffime purgantium, contuforum (quæ daocci el maratum vocant) drachmam, aut alterius medicamenti purgantis, ac nitri, vel falis modicum, Sic paratis his clyfteribus illi utuntur ad dolores dorfi, renum, uteri, coxarum, inteftinorum, atque capitis, ad vertiginem, apoplexiam, paralyfim, furditatem à frigida caufa concitatam. Prædicta vero decocta, quibus hos clyfteres parari diximus, parant etiam cum feminibus fæniculorum, aniforum, ammeos, vifnagæ, fænugræci, meliloti, daocci, ac aliis, facultate ventres calfaciendi, ac flatus refolvendi præditis. Ad firmandos ventres immodice dejicientes, præcipue à caufa calida, hunc clyfterem parare folent, accipientes, feminum coriandri, fumachi, berberis, an. dra. v. fucci acatiæ, lycii, hypociftidos, an. dra. iij. aquæ chalibeatæ libras tres; bulliunt omnia ad confumptionem tertiæ partis, ex quo decocto cum oleo myrthino clyfterem conficiunt. Plerique ad diarrhæam, ac dyfenteriam corpore prius probe purgato $\mathrm{R} r$ cly- 


\section{PROSPERIALRIN I}

clyfteres adhibent, eft decocto filiquarum immaturarum foliorum atque florum acatix, in quo aliqui quoque duos vel tres, ovorum affatorum vitellos diffolvunt, vel eofdem in oleo rofaceo vel myrthino diffolutos, cum decocto prædicto mifcent. Verum quomodocumque clyfter ex acatix filiquis recentibus immaturis, "vel foliis, vel floribus paretur, femper quafcunque fanguinis, vel aliorum humorum non naturales fluxiones cito ac valenter fiftit. In uteri profluviis firmandis nihil ibi mulieres habent præitantius, quo utantur. Joannes Mancinus nobilis. Florentinus Cayri olim mercaturam feliciter exercens, à febre continua, putrida cum diarrhæa biliofa, affidua, contabefcere inceperat, ex qua, cum clyftere ex acatix decocto parato bis tantum ufus effet, fanatus eft. Cum quidem alvi dejectio longo tempore copiofa, ac crebra perfeveraffet, eumque fere ad exitium duxiffet, febre minime (quamquam fatis micis effet) neglecta, probe illius corpore purgato, haud levata alvi diarrhæa, multis frufta tantatis remediis, confului, ut clyftere ex decocto immaturarum acatiæ filiquarum, foliorum, ac florum recentium parato, uteretur, ex quo bis.adhibito, fic illius alvus cohibita, atque adfrieta fuit, ut nedum flatus pofthac per anum exire potuerint. Qui quidem nocte fequenti intus retenti $i$, in dextroque hypochondrio collecti, feptum tranfverfum valide comprimentes, hominem fere fuffocarunt. Quo fymptomate nonnullis admotis cum igne cucurbitulis, ftatim leva tus efto Quamplures etiam clyfteres habent hyftericæ mulieres, ex decocto feminum freniculorum, aniforum, coriandrorum, ammeos, cumini, lauri, balfamique, \& nucis myricæ. fructuum, abfinthii, camomelli, anethi, rutre, atque aliorum multorum vim refolntoriam ac excalfaetoriam habentium, curn modico, vel agarici, vel turbit, vel colocynthidis, atque oleis calidis paratos, quibus familiarifime ad cos affectus nit folent: In quibus medicamentis purgantis loco libenter melle utuntur ex dulcibus filiquis exprefo, carnub appellato, vel Caffiam Egyptiam, aut hyeræ ex melle paratum electuarium, quod \& ipfi etiam componunt. Ad eafdem uteri frigidas affectiones. clyfteriorum quoque auxilio utuntur, ex ammoniaco, ferapi- 
no opopanaco, in urina pueri diffolutis, decoctoque ex feminibus apii, foniculi, anifi, ac aliorum dictorum medicamentorum, vim calfactoriam, ac refolutoriam habentium. Sed de his nunc fatis. Gomand. Verum dicis, fed olim ex multis audivi, quam plura apudeas gentes felecta, vel fecreta frequentari. Ea igitur fi quæ habes, tuis fermonibus digna, ad ea quæ hic confequi dicta funt, addas velim. A L P I N. Quibus illi ad curandas febres frequentius utantur, tibi jam potero explanare, quando pleraque alia, quæ plurima exiftunt, mihi ex memoria maxime exciderint, vixque ea jam recordari amplius porfem.

\section{A p. X V.}

De jecretis auxiliis, quibus CEgyptii ad febrium curationem uti folent.

\section{A L P I N U.S.}

A I I QUI pro fecreto habent, fynochas, \& ardentesfebres, A multam aquam anguriæ el navi vocatæ ægrotis propinantes, fanare, fi modo febricitantes ea multis diebus in cibo, ac potu fola utantur. Alii aquam ftillatitiam ex anguria, chateque cucumere, atque melone abdellavi, tempore vehementioris æitus largius, frigidamque potandam concedunt, qua epota ægrotos multis pannis contegentes fudorem procurant, quo non paucos audio ibi fanatos fuiffe. Alii pro fecreto habent, multam itidem aquam ægrotis potandam offerre, in qua tamarindi, berberis prunique damafceni fructus per diem cum paucis feminibus fæniculi infufi manferint. Quam tunc recte percolatam cum mannæ maftichinæ unciis duabus exhibent. Multi etiam curant has febres, fingulis diebus, vel faltem alternis diebus unciam folutivæ caffiæ cum faccharo candido, vel cum aqua ftillatitia melonis abdellavi, vel anguria el navi diflolutam exhibentes, \& alii libentius manna, vel fyrupo de granatis folutivo in is utuntur. Quæ folventia medicamenta nonnullis tan- 


\section{DROSPERIALPINI}

tum diebus decretoriis ægrotis danda cenfent; quocirca fingulis is diebus illi talium medicamentorum ufum exercent, quippe die tertio, quarto, quinto, feptimo, nono, undecimo, decimo-quarto, \& aliis fingulis, morbo minime curato. In quibus febricitantibus epithematis ex aquis multis ftilatitiis reirigerantibus cum aceto fupra thoracem, atque præcordia, plerique pro tutiffimo auxilio utuntur. Vigiliis vero correptis, ac ipfis admodum vexatis, fuccurrunt, emulfione albi papaveris, ac pfyllii in multa aqua lactuce diffoluta, vel hac haud plane fatisfaciente, cum fyrupo de papavere febricitantibus fæpe propinata, vel fanguinis vacuatione in pueris, mulieribufque à fcarificatis cruribus prædita, aut appofitis cum incifione cucurbitulis in partibus poft aures, prope nucham pofitis, aut in adultis fecta vena frontis, vel temporum, arteriarum altera, vel qux portaures pulfat: Utuntur etiam non ad has modo, fed ad quafcunque ex calidorum humorum putridine ortas, clyfteribus paratis, ut nuper etiam dictum à nobis fuit, ex decoctis feminum malvarum, altheæ, hordej, lactucæ, endiviæ, fonci, cucumeris, melonis, ac aliorum hujufcemodi refrigerandi, \&.humectandi facultate præditorum, cum oleis refrigerantibus, qualia funt, quæ ex floribus nenupharis, violifque parantur atque melle carnub mirum in modum. interna vifcera hos clyfteres refrigerare putant, tenuefque, ac calidos humores evacuare. Plures curant febres intermittentes à biliofis, ac pituitofis permiftis fuccis concitatas, in potu dantes fingulis diebus fuccum betæ calidum cum faccharo candido, ad uncias octo in aurora: atque nonnulli drachmam agarici, cum calido decocto chamedrios.; \& alii abfinthii decoctum, aliique chamedrios in tenuifimum pulverem redactidrachmam in potu per horam ante-acceffionem cum: aqua calaf: multis vero magis probatur infufio tamarindorum pulpæ cum faccharo, in aqua buglof $æ$, vel binas uncias terengibil in aqua multa endiviæ, feilicet in duabus ac etiam tribus libris diffoluti aliqui exhibendas laudant. In puerifque (quorum terrengibil proprium folvens medicamentum effe ii omnes exiftimant). uni tantum libræ aquæ diffolutum propinant. Et quibufdam magis probatur 
his febricitantibus drachmam rhabarbari fingulis diebus ante acceffionem exhiberi. Alii ante acceffionem per horam prebent devorandum bolum infra feripti electuarii, quod parant, accipientes rofarum communilim, dra. 5. radicis glyzurrize, cinnamomi, fpicæ Indæ, rhabarbari, maftiches chı, iandalorum alborum, flavorum, fructuum berberis, croci, an fir. 15. facchari candidi, dra. 10. fingula conterunt, ex quibus cum fyrupo violato permiftis electuarium formant. Pro fingulari valde fecreto apud quofdam celebratur potio quædam ante ac. ceflionem per binas horas ægrotis oblata. Quam parant, ex mannæ terrengibil vocatæ, pulpæ cafliæ folutivæ, tamarindorum, an. drà. 4. quæ in endiviæ ftillatitiæ, vel communis aquæ libra ufque ad confumptionem duarum partium ebulliunt, colaturæque mifcent olei fefamini binas uncias; nonnulli eodem tempore dant illis potionem ex aqua betonicæ, \& endiviæ, dra. 2. facchari candidi fèmuncia paratam, \& aliqui tribus diebus exhibent in aurora decoctum pentaphylli, agrimonii, ac althex, cum fyrupo violato, aut fex uncias decocti pulegii cum faccharo per horam ante accefionem. Non pauci etiam eodem modo potionem fequuntur, quam parant decoquentes in tribus libris aquæ, feminum melochiæ, funci, apii, endiviæ, melonis abdellavi, cucumeris chate, fænugræci, meliloti, an dra 3 . ad confumptionem duarum partiun. 'In cujus decocti unciis quatuor, veri opobalfami drachmam diffolvunt. Cujus opobalfami ufus eft apud multos ad has febres frequentiflimus; fumunt enim drachmam, \& plus etiam veri opobalfami in decoto chinæ radicis, \& f́picæ Indæ, vel in jure pulli, cum radice petrofelini vulgaris ebullito: quo aflumpto flatim pannis multis cooperti plurimum exudare conantur, terque hoc reme: dio ii uti folent Multi curant has febres epithematis lineis pannis exceptis, hypoctiondriis , atque univerfo thoraci admotis, fiquidem aiunt noxios humores febres foventes vi epichematis. refolvi. Non minus vero quam alia epithemata hoc ipfi exercent, quod parant fumentes, rofarum communium; florum camomilla, calaf, el hanne five ligutri Kgyptii, caffix folutivæ, violarum, boraginis, an. m. I. feminum funci, endi- 


\section{PROSPERI A L P I N I}

viæ, malvarum, melochiæ, bammiæ, meliloti, fæniculorum, fœnugræci, fefami, altheæ, hordei, pfyllii, papaueris albi, abdellavi, chate, an. dra.4. Quæ omnia modice contufa bulliunt in tribus libris aquæ ad confumptionem medietatis, atque colaturæ addunt ligni aloës, rofarum communium, fandal. rub. pulverizatorum, an. dra. I. croci, gr. 5, aceti albi, unc. r. s. fimulque mifcent. Utuntur hoc epithemate tepefacto, à cujus ufu fe cavent priufquam univerfum corpus aliquo medicamento, vel fanguine multo per venam fectam, aut per crurum fcarificationem, vacuatum fit. Aliqui hæc epithemata folummodo ex aqua hordei, calaf, endiviæ, aceto, \& croco parant. Quamplures more antiquorum pro fecreto utuntur ad omnes corporis partes, quibufdam linitionibus cum levibus perfrictionibus adminiftratis: quas aliqui præftant cum oleo rutæ, aut amygdal. amararum, aut camomelino, aut juniperino, \& nitro rubeo. Qua frictione cum linitione hac in multis ad fudorem aptis largum fudorem concitant, atque fic morbum finiunt. Hoc allxilium in peftilentibus febribus, in quibus exhanthemata apparere incipiunt, vel exituras fperant, plurima cum utilitate exercent femel ad minus in die probe calidam molientes linitionem; à qua ftatim febricitantes multis pannis cooperientes fudorem promovere, venenofumque humorem à vifceribus ad cutim trahere ftudent. In pueris vero, atque infantibus variolis fufpectis, vel malignis exanthematibus, nullum præftantius, neque ipfis familiarius habent auxilium. Sunt qui inungunt per horam ante acceffionem totam fpinam dorfi à nucha ad lumbos ufque oleo antiquo, fampfuco, ruta, artemifia, abfinthio, fpica Inda, maftiche, ac thure ebullito, ipfoque calido inungentes, præmiffa parva ac levi frictione. Nonnullis ex multis linitionibus hæe magis probatur, qua ad eandem fpinam libentius utuntur: quam parant ex olei antiqui, fucci rutæ, vini aromatici albi, an. dra. vj. theriacæ Androm. Senioris, dra.iiij. bullientes in phiala vitrea ad confumpt. medietatis. Sunt etiam alii multi, qui ad has febres tertianas varia medicamenta pulfibus brachiorum, ac crurum admota frequentant, ex quibus unum præftant, multis ex araneis, una cum fuis telis contufis ad 
modum linimenti cum oleo rofaceo miftis, vel araneas ipfas in oleo prædicto incoquunt, quo calido carpum ambarum manum inungunt. Alii urticam cum fale, vel nitro tritam eodem modo admovent per horam ante acceffionem. Hæc atque piura alia in curatione febrium tertianarum curatu difficilium illi profequuntur. Ad eas vero, quæ ad pituitofarum magis naturam accedunt, quas noftri fpurias ac notas tertianas nuncupant, longeque magis ad quotidianas, vel amphimerinas, multi pro fecreto habent ante acceffionem, chamedrios pulverizati drachmam in jure pulli exhibere, vel ex ea herba paratum decoctum cum faccharo multis diebus. Alii ad eafdem calidum decoctum eodem modo propinant, quod parant, in aqua bullientes florum violarum, bugloff, , boraginis, caffiæcalaf, rofarum communium, an. dra. ij. feminum malva, fœnu-græci, fœniculi, mei, endiviæ, abdellavi, chate, an. dra. iijj. liquiritiæ rafæ, paffularum, pulpæ tamarindorum, an. dra. j. zinziberis, fpicœ, carpobalfami, cannelæ, chamedrios, turbit, mirabol. chebul. an. dra. ij. foliorum fennæ, drach. xv. agarici optimi, dra. iij. rhabarbari electi, dra. ij. hæc omnia minutim incifa infundunt in aquæ endiviæ libra, quam poftea parum bulliunt, valideque exprimunt, \& expreffioni addunt oxymelis fimp. dra. iij. dividunt vero hanc potionem in tres partes, quam tribus diebus in aurora fumme calidam exhibent. Sunt aliqui, qui predieca omnia infundunt in tres aquæ libras, \& poftea per coqume ad duarum parcium confumptionem; cujus fingulo mane exhibent uncias quatuor cum faccharo. Quibus vero per hoc medicamentum feoris non tollitur, if exhibent etiam finsula die ante acceffionem femidrachmam theriacx Androm. Een. cum modico facchari rofati. GuIzand. Videntur hæc ex te narrata medicamenta ex eortim effenumero, quarationinon omnino adverfantur, propterea ipforum ufum minime fpernendum à noftris medicis, exiftimo. Sed perge, quod fupereft ipforum narrationi, dicere. AlpiN. Ex fecretis experimentis, qua ad quartanas febres 些gyptiis familiaria exiftunt, hæc quo que in memoriam fervo; quamplures enim ad id morbi genus pro felectifimo remedio habent, . grotis decoutum ex menta 
paratum ad femi-libram calidum, cum fpolii ferpentis pulverizati binis drachmis, ante acceffionem per horam propinare: Aliique majorem efficaciam tribuunt, vomitioni à decocto afari per os fumpto tempore acceffionis concitata. Nonnullis etiam probatur drachma catapociorum ante acceffionem, exhibita; quæ parant ex agarici, gentianæ, caftorei, myrrhæ, rutæ, an. dra. ij. piperis longi, calami aromatici, croci, an. fcr. iiij. theriacæ antiquæ, dra. iij. cum fyrupo de granatis dulcibus, \& aliqui aliud genus catapociorum parant, quo eodem quoque modo utuntur, ex diagridii, falis gemmæ, an. dra* s. aloes epatici, dra. iij. cum melle: Aliis ufitatius eft, quartana correptis exhibere drachmam agarici, cum myrrhæ fcrupulo diffolutam in decocto pulegii. Non paucos etiam fanatos audivi clyftere ex decocto amaraci, oleo laurino, cum duobus ovorum vitel. lis parato, fæpius adhibito. Nonnulli ad hanc febrem extollunt pulverem quendam ex maftiches, dra. iiij. fpicæ nardi, dra. i. s. euphorbii, dra. ii paratum; cujus drachmam in jure calido per horam ante acceffionem affumunt. Sed quæ febribus peftilentibus præfentanea effe auxilia ii putant, nunc etiam fubjungam, priufquam è memoria mihi excidant. Qui tuto magis has curare opinantur, præmiffo clyftere leniente eadem die, modo ægroti jejuni fint, fanguinem furarum fcarificatione copiofe vacuant: fecunda die alii tamarindorum acidam pulpam, alii-fyrupi de fucco granatorum dulcium folutivi, ac alii terrengibil uncias tres in aqua calaf; vel fonci diffolutas in aurora concedunt. Hos ægrotos à principio ad finem ufque perpetuo hunc potum fequi præcipientes, qui paratur exempligratia, ex aquæ endiviæ, rofarum, bugloffi, calaf, ex acido citri, vel limonis, ftillatæ, an. libra media, in qua per noctem, vel diem infundunt fructus Paliuri Athenei, nabca vocatos, berberorum, pulpæ tamarindorum, an. unc. ij. fem. citri 3 . $i$. factaque diligenti expreffione addunt vini granatorum acidorum, fucci citri, vel limonum, lactis feminum abdellavi aqua rofacea extracti, an. unc. ij. lactis fem. citri unc. i. mifcentque omnia fimul pro pota. Pauperes, qui multum fumptum ferre nequeunt, tamarindorum pulpam atque berberorum fructus, 
DE.MEDICINA $\mathbb{E}$ GYPTIORUM. IIB. IV. $32 \pi$

ctus, cum feminibus fæniculorum, vel citri in plurima aqua communi eodem modo infundunt, quam ægrotis pro potu toto morbi tempore concedunt: plurimumque in hujus potus ufu fperant; neque immerito, cum tum tamarindos, tum berberos illarum febrium putredini maxime obfiftere penes illos pluries expertum, ac cognitum fit. Primis harum febrium ita peractis diebus ad inunctionem totius corporis accedunt, cute quippe leniter perfricata, atque poftea calida inunctione inuncta, naturæa ad cutim expulfionem eo auxilio maxime adjuvantes, inunctionem vero ex oleo amygdalarum amararum cum nitro rubro, quod natron appellant, parant. In pueris, ut etian nuper dictum eft, variolis, vel puncticulis infectis hac linitione nullum remedium fecurius, vel præftantius habent. Aliqui hujus loco fudorem provocare ftudent, calidis medicamentis in potu fumptis. Quorum hoc ipfis familiarius obfervatur, quod parant ex theriacæ Androm. Senioris, fcr. ii. pulverifque infra dicendi drachma in aqua calaf, vel citri. Pulverem vero conficiunt ex fcordii, chamedrios, feminum citri, an. dra. i. ariftolochiæ longæ, Zedoariæ, dictami cretenfis, cornu cervi ufti, boli armeni, terræ figillatæ, rofarum, callaf, fpicæ, Margaritarum præparatarum, an fcr. ii. camphoræ, fcr. i. s. corallorum amborum, fcr. i. facchari candidi, dra. ii. omniaque tenuiffimum in pulverem redigunt. Quam potionem mane ante cibum, \& à cibo fpatio ad minus fex horarum calidam bibunt, a qua ftatim ægroti in lectulo pannis multis cooperiuntur, ut fudent, \& poftea toto corpore lineis calfactis pannis molliter fricantur, \& à frictione rurfum continuo pannis conteguntur, atque fudorem omni conatu procurant, repetuntque hoc ter ad minus in die. Aliis ad idem magis probatur potis ex aquæ rofatæ, calaf, florum citri, fucci limonum, an. dra. i. theriacæ fupradictæ, fcr. ii. croci, fcr. s. paratus. Nonnulli ufque adeo audaces exiftunt, ut quatuor cantaridarum capi$\mathrm{ta}, \&$ alas in pulverem redactas cum tribus unciis aquæ endiviæ ægrotis propinare audeant, quo medicamento, vel per fudorem copiofiffimum, vel per urinam peftiferum venenum vacuari, affirmant. Multi fingulo mane libram decocti calidi Ss äflu- 


\section{3.

affumunt, ex chinæ radice; feminibus citri vel limonis, abdellavi in aqua boraginis, vel calaf, vel etiam rofacea, atque modico fucci citri, parati - alii hune potum parant, chinam, tantum radicem, atque modicum pulpæ tamarindorum in aquam ex limonibus diftillatam, bullientes ad confumptionem medietatis, cujus decocti calidi libram bibunt, \& fatim fudare plurimum ftudent. Alii alium pulverem eodem hoc modo utendum cum aqua rofacea, vel calaf, pro fecreto ad has bebres habent, quem parant, accipientes dictami Cretenfis, albi, rutæ, maii Cretenfis, an dra. ii. bacarum juniperi, lauri, feminum peonia, an.-dra. i. s. calami aromatici, carpobalfami, "cinnamo$\mathrm{mi}$, ariftolochiæ rotundæ, zedoariæ, gentianæ, an. fcr. j. florum calaf, rofarum rub, citri, an. fcr. i. gariophyllorum, camphoræ, boli armeni, terræ figillatæ, lapidis bezaàr, Margaritarum, an. fcr. s. In pefte quoque habent in ufu nonnulla electuaria frequentifimo ad pracavenda corpora, ne inficiantur. Quorum unum, cui omnes maxime confidunt, componunt. , fumentes terræ figillatæ, dra. ii, fem. citri, acetofæ, an. dra. i. s. boli armeni, ariftolochiæ rotundæ, fcordii, zedoariæ, dictami albi Cretenfis, an. dra. i. theriacæ antiqua, cornu cervi ufti, dra. j. s. Margaritarum, fmaragdi, Hyacinthi, camphoræ, croci, an. fcr. ii. fandalorum omnium, corallorum rubeorun, albrum, ferici combufti, an. fcr. i. s. Quæ omnia in pulverem redacta, cum fyrupo de acido citri niffent. Cujus dofis eft à femuncia ad unicam. Ad idem hoc aliud fic componunt, fumentes zedoariæ, galangæ, fcordii, chamedrios, calaf, florum, corticum, atque feminum citri, acetofæ, terræ figillatæ, boli armeni, calami aromatici, cinnamomi, carpobalfami, xilioballami, coraliorum rub an. dra. i. dictami Cretenfis, fandal. rub. an. 1cri i. cornu cervi uft, camphoræ, an. fcr.ii.croci, piperis nigri, ligni aloes, molchi, fragmentorum fmaragdi, an. fcr. i. s. Margaritarum, drach. i. s. aloes fuccotrinæ, myrrhæ, an. dra. iiii. theriacæ antiquæ, dra. ji. inifce pulverizata cum fyrupo de acido citri, \& fiat electuariums dofis eft femuncia. Aliud ad idem, quod parant ex feminum itri, abdellavi, chate, acetofx, ocymi IEgyptii, quem ri- 


\section{de Medicina Egyptiorum. Lib. IV. 323}

han appellant, carpobalfami, an. dra. iii. dictami, bedeguar, fcordii, zedoariæ, an. dra. ii. cornu cervi ufti, terræ figillatæ, coriandriorum præparatorum, lapidis bezaar, an. dra. i. margaritarum, hyacinthi, fmaragdi, topacii, an. dra. i. s. fandalorum omnium, camphora, an. fc. ii. boli armeni, dra, $i$. facchari rofati antiqui, dra. viii. theriacæ antiquæ, dra. iiii. mitridatii, dra ii. cum fucco de acido citri pulverizatis pulverizandis mifcent, \& faciunt electuarium: cujus dofis eft à drachma una ad duas. Apud omnes Turcas atque alios nobiles $\mathbb{E}$ gyptios, opobalfami ufus eft frequentiflimus; neque immerito, cum ille fuccus tantopere adverfus omnem humorum putredinem præftet: eo enim inuneta cadaverum corpora diu imputria fervari multorum teftimonio conftat, Temperamento hominis naturalem calorem valde fovet, \& auget, plurimumque nobilia membra roborat, atque citiffime corporis partes permeat. Multos illius ufu à pluribus peftilentiis fuperftitiffe incolæ teftantur. Omnes fere, ut feipfos à peftis contagio deffendant, hujus liquoris ufui plus fidunt, quam ceteris aliis auxiliis; id in aqua ex acido citri, ftillatitia, vel ex flor. citri, vel in vi-, no albo, aut jure pulli liquatum bibunt, aut (quod fane valde celebre fecretum ad peftem habetur) cum binis ipfius fucci unciis, mifcentes myrrhæ, carpobalfami, ligni aloes, ter. ræ figillatæ, boli armeni, maigaritarum, lapidis bezaar, cro$\mathrm{ci}$, an. fcr. i. fumuntque hujus compofiti fingulo mane drachmam. Aliqui pefte infectis fic medentur, continuo cruribus, brachiis, \& inguinibus ea medicamenta, quæ noftri veficantia vocant, applicant, ex quibus ulcera multa in iis partibus, per quæ humores fumme putridi à natura extramittuntur, expurgentur. Cruribufque non unum, vel duo, at decem, \& plura etiam ulcera infligunt, atque non minus brachiis, atque hoc auxilium penes omnes Arabes, qui cum per deferta loca continue equitantes, fecum multa medicamenta habere nequeant, quibus utantur, hoc remedio utuntur, raroque ejus opera fruftrantur. Repeto aliud, cujus quidem fuperius quoque meminimus, ad curandos fane pefte infectos non minus apud Arabes celebre, \& ufitatum, quam nuper dictum fit. Quod illi moSs 2 


\section{7

liuntur, tres fcarificationes longas, \& profundas, quæ non fcarificationes, fed permagna vulnera apparent, utrique cruris furæ per longum intligentes, quæ non fanant, priufquam ægroti perfccte à pefte fani evaferint. Gurland. Hoc genus auxilii, quamvis barbarum præ.multo dolore videatur, tamen adprime utile pelte infectis judicandum puto, quod corpora non folum evacuentur, fed noxii humores non minus à nobilibus partibus ad ignobiles revellantur, continuaque putridorum humorum in toto morbi tempore per illa ulcera fiat evacuatio, ex qua ægrotos maxime juvari non eft hæfitandum. Hunc ego: hac perdoctus experientia in omnibus peftiferis febribus in remotis partibus corporis, ulcera omnia, profunda, \& lata, vel à natura protrudente venenofos humores, vel igne, vel exulcerante quopiam medicamento facta, plane laudanda cenfeo; præcipueque læfo jecore in inguine, corde in brachiis, atque. cerebro in occipite; vel in collo. His quidem ulceribus illa vifera facile utuntur ad extramittendos five vacuandos venefi-: cos fuccos à quibus ipfa in peftilentibus iis febribus, læduntur. Sed jamjam ceffo adloqui, ne amplius tuum coptum fermonem aliquo modo interturbem: fequere itaque reliqua. A LPIN. Quid amplius dicam? nulla videntur mihi fuperfuiffe dicenda, nifi de hecticarum tebrium curatione hæc quoque pauca tibi fubjungam. Curant enim ii hecticas febres, nullis putridis conjunctas, quæ exquifiræ hecticæ vocantur, victu præcipue frigido atque humido ex cucurbita, hordeo, lactuca, endivia, beta, ac aliis hujufmodi in jure coctis:- aliis magis probatur iii victu ufus anguriæe el navi, nam maxime refrigerat, \& humectat. Aliifque jufcula cum iifdem alterata Omnibus vero forbitiones maglub atque maftahaleb vocatæ funt familiariffimæ, quæ ex variorum feminum vim refrigeratoriam, \& humectatoriam habentium, parantur, quale à plerifque fic paratur, ex feminum lactucæ, endiviæ, fonci, malvarum, pfyllii, papaveris albi, melonis abdellavi, chate, cucurbitæ, angnriæ, hordei, piftachiorum, amygdalaruin dulcium ex Gaza adveEtarum (quas minus alii calfacere ii putant) fingulorum æqualibas partibus, quibus aliqui mifeent femina foniculorum, aur. 


\section{de Medicina NGyptoRum. LiB. IV. 325}

citri correctionis caufa, quæ omnia in marmoreo vafe contundunt, ac poftea lac cum aqua endiviæ, vel hordei exprimunt atque colligunt, cui addentes modicum aquæ rofaceæ, \& facchari candidi violati, forbitionem parant, quam hecticis aliorum ciborum loco offerunt. Sunt qui hoc tantum victu pluribus diebus ufi à febre illa evaferint. Alii hecticos curant lacte camelino, vel afinino, vel humano, maximeque confumptos. Utuntur etiam balneis ex lacte tepido paratis, corpora etiam illorum præter quod lacte irrorant, oleis quoque nenupharino, violaceo frigidis, vel tepidis inungunt. Non minufque illis in ufu familiariffimo dulcia balnea tepida, atque frigida exiftunt. Multi enim port balneum calidum frigidam in aquam, quæ tamen non multum fit frigida; fe immergunt plerique libentius tepida, quam frigida ad hecticos curandos utuntur. Divites, ut jam dixi, familiaria habent balnea, ex lacte camelino, vel afinino, vel caprino parata. Hæcque obiter memini, me, partim apud $\mathbb{E}$ gyptios medicos ad ufum febrium curandarum praxim cum iplis exercendo, obfervavifle, partimque à quodam medico fEgyptio doctiffimo accepiffe, quæ qualiacunque fint, tibi libentiflime nunc communicare volui. Guiland. Perpulchra fana videntur, minimeque inutilia, quæ dixifti modo, pro quibus non parvas gratias tibi habeo. Sed tempus nunc nobis fuadet, ut paululum quietis nunc capiamus, reliqua in altera die dicenda remittentcs, quando parum diei nunc fupererit; nam video, Solem pene ad occafum jam acceffiffe, ex quo etiam in hac die illa abfolvi à nobis non potuiffent.

\section{F I N I S.}




\section{N D E X \\ EORUM OMNIUM, QUÆIN MEDICINA ÆGYPTIORUM C ONTINENTUR.}

A.

A balassan, Carpobalfamum. 302 A Abderæ virgo multiplici vacuatione judicara.

Acatiaz vires ad fiftendam quamcunque fanguinis vacuationem.

3 I 4

- - fuccus duplex, quippe liquidus, $\&$ ficcus. 306

- . - fucci ficci ufum in AEgypto effe ad cariarios pro ringendis coriis.

Acariam arborem, cujus Egyprus eft ferax, non edere lachrymas, five ab ipfa arbore non diftillare lachrymas, quarum fit ufus.

306

Acori radices non efte calamum aromaticum.

Acoro vero Egyptii utuntur, quem Hehud vocant.

Achovan quid. 306

Achaoen, Vehoven, \& Alachuan idem.

Achaovam herba crefcir in Ægypto. 299

- - defcriptio.

299

- - an fit marum.

299

Achimbaffi medicus omuinm primus. 4

- - medicus medicis mederi volentibus authoritatem foluto pretio concẻdit. 4

- - officium quale fit.

- - à Beffa Cayri procreari foluto pretio.

4

- - Beffa non excellenriorem in medicina virum, fed eum, qui multos aureos folverit, procreare.

-.. ommes, qui pretium folverint, etfi medicinx artis prorfus ignari fint, mederi per urbem finir.

Ad bubones, rưmores, \& parotides peftilentes cucurbitula utiles.

164

- febres fynochas fecretum auxilium. 3 I 5

- febres peftilentes porus fingulares. $32 \mathrm{I}$

- Hydropem Egyptios uti ultione. 2 I 2

- fcorpionis morfum fearificatio partis affecta.

207

Advenx omnes, cum Cayrum ftatim ve. nerint ex potu aqua Nili diarrhæam pati foleut.

Adulterx mulieres cur maritis filios fimiles pariant.

88

Ad uteri frigidas affectiones clyfteres. 314 Edes balneorum gratia confructx. 2.28 - - balneorum in ÆEgypto quomodo factx fint.

228

Fdium pro bahneis conftructarum defcriptio.

228

Egrotos filios gignere $x$ grotos.

88

Ágrotis, quibus ante fanguinis miffonem aliquid cibi fit concedendum. 123

- antequam ipfis fanguis mittatur, aliquem frigidum potum cum aliquo fyrupo os ventriculi roborante effe exhibendum.

123

- quibus fit mittendus fanguis, tutius potum, yuam cibum dari poffe. $\quad 123$

Egypti regionis defcriptio. I8

- - firus. 18

Egyptus eft inter Æthiopiam, Arabiam, \& Marmaricam.

Egypti aërem funme calidum effe, qux oftendant. 


\section{I $N$ D E X.}

Ėypti incolarum triplex genus efle. 3 I Egypto venundari.

Egypcum nunc veris Ægyptiis hominibus carere.

92

Agyptus habet $\mathrm{ab}$ ortu Arabiam, ab occafu Marmaricam, à Septentrione mare Mediterancum \& à Meridie Æthiopiom.

18

Agyptum carere balneis naturalibus. 228 - habere homines pingues, ac craffos.

Agypti incolx omnes Vigiles exifunt. 37 Egyptum viris olim tum in medicina, tum III aliis fcientiis illuftribus foruit. 2 Egyptus prifcis freculis pluribus doctiffimis medicis floruit.

Egyptum totam pefte infertam accedente tropico cancri, ab omni pelte, peftifque contagio fanari.

Egypto regiones conterminx.

70

Eyprus a guibus ventis libere eventila tur.

296

25

- - Septentrionalibus ventis magis quam aliis eft expofitus.

25 Figyptum magis expofitum Septentriona. libus ventis, quam aliis, voluit Deus, ut refrigeraretur.

25

Egy ptus miraculo foeeunda videtur, cum folum totum arenofum habeat.

- - totan foecunditatem à Nilo fumine accipit.

26

IEgypum hominibus abundare, fic pinguibud, qui mammas longe maximis: feminarum mammis, majores habent.

32

Egyptii cur multo fanguine abundent. 32 Egypti habent ftomachum frigidum mul-

ta pituita featente.
AEgyptii à quibus ftomachum frigidum contrahant.

Egyptiorum corporum habitus.

Egyptii victu teuui ac admodum fobrio utuntur.

- pluries in die quam noftri comedunt, fed parum.

- morbi fparfím qui per urbem Cayri femper obfervanus.
- medici medendo utuntur illa univerfáii propofitione, quippe contraris contraria curari.

16

Agy ptios non recte intelligere propofitionem, qua eft contraria contrariis curari.

Agyptii errant in cognofcendis morbo contrariis remediis.

16

- medici in quibus morbis recte utantur medentes propofitione, contrariis contraria curari.

16

- in curandis morbis femper morbo. contrariis utuntur.

16

- omnes cur ad ufum refrigerantium maxime pracipitentur. I6

- quet modis mittant fanguinem.

- mittune fauguinem ab auribus f́carificatis.

- mittunt fanguinem à cruribus farificatis.

Egyptios nunquam cucurbitulis uti pro molienda totius corporis vacuatione.

12.6

Egyptii cucurbitulis occipiti, atgue ejus proximis partibus utunttr.

126

- cucurbitulas, neque igne, neque aqua, fed fpiritus atcractione admovent.

126

- medici cui medicina fecta adhareant.

Exgyptios merlicos fectam methodicam, atque empiricam fequi.

- - ad morborum curationem, neque partium lxfarum, neque caufarum, neque naturæ, neque xtatis, habere rationem.

Egyptii putant omnia mosborum genera fieri, vel à calidirate, vel à frigiditate. $\sigma$ - ob cxlum Egypti fumme calidum, putane à calore omnes morbos fieri. 6

- refrigerantium unedicamentorum ufum cur frequentent.

- quibus dent operam.

- - publicas feholas habent, in quibus varia fcientiarum genera ducentur. 3 Egvptios plurima fecreta auxilia præftantiffima harediraric à prifcis doctifinis 
medicis accepiffe.

Egyptii, quz ad medendum in ufu habeant.

- quomodo ab oculorum lippirudinibus prafervenzur.

Agyptios ob parcum victum longiorem viram ducere.

- - ab ufu aqux Nili fluminis longxvos fieri.

40

Egyprii quomodó præfciant futurum fluminis incrementum.

29

- - quid faciant, ut prefciant futurum fluminis incrementum.

Egyptios mittere fanguinem à fectis arteriis, atque à mulcis venis, noftris medicis non ufitatis.

AEgyptii hirudinum ufum ignorant.

- - in carnium efu funt parciflimi. 33

- humido cibo delectantur, eumque fequuntur.

33

- arietum caftratorum carṇibus vefcuntur.

- ab Hippopotamo fanguinis miffionem acceptam referunr.

- - quot modis mictant fanguinem. 4

Egyprios pro vacuando fanguine vellas lecare, noftris inufitatas.

Agyptii mittunt fanguinem ab arteriis fectis.

- - aftate loca terrena habitant, prope fontes dormientes.

19

- fiftulas intra ommes domos faciunt, ad refrigerandum aëtem.

- omnes veneri admodum indulgent.

Egyptiis conceditur plures uxores poffe ducere.

37

Egyptii otiofam vitam ducunt, Exceptis Arabibus, \& rufticis.

37

- - cur fic frequenter miffioni fanguinis indulgeant.

Egyptios errare, qui largius ac fxpius quam opus effer mitrer e falıguinem foleant.

Egyprii xgroti nimium fanguinis miffioni fident.

Ægyptios tribus modis fanguinem mitte- re. I 2.5

- per venarum, arteriarumque fectionem, atque per variarum partium fcarificationem mittere fanguinem.

Egyptii, ne dum uruntur, partes inflam. inentur quid preftent.

Egyptios ferro frigido fxpe partes iis qux iluruntur, proximas tangere, ne adoriatur infammatio.

210

Egyptii quid poif inuftionem preftant.

210

- quas partes corporis inurant. 209

- - uftione articulorum laxitatem ac de. bilitatem corrigent.

121

- - inuftione articulis robur conciliant, ut $a b$ humorum "fluxionibus deffenda11tur.

$21-0$

Egyptios quam plures exuftis temporibus Ipectari.

- ad urendas partes rectius quam no. ftros fe gerere.

2 I- 2

Egyptii ad uftionem moliendam cur nullo metallo utantur.

213

- - ad inuftionem, cur gofypio ignito urantur.

$2 \mathrm{~L}_{3}$

- quem modum fervent in fearificandis cruribus.

195

Ægyptios recte fe gerere pro crurum fcarificatione fanguinem mittentes in pueris, Eunuchis, atque aliis corporibus laxis, pinguibus, albis.

I 12

- languinem mittere cutis fearificationibus.

- fanguinis miffione gaudere.

Egyptii mittunt fanguinem in omnibus rtatibus, anni temporibus, \& ad omucs fere morbos.

82

- libentius fanguinis miffone, quam medicamentis uruntur.

82

Egyptios mirabili dexteritate multas partes corporis pro mittendo fanguine fcarificare.

- mirabili dexteritate arterias, atque venas fecare.

Agyptii in quibus corporibus confuefant fearificatis cruribus mittere fanguinem.

I. I I

Egyptio 


\section{N D E X:}

Eggyptio:um modus aures fartificandi. Eyptii ciborum muliplicitare non gaudent.

- - fimplici cibo funt contenti.

- ciborum varietatem abhorrent.

- carnium efil non admoduan deleEtanur.

- Mahometis affecle vino non utuntur lege eis interdicto.

Exyptiorum multi vino non fecus quan Germani indulgent.

33

Ëryptios medicos per fectas arterias mittere fanguinem non lecus quam à ve nis.

133

EEgptii mittunt multum fanguinem. II

- medici all errene non utentes cucurbitulis pro adjuvanda exanchematurn eruptione.

160

. - medici in nobilibus uti blandiffimis medicamentis purgantibus.

II

- - inurunt partes goffly pio atque panno lineo iginito.

- quo pacto partes corporis inurere foleant.

210

ÆTy prios coxendicum dolorem inuftione fanare.

210

- - in pefte infectis mulca ulcera cruribus infigere.

324

Ẽyp:ii curant febres exanthema:um peitiferas linitione ex oleo amygdalarum amararum \& nitro, parata cum frictione ad univerfas corporis partes. $\quad 321$

- - in fébribus peftilentibus fudorem provovant

Agyprios dividi in urbanos, Arabes, 2 Rufticos.

3 I

Asypci incolarum temperamenta. 3 I

Rgyp:iorum urben habitantium corporum habitus \& temperies.

Exryprii fato quodam Tyrannis femper fuere fubject.

12

- - ufum inurendi habent familiarem.

IEgyptiorum plerique hepar calidum, \& humidum habent, ex quo multo fanguine exuberant.
- muleos majores mulierun mizzinis mammis, mammas hebere.

- temperies à quibus mutata. 93 Egyprii quamobrem omnes fere ftom: chum frigidum obtineant.

- - omue genus morbi ex capitis diftil. latinne obortum, patiuntur. 20. Egyprios medicamentis refrigerantibus. indulgere.

Egyriis pulveres efre familiares exurentes, atque terræ ficcitate.

Exyptii cur timeant ufum cucurbitularum in febribus peitillencibus.

- - herbam comedentes.

$16 \mathrm{~s}$.

258

- - an à commanfa herba, atque aliis medicamentis vero optata videre queant.

259

Egyptii lactis acetofi ufum fequuntur. 252

Egyprii plurima habent iu medicina prifcorum dotifimorum medicorum antiquitatem redolentia.

- cur morbis frigidis potius quam calidis infertentur.

Egyptis victus atque medicamenta familiaria.

Egyprios nultos annos plus centum vivere.

Egyptii à quibus caufs fiant longrvi 38 Ægyptix mulieres, quid in balneis factstent.

Agypsias in balneis pinguedinem procurate

$23 \mathrm{~J}$.

- uri balneis ad pingaefcendum. $23 \mathrm{r}$

- ad coitus conciliandam volutatem variis ungentis recte olentibus uti. 230 IEyptios errare molientes purgationes quibuldam feminibus. validifime purgantibus.

279

E.gypiorum aliquos poft aftump:um purgans medicamentuin agrotis multum aqua frigid $x$ potand $x$ propinare. 28,5 Egyprios divites multos fyrupos, quos cum aqua per aftatem potant, domi parare. 268

- lapides è vefica cxtrahendi fine incifione modun callere. 
- componunt Theriacam pro Tutcarum Rege.

288

- - juffu Turcarum Regis Theriacam coniponere.

288

- theriaca cum advenis multum Iucri facere.

288

- - errare in componenda theriaca. 307

- tribus nominibus his, quippe Darfini, Cherfe \& Selica, intelligere cinamomum, canellam, \& cafiam. 304 Aër Æॄgyti qualis fit.

20

Aëris E Eypri temperies.

20

Aër Igypti eft calidus \& ficcus, inæqualis, icinuifinus.

- - cur hyeme aliquando infigniter frigidus fentiarur.

20

- - capur maxime offendit.

20

- - quando eft temperatifimus $x$ qualıfimus, morbifque cas eat.

- locorun fEgypei mari adjacentium qualis.

91

. - . - à mari elongatorum qualis

91

- nocturnus \& diurnus per hyemem in Ægypto qualis.

Aêris Æ̈gypti diuma \& nocturna alteratio.

20

Aërem fumme calidum continue marcefcere, ac fieri peflimum.

68

Aër in Ægypio non uniformis 91

- Locorum Egypri mari adjacentium eft frigdior atque humidior.

24

- - fecundx xftatis, xqualis, continuus, calidus.

72

Aëris mutationem ab xftuante calore, inxquali, in minus calidum, xqualem conrinum peftem dirimere.

72

Aërem Januario \& Februario menfibus effe quo ad primas qualitates temperatas.

$2 I$

Aër in Egypto Junio nenfe ex morbofo ftatu. in falubrem mutatur. 70 Aër fecundx xftatis in Aecypto mutationes $n$ on conferrim, fed fenfin recipit.

Aëris refrigerandi caufa mulis Agyp:ii u.thitur.
Aër $\mathbb{E} g y p t i$ multum à Septentrionalibus, ac Meridionalibus ventis alteratur, \& parum ab oriencalibus, arque occidentalibus

- - ab Egyptiis, frigida aqua mulis fontibu; refrigeratur.

Ig

Aërem 尼yptii retrigerant quibuldam vaftifrmis fifulis in fingulis domibus ea caufa conftructis.

I9

Aër $\mathbb{E}$ Eypti adveniente xftivo folftitio quomodo omnc contagium peftlens confumat. 77

- ante xftivum folltitium ribus menfibus in Egypro, eft in:errupre calidifimus ac fire animalia fuffocans.

Aëris camerarum balnei temperies. 228 Aëren quoad calorem varium in balneorum $x$ dibus elfe.

Exris infufum fanare hepatis lienifque obAtructiones difficiles.

IEftatis tempus penes Ærgypios. 282. ERtasin 21 nat, 2 I Fittatem in Agypto duplicem effe. 2I Ettas prima in Ægypto eft inæqualifima, inconftantifrma, \& funme calida 2I - prima plurimum corpora ladit. $2 I$

- Cecunda eft $x$ qualior, minufque $x[-$ tuora, \& minus corporibus noxia. 21 - prima elt menfibus Martio, Aprile, Majo

$2 \mathrm{I}$

- fecunda, incipit Junio menfe \& ufque ad finem Augufti protenditur. 2 I Ifftatis prima aëris conftiturio. $7 \mathrm{I}$ - prima pars unde inconftantintima, xftuofifima, atque inxqualifima fit. 22 Eftatis fecunda temperies. 24 Æfftatem fccundan morbis carere. 24 Eftatis prim $x$ calidiflim $x$ \& in $x$ qualifim $x$. caufx.

22

- calor facile à qunque fertur.

19

- aërem fumme calidum temperari à Nili flun inis incremento, atcjue à Sep. tentrionalibus ventis.

- ä̈r nifi à Nuli incremento, \& à Septentrionalibus ventis refrigeraretur, homines ibi vivere non poflent.

I? 


\section{I $\quad \mathrm{N} \quad \mathrm{D} \quad \mathrm{E} \quad \mathrm{X}$}

Eftatem Etefiis carentem admodum morbolam

AE:ius fecandi modum in hydrope docuit.

220

uftionem in atticulorm, atque aliis morbis laudat,

216

Etares purgationes non recte qux ferant.

279

Agatarchidis de Nili augments opinio. 28 Agarici uilitas ad quartanas febrs. 320 Agens proximum in generatione magis poteft quam remotum

88

Agricolx Ægypti fecunda xitate vitam otiofam ducunt.

Agricolx quando femina terræ committant.

24

Alcanna, five elhanne, quod eft liguftrum Egyptium, florum ufus.

254

Alexandrini hyeme oculorum lippitudinibus vexaniur.

52

Ale xandrix atque aliis locis mari adiacentibus largifime pluit

Alexandria fingulis annis autumno multis peftilentibus febribus vexatur.

5 I

- civitas tota fuper columuas marmoreas numero ferme infinitas polita ac fundara eft.

52

Alexandrix omnia loca fubterranea inania, ac pervia exiftunt.

Alexandria civitas cur viis ac inanibus fubteraneis locis conftrusta fit.

52

Alexandrix locis fubierranea pervia ac inania facta fuifle ne urbs terramotibus obnoxia foret.

- loca fubterranea pervia facta fuiffe, ut in is fufficiens aqux $\mathrm{N}_{1} \mathrm{li}_{\mathrm{i}}$ copia ad ufum incolarum per annum fervaretur. aliqui Egypriorum exiltinarunt 53

Alexauder Trallianus fentic in dyfenteria * mjrtendum efle fanguinem.

Alindaracoron throcifcornm compofitio, Egyptio, diverla eft ab ea, qua ufus fuit Gal.

Alimenrum immodicum refrigerare.

307

Alvi profluvii cauf $x$.

41

Amarus Lufitanus in dyfenteria mirrebar fanguinem, mulcofque hoc auxilio cu- ravit. II 7

Amatus Lufitanus quomodo à na:ibus fanguinem mittebat.

$17 \mathrm{I}$

Amatum medicum Lufitanum mulios puerulos fanguinis miffione curavifie.

Aor

Amentes inuftione fanaut Agyptii. 2 I 1

Ammeum AEgyptii Indicum habent, omnimm opiinum, quem Nanacuendi appellant.

Amomum amama vocant Agyptii. 300

__ verum habcre Egyptios. 300

- lignnin \& non femina vel fructus efle Egyptii a finrmant.

Amoni defcriptio.

300

301

Amomum quo Egyptii utuntur, non effe Rofam Hierici, ut falfo aliqui crediderent.

$30 \mathrm{r}$

Amomi hiftoria apud multos antiquos fcriptores varia.

$30 \mathrm{r}$

Amygdalas ex $\mathrm{Gaza}_{\text {advectas minus alis }}$ calfacere.

265

Anaxagorx de Nili fluminis augmento cpinio.

28

An crurum fearificatio in fura, ut $F g y$. ptii faciunt, vel porius in malleolo, it Gal. docuit, fit facienda.

203 - vicaria fit venx fectionis. - 188

Animalia in Esypto reperîri, quibus ars curandi morbos infica à natura exiftimerur.

Angurix, qux iutus nullam pulpam, fed hujus loco aquam dulciffimam concinellt

56

Anguriarum aquam hernias concitare. 56

Anguria aqua faculias.

57

Antmonium difficiles ac antiquos morbos fanare.

$28 \mathrm{r}$

Antinonio mulios ab incurabilibus fere mnrbis fanatos.

282

Antiqui ad quos morbos fectione uf fint.

An:iqui medici cur prevalidis pugan bus uf fucrint. $23 \mathrm{I}$

Antonius Palmerins Presbyer Cayri facra mulios annos miniftravit.

$2 c 6$

A 2

An- 


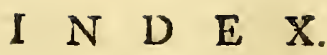

Antyllum, cucurbitularum ufum fcatifcarione praftutuna cognovifie.

Antyllus fcarificandi docuit modum 197 Annus ab Egyptiis in quot partes dividatur.

2 I

Aunum penes $\mathbb{E}$ gyptios in quaruor tempota, fed tamcn fecus quam à unftris fiat, dividi.

21

Anum Athenienfem cicutæe efui aflietam.

255

Aoim Chriftianum Cophrum vacuato plurimo finguine à venis retro aures fomno longifîno correptum fuile, non ramen fierilem evafife.

Apopiceticos inutione curari.

132

Apodyzeriam fu fipoliarium guid. 228

Acira op.jma neque concoltionem, neque concocti ditributionem, neque fangunis generationem, neglie nurritionem, ncque urinarum, fudorumque excreionem, neque corporum di ationem, juvat.

Aqquan nos juvare concoltionem. - hypochondriis non efte utilem. 43 Aquas optimas reperiri; quax neque infigiater frigidx, neque craflx, fed dulces exiftur, ac renrifimx.

46

- colentes elfe levilimas, dulcillimas, atgue tenuifimas.

Aqua, qux ex Galeno optima fit.

Aqua cptima eft qua clara lyncera, fine odore.

fig'ux optimx no:

Lrudx \& malre nota.

- ulum ad vitam producendam, magis quam vini, conducere.

- ufum Egypiis magis quam vilit, conducere.

- poms, qux noftris corporibus afteTat incommoda.

Ag̣uam ftomacho, hypochondris, hepatroje vel lieni obftructis, vel in tumo-

rem elatis plurimum nocerc.
ab AEgyptiis ad fanitatem confervasdam, vıro praponi.

Ariva dulcis tepita citem laxat, fangiimeill attcruat, atque attrahi.
Aqux potu fumme calida corpora juvari. 45

Aquam pueris, atque calidis \& humidis corporibus colfferre.

45

Aqua $N_{1}$ li Auminis clarefacta omnium eft limpicitima, purifima, levirima, $\mathrm{Cl}$ jufvis odoris expers, arque fubdulcis.

35

Nili quibas omnium hominibus uti. lifima, ac optima fit judicanda.

Aquan Nili fuminis corpora ex calore gracillina refrigerare, iucraflare, atgue impinguefacere.

- Nili fluminis hepar calidum refrigerare.

- Niii toram in fanguinem verti, cx quo Mofes Det pracepto aryuas in fanguncm mutavi, AEgptis perfualum eft.

82

Aquz Nili facultas.

Aquam Nili Joan. Jacob. Manne medicus, pro Tutca qui renum eahda intemperie laborayit, plurmum commendavit.

Nili fuminis clarefactam, tenucin; levem, fubdulcem effe.

$46^{\circ}$ - Nili epo:am aliquibus fudorem, aliquibus uinam, arque mulis ventrem movere.

46 N.li fuminis copiofe epotam hepats calorcm opine contemperatr.

Aqua Nili à longisfimo icuneris tractu fece a Sole coquitur.

Aquam Nili omnium effe minime frigidam.

- Nili fluminis Avicenna multis laudibus celebravi:. 36 - Nili, qux elt turbida, Galeni temporibu; Alexandrix pes fictilia vafa $A$ gyptii percolabaut.

- Nili conofam acturbidam quomodo cito clarefaciant.

- turbidam amygdalis dulcibus contufis, ÆEgypii clicfaciun:

36

- iurbidam ex Niloalportatam dulcibus amygdalis trum tantum horarum fpacio clarefaciuut. 


\section{I $N$ D}

Aq̣u Nili clatefactr epora ludorem movet, aliquibus uriuam, 品 quamplurimis veiztrem.

36

Aquam Nili diu, noctuque epotam cor-

pora non ladere.
Aqua Nili calida corpora plurimum juvantur.

37

- Nili epota vifcermu incendium contemperat.

37

Aquam Nili vicem gerere feri lactis 37 - Nili Egyptii mutari in fanguinen putarunt.

37

A qua Nili unde habuerit, quod in:ra corpora fufcepta, in länguisen muictur.

37

Aqux Nili, Deum deduffe, ut in fanguirem converteretur, Eryptii exiftimant.

Aqua Nili fuminis pro pou en jucundiffima.

35

Nili ceteris bonitate videtur praterenda.

35

Aquan Nili fluminis in potu Egyptios fectari.

252

Aqua Ni'i à dolore renum à calculis conci:a:um famare.

47

juvare.

Nili quo pacto pofít concoctionem

Aquam Nili clarefasam hypocondriis jecori, lienigue inflammatis auxilio efle.

Aqua Nili an corpora nutriat.

47

Aquam Nili, ex /Erypiorum fentenia nutrire.

Aqua Nili quando eft paucifima, \& fere ftagnans.

27

-.. Nili fuminis quomodo in Urbem Alexandriam veniat.

52

- Alexandriz antumno evadit counfa, palutitris, corrupta atque pefima.

52

- corrupta quomodo fit caufa pef́tilentium febrium, gux autumno Alexandria vaganttir.

53

Aquam Nili fumin!s per merium Cayri civizatis tranfelintis putrefactam varios iu pueris morbos concitare.

55
_. plurimam gelidam is propinari, quibus eft fanguis mizendu, oficere.

124

ante mifionem fanguinis multam cpotam, hydiopen facere. 124 N.li fumins modice fumptam poffe purgantis afiumpti vim forte, \& au. gerc.

286

- Nili callere faculiarc aliqua fubducendi alvum. 286 - cum purganti medicamento frigidam dandam Averrhoes voluit. 286 purt purgans medicameneum, Haly \& Rhatim concefille.

235

__ frigidan mulam ab afumpto purganti, aliquos Egypiorum bibere, à qua alvan txpe mulcum turbari. 285 Aque potu ab altumpio purganti cur aliqui commode fist purgati.

285

Aquam sullo pacto purganti aftumpto auxilio effe polle.

286 - Anguria elnavi fanare febrem $f j$ nocham.

315

Agua ftillatitia, qua fynocha febris, a:que ardeus curacur.

315

Arabum corporum habitus, atque tomperamenta.

${ }^{2}$

Arabes multus morbos inuftione fanare.

210

- cur mantur inufione. 2 Io fione extrahant.

224 farificatic nem crurum, vel ea non fuife ufos.

1.80

Archenda quid, \& cjus facultas. 242 eft pulvis liguftri Egyptu foliorum.

Archigenes fectionem ad liydropem $\begin{gathered}242 \\ \text { me- }\end{gathered}$ mini:.

242

Ardentes febres yuibufdam fecretis auxiliis ab Egypriis curari.

Arterias pro mirtendo fanguine REgypros fecare.

Arteriarum fecarum ad mittendum fanguinem ufum, no:? โecus ģuñm venarum in Egypro frequenari.

A 3

I 25 Ar. 


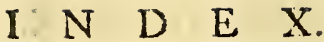

Arterix pro quibus morbis ab Egyptiis fecentur.

125

Arteriarum fectionem pro mittends fanguine boc tempore propriam eife Æ£gypiorum.

Arterias folos Arabes \& \& Egyprios pro mittendo fanguine andicre fecare. 125

Arterix fectio pro mintendo fanguine $E$ gypiis eft familiarifima.

133

- fectione ad qua mala $/$ Egyptii utantur.

133

- fectionem pro divino fecreto in Egypto ad diururnas oculorum opthalmias, inveteratas, atque ad capiris vifcerumque antiquos diuturnolque dolores haberi.

133

Arteriarum fectione mtitos interiite. 133 Arterias feetas ex quorundam fententia coalefcere non polle.

134

_- fectas magina cum difficulrate coalefcere.

125

fectas poffe coalefcere, maxime in pueris, corporibufque mollioribus. I34 Arteriam per fomnium monitum Gal. feculle, \& bene fucceflife.

134

Arteria cubiti fecta quendam Magiftrum à lateris dolore fine ulloaneurifmate fanatum Gal. memorix prodidit. 135 Artcrias quo pacto IEgyptii coalefcere faciant.

138

Arteriarum fectio, ut coalefcat, quæ pr $x$ ftent.

138

- prævalido motui, portquam eas lecuerunt, atcue fanguinem eduxerunt obfitume, frufto xris fectioni arterix fuperpofito.

Arterias tuto fecari ab Egyptiis.

Arteriarum fectione aliquos quafi miracu. lo Fanaros fuille.

Arteriam inter pollicem \&e indicem feEtam, heparis dolorem juvare. $\quad 137$

Arterias in funmis attubas, arque in capire fore fecandas in omnibus dolori. bus, à calida, fpirituofaque fubftantia, obortis. Gal, docuit.

135

Arteriam frontis ad qux inala Egypiii fecent.

136
Arterix frontis feetio quibus malis conveniat.

Arrerias fectas minto fanguine AEgyptios, neque extrahere, neque murere. 237 Arteriarum reiro aures lectio quibus morbis collvenias.

137

Arterias temporum ad prohibendos caratrhales ruxus in oculos Egypii inurume.

137

retro aures Hippocrates in quibus inurendas voluerit.

214

Arthritides vagari in Ægypto. 50 Arriculos à quibus caunis plerique $\mathbb{E g y p - ~}$ tiorum imbecilins habcant.

57 inurum Ægypiii ad podagram. 2 i 1 inurentes Egyptii fanant articulnrum dolores.

211 Arundinibus, faccharinis Egyptios vefei.

A fari decoeni vis ad curandas quart 252

320 nis miffione curatus.

Afclepiades Ethiopes trigefimo xtatis ai1no fenefcere, \& Britannorum quaniplures ad centefinum, ufque \& vigclimum annum pervenire menorix prodidit.

Afpalathus ubi reperiatur.

Afpalathi arbufti deferiptio. Aipalathum flores edere fuaviffimi odoris. 296

Aftis quid fit.

297

Afthma peetoris inuftione fanari. 212

Aftronomi à quibus corporum naturas cognolcant, ac fpeculentur.

86

\section{4}

qux confiderent. atque ftellarum in prima cxli domo inventarum, vel cam refpicientium. 86 Avenzoarem medicum filium fuum puemun fanguinis miffione $a b$ acuto morbo fanavifie. 105

Avershoes dammat fititiones in corpori. bus cruditaribus replaris. 243 - cur aquam frigidam poft aftumptum pur- 


\section{N D E X.}

purgans concefferit.

A viseuna de Achaouan.

285

299

A vicennam fenlifie nedicos poffe in pueris binos annos tantum agentibus mittere fanguinem.

105

Avicema non cognevit farificationis ufum. Imo confundis farificationes cum cticurbitulis.

I05

Avicennam ante fanguiuis mifionem $\boldsymbol{x}$ gro:is aliquibus aliguid cibi efre oferendum praxepiffe.

120

aquam folt purgans conceflifie.

286

Aures pro mittendo fanguine $\mathbb{E g y p t i i} 1 \mathrm{ca}-$ rificans.

128

infantibus fcarificantur ab /Egyptiis:

167

Aurium fcarificationem puerorum efie propriam.

128

Aures quo modo, ac ordine fcarificentur.

167

Nec talem fcarificationem coģnoviffe Gal.

169

Auftri temperies.

Aufter cum imbribus conjunctus quid faciat.

65

Auftrini flrus caput gravant, fenfufque hebetant.

154

Aultrum facere putridinem.

65

Aufter corpora diffolvit, humores fundit, purrefacitque, ubi conjunitus fit cum largioribus imbribus.

65

Autumnus conftat duobus menfibus, quip.

pe Septembri, Octobri.

$2 I$

\section{B.}

R alneorum ufus qualis fit apud $\mathbb{E g y -}$ 1 ptios.

229

Balneis nururalibus Rgyptum catere. 228 - tepidis cur Egyptii utantur. 229 Balneorum ufum penes Figyptios pro corporum abiterfone efle treyuentem.

ufu quæ accedat corporibus urilitas.
Balnea ex dulci aqua parata apud $\mathbb{E}_{g y}$ ptios cffe in ufu frequentifimo. 228

Balneorum dulcium apud $E_{i s} y$ ptos quis fit ufus.

228

dulcium facultas.

\section{8}

- dulcium ufu corpora refrigerari ux impingnefcere.

8,37

Balnea apud Egyptios qualia frequeutentur.

228

Balneorim gratia $x$ des in Fegypto conftructx.

228

Balnea dulcia in Egypto omnes ornatus gratia frequentant.

37

Balneis dulcibus utuntur Ægyptii, tum corporum ab itineribus infiammatorum refrigerandorum gratia, tum pro demenda fanguinis plenitudine.

Balneorum loca quomodo Æryptii calfaciunt.

228

Balnea hecticorum qualia effe debeanc.

Balneorum dulcium ufum effe in 229 at ad corpora ex ininere inflammata. 236 Balnea tepida refrigerare, \& humectare. \begin{tabular}{ll} 
dulcia quibus conducant. & 237 \\
\hline & 237
\end{tabular} lete.

237

Balueis utuntur nonnulli vacuationis gratia.

237

balnea pro pinguefaciendis corporibus qualia.

230

- calida in triplici efie differentia. 23 I

Balneorum calidorum vires.

Baluco tepido uti volentes pinguefieri.

Palnea dulcia quos morbos $23 \mathrm{I}$

Balnea dulcia quos morbos fanent. 243

Balneis uri $A$ gyptios ad ephemeras febres.

246

Balneorum ufus ad febres, ephemeras, pinrridas, hecticas, \& in amulnationes. $2+6$

Balneis ad guos morbos Egyprii utantur. 245 bus.

245

Balneorum dulcium differentiz, ac vires. 


\section{I $\mathrm{N} \quad \mathrm{D}$ E $\mathrm{X}$.}

Balnea dulcia, cribus féribas, \& infammationibus convenint.

246

- dalcia quo tempore febricantibus conducunt.

246

Ralneis dulcibus que febres ex ephemeris juventur.

246

Balnenrim ufus pro hecticis monunis, at muliplex.

245

Balnea cosporibus crudicaribus featentibus non convenire.

247

- cur neque in febrium principio, neque in atgments conveniant.

247

- dulcia corporibus colidioribus, \& exuftis maxime convenire.

247

Falneorum dulcium ufus varius quo ad varias febres.

248

Balnea in principiis morborum inurilia \&r noxia.

à cibo pinguefacere.

à cibo quamobrcm impinguefacianr.

$23 \mathrm{I}$

Balnesturi, neque horrere in balneo, neque imbecillum vifus habere neque cruditatibus abundare debent.

247

Balneis calidis gallica lue correpros polle fanari, nonnullis fuafum.

249

Balnea, quibus Ægypiii ad hecticos uri folent.

325

Balneorum ex lacte paratorum ufum divites Egyptios fequi.

Balfarni, authorem plantam viventem Veneciis habuiffe, ex qua opoballamum verum diftilafie mulii obfervarunt. 208 - fructus Ægyptios habere recentifimos, quibus ad componendam theriacam utuntur.

302

Ban quid, atgue ejus ufas. $\quad 254$

Barbaricorum corporum temperies habitufque qualie.

66

Barbarorum cerpora gmmobrem exeellentifnus purrefactionibus fun obnoxia.

Barbaros urere lineis petiis accenfis, 2 I 6 Baffandun.

Berberorum ufus proalvi fubductione. 2.53 Berberis truetibus ad medicamenta legyptios uti frequentillume. fructum un at qua. frufunm ulim in febribus \& puti-

lentibus Ægyp:ios fectari. 253

Be:berorum v1s adverfus purredinem. 323

Bernavi electuarium.

2.62

- operationes.

262

- alfumentes, guæ deliramenta pro. dant: 202

Bers electuarii compoficio, \& vircs. 263

- electuarii ulus. $\quad 263$

- electuarium.

311

Befla vocari perfectum.

Achimbafim creare, non medicum

excellentiorem, fed eriam medicina ignarum, fi modo phires aureos numos ei perfolveri-

Betx fuccus, ad curandas febres intermittentes

Bon feminis ufus apud $\mathbb{E g y p t i o s . ~}$

316

- arbor.

254

$2 \sigma_{4}$

Boream putredini obfiftere.

65

Borea fpirante omnia quam dituifime imputria durate.

Bofa quid, \& iplitis compofitio \& facu?tas.

262

C.

Cadi cffe Mahometis legis doctores. 3 —_ funs judices pratectus creat. 3 non rancum religionis legibus praefle, fed lites in jure civili, ac ponificin judicare.

Calaf quid, atque ejus ufus.

Calamo aromatico vero $A$ gyptii utunur.

297

Calamum aromaticum non effe radiccni, fed cannam, vel calamum. 2.97

Calami arcmatici notacx Diofcoride. 2.97 aronatici multam copiam ab $\mathbb{E} g y$. p:iis haberi pofle.

298

Calculis 7 gy ptiorum muli cur vexantur. 58

Calidiffmas reciones habitantibus difficillimas cffe pursationes.

Calidiatem vel per fe folum effe Desy. tiorum morborum cautam, vel falicu 


\section{I $\quad \mathrm{N} \quad \mathrm{D} \quad \mathrm{E} \quad \mathrm{X}$.}

eam aliis caufis ipfam concurrere, gyptii medici autimant.

Calida corpora ab ufu ciborum refrigerantium, dulcium balueorum atgue $a b$ immodica venere frigida evadere.

Calor vehementiffimus aëris ambientis remediis quibus contemperetur omnino vacat.

Calorem ftomachi ab ambientis caliditate refolvi.

238

Camplim vocatos ventos facere cerebri inflammationes exitiofiffimas. $\quad 55$

Campfinis ventis Spirantibus advenz ac plures incolarum ad fubterranea loca confiugiunt, in quibus morantur, quoufque ille ventorum ardor ceflaverit. 23

Campfini venti fi diu perfeverarent, nemo ibi vivere poffet.

Campfin cur ventos Euros, Auftrolque Egyptii vocaverint.

23

- vocatos fuiffe Euros, Auftrofque ventos. a Campfi vocato Álexandri Magni, multarum copiarum duce ab his ventis cum omnibus copiis fuffocato.

Canella in quo à Cinnamomo differat.

303

Canellx fapor dulcis \& acris.

Canella in longo itinere odore, \& fapore non deficit.

305

Cannabis foliorum ufum effe apud $x_{3 y}$ ptios.

$26 \mathrm{I}$

- per excellentiam herba ab Ægyptiis cur vocata.

$26 I$

Cantaridum ufus in potu apud quoldam Egyptios, ut venenum vel per fudorem, vel urinam evacuent.

324

Capitis dolori intra nares fearificatio convenit.

- partes \#gyptios urere. 211 quas pattes Ægyptii urant. 21 I partes ad quos morbos uri debeant.

2 I 1

Cardamomun. 306

Carnes, aceto, atque Cale jam diu imputres fervati. quibus Rgyptii vefcuntur.

33

Carnium ufus apud Egyptios eft temperariffimus.

33

Carnes arietum caftratorum Ayptiis elle multum familiares.

Carnibus multis, qui in victu utuntur, brevius vivunt.

Carnis atque vini immoderatum ufum hominibus brevioris vitæe efle caufam.

Carnium optimarum ufum augere 39 rem naturalem.

Carpobalfamum habent Egyptii ex Arabia cecentifimum.

Cafeus Gibnehalon.

Caflabel derira quid.

302

56

297

- derira Egyptiorum eft verus calamus aromaticus.

Caflix Ŕgyptiz úfus.

298

$32 \mathrm{r}$

- fructuum cognitio \& utilitas 973 differentix.

273

Caffam Damiatinam omnium minime utilem.

Cafria Abiffina ceteris prefertur.

273

Calfix Abiffinx ufus.

273

273

A biffinæ ufum ad acres diftillationes ex capice in pulmones effe apud Egyptios frequentiflimum.

273

254

Caffam effe alterius arboris corticem, minimeque canella.

Caltiam plane à cinnamomo \& 304 differre.

Caffix fapor amarus.

303

Catapocia quibus ad pfydracia, \& alope ciam Gal. utebatur.

280

— ex aloë appellata apud Gal. q!x.

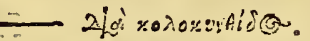

280

- ad cuartanas febres.

280

320 thociis ex alne, Icamonio, colocynthide paratis utebatur Gal. 280 - exaloë, colocyubide, fcammonio, agarico, bedellio, gummi Arabico paratis ad diftillarionem ex capite in pulnones falluginofan $\mathrm{Gal}$. urcbutur. 285 


\section{I $N$ D $\quad E$ X.}

Caufx, qux aërem in $x$ ftate refrigerant. pinguedinis.

Caufticorum medicamentorum facultas.

Caufticum quid.

Cayrus Aggypi metropolis.

$$
\text { olim Babylon, vel Babulis }
$$

Cayri civitas quautum diftet $a b$ Æquinoctio.

diei major longitudo.

diei brevitas.

fitus. civitas ventis Septentrionalibus ex-

pofita.

213

214

18

18

18

18

18

18

18

- civitatis aër à Sepsentrionalibus, atque Meridionalibus ventis maxime alreratur, ab Oricntalibus, Occidentalibulque parum.

18

- civitas eft prope tropicum Cancri.

18 civitas altilfmis elt fabricata ædibus.

19

locus in quo Ægyptii theriacam componunt.

288

mulros tum viros, tum mulieres reperiri, qui medicinam profitentur. 5 Cayri nullos reperiri qui medicinam ra tione faciunt.

Cayrini toto anuo oculorum lippitudinibus moleftantur, fed præfertion in prima xftace.

52

Cayri habitatores effe plurimarum nationum.

Cedemata curari farificatis venis gux intra aures funt.

127

Celfus in hydrope fupra talum incidi do. cuit.

Ceraftis quid.

Ceraftis ferpentis ex Aërio defciptio. 295

Cerebrj in flammationes lethaliffimas in prima $x$ itaris parte fieri

Chaova decoctum.

55

264

- necoctum quomodo paratur. 264

- decocti ex femine Bon parati ufus apud Egypuios. decoctum ad evocancios menfes mul-

tum mulieribus conducere. $\quad 254$

Chacræ decocti ufus ad menles ciendos.

decocti facultas.

254

264

Chaova fuppreflos menfes revocari. 264

Chamedrios vis ad curandas febres. 316

Cherfe caunellam communem Æggypii intelligunt.

299

Cheft, eft coftus A rabicus, quo noftri etiam utuntur.

$2: 99$

Chia mulier a dy fenteria fanguinis miffione fanata.

China radicis ufus in $\mathbb{E g y p r o .}$

253

utuntur.

253 fieti. decocto emaciata corpora pingue-

253

- decoctum faciem pulchram reddit.

253 decoctum pro pinguefaciendo quomodo ab Asgyptijs mulieribus parctur.

253 radicis decocti ufus in febribus peftilentibus apud Egyptios.

32.2

—_ radicis ufus ad pinguefaciendum. radicis decocto multas emaciatas mulieris pingues evafiffe.

$23^{5}$

Chirurgos Ægyp ios partes veuis minimis refertas, fcarificare.

127

Chirurgi Esgyptii in fcindendis venis longe noftris dexteriores obfervantut. I 27

Cibi optimi fupra modum aflumpti morbos frigitos generant.

41

Cibus immoderatus \& potus calorem n12turalem fxpe fuffocat.

Cibum non effe omnibas concedendum priufquam fanguis mittatut.

120

Cibi $Æ g y p r i i s$ familiares.

Cibus pauperibus $\mathbb{E g y p u i i s ~ f a m i l i a r i s . ~} 34$ Cicatrices in multis partibus corporis, 2 Egyptiorum frequentis inultionis ufus efle indicium.

209

Cinefiam Evagorx filium corpore inufto in cos:cioncm prodiiffe. 214 Cinna- 
Cinuamonum quid.

303 effe furculorum vel ramulorum tenuiffmorum arboris camnellx cortices, \& cannellam crafliorum.

303 in quo à cannella differat. 299 effe ramulos tenuiores, qui cito, tum fopore, tum odore exolvuntur. 299 Cinnamoma cur à mercatoribus in Egyprum vel Syriam uon convehantur. 304

Clyiteriorum ufum $a b$ Ibi volunt prodiit. fe.

- ufum Ægyptriis effe familiariflinum.

II aliquorum penes Egyptios ufus.

3 t2

Clyßteres ad Vigilias qui ab Ægyptiis parentur.

313

- lavarivi apud Egyptios.

313

ciendum familiares. Hyftericarum mulierum. ad uteri frigidas affectiones.

234

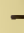

Clyfteres ad cohibendam alvum.

- ad fluxum fanguinis. 314

facultas.

Clyiteres ad febres putridas ab Egyptiis ufitati.

316

- qui refrigerent \& tenues fuccos lub. ducant.

316

Colis meatus quantum dilatari queat. 224 Collum, ac mentum, ad qua fcarificent.

129

Contagium à vehementi aëris caliditate confumi.

77

Contenta urinarum craffa quid fignificent.

Comam inuftione tolli.

159

Compofita medicamenta, qux ab Agypriis parantut.

211
$9 y-$
287

Compofitum ex opobalfamo \& aliis ad peftem utile.

323

Coriandrum viride, id eft, folia Æৈgyptios innoxie comedere: effe ejus ufum apud ipfos in ferculis quam familiarifimum.

252
Cornelium Celfum ufum Esgyptiarum cs:curbitularum noviffe. $\quad 144$ Cornelius Celfus ait ad mittendum fanguinem non xtatem, led vires couflderandas fore.

106

- Celfus ufum cacurbitularum in febribus quovis tempore utilifimum cenfuit.

142

Cornelium Celfum uftionem in coxendico dolore laudaffe.

$2 \mathrm{I} 5$

Cor atque hepar calidum \& humidum univerfum corpus tale efficere.

Cordis atque heparis à torius infpectione temperiem cognof ci.

57

Corpora unico tantum temperamento prædita nufquam reperiuntnr. $\quad 84$ - ubique multa reperiri variis conflata temperamentis.

84

- tarim enixa $\mathrm{ab}$ aëris temperamento multum alterari.

Corpus remperptam naturam obtinebir, quoties cor \& hepar xque appofita temperamenta habebunt.

86

Corpora à quibus neceffario alterantur, \&

à quibus non neceffario.

- quo humidiora, eo craffiora effe.

crapulis pinguefieri.

232

facile uinguefcentia, \& qux diffici

lius.

232

latioribus venis predita difficilius pinguefieri.

frigido temperamento, facilius pinguefieri.

232

- omnia à variis diverforum anni tem-

porum aëris conftitutionibus alterari ac mutari.

90

Corpus authoris ex immodico hepatis calore gracil'imum effectum, largiori potu aqux Nili fluminis, cornofum \& pingue evafiffe.

Corpora in aëre valde calido, continuo, xquali, difflantur, aperiuntur, evacuantur, arque ficcantur.

72

- fanguinda, quod aliis temperatiora fint, facilius putrefount

6I 


\section{N D E X.}

- extenuata dulcibus balneis à cibo juvari.

23 I

- balneis qux apta, \& gux ab his fint arcenda.

247

Corporum Ægyptiorum habitus \& temperamentum.

Corpora venerem immoderatam refrigerare.

8

— cur in Ægypto valde craffa \& pinguia reperiantur.

- pleraque $\mathbb{E}$ gyptiorum frigidiorem ventriculum habere.

8

- gracillima ex calore effecta in $\not{E} g y$ pto craffefcere, ac impinguefcere.

8

- gracilia ex calore cffecta ufu largioris aque uminis Nili pinguefieri. 8 _. Eypriorum non elle cacochyma, five mali fueci.

82

Corporum Agyptiorum temperiem terminatam cognofci non pofle.

$3 \mathrm{I}$

- Egyptiorum temperamenta.

Corpora cur habeant $\mathbb{E}$ gyptiorum nulti pituitofa.

8

- Egyptiorum eruditatibus fxpe moleftari.

8

- Arabum urbanis funt graciliora, \& calidiora.

32 rufticorum effe omnium gracillima, hirfuta, fqualida, ac fere combufta à Sole.

32 Egyptiorum pleraque illuvie, ac pediculis abundant

Ægyptiorum fudoribus abundare.

230

Egyptii putant omnia ab ufu aqux Nili fluminis, verti in fanguinem, five fanguinem generare quifque putat, plurinio fangume femper abundare. 82

- quomodoin prima $x$ tac fe habeant.

23

in prima xftate effe languidiffima,

\& abhorrere cibum.

23

lido aquali cum Etefiis, ficcari, tum per férfibilem tranfpirationem, tum affiduis fudoribus, a'que diffari.

77

Egyptiorum pleraque multo fan- guine abundare verum effe.

82

- Egyptiorum pleraque, aut fanguineo, aut pituitolo temperamento fpectari.

32

Egypiorum pleraque pinguia cur ibi fiant.

230

- in Egypto ufu dulcium balneorum masime refrigerari.

32

- Egyprorum quo ad varias partes inufta in Egypto mulca fpectantur. 209 - frigida, \& humida, qualia funt nulierum multarum, enunchorum, \& fenum multam evacuationem non admittunt.

202

bilitari.

118

Curporum largam fanguinis vacuationem ferentium notre.

110

Corpori laxo, molli, pingui, albo, gracilibus venis non effe aut mittendum fanguinem, aut parum.

110

Corpora cucurbitulis vacuanda prius per horam in balneo morari debere. 156. habitu pingui ac carnofo difficilius

quam gracilia purgari. duri, difficilius purgari.

279

fint.

cur evacuationi inepta

238

- puerorum habentex feipfis unde vacuentur.

- mollia, humida, \& calida ex quacunque evacuatione refolvuncur. 202 - fub calido colo degentia contimuis vacuationibus cffe fubjecta.

238

- imbecilla, rara . mollia, pinguia valide purgantia non recte ferunt. 278 - ex quacunque caufa refolubilia, fi purgari debeant, uti debent leniter purgantibus, atque à prxvalide purgantibus abftinere.

279

Corporibus omnibus non eadem purgantia convenire.

279

Corpora robufta valida expofcerc medicamelita purgantia.

imbecilla, leniter purgantibus effe rractanda. 


\section{I $\mathrm{N} \quad \mathrm{D} \quad \mathrm{E} \quad \mathrm{X}$.}

temperata valide purgantibus non purganda.

280

ganda,

- aliquando etiam ad animi deliquium purganda.

282

non debere purgariad animi ufque defectunu.

283

Coftum Syriacum tantum odore caput ferire.

Coftus verus qui.

Corendicum dolorem Figyptii curant mulis inuftionibus.

210

Coxendicus dolor quo pacto inuftione $a b$ Egypriis curetur.

210

Crapulas \& ebrictares effe caufas ex quibus homines, vel pauco tempore vivant, vel miferrimam à quamplurimis morbis afficti, vitam ducant.

42

Crapulis indulgentes difficulter purgantur.

279

Criricas omnes vacuationes bonas effe. 102

Cruris quxnam partes.

Crus dividitur in tres partes, \& exemplum pictum. 206

Crurum fcarificationes, quomodo Egyptii exerceant.

195

Crurum fcarificandi ordo. I 82, \&2 difcrimen inter eam, ac cucurbitulas. 182

- Icarificationem non eam effe, qualn noftri applicaris cucurbitulis frequentant.

I 81

Cruribus fcarificatis fanguis copiofus, non fecus quam à venx fectione egreditur.

182

Crurum fcarificatio quibus conducat, \& quo pacto.

172

- Icarificationis ufus in quibus morbis apud $R$ Eypcios frequentatur, \& in quibus corporibus.

199, 201

- fcarificatione pro fecreto curant Egyprii febres peftilentes.

yptii febres peftilentes. 320 nis grandiores effe.

Cucurbitularum uilitias.

Cucurbitulas, dolores folvere, \& inflatmationes minuere, arque flatus dilcu- tere. I42

Cucurbitularum ntilitas ounnes ex Oribafio.

142

Cucurbirulis preftiram fanguinis vacuationem minorem quam per venam fectam, facere fpirituum refolutionem. I10

Cucurbitulæ fant auxilia partis, minimeque totius.

158

Cucurbitularum ufus damnatur a Gal. ante totius evacuationens. 174

- operatio ex variis fcarificationibus. 150

Cucurbitula non funt utenda, nifi prius totum corpus vacuatum fuerit. I44 - impenu foras humorem in alro $12-$ tentem evocant.

$38 \mathrm{x}$ fanguinem fubtiliorem . puriorem, \& tenuiorem evacuant, minime cralfuns.

159

Cucurbrtulis non evacuatur magna fanguinis copia.

182

Cucurbitulas non effe vicarias venæ fectionis.

Cucurbitula nee fanguinem attenuant, nec cutim relaxans. Işo

Cucvrbitulas etiam craffum fanguinem educere poffe prxcedentibus frictionibus, $\&$ calidis fomentis fanguinem attenaancibus.

155 non poffe educere fanguinem craffiorem, etfi frictionibus, vel balneis fanguinis atcenuerur.

I 56

Cucurbitulis fanguinem tenuiorem vacuari, minimeque craffum.

I 49

Cucurbitulas plus fanguinem tenuiores, quam craffi vacuare, Avicenna docuit.

149

corporibus craffioti fanguine præditis non convenire.

149

Cucurbirulas cutaneum tantum fanguinem educere. obftructiones concitare.

149

Cucurbirula in quibus obftructiones concitare poffint.

156

Cucurbitulas, fanguinem tenuiorem educere, obftructiones concitare, fcarificatam autem labefactare, refrigerare, B 3 
denfare, arque obftruere.

Cucurbitulix languinem vacuantes pacto obftrueirt.

I 50

quo

150

- Canguine multo non abundanti, neque craflo, pro moderata fanguinis vacuatione interdum funt applicandx , fed prafertim crursbus.

159

Cucurbizularum ufum fape lethalem in febricitantibus pulfus intermiffonem confecutam.

159

Cucurbitula obftuunt ad internas corpo. ris partes eiiam trahentes.

158

Cucurbitulas à centro ad circumferentiam trahere, arque à circumferentia ad cen trum

I 5 I

Cucurbitulix quo pacto trahant à circumferentia ad centrum.

$15 \mathrm{I}$

Cucurbitulas purgatis prius corporibus $u$ tiles..

152

Cucurtitulas in plethoricis corporibus non efle exercendas Gal. prodidit.

152

Cucurbicule quo rempote in parte inflammata fint utend $x$.

I 53

Cucurbitularum ufum in febribus pefti. lentibus à Joan. Baptifta Montano damnari.

153

- incommoda in febribus peftilentibus.

153

Cucurbirulas cruribus cum farificatione applicatas efle proximas venæ fectioni ftatuit Avicenna.

154

Cucurbitula maxima eft utilitatis ad avellendos venenofos humores à membris præcipius, \& ad adjuvendas ommes naturx excretiones, five fymptomatica's, five criticas.

165

Cucurbitulas atque crurum farificationem idem effe, mulis arbitrantur. 158

Cucurbitulx an fint utend $x$ in plethoricis corporibus.

158

Cucurtitulis non tolli plenirudiuem, fe.l venx fectione, aut malleolorum fcarificatione.

158

Cucutbitula five cum farificatione, five fine, non funt admovendx, nifi evacuato toto corpore.

158

- ftatim ad partem eui affix $x$, attra-

hunt \& crudum \& coctum humorem. 162

Cucurbitulas aliquando effe auxilio febribus peftilentibus. 162 - Egyptii quibus partibus admorcant, $\&$ quibus non. 144 - fine farificatione Egyptios non uti. 142

uti. pro parris evacuatione, IEgyptios 142 Egyptios totius corporis vacuationem non præftare: 14.2 - non utuatur Eggptii, nifi prius totum corpus vacuarint. 142

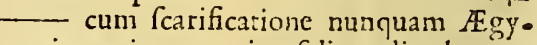
prios uti pro univerfali molienda corporis evacuatione.

126

- cum fcarificarione $\mathbb{R}$ gyptios uti pro alicujus partis vacuatione. 126

Cucurbitulas quilus partibus Ægyptii ad. moveant. 12.6

Cucurbitulis fxpe occipiti aflixis Egyptii utuntur, atque collo.

126

Cucurbitula Agyptiorum à noftris plane differentes exiltunt.

126

Cucurbitularum ufum diverfo modo, quo Itali faciant, Egyptios exercere. 126 Cucurbitulas Egypiii non igne, vel aqua calida admovent, fed fpiritus attractione cuti affigunt.

126

Cucurbitulis cur tolli non poffe plenitudincm Eyptii putent.

147

- fieri particularcm evacuationem. 148 - non uti Ægyptios in principiis morbo:tum, nifi totum corpus in primis fuerit vicuatum.

147

Cucurbitularum ufum pro fanguinis vacuarione facienda Fegytios non coginofcere.

Circurbitulas, neque in dorfo, neque in lumbis, neque in natibus, neque in cruribus, neque in aliis partibus (occipite, collo, \& averfa capitis parte excepcis; gusibus tanium utantur cucurbitulis) Rigypios exerccre.

144

Cucurbitulis non uti Rgyptios ad juvanda cxauthemata.

344

Cu- 


\section{I $\mathrm{N}$ B E}

Cucurbitulas, Egyptiis in febribus pefti. lemibus cum puncticulis, neque in variolis, neque in morbillis, ueendas non placet.

144

Cucurbitulis, nifi probe vacuato corpore, Egyptii uti non folent.

$1+7$

Egyptios quaitum volunt fanguiuis vacuare.

142

Cucurbitularum duo genera $\mathbb{E g y p t i o s}$ in ufum habere.

139

Cucurbitulis corneis, atque virreis uti Egyptios.

139

Cucurbitulas fpiritus attractione Ægyptios admovere, atque fanguinetn extrahere.

139

Cucurbitulis igne vel aqua admotis non utuntur Egyptii.

139

Cucurbitulas corneas quomodo Agyptii parent.

139

Cucurbitularum cornearum defcriptio.

I39.

Cucurbitulas corneas quonodo Egypui curi admoveant.

140

Cucurbitulis corneis cur $\mathbb{E g g y p t i i}$ utantur.

Cucurbitulas quomodo Egyptii exerceanr.

Cucurbitularum in occipire ufus frequentiffinus apud Ægyptios.

142

Cucurbitulas quibus partibus admovere Egyptii confuefcant.

143

Cucurbitula dorfi parribus admotæ in venas proximas cordi rrahunt noxios fuc$\cos$, \& evacuato fanguine, cutem refrigerant, denfant, ac ejus meatus obftruunt.

I 61

Cucurbitula in febribus peftelentibus, quo loco affigend $x$ evacuationis gratia. I 64

Cucurbitula foras ad trahendum venenum ceteris auxiliis prxtat.

Cucurbitulas in plerhoricis corporibus dor: fo appofitas ex toto corpore in vifcera trahere.

157

Cucurbitulam appofitam occipiti lippientes juvare.

I 46

Cucurbitula prope aùrem appofitx memi- nit Hippocrates.

143

\begin{tabular}{ll} 
_- in coxendice ufus. & 146. \\
\hline
\end{tabular}

- ufus ad firmandum fanguinis profluvium.

Cuct dolorem ventris. I 46

Cucurbitula ad lapides renum. $\quad 346$

Cucurbicularuin ficcarum ufum ÆEgyptii ignorant.

I 46

Cucurbitulis folis plena corpora vacuari polle Aggptii negant. $\quad 1.46$ Cucurbitularum occipiti affixarum ufum antiquis fuille cognitum.

145

Cucurbitulas cum fcarificatione collo ac mento affixas, gutturis maximas inflanmationes plurirum juvare. I29 - occipiti aftixas juvare capitis gravitates, dolores, inflammationes, ophtalmias atque alios omnes ex plenitudine in capite obortos morbos. 143

Cucurbitulx in interna alicujus vifceris intammatione dorfi partibus applicarx fumme funt perniciola, nec febribus conveniunt.

159

Cucurbitulas partibus imflammatione tentatis Gal. admovendas probat. 208 Ægyptios nunquarn dorfo, lumbis vel cruribus admovere.

I 12

- cum farificatione collo, \& occipiti appofitas gurturis inflammationes juvare.

143

Cucurbitula in pulmonis inflammatione pectori admovenda.

$1 \sigma_{3}$

Culcafix radicum ufum in cibo Ægyptiis effe familiarifimum.

252

Curatio febrium peftilentium quomodo à quiburdam moliatur.

- febrium intermittentium, quibuldam fecretis auxiliis.

316

Cur literarum ac fcientiarum cultores in Egypto defecerint.

Cute fcarificara Ægyptios familiariffime, in pueris, nulieribus, cunuchis, mittere fanguinem.

126

Cutis Icarificata quo pacto à cucurbitulis refrigeretur, \& ftipetur. I 56

Dar- 


\section{I $\mathrm{N} \quad \mathrm{D} \quad \mathrm{E} \quad \mathrm{X}$.}

D.

$\mathrm{D}$ arfini eft optima cannella, five cinnamomum.

299

Darfifahan eft afpalathus, \& ejus fubftitucum.

297

Daucum ex Creta Egyptii habent. 306

Decoctum, quo ad vomendum Egyptii utun:ur.

239

Decoctum ad febres pituitofas ab Agypriis ufitatum.

319

Dei fumma providentia fit, ut loca calidifima ali quid habeant, quo refrigerentçur, \& frigidiflima, quo calfiant. 19

Dejectiones bonix quomodo cognofcendx.

Dembalaflam, opobalfamum.

282

Dentes corruptos Egyprii in urunt 302

Democrivi Abderitz opinio de Nili fluminis augmento.

De fcarificatione diverfarum partium, qux in in? amatione, tumore, puftula, colore praternaturali, vel infigni do. lore torquentur, apud Agyptios celebrata.

207

De fcarificationibus aucium, narium, labiorum, gingivarum, quas $\mathbb{I E g y p t i i}$ pro evacuatione frequentant.

Diamufch elętuarium.

203

Diamefch electuarii compofitio, \& facul-. tas.

312

Diodori Siculi de Nili fluminis augmento, opinio.

28

Doctores Mahometis legum, Cadi vocari.

Dolores articulorum morbum effe Ægyptiis familiarem.

8

- articulares cur multos Aggptiorum continue invadaut.

8

- capitis, arque inflammatiouses quo. modo fanguinis vacuatione Agyptii curent.

142

- capitis incipientes curat cucurbita occipiti appofita vel cum fearificatione. vel fine.

129

- capris inyeteratos ex plenitudine \& gravitate, tolli vena frontis tufa. II9 Dolorem fanguinis vacuatione mitigari.

Dolores capitis curari fecta vena frontis. 129 graves, \& immanes fcarificatio lelenit, \& mirigat

D antiquos inuftione tolli. 210

Dolorem articulorum uftione tolli. 210 Dominicum à Rege in infula Cretx loco phrafc'ia appellato multas veri afpalathi radices excerpfiffe.

296

Dominicus à Rege afthmaticus, quomodo pectoris uftionem, ut fanaretur, præftiterit.

2. I 1

Donatus Antonius ab Altomare de mittendo fanguine in dyfenteria.

I17

Dyfenteria quid fit.

115

Dyfentericos curantes, fi neglecto jecinore, ulceribuss tantum medeantur, ægrotos precipitare.

II9

Dyfenteria quze fanguinis vacuationem expofcar \& qux non.

Dyfenteriam à cacochymia faguins 114 fione a cacochymia languinis mitfione non indigere. 114 - optimos medicos fanguinis miffiorie curare.

II 4

- cum qua magna fuerit humorum copia, aut fanguinis impelus valde urgeat, vel maxima inflammatio, aut dolor vehemens obfervetur, vel iscur male affectum fuerit, fanguinis mifione efle curandum.

II 5

—_ curantes medicos reite fe gererc, fi incipiant à fanguinis miffone, tanquam à caufarum àblatione.

II 5

Dyfenterix empirica curatio apud $\mathbb{E}$ gytios ufitata. $22 \sigma$

Dyfenericos fluxus quomodo aliqui curent.

226

E.

$\mathrm{F}$ brix cujuddam $\not E g y p t i x$ deliramentorum obfervatio.

262

Effectus conmunes à communibus caulis fiunt. 


\section{I $\mathrm{N} \quad \mathrm{D} \quad \mathrm{E} \quad \mathrm{X}$.}

Elchelimbat quid.

305

Electuarii Tarachel acrap compofitio. 310 elphilofopha vocari alia compofitio.

310

Elequarium phylonium Perficumab Avicenna vocatum, atque ejus compofitio.

3 I I

Electuarii diamefch apud Fegyptios compofitio.

3 I2

Bers diati, compofitio, \& vires.

Electuarium, quo febres intermittentes fanantur.

317

322

- ad peitem probatum.

né̀ pefte inficiantur.

Eliud ad idem.

Elephantialis Arabum quid.

322

322

56

Elephantes gnamplures homines Cayri femper exiftunt.

Elleborum album olim apud Hippocra. rem in ufu fuife.

280

Elleboro nigro ad purgandum Hippocratem ufum fuife, \& peplio.

280

Elleborum album effe purgans prevalidiffimum.

280

- mgrum ad quartanam febrem effe utile.

280

Empii, qui ex pleuritide, ac peripueumonia evadant.

221

Empiis pus fenfim, ac fenfim educen. dum.

217

Empii, inuftione fanantur.

217

Empios tutius inuftione, quam fectione curari.

222

Ephori opinio de Nili fuminis incremento.

27

Epithemata, quibus Egyptii febres ardentes \& fynochas curent.

316

Epichemara ad febres intermittentes. 3 I 7

Épilepticos quomodo Egyptii inuftione curant.

21 I

Etefix quando fpirare incipiant.

74

Erefías in $x$ itate fpirantes mulca mala prohibere.

Etefix quaudo in Egypto fpircnt. 72
Etefias in Eyypto elle rentos Sepentrio. nales, Junio menle rpirare incipientes. 74 non fieri à liquatis nivibus in montibus Sepeentrionalibus à calore Solis, à Cancri folltitio revertentis.

Etefiarum generationis in Egypto celeriori tempore praftix , vera ratio. 75

Etefias conftanier toto Junio menfe, Julio, Auguftoque placidifime firare.

Etefix in quo differant à prodromis vocatis ventis.

75

Peftis Junio menfe à qua caufa perpaluo finiatur.

75

Etefias quotidie in fecunda xftate plurimas urbes nigras in alcifimos Lybix, atque Ethiopia montes propellere. 28

Eudolemum coxendico morbo vexatum ex multis inufionibus interinfle. 217

Euripidis de Nili Auminis augmento opinio.

27

Eurorum, atque Auftralium Ventorum ftatum aëris effe morbolum.

75

Europai proprer crapulas, \& vinorum ebrietates lirevem vitam ducunt. 3.9

Exanthemata lumoris conjuncti funt notx.

161

Exanthematum eruptiones funt vitand $x_{\text {, }}$ \& qux rationes id fuadeant. $16 \mathbf{r}$

Excreriones bonx. 10?

Excmpla aliquorum, qui ab ufis cucurbitulis in pulfum intermittentem atque in febrem continuam inciderunt. 160 Extenuata corfora à cibo dulciluus balneis juvari-

23 I

E.

$F$ afciculo ex goffypio \& linea peria parato Ægyptii ad inurendum uruntur.

210

Febres à putredine bilioforum, extiftorumque humorum fxvifima habere fypromata.

$\sigma_{9}$

Febribus purridis fearificatio præfenta neun austium, Capitis paftiones, \&c C 


\section{$I N D E X$.}

offenlas atcet, \& clirat.

I99

Febricitantes quomodo balneis dulcibus uri debeant.

$24^{3}$

Febribus intermittentibus correpti quonodo balneis utantur.

248

- purridisnon conducunt cucurbitulx fearificata cuic.

158

- malignis fearificationes crurum eva-

cuant, \& velutum ad iguobiles parres artrahume.

194 mibus acutis mares fcarificatx opem ferunt.

168

Febrium, qux pituitolarum ad naturam magis accedurt, chatio.

- peltilamium curatio pecularis 320

Febribus peftilentibus cucurbitule opem. ferune.

$\mathrm{I}_{2}$

Febrim inermitentum curatio guibufdam fecretis auxilis

318

Febri quartane hellcborum album-conilucere.

280

Febres pefilenes, qux Alexandrix vagantur, quibus fignis manifeftantur. 5 I

Febrium peftileusum, qua fuut Alexandria, lympooma:a

$5 \mathrm{I}$

- pettilentium Alexandrix vaganium caurx.

$5 \mathrm{I}$

- peftilentium caufas Alexandrini putant, efle ventos à lucu Marcori fpirantes.

- peftilauium canfas nonumli Alexandino:um pueant, effe purtidos halitus à Subterraneis locis civitates excunres.

-..- pefilentium, Alexandrize incola5แm non pauci, aguam runc temporis ex defectu aqua Nili, paluften, ac corruptam, quam bibunt, caufam cfie pueant.

Eebres muitas pe?tilentes lethalifimas Alcxandrix autumun graffari. 52

- - rariftinas Cayri à calidis tenuibulque humoribus ortas oblervari.

8 - putridas plerumque ab humoribus crallis frigidis oriri.

Fchritim fynocharum arquc ardentium quibuham fecretisauxilis curatio apud $E$ - gyptios ufitata. is

Febres curari ab \&gyptiis quibuldan hnitionibus more antiyuorum.

318

- quattauas quibus remediis curent Egyptii.

Febrium hacticarum curatio apud $\mathbb{E}$ ypios fiequentata.

Fcllis vaccini ad pinguefaciendum ufus.

320

Fernclius aiguins 134

Fernelius fanguinis miffionem in pueris non alhoritu.

107

Ficus Sicomori quales.

252

Figurx, glianto facilius in humida materia recipiuntir, tanto minus duranto

quanto in materia ficciore, difficilius imprimuncur, tanto difficilius delentur, atque corrumpuntur.

Filios multos parenibus diffimiles fpectari.

87

Fiftule, quas faciunt $\mathbb{E g y p t i i}$ pro refrige rando aëre.

Fiftularum, per quas adiun aër refrigeratur, delcriptio.

Fiftulx Esyltiarum adium ventum Sepenirionialem excipiunt, atque ad terrena xdium loca demittunt.

19

Flammam parvam multo olco fuffocari.

Fluxus qua valenter firment. is $\quad 314$

Foecunditas terre $\mathbb{E} g y$ pti niraculo accelfiffe videtur.

26

Fcecunditatem Egypti à Nilo flumine fieri.

26.

Eraucifcus Valefius de aurium fcarificatione.

Fererius Gallas.

L 69

208

Francifcum Rigonum per fectam magni anguli oculi venam plurino fanguine vacuzto à difficili ac magna oculorum lippirudine fanatum.

I II

Frictiones $\mathbb{E}$ gyptios frequentare. $\quad 240$

Frictionum ulum in balnews onnibus $Æ$ gyptiis offe familiariflimum.

$25 \mathrm{r}$

Frictiones quomodo exercent.

242

Fricadi apud IEgypios uficatus modus. 


\section{I $N$ D $E$ E.}

- exctitatio, quam esgypii preftant. Frictionum differentix.

24 !

Ficandi prima direrentia.

242

242

242

2.42

Frictionis primx differentix utilitas. 243 Frictio conferens emaciatis corporibus, ut carnem aceipiant.

244

Frictionum onnium differentiarum util - $^{-}$ ras.

242,243

Fritziones tenuibus humoribus, \& calidis convenire, nequaquam vero frigidıs, \& crafis cxuperantibus.

243

- quibus concitari obftructiones \& febres poffiut.

243

Frictionibas plures $\mathbb{E g y p t i o r u m ~ c u r ~ l a d i ~}$ poffint.

243

Frigiditas äris multis remediis non eget, quibus emendetur.

91

Frigiditate obftructiones foveri, humorefque incrudefcere.

Fruictus Æ̇gy ptiis familiares.

quamobrem Agyptus gignat intrit dos.

- terebynthi pinguefacere.

\section{G.}

Calenus ait fe nullum vidiffe ex febre I acuta laborantem mortuum, in quo recte fanguis è uaribus eruperit.

104

Gal. voluit, non annorum numerun, fed habitum corporis ad mittendum fanguinem effe fpectandum.

109

Gal. dixilte, non effe mittendum fanguinem in puero admodum parvo. 109

Galeno fuife familiaria pravalide purganria.

280

Gal. cuidam habenti linguam prxtumidam catapocia ex aloë, fcammonio, colocynthide parata dedit devoranda. 280

Galenum in quartana febre album helleborum commendare.
- reprehendere Hippociatem qui dixit, icarificaris venis in aures, $\& c$.

Gallinas Muph ceteris pinguíores 130 gypto efle. - 233

Gallinis aliquibus egyptias uti, ut pnguefiant.

233

Gallinas arte factas comedunt Egyptix ad pinguefaciendum.

233

Genisi hominis fimilitudo qux fequatur.

89

Generantis fimilitudo in generato, quomodo fit intelligenda.

$8 ?$

Generatum generauti elle finile. $\quad 87$

Genuentes cur fic ufui refrigerantium nedicamentorum indulgeanr.

17

Georgius Selaccus de ufu cucurbitularum. 165

Gion fumen. $\quad 2 \sigma$

Gingivas atque dentes ad quos morbos Agyptii inurant.

$21 I$

Glacies in Egypto nunquam vel rariflime fit.

Golfypium accenfun levem dolorem concitare.

213

Gollypio ignito Egyptii ad inurendas partes utustur.

210

Golfypium ad inureudas partes quomodo paretur.

210

Grando nunquam in Ægypto fit. 24 Gumma Arabica quid lit, \& an gumma communis ex Alexandria convecta fit Arabica.

306

Gunimata Acatix arboris multa, ac inter fe varia, minimeque, ut dicebat Diofcorides, alba \& vermicularis. 306 Gutam rofaceam fanari fectis venis nafi.

128

\section{H.}

Tabitus corporum Egyptiorum qua1 lis. 32 Habitum Cayri habitatorum effe moderate carnofum, pinguem, aut-valde pinC 2 guem. 


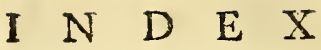

Ruem.

32

Haly Abbas, non negat pueris quandoque acuto aliquo morbo vexatis ven: fêtionem conducere poffe.

105

Abbas cognoville inultionis ufum.

216

Hebræx Egyprix, qux in balneis factitent, ut impinguefcant.

230

Hebræas $Æ$ Eyprias prxter ceteras fudium, ut impinguefcant adhibere.

230

Hecticorum curatio apud $Æ$ Egytios. 324 Hecticis forbitiones Maglub, \& Maftahaleb vocatx commodx.

324

Hedicroos paftillos quomodo Egyptii parent.

2,6

- diverfo modo, quo Magnus, \& Audromachus docuerunt.

206

Helenæ Agypria antimonio curata hiftoria.

$2 \$ 1$

Herbam, quam Affis Egyptii vocant, a ffumendi adagium unde venerit. 258

- comedentes $\mathbb{E g}$ gytios multa fomniare.

258

- comedere apud $\mathbb{E}$ bio dici.

258

Herba canabis uti Egyptios animi graria optata ad vifendum.

258

Heremitas mulcos in Egypti folicudinibus reperiti, Chrifto fervientes, vitamque alperrimam ducentes.

58

Heremirarum corpora qualia fpectentur, \& mores.

Hero docuit cucurbitulis poffe homines uti fpiritus artractione.

Herodotus de cucurbitulis.

139

141

Hermodactylos Agyptios, ut pinguefiant, non fecus quan caftaneas, multos comedere, idque innoxie, \& fine ventris dcjectione.

254 fcant.

234

- vulgares non folvere, seque movere alvum.

234

Hcrmodactylis falfis noftros uti pharmacopolas.

234

Hermodactylos vulgares, non effe colchi- cum Dioforidis.

234

Hernias carnolas mulas viktum cibornin craftum, lentum, pituitofun pue fancyuinem gemerantium, quo uruntur $A g y p-$ tii, facere.

56

Hernia omnes fpecies Cayri in multit $a b$ fervantus.

Hernias aquofas tuto fectione curari. 220

- inuitione curari.

218

Hepar plerique Egypriis effe calidum, \& humidum temperatum, ex quo ii mul.

to fanguine abuudant. gypiii inurunt.

212

Hieronymus Cardanus male interpretatur, \& declarat Galeni mentem de crurum fcarificatione.

181

Hieronymi Fracaltorii opinio de Nili augimento.

Hippocr. cur dixerit, fub cane \& ante canem moleftas effe purgationes.

279

Hippocrates meminit capitis uftiones. 214 Hippocratem ufum femper fuiffe prævalidis purgantibus.

280

- ad purgandum familiaria habuiffe helleborum album \& nigrum, \& peplium.

280

Hippopotamus equus marinus.

Hippopotamum fibi aliquando fecare venam pro fanguinis vacuatione.

Hippopotamus, quo medicamento, curet venam fecham.

Hippoporamum fanguinis miffonem pcr venas fectas docuiffe aliquibus fuafum eft.

Hirudinum ufum ad mittendum fanguinem, $\mathbb{E} g y p t i i$ ignorant.

126

Hirudinibus multi langurinem mittunt, \& prafertim in pueris.

Hiftrioncs, qux in conviviis apud $\mathbb{E g y -}$ ptios facere foleant.

202

Homo fi ex uno conftaret elemento, non doloret Hippocr.

82

Hominis ageus proximum; atque remotum.

Homines frigidarum regionum cur paucis 


\section{N D E X.}

annis vivant. frigidarum incolas mori.

40

in Exgy pto ira pingues effe, qui mammas, longe maxımis fœminarum mammis, majores habeant.

32 - aliquod viicus debile habentes à balneis arcendi fuut.

247

- crudutatibus exupcrantes à balneo arcendi funt.

247

Hominem fimul eodem tempore muliplicem vacuationem ferre poffe, $\& z$ ab ca juvari.

239

Horam Bei Tutcæ Sangiacn lapides c̀ vefica fine incifione extractos fuifle. 224 Horror quid balneantibus efficiat. $24^{8}$ Huniditatem in fanguine pinguem, levem, tetuem exiftentem pinguedinem corporibus conciliare.

Humida tantum putrefcere.

232

Humores proprio calore deftituta ab alicno facile putrefcere.

67

Humores proprio calore deftituti nequeunt impurres manere.

Humorum acrimonia à quibus caufıs fiat.

64

115

Humores calidos, \& tenues per cutim facile vacuari.

243

- biliofos, ac atram bilcm, putrefcentes, fyptomata vehementifima concitare.

69

Humorum crafforum abundantiam utinx fignificantes.

159

Humores five craffitie, five copia obftruentes aliquo tempore neceffario putrefount:

$\sigma_{5}$

frigidos craftolque per cutim ron evacuari, fed per fympepfim, id eft, concoctionem.

243

Hydropi, \& fupouratis pracipuum auxilium eft fearrificario.

167

Hydropicos fectione fanari.

218

Hydropem fanari uftione.

212

Hyárops qua inuftione curetur. 217

Hydropicos tutius fétione quam ufione uti.
Hydropicis anua fenfim eft educenda. 217 Hyens habet Novembrem, Decembrem.

Iivpochondrio flaribus diftento fere $x$ tum fuffocatum, admotis cum igne maltis cucurbitulis, continuo fuiffe, fanatum.

314

Hifpanos in pueris. fanguinem mittere.

107

fin preris mitrere fanguinem fcarificatis cruribus. $\quad 106$ Hyftericarum mulierum clyfteres. $\quad 314$

I.

Tacob. Contarenus Senator Venetus Clarifimus opobalfamum verun ex planta vivente Venetiis diftillafie obfervavir.

208

Ibim volucrem, ufum clyfteriorum oftendiffe.

Ibis quo pacto alvum fibi exoneret. 2

Idan balafian xilobalfamum. $\quad 302$

Iecori inflammato dexterum hypochondrium fcarificandum.

207

In Agypto olim medicinam primas habuiffe radices.

In $E$ gypto bruta animalia medicinam exercere.

In balneis mulri fape fudare, vomere vel fricari confuefcunt.

In balneis qux ex Galeno fint obfervanda.

246

Imbres in montibus Athiopix largiftmo fingulis annis in prima xftare fieri murtorum mercatorum relatione confat.

28

Incolx frigidarum regionum qualia medicamenta fequantur.

251

Incolis calidorum locorum frigida medicamenta effe familiaria.

251

Incolx frigidarum regionum, qุuantum aromatum ufui indulgeanr.

$25 \mathrm{I}$

In puerorum evacuandis corporibus fcarificationes aurium, aut crurum. $36_{7}$

In componenda theriaca Æ̇gyptios omnem C 3 acto 


\section{N D E X.}

athibere diligentiam, quando cam pro Turcarum Rege, arque ejus jufiu componutit.

288

In coxendico delore ac podagra uftionem lino crudo molicndam voluit, Folybius.

212

Indicatio pracipua curandarum febrium.

In exuptione exanthematim adjuvanda non funt utenda cucurbitula.

I $6 I$

Infantibus fcarificatis vel cruribus, rel auribus Fy poius mitcere fanguinem 1 I I

In febribus peltilentibus, prefertim in apparitione exanthequatum, an conveniant cucurbitula.

164

In febribus pentilentibus fudares frigidi multi, vonitus craffi \& vifcidi, urinx craffix, ac multx apparent, ob maximam colluviem crudorum crafforumque humorum.

161

Inflammatio gutturis tollitur, miffo fanguine primo\& fecta vena cubiti, \& poitea veinis fub lingua pofitis ambabus.

Infanmationibus internis fuccurrit fcarificatio.

Infufum ad febres peftilentes. 200

Infulo Tamarindorum, bro infulo Tamarindorum, herberorum atque prunorum fynochas febres muli Egyptiorum curant.

In maximis infammationibus \& doloribus purgandum ufque ad animi defe. Ctum aliquancio. 282

Inuftio quibus populis fit familiaris. 210

Inutio quid praftet.

210

Inuftiones antiquis cognitas fuifie. $\quad 214$

Inufio ad quos morbos utilis.

210

Inunionis ufus apud Egyptios.

203

Inurendi modus apud fisgypios frequentatus.

213

Inuftionem apud Fegypios non ferro neque ali's metallo fieri.

209

Inufiones que inftumento fiant. 210 Inutionem fieri apud Exyptios gollypio, atque pamo lineo ignito.

Inufionem modo REgypriorum preftitam xgroti, quiod levem dolorem concitet, non abhorrebunt.

213

Intilio medicamentis cauficis prxftira, an ultioni Egyptiorum fit proferenda.

Inufio Agyptiorum fit involucro ex gol: fypio \& linea peia parato ignito, parti inurend $x$ appofito.

212

goflypio accenfo praftita non eft horribilis.

212

Inurendi AEgyptiorum modum neminem vel ex antiquis, vel recentioribus probe novifle.

216

modus apud $\mathbb{E}$ gyptios frequentatus laudatur.

212

- modus, quo utuntur Egyptii, rationalis eft.

Inuftio in quibus corporis partibus $a b \mathbb{E}$ gyptiis exerceatur.

209

pro inflammatis pulmonibus ex Hippocrate.

$2 I 4$

$\longrightarrow$ ad fpurum fanguinis ex Hippocrate. 214 ad fippuratos ex Hippocrate. 215 ad hepar induratum. 215 per buxcos furos. 215 per fungos operanda. matum.

articulos, luxatos, dolentes, juvat.

Inuftionis articulorum utilitas.

215

utilitas ad coxendicum dolorem.

215

Inuftione Egyptii utuntur ad Empyos, hydropicos, herniofos.

217

Inultio pro capitis dolore cx Hippocrate.

Inuftionis ufus pro morbo laterali ex $\mathrm{Ga}^{214}$ leno.

2 I 4

Innftio fanat articulorum dolores antiquns, atque aliotum partium.

210

Inuftionem articulos roborare, humores in iis contentos refolvere, calfacere \&e ficcare.

210

ex capitis in pulmones frigidorum, craf- 


\section{N D E X.}

craforungue humorum diftillatione effectis fufpiriolis, conducete.

$2 I \mathrm{I}$ Inuftio fanat cumores frigidos.

211 Int?torem inopum effe reme lium. 212 Intitarum pectoris partium ad afthma fanándum ulcers diu aperta funt fervandi.

212

Inuruntur articuli, venxque fuperpofitx in podagra.

2 io

Immendi varii modi ad hydropicos, \& fuppuratos.

Indfione fanari hydropicos.

217

217

Inuftio quos capitis morbos juvet. 2 I I ___ juvat dolores dorfi, lumborum, colli, , articulorum.

___ ad podagras quomodo facienda.

216

Inopes à frigido ambiente alrerari ac pati, divitefque à calido.

- plures morbos tola inuftione fanant.

212

In omuibus infammationibus, vel fuxionibus duplex oritur fuccurrendi indicario.

208

Ii partes inuftas non facile humorum fieri decubirum.

211

In phtyficis, atque empy is pectoris uflionem apud Egyptios frequentari. - 2 II

In pulmonis inflammatione cucurbitula pectori admovenda. ... . 163

In purgandis corporibus Agyptios nion fimul omnes conveibire.

In purgandis nobilibus Exgyptiis medici quomode fe gerant.

270

In quibus valide, \& leniter purgantia conferant.

280

In quibus lenientia purgantia mon conveniant.

2.80

In fanguinis miffione qux fint obfervanda.

Infanientes, varices, \& hrmorrhoides fitpervenientes fanare.

104

Inftrumentum ad inurendas partes. 200 Fiter crurum fcarificationem, \& venz fefionem maximam efie convenicnian, ac finilitudinem.

I: 5
Joan. Tacöb. Mknne narsat tres cafus, qui is, qui confuevcrant opio uti, evencre. 251 calida renum incemperie aquam Nili $\mathrm{cla}$ refactam bonitate lactis fero pranlit.

Joannem de Lutiardis Cayri mercarorem olim nonnullos farces cinnamomi habuiffe, odorê tum, præ antiquitate atque fapore fere omnino deftitutos. 303

Joan. Ferdinandi Rochi fllius dyfentericus, faitguinis mifione curatus.

I 17

Joannes Mancinus diatrhaa correptus, a. catia decocto fanacus.

- - EV Vus Nubilis Anglus.

314.

Iralas Mulieres ad facici, cotiufque cal tis orurum omnem

Jura quibus Egyptix, ut pinguefant 230 tur:

$2 ; 3$

L.

T Acte acetofo uti omnes Egyptios.

- 252 Lac eft familiarifimus cibus Egyptiis.

Lacticíniorimm ornibia genéra Agyprii in vitu fegumenr.

Lactisi ulúad hecticas apúd $R$ gyptios qualis.

325

Lacte carinclino, ac afinino Agyprios heEticos curare.

Lapides quomodo $\mathbb{E g y p t i i}$ è vefica fine incifione extrahant.

223

- è vefica vento extrahi ab 2 Egyptiis.

224

Lapidis extractio flue incifione quomedo operetur.

224

Lapidem fine incifione extrahendi modus alius.

225

Larifla virgo multiplici vacuatione fanara.

Librum de omuibus $A$ egypiis, Arabicis, \& $F$ ithopicis plantis Arabice confcrip- 
cum apud Mahemetem pharmacopolam ex:are.

Liber ebnagelducam vocatus.

Leprz, arque elephamiafis caufx. $\quad 56$

Lienem indaratum \& refrigeratum uftione Sanari.

212

Ligno Indo Egyptii raro utuntur. 254

Linitiones ad febres curandas ex quibus paren: REgypii.

318

Iinitioncm ufum ad febres peftilentes in AEgypto efle frequeutifimum. $\quad 318$

Iinitionibus uti Egyptios ad adjuvandas exanthemathum eruptiones.

Lititionzin moliendi modus Kegytiis familiaris.

Linitionibus Egyptios fanare pueros variolis, atque morbillis infectos. $\quad 318$

Liniriones fpinx dorfi ad febres putridas ab EEgyptis ufitatx.

Linitio alia ad eafdem febres.

318

Lippitudines feu opthalmix oculorum multa hyeme Alexandrinos invadunt.

Lippitudinum Egyptios invadentium caufx.

Lippitudines oculorum Cayri in prima 2 ftate plurimas epidemicas vagari, \& Cparfim toto anno.

53

- oculorum tolli inuftis partibus poft aures pofíis.

2 I I

Iippientem alvi profuvio corripi bonum.

Locorum naturas quodammodo ufum $\mathrm{fa}^{103}$ miliarium medicamentorum detegere.

$25 \mathrm{I}$

Lygures longxvi funt ob parcum vikum, quo utuinar.

39

Lygurium Genuenfum multos centum annos vivere.

\section{M.}

M Acer vere Diofentidis qui. 279 Maglul ad hesticos, quomodo parent IEgyptii. 266 Maglub decoftum, gitomodo parcur, \&s ejus ufus.

Mahemet Theriaex compofitor. 288

Mahenetem theriacx compofitoren ì thay commorfum fola theriaca inus fumpta, exteriufque vulneri adhibita , fanacum.

Mahemetis pharmacopola. $\quad 288$ legum doctores in Egypto fummo effe pretio.

Malleolus quid. 204,205

Mallcolorum fcarificationes mulieribus, carnofis \& albis prodelfe.

175

Malleolorum, five crurum fcarificationem ad moliendam evacuationem auxilium efle antiquifimum, ac à Gracis fxpe, ac frepe ufitatum.

173

Mancipir mulieres mulex in Aggypto ex Abiflia, atque Erhiopia. 92

Manna, tamarindi, caffia, fyrupus de granatis dulcibus folutivus pro purgandis Egyptiis, apud ipfos in ufu exiftunt.

10

Manux differentix, atque ufus apud $\overparen{E}$ gyptios.

274

Manna maftichina.

274

- bombacina ex faccharo, \& manna adulterata.

274

- Siracoft.

274 terrengibil.

274

Mareus Pheirarius Venetus phatmacopola.

298

Mattahaleb forbicio quid.

Mafthaleb in febribus ufus.

266

- variis modis paratur ab EEyptiis. 266

Medendi modus à prifcis doctiflimis medicis inventus, ut fuorum dominorum tyramiidem effugerent.

12 _ malus modus penes. Egyptios à quo principium habuerit.

13

Medicinam in $\mathbb{E} g y$ pto primas habuifle radices.

Mcdicinx fcientix paucos operam dare.

Medicinam apud egyptios efte in viliori pretio. 


\section{N D E X.}

Medicinam à medicis conflulun in $\mathbb{E}$ gyptum conductis apud illos populos honorabilius exerceri.

3

penes Agyprios ufitatam mendofam effe \& Enıpiricam?

9

Medicina $F$ gypriorum cur mendofa evaferit.

Medicinam curatricem in tres dividi partes.

Medicina curatricis partes.

$8 \mathrm{I}$

Medicum effe narura imitatorem. 102

Medici unde fanguinis vacuationem, atque purgationem exercere coperint. 102

Medicos confulum Cayri in multa effe exiftimatione.

- Aggytios parum lucri facere.

Medicus Achimbaffi qui fit.

Medici Achimbafi officium.

Medicus Achimbaffi eft omnium primus, fine cujus licentia nemo in Egypto mederi poteft.

Medicos prif́cos doctiffimos à barbara $Æ^{5}$ gypto imperautium tyrannide male mederi copiffe.

II

Medici recte olim batbaris hominibus medentes, non raro ab ipfis male tractabantur.

I I

Medicos Ægyptios adulatores effe.

10

Medici Ægyptii ægrotorum deliciis inferviunt.

Io Egyptii febricitantibus concedunt angurias, cucumeres, melones \& alios fructus refrigerantes.

I0

Egyptii febricantibus quantum libet aqux crudx concedunt.

Medicorum $\mathbb{E} g y$ priorum finem non effe morborum curationem, fed agrotorum obfequium.

10

Medici adulatores ex Galeno qui fint. 10 - Egyptii obtemperant ægrotorum voluptatibus.

10

- Egyptii affirmant nihil à natura expecitum poffe ladere ægrotos. 10

Medicos adulatores multa etiam Italia loca prater Ægyptum habere.

ad mittendum fanguinem non de- bere annorum numerum confiderare, fed cutem corporis atque necefitatem, Rafis prodidit.

106

L Kgyp:ios in exercenda fanguinis mifione plurimum errare.

99

Medici Arabes volunt tenues humores efle craflefaciendos.

Medicorum Egyptiorum guoad ufumpurgantium, rectx.

- quorundam purgandi malus ufus. 270 282

Medici Ægyptii quibus ad rufticos purgandos, utantur medicamentis. II Medicis antiquis medicamenta valide purgantia fuife familiaria.

277

Medicorum aliquos prius devicta natura, à multis craflis, vifcidis fuccis in aliquo vifcere fuffarctis, mori finere quam validum purgans experiri velint. $\quad 282$ Medici ÆEgyptii pefti mederi non timent.

59 que que curare inon riment.

Medicamenta Egyptiis familiaria. $\quad 252$ - refrigerantia cur Egypriis familiaria.

Medicamentis refrigerantibus cur in putridis febribus ÆEgyptii utantur.

Medicamenta refrigerantia cur apud $\mathbb{E g y}$ ptios fint in frequenti ufu.

Medicamenturum valde refrigerantium ufum in febribus putridis effe apud $F$ gyptios frequentifimum.

valde refrigerantium ufu humores crudos incrudelcere, \& crafliores fieri.

Medicamenta putridis febribus convenire, qux deobftruendi vim habent, fed tamen fine multo calore, ut oxymel. $y$ Medicamentorum refrigerantium ufum putridis Æggytiorum febribus, neque utilem, neque noxium effe.

refrigerantium ufus veluti ad caufas febrium inurilis eft, fic febres juvare potelt.

$$
D \stackrel{-}{-}
$$




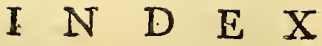

febribus, atque hecticis maxime convenire.

324

- refrigerantium ufum omnibus fe. bribus non conducere, neque effe in is tutum.

7

- refrigerantinm ufum venarum obftructiones fovere.

Medicamenta, quibus $\mathbb{E}$ gyptix ad pinguefaciendum, utuntur.

- quorum ufus apud $F$ gyptios eft ad fpectanda multa per fomnium animi gratia.

257

— quorum ufus apud Ægyptios eft ad provocandum fudorem in febribus peftilentibus.

321

- lenientia, qux in ufu ad purgandum, penes Egyptios exiftunt. 27 I

- purgantia prevalida in purgandis corporibus, aliquos Ægyptios merito timere.

272

ftris dici.

Medicamentorum, leniter, \& valide gantiun uier ufus prefter.

27.8

Medicamentis leniter purgantibus plerofque medicortm ubique nunc fequi. 278

Medicamenta purgantia prxvalida non nifi. corporibus robuftioribus convenire, veluti imbecillioribus leniter qux purgent.

278

- leniter purgantia robuftiotibus corporibus non convenire.

278

Medicamentis leniter purgantibus nihıl aut parum multos fuiffe purgatos. 278

_ valide purgantibus aliquos parum fuiffe purgatos.

279

Medicamenta purgantia, qualia olim apud auciquos medicos fuerunt in ufu. 277 - quibus purgationis caufa antiqui uti folebant.

277

- purgantia, qux apud Egyptios in ufu exifunt.

Io

- purgantia fingulis, aut alternis dicbus Egyptii exhibent, fed in modica quantitate.

10 - ex purgantibus, apud Eggptios ufr- tata.

- fcammoneata Egyptii effugiunt.

Melancholian fieri læha imaginatione. 259

- atrum colorem cerebrum obfidentem facere voluit Gal.

259

- fieri ab atro nigroque colore, negat Averrhoes.

Melancholicx dementix figna.

259

Melancholicis multis fancti exiftimantur, Ægyptum abundare.

58

Mel carnub ufus, fit expreffis feliquis dulcibus.

Meliceribus fthentomata, atheromataque vocata Ægyptii. quomodo curent. 227 Menfes provocare farificationes crurum. I 9 I, I 22

Meto multiplici vacuatione judicatus. 239 Modus pinguefaciendi, quo utitur quxdam medica Eg yptia.

234

cifione.

224

Moreftan eft locus in quo theriacam componunt.

288

Morbi Egyptiorum patrii qui fint. 50

- qui Alexandria autumno graftantur.

- plurimi ab inxqualitate aëris in $5 \mathrm{I}$ gypro fiunt.

Morborum omninm caufe fecumdum 20 gyptios.

Morbos omnes in Æygyto calorem pro caufa habere Egypiii putant.

- omnes à caliditate in $Æ$ gypto oriri, fallum effe.

82

- plures in /Egypto fingulis annis in prima parte $x$ tatis vagari epidemicos, atque lethalcs.

Morbus dem cl muia acutiffimus Cayri in prima xitate vagatur. 53

Morbi dem $\mathrm{cl}$ muia vocati figna. $\quad 54$ - dem el muia caufa. 54 Morfum thayr ferpentis non effe fic exitiofum, ut qui à cerafte infligitur. 225 


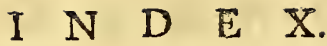

Morfum thayr ferpentis eadem concitare fyptomara, qux à viperarum morfibus concitari folent.

295

Mucilaginis pfylli, atque cytonis ufus. 267

Mulieres quam viri medicamentis purgan. tibus magis accommodatx.

279

Mulieribus albidioribus, tenuiori fanguine exuperantibus malleolorum fearificatione fanguinis vacuationem magis quam venx fectione praftare.

1 I I

- nigrioribus, gracilioribus, ac venis magnis magis preftare veno fectionem.

II 2

Mulier hydrope laborans, fectione fanara.

2 I9

- vidua ab imbecillitate ventriculi theriaca fanata

308

—_ timeftri foetu gravida multiplici vacuatione judieata.

239

Mulierem nigrum fœtum, ex crebra imagillarione nigri homınis picti edidiffe.

Mulieres Iralas ad faciei totiufque capiris culrum curam adhibere.

230

- Agyptias omnem curam adhibere ad cultum abditarum partium maximeque pudendorum.

230

- Rgyptias pudendis maximam curam adhibere in balneis, ipfaque variis unguentis odoratis exornare.

230

—_ Egyptix cur balneis indulgeant. 230 Egyprix quid in balneis factirent.

IEgyptix in balneis qux factiteut, ut pinguefiant.

Mulier Ægypria publice artem pinguefaciendi Cayri profitens.

234

- Turca Medica quibus medicamentis hiftericas mulieres fanet.

276

Mulieres pinguifimas Egyptus cur habeat multas.

230

Multiplex evacuatio in quibus $x$ grotis critice apparuerit

239

Multos $\mathrm{ab}$ antiquis lienis, hepatifque obftructionibus ftibio, vel æris infufo vel alio prevalidifimo purganti fanatos: 282

Multos à plurimo aqux potu poft affum. ptutn purgans ventre plurimum tumefacto, \& vehementifimis doloribus conflictato, quafi mortuos.

285

Mur, Myrrha: fed \& \& Egyprii Trogloditica caretit.

Mufa fructus.

301

Myrrha qua uruntur 252

Myrha, gua uruntar Kegyptii, $\quad 301$

Myrrlia Ergafima gux. 301

$\mathrm{N}$.

Tarium fcarificatio mulros, ac varios
morbos fanat. 170. \& hoc in diebus criticis. 170. \& modus, quo fearificanrur.

$17 \mathrm{I}$

- fcarificandi modus, \& ordo. $17 \mathrm{I}$

Naturam fubitaneas mutationes non ferre.

213

Natura humores tantum preparatos expellit.

I6I

- fimul multas vacuationes in corpore uriliter prodere.

238

Naturam Medicus imitari debet. $\quad 239$

Narura interdum propulfat humores morbofos è nobilioribus partibus ad ignob:liores.

199

quomodo exanthemata expellat, five quomodo excernat.

161

- prius concoguit \& moz expedit.

Natron quid.

I $\mathrm{I}$

Nirri ufus ad peftiferas febres 321 $32 I$

Nautam opii defectu in faftidiofiffimam. fyncopim lapfum, opio fibi oblaro fu. bito $a b$ ea levatum fuife.

$26 \mathrm{I}$

Nigrum flumen.

26

- flumen rivum effe Nili fluminis. 29

Nigrum flumen, itt Nilus eodem modo, arque tempore crefcere.

Nilus ubi nafcatur.

- tranfit roram Zonam torridam. 35 longo irinere fere fuam aquam concoquir.

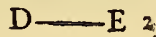

Nilus 


\section{I $N \quad D \quad E \quad X$.}

Nilue fumen omnium longiffunum. $\quad 26$ in Africa à Deo cur factus. 26

2 in Egyp:o arewofa lgca irrigando facundat.

- ubi nafcitur.

Nili curfus.

Nilus terram limo obtegit.

26

26

26

26

Nilum flumen Deus Fyyptiis conceflit ad arcendum fitis incendium, ex cam. pfinis ventis concitatum.

24

Nili. Huminis aqua omnibus cft prxjucundillima.

24

Nilus fingulis annis una die atque hora perpetuo angeri incipit.

27

Nili incrementi principium nunquam à confucta hora \& die deflexifie.

27

Nilus quautum fingulis diebus augeatur.

Nili quantum fiat augmentum.

27

Nilus $f e x$ \& viginti cubitorum altitudine auctus aliquando obfervatvs eft.

27

intra ripas ufque ad menfem Maitum decrefcit.

26

Nili aqua quando paucifima.

27

- augmenti principii rationem ab occulta caula pendere.

73

Huminis augmenti principii veram canfam non poîe principiis naturalibus indagari.

73

fiar.

fuminis incrementum à qua caufa

Nilus fiumen confantifime perpetuotcm. pore fingulis antuis menfe Junio die decima feptima incipere augeri.

29

- cur femper fingulis annis eadem die augeri incipiat ab Regyptiis ignoratur.

octodecim cubitorum altitudine auatus far eft al agrorun inundationem faciendam.

Nili augmentum incipit menfe Junio, \& plerumque ufque ad medium Septem. brem terminatur.

Nilum crefcere à pluviis Ethiopix. 28 - non à nivibus crefcere.

Nilus fundum habet conofum, \& aquam turbidam, neque admodum ad motum celerem. 34

Nili incrementum non effe in caufa, ut peftis Egypti finiatur.

Nives intra tropicos non fieri. 73

Nomades olim inufionem familiarem habebant.

2 I 5

- quas partes urere confueverint. 215 Nubes mulias eraflas cum Ægyptii ab Etefiis ad meriden pelli obfervant, $\mathrm{Ni}$ lum flumen plurimum auctum iri fperant.

- multas craffas tota fecunda $x$ ftate ab Etefiis in montes Lybix, atque Æthio. pix fingulis diebus advectas concrefcere, atque in pluviam mutari. 28

Nucem Indicam pinguefacere. 232

Nutrimentum, quod in ftomacho à calore vincitur, calefacit, \& quod vincitur, refrigerat.

Nutrimentum immodicum refrigerare caloremque fuffocare.

Nix in Egypto nunguam fit.

$4 \mathrm{I}$

O.

bxfitatem Fgyptias libidinis caufa
procurare in baluscis. $2 \geqslant 0$ Obferuatio Æggyptiorum, qui ad unguem ad quatos cubitus Nilus fit perventurus, vere prænofcunt.

29

Obftructiones venarum in febribus, vel à multis fuccis, vel craffis, vel lentis fieri.

Galenus.

_ venarum ab ufu medicamentorum valde refrigerautium augentur.

- cucurbitulis concitari poffe. I 58

Obftuctionem cucurbitulæ non concitant evacuatio roto corpore.

$\mathrm{I}_{2}$

Occipur cur urant ÆEgyptii. 211

OAtavius Roveretus. 225

Oetavium Roveretum alium extrahendi lapidem modum ab Egyptiis didicifle. 


\section{I $N \quad \mathrm{D} \quad \mathrm{E} \quad \mathrm{X}$.}

Oftavius Roveretus medicus Nationis Venet $x$ in Egypto.

225

Oculorum infammationes antiquatas fanari fanguinis vacuatione, featis venis magnorum angulorum oculorum. 128

Olera, quorum ufum in cibo Egyptii fectantur.

252 Ægyptia omnia effe noftris huniidiora, \&r magis infipida.

- in Egypro cur infipida, neque guftui grata exiftant.

Oleum pinguefaciens corpora.

Olea, quibus utuntur $Æ g y p t i x$ ad pinguefaciendum.

233

Omnem putrefactionem pro caula in qua fit, habcre humiditatem.

78

Omne nutrimentum quatenus nutrimenrum animalis calorem augere.

411

Offa fracta non cohxrent per unionem, fed per callum, porum, à Gracis vocatum.

I3.4

Opium, affion ab Egyptiis nuncupatum.

ubi paretur, quidque fit.

253

- Agyptii unde advehant.

261

$26 I$

quid faciant.

fumentes

quid fumentes

Opii, affion vocai, ufus apud Ægyptios.

261

$26 r$

255

Opirm innoxie aliquos Ægyptiorum ad trium ufque drachmarum pondus fumere.

255

Opii fymptomata, in his, qui id edere confuefcunt.

255

Opio cur $\not{L}$ gyprii utantur.

255

Opium fumere foliti nif folita hora ejus ufitatam copiam fumant, in faftidiofiffina fymptomata labuntur.

261

Opium fumentes an optata multa fomniare poffint.

257

_ folita hora Egyptios non fumentes in gravifima fymrtomata incidere. 261

- aftumere quotidis foliti, quomodo liberentur ab ejus ufu.

257

Opobalfamum ab arbufto Yenetiis viven- te, verum diftillaffe.

Opobalfami ufus ad febres curandas. 317 bres.

Opobalfamum fincerum ac verum in

gypto reperiri.

255

Opobalfami ufus.

254

Opobalfarmo fteriles mulieres focundas reddi.

Opobalfami ufum ad peitem apud Turcas nobiles, atque $\mathbb{E g y p t i o s}$ effe fre. quentifimum.

323

Opobalfamum vim adverfus putredinem habere prxexcellentem.

323

Opobalfami facultas.

Opobalfamum calorem naturalem fover, 323 \& augere.

Opobailamo quomodo ad peftem Ægyptii utantur.

323

Ophthalmias fieri à pulveribus, \& arenis ventis illuc afportacis.

22

Ophthalmix quo anni tempore epidemicx vagantur.

Oribafus alero crure fcarificato binas fere fanguinis libras extraxifie teftatus eft. I 82 Oryza eft cibus omnibus Rgyptiis familiarifimus.

P. Panis Egyptiorum qualis.
Panem Kgyptii omnes ex folo tritico paratum mandunt, neque alium cognofcunt.

Paracentefes magis quam uftiones ad 34 dropes confueta.

2 I9

Paralyticos inuftione fanari.

$2 I I$

Paris chriftianus morbo dem el muia vocato mortuus.

Pafta ex archenda humidos pedes \& laxos juvaus.

242

Paftilloram fcyllinorum compofitio apud Fegytios ufitata.

293

Partes fcarificatz qua multum fanguinem edant, \& qux paucum.

$$
\mathrm{D}-\mathrm{E}_{3}
$$

I 28 


\section{I $\mathrm{N} \cdot \mathrm{D} \quad \mathrm{E} \quad \mathrm{X}$ :}

Parres imbecillas uftione roborari. 2 II - uftione robuftiores redduntur, qua non facile fluxionibus vexentur. $21 \mathrm{I}$ - dolore vexatas uftione fanari. 210 - humores gignentes, atque mandantes, Ægyptios inurere.

2 I I

polt aures ad quos morbos uruntur.

2 I I

- qux Egyptiorum more uruntur, cur neque dolorem, neque calorem fentiant.

212

- modo Ægyptiorum qux uruntur, neque vehementem calorem, neque vehementem dolorem fentire.

2 I 3

Partem inurendam in primis obftupefacere.

$2 \mathrm{I} 3$

Paulum $\mathbb{E}$ ginetam inuftione ad veteres affectus ulum fuiffe.

215

Pauperes correpti peftiferis febribus quo potu in FEgypto uruntur.

32.0

Pauperculx $\mathbb{E}$ gyptix qux faititent, ut pinguefiant.

Peitus ad fufpiriofos ab EEgyptii uri. 21 I - à capitis diftillatione conflictatum Æggptii urunt.

2 II

in phtyficis ac fuppuratis urendum.

Pediculis cur Egyptii abundent.

211 colo frigidil

fimo reperiantur.

230

Peplio ad purgandum utebatur Hippocr.

279

Per animi defectionem in is qui aliquo medicamento purgantur, quid fit intelligendum.

283

Peripneumoniacis pectus fcarificandum.

Per purgationem ufque ad animi defectum faciendam, quid fic intelligendum. 284 Peftilentes febres quo rempore Cayri vagentur epidemicx.

Peftilentium febrium Cayri vagantium caufx.

Peftis, five peftilentia quid fit.

peftem duplicem habere caufam.

Pefis caufa efficiens.
Peftem Turcx non timent, neque $a b$ ea fugiunt.

Pefte Ægypti loca fxpe dezaltari. 59

Peftis, latius, freviufque quam alibi ferpat. 59

Feftem Turcz ommes non timent, neque ab ea fibi precavent.

- Turcarum credulitate cito excrefcere.

42

Peftis cur penes $\mathbb{E g y p t i o s}$ in immenfum crefcat.

- qux anno 1580. Cayrum devaltavit, quot interemerie.

Peftem plerumque Cayrum \& contagium accedere.

60

— in Ægypto rarifime ab aëre fieri.

Peftis Agyptum invadentis caufx. $\quad 69$ Peftem inngni aëris calidieate abfumi. or fingulo fepteunio in Ægypto nafci, falfum tife. GI

Peftis in $\mathbb{E}$ gyptum vel ex Græcia, vel Syria, vel Barbaria venit. GI

- omnium fexiffina, qux ex locis Barbarix in Aggytum proficifcitur. or - quxex Barbaria in ÆEgy ptum alportur, car omnium fit $f x$ vifima. 62 - contagium à Barbaricis locis adveEtum rehementius Ægytii incolas pervadere, ipfofque attrocius depafcere, diutiufque vigere.

62 - qux Cayrum vel ex Gixcix, vel Syriz locis venit, minus quam è Barbarix locis profecta, ferpit, atque devaftat.

$\sigma_{2}$

Peftilens contagium ex Barbaria profectum, cur ex aliis omnibus locis advecto favias exiftiofius, diururniufque fit.

$\sigma_{2}$

Peftis quo tempore Egyptum invadere foleat.

fima.

Exypto, qux ficomnium fxvif-

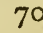

70 in Ægypto minus Cxva. quo tempore in Agypto definat. 70 qualifcumque fit magna, ac vehe- 


\section{I $\mathrm{N} \quad \mathrm{D} \quad \mathrm{E} \quad \mathrm{X}$.}

mens, perpetao Sole primam partem Cancri Junio meafe ingrediente, omnino tollitur.

70

Peftem nunquam Junio, Julio, \& Augufto menfibus in Egyptum afportaram, vidiffe Ægyprii affirmznt.

Peltis, qux Cayrum inficit, an ex Nili fluminis angniento tollatur.

73

- Egyptix extinctio coincidit cum Nili augmenti principio.

73

Peftem in Egypto ex aëris mutatione, quæ fit menfe Junio, finiri.

Peftis extinctio in Egypto Junio menfe obfervata, an in Etefiarum Spirationem referri poffic.

73

- extinctionem in Rgypto caufam ha-

bere $a b$ aëre illiufce temporis fumme calido, xquali, corpora diffinte, ficcante, arque $a b$ Ercfis eodem tempore fpirantibus, quibus vitales fpiritus reftaurantur, ac foventur.

- exftintionem fieri ab Etefis feu Septentrionalibus tune fpirantibus ventis, nulti Egyptiorum afirmant, 7.5

Peftilenti morbo optimum præfidium fcarrificatio crurum.

175

Pefte vexatis fcarificario tanquam divinum auxilium.

200

Philoropha electuarium.

Phlebotomi Ægyptionm longe noftris funt acutiores.

I 38

Phlegmones oculorum tolli, primo fectis venis magnorum angulorum oculorum.

128

Phrenitides exitiofifimx, qua aliquando in Ægypro vagantur.

50

- qua tribus quatuorve horis homines interimunt.

50

Philonium Perficum Avicennx. 3 II

Pinguedo in corpotibus quomodo generetur.

Pinguedinis qux fit caufa pracipua. - caufa materialis qua fit.

Pinguedinem à diminuto calore, atque à multo pingui alimento fieri.

pinguedinis caufa eft frigiditas.

237

(3)

232

232

232
Pifces, quos comedunt Agyptii. faliti fun apud $/$ gyprios in ufu frequentiori.

in Nilo fumine capti etfigutui admodum fint fuaves, tamen peflimi ad fanitatem exifunt.

- Nili fiuminis cur infalubres. $\quad 34$

Plenitudinem corporum non tolli fearificatis cucurbiulis.

147

Plenitudinem corporum tollunt Egyptii vel vena fecta, vel fcarificatis cruribus.

I 47

Plenitudo auferenda aut ven $x$ fectione, aut cruribus fearificatis. . 176

Pleuriticis latus dolens fcarificatum juvat.

207

- dolore ad hypochondria declinante nigrum helleborum \& peplium convenire.

280

Plinii opinio de Nili fuminis augmento.

28

Pluit rarifime in Fypto, maximeque in locis à mari remotis.

Pluvias largiores ficri oportere in prima Egypri aftate in locis prope Nili princtpium pofris, quod Lybiz montibus funt frigidiores, ratio, fuadet. 28

- largifimas in Ethiopia fingulis annis fieri. 28

- copiofiores, \& largiores fieri in montibus, à quorum radicibus Nilum nafci multorum eft opinio, multorum relarione conftat.

Podagra duplex caufa.

2.8

$21 \mathrm{I}$

- fit ab imbecillitate articulorum, atque $a b$ humorum fluxu.

211

Podagram non fieri nifi amba caufa concurrant.

2 I I

Podagra quomodo uftione fanctur. 215 Padagram curantes quas venas inurant.
Podagricos dolores evacuato toto corpore fearificatio loci larí fedat. 227

Polybus cognovit materiam inuftionis gua Ægyptii utuntur. 


\section{I $\quad \mathrm{N} \quad \mathrm{D} \quad \mathrm{E} \quad \mathrm{X}$.}

Populares.mulieres fibiipfis ungues manuum ac pedun archenda tingere. 242 Populi Turcarum, Imperio fubjecti, quibus delectantur.

Populos Egyprios multa optima remedia empirice exercere.

Populo Turcartim Imperio fubjecto fcientiis nunc non delectari.

Populi frigidarum regionum cur refrigerantia medicamenta, fic uti timeant, calfacentiumque ufum complectantur.

$25 \mathrm{I}$

frigidorum locorum, guibus malis ex victu fint obnoxii.

$25 \mathrm{I}$

-_ trigidarum regionum cur brevius vivalte.

$25 \mathrm{I}$

Populos frigidarum regionum, ut reete purgentur, egere pravalidiffimis purgantibus.

279

Potus Turcis \& Egyptiis familiaris. 267

I’otuum varia genera, qux xgrotis ante fanguinis miffionem conceduntur. I 123 Potum frigidum iis, quibus fanguis eft mittendus; fumme conducere. I 23 Potu frigidx aquax xgrotos à fyncope d:fendi.

123

Potus quem ante miffionem fanguinis $Æ E$. gyptii æxgrotis exhrbent.

123

potio fingularis ad febres amphimerinas.

3 I 9

fingularis ab Ægyptiis ad febres intermittentes celebrata.

318

_._ alia ad idem.

318

Potus fingularis virtutis ad cos, qui febribus peffilentibus, xgrotant.

ad fidorens movendum, qui ab $\mathbb{E}$. gyptiis parentur.

322

- ex berberis fructibus paratus quomodo ab KEgyptiis ad febrium ardentium, peftiferarumque ufurn parecur.

cx berberis frußtibus parati vires

253

Prafectus Befla, appellatus Cadi, fuos judices creat.

Prxcipuum agens in noftra corpora quod fit.

Profuvio alvi cum febre exiftente, non effe aliam moliendam evacuationem. 114 alvi in febribus exiftente, qui aut fanguinem mittere, aut ventrem movere tentarunt, xgrotos in graviora pericula duxiffe ipfe Galenus docuit. 114 Profperi Alpini natura ex cœeli fchemate. 86

Pudendis in balneis Eggyptias nulieres ftudium adhibere. 230 Pudenda, ut ornent, in balneo, quid $\mathbb{E}$ gyptix molianur.

syptis 230 nant.

23 I

- Hobilium Turcarum in balneis mufco, ambra ac zebet exornari. 23 I Puellam annos fepten natam fanguims miffione fecta vena dextri cubiti à febre curatam. I06

Puerulum octo annorum per fectam venam vacuato fanguine fanatum. 106

Puerum annos quinque natum pleariticum fanguinis miffione fanatum. 106 Puellam à febre maligna fanguinis miffione fuiffe liberatam. 106 - poft miffun fanguinem à fecta verna è varibus fanguinis fluxum, atque ventris dejectionem fuperveniffe, \& ftatim priftinam faritatem conceffam. 106 Pueri habent plurimum innati caloris. 107 Pueros multo fanguine abundare. 107 non recte ferre purgantia. 279

Pueris etiam fanguinis vacuationem conducere poffe.

Pueros multos naturam fanguinis vacuatione fanavifle.

- multos critica fanguinis è naribus ertptione furfe integre judicatos. 105 Pueri quamquam vitali faculcate valeant, tamen neque hi fanguinis fuftinente miffionem. 100

Puero vel ctiam fynocho correpto ante annum decimum quartum venam non elle fecaudam. 


\section{N D E X.}

Pueris Egyptios fecare venam pro fanguinis evacuatione. Iot s fcarificationes commod $x$, facile hi refolvuntur.

201

- fapiffime fine ulla noxia multum fanguinem fponte vacuari.

107

Pneritix profluvium fanguinis per nares eft familiariffimum.

108

Pueros vel etiam lactentes interdum inediam multis diebus fine noxa perferre.

I08

Preris ex modica fanguinis miffione non fieri tantam virium jacturam, ut aliqui putarunt.

108

Pueros interim copiofos alvi fluxus, atque fudores perferre fine noxa. 108

Puerorum corpora non mulcum extenuantur in norbis.

108

Pulmonum ulcera fauari non poffe ob continuam ipforum motionem.

I35

Pulveribus Aggyptum efle obnoxiam, à quibus incolarum oculi infeftantur. 230

Pulvere lentium nigrarum ut \&gyptios ad fanandum arterix vulnus.

138

Pulvis ad quartanam febrem.

320

- quo pro fecreto utuntur Egyptii ad febres pertilentes.

322

fingularis virtutis ad provocandum fudoren cum aqua diffolutus it feb. peftilentibus.

321

Pulfus rangendi à medicis in via conlue tudo.

55

Pulfuum fola oblervatione putant $\mathbb{E}$ gyptii medicos pofle, vel pollicem etiam digiti articulum dolentem cognofcere. 55

Pulfum intermittentem aliquando $\mathrm{ab}$ admotis cucurbitulis apparuiffe.

160

Purgationes ill $\boldsymbol{x}$ optima dicuntur, quæ naturæ optimas excretiones imitantes, nulla violentia humoris noxii copiam extrudunt.

186

Purgantia prevalida olım apud Hippocratem atque Galenum in ufu fuiffe. 279

Galeno olim familiaria qux. 288

Purgari poffe corpora interdum ufque ad animi defectionem.

282
Purgantem alvum non effe impoffibile fifti. 284

Purgantium prævalidorum ufus in quibus ufui leniter purgantium fit præferendus. 284

Purgantibus violentiflimis multos fere deploratos fanatos.

$28 \mathrm{I}$

Purgantia valida quibus conveniant. 279

- leniter quibus conveniant. 279 do non.

280

Purgationibus ptzvalidiffimis multos juvatos fuifle.

282

Purgantia prævalida, non nifi robuftioribus corporibus conveniunt.

Purgantibus lenientibus qui purgandi. 279

Purgantia eadem non omnibus convenire.

379

Purgantia medicamenta in corporibus exercenda, qux evarient.

279

- pravalida fuiffe in ufu apud antiquos.

_ prævalida Ægyptiis non convenire.

27 I

- medieamenta prævalidifima, quibus ad rufticos \& plebem $\mathbb{E g y p t i i}$, utu: :tur.

278

Putredo fit à quocumque calore immodico naturalem difipante, atque corrumpente.

64

Putrefcunt humores, atque partes corporis calore naturali ab extraneo corrupto, \& diffipato.

Putredinis cauf $x$ materiales.

Putrefactio quotuplex

64

Putrefcere tantum humida, \& non ficca.

Putredines fieri ab aliena caliditate fenic Ariftoteles.

64

Putrefacienria naturam corporum poreftate calida effe.

64

Putredo omnis ex materia gignitur bumi. da, ex caufa efficiente extranea \& pr $x$ ter naturam calore.

65

Putredines fieri humidis ac pluviofis temporibus.

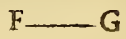

Pis 
Putrefcete promtiflime quxcunque funt calida \& humida.

Putredinem in ficca corpora accenfam effe praxcellentem.

66

Pfyllii feminum ufus.

255

Pfyllium venenum 11011 effe.

255

Pfyllinm \& coriandrum viridia in ferculis effe apud Egypsios in ufu frequentilfimo.

252<smiles>[O]</smiles>

ualia fint $\mathbb{E g y p t i o r u m ~ c o r p o r n m ~}$ temperamenta; atque habitus. 84 Quas partes corporis $\mathbb{E g}$ gytii inurant.

Qua pinguefaciant.

210

233

- evariant medicamenta purgantia.

279

Quibus morbis farificatio conveniat. I 99,200

Quomodo intelligenda fit Cententia Hippoc. atque Gal. dicentium, corpora ad animi ufque defectum purgare licere.

Qhot nationes Cayrum accefferint.

283

R.

R afim in pueris fanguinis vacualionem 1. interdum moliendam laudare. 105 $\mathfrak{x g}$ rotis antequam fanguis mittatur, cibum dandum conceffiffe.

I 2 I

Rationes ex Galeno ad reprobandam fanguinis miffionem defumptas non concludere.

129

Regionum frigidarum incolas minus $\mathrm{f}^{2}$ vam, quam calidarun, pati peftileniiam.

68

Remedium nullum majus invenit Gal. in maximis doloribus mifione fanguinis, \& purgatione.

115

Renes Egypiorum non paucorum debiles.

Rhabarbarum.

Rhavend Seni, eft Rhabarbarum. 300
Rhob Cathix, fuccus eft acatix, \& quo. modo ab Ægyptris paretur. $\quad 506$ Rufticorum corporum Ægyptiorum temperies, atque habitus.

92.

S.:

anguis in venis cutaneis contentus, $\circlearrowleft$ purior, ac tenuior exiftit. I 5 I

Sanguinis miflionem ab Hippopotamo hominibus monftratam fuifle.

Sanguinem quot modis mittant Egyptii. à mulris venis noftris medicis inufitatis Ægyprios mirtere.

_- Agyptios à fectis arteriis mittere. 4 tionibus.

Sanguinis miffionem apud Egyptios effe ufitatifimam.

Sanguinem mittunt Fyptii il omnibus xtatibus, anni remporibus, \& ad omnes fere morbos.

82

Sanguinis vacuatione libentius quam medicamentis Ægyptii uruntur.

82 - miflionem cur Ægyptii fic frequenrent. 82 - crebram miffionem ritalem fpirirum confumere arque actiones animales $l x$ dere, . 98 vacuationi corpora apta. $\quad 99$ Sanguinem $\not$ Egyptios vel etiam in infan1tibus mittere.

Sanguinis miffionem in pueris Egyptios, Arhiopes, Abifinos exercere. $\quad$ I00

- miflonem in pueris faciendam plures Arabum voluerunt.

Sanguinem facilius Agypiii in pueris mittunt farificatis cruribus.

109

Sauguinis miffionem non convenite corpoibus mollibus, albis atque valde humidis.

IIO

ferant.

I IO

Sangunem detrahunt, à Cearificatis auribus, collo, labies, gingivis, cruribus, \& na. 


\section{N D E X}

\& naribus.

I 27

Sanguinis vacuatio per fcarificationem mallenlorum cur albis, mollibufque $11 \mathrm{~g}$ is commoda atque urilis fit. I I I - miftionem cur Ægyptii ferc in omnibus morbis moliantur.

94

Smoninem in quibus fpeciacim morbis Eyyp:ii mittant.

95

- mitaeri Egyptios in omnibus fere morbis.

Sanguinis mifionem cur Fgyptii putent omilibus conducere.

Sauguis quot modis ab Egyptiis mittarur.

125

crafius cucurbitulis non poteft vacuati.

159

Sanguinis miffonem per hirudinum ufum Egyprii prorlus ignorant

I 26

Sanguinem mitentes in dyfenteria quid mali efficiant.

II 4

Sanguinis miflonem 位yprios exercere etiam in dyfenteria, diarthaa biliofa, in exanthematibus erumpentibus, punficulis vocatis, inque peftiferis tumoribus.

113

__ vacuatio $\mathrm{ab}$ inteftinis fluentem humorem revellit.

J15

- vacuatio prohibet, ad partem exulceratam humores ne amplins confluant.

I 16

Sanguine non vacuato in dyfenterix principio fanguinis profuvio non firmato plurimus fanguis per inteftina evacuabitur, qui vites maxime diminuer. 116 Sanguinis vacuatione dyfenteriam curandam multi prifcorum, atque recentiorum etiam medicorum fenferunt. I 16 miffionem effe exercendam in dyfenteria.

II 6 miflonem ad dy fenteriammaximum efle auxilium, fine quo difficillime curatur.

118

_- miffionem in dy fenteria quamplures medicos damnare.

113

Sanguinem fluente alvo non effe mittendum.

113
Egyptios mittere in principio omnium peltiferorum exanthematum, atque tumorum. 112 - à cibo Egyptiorum vulgus mittere. IL 6

in Agypto je uno fomacho mitrelites à vulgo niedicorum damnantur.

Sanguinem quibus de caufis plures $\mathbb{E} g y-$ priorum à cibo nuinimeque ftomaclio jejuno nittendum cenfeant.

120

- à cibo mittendum Grxciabhorruc-

re.

I 20

- non effe mittendum cxiftente in fto-

macho cruditate, neque priufquam $\mathrm{cx}$ crementa deicenderint.

$12 . I$

Sanguinis milfo cibo crudo exiftente in ftomacho, quid mali faciat.

121

miffionem prohibere os ventriculi nimium fenfibile, aut imbecillum, vel amara bile redundans.

122

- Egyptiorum a cibo mittendi ufum elle peffimum.

125

fe.

I 2 I

_ cur facta copiofa vacuatio è venis retro aures fectis fomnum profundiffmum \& longifimun inducat. I 5 I larga profufione ex venis polt aures fectis fomnum profundum excitari, neque fterilitarem iudusi.

I3 I

vacuationem affestæ partis, à proximis venis facicridam.

127

- vacuationem partıbus poft aures $\mathrm{fca}$ rificatis fomnum conciliare.

142

- miflionis ab occipite, atque à par- tibus retro aures praftitx utilitas. 142 - quantum volunt, cucurbitulis occipiti, atque circum iplum politis particulis admotis cum fcarificatione, evacuant

143

niffio in capitis averfa parte fcarificatione præftita, quibus noxia. I 43 - miffio à naribus procurata pro arcano à multis $\mathbb{E g y p t i i s ~ c e l e b r a t u r . ~ i 7 x ~}$ è naribus miffionem folvere $x$ gtitu$\mathrm{F}-\mathrm{G}_{2}$ dinem. 


\section{N D E X.}

åinem.

104

- miffionem dolorem vehementem tollere.

Sanguinem expuentibus caput, \& pectus Egyptios inurere.

2 II

Sanguinis fluxum fiftere decoctum ex filiquarum Horibus, ac foliis acatia paratum.

Sanguinis Ægyprii muratio à quibus. 92

Sang Arabi gumma Arabica, quam ex arboribus acarix colligunt.

Sarbet potus.

305

123 potus pro omnibus febricitantibus.

Sadegendi eft folium.

267

S.spor caffix eft amarns.

300

304

- canell $x$.

304

S.alfa parilla raro Egypiii utuntur. 353

Saraceni cur utuniur aurium fearificatione.

Sarvich.

I 69

Sca:ificationum varii apud $\mathbb{E g y p t i o s ~ u f u s . ~}$

167

Scarificandi modus, figura, five exemplar.

198

Scarificatio màlleolorum five crurum vicaria eft venæ fectionis.

I 47

- malleolorum fettioni venz proxima, \& vicaria.

176

- vires non deftruit, five labefactat.

199

Scarificationes fenfim, ac lente fanguinem educunt.

183

Scarificatio malleolorum plenitudinem tol. iit.

174

- corpore non evacuato molienda.

190

Scarificationis ufum variant corpora, $x$ tas, fexus, habitus, \& remperics. 200 Scarificariones mon tantum vitalis facultatis evacuant, quantum venx fectio.

1.75

Searificarionem crurum Arahibus medicis antiquis haud cognitam fuiffe. 180 searificario non vehementes inf:re par.

tibus doiores. à Gal. quot in locis celebrata. 187

- crurum ab Amaro Lufitano mirum in modum celebratur.

I 79

- crurum, \& cucurbitule adnotx incifa cute maxime differunt.

184

Scarificatione crurum, quibus in Italize locis fir eductus fanguinis, 178 . \& cum felici fucceffu, 178. \& quo agrotanribus morbo, \& pueris.

178

Scarificationem crurum interdum effe præferendam venæ fectioni.

158

Scarificationes, que EEyptii pro ufu cu. curbitularum, moliuntur.

Scarificatas partes debilitari.

142

Scarificariones pro moliendis cucurbitulis, quor ${ }^{2}$ \& quales ab Ægypriis fian:

Scarificant Ægyptii non epidermidem modo, fed fecundam curim, non minufque carnem.

145

Scarificationes quales ab Ëgyptiis cucurbitularum ufu, \& quotæ infligantur. 142

Scarificationum numerus eft varius, nee not plagarun magnitudo, 196. \& varii cffectus.

197

Scarificariones lnngas, \& profundas effe, confonum eft rationi cum evacuare tentamus.

198.

Scarificatione rami venarum craffiores fecancur.

I 92

fon omnis fanguis evacuarur, fed: fubtilis, imprimis au em craffus. 190 - fanguis craffus evacuatur, \& quomodo intelligendx varix Galeni fententix.

191

Scarificare debemus non malleolorum, led cruris ventrem.

205

Scarificatio malleolorum quibus conveniat, 173. modus qui recitatur. 173 in ficcis vieuperatur. $20 \mathrm{I}$

Scarificatione cutis fepifina Agyptii mittunt fanguinem.

126

scarificarin narium in omuibus febribusacutis eft prafentaneum auxilium. -168

__ Eunuchis, mulieribus, \& omnibus. nolli carne proditis, credutur, vicaria 


\section{N D E X.}

effe venx fectionis, \& quibus corporis partibus.

167

Scarificatione crurum Egyptios curare febres peftilentes.

3,20

Scarificare folent EEgyptii aures nares, labia, gingivas. ac quafcunque partes corporis extrinfecas.

I 67

Scarificatio in ammatam partem, vel vexatam cancrena, vel tumore, vel puftula fanat.

167

- aurium apud Egyptios in puerilis lactanribus exercetur.

128

- narium ad quae fit utilis.

171 malleoli ad hydropicos tutinr. 220 genes voluit.

220

Scarificarione malleolorum. Egyptios mittere fanguinem.

Scarificatis auribus Egyprios moliri vacuationem fanguinis.

Scarificario crurum apud quofdam $\$$ gyptios in pefte infectis ufitata.

Scarificationis crurum in pefte infectis laus.

3.24

Scientix cur fere omnes ab Ægypto in alia loca commigraverint.

Scientiam Mahometis apud Egyptios in fummo pretio effe.

Scirrhos inuftione fanari.

Scythæ uftione utebantur:

215

Scythas à fanguine p'urimo à venis retro aures vacuato in profundum fomnum labi, atque fteriles evafiffe.

143

Scopus præcipuus ad prefervenda corpora à pefte.

Scopos duss ad prefervanda corpora à peftilentia Gal. docuir, quippe corpora ficcari, atque difflari.

77

Scorpinnes Egyptios effe lethaliffimos, quales Diofcorid". defcripfit.

Scorpionum Egyptiorum defcriptio. 3,09

Sectionem ad hydropicos, antiquis medicis connitam fuiffe.

219

Sectione hydropicos fanari.

$2 !$

Sectro hydropicis quo tempore convenia .
Sectio non eft in hydropicis viribus languidioribus adminiftranda. 220

Sectiones hydropicorum calfactorio medicamento effe fovendas. 221

Secandi hydropicos varii modi. 219 Seclionem pro Empyis inter ficundam ac rertiam coltam plerique $\mathbb{E} g y$ priorum: faciunt.

22 I

Scctio in fupparatis quomodo adminiftetur.

222

Sectionem ad fuppuratos inter tertiam \& quarram coltani fieri deberc quibufdam videtur.

222

Sectionis ufus ad fuppuratos ex Hippocrate.

222

Selica eft vera caffia lignea.

2,9

Selicas mulras habeut Fisyptii \& quz. 299 Selica ambra.

259

- Cenda; eft macer Diolcoridis. 299

- per excellentiam calfia vocatur. 2,9

Secreta ad febres quartanas ab AEgypris quiliufdam ufirata.

Secreium ad febres lynoclias.

315

Senectutem purgationes non recte ferre.

Senes difficiles ad purgantia effe $\begin{array}{ll}279 \\ 279\end{array}$

Semina, qux apud Ægyptios funt in ufu.

Seprentrionales venti, \& Nili fluminis incrementum aëren Ægypti refrigcrant. 26

Septentrionalium ventorum falubrem efie aëris conftitutionem.

Septentrionales ventos peftilentibus conAtrutionibus adverßari.

75

- venti in $\mathbb{E}$ Eypto plus alis perftant.

Seprentrionalibus ventis Egyptum expofitam efle voluit Deus.

Serapio de calamo aromarico. $\quad 297$

Sicca non purrefacere. . 65

- qux putrefcant. Cg $^{-}$ dum putrefc:nt, quam humidrexcellentiorem fufcipere putrelinem. 68 Sicomori quales fructus. 252 Solim atque hominem, hominen gene? rare:

$$
\text { E_G } 3
$$

Solne 


\section{N D E X.}

Sol femper agit calfaciendo.

88

Somuos inmoderatos inutione Egyprii carant.

211

Sonuia turbulena, qua efrata fuclant.

276

Sorbinones qux ad hecticos ab Fypiis parcuitur.

325

Stwlacem hortenfem editam tumultucifa foninia facere.

260

Spenzula \& ludi in Egypto augefcente Aumine Nilo celebrantur.

24

Somachum habent Egyptiifrigidum, pi-

iuirolum

32

Somachus durus, quid mali à vonitu :ecipixe.

240

Subachum $R$ :yptis cruditatibus vexari faisiliatimum efle.

57

Stomachus Eypui incolarum à guibus caufis figidior fiat.

Sicmachum balnea efficere frigidiorem, ac linguidiorcm.

238

- Languidiorem Egyprii à quibus ob. tineant.

238

S:omaclus ad ques morbos fi: innurendus.

212

frigidus, humidus, à diftilatione vexatus, ftatulentus uftione juvatur. 2 I 2

Stomachum opobalfamo juvari. $\quad 255$

Stibiun prxparatum curare antiquas vi. fcerum obftructiones.

281

Stoliditatem inuftione tollunt.

2 II

Strumas quomodo Ægyprii curent.

227

Strumx curantur fectione.

227

Studium Gernel-hazar Cayri.

Stuporem inuftione tolli.

Succus Acatix.

- acatia duplex, liquidus, \& ficcus.

306

306

Sudores quomodo Æygyptii tuendx fanitatis gratia, fequantur.

Sudandi ufum Ægyprios fequi. $\quad 240$

240 Sudores criticos in omnibus acutis effe bonos.

Sudant plurimum Egyptiorum corpora.

Sudorem in febribus peltilentibus, quo me- dicamento Egyptii movere foleant. 32 I

Sudores nonullus Ægyptios in febb. pefilentibus, cantaridibus etiam vol in port !nmptis, movere.

322

Supellcetilia omuia Cayti peftifero qualicumque contagio infecta, mente Junio, omne contagium, amittere, ut omnes iis tuto uri queant.

70

Suppurari, qui ex pleuritide fiant. $22 \mathrm{I}$

Suppuratorum notæ.

$22 r$

- inufione fanani.

$2 ! 7$

Suppurans quomodo inufio facienda fit.

Suppurari cuando mais utione, \& 217 217 do fectione curari debeant.

223

Sura quid, \& quo differat à malleolo. 204 .

Syncopis excuifira quid. 205

Synciput cur inurant $\$$ Egyptii.

283

Syrorum aique Græcorum corporum ha. bitus ac temperies.

Syrupi Egyptiis ufitatores qui.

- ex tandalis preparatio.

269
— ex ligno aloë, vires. dactylis quomodo ab Egyptiis paretur.

Syrupus folutivus qui ex granatis dulcibus paratur.

275

- ex mauna folvens.

275

T.

7 abefcentes ftatim uri oporrere. 220 Talvina. 267

Tamarindorum differentix, atque ufus. 274

Tamarindi Buzzi, quid.

274

Tamarindorum infufionis per potum ad febricitantes ufus.

Tamarindi recentes in India faccharo conditur, ad ulum illorum qui deferta Arabix loca peragrant.

275

Tamarindorum vis adverfus putredinem.

Tarachelacrap, id eft, theriacx ad 32 I pionum ictus compofitio. 


\section{N. D E X.}

Tectum balneorum Ægyptiorum quale.

228

Temperamentum variorum corporum nafcenium ratio.

87 totius à cordis heparifque temperie prodire.

84 narivum Ægyptii à victu permutanr.

93

Temperamenta atque habitus purgationibus apta.

179

Tempora, pro quibus morbis Aggprii nuratie.

2 I I inuruu: Egyptii ad oculorum \& capitis diftillationem, autium, arque den. tium.

2 II

Terrengibil provenit in montibus Syriai.

274

- puerorum medicamentum proprium. ufus ad curandas febres.

316

316

Têrra Ægypti quando fit apta cultui. 24

Terræ figillatx defcriprio. 305

Tercenta millia aureorum pro ftudio Gemel- hazar quoliber anno difipari.

Tertianas febres balneis dulcibus juvari. 248

Tertianis febribus correpros calida balnea quomo juvent.

249

Thaime quid.

232

Thaleris opinio de Nili fluminis augmento.

27

Thayr ferpentis defcriprio. 295. ex quorum carnibus paraniur ab Ëgyptiis paftilli.

295

ferpentem effe viperam cornutam.

ferpentem non effe ceraftem 295

Thebarum loca papavera nigra multa gignere.

261

Theologicx fcicntix, qux pfeudepropheta Mahometis leges tractat, multos $Æ$ gyptiorum operam dare.

Theophraftum deceptum fuille in cafix ${ }^{3}$ cognitione.

304

- recte fenfiffe de cinnamomo. 303 Terebenthina qua ad componendam the- riacam Egyptii utuntur, guid. 305

Theriaca compofitio apud Ægyptios. 264 Theriacam pro Turcarum Rege ab $\mathbb{E} g y$. priis annis fingulis componi. 288 Theriacx apud. Agyptios ufitate defcriptio, in quo ab ea, quam Andromachus Senior tradidit, differat. 294 Ægyptiorum defcriprioni deeft alphaltus, centaureum, Galbana, thlafpi, malabatrum, opponax. 294 Theriacam non fine errore componi ab Ægyptiis.

Theriacx compofitionem ingredientium fecundum Fyyprios numerus. $\quad 294$ Theriacam nunerum ingredientium, numero $a b$ Andromacho perdocto non convenire.

294

Theriacx Egyptiorum defcriptio qux medicamenta habeat, in Andromachi de. feriptione non inventa.

294

- quam Egyptii fucrant ann 1574 . compofituri, compofitionis deferipiio.

2

Theriacam ubi $F$ gyptii crmponunt. 288 Theriaca quo anni tempore ab Ægyptiis paretur.

288

Theriacam apud Egyprios efle in fre. quentrfimo ufu.

388

Theriacx compofitionem ingredientıum ex Andromacho numerus.

307

Theriacam à noftris parari fine multis ingredienribus, qux leviffino labore ab ipfis haberi poffent.

Theriacx ufus apud Egyprios.

308 307 - Egyprix vires a carnibus cornuta rum, earum ferarum augeri. 308

Theriaca quibus morbis conveniar. 300 Theriacx ufus ad peftem, apud $K$ gyptios eft pracipuus.

310

Theriacam pueris quoque exhiberi. 3 Io - calorem naturalem fovere, augere, \& cos, qui ipfam frequentant longxvos facere.

310

_ Egyptiorum effe antidotum infigne multis viribus præditum.

Theriacx Egypia vires.
308 308 The- 


\section{N D E X.}

Theriacam Egyptiam cruditatibus ventriculi fuccurrere.

Theruace ulus ad febres.

308

Theriaca ad forpionum iftus quam com ponunt Esypiii.

Tiuma 310 villa am vocant.

Tiphomania quid fit.

Iria principia concurrere ad corporum generationem.

Tricicum quando in Agypro fericur, \& maturefcit.

Tunorem in angina, in collo confpectum, effe bonum.

Tumores omnes, \& inflammationes arcet, \& minuit fcarificatio loco lxfo infliftx.

207

- 2 dematofos, \& firrhofos inuftione curaros.

218

- à pituitofis humoribus uftione fanari.

2.12

Turca nulier, qux hiftericas mulieres quibufdam feminibus minuriffmis purgat.

275

Turcarum Inmerio populns fubjectos, fcientiis nnn delectari.

2

Turcx à pefte fugam non arripiunt. 5 ?

Turcas fibi quali morte funt moriendi, efle prædeftinatum putant.

60

milites vini potationibus indulgere.

\section{V.}

T acuationes fub canem \& aute canem efte fugiendas.

238

Vacuationes multas in balneo eodem tempore ferre aliquem poffe.

Variolx peftilentes fingulis annis in AEgyto vagari.

50

Variolarum annis fingulis Cayrum invadentium caufx.

Venz fectio cur univerfalem vacuationem praftet.

148

- dorfi ac lumborum in cute fcarifi

car $x$ cur totum corpus non fic evacuent, ut facit crurum lcarificatio. fectione præftita fanguinis vacuatio

cur uon conciter obftructioues.

149

qux apud $\mathbb{E}$ gyptios in ufu funt, ad mitrendum fanguinem.

127

- quas fecan: profanguinis molienda vacuatione ad oculorum lippititudines.

127

Venam frontis fcindere Ægyptios adoculorum lippitudines.

127

Venas in quibus morbis fecent. 125

Ven $\boldsymbol{x}$ a noftris non ufitatx, qux apud AEgyptios funt in ufu.

125 fronris fectio, quos morbos juver. 128

Venam frontis maxim-s capitis dolores, ac inflamnationes juvare.

128

Venx temporum, arque magnorum angulorum oculorum feet $x$ quos morbos juvent.

128

Venarum intra ac poft aures fectarum urilitas.

128

Venas nafi, nariumque in quibus morbis Egyptii fecent.

128

Venarum nafi, frontifque lectione dolo. rem capiris juvari.

128

Venas labiorum, gingivarumque in quibus fecent malis.

129

Venarum fub lingua pofitarum fectione Egyptios uti.

Venx pro mittendo fanguine ufitatx apud Egyptios.

Venas jugulares ab \#gyptiis fecari. poplitis ab Ëgypriis fecari.

_._narium ab Elgyptiis fecari.

Venas frontis Ægyptios fecare.

- capitis, ut commodo fecent, quo. modo Egyptii recte apparere faciant.

132

Venam jugularium quomodo Egyptii fecent.

132 poplitis quomodo Agyptii fecent.

132

Venarum jugularium fectionis vel etiam ufum ÆEgyptios fequi.

Venis jugularibus fectis, qui morbi tollantur. 


\section{I $\quad \mathrm{N} \quad \mathrm{D} \quad \mathrm{E} \quad \mathrm{X}$}

Vetıa altera jugularium fecta, atque plurimo ex ipfa vacuaro fanguine mulcos fere plane fuffocatos ad vitam rediifle,

130

Venarum jugularium fectio, guos. morbos curet.

130

Venas magnorum angulorum oculorum difficuleer fecari, \& cum periculo futuræ fiftulx, à quibus etiam paucus fanguis exit.

130

- magnorum angulorum feetas non efficere fiftulam.

I3 I - poft aures fectas fterilitatem inducere Hippocratem præcepifle.

$13 \mathrm{I}$

- magnorum augulorum oculorum fectas plurimum fang!ninem concedere.

1.31

Venam magni anguli oculi fectam in Francifco Rigono plurimum fanguinem profufife.

$13 \mathrm{I}$

Venerı Egyptios nimium libere indulgere.

230

Venena calore preftantiora, ac auctiora fieri.

Venenum petere cor quanam figna explicent.

162

Venenorum efui homines afluefieri pofle.

255

Ventriculum opobalfamo maxime juvari.

25.5

Ventres hyme cur fint calidifimi, \& 2 tate frigidiflumi.

Vertiginofos inuftione fanari.

32

Venti, quibus Egyptus eventatur.

Ventis Septentrionalibus Egyptum plufa quam aliis effe expofitam. $\quad 25$

Venti Septentrionales quo tempore in $\mathbb{E}$ gypto fpirent.

Septentrionales cur aërem Ægypti refrigerent.

25

Ventos Septentrionales Etefias vocatos tota fecunda $x$ ftate ob ortu folis ufque ad occafum in Agypto perflare.

29

- campfim ab ÆEgyptiis vocatos facere primam xftatem.

22

Euros, Aultrofque facere primam xftatem in Egypto.

22

Venti Euri, Auftrique plurimas infiammatas arenas in Egyptum afportant 22 Ventorum campfim vocatorum variz opiniones.

23

Ventos Euros, Auftrofque interrupte in Egypto fpirare.

23

- Enros, atque Auftros miltas ophtalmias gignere.

Venri Charonii in Egypro qui. 23

Venis Euris, Auftrinilque in prima $x$ ftate flantibus fieri plures peftiferas febres, atque inflammationos.

Ventorum auftrinorum proprium effe humores ad capur fúbvehere.

54

Ver apud Egyptios quot menfibus conftet.

Veficx os fic dilatari, ut per ipfum lapides fatis magni exire queant

224

Veficantium ufus in pelte infectis.: 32.3 - ufus ad brachiorum, \& crurum pulfus pro febribus intermittettibus $a b \not{E}$ gyptiis frequentatus.

3.8

Victus, quo Egyptii ututur. $\quad 3.3$

- Agyptiorum qualis. I9

Victum frigidum frequentant $\mathbb{E g} g$ prii. I 9

Vigiliis, ac deliriis $\mathrm{fcarrificatio}$ intra nares commoda.

I 71

quibus medicamentis Egyprif occurravi.

3.15

Vigilias quibus auxiliis Egyptii curent.

Vinum quibus fit utilifimum.

316

modice fumptum nativum calorem auget, \& immodice, refrigerat. 42 - immodice fumptum morbos frigidos facere. 42

- aqua preftat ad corporum fanitatem.

Vini faculrates.

Vinum in pueris Gal. damnat.

45 45

Virgas balfami

Virgas balfami odorem ac faporem diu non retinere.

298

Vires in dyfenteria plurimum ex crebra $\mathrm{H} \longrightarrow \mathrm{I}$ 


\section{I. $\mathrm{N} D \mathrm{D} \mathrm{X}$.}

dejectione, dolore, vigilia refolvi. I I4 Virium robur plurimam habere partem ad indicandam fanguinis miftionem. 109

Viridariorum atque hortorum terram quotidie aqua nedum irrigari, fed mulcum inundari.

Vitam bominis qux confervent \& cor-

rumpant. beant.

Ulcerum ad pefte infectos ufus.

Ulcera inteftinorum non fanari nif 324 lantur ipforum caufe fanguinis miffione.

II 6.

- quancumque partem corporis obfidentia effaru digna uon curari nifi prxcedant vacuatio, atque purgatio. I 16

Ulceribus ad cicatricem non devenienti bus fcarificatio utilis.

207

Hlcera orca ex uftione articulorum fubmucidorum effe lanabilia.

Umbilici circumvolutio, qua ad dyfen. tericos Egyptii utuntur quomodo porfit uxui dy fenterico efle auxilio. 226 [3nguentis rectè nléntibus $\mathbf{E g y y}$ tii abundane.

Unguentorum recte olentium copiam incredibilem mulieres Ægypcias ad vulva ornarum. i.e. ad corrigendum fotorem diffipare.

241

Vomere quos juver, \& quibus officiat. Vomituum aliquando afitatorum utilitas. 240 237 ufú multos à podagra 8 aliis morbis fe tueri.

249

Vomitationes; quo medicamento proyo- cant Ægypcii.

239.

Vomere in balneo facilius homines poffe.

Urinæ, qux craffos humores abund 23,9 gnificant.

craflix cum craffis contentis, quid.

Ufus dulcium balneorum cur apud $Æ g y-$ ptios fit frequentifimus.

balneorum pracipuus qualis. 229

Ufurn refrigrerantium medicamentorum cur Ægyptii frequentent.

- leniter purgancium ubique plerique fequuntur.

278

Ufus pravalidiffimorum purgantium in quiburdam morbis laudaur. $28 \mathrm{r}$ Ufum inurendi partes corporis antiquis fuifle familiarem.

220

_ inurendi partes cur Arabes frequentent.

210

Ufus inurendi partes ad quos morbos uti. lis.

210

- vel leniter purgantium, vel valide purgantium in purgandis eorporibus uter fit melior.

Uierum opobalfamo juvari.

278

255

$\mathbf{X}$ :

T ilobalfamum verum Agyptios habere. Xilobalfami loco carpobalfamum effe ${ }^{298}$ tendum.

298.

Z.

2 arotus Médicus.

278

\section{E I: N I. S.}




\section{PROSPERI ALPINI}

D E
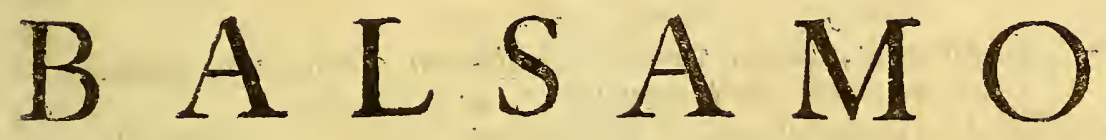

D I A L O G U S:

In quo veriffima Balfami Plantæ, Opobalfami, Carpobalfami, \& Xylobalfami co. gnitio, plerifque antiquorum atque jüniorum Medicorum occulta, nunc elucefcit. 


\section{N D E X C A P I T U M.}

\section{E B A L S A M O.}

CAP. I. Dalfami planta, Succo, Fructibus, Ë Virgis effe loquendum.

Pag. 8I

II. An Balfami planta, ejufque Juccus, fructus ac virge nunc reperiantur, ED in quibus locis proveniant. 84 III. Planta, que ab antiquis Arabia medicis Baleffan, da Gracis

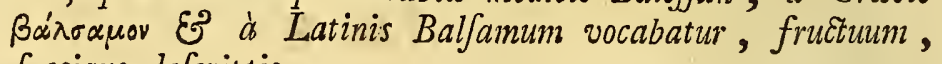
fuccique defcriptio.

94

- IV. Veri Opobalfanni cognitio unde fumatur. $\mathcal{E}^{2}$ qui ex antiquis verè bunc fuccum litteris prodiderint.

100

- V. De notis, quibus verum Opobalfamum d̀ non vero, fincerum ab adulterato tutd cognofcitur, ac difcernitur.

104 VI. Veri Carpobalfami, EO Xylobalfami cognitio, E confideratio. I I I VII. Cur Petri Bellonii objervationes in Agypto circa Balfami Plantam facte bic adnotate fint.

I 6 VIII. Agyptii Balfani- obfervatio ex Petro Bellonio in libro II. Itinerariarum Obfervationum, capite XXXIX. collecta.

\section{INDEX C A I T U M. \\ D.E RH P P O N T I C O.}

$\mathrm{C}_{\Lambda \mathrm{P}}$. I. Rhapontici planta, quam proximis annis in Rhodope Thracia monte vivere compertum eft, cur agendum fit. $\quad$ Pag. 125

- II. Rhaponticum quibus nominibus variis gentibus innotuerit, quidque ip. fum fuilfe conftet.

128

III. An hac atate verum Rhaponticum antiquorum ad nos convebatur, atque cognofcatur.

IV. Rbapontici planta an fuerit veteribus cognita, $E^{\circ}$ an bac atate alicubi vivat, छे qualis fit.

V. Plantam Rhapontici Thracicam, Lapathorum genere comprebendi, Eं quot fint ipfius $\int p e c i e s$.

I4I

- VI. Que inter radices Hippolapathorum, ad Rhei radices, quibus antiqui ad medicina ufum utebantur, proxime accedant, $i l-$ larumque loco à noftra atatis Medicis ufurpari polfint. 144 VII. De Rhapontici, Eे Hippolapatbi longifolii viribus atque utilitatibus in medendo cognitis. 
ILLUSTRISSIMIS AC SAPIENTISSIMIS

$S E N A T O R I B U S$

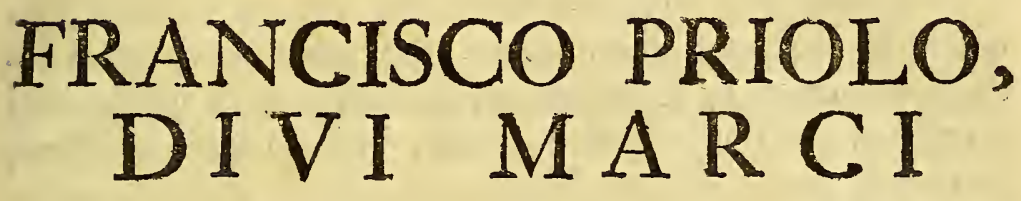

PROCURATORI,

Zacbarice Contareno,

A C

\section{LEONARDO DONATO \\ E QU I T I}

\& Divi Marci Procuratori,

Patavine Academia Curatoribus,

PROSPER ALPINUS S. D.

antæ laudis Senatores Illuftriffimi, Balfa.

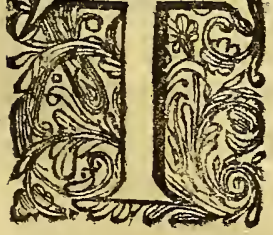
mi plantam apud antiquos junioreqque medicos fuiffe legimus, ut ejus oleum, feu fuccus, (quem opobalfamum Græci appellant) in toto terrarum orbe, ut divinum quoddam auxilium habitus atque celebratus fuerit. Vulgus etiam rem aliquam vehementer ad fanitatem accommodatam, 
balfamum vocare folet. Et quidem nihil in univerfa fimplicium medicamentorum fylva preftantius, \& dignius inveniri proditum eft : neque id hercle immeritò. Quibus enim in arte medendi verfatis ad ulcera, vulneraque fananda illius virtus eft ignota? quantum lethalibus venenis, fcorpionumque ictibus, \& viperarum morlibus obfiftat? Quibus etiam hujus fucci nobilitas, in pefte, peftiferifque febribus arcendis mira efficacia eft occulta? quandoquidem regum corpora eo olim imputria fervari multorum teftimonio conftet; non ne putridæ febres fæpe funt hoc ademptæ præfidio? Quid? non ne ex balfamo hominis corpus à cute ad vifcera ufque juvari experientia docuit? Mulieres eo fibi illitam faciem pulcherrimam efficiunt, obortafque in cute rugas abigunt. Atque hinc juventutem diu fervari vulgatifimum eft. Et ut paucis rem colligam, ac perftringam, caput, ftomachum, hepar, lienem, mefentereum, pulmones, renes, veficam, uterum, fpinam, nervos, mufculos, articulofque omnes plurimum juvat. Etenim obortam oculorum caliginem abftergit, vifum-que vitiatum, vel deperditum reftituit; aures dolentes, $\&$ in ipfis tinnitum fanat. Præterea convulfis, epilepticis, vertiginofis, refolutis, atque trementibus mirum in modum prodeft: tum refpirandi difficultati, tuffi, orthopnoeæ, pulmonum frigiditatibus, fluxionibus, $\&$ doloribus fubvenit. Stomachi calorem valde fovet, auget, atque roborat, \& idcirco ejus cruditatibus, ac flatibus à diminuto calore excitatis, præfentaneum eft auxilium. Meferaicarum vero à jecore, ac liene venarum obftructiones aufert, regiumque morbum curat. Interceptam fæpe urinam provocat, calculofque walenter frangit, \& ipfos à renibus abftergit, atque per 


\section{D. $E$ D 1 C $A$ I I O}

urinam expcllit. Uterum magis, quàm cæterá membra refpicit; atque omnibus ejus à frigiditate obortis malis præftantiffime fuccurrit ; Menfes ciet, partus, fecundafque educit, præfocationibus, \& flatibus tutò medetur. Et quod non minus a mültis defiderari, atque expeti folet, foeminam iifdem ex caufis effectam fterilem, foecundam reddit. Cumque tam eximix balfami dotes exiftant, $a b$ antiquis etiam præclariffimis medicis olim memoriæ traditæ, mirum non eft tantopere Romanis Imperatoribús Vefpáfianis caram eam arborem extitifle, ejufque caufa ab ipfis cum Judæis aliquando dimicatum fuiffe. Maximum ufum in medicina habuiffe fuccum, fruetus, ac ligna, apud omnes liquido conftat. Perficit enim multorum antidotorum compofitiones, præfertimque Theriacam, atque Mithridatium, quæ a noftriś, eó fublato, non fine artis dedecore parantur. Cum hæc aliquando hic inveniri poffe ignorent, audaciffiméque, oblatum fæpe ipfis hujus arboris verum fuccum, fructus \& ligna, vera effe negent; non poffum ego nón multum præfentem balfami calamitaten cum hujjufce temporis niedicis dolete; cùm, etfi in multa Italiæ loca ex $\mathbb{E}$ gypto ac Syria hujusce plantæ fuccus, früetùs, lignaque nunc verè comportentur, hæc tamen agnofcere noftri medici renuant; quinimo plerique affirment hoc tempore veram balfami plantan nuffuan gentium inveniri, minineque ejus fuccum, fruêus, \& virgas (quảe opóbalfarnum carpobalfamum; \& xilobalsanuim Grâci appellant) ad nos veras comportari- Atque horum alii afferunt fieri quidem non poffe, ut véri opobalfarni fatis, cujus quantitas non pauca fæpe in his locis circumfertur, inveniatur, cun Egyptus, ac Syria-balfami plantis om- 
nium confenfu nunc careant; quando etiam prifcis faculis ex tota Fgypto multis indem plantis referta, modicum quippiam illiufce liquoris haberetur. Alii ex Felici A rabia huc illum delatum fcientes, fincerum efre opobalfamum negant, afferentes folam Egyptum, ac Syriam illum olim habuife, neque alibi in enium plantarum fcriptores prodidife. Hifque rationibus perfuafum eft eis, fincerum opobalfamum his temporibus non reperiri, quod fi aliquando fibi à quiburdam ex $\mathbb{E g y p}$ to, vel Syria venientibus offeratur, eos irridentes, negant verum effe, atque à fe rejiciunt, $\&$ in in parandis Theriaca, Michridatio, \& aliis nobilifimis compofitis, eo haudquaquam uti volunt. Quod ego cum mea quidem fententia peffime, ac non fine artis magno dedecore ab iis factum judicaverim, cumque ad nos legitimum fuccum arboris, quæ à prifcis herbariis balfamus appellata eft, ligna arque fructus ex pluribus locis adportari certò fciam, non potui non fummopere iftorum ignorantiam, ac errorem fummum admirari, \& hujus eos erroris adductis rationibus redarguere, cum præiertim medicos omnes ZEgyptios, Arabes, \& Syros eundem fuccum, fructufque eofdem, atque eadem ligna uno omnium confenfu', citra ullam contradictionem, vel hæefitationem in componenda Theriaca, Mithridatio, aliifque nobilibus antidotis, commendare, atque arripere cognoverim; qui alium nunquam fuiffe opobalfamum, neque alias fructus, aut alia ligna ad medicinæ ufum recepta, atque apud illos uitata affirmant. An verò quis AEgyptiis, Syris, \& Arabibus in corundem. medicamentorum cognitione, uiu, \& experientia præferendos contendet Italos noltros? qui neque locum, in quo arbufculum vixerit, neque alibi illum vivere infpe- 
xerint? an potius illis credendum erit ; qui in codem loco cum iftac planta multos annos vixêre, \& jllam fæpe færiustum viderunt, rum fedulo obfervarunt? Quando etiam primi Baleffam plantam eam nominarint. Quo nomine alii omnes \& Graci \& Latini libentiffme ufi funt. Cum igitur illi Italis, cæterique omnibus nationibus in hujuice plantæ, fucci, fructuum, \& virgasum cognitione jure præferantur, atque hæc vera ab ipfis credantur; \& pro legirimis, ac veris ad omnia componenda medicamenta utantur, fuccumque ex $\mathbb{E}$ gypto, vel Syria huc advectum, nobifque interdum oblatum, verum opobalfamum effe affirment: Cui $\&$ nos iifdem uti, atque in medicinæ ufum eadem recipere recufemus, potius quam aliud pro ipfis ad componenda medicamenta fubftituere? hincque multi mirari non debent, fi Theriaca, Mithridatiumque hujufce temporis antiquam amplius illam præftantiam, ac nobilitatem non retineant, neque eximiæ illæ vires a feniore Andromacho decantatæ conferventur,

\section{Hac fidens aftu per rura vagabere Cefar, In Lybico quamvis progrediare Jolo.}

Quis enim medicorum erit, qui à viperis, gyptiifque cum afpidibus, tum fcorpionibus, vel ab aliis hujusmodi ferpentibus demorfos fola Theriaca, vel Michridatio curare hac atate confidat? vel horum fpe aconitum, vel napellum, vel toxicuís innoxiè affumere audear? Unde eft, quod Theriaca vel à nottris omni cura, ac diligentia confecta magnis illis careat omnino dotibus? Nifi quia antidotus hæc multa defidera: ingredientia, quibus antiquis illis temporibus parabatur. Inter quæ K 3

prin- 
principem fanè locum obtinent opobalfamum, carpobalfamum, atque xilobalfamum, quorum loco noftri pharmacopolæ alia medicamenta fubftituunt. Quamobrem multi Ægyptiacam Theriacam longe præftantiorem prædicant, quod vera, ac recentia nuper dicta medicamenta in ejus compofitione recipiantur. Id igitur ego, cum in AEgypto aliquot annos medicinæ caufa moratus, animadvertiffem vereque cognoviffem, vera illa medicamenta ad nos ex iis locis non raro adportari, quæ à noltris non fine componendorum medicamentorum ingenti jactura ab ufu medicinæ rejiciuntur, falfaque vel adulterata effe dicuntur, decrevi veritatis cognofcendæ ftudio, de balfami planta, fuc$\mathrm{co}$, fructibus, \& virgis, quæ funt ad medicinæ ufum ì veteribus medicis litteris tradita, atque nunc apud noftros fere obfoleta, librum olim in Egypto confcriptum, quo omnium iftorum cognitio comprehenditur, vobis Illuftriffimis, ac Sapientiffimis viris legendum ac fpectandum dicare? Ex quo, balfami veritate perfpecta ac cognita, operam detis, ut hæc præclara medicamenta, veftra omnium opera, ac auctoritate $a b$ omnibus medicinæ amatoribus dignofcantur, atque in priftinum medicinæ ufum revocentur: Anno falutis humanx M. D XCL. 


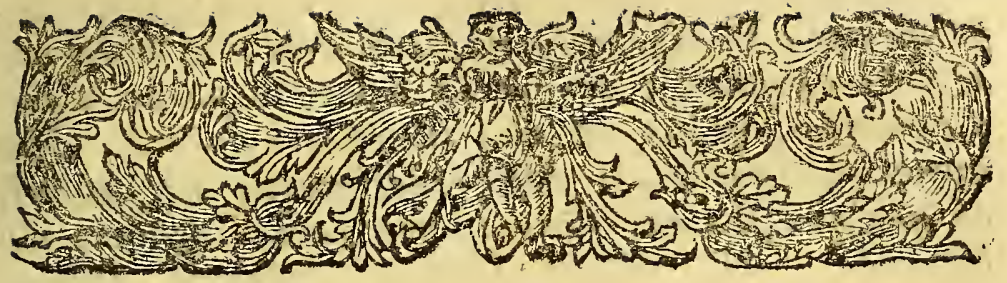

\section{PROSPER ALPINUS}

\section{A D}
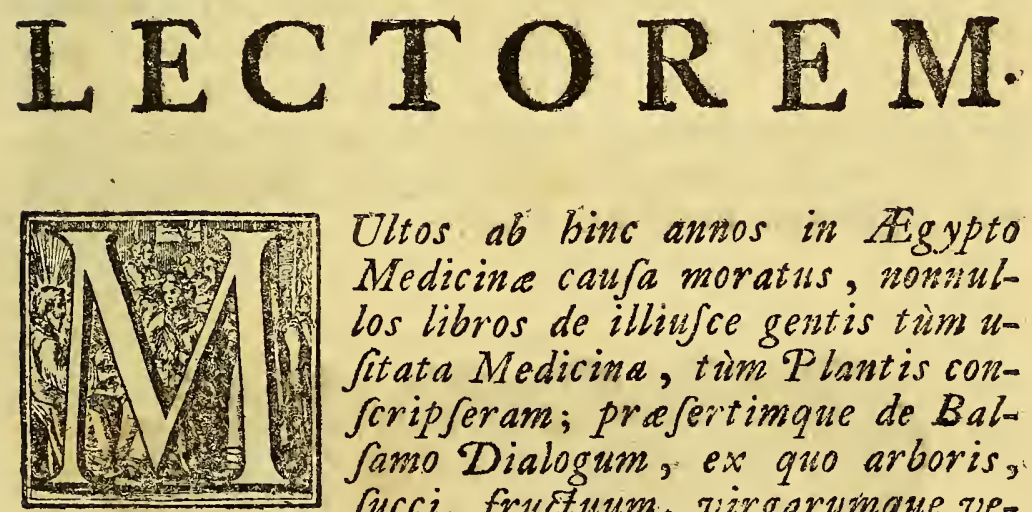

Ultos ab binc annos in Bigypto Medicince caufa moratus, nownullos libros de illiufce gentis tim $u$ fitata Medicine, tim $P$ lantis confripseram; prefertimque de Balfamo Dialogum, ex quo arboris, fucci, fructuum, virgarumque veritas bactenus plerifque Medicis, E़ Pharmacopolis obfcura, cognofceretur, claraque elucefceret. Quos omnes fane libros fimul in lucem prodere cogitabam. At bortatu quorundam amicorum, qui me aliorum librorum editionem non it a brevi: tem. pore publicaturum putarent, fententiam mutavi, maximeque nonnullis doctifjemis Pharmacopolis obnixè fuadentibus, qui Theriacam, Mitbridatiumque nunc paraturi, ab Excellentifimo bujus incly- 
te urbis Medicorum Collegio veri Opobalfami, Carpobalfami, \& Xyloballami veritatem, \&5 bifioriam agnofci exoptant, ut bis ad predicta paranda medicamenta, atque ad alia liberè uti popent. Non immerito Theriacam Mitbridatiumque bis ablatis $a b$ antiqua fua excellentia, won parune deficere dubitanies. Ne itaque ifrorum defiderio obfequi nolle videar, libellum bunc prius emittere non fum veritus. Hancque hujus celeris editionis caufam Candide lector veram effe putato. Interim libros alios de Medicina Egyptiorurn vocatos ( $f$ modo bunc meum libellum Medicine fudiofis aliquo pacto arrifffe intellexero) propediem in lucem venturos. expectabis. Iuque etiam quo animo ego Balfami difputationem banc, veritatis tantum agnoscende fudio, atque juvandi defiderio sum projecutus, todem legendam accipies. Viale.

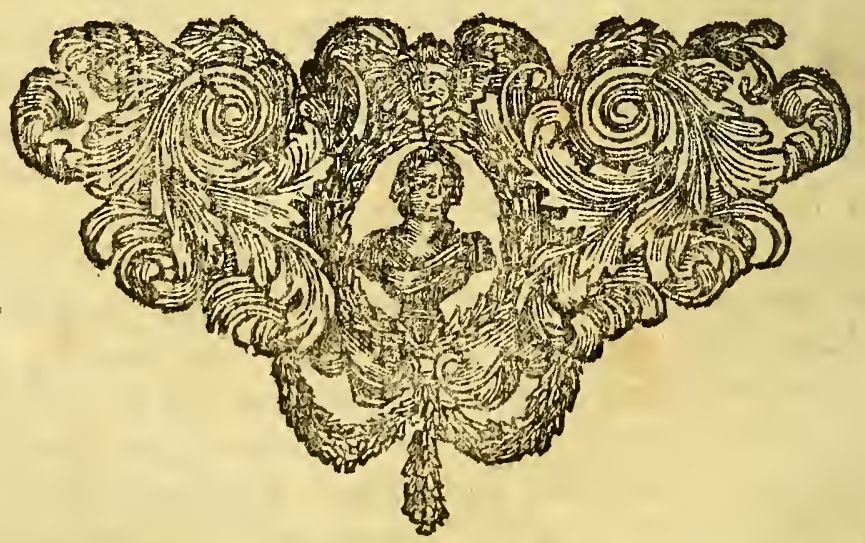

P R O. 


\section{PROSPERI ALPINI}

D E

\section{B A L S A M O D I A L O GUS。 C A P V T I.}

De Balfami planta, Succo, Fructibus, \& Virgis effe loquendum.

\section{ABDELLA Medicus Egyptius, ABDACHIM Hebræus, \& ALPINUS Italus.}

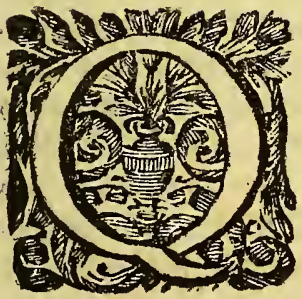

Uem ego nunc hominem confpicio per hoc viridarium el Mattharia greffus moventem; is certè meis oculis Abdachim Medicus videtur, vir honeftiffimis moribus (quamvis Hebræus) preditus, mihique multum familiaris: eum igitur conveniam, \& falutabo. Salve Abdachim, Quàm diluculò hoc viridarium es ingreffus; Quid tibi verò negotii eft, ut tàm fummo mane huic te recipias. $\mathrm{ABDACH}$. Te nunc huc conveniffe, valdè lator, quando jam dì̀ te exoptaverim videre, ac tecum colloqui, Tibi optata hæc fit dies, Ego ut viridarii hujus amœnitate, fuavifimoque florum cafiarum odore, auraque matutina frigidiufcula me aliquantulum recrearem, huc accefferam. ABDEL. Cur verò viridarii iftius plantas undique obfervas, neque te humi ftratum fub ficus hujus Egyptix latifimis ramis confpicio, ut quietiis ita tùm animum, tùm etiam corpus recreares ? ABDACH. Oculos hinc inde dimovebam, fi aliquam Balfami plantam viventem potuiffem infpicere, cujus odoris eximio olfactu animales fpiritus delectaffem, quas cuftodum negligentia exaruif- 


\section{PROSPERI A L P I I}

fe comperi, quod fatis ægrè patior, plurimumque me tædet hoc viridarium illis nunc carere plantis, multumque ornamenti hac de caufa hic deeffe videtur. ABDEL. Ne te ob id excrucies, quandoquidem fæpè aliàs aliundè adportatæa, atque hic inde infertæ plantæ perierint, quæ nunc fortaffe, aliis adhùc juffu prrefecti advectis, citò renovabuntur, ut frepè aliàs factum eft. Sed quem video ad nos venientem; $\Lambda$ n $\Lambda$ lpinus Veneti Confulis Medicus? ABDACH. Ipre eft, cui nos obviam ire honeftum eft, quòd humanus hic fanè vir. eft, atque affabilis. ABDEL. Quid iftud eft Alpine, quod nos te hic nune offendimus? tuus adventus pluribus de caufis eft nobis jucundiffimus. ALPIN. Viridarium hoc fpectandi gratia hue me contuli, vobifque pro veftra erga me humanitate, plurimum debeo, neque parim gaudeo, quod ambos vos hic offenderim, jam diu enim vos videre defiderabam, nec immeritò, cüm vos pluribus nominibus tantopere obfervem. Neque eft quod veftram ego nunc in arte medica doctrinam coram extollam, neque quantum à vobis in ea profecerim, vel didicerim. ABDEL. Bonus es cùm hæc exiltimas, utcumque res fe habeat, à te amari nos fummoperè expetimus. ALPIN. Gratias habeo, fed timeo ne importuno meo adventu jam cxptos veftros fermones interturbem : eorum tamen, \& veftræ jucundiffimæ confuetudinis fi fieri particeps mihi liceret, mirum in modum meus hic adventus mihi voluptati foret. ABDEL. Gratifimum nobis erit, nunc tecum vir doctifime colloqui, à quo pro tua doctina plurimum noftros fermones claritatis recepturos fperabimus. ALPIN. Vobis gratiam habeo. Quid iftud autem elt, de quo fermonem infitueratis? ABDACH. De Balfami planta, quam in hoc viridario aruiffe comperi, inter nos commentabamur. Cujus jacturam mihi $x$ grè ferenti Abdella nofter in plantarum materia exercitatiffi. mus, animum reftituit, multas è Mecha olim etiam pluries delatas huc, infitafque fuiffe, \& planè revixiffe narrans, atque etiam hoc modo fæpè Balfami plantas renovatas fuiffe, ut fperandum fit, nunc etiam præfecti Atgypti juffu, ubi ad illius aures harum jactura aliquandò pervenerit, denuò inftau- 


\section{DE BALSAMO DIALOGUS.}

rari poffe. ALPIN. Quid audio? illas plantas huc aliunde fuiffe adportatas, eoque modo perpetuo inftauratas? quafi Kgyptus illis proprium folum non fuerit; non in fermonem inanem fpero me nunc incidiffe, de Balfamo incretum: de quo 'non panca vobifcum loqui jam diù defideravi, qux fi vobis nunc grata fore putares, libenter proponerem. ABDEL. Gratam nobis rem facies fi hac de re diffutationem aliquam promoveris: ex qua plurimum emolumenti pro tua doctrina, atque humanitate nos effe confecuturos fperamus, proinde quicquid eft, quod à nobis fcire velis, nunc in medium profer. ALP. Multum vobis pro hac re debeo, veterumque $A$ Egyptiorum fapientiam \& humanitatem agnofco. Verum ne longiùs verbis rem producam, de Balfami planta, fucco, fructibus, lignis nunc vobifcum difputare defidero, quando ego hactenus Scriptorum varietate anceps, ac dubius fuerim. $A B D A C H$. Neminem Fgyptiorum, vel Arabum cffe nunc arbitror noftro Abdella in re plantaria magis verfatum: pluribus iifdem plantis $\mathrm{ab}$ eo cùm hic, tùm alibi infpectis, ac omni ftudio obfervatis, fed ut de hac re clarius differamus, in capita redigere te oportet, de quibus fit figillatim differendum. Quare iffæc om-nia nunc in medium profer. ALPIN. Dicendum à vobis primò cenfeo, an Balfami planta hoc tempore alicubi vivat, quando in hoc viridario, in quo hactenus à prifcis illis temporibus ufque adhuc vixit, planè exaruerit; atque non minus, an $a b$ ea collectus fuccus, fructus, lignaque ad nos perferantur, vel potilis unà cum arbore cuncta perierint. Hæc in primis à vobis enarrari mihi cupio, quibus cognitis, figillatim de fingulis agemus. 


\section{A P U T II.}

An Balfami planta, ejufque fuccus, fructus ac virge nunc reperiantur, Eु in quibis locis. proveniant.

ABDEL. Uamplures Balfami arbores in multis Arabix locis nunc vivere, quarum fuccus, fructus, ac virgx hùc ad nos à multis adportantur, certifímum eft. Neque id Egyptios, Syros, Turcas, \& aliarum nationum homines mul tos, Arabix loca peragrantes latet, quinimmò omnes annis fingulis Mecham, \& Medinam primarias Arabiæ Felicis urbes, peregrinationis gratia adeuntes, quantus in illis locis fit ex arbore Balfami proventus, planè fateri poffunt. Nam Mecham hinc euntibus, \& ad villam quandam Bedrunia ab his vocatam, qux diftat ab urbe Cairi fpatio dierum quindecim, accedentibus, mons pergrandis, arenofus., propè eam villam pofitus continuò confpicitur, Balfami innumeris arbufculis refertus, quas. ibi Mahemetis miraculo ortas noltrorum multis perfuafum eft; Sed utcumque ibi natæ fuerint, nobis id fufficiet, omnes ea loca quotannis peragrantes, innumeras ibi vivere comperiffe ; idque à quamplurimis hujusfce urbis incolis, qui olim, ex proximo etiam elapfo anno ea loca. peragrarunt, audire, atque verum effe fcire poteris. Multis quoque rationibus hxc veritas tibi à me perfuaderi poffet, fed fi hujus veridarii Balfamis olim multis refertifimi terram. aliquandò olfeceris, Balfami etiam nunc fuavifimum odorem redolere fenties, bifque, vel ter tantum, Sol fuum peragravit orbem, poftquam hæ plantæ cuftodum negligentia periêre. At quid taces Abdachim, quem millies hic te illas inipexiffe certo fcio? vel cur me Italo Medico incredulo veritatem hanc fuadentem minimè adjuvas? ABDACH. Quid? An hunc noftrum fodalem medicum, multos annos hic moratum, plantarumque omnium ftudiofum, hanc veritatem ignoraffe dubitas, 


\section{DE BALSAMO DTALOGUS.}

bitas? Ego certè Balfami plantas innumeras diverfis temporibus ex Arabia advectas, hicque infitas vixiffe, certo fcio, quas multi etiam alii Cairi incolx infpexerunt. ALPIN. Nefas effe, ac inurbanum putarim, tantorum medicorum teftimonio non moveri, qui præter herbarum peritiam, in qua illuftres apud plerofque Æegyptios habiti funt, una cum Balfamo in eadem terra nati, vixerunt. Sed, ut ingenuè $f a-$ tear, quamquam ego eum viris in medicina clariffimis planè fentiam, hujusque rei veritatem omnino cognofcam, tamen hæc veritas non adeò ufquequaque mihi fatiffacit, ut poffim aliis permultis Italix; aliorumque Europæ locorum medicis, atque Pharmacopolis incredulis hoc, ut cuperem, perfuadere; qui abfolutè affirmant, Balfami plantam nullibi hoc tempore reperiri, eamque planè periifle, ex quo fuccum, fructus, \& virgas hinc in Italiam apportatas falfas etiam effe ftatuunt. Atque prifcis freculis, cum Balfamum tantum in Aigypto \&. Iudæa vixiffe, Diofcorides ac alii prodiderint, quibus in locis nunc eam plantam cum amplius vivere nemo referat, planè omnibus in locis periiffe colligunt. Cuam fententiam ipfi pervicacifimè defendunt, neque omnino carere videntur argumentis, quibus proprimm errorem tueantur. ABDEL. Quomodo quæfo iftud effe poteft; tantos ne medicos, doctifimosque herbarum profeffores ita obcrcatos effe, qui non viderint, neque cognoverint, Balfami plantas neutiquam in fuo nativo folo periiffe? Quod autem Egyptium, ac Iudaicum falfo Diofcorides, atque alii crediderint, ex me paulo polt cognofces. Neque optimi illi funt Philofophi, qui ita facilè vegetabilium f́pecies, quæ juxta Philofophorum placita perpetuæ exiftunt, tolli omninò poffe, putent: Cælo etenim nullis caufis ad generationem facientibus nunc deftituto, terraque ac cxteris aliis elementis eodem modo nunc, ut olim, fe habentibus, cur terram eafdem nunc ferre plantas, ut olim faciebat, non poffe dicemus? Grave tibi non fit, quæfo, illos, qui Balfamum periiffe affirmant, mihi referre, \& quibus etiam rationibus in tàm falfam opinionem venerint, explicare, ALPIN, Parum interefle arbitror, te hofce hofce $\mathrm{L}_{3}$ ho. 
homines nominatim cognofeere, fed ipforum potius rationes audire, quibus negant hoc tempore Balfami arbores, atque ipfarum fuccum, fructus, \& virgas apud nos inveniri; id verò inceptæ disputationi fat erit. Horum fiquidem non pauci exiltunt, qui non modo ad nos in Italiam prædicta vera comportarinegent, fed ar. bores quoque, è quibus illa colliguntur, prorfus periiffe prædicent. Quam fententiam valdè auxêre Amatus Lufitanus Medicus in aliis non fpernendus, \& Nicolaus Monardus Hispanus, qui Syriacum atque AEgyptiacum Balfamum periifle aftirmantes, aliud genus Balfami in Occidentalibus Indiis nafci, prodiderunt: Baliamumque à Diofcoride, Theophrafto, Plinio, ac a multis aliis herbarum antiquis fcriptoribus celebratum, ac defcriptum, eò affirmant periiffe, quod prædictorum antiquorum Scriptorum teftimonio conftet, olim duobus tantum Judææ viridariis conceffum fuife, ut inter cæteros Plin. \& Theoph. teftantur, poftea verò quàm Judea à Ptolæmeo Primo, Rege Egypti, ac à Vefpafiano devaftata elt, Balfamum in vallem Hiericum appellatam tranfplantatum fuiffe, ibique vixifle Iuftino, Strabone, Solinoque Polyhifthore id affirmantibus, ftatuunt. Et ab Artaxerxe, Perfarum rege, primo, ac mox à Romanis Adriano Cafare rurfum tota ea regione bello everfa, prorfus Balfami plantan periiffe. Tandemque in Fgypto paucas hoc in viridario adfervatas vixiffe. Quo in loco non tantum prifcis feculis Balfamum vixit, fed multo etiam poltea, quafi ad hæc ufque tempora plantam hanc hic confervatam fuiffe afferunt. Nunc verò, à multis, qui hoc tempore Egyptum peragrarunt, hic quoque demùm eam aruiffe, confirmatur. Qua hic extincta, cum Diofcorides, aliique in Judxa tantum, \& Esypto Balfamum vixiffe prodiderint, cui dubium erit, nufquam gentium eam amplius inveniri poffe? Ex quo fuccum, fructus, virgas, pro vero Opobalfamo, Carpobalfamo, \& Xylobalfamo, ab Aigypto, vel Syria in Italiam adportata, vera efre quo pacto affirmabimus? Merito igitur hæc omnia falfa nos affirmafle videmur. Hincque tanta incredulitas, ac perinacia invafit eorum animos, ut potius in erroribus perfeverare, veraque fibi ipfis oblata rejicere, quàm 
quàm opinionem mutare velint. ABDEL. Vix me continre potui, quin fufceptum tuum fermonem interrumperem, ufque adeò animum adverfus illos concitalti meum, nullis rationibus, fed meris nugis Balfami omnes plantas periife, Opobalfamumque etiam, Carpobalfamum, \& Xylobalfamum apud nos inventum falfum effe afserentes, ut tanta illorum impudentia excitus, quafi quid loquar nefciam ac ne differam illis refpondere, dico, ac edico tibi, Balfami frutices neque etiam in Egypto planè periiffe dici poffe, quando frè juffu præfeeci Cairi, quem Baffa appellant, plantre multæ ex Felici Arabia delatæ in ilto viridario inferantur. Et nunc vix tertius agitur annus, cum Mefinoris, per id temporis Esgypti præfecti, jufiu, quadraginta è Mecha advectæ, hic infertæ fuerunt; quæ tamen cum per annum vixerint, rurfum cultodum negligentia perierint; quæe facilè etiam denuò renovari poffunt. In Arabiæ verò multis locis innumeræ propemodum magno cum illiufce gentis lucro, aluntur: neque fatis diu eft, quòd apud Arabes utilitas, \& lucrum hoc cognofcitur; etenim Opobalfami quantitas multa in Orientis loca comportatur, quibus in locis eum fuccum in fummo pretio effe, multi ex Arabibus, nunc Cairum habitantibus, narrant. Cujus fucci lucro ab iis cognito omnes certatim multos Balfami frutices ex arenofis, montuofifque locis in morbida viridaria transferre conantur. Quamobrem ibi innumera pulcherrima balfameta cernuntur. Lege tamen is populis interdictum elt, ne præter fifcum quis eam plantam ferere queat; neque fuccum, vel flores, vel ramulos, vel fructus fine publico mandato quis capiat. Idemque ibi de Balfami arboribus, atque hic de cafliis folutivis accidit. Solet etenim hic alicui caffiarum negotium locari, \& ideò non licet quemquam caffiam ex arbore capere, vendere, emere, aut emptam aliquo deferre. Quod itidem de Balfamo in Arabia locis obfervari, ex Arabum relatione planè conltat. At quid illi Egyptiarum ac Arabicarum plantarum ignari herbarii dicent, duobus ne tantum locis, quippè Egypto ac Syriæ Balfamum olim (Diofcoride, Theophrafto , Plinio, Juftinoque id docentibus) conceffum fuiffe? quafi aliorum antiquorum fcriptorum tefti. - 
teftimonio non conftet, in pluribus aliis etiam locis olim hajusmodi plantam vixiffe: nonne Diodorus Siculus 2. Hiltoriarum libro, in quadam Valle Arabix Balfamum nafci, \& non alibi memoriæ prodidit? Conftantinus verò lib. de Gradib ait, nafci in India; $\&$ Jofephus etiam in lib. 8. de Antiq Judaicis, Sabam Reginam Balfami plantam ex Arabia in Judeam tuliffe, Salomonique eam dono dedife, ex qua ibi alix pofteà plantæ propagatæ fuêre: \& Strabo in lib. fuæ Geograph. 16. hæc fcriplit: क His proxima elt felicifima Sabeorum terra, qux maxima na"tio elt. Apud hos Thus, \& Myrrha, \& Cinnamomum nalci"tur, in ora etian Balfamum, \& alia quedam herbula valde 0 . ", dorata: Necnon \& Paufanias idem in lib. 9. his verbis confir. mavit, dicens : "De viperis vero iis, quæ in Arabia inter Balfa„, mi arbores verfantur, diverfum quiddam accepi. Id hujufno. "di eft. Sunt Balfami arbores ea, qua mirti, ftirpis magnitus "dine. Folia illis, qualia herbx amaraco." Theophraftus verò in Afia etiam nafci prodidit, Incolæ quoque Bafiliani montis Libani, olim, Alexi Græcis imperante, in quodam loco illius montis Solis ortui expofito Balfami plantas non paucas, ̀̀ quibus tantum Opobalfami fufcipiebatur, quantum in Egypto hic colligi confuetum fuerat, diù vixiffe narranț. Ex quibus certe fciri poceft, olim non folum FEgytum ac Judrum, fed etiam Felicem Arabiam, \& alia loca Balfamum aluiffe atque habuifle. Qux veritas etiam ex ipfomet Diofcoride confirmari videtur, fcribente; Corpobalfamum, id eft Balfami fructus, fuo tempore adulterari feminibus hyperici timilibus, ex Petra oppido delatis; ex quo certo colligitur Balfami plantam alibi quàm in AEgyto vivere, atque femina producere. Præterea verum quoque hoc effe ex me audies, non in AEgptum ex Judxa, lit aliqui fomniarunt, ipfum veniffe, fed ex Felici Arabia femper fuife delatum: EEgyptiumque folum veluti neque Judaicum, unquam proprium, ac nativum ei fuisfe. In his locis Balfamum perpetuò peregrinam plantam extitiffe haud leve indicium eft, eam ubique viridaria tantum aluife, in ipfifque tantum vixiffe, ut Theophraltus, Plinius, Strabo, ac Solinus meminerunt. Plinius enim hoc hife verbis fignifica- 


\section{DE BALSAMO DIALOGUS}

ficavit, dicens: ,Sed omnibus odoribus prafertur Balfamum, uhi

')

93

,

Syrix provenit. Ejus arbulta duo tantum affirmant, alterum
viginti jugerum, alterum multo minus., Et Strabo de Balfamo "yiginti jugerum, alterum multo minus., Et Strabo de Balfamo 99

\& Baffami viridarium, qua arbor aromatica eft, \& fruticofa,

Cytifo \& Terebintho perlínilis. „, Quid ? nonne omnes obler"vant plantas peregrinas in viridariis tantum ali, ac cultodiri, quxedam verò ex patriis tametfi etiam in viridariis aliquando ferventur, nihilominus multa alia loca inculta, fylveftriaque iifdem fpontè natis non carere obfervantur ? At peregrine in viridariis tantum magno ftudio, ac diligentia aluntar \& confervantur; quod incultis, fylveftribufque locis fponte nafei, neutiquam confipici folent. Hic verò Balfami plantam perpetuò advenam, vel peregrinam fuife, \& perpetuò ex Fellcis Arabix locis advectam, plures unà nobifcum Cairun nunc habitantes certa fide confirmare poterunt, qui omnes, plantas Balfami, quas hactenus hoc habuit viridarium, exinde comportatas fuiffe variis temporibus obfervarunt. Multoque labore, ac cuftodum diligentia vixiffe', facileque ex levifirma etiam caufa aruiffe, quibus arefactis alias rurfum ab illis locis extractas, hic infertas renovatasque; \& hoc modo alternatis vicibus Balfamum in hoc viridario hactenus confervatum fuiffe. Nemo plantas tanto labore ac diligentia in viridariis adfervatas patrias dicet, quandò patriz ubique fponitè nafeantur, crefcant, ac nullo' labore in propriis locis vivant. Ex quibus nos planè certi effe 'debemus, Balfamum nunquam Agyptiis ac Syris patrium fuisse, cum in viridariis ibi multa diligentia, ac cura femper fuerit cuftoditum: quod tamen de Arabia Felici, cum Balfamuím ibi perpetıò vivat, minimè videtur dicendum, nullibi etenim nunc; quòd fcian, hujufmodi planta, nifi Felici tantum Arabixe conceffa, reperitur. Quam regionem Diodóri Siculi, Strabonis, Paufanizque teftimonio; ut nuper distum eft, conftat Balfami olim fera- 
cen fuiffe, quæ eodem modo etiam nunc innumeras ejus plantas fpontè natas alit. Quam Balfami fertilitatem omnes Egyptii, atque aliarum nationum homines annis fingulis Mecham, Felicis Arabix urbem, adeuntes, veram planè effe eonfirmant. Copiamque ibi Opobalfami infignem annis fingulis colligi, fructuumque non minus, \& virgarum (cum Balfami frutices frep quotannis putent) qux ad varias orbis partes vendenda ab his demandatur. ABDACH. At iftre vera. effe concedentes, dicent, quam pro Balfamo tu, atque noftri Felicem Arabiam nunc alere inquiunt, non effe Balfamum, fed aliam plantam. ALPIN. Notæ hujus plantæ $a b$ antiquis. Scriptoribus. defcriptæ ac memoriæ traditx, iftud recte docere poterunt. Nam omnes conveniffe videntur, (ut ex te fpero me magis diltinctè cogniturum) Balfami plantam fruticem effe, non admodum magnum, foliis rutx proximis, perpetuò virentibus', atque ex ftipitis cortice fcarificato liquorem in primis album oleo fimilem, eximio, acutoque odore proditum, manare. ABDACH. Millies tecum, Abdella, fruticem hunc ab Alpino defcriptum me infpexiffe in hoc virio dario fcio. Verum qui hujufce plantæ notas quxrit, quibusnam hominibus magis credere debebit,. Italis ne, an nobis Egyptiis, qui unà cum Balfamo in hac civitate hactenus viximus, eamque arborem frpius in hoc. viridario infpeximus? Nemo certe ita fatuus erit, qui hac de re vobis, quàm nobis libentius credere, ac fidere maluerit. Hanc verò plantam pro vcra arbore, qux ab antiquis Balfamus appellata eft, \& in pofterum memorix prodita, noftri omnes Arabes hucufque conftantifimè habuerunt, aliamque pro Balfamo ab áliis monftratam nemo noftrum ufpiam offendit, vel vidit, vel aliquem vidiffe unquam audivit. His addo nomen hujufce plantæ, quod eft Băleffan à noftris ei fuife impofitum, à quo \& Græci b littera carentes, in u mutata, $\beta \alpha^{\prime} \lambda \sigma \alpha \mu_{00}$ dixere, atque ab ipfis Latini Balfamum. Cur igitur Italis magis guàm noftratibus de hac planta credendum erit ? quando à noftris \& Itali, \& Græci, vel nomen ipfius plantæ acceptum, lidicerint. Quapropter Balfami cognitionem à. Diofcoride, 
Theophrafto, atque $a b$ aliis antiquis feriptoribus minimè petendam judico, fed ab AEgptiis \& Arabibus, qui loca, in quibus Balfami plantæ omnium confenfu olim vixerunt, habitarunt. Si Egyptii, Arabes, Syri, atque alii omnes Arabica lingua utentes medici, citra ullam difficultatem talem fruticem nunc in Jielicis Arabiæ locis cultis, atque incultis, domefticis, 'atque fylveltribus nafcentem, tanquam verum Balfamum recipiunt; eodemque tùm fucco, tùm fructibus, tùm virgis, pro vero $\mathrm{O}$. pobalfamo, Carpobalfamo, \& Xylobalfamo, nemine ipforum hæfitante, ad componenda medicamenta, utuntur, cuir Itali etiam, atque alii aliarum nationum medici ab illis, qui magis quàm noltri funt in ea cognitione, eoque ufu, exercitati, ac docti, idem facere recufant? Certè indignum facinus eft, ros hanc veritatem non fateri, fed potiùs, quo minus à multis ea dignofcatur, operam dare. ALPIN. Hæc doctiffimè à vobis prodita fuiffe arbitror, veruntamen quoniam cum medicis, Pharmacopolifque incredulis difputatio agitur, quæfo fi quid a liud apud vos utique fit, quod hanc veritatem adhtic etiam illuftrare poffit, ne vos me iftud quoque docere pigeat, ut pofteà quam ego in patriam, Deo concedente, rediero, facilius id incredulis illis hominibus poffim perfuadere. $\triangle B D E L$. Cum anno à Beatifímæ. Virginis partu MDLXXV. Petro Michaele viro Clarifime, pro Serenifima Veneta Republica Confuhatum hic agente, Eunuchus, Meffrr dictus, Ægypti Præfectus, Cairi civitatis hujus quæpiam loca inviferet, huncque præfertim locum el Mattharia nuncupatum devotionis gratia (quando hanc in proximam domunculam olim Beatifimam Virginem cum puero filio, Herndis iram fugiendo, fe recepiffe, multosque annos in ea manfiffe omnes Ægyptii opinentur, atque ob id hunc locum in fumma habeant veneratione) fingulis hebdomadis die Veneris, facrum, venerandumque hunc locum vifitans, viridarium hoc proximè politum aliquandò animi gratia ingreffus, vidit omnes Balfami plantas cuftodum negligentia aruiffe; qua re commotus, ut è Mecha quadraginta plantæ afferrentur curavit, eamque operam cuidam militum, ac peregrinorum duci, Mecham fingulis annis devotionis gratia profi- 
cifcentium, Haly Bei nomine locavit ; qui mihi admodum do mefticus, atque familiaris fuerat, eumque fæpè ex renum calculo peffimè ægrotantem inviferam, ac curaveram; plantafque illas quadraginta procifis ramis detulit, qux in confueto hujus viridarii loco inferta fuerunt, dumque fererentur ego, una cum Paulo Mariano eo tempore pro Gallorum Rege Confule medicinæ quoque caufa mihi familiari, atque cum multis etiam, Cairinis medicis in re plantaria valdè exercitatis interfui. Ex ipfo autem Haly Bei Cairum reverfo veri Opobaliami binas uncias dono habui, atque ab alio, qui poft hunc illud iter confecerat, vncias tres. Horrem Bei, alius Caravanæ peregrinorum dux, meus amicifímus, cujus in domo frè tum ipfius, tùm aliorum caufa medicinam feeram, peregre anno MDLXXX. Mecham profectus, atque fic à me rogatus, attulit multa femina, \& ramulos eximium odorem fpirantes, atque multum Opobalfami à Seriph Mechæ partim acceptum, cujus modicam portionem dono dedit Francifco Priolo, tunc temporis Cairi pro Veneta Natione Confule Clarifimo, \& partim' ab iis, quibus Balfami negotium locatum eft, emptum. Poftmodum Scander quidam, \& ipfe dux militum, Medinam Felicis Arabix urbem. pro prætore à Baffa miffus, mihi non minus quàm alii, medicine caufa familiaris, atque etiam quia ex. Infula Zacintho à Segurorum familia ortum duxerat, Balfami recentes ramos, fruEtus, ac fuccum mifit, ac per literas fua manu fcriptas, fignificavit propriis manibus ibi ea collegiffe, qux omnia apud me adhuc affervantur. Omnes prædicti nobiles Turcæ uno ore affirmant, propè Mecham \& Medinam, in montibus, planis, cultis, atque incultis locis innumeras Balfami plantas fponte natas fpectari, plurimafque etiam in arenofis, fterilibufque locis, qux tamen vel nihil vel minimum fucci producebant. Multa tamen femina ferunt, quorum multa copia ad nos quoque vendenda mittitur. Quales funt in monte arenofo apud Bedruniam Villam pofito. Nihil hx, atque alix in arenofis, fterilibufque locis viventes Opobalfami ferunt, ideo incola eas excerpunt, atque pingui in folo inferunt, focundiffimafque redlere ftudent. Addunt; apud omnes Arabes veterum memo- 


\section{DE BALSAMO DIALOGUS}

riis conftare, pafim in pluribus Felicis Arabix locis innumeras fponte naficentes, atque crefcentes Balfami plantas perpetuò vixiffe, numquamque illa loca iis caruife. Non multum temporis tamen effe, ex quo plurimi eas colere Jucri caufa cæperunt, cum filice Opoballami facultas ac vires ad quam plurimas Orientis regiones concefferint. Narrant adhic iidem omnes Arabes, uti Balfani fucco, fructibus, ac virgis ad componenda ipforum onnia medicamenta, atque ad alios medicin ufus, qux eadem planè exiltunt, quibus Asgyptii Syri ad ufum. nunc recipiunt, quaque à vobis varia in Europæ loca hinc advecta, negliguntur, atque rejiciuntur, falfaque eorum multi (te auctore) pertinaciter, ac inutiliter effe cifpetant. $\Lambda$ LPIN. Ex his, qux te vera dixiffe arbitror, me non parum pudet, quod cum illis tot annos in tanto errore permanferim, quem ex te nunc probè cognoviffe fateor. Cupio igitur plantam hanc fuis notis à te quoque defcribi, in quam attollatur magnitudinem, qualibufque floribus, \& fructibus obfervata à vobis fit, quo pactoque etiam ab ea planta: Opobalfamum diftillet, fponte ne, an, ut multi dixere, arte potius elicitum. $A B$ $\mathrm{DACH}$. Hic nullas, quas ego viderim crefcere, flores, vel femina tulife unquam fpectare potui, etfi fuccus interim paucus à cortice ftipitis fearificato aliquando diftillaverit.r. Verum hac de re Abdellam audiamus, qui hæc exploratiùs, \& reliqua docebit. : Interimque dum loquimur, mandes velim mancipio tuo, ut nobis hic è domo hujufce plantæ iconem, qux apud te eft, deferat, ut Alpinus nolter veram Balfami Iconem videat. ABDELL. Recte mones, libenterque faciam: ALPIN. Ego vero utrique veftrum multas hac de caufa gratias referam. Mihique iftuc acceptiflum um femper ierit. 


\section{A P U T III.}

Planta, que ab antiquis Arabie medicis Ba.

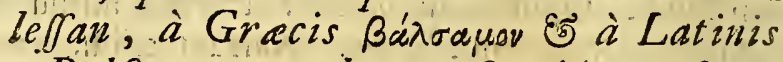
Balfamum vocabatur, fructuum, fuccique deforiptio.

ABDEL. $R$ alfamum arbufculum eft, quod crefcit ad altitudiB nem hanne, vel ligultri, vel cytifi, folia pauciffima gerens rutæ proxima, non tamen is candidiora, ut Diofcorides docuerat, fed potius colore viridi fubalbido, perpetuumque virentia. Ejus lignum gummofum leneque apparet, colore exterius fubrubro, cujus ramuli eodem colore confpicui funt, longi, reeti, graciles, paucis foliis inordinatim referti., foliaque fimul terna, aut quina, aut feptenas alx adnata, aliqúo pacto etiam lentifei foliorum æmula; funt ramuli odorati gummofi, digitifque contrectati eis tenaciter adherentes. Flores fert parvos, albos, Acaciæ proximos, ternos fingulis alis appenfos, quali in umbellæ formam, fummè odoratos, à quibus femina promanant, flava, folliculis nigris fubrubefcentibus contenta, valdè odorata, intufque humorem flavum melli perfimilem habentia, fapore fubamaro, parumque acri linguam ferientia, Opobalfamumque redolentia, Terebinthi fructuum figuræ, \& magnitudinis xmula, extrema aculeata, \& mediurn craffum obtinentia. Cui defcriptioni maximè quadrare videtur illa, qux fuit à Conftantino Africano tradita, qux his verbis apud ipfum in libro de Grad. legitur! BBalfamus eft arbor in India "crefcens, faliens fuper terram menfura unius brachii, vel " parum plus. Cujus rami rubeo viridique colore perfufi qua", fi rami titymali tenues funt, \& colorem viridem habentes faciuntque in capite quafi gemmas, parvaque grana in modum piperis producentes. Ex fifuris ramorum hujus arboris, egreditur quidam liquor in canicularibus diebus, ficut lac ex titymalo. "Opobalfamum menfibus Junio, Julio, Augufto, 
partim fpontè, \& partim ftipite ferro fcarificato, diftillat, in vitreaque vafcula recipitur; quod ftatim eductum, ut audio, colore elt albo, qui paulo polt in viridem, terciò in aureum, $\&$ demùm in melleum mutatur. Ejus fucci etiam fubftantia in primis turbida craffaque, ut oleum ftatim ob olivis expreffum cernitur, pofteà tenuifima atque clarifima, demum terebin- thi modo craffefcit, odore eximio inprimis atque acutifimo terebinthum redolens, cum fuaviori odoris fragrantia obferva. tur, faporeque amaro, acri, \&: adftringenti. Leviffimum eft in primis diebus, atque ufque adeo validi, \& acuti odoris, ut aliquibus inter odorandum, fanguis è naribus eruperit, \& præ multa ejus levitate in aquam ftillatum non defidet, fed ex alto in ea projectum parumper in ipfa merçitur, fereque continuò affurgens, fupra totam aquæ fuperficiem totum expanditur, eique mifcetur, \& citifíme ita in ea diffolvitur, ut ab aqua maxima cum difficultate feparatum fecernatur; in qua pauld polt concrefcit, atque coagulatur, coagulatumque ftilo totum $\mathrm{ab}$ aqua eximitur, quod tunc colore lactefcit, five album, quale lac, vilitur. Quanto hic fuccus annolior, eò fit inodoratior, atque ad motum fegnior. In primis itaque ftatim albo colore conspicitur, qui color paucifímis diebus in viridem, ut nuper etiam dixi, mutatur, oleique craffitie cernitur, qui poftea longo temporis intervallo depuratur, nonnullifque annis tenuifimus evadit, atque clarifímus, ex viridique colore in aureum fplendidifimum tranfit, Senio vero confectus, craffus qualis terebinthina fit, qui fi in aqua, vel lacte ftilletur, ftatim confidet, multaque cum difficultate, \& non nifi longo tempore denuò fupra aquam fertur, tardiffimeque in ea diffolvitur. Quare non fecus quam in animalibus omnibus quatuor conftituuntur ætates, quæ in ipfis maximam differentiam faciunt, \& Balfami fucco, quod Opobalfamum dicitur, proculdubio à noftris quatuor tempora tribuuntur. Quandoquidem ille fuccus ab arboris ftipite continuò elicitus ufque ad quintum circiter annum acutiffimi, validifimique odoris percipitur, levifimufque ufque adeo obfervatur, ut in aquan ftillatus, nihil vel parum confidat, facillimeque diluatur, quod ejus calor in 


\section{6 \\ PROSPERI ALPINI}

annis infantiæ plurimus exiftens, ei acutiem atque vehementiam priftet. Craffiori quoque fubftantia tunc cernitur, \& turbicta, quod cum multus in eo exuberet crudus humor, eo ob calorem in ipfo agentem valdè agitato, inltar urinz turbi$\mathrm{dx}$, qux in peftilentibus febribus fieri folent, apparet, \& quemadmodum puerorum corpora multa humiditate, atque multo calore prædita craffa, ac ferè tumentia videntur, ita Opobalfamum in pueritix annis conftitutum à multa humiditate excrementitia, cum validifimo calore in ipfa agente, craffum, ac turbidum apparet, quod in grandiori ætate ab ea purgatur, tenuifimumque fit, \& aureo colore clarinimo fpectatur; in quo ttatu confrltentix, ipfius xtate continuante, confervatur, pofteaque calore ejus nativo aliquatenus refoluto, ac imminuto, fenefcens craffum inftar terebinthinæ evadit, folitoque tùm odore eximio từn levitate deficit. Proinde neque fupra aquam enatat, neque multum, \& fuaviter olet. Hrcque de Balfami planta, fructibus, lignis, fucco tibi dicta fafficiant. ALPLN. Quæio ne te pigeat, ad nonnulla adhuc, quæ à noftris, Balfami defcriptioni repugnantia proferuntur, refpondere, ac fatisfacere, quando ea non parum hujufce plantæ cognitam veritatem obfcurare, ancipitefque nos reddere videantur. Antiqui etenim omnes balfami fcriptores inter fe in illiufce plantæ, fucci, fructuum, virgarumque defcriptione difcrepare videntur, ex quibus non videtur tutum fatis effe illorum cognitionem perquiri debere. Qui fuêre in caufa, ut noftri ipforum traditionibus imbuti, verum fibi oblatum Opobalfamum, fructus, virgas, veras effe non crediderint. ABDEL. Summum femper errorem effe putavi, homines plantæ hujus, fucci, fructuum, virgarumque cognitionem à Diofcoride, Theophrafto, vel aliis antiquis fcriptoribus velle expofcere, quando ifta inter eos in defcribendo frutice, fucco, fructibus, \& virgis, diverfitas certifímum ignorantiæ argumentum nobis fuerit. Ego fum hujus fententix, neminem illorum fortaffè accurrate arborem hanc vidiffe, ex audituque omnia de eis ab ipfis litteris prodita fuife. Olim enim non erat ita facile hominibus loca, in quibus Balfamum nafcebatur, ex longioribus difficili- 
oribufque navigationibus, quibus eo tempore antiqui utebantur, adire, proinde multa Diofcorides, Theophraftus, atque alii multi ex hominum potius relatione, quam ex infpectione de Balfamo fcripfere. Hincque mirum non elt, fi in pluribus noftri ipforum fententiæ inhærentes decepti fint, quando \& ipfos à falfis aliorum relationibus deceptos fuiffe putandum elt. An non Diofcoridem, Theophraftum, atque alios affimantes, Balfami plantx Figyptum, vel Judxam patriam fuiffe, cum dixerint eam folum in Rgypto \& valle Judæa vivere, maximè errafle fuperius demonftratum eft, cum illam plantam ex Agyptiorum relatione perpetuo ex Arabia Felici in 2 Lyptum veniffe certifimò conltet? Ex quibus mirum quoque non effet, in aliis eofdem deceptos fuiffe, præfertimque in fucci, fructuumque cognitione. Hincque his herbarum feriptoribus omnes medicos Pharmacopolafque planè fidentes, erraffe mirari non debemus, quando noc ab illis, ut etiam dixi, fed ab Agyptiis, \& Arabibus, qui tum primi Balfamum cognoverunt, atque obfervarunt, tùm etiam cum hujufmodi planta in eodem folo nati fint, atque eadem loca, in quibus vivit, \& vixit Balfamum, habitarunt, iftorum cognitio effet petenda. Sed quæ ea exiftunt, quæ nobis repugnent, fac ut ex te jam audiamus. ALPIN. Quæ de Balfami arbore à mulcis olim litteris tradita fuere, nunc in medium afferam; Reliqua verò de fucco, fructibus, virgis, ad ufum medicinæ memoriæ proditis, pofterius à me recenfenda arbitror. Multa igitur, variaque de hujufce ftirpis magnitudine, figura, fitu, foliifque à multis prodita funt, quæ non parum veritatem obfeurant, hominefque ancipites, ac rem hanc totam incertam efficiunt. Aliqui fiquidem plantæ iltius magnitudinem Lycii, Pyrachanthæ, vel Cytifi, vel terebinthi magnitudini compararunt, ut Diofcorides, Straboque dixere. Theophraftus vero dixit ea magnitudine Balfamum fpectari, qua magna mali Punici arbor obfervatur. Juftinus fimilem piceis arboribus affrmavit, \& Palifanias mirto; Plinius, Solinus, atque Africæ defcriptionis auctor, viti hane plantam compararunt. De ejus foliis non minor eft apud illos diverfitas, deque arboris figura. QuanN. 
do Diofcorides, Theophraftus, Plinius, Avicenna, Simeon Sethus Balfami folia rutæ proxima effe ftatuerint, \& Paufanias amaraco, Juftinus piceis, Solinufque \& auctor Africx vitium foliis. De forma etiam vel figura arboris, alii arbuftum, alii fruticem faciunt.Plinius enim de eo dixit: " In totum alia " elt natura, quam noftri, exrernique prodiderunt, quippè viti fimilior eft, quam myrto. "Q Quod eciam Solinum dixiffe ab illiufce verbis conftat, qux hæc exiftunt: "Similes vitibus ftirpes "habent: acjuftinus., siquidem palmeto \& Opobalfameto diftin"guitur. "Arbore Opobalfami formam fimilem piceis arboribus " habent. "Et Strabo: „Quæ arbor eft fruticofa Cytifo \& Terebin" tho perfimilis. , Nonnulli etiam affirmant, plantam hanc ali aqua, illaque tantum, quæ in proximo fonte illiufce proximæ domunculæ fcaturire cernitur, ajuntque miraculo id fieri; quando ipfa fit pluribus virtucibus præcita, quòd Virgo Beatifima olim ibi multos annos morata, ea aqua, tùm ad potum, tùm ad cibum, tùm ad mundandos panniculos Jefu Chrifti pueruli ufa fuerit: ex quo tanta in veneratione omnes viri mulierefque Egyptiæ, Arabes, etiam Mahometis affecle, eam habuerunt, ut ipfa ad multorum etiam morborum curationem confidenter utantur. Multique ex longinquis, remotifimifque locis hùc veniunt, ut ex hujufmodi aqua accipiant: quare nonnulli Balfamum hujus aqux beneficio hactenus hic vixiffe ajunt. Hæcque funt, quæ de arbore ifti dicunt... ABDEL. De Balfami fruticis altitudine, figura, ac foliis, ea qux ex te nunc propofita funt nihil veritatem hanc obfcurare poffunt. Namque Diofcorides, atque alii, qui hane plantam magnitudine fimilem effe lycio, cytifo, terebintho , \& pyracanthx, affirmarunt, minimè errarunt, cum hæc omnia arbulta magnitudine non multum inter fe differant, eifque planta Balfami major non fit, fed hic nullæ cernuntur arbores Balfami, quæ ita magnæ fpeEtentur, fiquidem grandiores, quas hic aliàs viderim, non asfurgunt ad majorem trium cubitorum altitudinem. Audio tamen in Arabix folo eas plantas ad prædictorum arbufculorum altitudinem, \& majorem etiam excrefcere. In AEgypto, \& Arabia mali 'Punici arbores parvæ exiftunt, ita, ut inter arbu- 


\section{DE BALSAMO DIALOGUS.}

fculorum fruticumque numero ibi connumerentur, neque ad tantam affurgunt altitudinem, quales in Italiæ locis obfervantur, quare neque Theophraftus reprehendendus erit, quòd fcripferit, effe magnæ Punicæ arboriBalfamum fimile, quando hæ noftræ Italicis longè fint humiliores. Jultinum verò, quod picei arbori plantam Balfami fimilem afferat, deceptum omninò fuife, credendum eft. Ex ipfiufque verbis error apparet confpicuus; nam piceis arboribus Balfamum fimilem effe dicens, fubdit, \& in vinearum morem excoluntur: quis tamen ufpiam vidit piceam arborem viti fimilem, \& in vinearum morem excoli ? Inter quas quanta fit differentia, non eft, quod nunc demonftretur. Fuiffe verò Balfami plantam ramulis fruticofis, ac farmentofis viti fimilem dubium quidem non eft, ut neque etiam, quemadmodum vites, annis fingulis putari, quod fit admodum fruticofa, \& farmentofa. Non tamen quod ad folia attinet, viti ea planta eft fimilis, cum foliis referta fit rutæ aliquatenus proximis, præfercim verò extrema tria foliola, quæ in fingulis virgæ Balfami alis cernuntur, quando ipfa fimillima fint tribus iis foliolis in extremo virgæ alæ rutæ pofitis; colore excepto: neque abfurdum eft, Paufaniam dixiffe Balfamum folia habere amaraci æmula, quoniam fufpicor ego ipfum plantam Balfami non adultam, fed tantum recenter ex ejus feminibus natam infpexiffe, quæ folio, magnitudine, ac figura amaraci foliis omninò funt fimilia, excepta earum crafitie, ac colore, quibus ea folia invicem differunt, nam in amaraco funt graciliora, \& albidiora. Balfamum, quod ex feminibus nafcitur, bina folia in primis habet, bifoliis nafcentis vitis maximè fimilia, \& quæ poft hæc, quæ funt tria, quatuor, vel quinque, produntur, amaraci foliis funt proxima; Qux verò tertio nafcuntur fingula trina exiftunt, rutæque proxima cernuntur. Repeto, prima nafcentia folia bina funt, fecundo nata, his multum diverfa produntur, inordinatimque in virga, Tertio producta trina cuilibet alæ appenfa, cernuntur, quæ rultæ funt proxima, tribus inquam, foliolis in extremo alæ virgæ rutæ confpicuis. Quarto, quæ nafcuntur in virga Balfami, foint quina, \& poftea feptena. Hrcque funt Balfami folia, aliter quam Scriptores antiqui defcripferint, in hoc viridario in fruti- 
cibus.Balfami frepifime vifa, ex quibus atque aliis fortaffe Dia. ofcoridem, atque alios multos antiquos Scriptores viventem. Balfami plancam non infpexiffe, jure fufpicamur. Hanc etiam. arborem in hoc viridario vixiffe certum eft, aqua ex hoc proximo fonte, in quo Beatifimam Virginem panniculos Salvato. ris noftri pueri olim perpetuo laviffe noftri omnes autumant, irrigatam; tamen in arellofis, fqualidifque locis non paucæ re-: periuntur, qua tamen quoad Opobalfamum fteriles exiftunt. Atque hxe obiter de Balfami planta dicta à nobis fint. Nunc ad Opoballamum deveniendum. Sed Balfami plantx ramos, quos mihi domo mancipium detulit, abfoluto de ipfo fermone fpectabimus.

\section{A P U T IV.. \\ Veri Opobalfami cognitio undè Jumatur, E़ qui: ex antiquis vere bunc fuccum litteris pro. diderint.}

ABDEL $\bigcirc$ uid inquies Alpine de Balfami planta? nonne à nobis probe, ut veritas exigebat defcripta eft, deque ejus foliis, floribus, fructibus, ac virgis, qux dicta a me funt, vera tibi effe videntur? ALPIN. Omnia fanè rectiffimè, ac veriffime es profecutus, fed fuperfunt tamen quæpiam de fucco quoque, fructibus, ac virgis dicenda, cum antiqui Scriptores, qui de Balfamo, fcripfere, fimul in horum deferiptione inter fe nihil ferè conveniffe vifi fint: quorum diverfitas, ut de arbore etiam nuper dictum eft, fuit caufa, ut multi negarint, qux pro Opobalfamo, Carpobalfamo, \& Xylobalfamo monftrantur, vera utique effe, nullumque ob id ipfos credere, fincerum ac legitimum Opobalfamum ad nos adportari: de quo primo fermonem à nobis haberi cupio, mox de cxteris. De Opobalfamo igitur multi hujus funt opinionis ut arbitrentur, fincerum ad nos non advehi, neque injuria . quando ex te defcriptum Opobalfamum, à nobifque fxpius in, fpe. 
fpectum, diverfum fanè videatur ab eo, quod omnes prif́ci rei herbariæ Scriptores memoriæ mandarunt. In primis enim album, multi ipforum, effe prodidere, Strabo fiquidem dicebat: " Bjus corticem fcindentes fuccum in vafis fufcipiunt ", tenaci laeti perfimilem. „ Et Plinius. „, Succus è plaga manat, ". quem Opobalfamum vocant, eximia fuavitatis, fed tenui gut"ta ploratu, lanis parva colligitur in cornua, ex his novo fietili " conditur, craffiori fimilis oleo, \& in multo candida. " Et Simeon Sethus, vir in Balfami hiftoria aliis non poftponendus, dixit: , Succufque inde manabat omni oleo vifu fimilis, quod „ ideo Balfami oleum nominatur, fuccus his aggregatus vafcu". lis excipiebatur, \& id quidem, quod fupernatabat, album ac "tenue erat, \& ideo preciofius. "Alii funt rurfus aflerentes, hunc fuccum non effe tenuem, fed craffum, veluti qui dixere in conchis furceptum coagulari: cum verò Opobaliamum, quod tu defcripfifti, \&r nos fæpè infpeximus, vel viride, vel aureum, vel mellis colore obfervetur, interdumque turbidum, interdum clarum, ac tenue, aliquando ut terebinthina craffum cernatur, (nemo enim noftrum eft, qui eum fuccum tot prædictis differentiis evariatum non viderit, fcilicet oleofum, viride, aureum, ac melleum, clarum, turbidum, tenue, craffum ) de ipfo varios, \& dubios effe mirum non erit. $\mathrm{ABDACH}$. Facile has ambiguitares nofter Abdella ex animis noftris abiget. Præfertin cum harum explicatio ex iis pendeat, quæ dudum ipfe attulit. Dixit enim Opobalfamum, juxta ejus ætates varias, variari \& ipfum, quoad colorem, fubfantiam, perfpicuitatem, odorem, \& levitatem; continuoque à ftipite inftillatum ac exceptum, albo colore confpici, præfertimque quod fupra enatar, veluti minus quod fubfidet, qui color paululo momento in fubviridem oleofum mutatur, qui polt quinquennium, ut fuperiùs etiam dictum meminimus, aureus fit, ac de. mum fenio confectus craffefcens, mellis colorem, obfcuriorem tamen accipit. . Tot etiam mutationes in perfpicuitate ; fubftantia, odore, levitate, ejus varias ætates facere aliàs dictum. eft, quandò Opobalfamum recenter eductum per quinquennium turbidum maneat, à quo tempore clarefcere incipit., per 
decenniumque ferè ipfun clariffmum, ac ut anrum fplendefcere obfervatur, poltea fenefcens turbidum rurfum evadit. A. ftipite etiam ftaim exceptum tenuifimum eft, pauloque poft parum craffefcit, atque hinc Strabo dixit, fufceptum in conchis coagulari, peractoque quinquennio, quod tempus pueritix datur, purgari, fremque in fundum vafis deponere, tenuifimumque fieri, \& totidem geminatis peractis annis fenefcens crasfum, craffiufque fieri, quo annofius. Odor non minus \& fapor, in recentifimo validifinus eft, in medio tempore odor fit fuavior, thus ac terebinthum redolens cum filaviori tamen odoris fragrantia, fapor eft amarus, fubacris, atque adftringens. Demum in fenio omnia hæc maxime remifla percipiuntur. Hinc. que Plinium deceptum fuiffe arbitror, qui putaverit, optimi hujus fucci lachrymam fricando percipi odoratam. Si quidem Opobalfamum fenio folummodo confectum inodoratum fit, ut tunc folum frictione dignofci queat. In principio etiam hic fuccus leviffimus elt, qui quam maxima difficultate in aqua, vel alio liquore inftillacus confidat, fed continuò in aquæ fuperficiem feratur, citoque cum aqua diffolvatur: annis verò confftentix medio fe habet modo, fenefeenfque, colore ejus imminuto, craffefcit, quo fit ut fubito in aquam projectss confidat, tardifimeque furfum in aquæ fuperficie feratur, difficillimeque ac tardiffime cum ea diffolvatur. Hsecque etfi non ita concinna oratione, tamen ad Tuarum difficultatum explicationem accommodata fatis effe Abdella nofter judicabit. ABDEL. Ego verò fic ea vera judico, ut omnes, qui de Opobalfamo fcribentes, aut loquentes ab his diffenferint, rem prorfus ignorent, ex quibus Plinium ex variis coloribus, ac fubftantiis in Opobalfamo infpectis, varias ejufce fucci differentias vel fpecies facientem erraffe clariffime patet; dixerat enim ille: , La" chrymæ probatio; ut fit pinguis, tenuis, ac modice ruffa, " \& in fricando odorata, fecundus candidus color, pejor viri"dis craffufque, pefímus niger., Nemo KEgyptiorum, vel Arabum album Opobalfamum nifi ex arbore recentifime ftillatum vidit, qui tamen color quam paucifimis diebus evanefcit, atque, ut dictum elt, in olei colorem vertitur, atque ab eo 
colore in aureum, \& denique in melleum obfcuriorem. Nigrum verò nunquam ab aliquo noftrorum, vel Arabum vifum eft, neque auditum... Nifi fortaffe produceretur novifime ab Occidentalibus Indiis delatum, à quibufdam pro legitimo $\mathrm{O}_{\text {. }}$ pobalfamo, ut fuperius quoque meminimus, receptum. Qued tamen falfum effe plane conftat, cum ii, .qui ejus hiftoriam fcripfere, affirment illum fuccum improprie Opobalfamum vocatum, in Occidentalibus Indiis ex procera, ac magna arbore nafci, quæ quidem magnitudine, figura, ramis, foliis, fructibus à vera Balfami arbore longiffime differt. Quod iis qui utramque norunt arborem, non erit difficile perfuadere; ALPIN. Simeon Sethus confirmare \& ipfe videtur, optimum Opobalfamum recentifime à utipite deftillatum album colorem habere, nee non, \& Strabo, qui Opobalfamum lacti fimilem effe fcribit. Sed quamquam hujufce fucci albus color pauculis diebus a ftillatione evanefcat, atque in alium colorem mutetur, nihilominus, quod non paucis valde admirandum videbitur, Opobalfamum oleofo colore infpectum, in aqua vel lacte ftillatum, album rurfum videri: \& idem etiam facere aureum, \& melleum, perpetuoque verum Opobalfamum cujufcumque coloris fit, in aqua, vel lacte ftillatum, ac liquatum album fpectabitur. Hincque Diofcorides doctiffime dixit:.;, Quin etiam „, fincerus in aqua, aut lacte celerrime liquatur, coloreque la". cteficit. "Nunquam quifquam Opobalfamum vifui non album effe" judicarit, quod tamen verum effe experientia docebit, fi inquam, quis finet ftillatum in aqua, liquari, ac coagulari, ipfum etenim liquatum fupra aquam ita album redditur, ut vix ab aqua diftinguatur, fed paululo momento in ea coagulatur, eique inftar telæ albæ incumbere, $\&$ in ea fupernatare cernitur, manifeltiorque ejus albus color fiet, $f \mathfrak{l}$ coagulatum ftilo quopiam áb aqua eximatur, aut extrahatur. Sed hxc illius fucci experientia per xftatis tempus eft facien$\mathrm{da}$, vel fi hyeme, prope ignem, Opobalfamo probe prius calore attenuato. At cur ex albo tam citò in alium colorem mutatur? ABDEL. An quod lactei illinffe coloris fubftantia mollis, ac tenuifima, quam citò refolvitur ac diffipatur? vel quia 


\section{ro4. PROSPERI ALPINT}

nondum ejus calor prevalidus in eum fuccum agendo ipfum turbavit? Idem in Zebet obfervatur, etenim ftatim è teltzibus extractus lacteo colore inficitur, pauloque ebullire incipiens, virefcit, \& tandem fubnigrefcit. ALPIN. Recte funt a te hase ctenus explicata, \& enarrata omnia. Nunc igitur ego idem a te fieri cupio, pro indagandis, ac docendis notis vel fignis quibus verum à non vero, fincerum ab adulterato rectè diftinguatur.

$$
\text { CA P U T V. }
$$

De notis, quibus verum Opobalfamum à non vero, fincerum ab adulterato tutò cognoscitur, ac difcernitur.

ABDELL. TI is notis quifque probè ac exactifime verum hunc - 1 fuccum, a non vero, \& legitimum ab adulterato dignofcet, neque $\mathrm{ab}$ aliquo ita facile decipi poteric, etenim fuccus is, qui nondum ad fenium inclinare ceperit, colore albo confpicitur (quod rarifímè, \& non nifi dum ipfum è ftipite ftillat, vel recentiffimè eductum videre contingit) vel viridis eft, oleofus fubturbidus, oleoque fubftantia \& colore valdè fimilis, vel aureus fulgentiffimus, tenuiffimus, atque clariffimus. Qui fanè omnes has notas habebit, vehementis erit odoris, \& quo magis etiam recens eft, acutioris, terebinthum cum alio fuaviori odore redolentis, gratifimusque olfactui erit. Guftu etiam fubamarus, adftringens, \& modice mordens percipietur, levis, diluique facilis, qux nota, eo inftillato in aqua vel lacte dignofcetur, levis enim exftabit, \& vel nihil fub aqua morabitur, vel parum, \&r. quafi continuò fulpra eam furfum affurget. In qua citò diluitur, vel liquatur, nil unctuofi retinens, vel oleofi, tenax, five lentore aliquo preditus eft; hifque omnibus notis verum, fincerumque Opobalfamum femper omnibus apparebit. ALPIN. Poffit ne quis aliquod factitium oleum ita fimile Opobalfamo pa- 
rare, ut eo multos decipiat? ABDEL. Sine dubio, cum Galenus fuo tempore etiam ipfum ufque adeo adulterari dixerit, ut vix adulteratum cognofceretur. Veruntamen quod adulteratur, neceffe elt, ut aliquo liquore, vel oleo, vel unguento vitietur. Diolcorides dixit, Opobalfamum vitiari polfe admifto terebinthi, cypri, lentifci, balanique unguento, \& fulino, metopio, melle, cypriaque cera liquida. Serapio his addidit oleum rofaceum, myrtinum, \& de alcanna, quod cyprum appellant. Plinius ex feminibus veri Balfami, quæ vocant Carpobalfamum, extrahi fimile oleum afferit, qua vi multi ex ipfis oleum exprimunt, vero Opobalfamo admodùn fimile, quod tamen ab eo difcernitur amariore fapore, odoreque Opobalfami longè obfcuriore. Prodit etiam ipfum adulterari poffe oleo rofaceo, cyprino, lenthifcino, balanino, terebinthino, myrtino, refina, galbano, \& cera cypria, quæ fanè eadem exiltunt, quorum nuperrimè Diofcoridem fub nomine vnguentorum meminiffe, dictum eft. Sed forfitan melius ipfe dixiffet, oleis, quàm unguentis adulterari poffe, quod ille fuccus tenuis perinde ac oleum fit, minimeque craflus, nif fenio fuerit confectus. His igitur Opobalfamum vitiari poteft, cujus maleficium facilè deprehenditur, oleoque adulteratum trifariam detegitur, atque in primis, quod digitis contrectatum, nullo lentore, vel vifcofitate adhæreat, quando verus Balfami fuccus lentore, ac vifcofitate quapiam non carere à nobis aliàs diEtum fit, à multifque $\mathrm{ex}$ antiquis fcriptoribus confirmatum, oleo fiquidem refinarum omnium tenacitatem abigi omnibus manifeftum eft. In aqua præterea inftillatum fupra ejus fuperfi. ciem orbiculorum formis expandi nemo noftrum ignorat. Quod fincerum Opobalfamum non facere pofterius docebitur. Demum in panno oleo infecto macula relinquitur, quæ \& diffcile aufertur, \& quotidie etiam magis majorem in circulum expanditur, quòd non fit in fincero Opbalfamo. His igitur notis Opobalfamum oleo vitiatum cuique patere poterit. His etiam comperietur vitium, fi unguenta iifdem oleis compofita mifceantur, fed hoc amplius ins aderit, quod in Opobalfamo parvi temporis fpatio in fundo valis unguenta fidere 


\section{6 PROSPERI ALPINI}

neceffe eft. Cera vero miftum comprehendetur turbido colore, nunquam clarefcente. Melle etiam infectum dulcis fapor detegit, atque ad ipfum, ut Plinius quoque teftatur, mufcas alliciet. Refina adukteratum in carbones inltillatum, nigriorem flammam edit, fubftantiaque craffiore quim in fincero fit, fpectabitur. Sincerum vero his notis innotefcet, namque præter ea figna, quæ illum juxta varias ætates præfeferre diximus, hæc etiam addidimus, fcilicet præterquam quod fit validi odoris, in aqua etiam ftillatum, tametfi parva fatis fit gutta, fupra totam aquæ fuperficiem expandi, eamque liquatum totam fupernatare, ac obtegere, atque in ipfa etiam citò coagulari, lactifque colorem adipifci; ac. non minus ex ipfa coagulatum rotum ftylo quopiam excipi, ac auferri, quodque fufum in laneam veftem, eam, ut oleum non inficit, quamquam ei adhæreat, lacque coagulat, etfi non ita, ut coagulum facit, quia lac non perfecte coagulat, quinimo cum ipfo coagulatur. ALPIN. Multo plura, quàm tu de finceri Opobalfami, ac vitiati notis complexus es, apud multos leguntur. Diofcorides fiquidem hæc utique nobis prodiderat. "Succi probatio eft, ". ut fit recens, validi odoris, fincerus, non ad acorem ver, gens, dilui facilis, lrvis, adftringens, ac modice mordens " gultu. Et ubi ea, à quibus Opobalfamum poteft adultera"ri meminerat, hrec fubjunxit. Namque merus in laneam "veftem fufus neque maculam facit, neque fi eluatur notam relinquit. Vitiatus autem inhæret, \& lac inftillatus coagulat, quod adulteratus non efficit. Quin etiam fincerus in aqua, aut lacte celerrime liquatur, coloreque lactef cit, vi9, tiatus verò olei modo innatat, fe convolvens, aut in ftellæ ". modum diffundens, fincerus fenefcens craffefcit, deterior"que redditur. Hallucinantur, qui aqua concretum pes" fum ire \& ad ima fidere, arbitrantur, poltea diffipatum fu"pernatare." Et Plinius ait, fincerum inhærefcere, \& in tepida aqua ejus guttam coagulari, \& ad ima fidere, lac coagulare, \& in velte maculam non facere. Et Avicenna : lac coagulare, aqurque ipfum mifceri, \& in ipfa denfari, denfarumque confervari, atque à goffypio receptum ablui poffe. Se- 
rapio eadem à Diofcoride jam recitata, de ipfo nobis prodidit. Simeon verò Sethus hæc \& ipfe fcripfit: „At verò nonnulli hac ratione probant, quod ferrum eo inunctum ignique admotum incandefcat, id quod \& oleo caphuræ, aliifque dietis oleis accidit. Alii quod in aquam datum mi-

99

93

29

29

93

93

nimè fupernatet, fed ftatim fundum petat. Vere hoc quidem,

fed enim quando hæc duo concurrunt, videlicet ferrum candeat, \& in aqua facile fubfiftat, de eo ftatim arripe. Eft enim legitimum, \& non factitium. Scire autem præterea oportet, quod dùm recens eft, $\&$ in proprio vigore fuper aquam enatat, actum ita probatur. Linteo in eo irrigato, ac poltea fublato à linteo totum recedit, non colorem, fed odoris duntaxat fuavitatem illi relinquens. "Hæc ominia, ac inter fe admodum diverfa cum apud hos ggravifífimos plantarum Scriptores legerim, atque Opobalfamum, quod tu vere fincerum affirmas, apud me fit, non omnia qux ab his Scriptoribus de eo perdocta, repræfentet, quinimo aliqua fint, quibus ipfum planè non refpondere videatur; quamquam enim ipfüm recens fit, minimeque ad ullum acorem vergens; validique odoris, oleofi coloris, turbidum in primis ejus annis obfervatum, mox clarum, aureum, fubamariım, adftringens, \& modicè mordens guftum, tenax, leve, dilui-facile, lacque coagulet, \& linteum non inficiat, atque, ut ait Avicenna, aquæ etiam ftillatum mifceatur, in ipfaque coaguletur, fupraque aquam coagulatum enatet, atque eo ctiam ferrum, ut Sethus ipfum hoc experientia cognofcendum voluit: inunctum probè in ignem pofitum candeat. Tamen, quod apud omnes prædictos antiquos Scriptores affirmatur, quippè ipfum laneæ vefti inftillatum aqua $a b$ lutum, omninò ab ea abigi poffe, nihilque ei adhærere, nunquam potui obfervare. Nullum enim reperitur Opobalfamum quod inftillatum in pannum, ei aliquatenus non adhæreat: ex quo ego etiam puto, nullum verum Opobalfamum eam experientiam facere poffe, quando ipfum; ut in aliis omnibus refinis obfervatur (cum fuccus refinofus fit, inter refinafque poffit fine errore recenferi) vifcofitatis ac lentoris non fit expers. Ex quibus valdè de hujus fucci figno, ab antiquis ferè omni- 
bus animadverfo dubius, ac anceps fum, cupioque tuam hac in re fententiam audire, ut in ea tandem acquiefcam. ABDEL. Dignus es cum ifto tuo fcrupulo non parva reprehenfione, qui uno figno magis quàm pluribus, quibus tuum Opobalfamun omnibus probè refpondere feis, fidere volueris, quod neque verum fignum hujus fucci dicendum effe puto, fiquidem quo pacto hic fuccus lentoris, ac vifcofitatis non expers ( cum ipfe nihil quidem aliud quàm refina quæpiam fit ) lineo, uel laneo panno, vel goffypio inltillatum aliquantulum non adhærebit ? Etenim non modo fuccus ifte tenax elt, fed ramuli quoque virides, fi digitis contrectentur, eis proculdubio adhærent, quod non nos modo, fed etiam aliquos antiquorum novife cerum eft, nonne Strabo dixit: ,Ejus corticem fcindentes fuccum in vafis „, fufcipiunt tenaci lacti perfimilem. „, Quid ? nonne Plinius notas finceri Opobalfami docens dixit? Succum Balfami fincerum debere inhærefcere? At ne amplius remorer defiderium tuum, paucis de nota hac à Diofcoride propofita dicam quid fentiam. Puto enim fincerum Opobalfamum non aliam ob caufam, Diofcoridem, atque una cum eo alios dixiffe, veltibus $v$ el panno non adhærere, nifi ut nos docerent miltum aliquo oleo, vel quopiam unguento hine deprehendi, quoniam, ut ego nuper etiam vos docui (quod à plerifque oleo eo tempore vitiaretur) oleo vitiatum in pannum inftillatum, laneumque præfertim, quod facilius fit ad emaculandum, inftar"olei inficit, eique perpetuò non modo adhrret, fed quotidiè magis in eo recepta macula augetur, ac dilatatur. At fincerum, quamquam paululum panno etiam inftillatum inhæreat, tamen ipfum ut oleum non inficit, neque maculam relinquit, quinimo fecus atque oleum panno adhærefcens quotidie decrefcit, ufque quo tandem omnino aliquo tempore fponte diffolvatur, atque evanefcat. Quamobrem fincerum Opobalfamum panno quidem; at non olei modo adhæret, neque aliquam maculam relinquit. Quod fxp̀ vobis meum Opobalfamum in meam veftem inftillatum oftendit. Verum non debet hoc experiri in pannis iis, quos vos in Italia paratis, noftris longe craftioribus, in quibus fortasfe cum olim veftri hi ciafí panni lana parati ex Italia huc non adpor- 
adportarentur, neque noftri his, ut nunc faciunt, uterentur: Diofcorides in his periculum faciendum non fentit, fed in noltris iis longe gracilioribus. Clarius verò hoc fignum Plinius docuife eft vifus, dum dixit , \& in vefte maculas non faciat, non autem, ut in Diofcoride habetur, „, vefti non adhæreat. , Verius fortaffe Sethus Opobalfami cognitionem ex hoc figno habendam tradidit, quod his verbis apud ipfum legitur: "Lin" teo in eo irrigato, ac poftea fublato, à linteo totum recedit, "non colorem, fed odoris duntaxat fuavitatem relinquens ": quod plane in noftro fic ad unguem obfervare licebit. Coterum ex his, qux ita diveríe de notis verum Opobalfamura à falfo diftinguentibus, apud diverfos antiquos Scriptores leguntur; dubitandum non immeritò à nobis exiftimo, hofce authores nunquam fortaffe, neque viventem plantam ufpiam offendiffe, atque multo minus fincerum ejus fuccum infpexiffe, cunctaque potius aliorum relatione, quam vera obfervatione de eo ab his prodita fuiffe : qua de caufa non ab antiquis Scriptoribus, inter fe de Balfami hiftoria difcordantibus veritas hæc petenda effet, fed ab his populis, præfertimque Medicis, qui loca in quibus Balfamum, omnium Scriptorum confenfu, vixit, perpetuò habitarunt, \& frepiffime obfervarunt. His etenim jure meritò de ipfo firmior fides habenda erit. Hi funt AEgyptii, atque Arabes, qui omnes uno confenfu afferunt, hoc excepto Opobalfamo, quod vos verum effe non creditis, nullum aliud ufquam vel in tota Egypto, vel in tota Arabia, vel Syria, fuiffe cognitum, aut ufitatum. Cujus veritatis clariffmum ac certiffimum fignum erit, aliud Opobalfami genus ab hoc diverfum, apud Turcarum Regem is locis imperantem, atque apud plures Turcas; qui variis temporibus his omnibus prædictis locis, præfertimque Egypto præfuerunt, nunquam fuiffe repertum, quinimo apud hos inventum idem planè efle cum noftro, atque nihil ab ifto communiter recepto differre. Rex enim Turcarum fingulis annis à Seriph, Mechæ atque Medinæ domino, binas, \& plures etiam Opobalfami libras dono miffas accipit, perpetuoque, poftcuam Asypto imperavit, ab ipfo Opobalfamum recepit. Quod fanè idem planè eft cum 
eo, quo omnes Agyptii, Arabes, "Syri, atque alii utuntur: ALPIN. Verum dicis; Nam ego certo fcio idem effe Opobalfamum vulgo receptum cum eo, quod apud multos dominos Turcas Confulefque Venetos habetur, quibus à præfecto Aigypti, ac aliis nobilibus Turcis dono datum fuit, idemque cum eo, quod apud Serenifimum Francifcum Medicem Ducem Florentix à Turcarum Rege olim ei dono datum, hodie confpicitur, quod cum meo etiam Opobalfamo ex Figypto, ad prædictum Sereniffimum Ducem anno fuperiori miffo, rectè ab ipfo comparatum, idem planè effe, certum eft. Quamobrem omnes qui negant vulgo receptum verum efle, fi ipfum cum Opobalfamo comparent, quod apud multos exftat Venetos, slim hujus loci Confules Clarifímos, atque apud alios plures, qui olim hæc loca peragrarunt, \& Opobalfamum à nonuullis Dominis Turcis acceptum illùc comportarunt, probè, an ipfum verum fit, cognofcent. ABDEL. Multum tamen Avicenam admiror, qui dixerit, à goffypio hunc fuccum aqua ablui poffe, cum tamen fuperius dixerit, ipfum in aquam inftillatum coagulari ac denfari: quod cum verum fit, quomodo in goflypio receptum, ac imbibitum, aqua ab ipfo ablui poterit? hoc enim fieri non poffe cuique patebit. Elt demùm alterum $\mathrm{O}$. pobalfamum ex feminibus Balfami expreffum, cujus etiam inter adulterata nuper recenfuimus, quod pro vero fucco Opobalfami aliquando venditur, quod tamen facile, ut dictum eft, ex obfcuriore ejus odore, amarioreque fapore à vero diverfum ab his effe comprehenditur. Ac de Opobalfamo liæc à nobis dicta fufficiant. Reftat modò, ut de Balfami fructibus, \& virgis loquamur, quando multi quoque non defint, qui contendant verum neque Carpobalfamum, neque Xylobalfamum elfe. 


\section{A P U T VI. \\ Teri Carpobalfami, Eீ Xylobalfami cognitio, confideratio.}

ALPIN. T actenus Balfami plantre, atque ab ea educti fucH ci ambiguitates omnes, vir doctiffimè, diffolvilti, veritatemque ita claram effecifti, ut de arbore, ac fuccó noftri amplius contendere non debeant, fed ipfum potius agnofcere, atque in ufum medicinx reftituere, quod quidem facientes fumma laude digni erunt, tantum auxilium in ufum revocantes, atque recipientes. Cum nemo noftrum dubitet amplius verum Opobalfamum ex $\mathbb{E}$ gypto, \& Syria in Italiam comportari, quod facilè à nuper adductis notis ibi an fincerum fit, cognofcetur. Reftat modo, ut de ejusdem plantæe fructibus, \& virgis, quod apud noltros dubii fuperfit ab illorum animis evellas.: Quando vulgaria femina, pro vulgari falfo Carpobalfamo à multis recepta, quorum ad nos fingulis annis multa copia advehitur, verum effe antiquorum Carpobalfamum me judice etiam affirmandum fit. Animadvertendum tamen eft, duplex genus Carpobalfaimi circumferri, \& utrumque pro Balfami feminibus apud nonnullos recipi, quorum unum femen eft terebinthi magnitudine, atque ferè etiam forma, rotundumque \& oblongum, ovo fimile, in extremis acutum, flavum, folliculo nigro rubefcente undique contectum; Hocque verum eft antiquorum Carpobalfamum., Alterum verò Pfeudo-Carpobalfamum huic admodum magnitudine, colore, figuraque eft fimile; differt tamen à vero, quia ipfo eft oblongius, ex medietate tantum folliculo contectum eft, nam illud extremum, quod fuo pediculo appenfum eft, folliculo caret, minimeque eo totum contegitur, fed tantum ad ejus usque medietatem. De hoc vero, quod falsò pro Balfami femine me judice recipitur, non loquimur, quamquam odoratum fit, atque aromaticum.: Illudque fortafse effet, quod olim Diofcoridis tempore ex Petra oppido Arabix pro 
Carpobalfamo adportabatur, \& quo verum Carpobalfamum adulterabatur, fi piperis faporem præfeferret. De altero verò $\mathrm{ab}$ hoc prædictis notis difcrepante, quod præfertim à falfo differt, quia totum folliculo fuo contectum et', quando falfi, ut jam dictum elt, tantum medietas folliculo contecta appareat, a nobis fermo habendus eft. Audin nunc Venetiis omnes Pharmacopolas, confilio excellentifimi collegii Medicorum, in componenda Theriaca, atque Mitridatio, pro veris Balfami fructibus Juniperi fructus fubftituere; quod quanta dignum reprehenfione fit, ac in quanto illi verfentur errore, vobis doctiffimis viris nunquam latuit. Et utinam nunc perfpectis rationibus iidem non permittant fine his tanto artis cum dedecore (quandò hæc omnia non fit difficile apud eos reperiri) Theriacam atque alia medicamenta amplius parari; fed vereor, ne magis in antiquis erroribus perfiltere, quàm rei veritatem amplecti velint. $\triangle B B E L$. Quid? etiam ne fructus Balfami, quorum in Italiam; aliaque loca hinc copia multa advecta, illis non deëlt, negant veros effe, atque pro eis in componenda Theriaca aliisque medicamentis baccas Juniperi fubftituunt? quid de te audio; pudet me tantorum Medicorum, qui hos hactenus veros fructus neglexerint, minimeque his utantur. Sed quibus rationibus adducti, negant ifta femina meritò ex te pro vero antiquorum Carpobalfamo recepta, veros effe fruetus Balfami? An non ipforum magnitudo, color \& forma ad eos recognofeendos fatis illis erunt? Theophraftus dixit: illos effe fimiles terebinthi fructibus magnitudine, figura ac colore. Et clarius Serapio ex Diofcoridis mente hunc in modum eos defcripfit: „Et granum quidem ipfius, quod nominatur Carpobal" famum, eft granum rotundum ad longitudinem aliquantu"lum tendens, ad acuitatem in ambobus capitibus, in medio "vero groffius. Cujus color tendit ad rubicunditatem, \& eft " plenum, grave, mordens linguam mordicatione aliqua non " multa, \& $x$ quandò frangitur interius habet humiditatem fimi"lem melli, \& ejus odor eft bonus. " $\Lambda \mathrm{t}$ Diofcorides addidit hoc femen redolere Opobalfamum. Certè, ut verum fatear, fructus Balfumi ab Italis tuis Medicis, atque Pharmacopxis 
neglecti, tùm Serapionis deferiptioni omnino refpondere cognofcuntur, tùm etiam notis à Theophråto allatis, quando hi colore, figura, atque magnitudine, verè fructibus terebinthi proximi fpectentur. Serapio verò eos multo diligentiùs ac exquiftiùs deciaravit, qui ipfos grana effe rotunda ftatuit, oblonga, extremis acutis, \& medio craffiore, ad coloremque fubrubrum tendentia, gravia plenaque effe, ac modicè guftum mordentia, qux intus fubftantiam melli fimilem habent. Ex quibus notis vulgare Carpobalfamum verum omnino effe certiffimè oftenditur, fed quamobrem ifti negant hos, veros Balfami effe fructus, fcilicet Carpobalfamum antiquorum. ALPIN. Omnes uno ore prædicta femina non una, at omnibus carere predictis notis, quibus ea predita effe Diofcorides, omnium antiquorum in plantarum deferiptione facile primus, memorix olim prodiderat, hifque fpeciatim verbis. "Quare eliga", tur flavum, plenum, grande, ponderofum, mordens guftum, "fervens in ore modice, Opobalfamum olens. " Dicunt itaque iftac femina à vobis pro Carpobalfamo monftrata, non flava, ut Diofcorides docuit, fed nigra, fubrubefcentia fpectari, vacuaque non plena effe, levia \& non gravia, parva \& non magna, neque guftum aliquo pacto mordere, neque Opobalfamum olere. Hifque rationibus negant illa femina verum Carpobalfamum antiquorum effe, fed potius ea, quibus olim ex Petra oppido Arabix advectis, verum Carpobalfamum adulterari Diofcorides animadvertit, quod ipfe hifce verbis docuit, dicens: "Adulteratur femine hyperico fimili, quod à Petra " oppido defertur, fed coarguitur magnitudine, inanitate, vi"rium ignavia, fapore piperis. "Idemque ferè Plinius teftatum reliquit. Atque hæc funt adverfus Balfami vulgares fructus à quampluribus Italix, aliarumque nationum Miedicis , \& Pharmacopæis difputata. ABDACH. Ex his duobus alterum verum effe arbitror, vel illos fcilicet viros, à te recitatas Carpobalfami notas, nunquam probè cognoviffe, aut nunquam hos fructus, vel femina, qux præ oculis omnes hi Pharmacopolse quotidiè habent, infpexiffe, quod fi, illi hæc aliquando infpexiffent, ac rectè obfervaffent, proculdubio fieri non potuiffet, 
ut ex omnibus notis ipfos non agnoviffent veros effe Balfami. fructus, quando non folum falfum fit ipfos omnibus notis à $\mathrm{Di}$ ofcoride traditis carere, fed ne unam quidem illis deëfle. Nam iftre femina func humiditate, melli fimili, plena, quorum fi multa facta intus ii infpexiffent, nifi cxci omninò fuiffent, fieri nullo modo poterat ut non id animadvertiffent. Cernuntur etiam longe hyperici feminibus majora ; funt gravia, cum aliqua mordicatione, atque Opobalfami odoris fragrantia, quorum faporem, atque odorem unufquifque gultu, ac olfactu minimè deltitutus, poterit cognofcere. Nemo mea quidem fententia erit, qui prius Opobalfamum olfecerit, ac guftaverit, mox ifta fracta femina olfaciendo \& gultando, in ipfis eundem faporem, atque odorem Opobalfami apertifimè non cognofcat. ABDEL. Verifima prædicas, neque indigna, ut ab illis Medicis audirentur, ac animadverterentur. Nam hæc femina vulgaria à nobis pro Carpobalfamo recepta, eadem effe, quæ in multis Arabix Felicis locis fupra Balfami frutices colliguntur; omnes, qui illa loca peragrarunt, vere teltantun: neque ullis unquam aliis Egyptii Pharmacopxi pro Balfami fructibus ad componenda medicamenta ufi fuere. Neque aliorum REyptiorum memuria conftat, unquam ex Petra oppido, quod nunc Mecha dicitur, alios, quàm hos fructus pro Carpobalfamo ad nos delatos fuiffe. Neque Galenus exiltimat homines in eorum feminum cognitione hallucinari, ad decipi pofre, quando in libro de Antid. dixerit, Carpobalfamum non poffe adulterari, idque meritò, cum minimè fieri poffe videatur, ut aliquis, qui vera Balfami femina femel tantum viderit, poffet ab aliis decipi; fed concedatur poffe adulterari, tamen cognofceretur id faltem, ut Diofcorides docuerat, inanitate, parvitate, \& faporc piperis. Verum non poffum non vehementer illos Medicos admirari, dicentes, notas à Diofcoride nobis Carpobalfami eo traditas fuiffe, ut ifta femina ab aliis diftinguerentur, quandò ipfe illas notas non ob id tradiderit, fed potius, ut iis homines perdocti feligerent ex feminibus Balfami, ea., quæ flava exiftunt, plena, majora, gravia, fapore atque odore Opobalfami pradita, quoniam hxc cæteris meliora exiltunt. Quis igno. 
ignorat, agricolas etiam ipfos aliqua femina ementes, five triticum fit, five hordeum, feligere plena: magna, ponderofa, optimi faporis, atque odoris, abjicereque inania, parva, levia? Quamobrem iftud? quia hac inutilia, illa optima exiftunt. ALPIN. Dicunt, fiavum colorem, quo vera femina Balfami fpectari Diofcorides tradidit, in iftis feminibus non confpici, cum ipfa fubrubra potiùs, \& nigrefcentia cernantur. ABDELL. Recte dicunt, fed hine conjicitur, ipfos minimè effe in horum feminum obfervatione exercitatos, feduloque nunquam ea infpexiffe, quoniam fi frè multa fedulò, variifque modis obfervaffent, proculdubio duplici colore referta effe cognoviffent, quippè nigro rubefcente, fuis folliculis veltita, hif que fpoliata, ac nudata, flavo. Ex qua obfervatione, nec Diofcoridem, docentem illud femen flavum effe, nec Theophraftum cum Serapione fubrubrum nigrefcens, falfum prodidiffe, patet. Quando hi femen veftitum fuo folliculo, quod nigrum fubrubefcens cernitur: \& Diofcorides, folliculo fpoliatum, quod flavum eft, intellexerint. Hxcque à nobis de Carpobalfamo dicta fufficiant. De Xylobalfamo verò non puto à nobis multa effe dicenda, quando non ita omnibus, ut Carpobalfamum, ignotum videatur effe, illas virgas conmuniter ab omnibus Pharmacopxis pro Carpobalfamo receptas, \& iis tamen non itantur, Argumentum erit certifimum, ipfas redolere odorem Opobalfami, \& Carpobalfami, eundemque guftui faporem etiam præfeferre. Optimæ autem exittunt, farmentofx, tenues, fulvx, \& recenter excifx, odorem Opobalfami manifeftifimum fpirantes. Quem odorem eximium fpirare à Theophrafto ac Serapione proditum eft. His verò recentibus Pharmacopxi uti debent, cum parvo etiam tempore omni odore ac fapore deftituantur ; tanta eft enim illius humidæ fubftantix, in qua odor, faporque fundantnr, tenuitas, ut cito exfolvatur, fimulque cum ea fapor, atque odor evanefcat. ALPIN. Fafcem recentifimarum virgarum Dominicus à Rege, nofter Pharmacopola, ab amico fuo Turca, apud oppidum Sues, illuc Mecha ad́vectum habuit, qui multum Opobalfami odorem fpirabat, qui tamen paucis menfibus ferè om- 
ninò exfolutus eft. Multas virgas recentes habui, quæ apud me adhuc affervantur; quas comparatas cum iis, quæ apud Venetos Pharmacopolas funt, eafdem utique effe fine dubio cognofcitur, quæ fi recentes confervarentur, veritas hæc omnibus effet manifeftiffima, ita validus, ac manifeftus in iis odor Opobalfami perciperetur, ex quo omne dubium ex ipforum animis fpontè excidiffet. ABDEL. Tibi fufficiat, hæc de Balfami planta, fucco, fructibus, virgis, ex-nobis audivifie, atque didiciffe, veramque hanc hujus plantæ iconem, nunc, $\Lambda \mathrm{l}$ pine, fpectare poteris, atque ex dictis ipfam recognofcere. Sed abfoluto de is fermone, cum jam Sol fupra Horizontem multum afcenderit, aëremque inflammare ceperit, fatiùs erit nos hinc abire, \& in urbem redire, priufquam augeatur caloris $x$ ftus. ALPIN. Rectè fuades, abeamus, vobifque, quod tantum hactenus fufceperitis laborem, multas gratias refero, meque ut pro veftra humanitate ametis, quemadmodum facitis, etiam, atque etiam rogo; valete. ABDEL. Atque tu interim vale; mementoque nos tui efle ftudiofifimos, teque multum, atque multum obfervare.

\section{A P U T VII.}

Cur Petri Bellonii objervationes in Egypto circa Balfami Plantam facta bic adno-tate fint.

Cum hifce diebus librum olim in Egypto à me de Balfamo confcriptum in publicum emiffurus effem, Ecce in manus meas perveniunt doctiffimæ itinerariæ obfervationes à Petro Bellonio Cenomano, viro tùm in aliis, tum in plantarum materia doctifimo, ante annos ab. hinc quadraginta litteris traditæe, atque hoc tantum anno in licem editæ. In quibus cum Balfami nonnullarum plantarum olim in Egypto viventium diligentiffimam obfervationem ab eo rectifimè exaratam, ac defcriptam legerim, optimum fore putavi., fi eam fub fine hujus 
jus libelli adjicerem, Siquidem fperavi, ex tanti viri in plantarum materia exercitatifimi, lectione, ea, qux dicta funt a nobis, ac litteris de Balfami hiftoria mandata, pofle haud parùm animos legentium confirmare, quod is omnia ferè complexus fit, quæ in meo libello leguntur. Hæcque, priufquàm Balfami obfervationem Bellonii hic adjeciffem, præfari libuit; ne ex abrupto hic ea inferta candido lectori viderentur.

\section{A P U T VIII.}

\section{Agyptii Balfami obfervatio ex Petro Bellonio in libro II. Itinerariarum Obfervationum, capite $X X X I X$ collecta.}

n quodam pago fpectatum ivimus hortum Balfami frutici1 bus confitum, qui à Cayro longius haud abeft, quàm Lendit à Lutetia. Quoniam porrò Balfami planta admodum celebris, preciofa, raraque eft ; hic fcribere libuit quidquid ad ejus hiftoriam pertinere arbitrati fumus. Quofdam efle fcimus, qui Matareæ Balfamum ex Judæa delatum effe putent : rem autem haud ita fe habcre, poltea demonftrabimus. In magno quodam horto funt, fed angulto loco muris conclufa, quos extructos fuiffe ajunt, poftquam Turca Egyptum Sultano ademit : Bacha autem à Turcarum Imperatore huic regioni præfectum, ea arbufta digna exiftimaffe, quæ peculiari loco concluderentur. Cum iftic effemus, novem, aut decem duntaxat frutices ejus aderant, qui nullum liquorem præbebant. Inter notas à veteribus proditas, quibus Balfamum dignofci posfit; una eft, ut perpetuo vireat : illud tamen in Matarea, apud Cayrum, pauca admodum folia Septembri menfe habebat: quod nobis infolens vifum eft. Nam reliquæ arbores, quæ hyeme virere folent, folia folum novo vere abjiciunt, cum videlicet nova germina produxerunt : folentque autumno magis virere, quàm novo vere. At reliquæ, quæ folia abjiciunt, id fub hyemem facere folent, ut æftate nova adquirant. Ideo- 


\section{PROSPERI ALPINI}

que nobis preter naturam videbatur, Balfamum folia abjicere, ut hyeme nova germina produceret: nobis enim id oblervantibus, quæcumque habuit folia, recens nata erant. Ejus juftam magnitudinem tradere nequimus; nam quotquot ejus frutices in horto aderant, ftipitem folum habebant pedis longitudine, \& pollicari crafitie, tenuibus ramulis præditum, raris foliis obfitis. Ubicumque autem tandem nafcantur, duorum aut trium cubitorum altitudinem non fuperant; \& pedali altitudine cum fint, in multos graciles ramulos anferinx pennæ caule haud craffiores finduntur. Balfami frutices Matarex jam recens putati fuerant, fic ut foli ftipites fuperefient, qui ramulornm rudimenta producebant. Ejufdem etenim eft Balfamum cum vite naturæ, quam fingulis annis putare neceffe eft, alioqui degenerat. Nova illa Balfami germina fubrubente cortice erant te\&ta, foliaque viridia habebant, lentifcinorum foliorum modo formata, hoc utrinque in nervo nata, ut in rofarum, vel fraxini, vel juglandis foliis videre eft, ciceris tamen foliorum magnitudinem non excedebant, ficque conltrueta erat corum feries, ut poftremum foliolum extimam alam occupans, imparem numerum efficeret: nam totius al $x$ foliolis numeratis, terna, quins, aut feptena inveniuntur, feptenarium certe numerum fuperare vix ammadverimus : extremum autem foliolum reliquis majus eft, facto etenim ab illo progreffu, reliqua fenfim minutiora fiunt, ut in rutæ foliis. Plinius in ejus Hiltoria Theophraftum per omnia fequutus eft, quemadmodum etiam Diofcorides, ejufque veftigiis infiftentes, Balfami folia rutæ foliis compararunt: quod veritati confonum effe deprehendimus. Quoniam autem primum in Matarea illud exacte non obfervaveramus, denuo illud fpectatum ivimus, ejufque ramulum nacti, ipfum, atque illius folia deguftavimus, qux facultatis nonnihil adftrictorix effe comperimus, pinguifque aliquantulum faporis, atque aromatici, ramulorum autem cortex his odoratior eft; gemino cortice præditi funt ramuli, extimo foris fubrubente, qui ut membrana intimum viridem operit. Is gultatus inter Thus \& Terebinthi folium fapit, faturejx filveftri fapore fimili, admodum grato, atque digitis tritus cardamomum olet: 
ipfum lignum candidat, odorifque \& faporis expers eft, non fecus atque aliud inutile lignum. Ipfius virgæ reetx funt \& graciles, rarifque foliorum alis fparfim \& confufo ordine nafcentibus obfeptx, qux (ut diximus) ternis, quinis, aut feptenis foliolis conftant. Varix funt auctorum, qui de Balfamo fcripferunt opiniones: \& nifi nos ipfi plantam confpexiffemus, nihil poft illos de eo fcribere aufi fuiffemus: atque in eam ferc̀ opinionem inclinaremus, illud Hierico planis numquam cultum fuiffe. Quia autem ipfum fruticem vidimus, diligenterque obfervavimus, de eo, tanquam de re quix diligenti obfervatione digna, differere libuit. Experientia autem didicimus lignum illud vulgo Xylobalfamum nuncupatum, quod ex Felici Arabia delatum à mercatoribus venditur, cum Esgyptio quod in Matarea colitur, convenire: nam deficcatum noftrum Balfami ramum cum eo, quod in officinis venale reperitur, contulimus, atque omnibus notis refpondere, deprehendimus : eftque ex duobus alterum neceffarium, aut Xylobalfamum \& Carpobalfamum, quale in officinis venditur, adulterinum effe, aut illud $\mathbb{E}$ gyptium, quod colitur in Matareæ horto, legitimumque Balfamum effe cenfetur. Nam cum in omnibus conveniant, certique fimus idem effe, afferimus, \& concludimus id, quod hoc nomine venale reperitur, fimile ei effe, quod ab omni antiquitate in ufu fuit. Balfamum nune temporis in fola Esgypto colitur apud Cayrum. Et licet Theophraftus in ea opinione fit, id filveltre \& fponte nafci non inveniri: afferere tamen audemus, ab omni $x$ vo in Felici Arabia füiffe, atque etiam nunc nafci, cujus lignum, \& fructus etiam olim ad nos perlata fuerint cum aliis Arabix mercibus. Atque demonftrare volumus ea non minus cognita fuiffe mercatoribus, quàm reliqua aromata, ut ex medicamentorum, quibus perpetuò injici folita funt, compofitionibus apparet. An non Mithridates in fuum Medicamentum intulit ? An non in officinis venalia reperiebantur ? Id ex fola Diofcoridis anctoritate probari poteft, qui in fua ætate Carpobalfamum adulterari conqueritur. Carpobalfamum (inquit) adulteratur femine hyperico fimili, quod à Petra oppido defertur: per Petram s-

op- 


\section{PROSPERI ALPINI DE BALS. DIAL.}

oppidum Mecham intelligimus, atque de Xylobalfamo : e ligni genere, quod Xylobalfamum vocant, probatur recens, farmento tenui, fulvum, odoratum, quadantenus Opobalfamum fpirans. Ex his liquido apparet vulgaris ufus inter reliqua aromata fuife. Sed \& ex Diodori Siculi vetuftifimi Scriptoris $\Lambda$ rabiæ Felicis opes enumerantis, verbis, manifelto liquet. Maritimis enim locis Balfamum producere, ait. Cultum igitur id effe non intelligit, fed fpontè nafcens. Paufanias etiam tradit Balfamum Arabix fruticem effe. Plerique tamen auctores de Balfamo agentes, inter fe non conveniunt. Nam Strabo prodit in Syria nafci apud lacum Genezareth, inter montem Libanum \& Antilibanum. Reliqui volunt folam Judæam regionem id producere, ejufque ramos offeo cultro, aut vitro duntaxat vulnerandos effe ad liquorem eliciendum, alioqui fi ferro cædantur, ftatim emori. Cornelius Tacitus feribit, ferro juxta adpofito, metu exhorrefcere, idcirco aliis quàm ferreis inftrumentis vulnerandum, fi liquorem elicere quis cupiat. Percontantes à mercatoribus Cayri de Balfamo, cum noftrum ramulum conferremus, nobis affirmarunt, quidquid Xylobalfami, vel Carpobalfami unquam vendidiflent, id omne ex Mecha cum aliis aromatibus accepifie; atque meminiffe fuo tempore Balfami frutices, qui nunc in Matarea coluntur, ex Arabia Felici delatos effe, magnis fumptibus Sultani. Quoniam verò id nobis tam multi affirmarunt, exiftimavimus fine ullo fcrupulo aut difímulatione nobis licere id fcribere. Laus Deo Opt. Max. 


\section{PROSPERI ALPINI MAROSTICENSIS, PHILOSOPHI, MEDICI,}

Et in Gymnafio Patavino Medicamentorum Simplicium Profefforis ordinarii, \& Horti Medici Præfeeti,
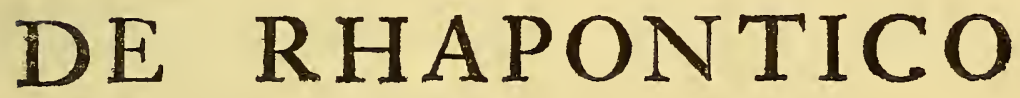

\section{DISPUTATIO IN GYMNASIO PATAVINO HABITA.}

In qua $\mathrm{T}$ hapontici planta, quam hactenus nulli viderunt, medicinæ ftudiofis nunc ob oculos ponitur, ipfiufque cognitio accuratius expenditur, atque proponitur,
A D

Perilluftrem \& Excellentiffimum

D.D. BENEDICTUM SYLVATICUM,

Patavinum, \& in Patrio Gymnafio Medic. Pract. Profefforem. 


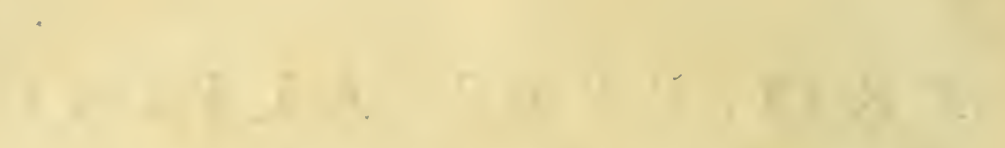

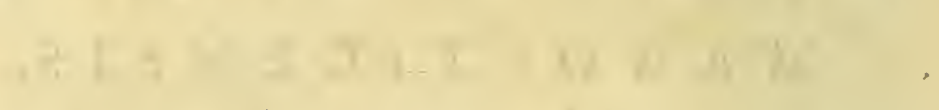

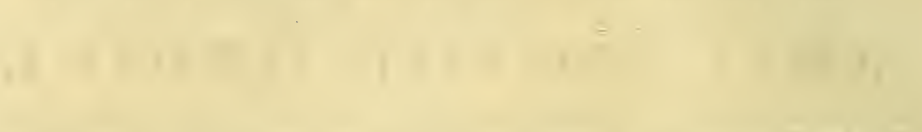

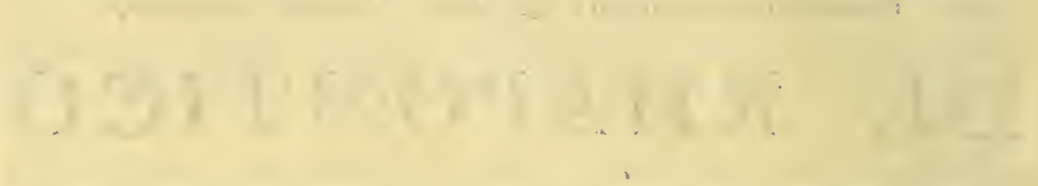

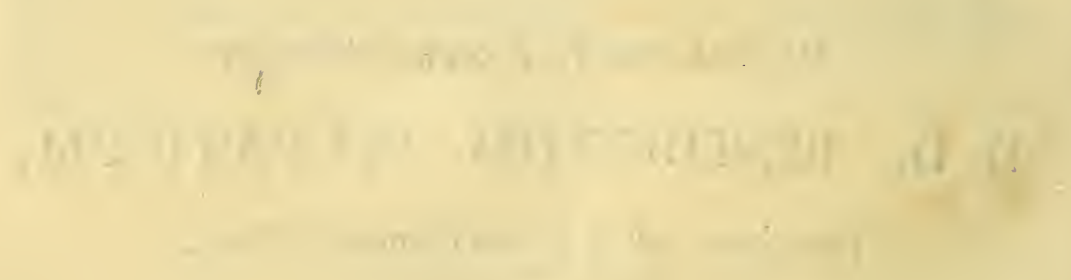




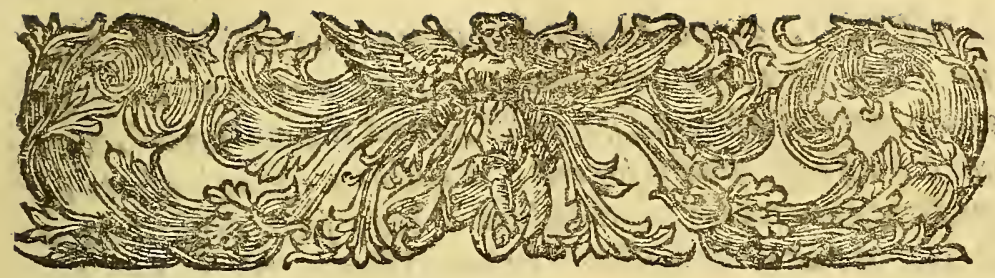

P E R I L L U S T R I AC DOCTISSIMO VIRO,

\section{BENEDICTO SYLVATI CO PATAVINO,}

IN PATRIO GYMNASIO MEDICINAE

\section{Praxim Profitenti,}

PETRUS BERTELLIUS S. P: D:

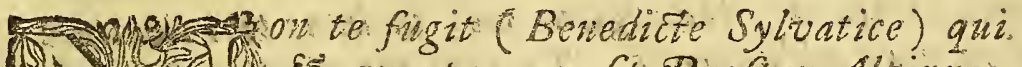

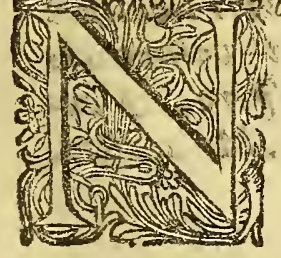

E. qualutus wer fit Prosper Alpimus, cum aliis bionis artibus, tam in medici$w a$, छ. in fcientia plantarum; Eౌ quam curet fedulo, mullis laboribus aut fitmtibus parcens, ut Horti Medici, quibus praeft, fint omni ftirpium, etiam exoticarum, genere inffructifimi. Ejus igitur difputationem de RHAQ2 PON. 
PONTICO, quam fummis omnes, qui illi interfuerant, laudibus profequebantur, recens nactus, eo melius mecum actum efle duxi, quod fi eam imprimendarn curafem, fudioforum, à quibus efflagitabatur, cupiditatem explere potuiffem. Non fuit difficile aut hoc impetrare ab allctore humaniffimo, ซु fud tiis juvandis nato, aut aliquem reperire, cujus nomine liber commendatior in lucem prodiret. Tibi enim proculdubio debebatur. Te enim unum ex omnibus pracipue colit, atque admiratur, non Alpinus modo, sed etiain Francifcus Crafjus, tuns olim auditor a fiduns, qui banc plant am noglro avo ignotam Italis, ac Transalpinis, femel हु iterum ex remotifimis regionibus buc advebendam curavit, $\mathfrak{F}$ Alpino dono dedit: ita ut wemo Sit, quem tibi anteponam. Accedit gentis tue Splendor, fatis ipse.notus per se, Eg feliciore doctorum virorum fylo celebratus. Cumulantur bec omnia animi tui bonis : precipuè vero bumanitate, litteris interioribus, atque ea medicina cum docende, tum facienda peritia, ut inter paucos excellas, plerofque omiles brevi fuperaturus. Neque enim eft quifquam quin fibi perfuaferit, ut parta jam gloria peperit exSpectationem, ita expectatio fit gloriam multo majorem paritura: Hac igitur me, ut bunc tibi libellum dicarem, adduxerunt. Iu eum maxima voluntat is erga te mere acceffone cumulatum, ut Spero, हु cupio, boniconfules. Vale Patavii. Dei.30. Maji. 1612. 


\section{PROSPERI ALPINI \\ MA AOSTICENSIS, \\ D E}

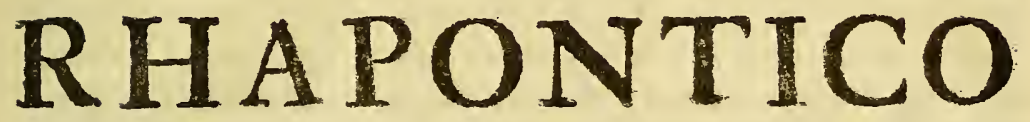

Dufputatio, in Patavino Gymnafio habita.

$$
\text { C A P U T I. }
$$

De Rbapontici planta, quam proximis annis in Rbodope Thracice monte vivere compertum eft, cur agendum fit.

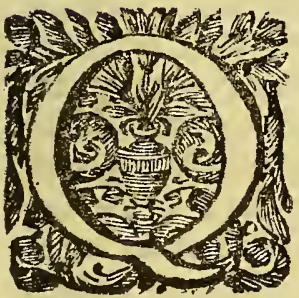

uod Rheon, feu Rhaponticum fuerit perpetuò magni ufus ad medicinam, \& ad præclariorem quoque antidotorum compofitionem magnopere defideratum, atque longo tempore omnibus medicis, pharmacopxisque ignotum (proximis enim xtatibus, non fine magno artis medic $x$, \& dedecore, \& mortalium damno, pharmacopæi pro Rhapontico fubftitutis utebantur) utile fore exiftimavimus, fi de hoc Medicamento præfenti hoc anno, priufquam legendi finem. faciamus, etiam ageremus, vobifque demonttraremus nos verum Rhaponticum antiquorum habere. Præfertimque cum ab hinc quadriennium (Divino bene afpirante numine) factum fit (quod jam diu multum, multumque defideravimus) ut Rhei five Rhapontici plantam antiquorum legitimam, Rhagufio, opera perilluftris, \& excellentifimi philofophi, medici, \& in fimplicium medicamentorum ftudio non parum exercitati, Fran- 
cifci Crafti Rhagufini, Patavium convectam, nacti fuerimus: cui profecto viro \& nobili, \& preliberali, hujus atatis medici firpiumque cugnitionis ftudiofi plurimum debebunt, utpote qui R hei plantain in Italias nullis antex vifam, nullifque cognitain, pre multa ipfius liberalitate \& videre, \& cognofcere potuerint. I Ixc (inquam) planta ter ex Thracix montibus khodopais vocatis (in quibus fponte nafci, \& vivere eam plantam ab aliquibus.fuerat prius animadverfum ) in planicie, ad. fonten Hebri fluminis poilita, eruta IR hagufium delata in itinere propè interierat, fed poltea denuo ex iifdem natalibus procuraa Rhagufum vivens deducta eft, quæ exinde Patavium incolumis convecta, milique à pradicto Francifco Crafto dono data in fecretiori meo hortulo fuit repofita. Qux ibi opportunum fibi folum nacta, ita perbelle multos annos vixit, \& mire aueta elt, ut merito quadam veluti infita majeltate ex amplifimis, latifimifque foliis mira arce ita confectis, ex caule, floribufque multis candicantibuss, non injucundè etiam 0 . lentibus, à multis hactenus herbariæe cognitionis ftudiofis, atque $a b$ innumeris ferè aliis viris nobilibus, illuffriffimifque plurimum admirata fuerit, multifque laudibus concelebrata. Hæc (ut ipfam defcribanus)folia liabet magna, ampla, quadamtenus ad lappre magnæ figuram accedentia, fed longe majora tamen, \& latiora, ad magna Colocafix E Egypiacæ folia itidem: multum inclinantia: veruntamen $\&$ ab his, atque ab aliis omnibus ipfa formanr differentem habent, atque ita, , ut nulltum folium in aliis plantis animadvertatur, quod iftiufce plantæ fo: lia exactè referre, atque æmulari videatur. Id verò proprii habent, 'ut ipfa in circumferentia quibusdam miris circumvolutionibus agantur, quibus magnas cavitates exprimere. videntur. Colore vero viridi in nigrum inclinante fpectantur: neque terram verfis procumbunt, at furfum in aerem ex fuis pediculis longis, Jatis, crafiss, intus cavis, extrà convexis, fèruntur. Qux folia cum pediculis fine odore funt, fapore verò linguam, fübacetofo haud' injiłcundo afficiunt. Planta verò̀ cálem è medio follorun producit unicum: ut femel' in hac planta vidimus, cubitalem, \& ampliorea etiam, foliis concolo- 


\section{DISP. DE RHAPONTICO.}

lorem, fed quadantenus ad rubrum declinantem, friatum, geniculatum, à cujus geniculis ramuli reeti exeunt duo vel tres utrimque, cum unico follolo circa cacumen in alios nultos fcopæ modo expanfos; divif, flofculis albis, floribus fambuci fimilibus; racematim undeguaque congeltis, contecti. Porrò flores non injucundè olent', guftuique faporem fubacidum gratumque inducunt. Ab ipfis femina producuntur parva, figura triquetra, nigrefcentia, fuis parvis folliculis inclufa, Hippolapathi feminibus omnino fimilia. Planta nititur radicibus multis ab uno germine, vel à multis gracilibus, centaurei majoris fimilibus, fed minoribus, ftatim alterra erutis, colore ex toto rufis nigrefcentibus, fed poltea radices ficcatæ exterius nigro colore fpectantur, interiusque rufa exiftunt, germini vero non rectè in terram deorfum, fed obliquè aguncur, atque protenduntur. Qux radices etiam ftatim è terra effof fine odore funt, fubftantiamque raram, laxam, levem, atque rufam habent, qux commanducata croci colore tingit, \& fi plufculum in ore agitet, glutinis modo lentefcit, fubacremque non expertem alicujus levis amaritudinis faporem guftui infert. Hæc planta, ut deprehenfum eft, fingulo triennio abfoluto floret, atque femina producit. Quix in agro Patavino fata ita facile nafcuntur, ut fperandum fit, brevi tempore Rhapontici plantam ubique locorum propagatam iri. Unde medici, \& pharmacopri non amplius opus habeant iftiufce plantæ radices peterè ex longinquis regionibus, in quibus nafcuntur, nempe ex Scythir, vel Thraciæ locis ipfus natalibus. Hoc noftro quoque ævo hanc plantan abundantius in Scythix campis vivere Joannes Quirinus Cinglerus Germanus, philofophus, medicus, \& in fimplicium medicamentarum ftudio apprimè eruditus, ab hinc annos multos, cum Scythice loca perluftraret, obfervavit: inquit enim fe in ipfius campis hanc plantam latiùs olim virentem offendiffe, \&.obfervafle, Medicumque Italum ibi medicinæ caufa commorantem cognoviffe, qui agrum habebat Rhaponticis refertifimum; quorum profeEtò radices, lucri caufa, quotannis ad exteras nationes transmittebat. Ex cujus fanè viri relatione perfpectum habui 
(ubi ipfe, qui meam Rhapontici plantam nunquam viderat, neque vidit, Scythicam Rhei plantam diligentiùs mihi delineasfet) Thracicum Rhaponticum, quod juxta montes Rhodopreos nafcitur, quodque in Patavino horto nunc alitur, idem effe cum scythico ab eo viro confpectum, atque obfervatum. Itaque iftiufce plantx, quam in horto nunc habemus, occafione, cum nos Rhapontici cognitionem fatis manifeftam confecuti fuerimus, eandem quoque vobis communicare volentes, de Rhapontico, hoc etiam anno, priufquam lectionibus hujus anni finem imponanus, publice in fcholis verba facere inftituimus. De quo quidem in prefentia fermonem habituri, primum quid Rhaponticum antiquorum fuerit cognofcere operam dabimus. Secundò, an hoc noftro ævo habeatur, \& cognofcatur: Qualiaque medicamenta fuerint à multis pro legitimo Rheo propofita. Tertio, an Rhapontici planta fuerit veteribus cognita, atque an hac ætate alicubi vivat, \& cognofcatur. Quartò, Thracicam Rhapontici plantam Lapathi genere comprehendi demonltrabimus : \& quot fint ipfius genera confiderabimus, \& ex radicibus Lapathorum, qux ad Rhaporticum, quibus veteres medici utebantur, accedant, quibusque fignis à legitimo diftingui debeant. A'que demum de Rhapontici viribus, atque ufibus medicinæ oportunis loquemur. Hifque omnibus perfpectis, probeque cognitis, addemus accuratiffimam \& plantre iftius, \& radicum oftenfionem.

\section{A P U T II.}

\section{Rhaponticum quibus nominibus variis gentibus innotuerit, quidque ip sum fuiffe conftet.}

$\mathbf{R}$ ha, \& Rheon Grxcis primum vocata, fuit radix quondam $\mathbf{R}_{\text {medicinæ ufui maximè cognita, à Scythix flumine Rha nunc }}$ Volga dicto (quoniam juxta ipfius ripas, ut Ammianus Marcellinus in libr. xxIr. cap. 8. fuarum Hiftor. eft auctor, eam plantam vivere deprehenfum fuerat). appellata. Deinceps verò Rheu- 
ponticum, \& Rhaponticum dictum eft, aut à Ponto ipfus folo nativo, ut Marcellus Virgilius voluiffe vifus eft, aut quod primo ipfum in Pontum convehi cxperit, ex locis fcilicet filpra Bofphorum Thracicum, in quibus familiarius nafcebatur, utpote ex Scythire planiciebus juxta furpercilia fluvii Rha tunc temporis nominati, qui altera flexione, ut à Geographis traditum eft, Tanai flumini, quod in Pontum Euxinum labitur; appropinquat. Itaque Rheon, aut Rha, vel quia Ponti radix fuit, vel quod primum in Pontum delata, ad alias exinde nationes dimittebatur, propterea ibi quafi nomen, cognomenque nacta, Rhaponticum dicta eft. Quare \& Mefuem hanc fortaffe radicem $R$ ha Turcicum haud injuria appellaffe aliqui exiftimarunt, ̀̀ Turcis nimirum, qui olim ultra Tanaim fedes habuerunt prope Sarmatas Zygos, nunc Circaflos dictos, in patentibus illis campis Rhaponticum ad exteras nationes mittebant. Turcx verò ipfum Rhavend primi appellavere, à quibus poftea \& Arabes eodem nomine ufi fuerunt. Et exinde etiam, quia radix barbarica (vulgo Rhabarbarum dicta), quæ ex Indix locis adportari poftea cæperat (quod cum Rhavend magnam fimilitudinem in radice, colore, faporeque, \& viribus habere vifa fuerit) idcirco Arabes, cum primum ad ipfos ex India delatam hanc vidiffent, eodem nomine \& ipfam dixerunt, fcilicet perfuafi Rhaponticum à Barbara radice fpecie non differre. Horum verò aliqui à natalibus, ex quibus radix deferebatur, Rhavendfeni, à Chinæ regione, in qua nafci eam radicem putabant, nominarunt, aut Sceni, vel Cini à Scenitis Parthorum natione, qui Ariæ, \& Margianz montes habitant, in quibus Rhabarbarum provenit. Namque Arii, Margiani, Arachofii, \& alii populi provincia Tangut, Campionenfibusque fnitimi, communi vocabulo Cini, \& Maucini etiam hac ætate nominantur; \& optimum quoque Rhabarbarum Rhavend Succuir à quibufdan dietum eft, quod fcilicet nafcitur in montibus Succuir, civitati pofitæ in provincia Tangut, proximis. Hisque nominibus Rha, feu Rheon antiquis innotuit. Quibus præmiffis, quid Rha, feu Rheon, feu Rhaponticum, feu Rhavend fuerit apud antiquos, nunc fupereft cognofcendum. Cum 
vero fimplicium medicamentorum cognitionem ex uno pras fertim Diofcoride venari, acque affequi teneamur, meritò primùm qux ipfe de hoc medicamento pofteritati tradiderit, funt a nobis animadvertenda. Inquit autem in lib 3. de Mac. Med. c. 2. "Rha ailqui Rheon, aliqui Rhiam, Latini Rhaponticum "vocant; provenit in iis, quæ fupra Bofphorum funt, regionibus, 2, ex quibus affertur. Radix nigra centaureo magno fimilis, fed "minor, ac intus rubicundior, laxa, feu fungafa, aliquan"tum levis, fine odore: optimum habetur quod teredines non " fenfit, fi guftatum cum remiffa adfrictione lentefcat, manducatumque colorem reddat pallidum, aut quodammodo ad "crocum inclinantem.", Hactenus Diofcorides de Rhapontico. Ex quibus quidem nobis conftat Diofcoridis ætate Rhaponticum radicem fuiffe centaureo magno fimilem, minorem tamen, exterius quippe in cortice nigram, interius rufam: qux cum mandebatur, tingebat pallido colore ad crocum inclinante: cujus fubftantia fungofa, \& aliquantum levis erat, fine 0 . dore; quxque guftata, cum remiffa adftrictione in ore lentefcebat. Serapio ex Diofcoride in lib. Simpl. c. 206. addidit faporem amarum, quem faporem nulli codices ex iis, qui nunc extant, habent. Avicenna in libr. 2. tract. 2. c. 585 . ait in ipfo efre amaram fubftantiam. Galenus in 1. de Antid. cap. 14. verò fcripfit, quod fi plufculum mandatur; fubacrem faporem edere. Veritas eft, Rhaponticum habere fubacrem faporem cum leviffima amaritudine, vel effe cum levi excalfactione. fubamarum. Diofcorides nullum ejus faporem, ut ex Gracis codicibus, qui nunc extant, colligitur, expreffit, fortaffe, quia fapor amarus \& calidus fit admodum obfcurus, qui non nifi (ut Galenus animadverterat) in ore plufculum radice agitata, fentitur; vel etiam quia pro fapore exprimendo fat fuiffe credide. rit dixiffe (manifeltiorem ipfius faporem notando) quòd guftatum in ore cum levi adfrictione lentefcat. Caterum ex Galeno redditur admodum confufa, atque incerta cognitio de adftrictione in hac radice obfervata, atque de ipfus fubftantia, quando vifus fuerit nobis expreffife optimum Rhaponticum, fincerum, non adulteratum effe vehementer adftrin- 


\section{DISP. DE RHAPONTICO.}

Fens, \& ex toto ipfius fubftantiam efle compactam, quandoquidem adulceratum (ut inquit) remiffam habeat adfrictionem, \& fubftantiam non compactam, fed laxam. Antiqui enim Rhaponticum hac ratione (inquit ille) adulterabant: Erutas è terræ radices in aqua ebulliebant, qua ebullitione fuccùm à radicibus extrahebant, in quo virtus præcipua ac maxima confiftit, fervabantque ad ufum, \& radices ita elixatas poltea ficcabant, ficcatasque vendebant, atque hoc erat Rhaponticum adulieratum ex Galeno. Quam rem Galenus nobis ita expreffit, dicens in lib. 1. De Antid. c. I4. , In Rheo quoque fraus ", committitur. Nam quibus in locis nafcitur, fimulaique e", vulfum eft, ipfum elixant, quo fuccum remittat, ac tam , fuccum ut fincerum \& aqua impermixtum, quam Rheon exficcatum ut non elixum ad nos poftea mittunt. Quamobrem fcientia opus eft verum ab adulterino difcernendi, quam facillimè confequuntur, qui fuæ fpontis Rheum ali quando viderint. Nam elixi pars, qux fub afpectum venit, denfa per totum \& compacta non eft, fed rarior, \& guftu tentata faporem adfitringentem vel nullum vel obfcurum remittit; cum tamen, fi adulteratum Rheum non fit, vehe.

menter adftringat." Hæc Galenus. Qua fi vera funt, profecto nobis Diofcoridem pro optimo Rhapontico adulteratum, \& non bonum expreffife liquido conftabit; fiquidem dicebat Diof corides: "Optimum habetur, fi guftatum cum remiffa adftrictione lentefcat: "Affirmabat quoque radicem effe fungofam, \& aliquantum levem. Si autem Rhaponticum fincerum \& optimum ex Galeno' debeat habere vehementem ad. ftrictionem, \&r radicem ex toto denfam, \& compactam effe oporteat, profecto, dicendum erit perperam Diofcoridem do. cuiffe optimam Rhei radicem fungofam, \& aliquantum levem effe oportere, \& guftatam cum levi adfrictione in ore lentefcere; quinimo res contra fe habebit, nimirum, quod optima Rhei radix (ut Galenus voluic) erit denfa undique, compacta, gravis, \& guftata faporem vehementer ftipticum præ fe ferat: Quid igitur dicemus? quid in hac controverfia ftatuendum? An non cum Diofcoride erit fentiendum? fcilicet 
optimam Rhapontici radicem debere effe raram, fungofam; levem, cum remiffa adftrictione?. Certè quidem à nobis ita creditum eft: Neque immerico fanè, cum omnes, qui de tem= peramento, \& facultate Rhei radicis feripferunt, affirmaverịnt Rhaponticutn quiảaam terreftre frigidum, quo adttringat, habere, non multum, quo multum aditringat; atque miftam habere aëream fubltantiam, qua neceffe elt, ipfam radicem non oportere ex toto denfam \& compactam effe, fed aliquanto laxam \& levem, ut Diofcorides expreffit. Quid amplius? an non ipfemet Galenus in libris Simplicium confirmaffe vifus eft Disfcoridis fententiam, quod nimirum radix Rhaponticj fit laxa, \& aliquantum levis, cum levi \& non multa adftrictione. Hoc fanè ex ipfius verbis apertifímè cognof́citur, cum ita 8. lib. Sinpl. de Rhapontico f́cripferit: „, Reum (quidam id "Rha nuncupant) mixcam habet tum temperaturam, tum fa"cultatem: habet enim quiddam terreftre frigidum, ceu indi" cio eft adftrictio, \& adjuncta eft quxedam illi caliditas: fi"quidem fi plufculum mandatur, fubacre confpicitur: Quin"2 etiam aërex cujufdam fubftantix fubtilis eft particeps : quod "indicat tum laxitas, tum levitas." Ex quibus verbis conltat Rheum aliquid adftrictionis habere, cum dicat quippiam terreltre frigidum habere, non multum, in quo multa adftrictio fundatur: ergo non vehemens adftrictio optimo Rhapontico ineffe poterit, cum terrena fubftantia, in quo adftrictio confiftit, modica fit. Quid clarius? Fatetur poftea ex aërex fubftantix mixtione radicem habere laxitatem, \& levitatem. Qux omnia is, qux in primo de Antidotis feripferat, planè videntur contraria. Unde furpicari meritò poffumus, eum, quo tempore feripferat libros de Antidotis, haud probam Rhapontici cognitionem habuife. Contraria iis, quix ibi Galenus ferip fit, Avicennam quoque tradidiffe conftat in lib. 2. tract. c. 58. Ita enim fcribit: "Quandoque adulteratur hoc mo9, do: Decoquitur, \& affumitur ejus aquofitas, \& deficcatur " fuccus ejus, deinde exficcatur fub/tantia ejus poft illud, \& "2, venditur ficut eft: \& purum eft vehementius, rarum; \& 9. minus ftipticum, \& eft crocex tinctura.' "Et poftea idem 
affirmavit dicens: "Et quod de ipfo purum eft, eft minus fti"pticum. "I Itaque ex. iis colligimus cum Diofcoride, radicem Rhapontici, qua optima eft, oportere effe leviter adftringentem, raram, \& aliquantum levem. Notandum tamen ex is radicibus illas, quæ annofiores funt, duriores magis, magisque adftringentes effe, minus laxas, minufque leves, quam fint juniores, \& teneriores; hæ namque laxioris, \& levioris fubftantix exiftunt, \& minus adftringunt. Quas juniores Galenum pro adulteratis, fcilicet elixatis, in primo de Antidotis forfitan accepiffe' fufpicamur : cum ha fint minus probandæ ad ufum. medicinx, quam illex, quæ adultioris funt ætatis, annofioresque: nam ha duriores, \& compactiores funt, \& plus juniori. bus adftringunt: Unde has fortafle credidit Galenus efle, quae fua ætate non adulteratæ, fed finceræe ab omnibus eftimabantur. Plinium in lib. 27. Hitt. Nat. c. I2. quoque fuum Rheum, quod Rhacoma ab ipfo dietum eft, notis \& fignis à Diofcoridis Rhapontico haud diffimilibus depinxiffe conftat : Cum ita de eo frripferit : "Rhacoma affertur ex iis, que fupra Pontum „. funt, regionibus. Radix cofto nigro fimilis, minor, \& ru" fior paulo, fine odore, calfaciens guftu, \& adftringens: ea" dem trita vini colorem reddit, ad crocum inclinantem. In. ". clinat enim hæc radix ad calidum, cum aliquali ftiptica fa" cultate. "Hæc funt, qux pro cognofcenda Rhei radice fuerant à nobis præmittenda, atque animadvertenda. De iftius verò radicis planta neminem veterum feriptorum feripfiffe conftat, uno quodam excepto Hefiodi antiquiffimo commentatore (quam rem nos pofterius diligentius confiderabimus) qui dixiffe vifus eft, lapathi radicem olim Rheum appellatam tuiffe. 


\section{CA P U III. \\ An bac etate verum Rbaponticum antiquorum ad nos convebatur, at que cognofcatur.}

Superiori ætate antiquorum Rhaponticum nobis minimè no5 tum fuife, eo argumento deprehendimus, quod non paucos pro ipfo fubftitutis ufos fuiffe conftet. Alii namque ex pharmacopris, \& medicis, Rhei loco radice centaurei majoris ad medicinæ ufum uf fuerunt; -cujus quidem plantam incoIre montis Sancti Angeli, in quo copiofius provenit, in Apulia Rheuponticum appellare Andreas Matthiolus eft anctor. Alii illiufce plantæ, quam Lobelius Rha capitatum nominavit, radicem pro Rhapontico fubftituerunt. Non pauci verò cum Rhabarbarum, tum iplius Rhabarbari radices graciles, caudatasve Rheum antiquorum effe voluerunt: cujus opinionis $\mathbb{A}$.gyptios medicos fuife eo tempore, quo in $A$ Egypto medicinæ exercendæ caufa olim demorabamur, animadvertimus, filicet quod Rhabarbari radices eas parvas, gracilesque crederent legitimum R haponticum antiquorum. De qua re nos paulo poft accuratius. Harum verò ftirpium radices pro Rhapontico non effe recipiendas, neminen medicorum, qui fedulo in ipfis Rhei veri notas recognofcere voluerint, latere putamus, nam quis (quæe) recipiet pro Rheo centaurii magni radicen? Cum fit radix centaurei magni à Rhapontico fpecie diftincta? neque fit laxa, \& levis, neque gultata cum remiffa adfrictione lentefcat, neque rufa fit, ut exprefit Diofcorides, qui inquit Rhei radicem centaurei magni radice efre rufiorem, feu rubicundiorem. Centaurei enim radix dura eft, denfa, gravis, nigra fere ex toto, licet intus ex rubro nigrefcat. Hæc, inquam, fuperiori ætate, magno fanè artis pharmacopeicr cum dedecore, locum habuit in medicinse ufu pro Rheo antiquorum. Quid de Rhacapitato Lobelii dicemus ? Cujus quidem radicem verum antiquorum Rheum, five Rhaponticum effe Lobclius nobis tradidit? Profecto hanc radicem. 


\section{DISP. DE RHAPONTICO.}

minus etiam, quam conveniat centaurei magni radix, cum Rheo convenire, ipfamque erie magni centaure fpeciem affirmare auderemus. At quid de Khabarbaro; qux radix pro vero antiquorum Khapontico perperam à multis recepta eft, dicemus? An non viri alioquin eruditifimi mordicus tenuerunt, Rhaponticum antiquorum, atque Rhabarbarum vulgo vocatum, unum idemque effe medicamentum ?. Hujus opinionis primus auctor fuiffe vifus eft Joannes Ruellius, quem \& Aloifius. Anguillara, atque alii itidem multi fuerunt fecuti. Nos olim $\mathbb{E}$ gyptios medicos, \& pharmacopros iftius opinionis fuiffe animadvertimus, qui Rhavend nomine nihil aliud, quam Rhabarbarum, ad ufum medicinæ cognoverunt. Quid vero de hoc dicendum? Nos, pace tantorum virorum, non dubitabimus affirmare illos in Rhei cognitione maximè fuiffe hallucinatos. Quomodo enim (fi vera fuerunt, qux Diofcorides, atque alii ex veteribus fcriptoribus de Rhapontico fcripferunt, fcilicet, quod radix fuerit centaureo magno fimilis, nigra, minor tamen, fine odore, guftata cum aliquanta adftrictione in ore lentefcens, laxa, aliquantumque levis ) radix Rhabarbari cum fit magna, craffa, denfa, gravis, Rheum antiquorum effe poterit? quomodo, inquam, effe poterit, cum fit odorata, ncque commanducata in ore glutinis modo lentefcat, fed potius linguam exafperet, intenfeque amara fit, \& valenter purgatoria?. Neque eft, quod ii refpondeant, hafce radices, Rheum Ponticum fcilicet, ac Barbaricam radicem, aliquantum inter fe differentes reddi primum ex cæli, in quo nafcuntur, \& vivunt, varietate, quando Rheum nafcatur in Scythix locis vehementer frigidis, \& Barbarica radix in Indix locis vehementer calidis : deinde ex radicum maturitate, atque immaturitate, feu perfectione, \& imperfectione.. Dicunt enim Rhei radices idcirco, quod naf́cantur in cælo admodum frigido, effe admodum viribus imperfectas, \& ob hanc caufam non augeri ad ean magnitudinem, qua radix Barbarica cernitur, neque effe odoratas, neque habere eam vim valenter purgatoriam, qua barbarica radix prædita eft :-Vel hoc idem evenire etiam quod radix, qux pro Rheo affertur, fit 
eadem Barbarica radix, fed qux junior fit, minimeque ad-congruam magnicudinern aucta: unde cum imperfecta fit, mirum non effe, fi neque fit magna, neque odorata, neque purgatoria. Cum ad hafce illorum raciones doctifir ${ }^{\circ}$ e ab Andrea Matthiolo in doctifimis fuis ad Diofcoridis libros Commentariis fuerit refponfum, non eft opus, ut nos quoque ad ipfas iifdem. refpondeamus : fiquidem à Matthioli argumentis ipfos plane victos fuife conltet. Hoc folummodo dicemus, quomodo esfe quear, quod una eademque planta natalia ferat oppoliti, contrarique temperamenti? quod tamen fatendum erit, fi concedatur Rhaponticum, atque Rhabarbarum, unum, idemque effe medicamentum. Conltat fanè longa experientia. comprobatum, \& plantas, \& animalia habere propria loca natalia, in quibus ponte nafcuntur, \& vivunt: quæ in cælo contrario fuis natalibus neque fponte nafcuntur, \& ibi fi nafcantur, aut ad ea loca devehantur, agerrimè vivunt, neque diu. Quam ob caufam etiam ex animalibus camelus, paróus, leo, elephas, \& alia animalia in calido czlo nata non æquè vivunt in frigido, ut neque urfus, lupus, \& alia in frigido ambiente producta, pari diuturnitate fuperfunt in calido. Ex plantis innumeræ in orientalibus locis velut in patria natæ, ut in feptentrione æquè vivant minimè funt aptæac difpofitæ. Neque enim balfamum, neque cafia cathartica, neque acacia Egyptiaca, neque tamarifcus, neque paliurus $\Lambda$ thenxi in nofiro crlo frigidiore vivunt. Cuomodo itaque effe poterit ut Rhaponcicum, \& Rharbarum, quorum diverfa temperamento natalia func, iftius calida, illius, frigida, fponte in utroque crelo, \& calido, \& frigido naf́cantur, \& vivant ? Quod verum utique erit, fi conceflerinus illis, $u$ dictum eft, Rhaponticim \& Rha barbaricum unum, idemque effe medicamentun. Fieri profecto poceft at Rhabarbarum ex India delatum apud nos, if fedulo cultodiatur, atque in Scythia ctiam in hypocauftis calidis fervatum, aliquantulun vivat; ficuti Rheum econtrì in India locis ad feptentrionem expofitis aliquandiu bene itidem cuftoditum: at alterutrum in utravis plaga fponte nafei, \& copiofus ibi abundare fi quis credat, vel affrmet, 
a- ratione plane abhorret. Quare non eft credendum Rhei plantam à Rhabarbari planta ex natalium diverfitate fpecie non differre. Huc accedit, radicem Barbarican figura, \& magnitudine diftingui à Rhapontico; quando hæc longa, \& gracilis; atque illa magna, crafía, \& brevis fpectetur. Qux varietatis ratio cum illos, qui Rhabarbarum cum Rheo unum idemque fecerunt medicamentum, non parum turbaverit, atque non minus etiam mercatores, qui ad nos $\mathbf{R}$ habarbarum. deferre folent; exinde cæptum eft, ejufdem radicis magnæ, craflæque longas, gracilesque fibras, ramos, aut veluti caudas, a Tangut Incolis effodientibus Rhabarbarum in proximis montibus, de crafla radice, abf́ciffas, \& fejunctim fervatas, mercatoribus pro Rhapontico venditari. Quæe etfi centaureo magno magnitudine, atque figura fimiles quadantenus videantur, exteriusque nigrefcant, \& intus rufiores videantur; tamen fraudem detegit ipfarum intenía amaritudo, odorque acutus, atque etiam quod gultatx in ore non lentefcant, neque lax,$\&$ leves, fed compactx, \& graves exiftant, \& non expertes facultatis purgatoriæ. Quare neque eæ radices Barbaricæ parvæ, graciles, quæ Rheum referre figura, parvitate, atque colore videntur, Rheum utique effe poterunt, cum odorat fí amara, gravesque fint, nec cum remifla adfrictione guftatre in ore lentefcant: Quæ notæ Rhei legitimi antiquorum fuerunt. Quid igitur dicemus? Hac noftra xtate verum Rhaw ponticum defiderari? Nequaquam: quinimò ab hinc annos multos cxpifle ad nos ex Scythix, Thracixque locis adportari, ut viri alioquin doctifimi in fimplicium medicamentorum ftudio cognoverunt. Manardus ille Ferrarienfis in libr.6. Epift. 2. qui antea crediderat Rheum, \& Rhabarbarum idem effe fpecie medicamentum, poltea mutata fententia, ad Nicolaum Leonicenum in libr. 5. epift. ult. ita fcripfit, „, Rhaponticum pri" mum vidi ego Venetiis in officina ad Medici infignia è Con"ftantinopoli allatum, ac deinde aliis pluribus in locis etiam " ex Alexandria convectum, quod nullis reclamantibus notis "verum antiquorum Rhaponticum refert. "Quam veritatem \& Bartholomxus Maranta, in 2. libr. Meth. Cognos. Simpl. c.7. 
\& alii permulti cognoverunt. Nune verò quisque poteft in multis officinis ipfun videre, fimulque \& alia nobiliora medicamenta; quorum cognitio ferè ex toto apud medicos, \& pharmacopæos proximis xtatibus obfoleverat. Hoc vero Rheum radix eft fenidigitum longa, five radicis fruftulum in utroque extremo obliquè diffectum, femidigiti longitudine, at crasfitie majoris digiti, exterius in cortice nigricans in rubrum, $\&$ interius rufa, quæ quando manditur, remilfa cum adftrictione in ore lentefcit, obfcuramque acrimoniam aliquatenus ama. refcentem guftui prabet, linguam etiam pallido colore ad crocum inclinante tingit, nullum olfactui odorem exhibens. Qure radix, nullis reclamantibus notis, verum antiquorum Rhaponticum refert. Sanè hæc radix fimilis centaureo magno exiftit, nigra, fed minor, \& rufior intus, \& cxteris aliis infignita notis, gुuas de Rhapontico Diofcorides exprefferat.

$$
\text { C A P U T T IV. }
$$

\section{Rbapontici planta an fuerit veteribus cognita Eง an bac etate alicuhi vivat, E़ qualis fit.}

1 olteaquam Rhapontici radix cognita à nobis eft, fupereft 1 ut de ipfius planta nunc agamus, de qua illud in primis: erit difputandum, an antiqui eam cognoverint, atque poftremò, qualisnam ex ftirpibus tunc temporis cognitis pro vero antiquortim Rhapontico à medicis recipi poffit. Plerisque creditum eft antiquos Rhei plantæ radicis, qux medicinx caufa ex regionibus fupra Bofphorum deferebatur, notitiam habuiffe, nequaquam verò ftirpis radicem producentis: idque ex eo conltare, quòd nemo ex pracipuis medicinx icriptoribus Rhapontici plantam docuerit, atque defcripferit: Aloifius vero Anguillara in fuis Simplicium Medicamentorum Difcurfibus in difcurfu De Rumice, quendam Joannem Tzetzem, Hefiodi commentatorem, memorat, qui fcripferit lapathi radicem olim Rheum $\mathrm{ab}$ antiquis fuife appellatam: Hxc autem ipfius verba fu- 


\section{DISP. DE RHAPONTICO.}

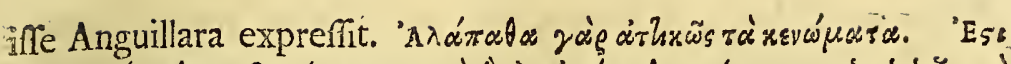

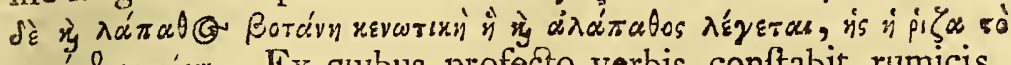
$\lambda \varepsilon \gamma$ offuar picuv. Ex quibus profecto verbis conftabit rumicis, feu lapathi radicem fuiffe prifcorum ufitatum Rheum, five Rhaponticum. Quam veritatem Andreas Cæfalpinus, fuperiori ævo medicus maxime præcelebris, planè confirmaffe vifus eft, cum is in libro quarto De Plantis cap. 29. hæc habeat. „Ex hoc ge" nere videtur efle Rheum ab antiquis appellatum, ut teftatur " quidam Hefiodi commentator, qui lapathi radicem Rheum. " appellari afferit. "Cui fanè opinioni \& noftram libenter quoque fententiam fubfcribere nunc voluimus, pofteaquam legitimam Rhapontici plantam ex Thraciæ montibus Rhodopæis primò Rhagufum, \& hinc poltea Patavium convectam nos à perillufri \& præcellentifimo (uti fuperius meminimus) Francifco Craflo dono accepimus, eamque fedulo infpeximus, \& animadvertimus; quam profecto plantam rumicum, feu lapathorum magnorum genere comprehendendam affirmare non dubitamus: de qua re paulo poft nos clarius. Quod verò hæc planta (cujus defcriptionem, \& notas audiviftis in iftiufce difcurfus principio ) fit verum Rheum five Rhaponticum antiquorum, vel hoc unico argumento cuique noftrum demonftrabitur; feilicet, quia ipfius radix cum Rheo Diofcoridis ita convenit, ut ne vel una nota, quod fit legitimum Rheum, defideretur. Quæ veritas cuilibet diligenter in ipfa radice notas animadvertenti, facile innotefcet; primò enim radix (inquit Diofcorides) elt nigra, magno centaureo fimilis ; fed minor, , \& rufior, fungofa, aliquantum levis, fine odore: optimum "habetur, quod teredines non fenfit, fi guftatum cum remifla "adftrictione lentefeat, manducatúmque colorem reddat palli"dum, aut ad crocum inclinantem.," Quæ notæ Rhapontici Diofcoridis cum fingulx in noftri Thracici Rhei radice eluceant, quis, quæfo, dubitabit amplius, radicem noftri Thracici Rhapontici effe verum Rhaponticum, atque ejus radicis plantam itidem Rhaponticum dici oportere? cum præfertim radix fit centaureo magno fimilis, fed minor, exteriufque nigra, nimirum ficcata (cum vero ftatim effoffa eft, \& recens, 


\section{0

iufo colore vilitur, ficcata antem exterius in corcice nigrefcit) interius centaurei radice rufior, fungofa, aliquantum levis, fine odore (vel enim ltatim à térra eruta, \& recens quoque cujufvis odolis expers videtur) qua gultata cum remiffa ad1trictione in ore lentefcit, manducalaque colorem reddit pallidum ad crocum inclinantem. De fapore ejus Galenus inquit, fi plufculum mandatur, fubracrem conf́pici. Serapio verò amarum elle exprefít. Vere quidem animadvertitur in Rhei radice, fi plufculum mandatur, fentiri faporem fubacren, \& fenfum obfcuræ calidicatis, atque fimul levininæ amaritudinis, ex quo ambigatur, an ejus radicis fapor vel ad acrimoniam, vel ad amaritudinem vergat. Quem faporem fortafle dedita opera tacuit Diofcorides, fatis apertiorem, \& magis confpicuum cum expreflerit faporem, dicens: quod in guftu (ita vertente Marcello Virgilio ex Oribafio forfitan ita legente) glutinofum cum levi adfrietione lentefcit. Si itaque vertum elt noltra Thracice planta radicem omnes hafce notas habere, cur iphus radicis firpem haud Rhaponticun quoque effe dicemus? Atque etiam, cum in Thracia fponte hxc planta. nafcatul Ponto contermina, \& non minus in Scythre locis, per qux fimmen, olim Rha, nunc Volga dictum, labitur, juxta cujus ripas olim fponte nafcebstur, ut Ammianus Marcellinus in libr. I2. Hift. elt austor, cxindeque ipfus radix ad noitras nationes deferebatur. $\Lambda$ ddo ego ( ut fuperius quoque memini) Joannem Qurinum Cinglerum Germanum, virum profecto in herbarum ftudio maxime eruditum, mihi aliquando aftrmavife, fe hanc plantam in Mofcovix (quam olim Seythiam vocarunt) locis copiofius prodire, ac vivere confpexiffe. Sed quid tandem dicemus de jis, qui libi iplis perfuaferunt Khapontici plantam efie centauew majoris fpeciem? $M$ loyfus Anguillara plantam magni centaurei in monte fandi Angeli in Apulia incolas Rheuponticum appellare tradidit, \& Carolus Clufius centaureum magnum folio indivifo, quod fupra Olyfi:ponem nafci obfervavit, a I culitanis itidem Rhaponticum vocari fcriptum reliquit. Unde \& I,obelium, virum eruditif:mum, eam plantam, guam ipfam Rhacapitatum nuncupavit 
vit, Rhaponticum efle putaffe aliqui crediderunt. Quod \& alias notavimus. Quid igitur dicendum videtur ? an non hæ quoque Rhapontici plantæ dicentur? quadantenus à quadam fimilitudine, quam habent cum radice magni centaurei, cui Rheum Diófcorides comparavit, polfe ita vocari, ne contendamus, non inficiamur: At effe Rhaponticum verum antiquorum omnino negamus, cum radices iftarum plantarum in nullis ferè cum Rhapontico conveniant. Quod cum fuperius fatis fuperque demonftraverimus, in præfentia idem repetere noluimus. Sed ex his cognitis cuique noltrum fatis fuife demonftratum putamus plantam, quam nos ex Thracia obtinuimus . efle verum antiquorum Rhaponticum.

\section{A P U T V.}

Plantam Rbapontici Tbracicam, lapatborurn genere comprebendi, Eु quot junt ip fus species.

um plantam, quam ex Thracix Rhodopæis montibus ac-s cepimus, verum ac legitimum Rheum antiquorum effe fatis fuperque oftenderimus, reftat ut cognofcamus fub quo genere plantarum cognitarum hæc planta verè comprehendi queat, qualifque fit planta ad cujus genus accedere videatur. Supra in fine fecundi, \& principio quarti capitis diximus, ex Antiquis Joannem Tzetzem, Hefiodi commentatorem, lapathi radicem, quondam Rheum vocatam nobis tradidiffe. Unde Rhaponticum antiquorum ad lapatha quadantenus accedere nuperrime dictum eft, cujus opinionis complures viri in Botanica cognitione doctiffimi fuifle vif funt. Hieronimus Tragus fcripfit Hippolapathum, five magnum lapathum, à Monachis Francifcanis Rhabarbarum vocatum fuiffe, ex radicis colore mroceo Rhabarbari colori fimili, atque etiam, quod, ut expecentia fe didiciffe affirmat, vi purgatoria valeat, qua drachfix pondere cum fcrupulo gingiberis epotum perinde ac Rha$S_{3}$

bar: 
barbarum purget bilem, atque pituitam. Quem fortaffe Leonardus Fuchfius fecutus radicen itidem magni lapathi ad Rhibarbarum accedere credidit, atque ita, ut ipfum, Rhabarbari modo, purgare humores fibi perfuafum habuerit. Poft hos herbarum fcriptores noftra atate acceffit Andreas Cæfalpinus, vir undequaque eruditifimus, \& qui ipfe Rheum ar. tiquorum ex lapathorum genere effe credidit. Hi verò fcriptores, quod Rheum, \& Rhabarbarum, unum idemque medicamentum fuerint, propterea magnum lapathum Rheum antiquorum effe facile fibi ipfis perfuaferunt. Sed quid wos, qui Thracicam Rhapontici plantam per quadriennium in horto habuimus, eamque affiduè obfervavimus, affirmabimus? Profecto magni rumicis, feu lapathi fpeciem ipfam effe negare non polfumus, neque à magnis lapathis ipfam itidem non posfe fegregari, cum hæc planta primo folia Hippolapathi five magni. lapathi habeat, duplo tamen (fi folia adultæ plantæ fpectemus) latiora, longioris trianguli in modum (licet rotunditatem quandam habeant) efformata, magnæ lappæ magnis foliis figura quadantenus fimilia, fed duplo (ut modo diximus) fere majora, cum debitam magnitudinem ætate nacta fuerint. Caulem deinde hæc planta fert è medio foliorum cubitalem, ftriatum, geniculatum colore, viridi in rubrum inclinante præditum, magni lapathi cauli planè fimilem: à cujus geniculis exeunt ramuli in multos alios divifi, qui primò flofculis albis undique conteguntur floribus hippolapathi proximis; fed in hoc ab ipfis differentes, quia funt coloris albi, fambuci floribus perfimiles, non infuaviter olentes; magni verò lapathi flores colore virefcant. Ab his floribus femina parva, nigrefcentia, triquetra figura, lapathi magni feminibus omnino fimilia producuntur. Folia, caulis, et flores fapore fubacido haud ingrato guftum afficiunt. Radices vero iftiufce plantæ non rectc̀ deorfum in terram, fed obliquè aguntur, gracilesque funt magni centaurei perfimiles, minores tamen, ì terra ftatim erutx exterius rufo colore in obfcurum declinantes cernuntur, \& ficcatæ nigrefcunt, interius autem rubicundr; funtque fungofie, leves, gultui cum remiffa adferictio- 
ne lentefcentes, fubacres, cum levifima obfcuriffimaque amaritudine, \&, fi mandantur, tingunt pallido colore ad crocum inclinante. Quræ note iftiufce plantæ, radicisque prefertim, ferè omnes in magni lapathi radicibus animadvertuntur. Porrò duo hipjolapathi, feu magni lapathi genera obfervavimus, unum quod latifolium nominavimus, atque iftud eft Rheum noftrum Thracicum; atque alterum longifolium: vocatum: quod itidem duplex obfervatur : Primum eft hippolapathum. fativum à Lobelio nominatum: Quam plantam nos pro Rhapontico ab hinc plures annos accepimus à Joanne Pona Veronenfi pharmacopæo percelebri, \& in medicamentorum cognitione adprimè erudito, mihique amicitix vinculo conjunčtiffmo. Secundum vero lapathum, feu lapathi longifolii genus magnum multis in locis proveniens, eft id, quod vulgus. herbariorum Rhabarbarum monachorum appellat, \& Matthiolus Hippolapathum fativum vocavit. Quod à priori in multis differre deprehenditur, in foliifque præfertim, \& in radicibus, folia enim majora quam in altero animadvertuntur, \& in cacumine magis mucronata, neque fingula funt circa pediculum in folii initio perfoliata, qualia prioris magni lapathi confpiciuntur. In radicibus quoque differentix obfervantur, namque hippolapathi prioris longifolii radices minores funt, ac graciliores, deorfumque in terram rectè aguntur, \& colore, fapore, fubftantiaque, dum virides funt, noftri Thracici Rhapontici radicibus proxima exiftunt. 


\section{A P U T V V}

Que inter radices bippolapatborum, ad $R$ bei radices, quibus antiquiad medicina w um utebantur, proxime accedant, illa-

rumque loco à noftre etatis medic is ufurpari pofint.

uoniam demonftravimus hippolapathum, feu lapathum magnum noftrum, latifolium, Thracicum, radicem habe. re, qux eft legitimum Rhaponticum antiquorum, \& hippolapathorum omnium radices figura, magnitudine, colore, fubftantia, atque fapore fimiles Thracico quadantenus animadverti; dubitari non injuria poterit, an fingularum harum piantarum radices fint Rheum? Porrò fuperius dictuin eft complures fuisfe viros, alioquin eruditiffimos, deque re herbaria plurimum benemeritos illius fanè opinionis, quod radix vulgaris hippolapathi fit Rhaponticum antiquorum, quod \& idem cum Rhabarbaro effe crediderint, propterea magnum lapathum fuifie Rhabarbarum à Monachis Francif́canis nuncupatum, atque ab aliis deinceps, tum propter radicis craffitiem (poft quinquennium cnim hæc planta radicem nancifcitur magnam \& craffam, Indico Rhabarbaro proximam ) tum maxime ob colorem, fubftantiam, odorem, atque faporem, Rhabarbarum itidem fuisfe appellatum. Addunt fuiffe experientia cognitum, magni lapathi vulgaris radicem habere facultatem purgatoriam, cujufmodi ineft Rhabarbaro, fed minus tamen efficacem. Verum enim vero fatemur \& nos quoque magnorum lapathorum radices plurimum, priufquam adolefcant, fcilicet bimas, vel trimas, ad Rheum proxime accedere. Qux etfi vera cfle deprehendantur, nihilominus folæ radices hippolapathi Thracici noltri Rhodopxi \& Scythici, Rhei nomine dignæx ælimari debebunt, cum ipfe folre notas omnes, quas Diofcorides Rheo tribuit, habere confpicianur, atque etiam ne una quidem 
dem ex legitimis notis Rhaponticum Ifacientibus , defideretur, quemadmodum à nobis nuperrime fuit demonftratum. His proximè accedunt hippolapathi primi longifolii radices ficca-' tæ, vix enim \& forlitan nullo modo poterunt à Rheo Thracico difcerni: cum in ipfis ficcatis omnes notæ eluceant, ut ex illarum oftenfione cognofeetis. Vulgaris verò Hippolapathi fecundi longifolii radices, magis ad Rhabarbarum (dico adultas, \& plurium annorum, feu poft quinquennium) accedere quam ad Rheum videntur, cum ipfæ non laxæ, fed duræ, \& compactæ'fint, graves, graviter olentes, atque cum manifeltiori amaritudine. Atque hæc de convenientia \& frmilitudine, quam habent radices magnorum lapathorum longifoliorum cum vero Rhapontico, id eft magno lapatholatifolio, á nobis dicta fufficiunt. Nunc quam breviffime Rhei Hippolapathique longifolii vires, ac ufus medicos etiam confideremus.

\section{A P U T V.I.I.}

\section{De:Rhapontici, \& Hippolapathi longifolii viri- bus atque utilitatibus in medendo cognitis.}

Tofcorilles in libr. 2. De Mat. Med.c. 2. de Rhei viribus, \& commodis ad medicinam feribens, ait: "Vis ejus eft adftringens etim aliquanto calore. , Et Galenus in 8. Simp. inquit: ", Rheuń uniftatm habet tum temperaturam, tum faculs, tatem: habet enim quiddam terreftre frigidum, ceu indicio 5. eft adftrictio, ck adjuncta eft quædam illi caliditas: fiqui$\Rightarrow$ dem fi plufeulum mandatur, fubacre concipitur. Quin etiam " aëré ejufdam fubttantire fubtilis eft particeps, quod indicat ", tum laxitus, tem levitas verum \& opera: ob id enim non 3.) tanttin ocontulfis, fed \& ruptis, \& orthopneæ prodeft. or Sic quoque liventia \& Gichenas fanat illitum cum aceto. g. Porró quod aftrietionis opera haud infrenua funt, hinc is difcere licebit, qtod fangtinem exfpuentibus, cxliacis, dis) fentericis énférat: necenim refuctatur terreftri frigido te-

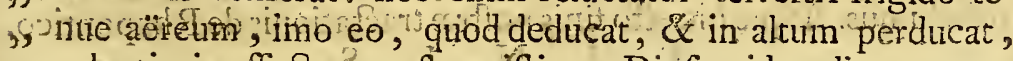
", valentioris effectus caufa exiftit., Diofcorides alios quoque ufris addidit, fcilicet utile effe ad magnos dolores inflationesque eTi 


\section{$\pm+6$ \\ PROSPEIRI ALPINT}

potum, \& ad lienofos, hepaticos, coxendicosque dolores, ad fingultus, ad febrium circuitus, atque ad venenatos morfus. Quibusdam vifum eft Rhapontico ineffe vim purgatoriam, quod perperam collegiffe videntur ex Diofcoride dicente (ut Serapio a $u$ Et or fuiffe vifus eft) $R$ heum dari in omnibus malis, in quibus daturagaricus, ea emque menfura. Præterea id ex eo confirmant, quod per os affumptum hepaticis \& lienofis medeatur, quam utilitatem illis vifceribus affectis non nifi humores purgando inducere exiftimant. Addimus Francifcum Craffum prænominatum relatione accepiffe, quosdam Monachos in Thracia prope montem Rhodopem habitantes, habuiffe in ufu familiariffimo, purgationis moliendæ gratia, Thracicum Rhaponticum duplicato pondere ad Rhabarbarum : Imò refert ex nimis frequenti ufu illarum radicum, qui apud eos Monachos atque apud alios invaluit, ita eas plantas Rhei ibi nafcentes fuiffe confumptas, ut nunc pauciffimæ ibi reperiantur: unde etiam illarum ftirpium, quibus quodam tempore ea loca abundabant, nunc penuria indigenæ eorum locorum laborent. Forfitan ea facultas (fi tamen aliqua Rheo Thracico ineft, quod nondum experientia deprehendimus) Diofcoridi, Galeno - atque aliis antiquorum non fuerat animadverfa. Rhapontico Lapathum magnum viribus videtur ita proximum, ut ipfius effentia ex duplici fubftantia etiam conftare videatur, partim , fcilicet, frigida, partim calida: Subftantia enim terrena, frigida, \& craffa radicis haud inftrenue adftringit, aleo, ut linguam deguftata, non parum exafperet, atque in hoc à $R$ heo differre videatur, quoniam guftata in ore non ita lentefcit. At verò fubftantia non parum calida \& tenui , quæ acrimonia aliqua fe prodit, valenter digerit; craffa verò fimul \& calida à tenui adjuta fubftantia, vi prædita eft deterforia, quam nobis indicat ipfius evidens amaritudo non abfque calore per cepta. Unde lienofis, hepaticis, afthmaticis epota medetur, non minus, quam præftet ex aceto illita ad fanandos $\&$ detergendos in difcoloratione $\&$ impuritate fitos cutaneos affectus. Sed de ipfius purgatoria \& dejectoria vi ex aliorum opinione cum fupra quædam complexi fuerimus, ne verbum quidem amplius de hac radice habebimus. Atque hic efto finis noftræ tractationis de Rhapontico. F I $\quad \mathrm{N} I \mathrm{~S}$. 


\section{N D E X \\ I N L I B. \\ PROS P. A L P I N I \\ DE BALSAMO Ex RHAPONTICO.}

\section{A.}

Agypti locus, qui olim Balfamums 11 altit.

Wigyptum nunquam Balfamo patriun ac nativum fuiffe.

88 Albedinem Opobalfano in aquam filla. to propriam elle.

103 Aaratum Lufitanum \& Nicolaum Manardum affirmare Balfami plantam planè periifje.

Antiquos Scriptores de Balfamo fuiffe onnes inter $\int e$ opinione differentes. 96 Antiquis Scriptoribus de Balfamo plane non effe fudendum.

Antiquos Scriptores fuiffe inz caufa, ut noftri non credant, Oppobalfanio, Carpobalfano, ex Arabia delatis. ibid. Antiquorum de Baljamo diverfitatems fignum effe eorum ignorantice. 97 Antiquos de Balfamo multa ex auditu litteris tradidifle. Antiquos fortalfis non vidifje Opobaljamutrin?

Ic9. 110 Antiquos deceptos, dum crederent, $B \Omega l$ famum olim tantimn Bisypto atque Indice fuide concel(Jun. 97.98 Aqua font is, quâ olim usa fuit Beatiff. Virgo, Baljamum ali feu irrigari, atque ejus mire facultates. $\quad 98$ Aque fontis Mattbarece qua virtutes $a b$ Esgyptiis tribute fint. 98 Arabes lucri caufa creperunt Baifomi arbores colore, Eo qiando.

Arabian Felicem innumeras Baljami plantas nunc alere.

87

Arabiam Felicem perpetud Balfamum babuiffe.

I 9 Arabes oinnes ad componenda medica- menta , Opobalsamo, Carpobalfano, $X y l o b a l f a n o q u e ~ v i s l g a r i$ ac venali isti.

Arbores Balfami que in Egypto aluntur ai quam magnitudinem crefcant.

g6

Arbores Balfami in Arabia viventes qui magnitudine Jpectentur, feu crefcaiat.

Arbores Balfani multas in Arabia vivere.

Arborem Balfani fruticofam elle, हु) farmentofam.

Arbores Ballami Aigyptii , E Indi differentic.

Ios

Auctor cur de Balfanno librum ante alios libros inprimi curaverit.

$B$.

79

D alfani plantas Felicem Arabiam perDetuò aluifje.

Balfami plures plantas Beảnunia Arabice locus munc alit.

84 Balfani inmumeras plantas Bedrunia locum Arabice arenoflum miracalo $M a$ bonsetis alere Esgyptii, illifque affeclie, putant.

85

Balfami immumeras plentas Spontè natas in Arabice locis vivere, maltoruns teftinonio.

85

Balfami plante quando Cayri exarusrint.

85

Balfanmon qui negant boc tempore reperiri.

Balfami plantan omnibus in locis periifje multi affirmant.

Balfuni plantis quibus rationibus omnia loca munc carere fuadeatur.

87

Babfami plante miltee ex Arabio quan. do in Fis gytum fuerint illate.

$\mathrm{T} 2$

87 Ba!. 


\section{$I N D E X \quad I N$ LI B.}

Balfami ex Conftantino Africano dejeriptio.

Balfameta innumera in Arabia Specta-

Baljami arbores in Arabia a Geripfo $\%$. licui locari, at Cayri CaJias.

Balfami plante icon.

Baljani plantee in Fudaea quomodo pro. pagatce fuerint.

Ballaffan nomen ab Arabibus Balfani planta primò impofitum fuifje.

Balfamum ex Indiis Occidentalious delatum.

Balfami planta quibus in locis tantim olim vixerit.

Balsami plantce quomodo diu in Egypto confervate fuerint.

Balfamum nunc in Arabia Felici tantum vivere.

ibid.

Balsami plantas in IEgyptum aliunde advebi.

82

Balfani plantce quo pacio in Figypto longo tempore fint propagate.

Bulfami plantas è Meccba omnes in IE. gyptzsin venifle.

Balfami plantas AEgyptium folum proprizsm numquam fuifje.

Balfamum Foudcece atque Is gypti plantam fuifje peregrinun que fuadeant.

88

Balfamum Semper trtm in . F Esypto, tum in Fudaa in viridariis vixifle, $\mathbb{E}^{2}$ non alibi.

ibid.

Balfamm non in Rgyptum ex Fudaca, fed ex Arabia Telici veniffe. ibid.

Balfani plantas nafci in Arabia, qui $c x$ Scriptoribus prodiderint.

87

Balfami plantas Arabes ex filveftribus locis in morbida viridaria transferre.

Balsami plantan quibus plantis varii Scriptores compararint.

Ballami diverfitas à magnitudine.

Balfami diverfitas a figura.

Balfami diverfitas à bocis.

BalJami plantam fruticem efje.

Balfani plante defcriptio.

98

80

89.93
Balfami plantam in Egypto olim viventem pro legitimo Baljamo Arabes atque Aigyptios ommes perpetud babuiffe.

Ballami cognitio à quibrus petenda Balfcomi arbufti folia non elfe alba, ut

Diofcorides voluit.
Balfani quot frutices Cayri Bellonitus olim injpexerit.

118

Balsamum perpetuo vivere. $\quad$ I 8 Baljami Fruticum Cuyri infpectorum de. frriptio.

I 8

Balfamum fingalis annis putatur. 118 Balfami plante virge.

I 15

Balfami fruttus Terebintbi fruetibus $\sqrt{0}$ miles.

IOI

Bedrunia locis Arabice Felicis, qui balfami multas plantas alit.

Be $\iint a$ Meniflinor plantas balfami in सEgypto renovarit.

\section{$C$.}

Carpobalfamuin verum.

I. II Carpobalfami duplex genus circumferri.

$31 \mathrm{I}$

Carpobalsami veri descriptio.

I 2

Carpobalfani copiam in Italiam ex Eg $_{g}$ pto convebi.

II 2

Carpobalfami notee.

113

Carpobalfamum venale verum effe. I I 5 Carpobalfami defcriptio ex Sernpione

II 3

Carpobaljami veri nota d Diofcoride.

Carpobalfamum venale, quibus rationibus aliquidenionftrent verum non effe.

is 3

Corpobalfamum veruale omnes notas babere, quas legitimo Diofcorides tribuit.

114

Carpobalfamum ex Galeno non poffe adulterari.

II 3

Carpobalsami loco quid fubfituant Veneti Pbarmacopola.

$i b i d$.

Confules Venetos multos vero Opobalfa. nno non carcre.

I I I
Conceptiones Palmanun admirabiles. 99

Conftuntinus clixit balfamum nafci in In- 


\section{PROSP, ALPINI DE BALSAMO.}

dia.

Cur noftri in cognitione balfami decepti fint, है ä quibus.

D.

97

Tiofcorides cur de balfamo dixerit in Sum panno adbarere.

108

Diofcorides etidm Balfamum alibi quam in AEgypto, $8 \sigma^{\circ}$ Fudaa vivere affirmare videtur.

F.

Glores Balfami.

Folia Balfami qualia jpeEtentur. 94 Foliorum Baljami defcriptio.

Francifcus Priolus Conful Risortio 99 Fructus Balfami qui. 1 I 2 Fructumu Balfami copiam miltam ex Esypto in Italiam asportari. ibid. C G.

Ireci B. litterc carent. $H$.

90

T alybei quadraginta Balfani plan. 1 tas è Mecba Cayrum jrufu Pre. fecti tulit.

91 Hiericum Balfamum olin babuifJe. 86 Horrem Bei dux Caravana peregrinorum.

Horrem Bei è Mecba multum OpobalSami, Xylabalfami, Carpobalfami Cayrumi detuliffe.

83

Hortus Balfami fruticibus confitus ubi.

II 7

Hortus Balfami in IEgypto defcriptio.

\section{I.}

Tncole Bafliani montis Libani olim Balfamum ibi vixiffe affrmant. 87 Fofepb, Sabam Arabia Reginam Salomoni in Fudea balfami plantan refert dono tuliffe.

88

Fuftimum de balsanoarbore deceptum. 99 Funiperi fructus pro Carpobalfamo Venetos pharmacopolas fubftituere. II 3

Tignnm Balfami quale.

$$
\text { L. }
$$

Lorus Rggyti, ubi Virgo Beatiffima mublos armios vixit, ac menfes.
$M$.

attbarice locus in quo Beatiffimo Virgo annos cam puero ejus Fil lio manjit.

Mattbaria eft locus Cayri Civitatis, in quo erat Baljami planta.

Mattbarice locum in quo alebatır $\mathrm{Bal}$ famum, munc eo carere. 82

Mecbam Opobalfano abundare. $\quad 90$ Medina Arabie Felicis civitas. 92 Marcatores Cayri Carpobal ami, EO Xylobalfami totum quod babent ex Ara. bia convebere.

\section{$N$.}

119. 120

Tote finceri Opobalsami ex Diofco. ride atque aliis tradite. 107 O.

bjervatio Petri Bellonii de Bal a mo. I16. 117 Opobalfani copiam multam in Arabico Felici colligi.

Opobalfami copiam Arabes in multa 0. rientis loca comportare hucri canf $\hat{a} .87$

Opobalfamin ex feminibus balfami elici.

I I 0

Opobalfami nòte.

87. 88. I0I

Opobalfamum verum musquan inveniri multi affirmant. I0०. quamobrem id fiat.

ibiden.

Opobalfamum quomodo album multi pro. diderint spectari.

IOI

Opobalfamo guas notas multi tribuant.

Opobalfami mutationes ex variis ejus atatibus.

Opobalfamus quando tenuifimum, Eे clariffmam.

$10 \mathrm{I}$

Opobaljamum Sereniflini Ducis Florentice verum effe.

103

Opobalfamum quomodo ex arbore eliciant, $\mathcal{O}^{2}$ quando, E quale fit. - 96 Opobalfasmum ftatim eductum quale. 96 Opobalfani defcriptio. Opobalfami varietates ex atate $E^{\circ}$ aliis 95. 96 Opobalsamo quatuor atates as animali, convertire.

$T_{3}$

95.96 Ofo. 


\section{INDEX IN LIB. PR. ALP. DE BALSAMO.}

Opobalfamum etiam Galeni temporibus aduiteratum.

106

Opobalsamum quibus adulteretur. 105

Opobalfami adubterati cognitio. $\quad 105$

Opobalfami oleo vitiato cognitio. 105

Opobalfami finceri cognitio. $\quad 105$

Opobalfamum onne in aqua ftillatum, Eे coagulatum album videri. 103 .

\section{$P$.}

104

Dulus Marianus Venetus pro Gallo. rum Rege Confulb. Paufanias Balfamum in Arabic nafci prodidit.

Petrus Bellonius.

88

Petrus Michaël Conful AEgypti.

Plantas Balfami in Aigyptusn aliunde advebi.

Plante quadraginta balfani è Mecba delata atque Cayri in loco quando in. Serte.

Plantas Balfami planè non periiffe. 85 Plante Balfami in locis fterilibus viventes quad Opobalfamum fteriles. 92

100

Plante peregrince fervate in viridariis

88

Plantas non in viridariis, fed ubique vivere.

Plinius de Ballanizo.

88.89 ibid.

I I I

PSeudocarpoballamum E sjus defcriptio. ibid. $R$.

Dbapantici of Rbabarbari defcriI. pito, vires, usus Eेc. $125 . \mathrm{E}^{9}$ Jeqq.
$S$.

Cander Bei Medine civitatis Pre

$\checkmark$ tor ex Zacyntbo Infula à Segurorum familia ortus, Balfami recentes fructus, ac Juccum Cayrum mifit.

92

Seimina Balfami copiofîfimè ex Felici $A$. rabic in $B$ gyptum deferri.

92

Semina Balfami qualia.

II2

Semina pro carpobalfamo vulgo recepta effe verum carpobalfamum.

ibid.

Semina Balfami cum folliculo ede nigra fubrubefcentia.

Serapio de Carpobal Samo.

II5

Seripbis Meccbe EO Medine plurimum veri Opobal/ami Regi Turcarum fin: gulis annis dono mittere. IO9 Species vegetabilium effe perpetuas. 85 $T$.

Theopbraftus de Baljamo. $\quad 88$

1 Tbepbraftus rectè Carpobalsanum defcripfit.

I 12

Turcas $\mathcal{E}^{\circ}$ Arabes omnes affirmare, innumeras Balfami plantas omnia $A$ rabia culta EO inculta loca alere. 92

Turcarum Rex unde plurimum Opobalfami babeat.

$\sqrt{T}$ irgarum Balfnmi defcriptio.

$X$.

108

Tylobalfami cognitio.

1Xylobalfamum citò odorem Es faporem omnem relinquere, E quamobrem.

II 5

Xylobalfamum ex Bellonio venale idten effe cuin PEgyptio.

$Z$.

119

7 ebet album nafsi, Eפ mox turbar ri. 
J A C O B I B O N T I I

IN INDIIS ARCHIATRI,

D E

MEDICINA INDORUM,

L I B R I IV.

1. Notæ in Garciam ab Orta.

2. De Dixta Sanorum.

3. Meth. Medendi Indica.

4. Obfervationes è Cadaveribus. 


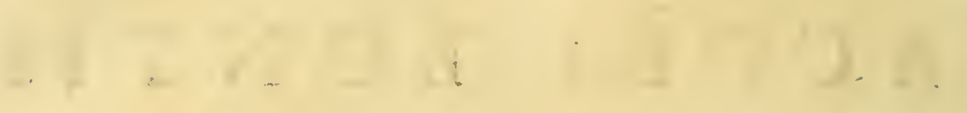

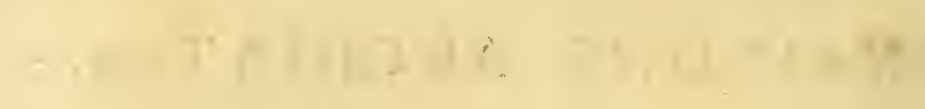

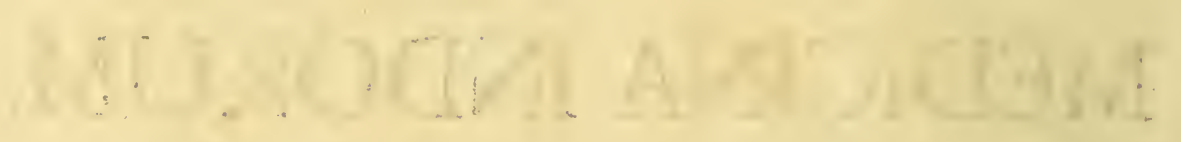

.7 I II I I I I

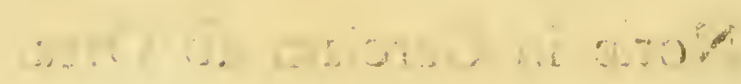

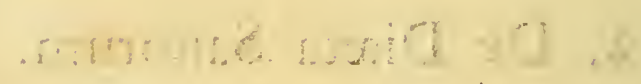

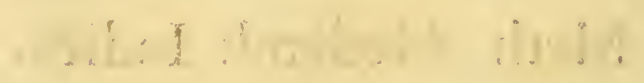

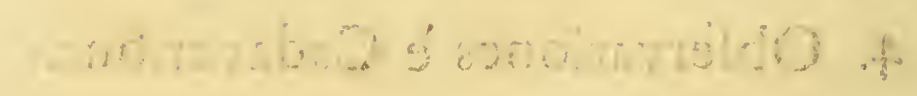




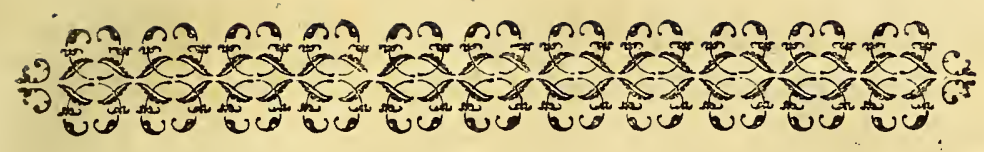

\section{FRATRI SUO CARISSIMO}

\section{WILHELMO BONT

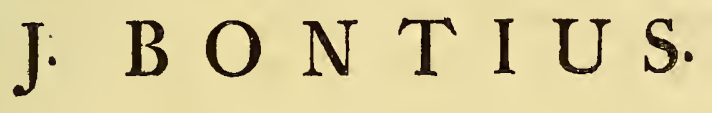 \\ S. $P . \quad D$.}

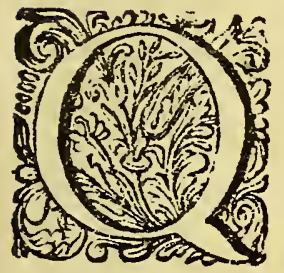

nem haberem.

UAMPR IMUM in Indias bafie. Orientales veniffem, copi animum intendere, ut non folum berbarum bic in Fava nafientium notitiam nancifcerer: Sed ut $\sigma^{\circ}$ aromatum, quorum feraciffima noftra eft Fava, pleniorem cognitioScriptores aromaterios Garciam precipue ab Orta Proregis quondam Goenfis Medicum, ac Chriftophorum à Colta: copi igitur eos diligentius paulo rimari: aft inveni ipfos plurima ex aliorum relatu baufiffe, quee ego $a b$ aitw $\psi_{i a}^{\prime a}$ edoctus longe aliter fe habere reperi. Sed certe confiteri libet hos viros, presertin Garciam ab Orta, in iis que ufu ac vifu comperta babuere, bona fide eziffe: ego itaque non ut corrigam eos firipiores, bas Animadverfiones illis adjeci: Seu, qujd malignitatem faperet, ut ipfis, me doctioribus, detrectar:m: jed ut ofiendan oculatuin teftem wnum pliss valere, 


\section{$\begin{array}{lllllllllll}54 & \mathrm{D} & \mathrm{E} & \mathrm{D} & \mathrm{I} & \mathrm{C} & \mathrm{A} & \mathrm{T} & \mathrm{I} & \mathrm{O}\end{array}$}

quam auritos decem, Eo quod fanna fit tam fidi, pravique tenax, quam nuncia veri. Nicolaus Monardes multa quidem fic fatis accurate foripfit, aliqua ofcitanter quoque tranfiliit. Diligentiffimus rei berbarice indagator Carohs Clufius, conatus etiam fuos laudandos huc attulit: Sed pace doctiffini viri, in multis operant perdidit, quod in progreffu patebit. Ego itaque ne mibi foli vivere videar, que oculis percepi, ac ufu quotidiano comprobavi in his locis, conterraneis meis fincere ob oculos ponam; tum etian ut oftendam nuaterice tam nobilis Atylun, quanivis tenuem, deeffe non debe$r$. Itaque hec qualiacunque tibi, frater Cariffine, ex merito offero, quod fiam, te borum auctorum diligentem femper lectorem fuiffe, tum quod mece fortunce quafi fabricatorem te agnofam : ut qui mibi auctor inter ceteros fuifti, ut, relicto patrio folo, ac Aterili propter medicafts:orum ibifrequentiam, proventu, uberrimos fava campos peterem, ubi, abfit verbo invidia, virtutis paulo major ratio babitur. Accipe igitur has Animadverfiones in fraterni erga te animi Symbolum, ac expecta anno fequenti, fi fors mibi vita fiper fit, amplain defcriptionem Plantarum, ftirpium, fruticum, ac Arborum adjecta uniufcujufque ad vivum delineatioñe. Quce Exotica, ac patriis auribus incognita, forte equus rerum efimator, non parvi faciet. Tanden fi bee prolo digna videbuntur, cunn ceteris meis Indicis tratiatibus, Methodo fillicet medendi in bifie locis, ac direta (que bic cum funma cura obfervanda venit) mea Indica, quan bic fubjeci, exeant in lucem: fin mimus limata cenfentur, domi apud te, boni erga te at fraterni mei affectus indicium ferva.

Tuus tui obfervantifimus frater,

JACOBUS BONTIUS. 


\section{ANIMADVERSIONES, \\ I N C A P U T III.}

\section{Garcice ab Orta quod infcribitur de Altibt, feu Affa} foetida. Favanis ac Malaiis Hin' dicza.

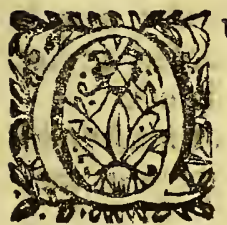

von IA præcedentia duo Gapita abunde \& fufficienter de ambaró ac aloë egerunt, ego, quod in ea commentarer, non habui: fed quia auctor hoc cap. negat non folum fe vidiffe hanc herbam, fed nil certi de ejus forma adfert; ego quæ vobis adfero. de affa fotida planius comperta habeo, hoc

Itaque planta è cujus radice affa exprimitur, magna quantitate crefcit in imperio Perfico inter Laram ac Gamaron civitates, quarum prima non longe diftat à mari, ac noftris mercatoribus ac Anglis etiam frequentatur. Eftque hæc planta duo. rum generum: prima farmentofa eft, ferme ut Salix aquatica, ex cujus foliis ac ftolonibus incifis affa fotida per torcular exprimitur, quæ, ut reliqui fucci, Sole indurata in confifténtiam evadit, qualis eft aloës.

Secunda porro affæ fpecies longe fœcundior eft, eftque fuc. cus expreffus ex radicibus hujus plantæ, quæ craffifimos raphanos referunt, folia autem Tithymali folia referunt. Hujus generis ego aliquot radices domi habui, à mercatore Armeno mihi amico donatas, qui illas huc è Perfia detulerat, ac etiamfi jam effent exfuccie, tamen tam fortis erant odoris, ut totas ædes foetore replerent; qui infuetis vix tolerandus effet. Quo Javani, ac Malaji, ac ceteri Indiarum incolæ negabunt, fe quicquam odoratius naribus unquam percepifle: apid hos Hin' hic fuccus nominatur eftque in tam frequenti ufu in cibis condiendis; quam atthor hoc cap. refert, ut propter hanc caufam 
una fit cum opio ex præcipius mercibus, quæ per Indiam diftrahuntur: ac femper focietas Indica magnam quantitatem hujus fucci in armariis habet, quam incolis Javæ, permutatione aliasum mercium aut pecunia impertiantur.

\section{In Cap. IV.}

\section{De opio. Fol. 2r.}

Gecundo paragrapho, hujus Capitis auctor mentionem facit opii Meferi dicti, quod putat opium Thebaïcum fuiffe: nam in Agypto Thebæ iftæ Centi - portæ extitere : ac Meferi ac contracte Mifti Ægyptus hifce incolis ac reliquis Indis eft.

Paragrapho. 3 . inquit eos, qui opio utuntur, dormitabundos videri: tamen nil minus quam ftultæ funt hæ nationes in mercaturis exercendis ; armis ac arte belli ab Europæis forte fuperantur. Certe laudes hujus fucci è papavere expreffi fi vellem referre, viderer Chymicis velle fuum honorem præripere, hoc faltem dico, fi nobis hic de Opio; ac opiatis non effet profpectum, fruftra in calidiffimis his regionibus medicinam faceremus, dyfenteriæ, Choleræ, febribus ardentibus, ac reliquis biliofis affectibus orgafmo turgentibus: \& ne vobis fucum videar obtrudere, quid in noftris regionibus confectiones opiatre tantopere celebratæ, Theriacam, dico, ac Mithrydatium? quid denique Philonium? quæ nifi opio tanquam bafí fuffultæ effent fruftra ab iis effectus tam manifefte juvantes quis expeEtet. Et profecto infignis eft ofcitantia ifta, quæ in abufum medicamenti, ac minus bene præparati dicuntur, in ufum nobiliffimi inter omnia pharmaci velle referre; fine fundamento fæpe, ac in Scholis fine Experientia.

Pauperes porro Indi, ex foliis, ac ftolonibus Papaveris opii fpeciem viliorem excoquunt, quam Soli porro indurandam exponunt: hoc medicamentum Pouft vocant, quique eo utuntur, contumeliæ ergo Poufti à ditioribus vocantur, tanquam fummonianos, ac proletarios dicas. Pauperiores porro in divites convitium regerunt eos affionii vocantes, tanquam fi luxuriam, 
ac delitias vellent exprobare. Affion enim, ac quibufdam Amphion, Arabibus ac Indis opium Græcorum eft: indeque magis adducor, ut credam Græculos, à vetuftifimo populo vocabulum opii derivaffe, cum ab omni memoria illi eo ufi fint. Græci vero tantum noxas hujus medicamenti videntur noviffe, ufum verum, ac virtutes ejus plane divinas non fatis exploratas habuiffe. Porro ego hic Extractum utiliffinum ex opio, \& Croco Indico, 1. curcuma ad quod in Extremis tanquam ad facram anchoram confugere foleo: in jam ferme defperatis Cholera, dyfenteria, phrenitide, ac fpafmo hic admodum frequen: tibus: fed hoc melius è metbod. med. Indica noftra videbitur.

\section{In C A P. V.}

\section{De Gummi Benjoin. Fol. 26.}

Daragrapho I8. author ait benjoiferam arborem valde effe proceram ac vaftam, \&c.

Ego vero benjoiferam arborem hic in Java, ubi optimum Benjoin colligitur longe alia facie vidi, quam qua hic defcribitur; immo vero videtur planta (feu fi arborem appellare malis) ex pluribus farmentis coalita, qualis eft Smilax afpera, feu falfaparilla, nifi quod farmenta hic brachii craffitudinem æquent, vel etiam fuperent, ita ut in medio fape truncus arboris continuus fatis craflus appareat; fubtus vero, ac fupra Cœlum per farmenta à fe invicem diffita liceat contemplari. Sæpe quoque alia virgulta, à benjoifera arbore fpecie plane diverfitatem foliolitione includuntur: itaque fi quis ignarus diverfitatem foliorum in hujus arboris farragine videat, miretur fane: fed hoc etiam fieri in trunco aloes feu calamba poftea docebimus. Et porro ex hujus feu ftirpis, feu arboris cortice incifo fæpifime odoratiffimi benjoini gummi frufta aliquoties collegi.

Paragrapbo bujus Cap. 20. quia anctor ait gummi hoc propter Tygridum frequentiam minus multum colligi, qnamvis parergoos ac extra ordinem, ego tamen de Tygridis natura hoc adjiciam. Ferociffima igitur hæc beftia, proh dolor! ni- 


\section{i58 De Gummi Benjoin et Lacca.}

mis frequens eft in Javæ fylvis, quod è triftibus difcerptorum cadaverum exemplis fæpe difcere cogimur: nam tam ingenuos, quam fervos venatum feu lignatum in fylvas abeuntes, ex infidiis, nec opinantes hæc fera impetit, ac exfucto prius fanguine, cujus avidiffima eft, devorat. Quod infidiis hominem impetere dixi, eo hoc evenit, ut oftendam Plinii errorem, fagaciffimi alioquin naturæ indagatoris, $1.8 . \mathrm{c}$, I 8 . qui illic aic Tygridem effe animal tremendæ velocitatis: ac nefcio quas fabellas de venatione catulorum ejus affert. Quin hæc fera tardigrada eft, ac hominem (multo minus aliam feram) vix curfu affequeretur: hine eft quod apri, tauri fylveftres, cervi fagacius hoc animal odorantes ejus ungues curfu facile eludant: ideoque in cataractis, ac inter virgulta latens circa flumina, quo prædictæ feræ ad potum veniunt, faltu obliquo in aliquam earum fertur, non fecus ac feles in mures ac glires impetum faciunt; fic etiam ex infidiis hominem aggreditur, ac fi (quod fæpe fit) nimia cupidine prædæ aberraverit in faltando, lente ac rugiens recedit: fi quoque ab homine detectam fe fentiat, abibit; ita natura huic truculentiffimæ beftiæ aliquem adhuc noftri metum inculcavit - nam alias, neque in oppidis, neque in civitatibus nobis, tantillarum virium creaturis, hic tuto vivere liceret.

Dum in his defcribendis occupatus fum, fub initium menfis Maji anni I 630. Tygris capta fuit, prope foffas ipfas civitatis Batavæ, præfente generofo Domino noftro Generali Jacob Specx, quum aliquot dies, ac noctes non fine ingenti metu circumhabitantium, horrendum rugïfet. Cetera de robore hujus feræ refervamus in alium locum.

\section{A p. VIII. \\ De Lacca. Fol. 29.}

A UTHOR hic formicarum iftarum, quæ laccam elaborant, A mentionem facit: unicum hoc addo, quod formicx ifte alatæ funt ac coloris punicei, ac fuper flores, frutices, arbo- 
De Lacca, Tutia, et Ebore, etc. 159 rès ac herbas circumvolitant, ex quibus, non fecus ac apes; laccæ conficiendæ materiam colligunt ac in communes operas conferunt; non alatæ autem formicæ eam elaborant.

\section{A p. XIII. \\ De Tutia. Fol. 48 .}

Fulfitur vehementer hic nofter Gorcias ab Orta, quod Tu* H tiam è cineribus cnjufdamarboris oriri dicat: fed confitetur hoc fe auditu percepiffe, itaque deceptus fallit alios.

Nam fit ex terra quadam argillæ inftar glutinofa, quam colligentes Indi, ollis in eam rem ex argilla, longe fortiori quam in noftra patria, confectis indunt, ac aquam addentes eam curiofe baculis circumagitant, dein fornacibus in hune ufum effictis imponunt, ac per ignem exficcata omni aqua, dein terra hac calcinata lateribus prædictarum ollarum, demptis fordibus quæ in fundo hærent, Tutiam lateribus affxam abradunt, quam arcis inclufam venalem ferunt per totam Indiam: ejus enim ufus eft in depilatoriis apud hafce gentes, præfertim fæminis, dum fe in balneis, fluviis lavant.

In Perfiæ autem Provincia Kirmon dicta hujus terræ argillaceæ ex qua Tutia coquitur, à Perfis ac Armeniis mercatoribus qui negotiandi caufa huc advehuntur, magnam copiam reperiri non femel audivi, qui etiam ut lucrum ex Tutia, quam Perfica lingua Tutyath vocant uberius faciant, eam diftribuunt in lapidem Tutyath ac in pulverem ejus magis vilem, quam feorfim volentibus tum divendunt.

$$
\text { C A P. XIV. }
$$

De Ebore, ubi quadam fcitu non injucunda de Rbinocerote. Fol. 49.

Dagrapho 10. Auctor fatetur fe Rhinocerotem nunquam vidiffe aft ego eum non tantum centies caveæ inclufum 


\section{DE E B ORE, \&C.}

vidi; fed $\&$ in fylvis vagantem. Cute è nigra eft cinericea, inftar Elephantinæ, rugofa admodum cum profundis plicaturis circa latera ac in dorlo: craflam admodum habet pellem, ut quæ ictui Japonicæ, machæræ facile refiftat. Neque enim hæc beftia (uc apud nos pingitur) fcutis munita eft; fed hæ plicaturæ hos clypeos mentiuntur, neque una pars durior eft altera. Roftro eft porcino; fed ante acutiore neque tam obtufo, in cujus extremitate cornu iftud extat; unde nomen fortita eft bellua, aliud altero majus pro æatate Rhinocerotis. Colore etiam cornu variat, modo nigrum, modo cinericeum, modo album eft. Magnitudine autem corporis mediocris ftaturæ, Elephantem proxime accedit mediocrem, nifi quod pedibus fit longe humilioribus; \& propterea tam confpicuum etiam non eft animal. Ceterum innoxium eft, nifi laceflitum neque crudivorum eft ut Tygris; fed herbis vefcitur ac virgultis, ïfque perquam fpinofis, nam linguam (ut infra dicetur) habet afperrimam: fed fi irritetur hominem fimul, ac equum tanquam pulicem profternit, quam dein lambendo necat, dum afperitate linguæ cute ac carne ufque ad offa hominem denudat. Carnibus ejus Mauri vefcuntur: fed nervofa plane eft, ac ferratos Plauti dentes poftulat. Ut porro ferocitatis hujus exemplum habeatis, attendite. Vir mihi notiffimus ac familiaris retulit, fe duobus aliis comitatum in fylvas exfpatiantem equitem ivife, ac reperiffe Rhinocerotem femellam cum catulo. fuo in luto fe volutantem; nam hoc animal æque, ac fues \& apri, cœno mirifice gaudet: bellua ipfis vifis affurgit ac lento paffu recedens pullum fuum præ fe roftro trudens agebat. Unde unus ex tribus temerarie fatis feram infequitur, ac exerta quam ferebat machæra Japonica belluæ nates ac tersum ferit, nullo fequente fanguinis fluxu, veruntamen diffecta aliqua ex parte cute, ftrix lata ac albæ apparcbant, quod patienter beftiaferebat, donec fylvæ appropinquans, catulum fuum inter vepres \& falicta occultaviffet, tum vero retro converfa ac horrendum grunniens, equitem noftrum invadit: fed bonis avibus equus perterritus retro faliit, fed Rbinoceros tamen femoralia equitis mordicus apprchendit, \& quia è ferico materia leviffima confecta erant, 
difcerpit, ac nofter fe in fugam, quantum poteft, dat infequente eum acricer Rhinocerote: ipfo perveniente ad derelictos focios, qui impecum belluæ declinantes, poft duas ingentes arbores vix duos pedes latos à fe invicem diftantes, fe ftiterant: fed beftia furore correpta, priore equite relicto quos pedites impetit, nam equos ligatis pedibus paftum dimiferant: fed feu ingenito ipfi ftupore, feu furore impedita viam inter duas iftas arbores omni vi quærebat, quas quidem horribiliter tremere faciebat: fed vim ejus craffities ipfarum infignis impediebat tantifper, donec ipfis daretur tempus fclopeta fua expediendi ac fefe colligendi è metu, tum belluam iteratis ictibus in fronte feriunt per cerebrum, quam collapfam mox Mauri fervi, qui lignatum in fylvas abierant $a c$ ab equite periculi admoniti erant, fecuribus ac dolonibus \& lanceis interfecere, fociis non parum maledictis in equitem $\mathrm{fe}$ invehentibus, non fine reliquiis ingentis terroris, ac fic fortiffimæ belluæ ferociam evafere, nam hoc animal fi fclopeto læfum, aliquando per fylvas fugit, quicquid obvium eft cum fummo fragore, ac horrore audientium, profernit etiam fatis craffas arbores: fed hæc de Rhinocerote fuffciant. Quicquid porro de Elephantis docilitate dicitur verum. eft: ac defino, fi prius Plinii, ac \#iliani errores detexero, qui inflexibiles pedes, \& crura fine flexuris Elephantos habere fcribunt, quod adeo falfum eft, nam præterquam quod hominibus tantum circa crura, ac femora articulationes funt, Elephantibus præterea, flexuræ in medio tibiarum funt. Probofcide porro (ut bene Plautus) tanquam manu utitur in cibo capiendo, ac ea tanquam manu in os ingerit."

\section{In CA P. XVI. \\ De Agallocho Seu ligno Aloës, Calambac Indis dicto. Fol. 6f.}

Tignum aloës præterquam quod in Infula Sumatra, directo in confpectu Javæ fita, nafcatur : etiam frequens oritur, ac optimum in Champac vicina Chinæ regno regione, \& in X 
Cochinchina. Ac quod cortice nudatum hine in patriam feratur, non ideo evenit, quod fine cortice crefcat: fed quod fape quafi uno trunco etiam diverfa fpecies virgultorum ac ftirpium temporis diuturnitate coalefcant, haud fecus quam in benjoifera arbore fieri diximus, nam hoc mirum nobis videri non debet, cum fciamus per artificium etiam diverfe fpeciei arbores alienæ fpeciei inferi. Ceterum hoc modo incolæ lignum aloës, ab aliis virgultis ac ligno feparant. Truncosaloës cæfos deponunt in ripis Huviorum in cœno ac luto, ut diverfi generis lignum carie confumptum fe à ligno calamba feu aloës feparet: unde cortice calamba confumpto, qui tam oleofus non eft, quam ipfum lignum, quod præterea minus teredinibus ac putredini obnoxium eft, tale quale in officinis in patria, ad nos quoque defertur. Lignum hoc porro Aloës guftu plane aromaticum eft ac fubamarum, unde forfan aloës nomen mutuatum eft. Pulvis ejus ad fcrup. I. pondus fumptus choleræ medetur, quan mordexi incolæ vocant, ac omnibus inceftinorum affectibus frigidis ac ventriculi medetur egregie. Tum tineas, ac afcarides puerorum efficaciter necat. Chinenfibus porro ac om nibus mauris ethnicis, in facrificiis pro fuffumigio eft.

\section{In $C_{A P} . X V I I$. \\ De Santalo Fol. 68.}

D arograplso tertio, auctor nofter refert, pallidum ac flavum Cantalum plurimum in Tymor infula nafei, de quo hoc por. ro memorabile hic certo accepi, è mercatoribus noftris advehendi fantalini ligni gratia eo commeantibus. In hac infula nafei febris continux ac ardentis quandam fpeciem, quæ fit è fynochi putridx genere, cum delirio ac mentis alienatione mi. ra; durante nanque exacerbatione, que plerumque quatuor eft horarum (nam hoc obiter fciendum eft, quamuis ad apurexiam hæc febris non perveniat: tamen exafperationes fuas habere, non fecus ac tercianas continuas) ridiculas adnodum actiones æegri edunt, id opificii, vel muneris imitantes, quo 
lani functi funt (ut latius in Method. metendi mea Indica) ac aftantibus rifum excutiunt. Tenentur quoque bulymo, ac fame canina infatiabili, ut quicquid iis obtuleris etiam foedum (ut mos ex nauticis noftris fociis eo generefcurrilitatis delectasi) avidifime devorent, extra exafperationem eam, cetera fani ac mentis integræ. Hunc porro affectum ortum fuum trahere ex recens cæfarum arborum fantali cortice viridi, incolæe certo certius affirmant: nam cortex tum virofi nefcio quid expirat, ac cerebro inimici, tum cito in corporibus cacochymis, ac pejoris diætæ, ut funt nauticorum noftrorum, tales effectus edit. Sed latius in præd. meâ meth.

Antequam cædantur arbores fantali, cortice incifo exploratur ab expertis odor, num maturæ fint ac tempeftivæad fecandum. Aucior porro fantali fructus ait efle cerafi magnitudine: baccas lauri non male referunt, nam exficcatas habui, ac mafticati purpureo ac morino colore inficiunt. Fruetus hi avide comeduntur à turdorum quadam fpecie, ut baccæ orni in patria, quos denuo per alvum excernentes, arva acmontes novis arboribus conferunt, ita ut quamvis tanto tempore tot millia arborum cæfa fint à Lufitanis ac noftris, tamen Sylvæ nunquam deficiant.

Porro cum Auctor mentionem hic faciat unguenti ex fantali pulvere: ego hujus compofitionis ufum, in gratiam tyronum medicinæ hic fubjiciam, ac primum hoc modo paratur. $\mathbb{R}$. fantal. tenuiffime moliti florum Champac. florum mogori an. $m$. I. his parum contuf. adderad. curcum unc. ij. camphor.q. s. ad gratum odorem : hæc omnia in plano marmoreo lapide piftillo fubigunt, addendo fub finem olei nucis Indicæ recentis $q . s$. ung. formant in pultis confift. Hoc inungunt tam viri, quam mulieris Malaïe totum corpus, \& quamvis propter flavum colorem, quem è curcuma contraxit, primo afpectu foedum fit;-tamen fuavifimo ac faluberrimo odore nares ferit. Prodeft vexatis á Solis, vel etiam à febrili æftu, rigorem quoque in febribus tollit, ac nimias vigilias arcet; impofitum quoque regioni ventriculi choleram fiftit \& corroborat. Quæ latius in præd. Meth. 


\section{In CA P. XVIII.}

\section{De Betele pynang, Sirii Poa, foc. Fol. $7 \mathrm{r}$.}

Dragrapho tertio, priorem fuccum exfpuunt) quod priorem fuccum exfpuant prudenter me judice faciunt, nam alias calx admixta, gingivas ac palatum excoriaret. Hoc quoque ubiter notandum eft. Quod fi betele, ac arecca fine calce mafticetur, fuccus inde mafticatione elicitus viridis eft, addito vero calcis modico fuccum eumdem magis rubicundum, quam fanguinem confpicies. Quod me in principio vehementer fefellit, quod crederem eos excreatores fputo fanguinis laborare. Quid porro de ufu hujufcemodi herbarum credam, paucis ac plane aperiam: ego mafticatorium hoc longe antefero fumigio tabaci, veruntamen ipfius longus, ac continuus ufus (ut hom:nibus hic mos eft) non folum dentes, ob admixtam calcem erc. dit: fed etiam excidere' facit: immo non femel vidi aliquos, qui nondum juventutis terminos egreffi omnibus dentibus carcbant ob ufum Syrii pynang. feu betele ac arecca cum caice, quam Malaji caput vocant. Hinc etiam videas Javanos, ac ceteros Indos rariores oftendere dentium ordines, in quorum vacuos loculos ditiores aureos reponunt dentes. Præterea ubi nux faufel feu fructus pynang nondum maturuit, quod Javani Pynang Mouda vocant, quafi juvenem dicas, repentinam vertiginem capiti inducit, quæ quamvis comefo pauco fale, vel hxuftu aquæ gelidæ cito evanefcat ; tamen hinc conjicere licet, id medicamentum quod tam repente arcem divinam mentis afficit, non admodum cerebro, ac nervis amicum efle. Ergo ut concludam moderatum ejus ufum pro dentifricio, ac ad commendationem halitus oris laudo, ceterum abufum, non minus ac Tabaci vitupero: nam mea quidem fententia dementia fumma eft, ea pro alimento velle habere, quæ medicamenti tantum vim obtinent. 


\section{In $\mathrm{CA}_{\mathrm{A}} \mathrm{p} . \mathrm{XX}$.}

\section{De Maci. Fol. 79.}

Teruntur è Banda Moluccaruminfula grandia vafa ficillia, huc perque reliquos aliquando (cum permilfione fuperiorum) in1ularum circumjacentium tractus, plena Nucibus myrifticis, aceto ac muria condita: nam fine permiffu nullo modo efferre licet', quod infulæ Bandenfes noftris armis fubactæ provincia Batavorum factre fint. Nuces has maceratas per diem, unum, aut alterum, dein leviter excoctas faccharo condimus hic.

Ceterum de Cortice nucis hujus condito hoc dictum fit, ac de nuce quoque ipfa, iis parcius in his locis effe utendum, quoniam oleofi, ac pingues vapores ex efu ejus in cerebrum, elati, obftructionem ventriculis cerebri afferunt, ac inde fomnolentiam, immo fuporem quendam univerfis fubjectis membris in. ferunt. Et quod majus eft, ex nimio hujus Nucis ufu aliquot periclitari vidi, qui amplius, quam per diem naturalem fine fenfu, ac motu jacuere, tanquam caro correpti, certifimo indicio cerebrum, ac univerfum nervorum genus non leviter correptum fuiffe. Præterea incolæ in Banda, ac jam etiam noftrates, ex viridicortice nucis myriftice pultem excoquunt non infuavem, qux ferme fapore refert iftud ferculum, quod in patria conficitur ex pomis acidis coctis: fed qui ea pulte ufi funt ex fide mihi retulere, ftuporis ac fomnificos jam dictos effeEtus edere.

\section{In CA P. XXII. \\ Dé Pipere. Fol. 86.}

Non tantum Piper provenit in Malabar ut Auctor 10. para1 grapho, ait: fed maxima etiam quantitate nafcitur in Regno Java, præfertim in Bantamenfi provincia: Præterea cre. fcit abunde in Jambienfi Sumatræ tractu, qui peculiarem regem obtinet non fubjectum imperio regis Achinenfis, qui po$\mathrm{X}_{3}$ 
tentifimus hujus infulæ Tyrannus. Ex hac provincia ab amico rege, noftræ naves quotannis bis terve petunt:

Quod porro Auctor parag. I. 1. fol. 89. inquit, aceto ac muria condiri piperis racemos virides, verum eft. Ac quia aliquoties repetendum erit, id condituræ genus Indi generali vocabulo Achar vocant. Ac tali modo condiuntur etiam Zinziber viride, radices galangæ, caryophyllorum racemi. Hoc modo etiam faliunt cucumeres juvenculos, quos agurcas Lufitani vocant; præterea mangas, addito cæep, allio, ac porro. Et certe in his locis, ad orexin excitandam ac ciborum concoctionem, nihil fanius reperiri poteft. Cum propter aëris in hoc clymate calorem fimul ac humiditatem fubjectæ capiti partes, ut funt Pulmones pracipue, ac ventriculus atliduis Catharris infeftentur: ad hune ufum genifta quoque hic crefcens ac cappares è Perfa, ac furatæ adferuntur hue.

AltEtor porro hujus Capitis paragrap. 12. refert ridiculam Indorum de piperis qualitate opinionem. Quam etiam hic Javani confirmant, nimirum quod frigidum fit piper, credo forte ea ratione, qua quondam quidam perverfi Sophiftæ, argumentabantur ignem frigidum, ac Nivem feu glaciem calidam efle, vel ut Hyperbolice Poüta, ait, Penetrabile frigus adurit: Contra quos tamen bene monent Ariftoteles non effe difputandum, nifi. fola experientia; nifi forte vellent nimio ufu, calorem nativum diffipari, ac debilem inde reddi: aft illi (credo) tam alte non philofophantur.

\section{In C A p. XXIV. \\ De Cardammomo. Fol. 94.}

nfigniter hoc Capite paragr. $\sigma$. hallucinantur Garcias ab Orta, 1 quod dicat piforum inftar feri, ac fimili modo filiquas dejendere è farmentis, quippe ego qui millies crefcere cardamomum vidi magna copia inftar arundinetorum; nam \& Caulem habet arundinis omnio fimilem, internodiis quoque diftinctum, fed intus fpongiofum, non concavum; folia quoque ariundinis 
folis perquam fimilia funt, nifi quod non tam faftigiata, ne: que in pyramidis acumen definunt, verum Coni inftar, teretia magis funt: Siliqua autem hoc modo crefeunt, exit circa radicem fpica primum viridis, qualis eft fpica Nardi, quæ fe. fe aperiens emittit in faftigio flofeulos intar anagalidos, nifi quod albi fint luteo colore diftincti, odoris aromatici plane ac fuavifimi; maturefcens porro fpica cerealem tritici colorem induit, \& hac continentur filiquæ iftæ, quæ femen continent, guod virefcens colore eft albo, purpureis maculis pulchre intermixto; arefcens porro, ac ubi ficca evadit, puniceum iftum colorem induit, quem apud nos in officinis oftendit: fed alibi in Exoticis meis Indice plantis hiftoriam cum pietura ad vivun exprefla, vobis oftendam, quod nullum ante me fecifle, eft quod glorier:

Cardamoni porro femen palatum grato calore afficit, ac blando: Ac ego arbitror nullum inter aromata effe, quod fanius pectori, ac ventriculo fit, nam nullum Empyreuma (ut reliqua omnia aromata) in ore, nec vifeeribus relinquit.

\section{In CAP. XXVI.}

\section{De Nuce Indica, Coquo, Lufitanis dicta. Fol. 120.}

arolus Chifuis in annotationibus ad hoc Cap. fol. IIg. refert, folere Indos foliis hujus palmæ infcribere literas fuas; immo, quod vero proprius, literas hifce foliis oblongis infeulpunt ftylo ferreo, atque id adeo artificiofe faciunt, ut vel ele. gantiffimum fcriptorem è noftris longo intervallo poft fe relinquant, \& tam emendate characteres fuos Indi (Arabicis autem utuntur ) hifce foliis imprimunt, ut fubirafci mihi aliquoties contingat noftris Europæis \& præfertim noftræ nationi; quæ ferme nil nifi fua admirantur, ac has nationes barbaras vocitant, cum multo fignificantius paucis charaeteribus, more Laconum animi fui fenfum exprimere queant, gam noftri longis periodis, ac verborum farragine inutili. Praierea quamvis regnum in Java videatur Tyrannicum imperium: tamen id 
ita pro conditione gentis fuæ politice gerunt, ut aliquis, cui non cornea fibra ef, neque de genere eft Arcadici pecoris, hic fatis cito addifcere queat, compendiofam hic politices viam efle regibus bene imperare, ac fubditis melius obedire.

\section{In Ca e. XXVII. \\ De Myrobalanis. Fol. II r.}

yrobalanos Emblicos ac Bellericos officinis Europæis vo1 catos, fæpe hic nafci in Java vidi: ac præter folitas myrobalanorum fpecies hic nafci vidi hactenus noftris incognitas, figura plane rotunda, ac quæ ine ftriis, ac incifuris fint, leves plane ac æquales: ceterum trunco, foliis, ac fapore reliquis myrobalanis fimiles funt, nifi quod de purgativa ceterorum myrobalanorum virtute non participent, ac inde conftat non temere palato aftringentem magis reliquis guftum addere. Himyrobalani conditi nobis quotidiano ufu funt pro decumbentibus in nofocomio è dyfenteria, Cholera: ac biliofis febrium caliditatibus, quod caput rei, putredini egregie refiftunt.

\section{In CAP. XXVIII.}

\section{De Thamarindis. Fol. 115 .}

uod paragrapho 4. hic Garcias ab Orta dicat folia Thamarindorum effe minutim incifa, verum eft, ac vere referunt formam, ac virorem ciceris aërietini: ut \& quod eodem parag. dicit folia Thamarindorum ad eryfipelata valere, cum fint adfringentia, ac fumme ficcantia, tum frigida. Saporem quoque plane referunt acetofæ, feu oxalidis, hinc ad dyfenteriam, ac Choleram fumme utilia funt. Ut porro potus nobis quotidianus ex infufione Thamarindorum, ac facchari conficiatur, admixtis malis citreis, dixi alias in method. mea medendi Indica, Thamarindorum porro arboris figuram in Exoticis meis videre licebit. 


\section{De Cassiatet Calamo, \&c. In C A P. XXIX.}

De Caffia Solutiva. Fol. I17.

( uod huic Capiti addam, vix quicquam habeo, nifi quod Auctor parag. 4. ubi facit mentionem locorum, in quibus Caffia crefcit, Javam præteriit, in cujus tamen fylvis copiofe provenit, hujus pulpæ ufus frequens eft apud Malayos in renum, ac veficæ morbis, ac omnibus nephriticis morbis, in gonorrhæa quoque ex impura Venere contracta, fi mifceatur ei pulvis therebinthinx coctus. Non aufim tamen in dyfenteria vera hic frequentiflima, ac Cholera nifi cum cautione exhibere, quia ut $\&$ manna facile in bilem convertitur, ac morbum hoc modo per fe periculofum longe magis lethalem faceret.

Porro hoc Cap. par. 9. fol. I I9. ridicula refertur quorundam opinio, nempe boves hic affiduo alvifluxu laborare ex paftu foliorum arboris Caffix, \&c. Caufa autem vera hujus fluoris mea quidem opinione eft, quod regiones fub vel circa æquatorem fitæ, aërem fortiantur calidum, ac humidum, ut alia latius explicavimus, qui vifceribus, jecori, ventriculo, lieni, ac inteftinis putredinem inurit, ac fluxus inteftinorum, ac Hepatis inducit.

\section{In CAP. XXII. \\ De Calamo Aromatico. Fol. 125.}

Dræter ufus excellentes, quos præftat in medicina Calamus aromaticus hoc Cap. defcriptus, etiam Malaïcis mulieribus in culina infervit, in condiendis pircibus, ac carnibus elixis, cum radicibus Zinziberis recentis, radice Curcumæ, ac Galan$\mathrm{gx}$ ac reliquis aromatis, ac fic cibis odorem, ac faporem fuavem conciliat, ac concoctioni ventriculum, ac inteftina apta efficit. Ceterum ut hoc parergoos dicam, hæ nationes, quantum noftris barbaræ vocatæ, Polonos, ac Germanos in con- 
io De Calamo Aromatico, et Nardo.

diendis pifcibus fuperant, qui tamen hic palmam fibi vindicare non erubefcunt.

Ceterum Auctor ait Calamum aromaticum, nec Galangam, nec Acorum effe; bene quidem cum Acorus, ac Galanga, quantum ad folia potius ad Gladioli fpecies debeant referri; ac Calamus aromaticus fit Gladioli fpecies.

\section{In CA P. XXXIII.}

\section{De Nardo. Fol. 128.}

7. Jardus Indica in Java magna quantitate crefcit, ejufdem in 1 culina apud Javanos ufus eit, qui Calami aromatici, ac Junci odorati; nimirum in condiendis jufculis pifcium, ac car: nium elixarum. Plantam Nardi viridem hactenus non vidi, quod in montibus circiter 14. leucas ab urbe Batavia crefcat, \& nos eo propter prædones Javanos, \& tygrides excurrere non audemus. Nos hic, non fecus ac Calendule flores exficcatos in patria, Nardum infundimus in aceto, ac dein Syrupum quoque inde conficimus adverfus frigidos vifcerum affectus, hepatis, nimirum, lienis, ac menfenterii obftruetiones, qua poftremæ hic adeo frequentes funt, ut hinc mifere multi extabefcant ac marafmo moriantur, fine dolore tamen, ac pauco fen$\mathrm{fu}$, de quo latius in metbod. med. mea. Acetum porro, ac fyrupum hunc nardintim (certo mihi confat) ad morfus venenatorum, ut ferpentium, Scolopendrarum, Scorpionum, \& fimilium valere impofita, vel intus fumpta: quod experimento comperi pracipue in uno, qui morfus erat à ferpente quodam, quem Lufitani hic Cobra de Capello vocant: atque hujus morfus hic adeo venenatus, ut certe luftani hunc regulum. feu Bufilifeum effe putent: fed de eo aliquid inferius dicemus

Sequentibus de Funico odorato nibil acdo, quam quod auctor fallatur, qui dicat Junici odorati nullum alium effe ufum apud Indos, quam fubfternendis equorum cubilibus, cum etiam eo in culina ad condiendos cibos ut Calano aromatico Indi utan- 
tur: quapropter etiam, quamvis in fylvis copiofe crefcat, ftudiofe à mulieribus Malaicis in hortis colitur, tum quoque ad lavacra, fomenta, infeffiones, utilifimus eft; ut \& ad omnes muliebres affectus; \& cum fit graminis fpecies, ac fimplicis, vulgaris graminis ufus, in multis tantopere commendetur, quis neget gramen hoc plane aromaticum vires longe excellentiores poffidere?

\section{In $\mathrm{C}_{\mathrm{A}}$ P. $\mathrm{XXV}$. \\ De Cofto. Fol. 137 .}

uEtor hoc capite tantum unicum genus Cofti effe afferit, A quod \& ego affirmo: nam vetuftiores Medici, fua triaCofti genera diftinxere magis à carie, \& vetuftate corrupta Cofto. Cofti porro radices huc è Cambodia plenis faccis adferuntur, cum plurimus ejus ufus fit in medicamentis apud omnes Indos, ac Chinenfes præcipue. Ceterum Coftus vulgato vocabulo inter mercatores Indos Pucho, Chinenfibus Potfiock vocantur. Notas omnes hæc coftus habet, cum ea, quæ hoc Cap. defcribitur. Cum ego primum radicem Cofti viderem, putavi effe Hellebori albi radicem, \& nifi me odor monuiffet, in ea opinione adhuc hæfiffem, quia Cofti radice per medium fecta tot initia fibrarum, quot in Hellebori radice reperies: Adulterari porro radicem hanc, ut Alictor ait, non credo: nam vidi ego integrum Picol, quod pondus centum ac vigintilib. in auctione decem realibus diftribui.

Auctor fequenti cap. xxvi I 1. de Radice Chinæ, multas, ac veras laudes refert. Quibus ego hoc tantum addo: quod hæc radix non tantum ad affectus Venereos utilis fit: fed \& ad omnes Chronicos morbos, qui communiter graffantur , ut funt Cachexia, Leucoplegmatia, Hydrops, denique paralyfeos ea fpecies, quam beriberii in meth. mea Indica medendi vocari dixi, ad quam curiofum remitto, quod in me ipfo dum moleftiffimo hoc malo per quatuor menfes decumberem expertus fum, cum ante ejus ufum neque pedes, neque brachia commodo movere pofiem, quod \& in plurimis aliis experientia didici. 
172 De Croco Indico, seu Curcuma.

\section{A R. X X IX. \\ De Croco Indico, Jeu Curcuma. Fol. 153.}

rocus Indicus, quem author hic defcribit, nil aliud eft, quam radix Curcumæ officinis patriis dictæ, hic in fylvis tam copiofe crefcit, ut inde vel integras naves onerare poffis: verum feritur etiam in hortis. Folia habet oblonga longe latiora, quam folia Cardamomi, quibus alias non funt abfinilia, caule variat, qui in Cardamomo eft internodiis tanquam arundo, diftinctus: aft in Curcuma lævis, ac æqualis. Miror ego Garciam ab Orta, hanc nobiliffimam plantam tam leviter tranfiifle, cum apud omnes Indos, nulla planta fit in frequentiori ufu, quam Curcuma. Nomen Croci fortita eft, non quod ullam habeat fimilitudinem cum Croco Anglico, qui optimus jam eft in toto terrarum orbe: fed quod radix ejus, non fecus ac Crocus verus colore flavo tingat.

Unde etiam Lufitanis faffran da tierra vocatur, quafi Crocum fubterreftrem dicas; Malaii communiffimo vocabulo borbory indigitant, cujus ufum infra docebimus. Unde \& tota nobiliffimi paulo fupra defcripti unguenti compofitio nomen fuum fortitur. Flore eft pulchre purpureo, qui in fummitate plantæ emergit, fimilitudine referens flores gladioli cujufdam, qui in Hollandia menfe Junio aut circiter, egregie purpureos flores profert. Quod nofter auktor. dicat, parag. 5. fub finem hujus capitis, fe exiftimare fine noxa hanc radicem poffe fumi, audacter quamvis meo periculo dicito, neque ullum frequentius condimentum apud noftros Indos eft, in coctis pifcibus, ac carnibus elixis. Præterea nobiliffimus ejus eft ufus in medicamentis, tam topicis, quam intro exhibendis in omnibus obftructionibus vifcerum, ac mefenterii hic frequentiffmis: tum in mulierum morbis nullum æque celebrant Malaïcæ mulieres, quam hơ borbory, tam divinis laudibus efferunt in facilitando partu, ac urinæ difficultatibus, ac Renum affeEtibus. Tum in utero remedium eft fpecificum. Ac certe ut 
verum fatear, nihil in his affectibus præftantius in quotidiano ufu reperi, quam præftantiffimum hoc inter omnia medicamentum: fed de hac radice latius, in in meth. medendi.

\section{In CA P. X L. \\ De Galanga. Fol. 153 .}

um author hoc capite de Galanga fatis fuperque dixerit, nil habeo quod huic addam, nifi in acetariis eundem hujus radicis ufum efle, qui virentis Zinziberis radicis, ac loco capparum ad orexin excitandam ea Indos cum affis pifcibus accarnibus uti, hanc condituram, cum muria, ac aceto jam aliquoties achar incolis vocari diximus.

\section{In CA P. X L IV.}

\section{De Ligno Colubrino. Fol. $\mathbf{4 5}$.}

$\Delta$ it boc capite author lignum colubrinum valere adverfus cirA cuitus febrium intermittentium; hoc verum effe non femel experientia didici, præcipue in Tymorenfibus febribus cum delirio, ac fæpe phrenitide conjunctis, de quibus \& de earum cura alibi. Lignum colubrinum hoc vehementer denfum eft, ac fi quandö Indi velint eo uti, fricant fortiter cum aqua in marmoreo lapide, \& friabile cum fit, teritur facile, ac fic cum aqua aut alio liquore ægro exhibent, guftu eft longe amariore, quam lignum aloës: valet quoque ad tineas, lumbricos ac afcarides, ac potenter ictibus venatorum animalium refiftit.

Paragrapho porro tertio, mentio fit Serpentis cujufdam quem Lufitani Cobra de capello rocant: hi ferpentes cum irritati funt, duas bullas in cervice erigunt flavo colore, quales ranæ iftæ paluftres coaxantes in temporibus attolunt, ac hæ bullæ forfan coronæ fpeciem authori fecere. Ceterum ferpens hic, non multo craffior eft digito minimo articulari humano, in tergo colore eft nigro, in ventre fode flavo.

Quod Jeq. paragr. dicitur de pugna viverræ cum hoc ferpenY 3 


\section{4

te, non adeo diffonum eft, cum ego fæpius à felibus occifos viderim, fed nunquam de carnibus eorum guftant, cum reliquos ferpentes, præfertim aquaticos avide devorent. Signo inter cetera evidenti quam virofum fit hoc infectum. Vidi enim Miaurum quoddam arundineti genus cædens, quod tottang Indi vocant, ac eo omnia ligant, ut apud nos hoc funibus fit, quorum hic vicem fupplèt, \& dum inprudens unum ex ferpentibus his lædit, ab eo morfu in mufculo policis eft petitus veftigio vix exftante, \& cum, ne venenum altius ferperet, brachium ipfi arctifime ligaretur, ac ille pre dolore vinculum laxari obnixe oraret, quo facto ftatim mifer experiavit, corpore in fædum in modum intumefcente, tanta erat vis veneni ad cor momento penetrantis.

\section{In CA P. X L V. \\ De Lapide Bezabar. Fol. 165; Perfis $\mathrm{Pa}-$ zahar.}

Daragr. Secundo hujus cap. author ait lapides Bezahar paleam vel quid tale intus habere, quod nunquam fallit niti in adulterinis, \& fi fuperficiali tunica abraf́a, non fuecedat alter orbis cxparum modo, donec ad paleam iftam deventum fit, fictitius eft lapis proculdubio: fed fequenti modo ejus adulterium melius percipitur. Si lapidem frices panca calce, \& fi in loco fricato puniceus color appareat, conftat verum efle, ac genuinum: fecundo fi ponderatum accurate lapidem conjicias in pelvim aqua repletam, \& poft duas aut tres horas eundem eximas ac rurfus ponderes, ac fi nihil de priori pondere aut perdiderit, aut eo gravior factus fuerit, verus eft lapis Bezahar: verum fi calce fricatus rimam ducat, aut fi aqua exemptus, de pondere amiferit, vel co auctus fuerit, falfum ac adulterinum effe audacter dicito.

Paragr. 6. Garcias inquit lapidem hunc non folum generari in Perfia, fed etiam in aliis commemoratis locis: fed quoniam - nullus quod fciam ante me verum etymon hujus lapidis edidit, 
nec quomodo, aut ex quo generetur, pancis aufultate rem. Perfæ igitur hunc lapidem vocant $\mathrm{Pa}$-zahar compofito vocabulo ex Pa, \& Zahar, quorum prius fignificat contra, ac fecundum venenum nominatur, ac fi græco vocabulo antidoton dixeris: hic perfpicitur quam fallax fit ifta etymologia, qui a $\mathrm{Pa}$ zar vel Bazar lapidem hunc dictum volunt, cum nullus ungiam hunc lapidem venalem in foro viderit. Nafcitur hoc porro mo do lapis Bezar in Perfia, ut ab Armenis, ac Perfis mercatoribus fide dignis certo accepi. Eft locus in Perifa Stabanon dictus, trium dierum itinere fupra Laram civitatem celebre in Perfia Emporium, in cujus campis nafcitur herba quædam croco, ac hermodactylis admodum fimilis, in cujus campis caprorum copia pafcitur, in quorum ventriculis ex efu hujus herbulæ hi lapides in ventriculis caprarum concrefcunt, qui apud Reges Perfiæ in tanto pretio funt fupra reliquos, qui in aliis locis gignuntur ut magnus Xa Abas Imperatorum Perfarum ultimus mortuus anno 1628. inibi vigiles locaverit, ut omnes iftos lapides Bazahar, qui certum pondus excederent, fibi vendicarent: Itaque quod caufa materialis hujus lapidis fit caufa fupra dicta, non folum Armeni, ac Perfa mercatores mihi retulere: fed idem ferme affirmat $P$. Texteira Lufitanus in tractatu fuo eleganti, quem Hifpanica lingua confcripfit de rebus geftis Regum Perfiæe, qui, inquit, Infulam quandam effe inter Ceylon infulam, ac terram continentem Chormandel, quæ à Lufitanis Ifla de vacas vocata (quod infulam vaccarum fonat) noftris naucleris etiam optime nota, in qua etiam nafcitur copia prædiEtorum lapidum, quam ob caufam etiam ibi multæ capre pafeuntur. Atque idem author ait quod anno 1585. hanc infulam maxima ac horribilis inundatio invafilet ac etiam totam continentem terram Chormandel, ita ut hæc infula tota fubmerfa fuerit, quæque fervari inde capræ poterant alio tranflatæ defierunt gignere iftos lapides, quod prædicta herba ibi non crefceret: fed elapfis paucis annis, cum infula falfugine maris liberata rurfus hanc herbam produceret, capræ ejufmodi iterum eo tranflatæ lapides hos ut ante produxere. Hæc mili vobis communicare vifum eft, quoniam \& mercatores noftri, 


\section{De lapide Bezahar, ex lapide Porcino:}

ac Angli idem certo confirmant. Ceterum quantum ad hyper: bolicas hujus lapidis virtutes, ac facultates portentofas, non tantas in eo mille experientiis edoctus inveni, alioqui etiam natura non pronus fuperftitiofas medicamentorum facultates facile admittere, nifi experientia id verum invenerim. Quoque, id magis credatis, dapides hi miferis hircis, ac capris tam molefti funt, quam hominibus lapides veficæ, ac renum. Capræ iftæ non abfimiles valde funt capris Europæis, nifi quod habeant erecta, ac longiora cornua, ac quædam ex iis verficolore funt pelle ut tygricies pulchro afpectu, quales duas hic in arce Bata. via noftra quotidie videmus, itaque hæ capræ prout magnum lapidem, aut parvum gerunt, unumque, aut plures, eo moleftius, vel citius incedunt, quod aftutiffimis Armenis, ac Perfis perbene notum eft. Porro vidi \& lapides $\mathrm{Pa}$-zahar natos in ventriculis fimiorum, qui Teretes funt, ac longitudinem digiti aliquando excedunt, qui hic præftantiffimi omnium cenfentur.

\section{In $C_{A}$ P. X L V I.}

\section{De Lapide Porcino. Fol. I68.}

T apis ifte Malacenfis, cujus author hic tranfitorie meminit, in memoriam mihi revocat alterum lapidem quendam genitum in felle porcorum, aut etiam ventriculis hiftricum oblongis pinnis præditorum, quem Lufitani propterea Piedra de Puerco vocant: mollis, ac pinguis eft attactu, ac fi faponem Hifpanicum tractes: ego duos domi habeo, unum parvulum ex hiftrice, alterum ex apro excifum. Infunditur hic lapis in vino adverfus choleram, quam mordexi hic infulani vocant, ac hic tantopore timetur, quam peftis in Hollandia, utpote quæ hominem aliquando foleat occidere pauciffimis horis: Prægnantibus tamen hic lapis non bene datur: nam abortum provocare adeo certum eft, ut fœminæ Malaicæ mihi retulerint, ut fi quando manftrua earum purgatio non bene procedat, fi faltem hunc lapidem manu geftent, juvamentum fe inde fentire. Sed profecto mihi confideranti judicium humanum de omnibus hifce 
hifee concretis lapidibus in ventribus, ac cavitatibus animalium rationis expertium, ridiculum mihi videtur lapidem concrecun in vefica humana, ac fæpe è renibus elapfum, ac per penem redditum in nullo pretio haberi, cum homo non tantum fit animal longe nobilifimum, ac qui delicatiffmis cibis vefcatur: ac certe quod dixi, de ciriculis iltis inftar cæparum in lapide Pa-zabar repertis, fimiles circuitus ac orbes in lapide humano videre eft. Et ut propius ad externam fuperficiem pervenias, ut lapis Bazahar, friabilior, ac mollior eft, donec ad parvum nucleum circulis his inclufum pervenias, qui rubro fuo colore non obfcure lapidis originem è renibus effe oftendit. Nil porro de his lapidibus addo, ne videar lapides bazarticos elevare, $\&$ lithotomos monere, ut vel cum periculo plures mortales fecent. Hoc certe compertum habeo lapidem in vefica hominis repertum urinam ac fudores probe ciere, quod tempore ingentis illius peftis, quæ anno 1624. \& 25. Leydam patriam meam ac reliquas Hollandiæ civitates miferandum in modum vaftabat, in penuria lapidis bazaartici nos exhibuiffe memini, \& fudorificum (aufim dicere) melius, ac excellentius inveniffe, cum admixta theriaca, aut mithridatio, cum olei fuccini, aut Juniperi guttis aliquot.

\section{I $\mathrm{N}$ L I B R O II.}

\section{Garcice ab Orta, de Plantis quibuldam Indicis Jacobi Bontii Animadverjiones.}

In C A P. I.

De Arbore trifti dicta Pariz.

UoD hæc arbufcula noctu flores expandat, inde eam Lufitani, Arvore da Notte vocant, copiofe in Java flofculos fuos profert, quos fervi venales in urbem ferunt, $\mathrm{Z}$ 


\section{De Arbore Tristi Dicta Pariz, et Negundo \&rc.}

faciendis corollis, ac intertexendis capillis mulierum Malaicarum.

Paragr. 6. Auctor. mentionem facit florum fula Mogori dietorum: hi flores in arbuftis crefeunt non inepti texendis fepibus, humanam altitudinem vix hoc arbuftum excedit, flores quoque albos fert odore gratillimo, ac afpectu longe pulcherrimo. Stillatitius porro liquor ex floribus arboris triftis, ac hac arbufcula igne elicitur, qui cordialis admodum eft, quo circa ad lypothymias, qux in febribus continuis, Cholera, ac dyfenteria cresro accidere folent, fummum adjumentum præftant.

Paragr. 7. Author mentionem facit hic florum fibi Champe dictorum, Javani, autem cum arbore eos Champacca vocant. Arbor eft mali Perfici folio, fed craffiori paulo; flores porro colore inter fefe variant: nam alii funt è colore viridi dilutiori, ut potius primo afpectu ab arbore avulfi ; fafciculum foliorum mentiantur: fed pediculi intus in calice, quales ferme in rofis, flores effe declarant. Sunt \& hujus arboris flores alii colore aureo fubtiavo (quem colorem nottri Oranje vocanc) uterque flos. æque eft odoratus admodum, verum caput gravat, non fecus ac camphoræ odor infuetis gravis eft. Indos quoque author ait bonis odoribus effe deditos. Ut \& reliqui, qui Mahumetis fectam fequuntur, omnes, ita ut nunquam ferme mulierem Indicam in publicum prodire videas, quam cum hifce floribus capii vel capillo (ut dixi) impofitis ut gratiores maritis, vel fæpe amatoribus fuis occurrant.

\section{In $C_{\text {A p. III. 1. } 2 .}$}

\section{De Negundo or Lacrondi, feu Liguftro Indico.}

Tane arbufculam melius deferibit Profper Alpinus lib. de
\& plantis Bt.gypti, cap. I 3. fub nomine liguftri Aigyptii,
\& Aleanne, \& certe ligufro omnino fimilis eft quantun ad
folia: fed ramos latius effert, non fecus ac falix aquatica apud
nos, tum baccæ, qua floribus fuccedunt, rariores quidem
funt, 
De Negundo et Lagondi, seu Ligustro Indico. 179

funt, quam baccæ liguftri feu vaccinia: fed nigro quoque, ubi maturuerint funt colore, fed floribus variant: cum liguftrum hoc Indicum habeat flores coloris ex pallido cyanei, cum liguftrum patrium gerat flores nive candidiores, unde Virgilius; Alba liguftra cadunt: Vaccinia nigra leguntur. Vaccinia enim funt baccæ Liguftri. Odoratior quoque eft hæc arbufcula, quam liguftrum, unde merito inter aromaticos frutices venit, numeranda. Quod Profper Alpinus liguftrum hoc confundat cum alcanna, poteft id quidem fieri, quod alcanna, atque hic frutex in $Æ$ gypto indifcretim habeantur, nam liguftro alcannæ frutex omnino fimilis eft quoad folia: fed ea funt paulo minutiora, præterea alcannæ folia pulchre rubro colore tingunt, $f$ fuper marmoream tabulam, cum pauca calce terantur, ac per noctem in aqua macerentur. Hoc pigmento Javani utriufque fexus tingunt ungues, ac labia; tum Perfæ, ac Turcæ caudas equorum fuorum hoc rubro colore eleganter inficiunt. Crefcit uterque frutex in Java, ac ftudiofe in hortis colitur, \& tanto funt apud has gentes in honore, ut in omnibus ferme morbis hinc balnea, fotus, cataplafmata quoque concinnent, immo divinam hanc herbam ferme putant, \& certe nobis hic egregie defectum fupplet meliloti, ac chamomæli. Præterea nihil ad difcutiendum melius reperiri poffe confido, quam hæc folia, præterea in omnibus doloribus, etiam inveteratis fummum anodynum eft. Mulieribus in fotu menftrua ciet, partum facilitat, affeetibus omnibus denique vulvæ medetur, intus fumptum hoc medicamentum, urinas movet, renum ac veficæ malis fuccurrit, colicos porro dolores compefcit, \& ut verbo finiam, veterum Panacea nihil ad noftram hanc. Negundo, \& Niergundo hunc fruticem nominat auctor, Javani porro paulo aliter inflexo vocabulo Lagondi indigitant. 
180 De Jaaca Fructu, Jangomas, et Carambola

\section{In CAp. IV. 1. 2.}

\section{De Faaca Fractu.}

Dræter bene defcriptam hic Jaacæ fpeciem crefcit \& altera Thic in Java in magna, praalta ac vafta arbore, folia lata Platani folia plane referunt: fed multo viridiora funt, nec lanuginofa, fert fructus longe minores hac Jaaca nec ejufdem, fed delicatioris aliquantum faporis: quique non è trunco, fed ex ramis dependet, naufeabundus eft hic fructus, \& ut author ait, infalubris.

\section{In CA P. V. \\ De Fangomas, 1. 2.}

angomas funt prunorum fylveftrium fpecies, quales apud nos funt, quas Belgice Sleen vocamus; ubi maturuerint colore. - funt flavo, cum noítrates fint è nigro purpurafcentis coloris. Jangomas funt porro fapore admodum aftringenti, arbor in $\mathrm{Ce}$ rafi alcitudinem affurgit. Spinofa eft plane: unde etiam Profper Alpinus eam Paliurum indigitavit: ut Virgil. Carduus Eे Spinis furgit paliurus acutis.

Ceterum qualitate hi fructus funt frigida \& ficca, ideo cholericis morbis medentur, choleræ fcilicet, dyfenteriæ, febribus ardentibus, cujus calorem temperant ac bilis orgafmum fifłunt: unde hinc etiam Syrupum hic conficimus non minus utilem quam fuccus eft acaciæ, tantopere veteribus decantatus.

\section{In $C_{A}$ P. XV. \\ De Caramabola. 1. 2.}

Aror Garciam ab Orta hujus arboris defcriptionem tam le1 vi pede tranfiliiffe, cum inter faluberrimos Indiæ fructus merito cenferi debeat. Folia hujus arboris, pruni folia non male 
male referunt, ac fubtus, ut populea folia albefcunt: flores admodum grato colore è pallido puniceo fert, eofque fafciculatim magnitudine anagallidis floribus refpondentes. Quibus decidentibus fuccedunt filiquæ oblongæ quadrangulares, ac fæpe pentagonæ interftitio intercedente fingula membra, non fecus ac in filiquis coronæ imperialis Clufii femen continentibus. Saporis funt fubacidi ac aftringentis. Immaturi quoque muria ac aceto condiuntur, ut de aliis fructibus diximus. Præterea Syrupus ejus, non fecus ac Syrupus è billinbing dietis fructibus, conducit choleræ, dyfenteriæ, febribus ardentibus, ac faccharo in eundem ufum a Chinenfibus conditur: maturus fructus flavefcit, \& tum è dulci vinofi eft faporis.

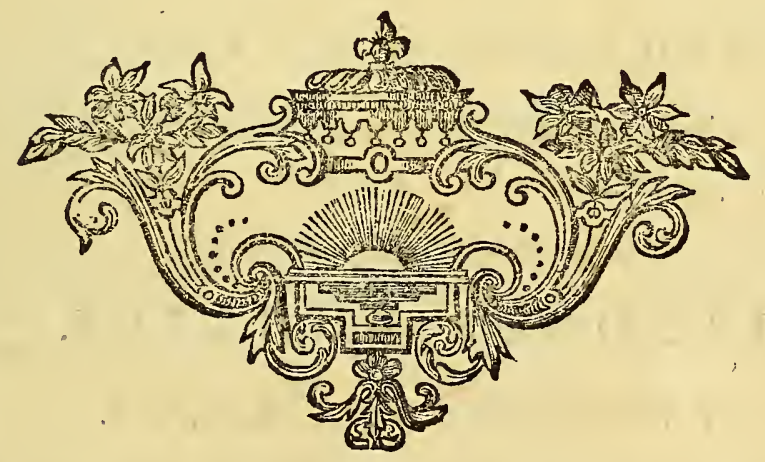


Pag. 182

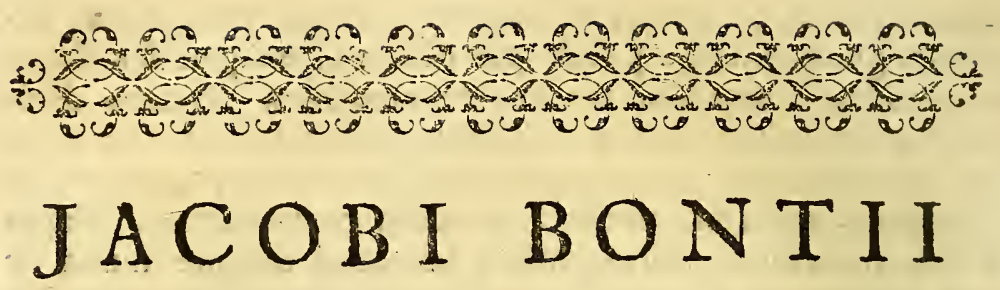

In Indiis Orientalibus in Infula Java civitati, Batavix novx, ac arcis Medici ordinarii de confervanda valetudine, feu de dixta fanorum in Indiis hifce obfervanda.

\section{I A L O G I. \\ DIALOGUS PRIMUS.}

De aëris qualitatibus, anni temporibus, die. rum intervallis, ac ventis in Indiis bifce famillariter Spirantibus.

\section{J A C O B US BON TIUS. ANDREAS DUR EUS.}

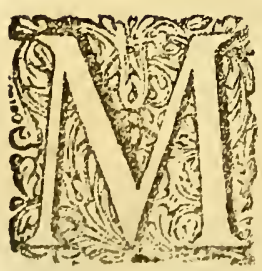

I Bonti, quoniam matutinis ægrorum vifitationibus jam tempeftive admodum defuncti fumus, fi libet eamus extra pomøria civitatis aliquanto longius deambulatum, ut dum nondum fol calore fuo aërem prorfus excalfecerit, inter nos conferamus, quali diæta in hifce locis præcipue fit utendum. Bontius. Bene mones, mi Duree, præfertim cum quotidie videamus, 
in Nofocomio noftro hoc Batarico, non folum plerofque $æ$ gros, jam à morbis convalefcentes redicivas pati, propter malam diætam ac inopportunam, fe ipfos in mortem certifimam præcipitare: verum etiam bene fanos ob eandem caufam periculofos morbos incurrere: Hinc enim obftructiones hic frequentes vifcerum, hydrops, ac denique marafini infanabiles; fed cum diata confintat apud Veteres in VI. rebus non naturalibus dictis, ecrum veftigiis nos quoque, infiftentes, ne hæretici in Medicina videamur, Colloquium noftrum finiemus. Durfus Quas tu vocas res naturales Bontius. Quæ corporis hmmani fabricam non conftituunt, neque intus in nobis funt: fed quæ externe accerfenda funt, ut ufui humano inferviant. 'Tales funt aër, cibus ac potus, fomnus ac vigiliæ, motus ac quies, excernenda ac retinenda. Affectus denique animi; de is igitur fingulatim nobis hic agendum eft. Ac primum, ut ordine cunEta percurramus, de aëris conftitutione hic dicendum erit, quum eo vel invitis mortalibus fit utendum, dum refpiratione ac infenfili tranfpiratione, carere non poffumus. Dur. Optime, fed quoniam aëris calor hic vehemens toto anni tractu, clyma hoc quoque ficcum valde exiftimarim. Bont. Mimine vero, immo aër hic in circumjacentibus infulis, ac in continentibus regionibus, hic humidus valde eft. Cujus rei, quam plurima argumenta poffim adferre fatis valida, vulgaribus omifis hoc unum dicam, quod vel ficciffima in his locis anni tempertate, ferrum, chalybs, æs, argentum denique hic citius rubiginem ac aruginem contrahunt, quam in Europa pluviofo, ac autumnali anni tempore. Dur. Verum dicis, cum \& veftimer. ta arcis bene inclufa fitum breviffimo momento contrahant, \& nifi ventis interdiu fpirantibus ac foli exponantur, facillime putredine corripiantur. Sed fi placet explica, qualem hic circa Bataviam aërem experiamur. Bontıus. Aër in circumvicina regione hic non admodum falubris exiftit, tum quod calor ic humiditas putredinis effectrices ac genitrices Phyficis dicantur, tum propter ftagna ac loca paludofa hic frequentia, dum igitur venti è montibus fpirantes, fretidos ac craffos, ne dicam propter multitudinem infectorum, venenatos vapores fupra urbem noftram adigunt ac ita aërem inficiunt. Iraque ventus hic 

184
D E A E R E.

è continenti oriundus ferio nobis cavendus eft, atque is præcipue, qui poft gallicinium è montibus fpirat ob primarum vigiliarum tepidum calorem, ac aperta inde in homine fudaria, leu corporis poros, vehementius propter fubtilem ac penetrantem qualitatem corpus afficiunt, quam vel frigidiffimus Boreas media hyeme in patria: Hinc gravedines hic longiores ac Catharri difficiliores oriuntur, quam in patria. Penetrabilis præterea hujus aëris natura, miferabilem illam paralyfeos fpeciem producit, qua berebirii in method. mea med. Indica nominatur, quo lectorem remitto. Dur, Montanorum quidem ventorum nobis naturam explicafti: velim ut fententiam feras, de auris è mari fpirantibus. BonT. Eas ego autumo longe fallbriores terreftribus effe: Caufa in promptu eft, quod illæ frtidos illos ac paludofos vapores longe à nobis rejiciant ac aërem vertant ac expurgent, inde Spiritus alacriores, ac vegetiores ad functiones peragendas reddunt, humorefque, qui in nobis funt, $\mathfrak{a}$ putredine confervant. Dur. Hæc, quæ dicis, in memoriam mihi revocant, quæ de ventis in Gallia Narbonenfi, ac vicinis in Hifpanicæ locis, ac in Italia in Romæ ac Neapolis territorio, è montibus fpirantibus, incolis Serenæ vocantur, qui blandiente frigore homines incautos, advenas præfertim pervadunt potius, quam invadunt, inde crebræ in iis locis Hæmoptofes, Phtifes, ac Aftmata, ceteraque, Pulmonum vitia, fæpe incurabilia. Bont. Ita eft ut dicis: hinc non inconcinne $H_{0}$ ratium ceciniffe memini.

Matutina parum cautos jam frigora mordent. Dur. Quum porro iu omnibus terræ locis, quotannis infignes in aëre mutationes in Elementorum primis qualitatibus fentiantur, ac pro iis anni tempora Phyficis diftinguantur, velim ut mihi etiam viciffitudines ilias tempeftatum in Java noftra demonftres. Bont. Lubens fecero, itaque cum per totum anni decurfum, hic tantum in ficcitate, ac humiditate, mutationes infigniores oriantur in hifce locis, tantum duo anni Tempora hic novimus. Nam quoad mutationem caloris ac frigoris: calor plerumque hic femper eft æqualis, cum Sol hic à linea æquinoctiali non longe recedat: itaque anni tempora in ficcum ac pluviofum dividemus, quæ nowis hic æftatis, ac hyemis vicem fupplent. DUR. 
DUR. Quando hic igitur æftatem incipere exiftimas? BonT. ubi perpetuæ pluviæ cadere incipiunt: nam tum Sol propior Æquatori è directo nos feriens, ac è mari, paludibus ac ftagnis nubes in altum cogit, ac incipit hæc Tempeftas, à Novembr. initio, ac ufque ad initium IViaii excurrit, cælo tum temporis tam irriguo, ac tam pluviofo, tum cadentibus continuis pluviis, ut infolitis merito fecundum Deucalionis diluvium metuatur. E contra à Maii initio, ufque ad Octobris exitum, ficcus plane ac ferenus eft aër, vix pluvia tota fex menfium intervallo decidente, contrario plane modo, quam in Patria noftra, ubi recedente fole pluviofus fit aër, appropinquante vero fole ficcior evadit. Sed terra tamen his non obftantibus hic longe feraciffima eft, tum ob roris noctu cadentis copiam, tum propter temperatam hic matutini ac vefpertini temporis naturam, quæ veris hic qualitates æmulatur: fed de eo infra. DuR. utrum tempus anni exiftimas falubrius effe? BonT. ex dictis prudenti conftare debet, Tempus pluviofum feu æftivum maxime infalubre hic cenferi, quod nimirum aëris calor ac humiditas naturalibus Philofophis putredinis effectrices merito putantur effe: Nam nifi tum temporis venti fucceflivi matutini, ac vefpertini, tum aëris craffities ac nebulofa conftitutio æftum arcerent, terra hic propter calorem non ferendum inhabitabilis effet : fed de his docte ac ampliter philofophatur $\mathscr{F}$ ofephus à Cofta ex propofito I. Naturalis Indiarum Hiftor. quem lector curiofus adeat. Tempeftate porro anni ficca ac fereno aëre. ut convenit corpora hic funt bene fana, ac tum venti etiam aliquanto frigidius fpirantes aërem melius ventilant ac expurgant. DUR. Ut ex dictis intelligo, dum æftatem ac hyemem vicinitate, ac abfentia folis metiris, hic in Indiarum hoc tracti patimur hyemem, cum in Hollandia ver ac æftas florent, \& è contra hic æitas eft, cum in patria hyems ac boreas fæviunt. Bont. Ita fane eft. Dur. fed quid de dierum intervallis, ac eorum temperamentis fentis? BonT, Diei tempora hic commode diviferim in Matutinum, Antemeridianum, Poftmeridianum, ac Vefpertinum, fub quo quoque noctem comprehendemus. Quoad qualitates fingulorum, Matutinum ac Verpertinum diei tempus A a falu. 
falubrius reliquis, ac actionibus accomodatius peragendis eft. Quod tum temporis, venti, è mari ac montibus fpirantes aërem ventilant ac refrigerant: Ut autem à mututino tempore incipiamus: Ego illud definio, quod ab hora quinta ufque nonam fe extendit, hic tum auræ molles blande aërem temperant, ac $\mathrm{fi}$ in Hollandia Maiales ventos fentires. Antemeridianum à nona porro ad duodecimam fe extendit, quo tempore fole altum fcandente, maximus æftus fævit, qui temperari paulatim poft duodecimam ufque ad quartum pomeridianam incipit ob auras è mari furgentes. Vefperam autem terminabimus à quarta pomeridiana ad fextam, aut paulo ultra vefpertinam, qua Sol fe condit. Itaque fi quid negotii gerendum fit interdiu, id fiat vefperi ac mane - antemeridianis jam commemoratis horis progreffus in publicum plane vitandus, ob fervoris violentiam, quod tam manifefte quifque fentiat, fe tum temporis magis quadrantis horæ fpatio defatigari, quam fpatio duarum horarum alio tempore. A duodecima porro ad quartam pomeridianam, etiam fuadeam à negotiis publicis abftineri, fed tamen hæ horæ tam infalubres non funt, quam antemeridianæ nominatæ.

\section{I A L O G U S II.}

De cibo ac potu: ubi de Carnibus, Prcibus, fruct bus, Herbis, Oleribus, Potu, Pane, ac Oryse qualitatibus.

If Xpofitis aëris Indici in his oris qualitatibus, tum anni tem1 poribus, horis diei ac ventorum temperamentis, vellem, ut mini tuam fententiam diceres de cibum fumendi tempore.

Bontius. Lubens faxo, iraque hoc in genere accipe jentandum hic largiter, prandendum mediocriter, cœnandum parum: non quod mex opinioni alios ita fricte alligare velim, fed ego mei judicii rationem reddere conabor. DuR. Rationem itaque relim mihi dari. Bont. Ea in promptu eft, quod tempore matutino, ob nocturnum frigus ventriculi hic melius ad digeftio- 
nem funt difpofiti. Prandendum porro hic mediocriter fuadeo, ne dum meridiamur hic plerumque ob fummum calorem aliquantulum ftomachus à nimietate cibi gravatus, cruditates, ac inde morbos hic folitos oriri gignat; nam plurimi morbi hic à frigida caufa gignuntur. Dur. Hoc adeo durum mihi videtur, in calidis regionibus frigidos morbos prædominari. BonT. Aft ubi caufam infpexeris, fortaffis minus mirabere, quod nempe propter affiduas fpirituum per fudores ac cutis fpiracula evaporationes membra naturalia concoctioni ciborum infervientia calore deftituantur; inde frigidiores ventriculi ac inteftina ob concoctricis facultatis labefactionem, cibos omniuo mutare non valentes crudos ac incótos humores, ad mefenterium, dein ad Hepar, tandem per venas ac arterias in univerfum corporis habitum tranfmittunt. Hine quoque non mirum eft populos ad feptentrionem fitos vivaciores longe effe hifee meridianis gentibus, nam ambiens frigus, per antiperiftafin calorem ad interna cogit, hinc eft quod Hippocrates, etiam dicat, ventres Hyeme effe calidiores, ac alibi, propterea byeme largius effe cibandum affirmat. Dur. Satisfecifti huic fcrupulo, veniamus fi placec ad genera ciborum hic utilia vel refpuenda. Bont. Age ut hoc fiat, imaginarium tibi opponam prandium, quia nemo quod fciam nos hodie vocavit. Dur. Dummodo ne Chama. leontes è nobis facias, qui vento vivere dicuntur, fed falfo. Bont. Bona verba quæfo, ant ejus loco aures tuas lepidis fermonibus opplebo. Itaque cibos primum per claffes diftribuamus; ac primo loco carnes in confiderationem veniant, earum itaque faluberrimæ funt gallinarum, quibus hæc Infula abundat. Aves montanæ ac fylveftres, quales funt turtures, columbæ, coturnices \& minutiores, ut funt, pafferes, fringuillæ, tum ficedulæ feu fclopaces, turdi, quas omnes volatilium fpecies nobis abunde campi ac fylvæ fuppeditant. Dein Anates \& anferes, \& ceteræ aves aquatiles hic carnium bonitate præftant. Dur. Miror te hæc aquatilia inter falubres reponere cibos, cum in Patria inter infalubria alimenta numerentur, quod nimirum in ftagnis ac paludibus verfantia, limo ac alga fe ingurgitent. Bont. fateor \& recte: féd hic longe eft 


\section{i88 De cibo ac potu: ubi de Cárnieus, \&c.}

alia ratio, tales enim aves non hic in ftagnis, nec paludibas verfantur: fed in profluentibus fluviis, unde carnes ipfis longe meliores, præterea licet domi ipfas alere oryfa ac panis fruftulis, ac tum carnis tam delicatæ evadunt, ut cum gallinarum ac caponum carnibus contendere poffint. Sunt præterea hic grues, ac ardeæ, quas quoque contemnere non licet: Dur. quas carnes porro in fecundo bonitatis gradu locas? Bont. Caprillas: nam ab ovibus, propter penuriam hic abftinendum eft. Dein vitulinas ac bovinas, \& illis quidem præftantiores habemus hic feras, fylveftres. Bubulinæ carnes non funt omnino contemnend $x$ : fed has juvenculas intellige: nam vetuftæ propter infignem nervolitatem fortiffimi animalis vix ferratos Plautini pairafiti dentes admitterent: Dur. Sed quid de ferinis carnibus fentis? Bont. Haud male mones, inter has itaque præ1tan. tiffimas effe puto aprinas, cum \& porci domeftici hi optimi fint, ac facilis concoctionis, fecus quam in patria: nam \& $æ-$ gris hic fuilla caro bene præfcribitur. Cervos denique (ut fcis) hic quam plurimos habemus, \& has omnes ferinas carnes milites, \& cives fclopetis à fe occifas huc in urbem quotidie venales adferunt. Dur. ita eft: fed omiffis carnibus tranfeamus ad pifces. BONT. ut hoc commodius fiat, diftribuemus pifces in marinos, ac fluviatiles. Inter marinos (meo quidem judicio) præftat ifte pifcis, quem Incolæ cacap vocant, qui è cyprinorum faxatilium eft genere, quem noftri Hollandi fteen-braafferns vocant (quique tam grandis aliquando capitur, ut $\&$ afellum callarium æquet.) Dur. Habemufne hic afellos majores iftos, quos Cabeljau Belgæ indigitant? BonT. Capitur hic quidem fpecies aliqua eorum, quam nautici focii noftri $\mathcal{J}_{a c o b}$ Evert fen vocant, ob nigros in flava cute fparfos nævos ac maculas, quaJes habuiffe, quendam ejus nominis nautam dicunt. Eft præterea hic magna quantitas petroforum cyprinorum, figura varia, lata, rotunda, oblonga; inter quos excellunt ii, qui rubri funt coloris. Scaros quoque delicatiffimos habemus, quos Belonius in obfervationibus fuis 1.2. defcribit, qui nobis his percarum loco funt, Capitur præterea Salmonis quoddam genus, quod Jean-Banda Milai vocant, quod Bandenfem pir- 


\section{1)e Cibo ac potu ubt de Caringus, \&c. 18?}

cem fignificat, quod in litoribus ejus infulæ frequentius capiatur. Certe præter colorem à falmone non differt, qui in hoc pifce albus eft, in falmone caro rubra elt: fed noftri ficcioris funi carnis, ac proinde falubriores, fi Piinio credamus, qui omnem pifcium pinguedinem proficetur malam efle, præter Anguillarum, quæ fic peffima. Dur. quid de Auratis, Corcavadis, Bonitis, \& id genus pifcibus fentis? Bonr. Omnes hos pifces effe è thynnorum ac delphinorum fpecie, tum propter natationis fummam velocitatem, qua expanfis velis navigantem navem. tranatant, ac etiam è mari exiliunt ad duos quatuorve cubitos in altum, ut venentur hirudines aquaticos, feu pifces volaticos dietos, qui etiam funt boni faporis, ac demtis alis, Halecem non male referunt \& forma, \& fapore. Ceterum inter delphinos iftos palmam fert Aurata ab aureo colore Dorado Lufitanis dicta , ceteri funt carnis durioris ac proin concoctu difficilioris. Sanis tamen ventriculis bene conveniunt, quum fanis, ut, inquit, Latinus Hippocrates Connelius Celfus, non opus fit exquifita diæta. Dur. quid de planis pifcibus marinis? an illos omnino oblivioni trademus? Bont. immo vero ego in hoc eram ut ipfos hoc ultimo loco refervarem: nam extra controverfiam è faluberrimorum pifcium funt genere. Tales inter præcipuos funt, Rhomboides, Lingtiacæ ac Rhombi, quorum Rhomboides optimi inter pifces funt nutrimenti; dein lingulaca, ac ultimo Rhom$\mathrm{bi}$, qui adeo confuevere in delitiis apud Romanos effe, ut inde materiam cæperit ingeniofus Fuvenalis Satyr. falfiffima in crudelia \& nugacia Domitiani iempora eiaculandi. Rayas habemus præterea clavatas ac læves, quæ quo juniores, eo meliores concoctu; à vetuftioribus enim jubeo abftinendum, ut de lamiis, ac laris pifcibus Hayen, qui acutifimis fuis dentibus raftratim ftipatis tam multis fociis navalibus temere natantibus. exitium intulere. Paftinaca marina ipfis Chinenfibus pifcatoribus confitentibus venenofum è tranfverfa cauda enafcens telum gerit, quo abfciflo edulis eft, fed carnis infalubris, ac faftidio$f_{x}$, ideo ego Chinenfibus, ac Mauris, qui is avide vefcuntur fuas delitias reliquerim, contentus fupra commemoratis Neptuni pescoribus, ut eos Plautus vocat. Dur. Marinis pifsibus viA a 3

deor 


\section{ino De cibo ac potu ubi de Carnibus, \&c.}

deor jam affatim fatiatus: velim mihi fluviatiles etiam apponas. BONT. in me non eft mora. Igitur primo loco milhi occurrit carpio, feu cyprinus rotundus, quem ego carne, ac guftu meliorem effe judico patriis, utpote qui hic in fuviis, non in ftagnis ac paludibus ut apud nos plerumque capitur, \& ut quod diximus anates hic præftantiores funt, fic $\&$ hi pifces ob prædictam caufam laudabiliores hic capiuntur, nec enim tam limofum fapiunt. Hi porro tam infigni mole aliquando capiuntur, cute candida, ac carne delicata, ut is nil ulterius addi poffe confidam. Sunt præter hos lupi pifces in alveis fluviorum, quos propterea num inter marinos, aut fluviatiles numerare debeam, dubius hæreo: fed certe magis in mari capiuntur magna mole, pelle alba, guftu five affi, five elixi fuaviffimo. Mugiles porro barders, ac ea pifcium fpecies, quam ob eminentiam nafi nafutos appellant accolæ Mofæ in Hollandia, ac vernaculo vocabulo Houtinck indigitant hic affatim capiuntur, ita ut pauperioribus etiam in cibum cedant. Hæ duæ pifcium fpecies 1tatucis temporibus, ab Octobre nimirum menfe, ad Aprilem. ufque propter pluvias quæ falfam aquam edulcorant (nam hi pifces etiam in alveis fluminum capiuntur) pingues ac fuaviffimi funt Sicciori vero tempeftate carne funt durioris ac fpinofæ. Aiburni voornen præterea hic noftratibus fimiles hic in fluviis capiantur boni fane faporis, ac nutrimenti. Congri Congerael quoque infignes aliquando in fluviorum ore frpius in mari capiuntur, unde eos potius inter pifces marinos locaverim. Infalubriores jam porro pifces enumerare libet, quales funt anguillæ, quæ cute funt fuperne nigerrima, fubtus fœde flava, tum etiam cum liydris coire certiffimum eft, \& quamvis $\&$ plurimi eis fuaviter utantur, eas ego tamen ob prædictas caufas ac propter naufeabundam illorum pinguedinem facile contempferim. Eft præterea pifcis quidam duriffmis fquammis obfitus quem Ican Cabofch Malai vocant, ego à figura, \& capitis, ac reliqui corporis Mugilem fluviatilem dixerim, qui in limofo hæret fundo, ac originem fuam non obfcure fapit: Habemus hic porro Tencarum Seelt quoddam genus fine fquammis pelle lævi, teretes cum duabus pinnis ut anguillæ, ac capiuntur hic in ma- 
gna copia ifti pifces (quos noftrates à capite bufonis Puytael vocant) fed ego, ut murænas fluviatiles omne id genus cupientibus non invideam; Poffem ego jam alias pifcium fpecies enumerare quæ plurimæ reftant, fed quia non hiftoriam, fed tractatum de direta Indica fcribere geftio, ideo his cancros tantum ac aftacos, oftrea quoque, fquillas ingentes tibi jam apponam, quæ omnia præter reliqua oftracoderma, hic delicatifma funt. Tum teftudines amphibias addo, cum ovis fuis ac carne fuaviffima, ut ajunt ii qui de iis millies fe guftaffe gloriantur: fed credo ego ipfos famem fecum, optimum condimentum attuliffe, ego teftudinum carnes. inter medicamenta ifta collocaverim, feu mavis alimenta medicamentofa, quæ phtificis, Empyematicifque conveniunt; quia glutinofæ cum fint, pulmonibus confolidandis conveniunt.

\section{I A L O G U S. III.}

De oryza, oc Pane in Iudiis. De potu, Vino, Arac. De potu ex agua, faccharo. Thamarindis concinnato, de naturalbus liguoribus potu. lentis ex arboribus depromptis.

DuReus Quoniam in his locis oryza cocta plerumque propane utimur, velim ut mihi narres, quid de hoc nutrimento fentias, præfertim cum cibus fit folidior, \& quæ tanquam bafis fuftinere debet reliqua alimenta, ne in fnndo ventriculi fluctuent? BonT. Certe, fi id, quod res eft fatear. Si tritici (ut folet) copia nobis è Japonia \& Zuratte advehatur, oryza libenter carere velim, cum è farina tritici panes hic confecti patriis bonitate non cedant, \& melioris (meo quidem judicio) quam oryza fint nutrimenti: fed fi tritici adfit inopia, tum oryza ifta eligenda eft, quæ colore fit candidiffima: \& quæ manu contenta bene ponderet, \& colore quafi perfpicua cernatur: fed cum excocta eft, antequam ea utare, expectes. oportet, donec refriserit: nam experientia confat calidam ory- 
cryzam non folum noxiam effe ventriculo, verum cerebro, ac univerfo uervorum generi: hinc quoque fit à vaporibus craffis $\&$ liccis ex hoc cibo in cerebrum elevatis nervos opticos fæpe in tantum obftrui, ut cæcitas inde oriatur, de qua, \& de ejus cura latius in methodo mea medendi Indica ex profeflo egimus: hinc etiam non facile videas Javanos, ac Malayos edere calidam oryzam, quia Indi (li quæ gens alia) fanitatis confervandæ fuæ funt apprime curiofi, inde fobrii exiftentes fumme exactam diætam obfervant. Dur. fed heus tu ! nimium ficcum in pictura convivium apponis, \& interea. Nos mi/eri aremus, rec quod potemus babemus: velim potum nobis præbeas. BonT. haud male mones, nam \& mihi loquendo fauces folito ficciores funt, verum de fluente licet nobis accipere, quoniam alterius liqucris hic nobis non eft copia, ac primum àe aqua puriffima, ac fimpliciffima fecundum elementum fuum nativum agamus, namque hæc potio etiam nobis cum reliquis animalibus eft communis. Dur. Quid igitur de fluvio hoc Bataviam noftram interfluente cenfes? BonT. aquam eam qualitate quidem non elle malam, fi altius è filuminc petatur : nam in ore fluvii propter affluxum maris falfedine imbitur : \& hæc eft illa caufa, quod cum anno I 628. à Javanis Matarranenfibus arcte obfeffi effemus, \& propterea ex fluvio altius aquam petere non auderemus, multi è potu falfo in dyfenteriam inciderent, addito etiam infuper hoc, quod cadavera Javanorum a nobis quotidie excurfionibus occiforum in fummo natarent ac aquam non folum tabo defcendente flumine; fed \& aërem, putredo halitu inficerent: DuR. Sed licet nobis hic potum factitium bibere, quid tu de eo fentis? Bont. Quoniam cervifia nobis deeft, non quod coqui hic non poffit: fed quod propter calorem aëris, citiffime acefceret, ajioqui non minus bona, quam in patria parari poffet: nam (ut dixi) triticum, è Suratte nobis abunde fubvehitur, tum quoque ex oryza, non decorticata iftud frumenti genus commode confici poteft, quod Mout in patria vocamus. Cujus rei exemplum vidimus apud Marefchallum mercatorem bene cognitum, qui in hac urbe ex predicta niateria cervifiam coquebat, nulla ratione Hollandicæ cedentem, quæ non fecus ac pa- 


\section{De Cervisia, et Vino, Lic.}

cria quoque cerebrum tentabat, ac guftu non deterior erat: fed durabilis non erat propter fummum in his locis calorem, ac cito acefcebat: fed hunc potum falubrem minime hic effe certum eft: fed falubris ifte eft potus, qui modo feqtienti paratur. Sume vafculum ferreis vinculis bene cinctum, triginta, aut amplius (pro familiæ magnitudine) amphorarum, quod imple aqua fluviacili pura, cui facchari Javanici nigri infunde lib. Ir. Thamarindorum unc. IV. Citreorum malorum diffectorum No. I I I . bene obturata hæc reponantur loco frigidiore a folis radiis libero, hæc fermententur fimul per 24. horas, \& quod miror., hæc fine fubjecto igne ebulliunt, ut eminus aftantibus exaudiri poffit fonus, non fecus quam valido igne coquitur cervifia noftra patria, tum fæces in altuin ejicit, quas aperto operculo abjicimus. Hic potus nofter eft quotidianus guftui jucundiffimus, ac vifceribus minime ut præcedens gravis. Et certe illi, qui noviter huc è patria pervenere, à me ridendi gratia deceptì difceffere putantes, me iis Anglicam vel Martiam cervifiam propinafe, cujus faporem magis æmulabitur, fi manipulum cariophyllorum in vas conjicias. Dur. Sed quid de potu ifto exiftimas, qui hic ex aquæ partibus fex, \& vini duabus eodem modo fermentando in cantaris Hollandicis lapideis anguftioribus conficitur? BonT. limpidus fateor ac frigidus hic eft potus: ideoque etiam tempore cibi fumendi utiliorum effe puto: fed altero utendum cenferem interdiu, quod hic pectori paulo fit infeftior nefcio quid acidi penetrantis fapiens. Dur fed utrum vinum hic falubrius effe exiftimas, Gallicumne an Hifpanicum? Bont. funt qui Gallicum præftare putent: fed meo quidem judicio hallucinantur, fanius enim credo in his locis vinum Hifpanicum effe vel Creticum; Dureus. attamen hoc rationi plane contrarium videtur, quod fub climate calidiffimo, calida vina, ac polygophora exhiberi velis. B o NTIUS. ubi rationem audieris, mirari defines: nam cum calor hic interdiu, præfertim à decima matutina ufque ad pomeridianam tertiam horam, admodum fit vehemens, necefie eft homines multo fudore, diffluere, unde quoque calor nobis ingenitus debilitatur, proin partes naturales coctioni ciborum infervientes, $\mathrm{Bb}$ 


\section{De Cervisia, et Vino, \&c.}

ac chyli debito frigidiores remanent, fecus quam in partibus feptentrionalibus accidit, ubi ex Hippocratis decreto ventres hyeme funt calidiores, ratio eft quod per antiperiftafin externus aër internum calorem augeat. Huic quoque argumento fiden addit experientia mercatorum per deferta Arabiæ in Perfiam, aut Turciam iter facientium, qui in fummis caloribus fitim optime fedant haufto fpiritu vini, vel fortiffimi vini Perfici, vel Hifpanici: nam fi ob inexplebilem fitim affiduo aquam ingererent, in cachexiam proculdubio, ac in ventris infignem tumorum, ac ipfum denique hydropem inciderent. Adde quod vinum Gallicum, quod huc è patria adfertur, œnopolæ apud Hollandos liberalius ifto fuffumigio imbuunt, quod lucht vocant, quod cum arfenico fulphure, \& colophonia conftet, vino perniciofam ac caufticam qualitatem inurit, quamvis efficiat ut fapor diutius illi incorruptus confervetur. Unde ego hic aliquos vidi ex folo Gallici vini potu largiore in lethalem dyfenteriam incidiffe. Dur. Ex prædictis apparet te etiam à vino adufto, nec Arac Chinenfe abhorrere; Bont. ufum commendo, abufum abominor; fi quis igitur mane, aut vefperi ventriculi roborandi gratia unc. ij. aut unc. iij. iftius liquoris fumat, haud male, me judice, fecerit: fed fi id vinum diftillatum haberi poteft, quod è Gallia venit, non eft quod Arac hic confectum defideremus: fed fi ejus copia hic non detur, quod hic conficitur è liquore nuce Indica contento, ac ex ipfa arbore diftillato cum oryza eligendum eft: at cane pejus \& angue vitandum eft, quod Chinenfes avariffimi fimul, ac aftutiffimi bipedum mixtis holothuriis in mari fluctuantibus parant, quæ excrementa maris Belgæ quallem vocant, eaque tam exurentis funt caloris, ut folo attactu veficas in cute excitent, atque hinc exulcerationes pulmonum, fanguinis fputa, tabes ac mors ipfa adveniant, atque hoc eft quod ut Plautus ait, homines hic tam brevem vitam colunt, cum inftar ftrigilum inteftina abradant, ac exedant. 
De Potionibus Naturalibus, \&c.

\section{I A L O G U S IV.}

\section{De Potionibus naturalibus ex arboribus depromtis in India Toruvat, ac Saguër dictis, tum de liquore nuce indica coniento.}

UR. In omnibus his mihi abunde fatisfecifti, jam fenten: tiam tuam explices velim de liquoribus iftis potulentis, qui vel ex fructibus arborum vel ex ipfis arboribus depromuntur. Bont. Sciendum itaque eft, tres hujus potus effe fpecies; primam, qux continetur in nucis Indicæ caviaare; fecundam, quæ è floribus ejufdem arboris elicitur, tercia, frequens eft in Banda ac reliquis infulis Moluccis, quæ diftillar ex arbore non abfimili palmæ Indicæ, ifque potus indigenis Snaguër vocacur, $\mathrm{h} æ$ tres potus naturalis fpecies per totam Indiam admodum familiares funt. Ac hoc in genere de iis dictum fit, ipfos frigida qualitate excellere, ac proinde nervis effe infeftos, fi quis nimia quantitate iis abutatur, præfertim corpore per exercitium aut folis ardorem excalefacto: non fecus ac vidimus fæpe in patria noftra, fi quis æftate, vel oriente canicula, curfu defatigatus ac fudore perfluens, intempeftive nimis avide frigidum, vel lactis preffivum hauriat, ipfum in momentaneam mortem incidiffe, vel fummum vitæ periculum. Itaque potu ex his arboribus parcius eft utendum: nam conftat frequenti illorum ufu præfercim liquoris Saguër dicti, non folum diarrhæas diuturnas ortas: fed \& paralyfin beriberii dictam hinc natam effe. Hine eft, quod in Banda, ceterifque Moluccis infulis, præfertim quæ noftro fubfunt imperio, plerique homines cacheetici fint, ac foedo colore ad luteum vergente, \& vix unus, aut alter è noftris Batavis paralyfin prædictam effugit, quod \& norunt Lufitani, qui non folum in hoc potu: fed in reliqua omni dixtz temperatiores funt, quam noftrates. 


\section{I A L O G S V.}

De Aromatis, ac de usu illorum, ubi quadam à Gara cia ab Orta, ac ceteris aromatariis fcriptoribus non Satis liquido tractata explicantur.

DUR Æus. Cibum jam ac potum nobis affatim in pictura appofuifti: fed fimplicem, ac nullis condimentis imbutum, cum tamen nullibi copiofius aromata proveniant, quam in Java. Bont. quam tu delicatus es! an nefcis naturam fimplici victu effe contentam: veruntatem, ne videamur earum rerum per negligentiam curam non gerere, in hoc te non deferam. Ac de aromatis dicam, non quod auditu percepi, fed quod fenfu pro. prio ac vifu verum effe didici. Ac piper primum attingamus, cujus qualitates cum per totum orbem notiffimæ fint, non eft quod pluribus de eo hic agamus. Certe convolvuli eft fpecies fi modum crefcendi refpiciamus, nam arbores ac bacillos eodem modo, quo convolvulus feandit, condiuntur hujus viridis racemi (nam ut uvæ Corinthiacæ, crefcit) muria ac aceto ad orexin excitandam, ac cum carnibus affis aut elixis hic apponuntur: eodem modo hic incolæ condiunt radices recentes Zinziberis, Galangæ, cum fruetibus manga, carambola, billingbing, curcuma, tum cucumeribus primum adolefcentibus, melonibus infuper ac peponibus, quæ nobis hic capparum vicem fupplent ac olearum, quanquam $\&$ hæ delitiæ nobis non deficiant, cum quotannis eas defiderantibus fatis copiofe huc è Perfia , \& Suratte advehantur: ridiculum porro eft, quod Garcias ab Orta peculiari cap. de pipere refert, de opinione Javanorum ac Indorum dé piperis qualitate, ipfum nimirum efle frigidum. Credo ea ratione, qua quidam fophiftæ olim ignem frigidum, ac glaciem, ac nivem calidam effe affirmare aufi funt: quibus ego cum Arifotele refponfum velim, fola experientia contra hos ineptos affertores effe difputandum: nifi forte velint calorem nativum, nimio ejus ufu foras pelli, ac intus debilitari, ac hoc modo corporis temperiem verfus frigidam 
mutari. Sed Indi credo tam alte non philofophantur. Idem quoque Indi de Cariophyllis eodem modo conditis fentiunt. Dur. quid de maci \& nuce myriftica condita fentis? BoNT. iis ego dico parcius in his regionibus elle utendum: nam ventriculum fua oleofitate ac pinguedine gravant, tum vaporibus ad cerebrum elatis fomnolentiam ac ftupiditatem inducunt, immo ego vidi ex nucis myrifticæ nimio ufu, aliquot non parum periclitatos effe, qui per diem unum atque alterum, non fecus ac caro correpti immobiles, ac muti jacuere, certifimo indicio cerebrum ac nervos non parum male affectos effe. Porro è corticibus viridibus nucis myriftica in Banda infula coquunt pultem, ac faccharo condiunt, ac tum faporem referunt acidorum pomorum fic coctorum in patria. Sed \& nos hic in Java in corticibus falitis ejufdem nucis, primum aqua maceratis, non infuaviter fimile condimentum conficimus: fed experientia quoque conftat fomnum accerfere, ideoque cautius eo utendum cenfeo. Dur. itaque ut audio nimium in cibis aromatum ufum non laudas. Bont. ita eft. Cardamomo excepto, quod blando fuo calore, ac naturæ noftræ familiari, mafticatum nullum empyreuma vifceribus inurit. Crefcit copiofe hæc planta in Java, ac mulieribus Malaicis frequenti in ufu eft, condiendis pifcibus, ac carnibus elixis. Dureus. calamum aromaticum qui hic tam familiariter crefcit, nonne in ufu hic in culina effe autumas? Bontius. \& quidem commodiffime, quamvis Garcias ab Orta illius ut \& junci odorati, nullum eorum in India ufum agnofcit, quam fubfternendis equorum cubilibus, verum fi tam diligens fuifet in rimandis aromatum qualitatibus, quam perfpicax fuit in legendis Medicis Arabicis, non debuiffet commoditates earum plantarum ignoraffe, nam per totam. Indiam vix pifces coquuntur, aut carnes, quin fafciculus ca. Iami aromatici, aut junci odorati is injiciatur, ad gratum faporem, ac ventriculi non levem corroborationem: idem de nardo, quæ hic in montibus crefcic, efto judicium. Hæc quoque aceto infufa per aliquot dies, ut flores calendulæ exficcatæ apud nos, putredini ac corruptioni humorum egregie refiftit: ego viridem nardum hactenus non vidi: quia montes hic B b 3 ins 
inacceff nobis funt propter Tygridum inibi frequentiam, ac prædones Javanos. Dur. dixeras antea etiam curcumæ radicem incoqui cibis. Bont. \& recte quidem \& hanc radicem Garcias ab Uita vocat crocum Indicum, non quod Croci Britannici fila.nentis fimilis fit: fed quod flavo colore tingat. Eafdem ra. dices quoque crefcentes quia Garcias non vidit, putare fe ait fine noxa intra corpus fumi poffe, ejus rei audacter fponforem me ei do, nam ego qui plantan millies vidi, \& alibi largius defcripf, non folum cibis utiliter incoqui affirmo, fed egregios etiam ejus ufus in medicina alio volumine oftendi: atque hæc de aromatis dicta hic fufficiant. Dur. perfæpe ego miratus fum Malayos, ac Javanos, tum Chinenfes quoque Mandragore iftius fructu, quam Lufitano Pomo d'oro vocant, tam avide vefci, cum in fummo gradu funt frigida? BonT. Bona verba quæfo, an nefcis eos addere fructum ricini Americani, quod lada Chili Malaii vocant, quafi dicas Piper è Chile Brafiliæ conterminæ regione, ita alterius fummam frigidatem, alterius exceffivo calore temperant, ac aceto, ac oleo fuperinfufo non male cum carnibus, aut pifcibus affis comedunt: funt qui mafticationi iftus ricini ita affueverunt, non fecus ac fumigatores ifti nicotianæ: quantum ad me, eo tamen ego libenter caream, nam dum animi gratia idem tentare aggreffus effem, totum mihi palatum ac linguam excoriavi, a cauftica iftius Ricini vi: hinc videre eft quantum faciat confuetudo.

\section{I A O G U S VI. \\ De Fructibus, ac omnigenis oleribus, ac acetariis berbis in Fava.}

Ureus. Quoniam convivium noftrum jam ad finem tendere videtur, fine bellariis credo hoc non dimettes? BonT. Nullo modo, itaque á fructibus incipiamus, quorum non parvus eft habendus hic delectus, optimi enim inter eos funt, qui guftu funt aftringentis, pejores, qui faporem dulcedine fallunt: fed ut de fingulis aliquem fermonem guftemus. Prini nobis 
occurrunt Manga dicti fructus, qui in altiflimis ac expanissarboribus crefeunt, quæ forma quercua noftratem non male $æ$ mulantur, qui dum immacuri funt, acidiflimi funt faporis, unde nobis hic demptis corticibus \& nucleis ex medio puls coquitur fapore acido poma acida, aut uvas crifpas coctas referens, ut quis vel exquifitifimi guftus, faporis differentiam vix agnofcere fe fateretur, atqui fructus Manga hoc modo præparati ventriculo ac inteftinis corroborandis conveniunt, maturi non tam funt falubres, fed tamen fi quis iis parcius utatur, nullam noxam inferent. Dur. de Durionibus, Jaacis, ac ceteris echinatis fructibus quid fentis? Bont. Duriones ob fotorem allium referentes, primum guftantibus fateor faftidiof funt ac naufeabundi, tamen inter fructus faluberrimos Indicos eos merito repono; nam diuretici funt, ac fudores eliciunt, tum flatus difcutiunt, tamen fi nimia quantitate eos quis fumpferit propter calidam ac ficcam, qua præditi funt qualitatem, inflammant fanguinem ac hepar, ac puftulas in facie exitant, itaque eos reponamus inter medicamenta alimentofa, de quibus in method. Indica mea medendi. Dur. haud difficulter mihi perfuades: fed quo gradu locas Ananas fructus fapidiffimos ac odoratiflimos? BonT. Si qualitate ceteræ fupra dictis à te refponderent, nobiliorem fructum in toto orbe terrarum non nafci contenderem: fed tam erodentis porro funt qualitatis, ut fuccus eorum chalybem, ac ferrum erodat, unde nifi vino, aut aqua per aliquot tempus macerentur, palatum, ac linguam excoriant, ac horribilem, choleram, ac lethalem fæpe dyfenteriam creant. DuR: Jaacas puto fapor dulcis commendabit? BoNT. immo ego illas maxime infalubres effe puto, cum carnis fint tenacis ac duræ, \& quæ incoctæ ac crudæ, ut ore affumuntur fere per alvum dejiciantur: unde etiam cruditates in ventriculo, ac inteftinis gignunt, quæ moleftas ac diuturnas diarrhæas creant, dein tenefmum, cui fæpe fuccedit mortifera dyfenteria. Dur. qui fructus funt ergo, quos mox ob aftrictiorem faporem commendabas? BoNT. ii funt primum Jambos fructus vocati pulcherrimo ex albo ad purpureum vergentes colore, fapore funt ferme, ut capreæ vitis, ut bene monet Cbriftoph. à Cafta, aftrin. 
fringunt vehementer, ac proinde dyfenteriis ac choleris accommodatum eft remedium, de quo alias. Adfertur ad nos præterea fructus quidam Lances vocatus, qui racematim ut uvæ crefcit, rotunda plane figura, magnitudine pruni, intus nucleum habet, qui veftitur carne alba, ac faporis vinofi, qualis tere eft in uvis urfinis in patria. Huic confimilis guftu eft fruetus Javanis Boa Rampout vocatus, quod crinem fignificat, quod cortex externe fructum ambiens multis capillamentis fit prædicus, nucleus plane fimilis eft prædicto Lancium, ac qualitate frigida conveniunt; cortex Lancium tamen fuccum lacteum emittit, qui amarus valde ac corrofivus eft. Eft hic præterea fructus Billinbing indigenis dictus, forma adolefcentis primum parvi cucumeris, adeo acido fapore, ut acorem ipfum dicas, in quo illud miri obfervatur, quod fi ab aliis acidis fructibus cuipiam obftupefcant dentes, ifto fructu comefo ftatim acor abfcefferit, credo ea ratione, qua in affectibus præter naturam major dolor minorem obfcurat. DuR. Quid tibi de ficubus noftris Indicis videtur? BoNT. hos fructus Propper Alpinus Mufam vocavit, Malaii Banana indigitant, Javani Pyfang. fapore quidem grato funt ac pyro noftro æmulantes, quæ ob dulcorem Batavi Suyker peren vocant, hi fructus fi crudi comedantur, flatuofi admodum funt, \& naufeabundi, unde infolitis ftomachum fubvertunt: fed melius comeduntur cum pane ac oryza coeta, juncto cafeo, alias quis facile in dyfenteriam, ac ipfi congenerem choleram inciderit. Non fecus ac fi in Gallia, aut Hifpania quis, qui recens iftuc advenerit, uvis fine pane fe affatim ingurgitet, næ ille certo certius in fluxum dyfentericum incidit. Hi fructus cum ovis fricti in fartagine multo falubriores funt, \& tum phtificis, afthmaticis ac ceteris malis pectoris admodum utiles funt, tum extus impofiti inflammatorios tumores quofcunque ad maturitatem perducunt. Dus. Aft ubi relinquis Mangoítan, Jambos, ac Cydonia bengalenfia? Bont : Ego ea pro bellariis refervabam, ut fimul cum Chinenfium potu The vocato, \& Tchia Japonibus dicta convivium finiremus, \& quod hic moris eft ut Syrii pynang: wobis apponeremus. Jambo igitur primum arbor eft magnitudine 
dine pruni, \& nifi quod paulo acutioribus fit foliis, ipfi plane refponderet, flore elt rubro, fructu pulcherrimo \& candido purpurafcentis coloris, guftu funt aftringenti, ac fapore ferme vitium capreolas referunt, fapore itaque minus præftant, quam colore promittunt, frigidæ funt naturæ, ideo æltuantibus utiles five ab exercitio, five à calore febrili, Cydonia Bengalenfia defcribit Garcias ab Orta, lib. 2. cap. I4. Itaque de is hoc tantum addemus, quod his pyris feu malis cotoneis eximant nucleos, oc totos faccharo, vel muria, \& aceto condiant, quæad. nos ex interceptis Lufitanorum navibus, quæ Malaccam verfus navigant, à Suratte, ac ora Chormandel. Nam nulla gens in mundo ita affuevit condituris ejufmodi, quam Lufitani, ita ut per totam Indiam in proverbio fit; Indos odoribus, Lufitanos condituris rem difperdere. Sapore æmulantur pyra ifta, autumnalia grandia noftratia, quæ vulgus winter peren vocat, fructus porro Mangoftan dicti tam excellentis funt faporis, ut mea quidem fententia omnes ceteros in his regionibus fructus anteeant, cortex plane mali granati cortici fimilis ef, nifi quod in fuperiori parte coronam habeat ut papaver, cujus quot funt radii, tot nucleos intus habebis, veftitos carne nive candidiori, fapore ex dulci vinofo, fuperante fragra, ac Ananas in India. Dur.: memineras de Chinenfium Thee vocato Potu, quid tu de eo fentis? BonT.: herbula unde hoc The conficitur, bellidis feu confolidæ minoris folia refert, cum parvis in ambitu incifuris, hujus foliorum exficcatorum manipulum in ferventem lebetem ad hoc paratum conjiciunt ad fufficiens tempus ebullire finunt, ac hunc liquorem, qui fapore fubamarus eft, calidum forbent. Hunc porro potum tanquam facrum Chinæ obfervant, \& hoc venientes, hoc abeuntes hofpites excipiunt, \& non creduntur jus hofpitalicatis impleviffe, nifi tibi hunc potum propinaverint, non fecus ac Mahometani fuum Caveah exiftimant. Exficcantis eft qualitatis, ac fomnum prohibet, dum vapores è ventriculo in cerebrum afcendentes abfumit, præterea afthmaticis, ac fufpiriofis prodeft. Quid jam poftremo tibi memorem mala aurea, citrea, granata, \& ceteros fimiles fructus, quorum hic fumma eft copia, cum ifta in noftra En- 
ropa notiffima fint, \& nos hine Syrupos conficiamus, quique fitientibus aqua mixti julapii locum in fanis, ac ægris obtinent? Vites taceo, qua fi diligentem putatorem, ac cultorem nancifcantur, quater in anno maturos fuos fructus proferunt, itaque fi diurnus calor hic non adfit, propter perpetuun virorem femper hic ver, ac veri hefperidum horti.

\section{I A L O G U S VII.}

\section{De oleribus, ac leguminibus in Indiis ac radicibus quibufdam edulibus.}

7 UREus. Finito jam imaginario tuo convivio, domum remeantes faltem aliquid olerum in vefpertinam coenam colligamus. Bont. Dic modo quid primum expediri velis. Dur. Radices eas narres mihi velim, quas Batatas hic vocamus. BonT. Pleni quidem eas nutrimenti effe, attamen fuccum melancholicum producere, non fecus ac caftaneæin Europa, quarum faporem ha radices fub cineribus toftæ, vel etiam elixæ cum carnibus plane referunt, nifi quod fint humidiores, ac molliores paululum: fed fi fale, oleo, pipere, ac aceto perfundantur, betæ rubræ coctæ nobis loco funt in acetaris. Dur. Raphanos hic plurimos fativos habemus, quid tu; de iis fentis? BonT. Horum ut fcis habemus hic duo genera, primum breve, ac rotundum, vel cylindri faltem formam referens: hi cocti loco raparum nobis in familiari funt cibo; fecundum eft oblongum, ac teres ut Hollandicus raphanus, quod cum pane, butyro, ac fale crudum more patrio comeditur. Ceterum longe præftant hic raphani patriis, qued non fint tam lignofi, nec à teredine ita perforentur, fed hic efculentiores, ac fapidiores fint. Dur. Quid Inde de oleribus fentiunt. BonT: Illi ifta, \& omnes herbas edules in magno pretio habent; nam qui à Suratte, ac ora Chormandel huc adveniunt plerique ferme folis vegetativis vefcuntur, fequuti Pythagoram.

Cunctis animalibus abftinuit. qui

Tanquan bomini, ac ventri indulfit non omme legunen.

[ Flvenalis, Satyr. 16.] 
Ita hi homines etiamnum abftinent fabis rubris, ac quicquid inter herbas rubrum colorem obtinet. Hinc etiam fit quod homines in ceteris rebus idiotæ tam exactam herbarum, ac ftirpium nanfcifcantur fcientiam, ut fi vel doctiffimus Paurwius noftri-ævi Botanicorum princeps è mortuis refurgens huc veniret, miraretur fe ab his hominibus barbaris doceri poffe. Ceterum olera omnia, ac manfiles herbas Malaii generali vocabulo Seir vocant, contra herbas medicamentofas, ac venena quoque $\mathrm{Ou}$ bat indigitant. Ut rem in pauca contraham, \& ne tractatus modum excedam, enumerabo reliqua olera hic in nutrimentum hominum nafcentium; habemus hic utramque betam rubram ac albam; petrofelinum quoque hic luxuriat. Lactucarum omnes fpecies. Anethum quoque habemus, ac fœniculum, tum afparagos quoque non infeliciter hic ferere incepimus. Tum fructus terreftres quoque hic proveniunt, ut funt melones aquatici, pepones, cucumeres, citrulli; fed cum hæc omnia in patria abundent, de iis ad faftidium nolo dicere, ac femina horum fructum eundem ufum hic in medicina præ: ftant, quem apud Batavos antiquos. Legumina hic non folum in farmentis, fed in præaltis arboribus, ut alibi diximus, nafcuntur; fapore bono \& nutrimenti ejufdem ut apud nos flatulenti, \&c. Habemus præterea fructum quendam, quem focqui $\mathrm{Ma}$ laii indigitant cubitali fæpe magnitudine, brachium humanum craffitie fæpe æquans ac teres. Hic eodem modo quo cynara coctus cum vino ac pipere $\&$ butyro ei fapore non cedit: figuram in Exoticis meis Indicis videre eft ac defcriptionem, quæ proximo anno faxo habeatis. Sed hæc de oleribus fufficiant, tranfeamus ad exercitia, ac animi pathemata, ut tandem optatum portum attingamus. 
204 De Exercitis, somino, AC vigilia, \&c.

\section{A L O G U S. VIII.}

De Exercitiis, fomno, ac vigilia, fanguinis mijfione, purgatione, ac de animi affertibus.

7 UR. Quid de reliqua diætæ parte cenfes, quæ in exercitiis feu motu ac quiete confiftit? BonT. Ut hæc obiter percurramus, Exercitia hic extra controverfiam moderata effe debent: nam propter humidam ac calidam aëris temperiem corpora hic fluxa efie extra controverfiam eft. Et hæc quidem matutino vel vefpertino tempore inftitui debent, cum fol non ita fervidus eft, itaque commoda deambulatio, iis temporibus fanitati conducit, tum equitatio modefta, ut hic ditioribus mos eft, vectatio per fluvium cum navicula, ut amœniffmas fylvas, ac Auminum oras tranfvehamur, quæ floribus ac herbis confite perpetuo virent. Dur. Quid de fomno; ac eum capiendi tempore autumas? BonT. De fomno nil habeo, quod addam, nifi iftud antiquum ut moderatus fit. Sed vereor, ne hic A pocryphus fim, fi fomnum meridianum hic fanitati conducere dicam: fed ut res cafura eft, ego ab ifta opinionenon recedam, nifi melius edoctus: \& certe fi in memoriam revocare velis, quæ ante dicta funt, quod mane propterea quod poft nocturnum frigus concodtioni ventriculi hic magis apti fint, quapropter etiam largius jentandum præcepi. Meridianus fomnus hic non folum utilis, fed \& neceffarius ferme cenfebitur. I'ræfertim cum hoc tempore tantus calor aërem occupet, ut vel leviffimus motus te defatiget, ac fudore diffluere faciat, quid obftat, quominus lectione jucunda, feu levi fomno curas diluas? Nam \& illi qui Hifpanias, Italiam, ac Gallias frequentavere, hoc in is locis folitum effe affirmabunt, cum tamen nullo modo calor ibi tantus fit, ut in his locis. Secus habet in locis Septentrionem verfus fitis, ubi femper largius prandemus, \& digeftioni ciborum motus levior, vel deambulatio conducit, fed hic parce prandendum cum fit, fomnus concoctioni ciborum nullo modo officit: fed eam magis promovet. Dur. Quid 
cenfes de retentione ac vacuatione humorum? BoN. Non eft quod hoc à me expectes, purgationem, aut venæ fectionem eam, quæ in morbis adhiberi folet; fed eam, quæ fervandæ valetudinis gratia contra affectus non naturales inftituitur. Ergo fi alvus folito aftrictior fuerit, eam commode folvemus præitantifimis hic nafcentibus laxativis, thamarindis nimirum, ac medulla Caffiæ fiftula : vel fi paulo validius medicamentum defideres, addatur his Rhabarbari extractum vel Syrupus "ejus. Si porro fanguis mittendus, ratio hic etiam talis eft habenda, qualis in patria, plenitudinis nimirum vocatæ ad vafa, ac ad vires, prior fi adfit plethora, fecundum Hippocratem libro primo Aphorif. large aliquando fanguis mittendus, altera ad vires, fi adfit ventilandis vifceribus præfertim hepati ac cordi, fecundum judicium fanguis mittendus vel femel, vel iterato. Si porro alvus fit folutior, ac inde dyfenteria \& diarrhæa metuatur, Syrupus fumatur è fucco granatorum, vel decoct. è corticibus eorum. Sed quia hæc magis ad morborum curam attinent, illa in aliud commodius tempus rejiciamus. Dur. Reftat parvus fcrupulus de animi affectibus ac perturbationibus intempeftivis. Bont. De iis Medici multa ac varia fcripfere, quomodo domari vel temperari debeant. Verum cum motus animi vix fint in poteftate noftra: Ego illis illud Horatii objicio: quod animus, qui nifis fervit

Imperat; bunc frenis, bunc tu compefce catenis.

Quod uni facile, alteri difficile factu effe pro diverfo temperamento quis non fatebitur? ideoque de affectibus ac pathematis animi certam regulam velle ferre, nugatoris magis puto efle quam Philofophi naturalis: ac etiam hoc cogitandum nobis, ut jejunium noftrum folvamus, ne nobis Plautinum iftud eveniat, dum de frænandis animi paffionibus difputamus, fames $\&$ mora bilem in nafum conciat: itaque fuadeam, dum fol nondum radios in verticem noftrum dimittat jentatum eamus. Dur. Opportune mones, nam \& gula me monet ventrem famelicum carere auribus. Ergo, fi placet, in urbem nos recipiamus. Bont. me lubente fiet.

Dedit Deus bis quoque finem, r63. F. Fanuarii I8. Batav. Facatr. F $1 \mathrm{~N} \mathrm{Cc}_{3} \mathrm{~S}$. JA. 
Pag. 206

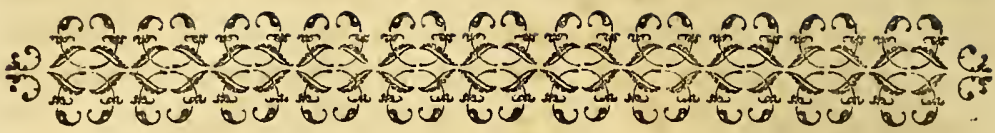

\section{J ACOB I BON T I I}

Medici Methodus Medendi, qua in Indiis $\mathrm{O}$ rientalibus oportet uti, in cura morborum illic vulgo ac populariter graffantium. Additæ quoque ad finem funt Obfervationes aliquot nobiles, præcipue $\mathrm{cx}$ durotía ac cadaveribus diffectis.

Ampleflimis, Magnificis, ac Prudentifimis Viris,

NEGOTIORUM IN INDIIS ORIENTALIBUS

PRAFECTIS MAJORIBUS;

Dominis meis mibi Jumma obfervantia colendis.

S. P. D.

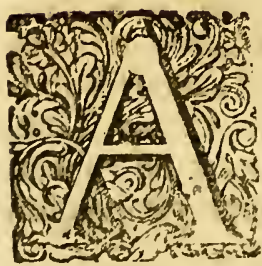

NNI jam fere tres clapfi funt (Viri Ampliffimi) quod operam in re medica meam, $V$. A addixi: quam, cum primum in Indias veftras veni, non fterilem jacere paffus fum: Jed frenue in adum traducere crepi. Ut eo oftenderem, me non velle, ut fimptus à wobis in me collati, 


\section{$\begin{array}{llllllllll}D & E & D & I & C & A & T & I & O & 20 \%\end{array}$}

fruftranei effent: Itaque, quod interdiu in praxi me. dica notatu dignum menti reponebam, nocte à curis aliquanium vacuus charte concredidi, quod jam in lucem protrudere libet. Ut faltem ex parte debita mea, erga $V$. A. objervantice fatisfacerem: nam in folidum folvendo imparem me effe reperio. Ex iis igitur, que precipue obfervari debere putavi, Metbodum Medendi banc concinnavi. Eofque morbos defcripfi, quos Endemios elfe, ac populariter bic graffari animadverti. Neque in cura quicquam addidi, quod non folida prius experientia conprobatum effe vobis affirmare aufim. Siribant alii, quibus ifta mens eft, miracula ex auditu: Ego, quod hifce oculis, Eo qualicumque meo judicio percepi, vobis jpectandum propono. Quod cum nemo ex noftris Batavis (ut credo) affequutus fit: immo, ne tentaverit quidem ante me; ideoque cum ego, qui primus in hanc arenam defcondo, non fine cauja, malevolorun tela metuam, patrocinium mihi $V$. $A$. quarendum erat, quo adverfus eorum ictus, velut, clypeo bac contegerentur. Ouss autem cequiores patronos me invenire poffe confideren, quam vos (Viri Anpliffini) qui me bactenus favore veftro profequuti eftis, quen fi fenfero erga me continuari, animum mibi, ac vigoreme addezis, bifce nuajora, Ev auribus veftris digniora tentandi? Et fi vita /patium mibi fuperfit, oftendam me non indigrnum, cui bac lacra medica concredita fint. Interea (Vivi Ampliffoni) chartaceinn boc mum fculum, quo jolus valeo, eo animo accitere digneinini, quo ego T. $A$, infcripfi, Eo quio adhuc me ipfum, Eo quicquid in me eft fincere vobis offero. Quod $V$. A notius reddan, ubi qua de firpibus, arboribus, ac herbis, in Java crefcentibus, cominemta- 


\section{D $E$ E}

ri capi abfolvero, Go demonftravero alios, quorum nomen tamen celebre inier doctos eft, boc negotium nimis levi pede tranfcurriffe. Valete, Viri Ampliffimi: ego interim D. O. M. Jupplex veneror, ut, ad crefientis veftre Batavia, Go rerum porro Indicarum augmentum, wos nobis diu incolumes confervet. Datum Colonice Batavice Nowa, in regno Facatrenfi Anno I 6=9. Novembris 19.

\section{A. addictiffimus Cliens, Jacobus Bontius M. D.}

\section{AURELIUS CORNELIUS CELSUS}

De Re medica: l. 5. Cap. 26. Confilium Practicum: boc nnbile medicis relinquit.

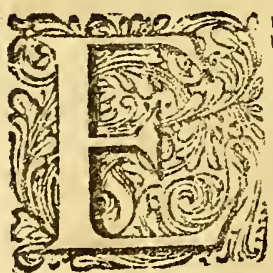

ST prudentis hominis; Primum, eum, qui fervari non poteft, non attingere; nec fubire fufpicionem ejus, ut occifi, quem fors fua peremit. Dein ubi gravis motus, fine certa tamen defperatione, indicare neceffariis periclitantis in difficili rem effe, ne, fi victa ars malo fuerit, vel ignoraffe, vel fefelliffe videatur: Sed, ut hre prudenti viro conveniunt, fic rurfus hiftrionis eft: parvam rem attollere, quo plus præeltitiffe videatur: obligarique æquius eft, confeffione promptze rei, quo curiofius etiam circumfpiciat, ne, quod per fe exiguum eft, malum majus curantis negligentia fiat.

Invide quid teintas abrodere mordicus ungues, Vel mea ne carpas foripia, vel ede Tua. 
De P.araysios Quadam SPECIE, \&c: 209

\section{A P U T. I.}

\section{De Paralyjeos quadam specie, quam Indigenie Beriberii vocant.}

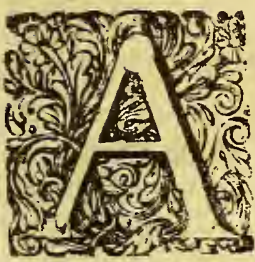

FFEctus quidam admodum moleftus, hic ho. mines infertat, qui ab incolis Beriberii (quod ovem fonat) vocatur. Credo quia, quos malum iftud invafit, nictando genibus, ac elevando crura, tanquam oves ingrediantur. Eftque fpecies Paralyfeos, feu potius Tremoris: Nam motum, fenfumque manuum, ac pedum, immo vero aliquando totius corporis depravat, ac tremere facit. Caufa hujus morbi præcipua eft craffus, ac lentus humor pituitofus, qui nocturnis temporibus, præfertim pluvio colo (pluviæ autem affiduæ cadunt ab initio Novembris ufque ad Maii initium) nervos corripit, dum nimirum homines diurnis caloribus defatigati, noctu omne tegmen ac lodices à fe rejiciunt, unde facillime, jam in cerebro præcipue genitus, nervos ifte humor phlegmaticus invadit. Nam noctes, in his locis, comparatione caloris diurni, frigidæ appellari poflunt. In hoc cafu artus prolongantur, non contrahuntur, infinuante fe inter juncturas phlegmate, ita ut nervi ac ligamenta inde laxentur. Quamvis autem hoc malum plerumque per gradus, ac pedetentim homines invadat, tamen aliquando valde fubitum eft, dum nimirum homines æftu defatigati, potum ex Palma Indica copiofe ac confeftim ingerunt; non fecus ac in patria, diebus canicularibus aliquando vidimus fieri, cum quis curfu, aut aliquo alio vehementi motu calefactus, potum cervifiæ, aut lactis preffi, nimis avide haurit, ita ut inde fæpe fummum vitæ dif́crimen, immo ipfam mortem incurrat. Porro figna hujus mali afpectu obvia funt. Adeft enim fpontanea univerfi corporis laffitudo; motus ac fenfus, præcipue manuum ac pedum depravatur, ac hebefcit; ac in iis fentitur plerumque titillatio talis quædam, qualis in patria frigida, ac $\mathrm{Dd}$ 
hyemali tempeftate mannum, ac pedum digitos corripit, nifi, quod hic tantus dolor non adfit. 'Tum etiam vox aliquando ita impeditur, ut æger vix articulate. loqui poffit: quod mihi ipfi accidit, dum hoc morbo laboranti vocis fonus, per integrum menfem tam exilis effet, ut me vel proxime affidentes vix intelligerent. Adfunt, præter hæc, aliquàndo multo plura figna, ac Symptomata, quæ tamen omnia tenacem, ac frigidum humorem fapiunt: fed præcipua enarraffe fufficiat. Accingamur ad curationem itaque, quæ plerumque hic in longum trahitur; dum nempe humor ifte lentus, ac frigidus ægre difcutitur: per fe tamen (ut plurimum) lethalis non eft: nifi mufculos pectoris, ac thoracis invaferit, \&, hoc modo, fpiritus, ad vocis viam intercludat. Sed hoc imprimis curandum eft, ne ( fi ullo modo fieri poffit) te lecto affigas decumbendo: Sed vel ambulando, vel equitando, vel fimili aliquo motu validiore omni conatu te exerceas:- currere quidem impoffibile eft. Frictiones quoque fortes, ac dolorificæ hic fumme neceffariæ funt, quas commode hic fervi Bengalenfes, ac mulieres malaycæ adhibent. Nam noftra gens tali exercitio non affuevit, ut nec balneis, quæ hic frequentia funt.. Fomenta, ac Infeffiones hic conficiunt ex herba nobili Lagondi dicta, quæ folio quidem Perficariam refert, eftque odoris fuavis, ac aromatici. Certe nobis non tantum ufum Chamomeli, ac Meliloti præbet, fed difentiendi, ac refolvendi viribus iis, meo quidem judicio, præftat; pedes, ac manus præterea inurigendi funt oleis Cariophyllorum, ac Macis: fed mixtis ol. rofaceo, nam fola adhibita nimis cauftica funt, \& cutem facilli. me eroderent. Habemus præter hæc nobilem Naphtæ fpeciem, allatam ex Sumatra, Javæ regno è regione in confpecti fita. Quam Minjac Tannah Indi vocant, quod oleum terræ fignificat, quod, non fecus, ac nobis cognita Naphta, quod oleum petræ vocamus, è terra erumpat; vel ex rupibus, in fubjectafflumina precipitetur. . Hoc oleum à Bărbaris in tanto pretio habetur, ut rex Achinenfis, qui potentiffimus iftius infulæa eft Tyrannus, fub capitali pæna iftud evehi inde prohibeat: ita ut incole, noste intempefta, fi que noftra, aut Anglorum 
navis eorum litoribus adpellat, ad nos iftud furtim deferant. Hoc oleum, partibus affectis illitum, miraculi inftar ægros confolatur. Odore eft porro gravi : fed tamen non faftidiofo.

Sed cum hic morbus fit chronicus, ac longi temporis, nihil æque prodeft, quam decocta ex radicibus Chinæ, Salfæ parillæ, ac Ligno Guajaco; quæ blando, ac amico noftro corpori calore, frigidos iftos, ac craffos humores per fudores, ac urinas egregie difcutiunt, ac evacuant. Interpofitis tamén fubinde commodis per alvum evacuationibus, inter quas principem locum obtinet Extractum, quod hic conficimus ex aloë, \& gutta Cambodia dicta vulgo (corrupte apud nos gutta gamba) cujus defcriptionem inferius videbitis.

Sanguinem hic mittere nefas: non enim plethora, fed cacochymia in vitio eft: \& quis fanguinem fontem caloris, ac thefaurum vitæ non effe intelligit?

Hujus affectus reliquiæ porro commode difeutiuntnr Theriaca, Mithridatio, \&c. fudorem, ac urinam moventibus, ac nervos roborantibus medicamentis. Reliquas hujus mali moleftias opportuna exercitatio, ac valida Naturæ vis fanabunt.

\section{A P. II. \\ De spafmo}

ui apud nos in Hollandia rarus eft fpafmus, hic in Indiis tam familiaris eft affectus, ut merito inter Endemios, ec populares morbos numeretur.

Tam repentinus, ac fubitus eft aliquando ejus impetus, ut, dicto citius, homines rigidi non fecus ac ftatuæ permaneant; dum vel in anteriorem, vel pofteriorem corporis partem, mufculi, involuntario motu, verfus principium fuum trahuntur: Crudele (me Hercules) malum, quod fanis partibus vitalibus, ac naturalibus cum fummo cruciatu miferos mortales, intrabreviffimum temporis fpatium, è vivis ad mortem rapit: dum nihil, nec efculenti, nec potulenti per cefophagum in ventriculum deducere queunt. Sunt \& alii particulares, crurum, ac Dd 2 
fúrarum fpafini: Sed de his, quia leviores funt, \& per fe tranfeunt, hic non agimus.

Porro hoc malo affecti truculente admodum aftantes intuentur, præfertim (quod fæpe fit) interveniente 1pafmo Cynico, feu convulfione canina cum utraque maxilla aures verfus trahitur. Ruber ac viridis color ex oculis, \& facie oritur;-dencibus ftrident, ac murmur inconditum, vice vocis humanæ, edunt, tanquam ii; qui à cella fubterranea loquuntur: ita ut imperitis vere dæmoniaci appareant:

Cura in hoc affectu è copiofa fangainis miffione inchoanda eft. Tum frictiones, ac ligaturæ validæ adhibendæ. Inunctiones quoque fiant oleis Macis Cariophyllorum, permixtis oleo Anechi, aut Rofarum. 'Tum ol. Therebinthinæ ac Spicæ Indicæ, quam Java copiofe fért, Cucurbitæ quoque vitreæ, ac amplæ, cum multa flamma, fine fcarificatione affigendæ cervici, lumbis, humeris, ac mammillis; ita enim, ferofus ifte, ac biliofus humor, commode a nervis, \& mufculis revelletur.

Si remediis iftis paroxifmus paulo mitior evaferit, ac æger aliquo modo jam deglutire incipiat, Antidota adverfus hane peitem, in forma liquida, exhibenda funt, quæ venenofam hanc, ut plurimum, materiam, impugnando, per fudores, ac urinas celeriter ejiciant. Talia func Lapis Bezoar, . rafura cornu Rhinocerotis, cum Theriaca, ac Mithridatio mixta, \&c. quæ in progreflu videbitis. Tum vomitoria ex Infufione guttæ Cambodia, ac Hepate Antimonii feu Croco Mëtallorum, dëglutienda funt: In hoc porro affectu nil procraftinandum; cum fit morbus acutiffimus, qui, fi quis alius vehementer, cito $\&$ cum periculo movetur. Si autem malum invaluerit, \& æger deglutire non valeat per acerrimos clyfteres alvus eluenda eft: Quorum hoc fit exemplar.

re. Hébæ Lagondi dictæ, Abutali Avicennæ, Bifmalvæ, que omnia hic crefcunt an. m. j. fem Anis. Fœnicul. $\mathrm{Cu}-$ mini Anethi an. dra. ij. Coq. in. S. Q. aq. Fluvii ; Colatur. Jib. j. add. pulver. Cólucynthid. hic crefcentis, drachi. fem. Salis Armonaci, vel Salis Nitri dra. j. Electuarii fratris mè IR: BONTr, cujuis defcriptiönem mox dabo unc... I. fem. d. Anethi unc. iij: IM. F. Enema... 
Dein æger à capite ad calcem inungatur oleis fupradictis, ac Naphta Sumatrenfi feu Minjac 'Tannah. Balnea quoque ac fotus fiant ex Herbo Lagondi, \& foliis fruticis cujufdam Davulloncas incolis dicti, qui frutex in humanam altitudinem aflurgit, folio ad marginem diffecto , Balfaminæ, cujus odorem etiam proxime refert. Specifica quadam vi hæc folia crudelifimum hoc malum impugnant, \& funt anodyna doloremque fedant, qui in hoc malo, ex contractione nervorum, violentiffimus eft. Lapis, ac fal prunellæ per os fumptum peculiare-hic eft remedium, ac materiam biliofam per urinas copiofe excernit, \& , fi febris adfit, cor ac arterias refrigerat benigne. Imprimis vero liabenda eft ratio, fæviffimi fymptomatis doloris nimirum, cui omiffá tantifper caufá principali, fæpe cogimur occurrere. Qurod commode fiet Laudano Quercetani, Philonio five Euphorbio, fed præcipue Extracto Croci, quod infra defcribemus. Fortaffis feiolus quifpiam, negabit his remediis, propter vim ftupefactivam, ac narcoticam, nervifque inimicam, effe utendum: Speciofa hæc quidem prima fronte videntur, féd tamen vana funt: nam præcerquam, quod calidiffima hujus clymatis temperies hoc requirit , certuffimum eft, in tali neceffitate, fine his ægrum evadere non poffe. Adde quod nos tam rite Opium hic præparamus, ut vel infanti innoxie detur: \& fáne (ut verbo abfolvam) fi opiata hic nobis deeffent, in morbis calidis, hic graffantibus, fruftra remedia adhit e emus, quod, etfi imperitis durum, ex progreffu tamen me nihil temere dixiffe patebit. Circa victus rationem hic non admodum curiofi fümus: quia vehementia, celeritafque mali, ac atrocitas, nobis lic longiorem deliberationem eripiunt; inclinante tamen morbo gallinis, achædina, \& vitulina carne utendum, cujus jufculis incoctum fit Cardamomum, ac Thamarindi, quæ duo iimplicia Java copiofe fert, ut medicamenti fimul ac alimenti. vicèm fuppleant. 


\section{CA P. III.}

\section{De Alvi profunviis ac primum de Dyenteria Vera.}

uoniam profluviorumalvi, hic (ut \& apud nos) variæ funt fpecies, de fingulis hic agemus, partefque affectas demonftrabimus, tum caufas inveltigabimus, \& fymptomata denique obfervando, curam his annectemus. Et primum de Dyfenteria vera loquemur, horribili ifto, ac confuetiffimo his regionibus malo, quod plures hic homines necat, quam affectus quifpiam alius præter naturam. Dyfenteria igitur vera eft Exulceratio inteftinorum cum affidua dejectione, mucofa primum, cruenta dein, ac ultimo purulenta cum ramentis, ac ipforum inteftinorum fubftantia, cum dolore intolerabili, ac torminibus ventris: Hoc vitium partim contrahitur ex aëre calido, ac liumido: Falluntur enim (ut hoc obiter quoque dicam) qui, propter lineæ æquinoctialis proximitatem, aëris temperiem hic ficcam, ac calidam effe putant. Cujus rei invictifimum, inter alia, argumentum eft, quod chalybs, ac ferrum, tum æs quoque, ac ex his confecta inftrumenta, rubiginem citius, ac æruginem contrahant, etiam ficciffima anni tempeftate, cum nullæ pluviæ hic cadunt, quam, in patria antumnali tempore pluviofiffimo. Præterea fructus hic nafcentes maximum huic nalo fomentum præbent, quibus, fi quis cum fumma cautione non vefcatur, \& cum oryza, vel pane \& pauco falis, vix unquam hoc malum effugiet, non fecus quam in Gallia, ac Hifpania, qui uvas avidius fine pane vorant, ftatim diarrhæam, vel Dyfenteriam incurrunt. Tales hic funt fructus Indici: Ficus nempe Indicæ; quas Bananas, ac Pifang incolæ vocant; Garcias ab Orta. \& Propper Alpinus Mufam appellant. Duriones deinde, Jacas, Ananas, Adde his Cucumeres \& Melones aquaticos, \&c. Quorum defcriptionem apud eundem Garciam, \& Foannem à Linfchoten videte. Hi fructus præterquam quod horarij fint, etiam humiditate fua, ac calore, temperamento noftro infefti funt. Melones, ac Cucume- 
res excipio, qui præter frigus, de humiditate non parum par. ticipant. Præcipua vero hujus mali caufa eft, potus vini adufti, quod Arac vocatur, \& quod Chinenfes ex Oryza, admixtis holothuriis, in mari fluctuantibus, conficiunt, quæ nos Belgice quabben \& quallem folemus vocare. Hæc holothuria tam acris funt caloris, ut attactu cutem exulcerent, ac veficas inducant, \& utinam noftri navales focii hoc potus genus non tam avide biberent, non tot funeribus extuberaret hic humus: Quantum ad curam, commune remedium eft infufio Rhabarbari in decocto Thamarindorum, ad minuendum (ut ajunt) ac temperandum acrem hurre fuccum: Sed bene notandum hic eft, hoc remedium fæpe non prodeffe: fed aliquando ægros in certam perniciem conjicere, dum nimirum bilis acerrima turget, ac orgafmo fertur: ac metus eft, ne ex leviffimo laxativo, irritetur, ac majore cum impetu, ad partem affectam feratur, cum incredibili ægri cruciatu, \& certa fæpe pernicie. Adde fumman plerumque in hoc cafu virium imbecillitatem, quæ reftaurativi potius aliquid, quam purgativi requirat. Itaque caute medico circumfpiciendum hic eft, quid agat. Ego, quod experientia longa verum effe didici, ad ægrorum falutem libere in medium profero. Potus quotidianus itaque fit deco. Etum Oryzæ, quod Caudgie Indi vocant; cum Endivia, ac Cichoreo, quod ex femine allato ex patria, hic in hortis luxuriat. His addatur Lingua cervina, feu Phyllitis, quæ hic circa fluentia copiofe crefcit, ac aftrictiora fua vi, Hepar, ac Inteftina roborat, tum acrimoniam iftius. furentis humoris infringit.

Si vero propter fevitiam fymptomatum, doloris præfertim acerbifimi, temporis anguftia, tam longam in cura moram non patiatur, ftatim ad Extractum Croci deveniendem eft, quo remedio (aufim dicere) nullum humana cura exquifiti us excogitare potuit; putoque veriffimum hujus morbi, fæpe etiam venenati, Antidoton effe Speciatim porro hic omnia remedia ad hune affectum referre mei inftituti non eft, \& ego tantum ea requiro, qua non primis modo qualitatibus, fed proprietate etiam fubftantia, huic morbo favifimo adverfen- 
tur. Et in hoc folo, maxime nafcuntur. Fruetus etiam illi,g quos Mangas vocamus, qui conditi, propter aftringentiam, ac aciditatem, hic fumme utiles func. Inmaturi quoque coquuntur.cum ovis, ut apud nos uvæ crifpæ: neque facile quis, etiamfi exquifitiffimi guftus, faporis differentiam cognofcet. Conficitur etiam ex iifdem fructibus conditum feu miva, non fecus ac caro cotoniata in patria ex cydoniis malis, cujus vicem hic fupplet; nefcio an \& fuperet. Ad ulteriorem porro vifcerum corroborationem egregie confert fyrupus è Granatorum fucco, recens ex arbore decerptorum; tum flores ipforum conditi excellens in hoc malo remedium funt.

\section{CAP. IV.}

\section{De Fluxu Alvi Hepatico.}

Cluxus alvi hepaticus, etiamfi non minus quam Dyfenteria - periculofus, non tamen tam fevis fymptomatis concomitatus eft. Adeft enim multo minor ac fape nulla inteftinorum excoriatio: nam in hoc cafu plerumque purus fanguis dejicitur, vel propter debilitatam jecoris vim retentricem, vel propter acrimoniam fanguinis ofcula venarum referantis per anaftomofin, vel denique cruor propter copiam regurgitat in venas meferaicas, \& inde in inteftina, \& fic per alvum rejicitur, \& hic quidem omnium fluxuum hepaticorum minus periculofus eft, \& fæpe plus terroris, quam damni infert. Si itaque acrimonia fanguinis in caufa eft, frigidioribus decoctis utendum eft, è feminibns Cucumerum, Cucurbitarum, Citrulli, Peponum, ac Melonum aquaticorum, quorum omnium hic fumma eft quantitas. Ex iifdem conficiuntur quoque emulfiones, eclegmata \& pulveres ad idem malum perutiles. Tum ad peccantis humoris revulfionem, cucurbitæ cum fcarificatione lumbis, \& natibus admovendæ, tum diureticis fupra nominatis cum faccharo cibi condiendi. Sin autem quantitate nimia fanguis luxuriet, fine mora vena media pertundenda eft, habita femper recta ratione virium, quia in his regionibus propter aëris ambien- 
bientis calorem, \& evaporationem fpirituum affiduam, homines præfertim ægri funt debilifimi. Hinc (ut obiter hoc dicam) non facile nifi in fumma necefitate ad venæ fectionem defcendo, quod corpora noitra mollia, ac à calore fupradicto effeminata, iftam evacuationem non facile tolerant: Secus eft in compaetis corporibus Javanorum ac Lufitanorum, quæ calori aflueta, venæ feetionem largam admittunt. Expertus, credite, loquor. Sed femper, in anguftiis, ceu ad facramanchoram confugiendum ad nobile iftud Extractum Croci jam aliquoties commemoratum. Cujus deferiptionem hic fubjicio.

12. Opii electiffimi (quod Mifti vocant, \& antiquorum eft Thebaïcum, nam Mifti eft Ditgyptus) Sanguinis draconis, gummi Benjuini, Croci Orientalis, ex Perfia an. partes æquales, Ambræ Japonicæ feu nigræ partem tertiam; conjice in vas vitreum oblongi, \& angufti colli; adde aceti fortifimi ex vino, ut materiam feu maffam in fundo fuperemineat, tres, aut quatuor digitos. Vitrum bene claufum exponatur radiis folaribus, qui nobis hic, propter fervorem, funt inftar ignis chymici; colata hæc omnia \& expreffa fortiter, eodem fole infpiffentur in confiftentiam extra\&ti.

Hujus dofis eft à granis fex, ad novem; in formam catapotii coactum, vel in cochleari, vino, vel convenienti aliquo alio liquore diffolutum. Detur præcipue circa noctem, quo tempore obfervavi omnia inteftinorum, mala hic exafperari. De lienteria, feu lævitate inteftinorum, quæ plerumque dyfenteriam diuturniorem fequitur, \& etiam de diarrhæa volens taceo, quia notifima hec funt in patria, \& quorum cura fxpe fuperiorioribus annexa eft, \& tantum fæpe, in corroboratione ventriculi, \& inteftinorum, confiftic. Sed de reliquis alvi fluoribus dicamus. 


\section{A p. V.}

\section{De Tenesmo.}

7 enefmus, propter fummam moleftiam, quam fecum conjunctam habet, hic magis metuitur, quam Dyfenteria ipfa, \& certe fi eam precedit, utplurimum lechalis efle folet, quia omnes morbi, qui fuccelfione augefcune, primogeniis funt magis calamitofi: Sin autem dyfenteriam fequatur, facilior ejus eft curatio, quia tantum reliquix ipfus funt, ab acri humore partem affectam exulcerante. Eft autem Tenefmus exulceratio inteftini recti, cum crudeli \& affiduo dejiciendi conatu, ubi pauca, \& mucofa permixta fanguinis aliquot guttis, extremum pus excernitur: unde noftrates perappofito vocabulo hunc affectum den drityploop vocant, quod fillatim, ac guttatim humor peccans dejiciatur: Mulieres gravidæ hoc affectu correptæ (ut fere femper) abortiunt, vel ante tempus fcetum excludunt. Uterus enim inter anum, \& veficam fitus, ex affiduo, \& forti ifto conatu embrycnem ante tempus ejicere cogitur. IX eadem etiam caufa, procidentiam ani infert, ac hæmorrhoidas, \& fi diutius perfeveret (quod fæpe vidi) Hydropem; \& hinc Extabefcentia, \& poft fæva tormenta Mors. Quoniam autem hic affectus tantum occupat inteftinum rectum, ac anum, cura ejus præcipue confiftit in clyfteribus, fomentis, ac infeffionibus, quæ parantur ex herbis partim emollientibus, partim detergentibus. Talia funt fol. fuprad. Dauullontas ac Lagondi, Bifnalvæ, ac Abutali Add. fem. Cumini, Anifi, Foniculi, \&zc.

Cum his, \& fimilibus ulcus jam ex parte mundatum fuerit, ac dolor fedatior, aftringentibus decoctis pro fotu utemur, \& hoc eo magis fi ani procidientia fimuladfit. Ejufmodi funt Lingna Cervina, feu Phyllitis, folia Thamarindorum, tum fructus quoque, \& folia Bilinbing fuprad. Qui magnitudinem \& formam referunt primo adolefcentium Cucumerum, quos Agureas Lufitani, ac Itali vocant, quibus fructibus puto naturam 
nihil acidius è terra produxiffe: Nam fi cui dentes aliis cibis acefcunt, his comefis omnis aciditas evanefcit. Ferme ea ratione, qua major dolor minorem obfcurat. Has herbas hic præcipue in fcenam produxi, ut fciant curiofi Medicinæ indagatores, ubi fupra commemorati morbi, \& mala ita frequentia fint, ibi D. O. M. per naturam contraria his remedia larga manu, ex terra, produxiffe. Ceterum remedia, in patria cognita, hic leviufcule volens tranfeo, quia potifimum iis $\mathrm{Me}$ dicinæ amatoribus prodeffe ftudeo, qui mecum, aut poft me in longinquis hifee regionibus praxim medicam exercituri funt. Et utinam hactenus per morbum, quo circiter quatuor menfes decubui, tum per undique nos cingentes Javanos, nobis, ut in principio mei in has terras adventus, licuiffet in amœniffimas Javæ fylvas exfpatiari: \& herbas hic, nobiliffimas, ac plurimas, exactius nofle: Dabo tamen alio volumine, nomina multa arborum, fruticum, ac herbarum hic paflim nafcentium. Tum avium, ac pifcium, quorum femper curiofus fui, quique in his regionibus capiuntur, naturam, ac indolem vobis explicabo, \& quid exotici, ac alieni in iis, \& in quibus cum noftratibus conveniant, vos docebo. Interim hoc caput finiendum eft aurea C. Celfi fententia, quæ talis eft lib. Iv. c. $x v r$. Cum in omni fluore ventris, tum in hoc præcipue (de Tenefmo loquitur) neceffarium eft, non quoties libet defidere, fed. quoties neceffe eft, ut hæc ipfa mora in confuetudinem ferendi oneris inteftina deducat.

\section{A p. VI. \\ De Cholera.}

1 ræter jam dicta alvi profluvia, etiam Cholera hic familiariter ægros infeltat; cujus caufam, figna, acfymptomata, curam denique hoc capite abfolvere eft animus. Fit itaque Cholera, cum materia biliofa, ac prætorrida ventriculum, ac inteftina infeftans, per gulam fimul, ac per anum concino ferme, ac cum magna copia rejicitur: Morbus eft acutiffimus; Ee 2 ideo: 
ideo præfenti eget remedio. Caufa præcipua hujus mali, præter aëris calidam ac humidam temperaturam, eft nimia fructus hic edendi licentia; qui quod plerumque fint horarii, ac putredini obnoxii, tum humiditate fua fuperflua ventriculo in. fefti funt ac infueti etiam, ac bilem æruginofam hanc gignunt. Hæc excretio, \& non fine caufa, alicui videretur falubris, quod talia purgentur, qualia oportet: tamen quia cum tanta quantitate fimul effunduntur fpiritus vitales, ac naturales, debilitato quoque per foedos halitus corde, caloris omnis, ac vitæ fonte, utplurimum commoriuntur ægri, idque celerrime, utpote qui intra viginti quatuor horas vel etiam pauciores expirent, ut accidit inter plurimos, Cornelin van Royen, ægrorum in Nofocomio Oeconomo, qui, hora fexta vefperina, adhuc valens, fubito Cholera corripitur, \& ante duodecimam noctis horam vomendo fimul, ac per alvum dejiciendo, cum diris cruciatibus, ac convulfionibus, miferrime expiravit; vincente morbi violentia, ac celeritate omne remediorum genus: Si tamen, últra prædictum fpatium, pernicies itta protrahatur, magna curæ fpes eft: Pulfus hic admodum debilis eft, refpiratio molefta, membra externe frigent. Calor vehemens, ac fitis interne urgent, vigiliæ adfunt perpetuæ. Jactatio corporis inquietiffima, qux fi comitetur frigidus ac fotidus fudor, mortem in propinquo effe certifimum eft. Danda in hoc affectu primum opera, ut acerrimus inte humor, qui tanto furore, ac orgafmo fertur, mitigetur. Quod fieri poterit maxime per aftringentia medicamenta, ac ventriculum, \& inteflina corroborantia, \& fimul modico frigore furorem materia morbifice refrænantia. In his præftantifimus eft fyrupus ex Billinbing. fuprad. Tum fructus ejus faccharo conditi, adjecto Croco: fyrupus preterea è fucco Jimonum recentium, in Java nafcitur præterea ad hunc affectum Pfeudomyrobalanus, qui forma Bellericos refert, Et magna copia a Nigris in urbem venalis adfertur. Et fola aftrictoria vi præftat, cum ceteræ Myrobalanorum fpecies etiam laxativi aliquid habeant; hine conditus hic fructus, utilifimus, ad Choleram non folum, fed ad ceteros, omnes alvi fluores nimios. Cum cornu Cervi ufto, lapide Be:- 
zoar, rafura cornu Rhincerotis, vel Margaritis præparatis.

Sed his non adferentibus juvamen, confefim ad extractum Croci deveniendum eft, tum, ut vigiliæ arceantur, ac fomnus concilietur; qui propter fummam virium dejectionem hic necellarius eft, tum ut, tantifper mitigato atroci ifto humore, natura fortior denuo ad vicendum hoftem infurgat: Cholerici (ut fere femper) convulf moriuncur.

\section{Ca p. VII。}

\section{De Affectibus Hepatis Vifceris nobilis: ac primum de ejus ObftruEtione, ac Inflammatione.}

Jullum vifcus, preter inteftina, frequentius in his regionidicta, victus ratione mala, à potu iftus maledicti Arac non tantum in temperamento immutatur, fed eiiam in fubftantia fua corrumpitur: Dum enim ejus haufu ebriofi ifti excalfacti, ingentem aqua copiam in ventriculum ingerunt, ut conceptum xftum reftinguant, dein humi, tanquam pecudes, procumbunt, \& in navibus, fe rori, qui poft fecundam, aut tertiam noctis horam copiofe hic cadit, exponunt: unde venenatos vapores è terra erumpentes, intra corpus recipiunt, \& fic obftructionem hepatis facillime incurrunt, cui adeft tenfiva, in hypochondrio dextro, gravitas, dolorque obtufus, ac quafi pondere premens. Dificilis quoque adeft fpiratio, propter - gravitatem vifceris, diaphragma deorfum trahentis, cui, mediante ligamento fufpenforio, annectitur: hæc infaretio fi perfeveret, humor hepar obftruens, dum non ventilatur, facillime putrefcit. Unde febris etiam oritur, ac ipfius hepatis inflammatio, cum dolore acuto, ac pungente, febrifque augefcens, in ardentem tranfit, cum fiti intolerabili, faciei rubedine, ac difficili, ob prædictás in obftructione caufas, refpiratione: $\mathrm{Hi}$ duo affectus cum, quafi invicem, concatenati fint, \& unus, ex altero ferme nafcatur, curam amborum hoc capite conjun.

$$
\mathrm{E} \text { e } 3
$$




\section{De AfFectibus Hepatis, \&ec.}

gam, incipiendo (ut par eft) ab obfruetione: itaque in hac primum obfervandum eft, ne nimium calidis medicamentis in principio utamur, ne minutæ iftæ hepatis venæ, \& capillares, ab exficcante calore magis obftruantur, \& ne hoc modo quod in proverbio eft, oleum camino addamus. Ergo temperate calidis, \& per confequens leniter deobftruentibus, ac materiam peccantem incidentibus opus eft, quæ familiaritatem quandam cum noftra natura habeant. Talia funt, quæ a practicis Anodyna vocantur: nimirum femina Anifi, Frniculi, Cumini, quæ nobis hic fuppetunt. Tum radices Graminis cujufdam aromatici, ac Caryophyllatæ odorem æmulantis. Adde his (quod in principio dici oportuit) Calamum aromaticum verum, quem paftum Camelorum vocat ab Orta, qui hic abunde crefcit, quo etiam incolæ cibos, præfertim pifees, non infuaviter condiunt. Ceterum reliqua addantur, que, blando calore diuretica funt, ut vifcus hoc nobile ab infaretu liberent. Præparata jam morbi materia, eam medicamento non femel nec fimul, fed iterato ftudebimus educere. Ejufmodi, funt Thamarindi, Caffiæ filtulæ pulpa, adjecto pulvere Therebintinæ coet. f. a. mirum enim quam blandæ hæe fimul per alvum, ac veficam morbificum fuccum ejiciant, fi paulo fortius defideres adde drach. I. Rhabarbari, mifceatur cum fupradictis in formam bol, Inflammationem porro in procinctu efle cum compereris, ex febris augmento, \& dolore vehementiori, ac magis pungente, ftatim venam fecato copiofe, pro viribus $æ$ gri. Cibis, ac fyrupis ac confervis refrigerantibus, jam aliquoties commemoratis utere, qux, ne actum videar agere, ego hic lubens omitto. Conficitur hic conditum ex fructibus, quos poma Amoris vocamus; Italis Bella Dona, \& Lufitanis poma d'Oro, appellantur. Certe fpecies Mandragoræ eft. Hanc. Chinenfes inter acetaria in hortis colunt, \& toftam fub cinericum aceto \& pipere edunt. Hæc planta, etiamfi frigida eft tertio gradu, tamen in clymate hoc calido, \& bile acerrima dominante, maximum hepati, ac reliquis vifceribus vicinis, per confenfum laborantibus, preftat refrigerium. Condiuntur quoque muria, ac aceto addito Pipere, \& Aromatibus. 
Quod genus condituræ communi nomine Achrr Indi vocant. Denique Hypochondria, præfertim dextrum inungendum eft, unguento nobili, quod Indæe mulieres hic conficiunt, cujus ingredientia præcipua funt. Radix Curcumæ (quam Borborii incolæ vocant) unde univerfa compofitio hæc etiam nomen fortita eft. Santali, omnibus fpeciebus, addita Caplura: \& oleo recenti ex Cocco exprefl. vel fi mavis, Rofaceo; quod nobis ex Perfia fuppetit: Hæc omnia in marmore fubiguntur in unguenti confiftentiam. Hoc oleo, feminæ, fimul, ac viri, totum corpus inungunt adverfus æftus. Et quia colore propter Curcumam eft flavo, homines quafi Croco tincti fpectantur, odore tamen eft adnodum grato, \& cerebro utili: (Curcumæ meminit ab Orta lib. 2. cap. 39. Et quamvis eam ibi defcribat, tamen fatetur id fe ex auditu facere: ego millies vidi, \& à terra evulfi, Defcripfit autem fub nomine Croci Indici 3 . Folio eft Pfeudoridos, feu Gladioli, ) Præterea, ad idem, oleum conficimus ex floribus cujufdam arboris, non nimis altæ, ferentis folia, Perficæ arboris fimilia. Flores funt viroris dilutioris, quem Belgre Zecgroen vocant, \& primo intuitu, potius fafciculum foliorum putes effe, fed pediculi intus in calice, quales in Rofis funt, flores effe arguunt, Arboris fimul, ac florum nomen Sampaga incolis cft, \&z apud eos in fummo funt honore: Nam Indi, fi quæ gens alia inter Mahumetanos, otoris grati funt aridifimi: hine nullas ferme in plateis mulieres confpicias, quæ non capillos intertextos habeant, his \& $\mathrm{fi}$ milibus floribus ut gratiores fe maritis, aut amantibus fuis fe reddant: Sed in viam redeamus. Si (quod fape fieri folet) quis dolor in Hepate, \& ligamentis fit intolerabilis, caufa tantifper omiffa, huic fymptomati occurremus. Quod fiat per extractum aurum Croci: quo vel folo (aufim affirmare) ægros plurimos curavi, natura, per quietem, ad fe redeunte $\&$ virus peralvum, urinas, ac fudores ejiciente. 


\section{CA P. VIII. \\ De Apoftemate Hepatis, ac ejus cura unica.}

\section{Q} uod fi hepatis inflammatio non bene fanetur, vel pertinacius curæ refiftat", confequitur admodum miferabilis affectus Hepatis, nim. Apoftema; quo, fi parenchyma feu fubftantia ipfa jecoris occupetur, jam incurabile eft malum; Ideoque de eo hic fuperfedeo dicere. Sed fi pus hæreat, inter membranam cingentem hoc vifcus, \& ipfius carnem (quod perfæpe hic fit) unica falutis fpes eft in aboftematis apertione; quæ hoc modo fieri debet. Primum in regione Hepatis applicetur cauterium potentiale ita, ut efchara tantum penetret abdominis mufculos, nec inficiatur peritonæum; Deinde, parvo foramine per fcalpellum in ipfo fecto, per id immittatur inftrumentum argenteum concavum, quali utuntur in fectionibus calculi lithoto$\mathrm{mi}$, dein fatis late vulnus dilatandum: Et tum ftatim in confpectum fe dabit membrana jecur ambiens, vehementer tumefcens ab amurca intus latente. Ea pertufa, faniofus humor, carnium lotura fimilis, effluet, qui quo minus foetet, eo major curæ fpes eft. Poft hæc vulnus detergendum, modice ficcantibus \& mundantibus. Flo. n. Rofarum. cortic. Granatorum, add. Mell. Rofac. \&c. Dein farcoticis, ac epuloticis, à perito Chirurgo vulnus ad citatricem perducendum. Interea ægro omnino à Pbarmacis ac catharticis abftinendum, \& tantum roborantibus utendum, ut conferva Rofar, cum pulvere Santali rubri, cui mifeeatur cornu Cervi uftum, rafura cornu Rhinocerotis, qui hic plurimis in fylvis eft, Margaritæ, ac Corallum rubrum preparatum. Adhæc fyrup. condita, ac mivæè Billimbing, Mangas, Granat. è fucco Limonum, qux omnia refrigerantia fimul ac hepar roborantia xgro folamen adferunt. Porro debili (ut fere femper) exiftente xgro, lapidi Bezoar non eft parcendum. 


\section{A P. IX.
De Hydrope, Familiarifimo in Indiis morbo.}

Hæc pauciffima de Hepatis apoftemate: quia cura non verHis , fed agili Chirurgi expertis manu, \& prudentis Medici ingenio peragenda eft. Jam ad hydropem, frequentiffmum in his locis malum, adveniendum eft.

Hydrops, ut omnes docti confentiunt, oritur ex frigida hepatis intemperie, quæ fæepe à diuturna obftructione originem ducit. Hæc vero obftruetio nafcitur ex cibis mali fucci, \& fructibus fupra defcriptis: hinc fit, ut fanguificatio vitietur (Hepar enim eft fanguinis officina) Jecur enim dum chylum ex venis meferaicis attractum in fanguinem convertere nequit, ejus loco ferofum illum ac aquofum humorem gignit; intumefcitque (ut $\&$ in Patria ) vel univerfum corpus, vel abdomen, idque vel à flatibus vel humore ferofo. Unde illa tres tantopere decantatæ Hydropis fpecies, Anafarca, Afcites \& Tympanites, hic proh dolor! nimis frequentes funt in Indiis. Pars tamen principaliter affecta, eft nobile vifcus hepar. Tuffis propterea ficca comitatur ac refpirandi difficultas, quia jecur infita fua, \& jam per morbum adaucta gravitate, deorfum feptum tranfverfum trahens, thoraci ac pulmonibus hanc moleftiam infert. Adeft febris plerumque lenta, urinæ ob cruditatem, ac functionum naturalium debilitatem, tenues ac albæ. Sitis propter ferofi humoris falfedinem adeft indefeffa. Præterea univerfi corporis fpontanea laffitudo. Hæc fult aqua intercutis præcipua figna: fi quæ fint leviora, ea prudens prætereo, quia mihi non eft animus formare medicum : fed jam formatum docere, quid hic in praxi opus eft. Antequam hujus morbi curam aggrediamur, fciendum hoc eft in genere hydropem in his locis facilius fanari, quam fub noftro clymate. Itaque cautus medicus non temere judicium fuum præcipitet, nec primo afpectu lethale dicat, quod paulo poft cum ingenti fua irrifione, à mulierculis, vel potius ipfa natura obfervata tantummodo convenienti victus ratione, fanatur. Præcipua vero cura 
confiftit in præparatione primum, dein aduftione humoris peccantis; tum reliquiarum difcuffione, denique in correctione intemperiei in hepate conceptæ. Diæta quoque fit boni fucci, ut funt gallinæ (quod avium genus hic frequentiflimum) eæque fint elixæ pocius, quam aflæ; fed inter ceteras iftud genus eligendum eft, quod carne fit nigra; nam has habere vim medicamenti diuretici longo ufu ab incolis compertum eft; Harum jufculis incoquantur femen Anethi, Fœniculi tum radices Cichorei, tum WJajorana, ac Bafilicum, quibus omnibus, hic abundamus. Eodem.modo præparatæ etiam carnes caprinæ hic medicamenti fimul ac alimenti vim præftabunt: fed nihil æque confert, quam quotidianus ufus decoct. radicum Chinæ, Salfa parillæ; adjectis Curcumæ radicibus, Succifa ac Scabiofa, quarum herbarum vires mulieres Malaicæ obftetrices, ufque ad irrifionem-extollunt. Sic quoque prodeft decoct. Gua= jac. cum corticibus ejus.

Humorem hoc modo præparatum educere per alvum ftudebimus vehementioribus catharticis, ne fi imbecillibus utamur, fuccum peccantem moveamus potius, quam promoveamus. Inter quæ præftat extract. gutt. Cambodja, quod paratur hoc modo a me. Recipe. Aloës Socotorinæ.

Cuttæ Cambodja.

Gummi ammoniaci an. partes æquales.

Aceto vini acerrimo diffolvantur; pone in vafe vitreo ad fo... lem, fortiterque colatum, exponatur. rurfus, donec contraxerit confiftentiam maffæ pillularum.

Dofis a drachm. fem ab drachm. r.

Crefcit hic quoque in fumma copia, Cucumer afininus; unde: Elaterii fuccum non femel confecimus, cujus fcrup 1. ad drachm. fem. non fine magno fucceflu ægris fæpe exhibuimus. Dantur enim commode extract. Efula grana x. vel xv. in convenienti aliquo liquore. Et quia frpius incidimus in mentionem guttæ Camdodja, ac Efulæ iftius Javanæ, utriufque defcriptionem hic à me accipite. Nafcitur hic in fylvis Tithymalli quædam fpecies, in tantam altitudinem, ut acumina niagnarum arborum, quas inftar hederæ amplectitur, æquet, 
imo fuperet: craffities ejus eft brachii facile humani. Hujus caule vuinerato, lacteus humor effluit ubertim, qui collectus., \& in extracti confiftentiam redactus, ad ufum fervatur Planta ifta, quæ guttam Cambodja fert, feu lacrymam iftam flavam, quam in patria habetis, fupra dictæ adfimilis eft: nifi quod non tam alte excrefcat: ita ut ferme folo colore fucci hi inter fe differant. Crefcit hæc planta, ut Aloë in maxima copia in Cambodja regione Chinæ vicina, unde etiam nomen fortita eft: De Paracentefi, aut de umbilici perforatione, hic nihil addo, non quod hic non frequenter exerceatur, fed quod hæc Chirurgo \& Medico experto cognita efle debet. Adde, quod in his regionibus maxime familiaris eft, \& magis mihi curæ eft bonum practicum agere, quam in fcholis de omnibus morbis, eorumque curis otiofe difputantem \& medicum in charta fuperbe agentem, \& hoc aufim affirmare (abfit verbo invidia) fi hane methodum Medici \& Chirurgi fequantur, non longe à fcopo aberrabunt. Evacuato maxima ex parte hoc ferofo humore, ne recidivam patiantur ægri (quod alias fæpe fit, \& à recidivis hic in Indiis ferme ad fanitatem nunquam eft reditus. ) reliquiæ hujus mali difcutiendæ funt, \& hepar, quantum fieri poteft, ad priftinam temperiem reducendum eft. Ad quod præter folita antidota fudorifica, Theriacam, Mithridat. \&c.) Decoctum levius Salfæ, radicis Chinæ, \& Guajaci per aliquot dies continuandum eft, quod tum in hoc, tum in aliis chronicis morbis longe præftantiffimum ac indubitatum eft remedium.

\section{$C_{\text {A P. }}^{-} \mathrm{X}$.}

\section{De IEtero in Indiis.}

W orbus regius, feu icterus, inter quotidianos in India morbos hic merito numeratur. Hic quoque vel morbos alios comitatur, vel eofdem fequitur. Exempli gratia inflammationem, fchirrum, Apoftema denique hepatis, \& quia tum ut plurimum fymptomaticus, \& ex violentia morbi ortus eft, ut feFf 2 
re quoque femper lethalis eft. Præterea quia ejus cura cum primariis affectibus conjuncta eft, de eo hic fuperfedebimus dicere; verum eft, altera. IEteri fpecies, ubi folliculus fellis obftructus, excrementum fuum ad alvum non tranfmittit, unde etiam in ftercore color albus apparet, urina vero croceo plane colore, lintea tingit. Nam bilis, verfus jecur regurgitans, cum fanguine dein per venas, \& arterias in univerfum corpus diftribuitur, cutemque tingit colore luteo, ut \& in oculis manifefto appareat. De hoc affectu nobis hic eft fermo. Sæpe hic ita momentaneus eft, ut intra pauciffimos dies oriatur, ac occidat, quod eis ante paucos menfes accidit doctiffimis, ac reverendis viris $D$. Fufto Heurnio, ac D. Abrabamo de Roy, quibus amicifime fimul ac familiariter utor, qui aliquoties exhibito pharmaco fudatorio, \& cordialibus, intra breve temporis fpatium curati funt. Qui autem diuturnuir eft Icterus, majorem in cura diligentiam requirit, quod in eo longe validior fit obfructio: :adde quod fæpe dilirium, ac phrenitidem infert, bile flava per metaftafim ad mentis arcem elevata: hic neglectus certiffimum hydropem infert. In eo igitur iifdem medicamentis utendum, quæ fuperius in obftructione jecoris adduximus. Aviculæ quoque Chlorides dictæ, propria \& occulta qualitate adverfus hæc fymptomata valere incolæ produnt. Excellit hic decoctum Chinæ \& Salfæ, quo copiofe fudores eliciuntur. Ium porro ad evacuationem eandem recipe folior. Sennæ unc. I. infuf. in decoct. Thamarindorum cum Rhabarb. drachm. I. fem. Sed fi propter fortem obftructionem paulo valentiori pharmaco fit opus, Electuario fubfequenti utatur $æ$ ger, quod à fratre meo $P$. M. Reynero Bontio, dum viveret Principis Auraici Mauritii Archiatro, Eे Medicine Profeffore in. Academia Leydenfr,

Recipe Ligni Guajacini libr. ij.

Salfæ parillæ unc. viij.

Cortic. ligni Guajac. unc. iij. poft macerationem in f. aq. fluvii per 24 . horas, coquant. q. f. hujus colaturæ ferventiffime adde.

Folior, Sénno mundator $\therefore$ lib. j: 
Polypodii libr. fem.

Sem. Anif. Fæniculi. an. unc. iij.

Hellebori nigri unc. vj.

Myrobalanorum omnium.

Thamarindorum an. lib. ij.

Bulliant q. s. in fupra dicto decocto, colaturæ rurfus adde.

Pulpæ Caffiæ Fiftulæ, unc. xij.

Pulveris Sennx.

Pulveris Rhabarbari an. unc. $\mathrm{x}$.

Pulveris Cortic. ligni Guajacini, unc. $1 \mathrm{r}$.

Scammoneæ elect: pro quaque electuarii lib. j. ad unc. $j$. Sacchari albiffimi q. $f$. ut $f$.

Electuarium molle, Cujus dofis eft à dra. iij. ac unc. j. Pleraque ingredientia hujus electuarii hic inveniri fcitote: Nam Polypodium; hic craffius longe, ac fucculentius in Mangiferis arboribus, non fecus ac in Quercubus in patria, crefcit. Si porro Helleborus niger defit, ejus loco utimur Hellebori albi fpecie, quam Potfiock Chinenfes ac Javani vocant, eftque in fummo pretio. Thamarindi quoque ac Caffia hic in fylvis paffim crefcunt. Loco Scammoneæ, quæ tamen, ut \& reliquæ Convoluvulorum fpecies, hic abunde nafcitur, uti commode poffumus gutta Cambodja prius per aliquot dies in aceto macerata, vel fpiritu vini. Nam hoc modo vomitoriam ac infeftam fuam ventriculo qualitatem plane deponit, \& blandius, quam Scammonea, alvum ducit. Pro potu utatur æger fecundo Decocto Chinæ, cum radicibus Curcumæ, quas Lufitani Saffaram de tierra nominant; ac fi Crocum fubterreftrem dicas. Tum pulvis ejus melle exceptus, \& in electuarii formam redactus $\dot{a}:$ dra. fem. ad drach. j. tanquam fpeceficum hivic morbo remedium exhibetur, \& tum per urinas egregie humorem: qui in vitio eft, educit. Flatus, qui in hoc morbo affidui funt, feminibus Carminativis, \&. ol. Anifi, difcutiuntur. Crefcunt enim hic omnia hæc, \& à Javanis, \& Chinenfibus in fimiles ufus refervantur:- 


\section{CA P. XI.}

De Atrophia, feu Extabefcentia quadam, Indicis regionibus familiari, ab obftructione vifcerum prasertim Mefenterii orta.

Gape hic fine manifefta caufa ægri extabefcunt, ac emacian3 tur, febri nulla vel faltem lentiffima fe huic malo jungente fine magno fenfu doloris.: 'gravitas tantum quædam fentitur circa umbilicum, ac Hypochondria. Hoc malum, præter obftructionem vifcerum, fæpe caufam latentem habet in venis meferaicis, vel in ipfa Mefenterii fubftantia, quæ fepæ infignem abfceflum patitur: quod in diffectis cadaveribus non femel obfervavi; Immo reperi aliquando totum Mefenterium abfumptum; ac tamen inteftina cohærebant, aut potius inter fe confundebantur nullo ordine, tenuibus peiliculis, feu membranulis adnatis. Ita miferi mortales ad extremam maciem perdueti, ut jam magis fceleta, quam corpora carne veftita dici poffint, abfumpto calore nativo, vita excedunt. Notabile in hoc malo eft , plerumque adeffe $\beta \tilde{8} \lambda_{\imath} \mu \circ v_{0}$ ac appetentiam caninam: cui fe lienteria, feu levitas inteftinorum conjungit; unde cibi nihil, aut parum immutati, \& incocti per alvum ejiciuntur. Taliter affecti, quamvis plerumque commoriantur, tamen ne omnino defperare videamur, aliquid tentandum eft potius, quam nihil. Si forte natura benignior, adjuta autem blandis medicamentis exterius, vires refumens, ex defperato fanabile faciat malum. Temperate itaque calidis, anodynifque moderateqne, citra infignem calorem deobftruentibus utemur. Talia funt decoct. \& condita ex feminibus Anif. Fonicul. Carui, \& reliquis carminativis fupra relatis. Præterea crefcit hic quoddam Gramen, cujus nomen, ac defcriptionem videre eft apud Profperum Alpinum, libro de plantis AEgypti capite xL. quod merito Gramen crucis vocatur, quia quatuor fpicas è fummitate caulis emittit, quæ perfecte crucem formant. Radix hujus Graminis, quæ tantum in ufu eft, odorem habet aromaticum, 
$\&$ proxime ad Cariophyllatæ radicis accedentem, guftu quo. que eft qauxízıspos, id eft, è dulci amara. Hujus radicis decoctæ mirabiles effectus expertus fum, in calculo Renum ac aliis longioribus obftructionibus, qualis hæe eft de qua loquimur. Confert quoque Anagallis aquatica, feu Becabunga, quæ cum elegantiffimis flofculis fuis albis in ripis fluviorum hic crefcit. Vefcatur æger carnibus Turturum, ac Fringuillarum, quas milites \& Mauri fclopetis occifas quotidie venales in civitatem ferunt. Lac quoque caprillum mirifice prodeft, dum nitrofitate fua, quæ fero ineft, venas meferaicas detergit, ac. obftructione liberat. Abftinendum denique à purgantibus medicamentis, ne, dum humorem violenter conamur revellere, obftructiones per acrem calorem, qui folet pharmaca ifta comitari, adaugeamus. Adde quod in hoc cafu, propter alimorix defectum, vires femper fumme imbecilles funt. .

\section{Cap. XII.}

De quibufdam Pulmonum vitiis, que bic grafsantur: ac primum, De Hamoptofi, Jeu fanguinis Sputo, or Phtifi, fen Ulcere Pulmozam.

Ebuifem quidem hos Thoracis affectus præmifife fecundum ordinem, qui in fcholis obfervatur; tamen ego, qui non umbras rerum, fed res ipfas, tanquam practicus fector, nihil ad curam referre arbitratus fum, utrum id prius, an pofterius agam.

Quoniam itaque, ut \& fupra retuli, aëris conftitutio hic eft calida \& humida, fæpe fit, ut acribus catharris caput oneretur; unde hic etiam gravedines tam frequentes, \& 1æpe diuturniores quam in patria oriuntur. Tum milites \& focii navales, bene poti humi fine ftragulis dormiturientes, vaporibus ̀े terra adfcendentibus, \& rore è coelo cadente obruuntur: unde hoc notandum eft obiter, habitationes in fuperiori ædium parte longe effe falubriores quam in inferiori, quæ propter humiditatem foli formicis, Scorpionibus, ac fcarabæis (guos Caccar- 
laccas vocant) fcatent : fed hæc parergice: ad rem veniamus. Hi catharri fæpe ad fubjectos pulmones è cerebro præcipitantur, ipfofque falfedine, ac acrimonia fua erodunt, unde $\mathrm{H} x$ moptofis, hinc Tabes, \& dein Empyema, feu fuppuratio. Affiduam tuffim, difficilem anhelitum, febrem tandem hecticam hic lubens prætereo, tanquam nota practicis, \& jam ad curam me accingo. Et quia, in his regionibus, affectus hi à catharris, ac deftillationibus utplurimum oriuntur, ifti per commodas purgationes divertendi funt. Ejus ergo fiat catapotiorum maffa hoc modo.

Re. Aloës Socotorina.

Guttæ Cambodja.

Colochynthidos pulverifatæ.

Scammoneæ elect. an. partes æquales: infunde in aceto, vel Spiritu vini, modo jam fæpius dicto, \& fole evaporentur in maffam pillularum: dofis eft à fc. j. ad. dra. fem. vel in valentioribus ad dra. j. Nam hoc in genere fciendum eft, quod ut fluores alvi (ut Celfus vocat) hic funt violentiores, ita quoque è contra obftructiones validæ, ac pertinaces funt: quæ non nifi valentioribus catharticis cedunt. Electuarium fupra dictum fratris mei, hic etiam maximum emolumentum adfert. Averfa jam per alvum materia, reliquiæ particularibus remediis tollendæ. Caputpurgiis nimirum, Errhinis, ac Mafticatoriis, è Pyrethro, Staphidos agria, femine Raphani, Nafturtii, Pipere, \& ceteris notis. Præter hoc peculiare hic habemus nobile medicamentum, quod conficitur ex Arecca \& Betele, \& calce viva ex oftreorum conchiliis ufta, quod mafticando pituitam è capite elicit, eamque, quæ in ventriculo eft, confumit, ac prohibet, ne vaporibus caput impleat, unde hi catharri nafcuntur. Medicamentum hoc, Malaice vocatur Sirii Pinang. Ejus defcriptionem, \& reliquas infignes virtutes, quibus fine dubio præditum eft, vide apud Garciam biftoria Aromatum capite de Betele, ac Arecca. Eft quoddam genus iftius Pinang quod Mabock Indi vocant, tanquam ebrium dicas, qui pauco tempore cerebrum eo modo, quo potio vini nimia, afficit. Sed manfo paulo falis, ftatim vertigo ifta evanefcit: 
Cum jam ifti catharri, aut negledi, aut non bene averfi, per falfuginem fuam, qua præditi funt, aut pulmonum venas eroferint, aut acrimonia fua per anaftomofin ora vafculorum referaverint, \& æger in hæmoptofin, feu copiofam fanguinis excreationem inciderit, cum tuffi valida præfertim, ftatim fanguis ad revulfionem copiofe detrahendus eft. Poft pectoralibus incraffantibus, ac fanguinem fiftentibus, utendum, quorum defcriptionem inferius dabimus, ne neceffe fit ifta repetere. Si patientes contingat evadere tantifper fanguinis fputum, tum, neque tamen tuffis minuatur, \& per eam pus exfpuatur, fignum eft, affectum hunc jam in tabem, feu ulcus Pulmonum tranififie, cui, fi fupervenit febris hectica, fequitur marafmus, quem dein comitatur certiffima mors. In his duobus morbis, quia agnati funt, \& alter ex altero fæpiffime oritur, eandem, vel perquam fimilem medendi rationem fequimur: Utendum eft igitur in principio Diatragacantho frigido, cui optime conficiendo hic nafcuntur femina Cucumerum, Cucurbitarum, Melonum \& cetera : tum è Suratte Amygdala fuppetunt, \& Papaveris femen; tum cum aliis fpeciebus, quas hic etiam abunde habemus, in formam liquidam electuarii, aut etiam in tabulas concinnata ad ufum fervantur. Sed nihil $x_{-}$ que prodeft, quam toties commemoratum extractum Croci, quod non tantum fanguinis fputum fiftit, fed \& Tuffim fedat, pus incraffando habilius ad expectorationem reddit; quinetiam pulmones jam exulceratos confolidat, ac ad cicatricem perducit. Eoque folo remedio plurimos jam defperatos fanavi. Sumant præterea ægri, ad minimum ter quotidie, hauftum decocti jam defcribendi.

1.. Scabiof. morfus diaboli; Linguæ Cervinæ an. m. j. Capitum papaver. demptis fummitatibus num. Iv. Glycirrifæ raf. unc. j. coq. in f. q. aq. comm. Colatur. lib. ij. fem. adde ol. Sulphur. q. 1. ad gratum acorem. m. f. Apozema.

Si in Tabe, feu Phtifi pulmones paulo magis mundare velis, add. huic decoct. unc. ij. mellis Rofacei, tum ad eundem effectum, faciliorem expectorationem hac conferva utamur. 
R. Confervæ Rofarum è Perfia antiquæ unc. ij. Sem. Papaver. albi contufi, unc. fem. Flor. Sulphur. drach. j. fem.

Pulver. Solidaginis Saracenicæ, \& pulveris Scabiofæ, an. dra. $\mathrm{j}$.

Ol. Sulphur. q. f. ad gratum acorem M. f. Conditum. Pro potu communi utatur decocto fecundo fuperius Chinæ, aut Salfæ relato.

\section{CAP. XIII.}

\section{De Empjemate, of fuctuatione puris fuper. Septum tranfverfum.}

mpyematis quidem per eadem jam dicta medicamenta, fed 1 longe tamen difficilior eft curatio; quod pus, ac fanies libere, $a b$ alterutroque vel etiam utroque latere, fuper diaphragma fluctuet \& pulmones; \& quamvis ejus portionem fæepe aliquam, tamen totam exfugere non valeat. Et tamen per alteram viam, quam per Tracheæam arteriam purulentæ iftimateriæ non eft exitus, quicquid illi dicant, qui ejici aliquando affirmant hoc pus per finiftrum cordis ventriculum, ad majores venas inde deferri \& hine ad Jecur \& venas meferaicas, \& hinc per alvum exónerari, vel ad Renes deferri quoque, \& critice per urinas evacuari. Eorum quidem fidem, qui hæc fcripferunt ego non elevo: fed nunquam tam fortunatus fui, quamvis in fiequentifimo praxi, ut talem excretionem mihi videre contigerit. Sed hoc quod jam præponam, etiamfi anceps ac dubium fit remedium, tamen fine dubio nugacibus verbis, $\&$ : loquacitate tam feminarum futilium, quam virorum relicta, longe præftantifimum eft; fupra diaphragma, inter quartam. ac quintam coftam, mifculi thoracis intercoftales, cauterio admoto potentiali adurendi funt, donec fatis lata efchara oriatur; quod circiter fpatio trium horarum plerumque fiet, dein iftud fatis lato vulnere pertundendum eft, \& (ut hoc obiter dicam) hoc eo opus eft, ne fi fine tali cauterio, incifio fiat, vul- 
vulnus nimis cito coalefcat \& citius quam neceffe eft: fed oportet ut labiis longifíme à fe invicem diftantibus (quod in rotundo vulnere fieri certiffimum eft) facilior exitus puri, ac amurcæ ifti fiat: fed ante omnia curandum eft, ne confertim pus, ac fanies unica vice: fed repetitis vicibus emittatur, pro ægri viribus; quarum in his regionibus maxima habenda eft ratio. Hoc remedio miraculi inftar aliquot curatos vidi: \& inter plurimos viator quidam, \& miles (Corporalem quem vocant) hic in arce Batavica funt, qui cum me vident, non officjofe tantum falutant, fed pene importune adorant; fed de his in obfervationibus particularibus acturus fum. Si hæc vobis placuifle intellexero, efficiam, ut non otiofe tempus in Indiis me exegiffe boni feiant. Nam de mallevolis mihi nulla eft cura, quo niam ego me fupra eorum invidiam effe arbitror; $\&$ abunde mihi fufficit, fi hic domino Generali ac Indiæ Confiliariis non difpliceam.

\section{CA P. XIV. \\ De Febribus in Indiis.}

Hebres, quæ in Indiis nafcuntur, pleræque aut funt fymptomaticæ, aut continuæ per fe, ac (ut fere femper) Synochi putridæ. Quæ vero certam periodon fervarent, cum intermiffione feu $\alpha \pi u p \xi \xi i \alpha$, vix menimi me vidiffe; nifi unam ac alteram Quartanam, eamque cum ægro è patria delatam, quæ hic miferrime in hydropem, \& inde in certiffimam mortem defiere. Itaque erraticæ plerumque hic febres fine certo ordine, quibus fingulis, fi nomina dare velis, Oedipo conjectore tibi opus erit. Non tamen Tertianas intermittentes, hic aliquando oriri negaverim: fed hæ tam raræ funt, ut liceat hic dicere, quod in proverbio eft, quod hirundo unica non efficit ver. Præterea propofitum mihi eft fcribere de is affectibus, qui utplurimum, ac quotidie hic eveniunt. Hoc faltem in genere verum eft, morbos quibus febris fupervenit, hic magis periculofos effe, quam quos à principio comitatur febris. De curaG.g 2 
igitur febrium, \& fymptomatibus earum, quia cum affectus primarii fanatione conjuncta eft, fuperfedebimus actum agere. De continuis ergo aliquid agendum, quæ plerumque cum tanto furore hic mortales invadunt, ut tanquam attonitos de ratione mentis ftatim dejiciant, \& fape intra pauciffimos dies, imo, aliquando horas cuin phrenitide, ac continuo delirio ægros è vita rapiant. Adfunt perpetuæ vigiliæ, vomitus varii coloris, præcipue viridis, ac æruginofæ bilis. Externa rigent. Calor interne cum ingenti fiti vitales ac naturales facultates depafcitur. Cum febris hæc itaque fit fynochi putridæ fpecies, ubi fanguis tam qualitate, quam quantitate peccat, duo magna antiquitus decantata remedia hic neceffaria effe quis dubitet? Sed utrum illorum præmitti debeat, in quæftionem poffet venire: Sed nos, fubtilibus fcolafticorum difputationibus, ac altercationibus omiffis, purgationem debere præcedere autumamus; ne in venis major perturbatio fiat, quam emolumentum ex præmiffa phlebotomia fperari poteft. Et ne humores ifti mixti aliquam ex principibus partibus, per motum, occupent, ac terribiliffima fymptomata excitent. Itaque in principio leniter, ut Thamarindorum \& Caffiæ. pulpa, ægri purgandi funt. Injecto quoque Clyftere communi, \& adjecta electuarii, fupra defcripti unc. j. His peractis, jam tuto vena copiofe fecabitur, vel etiam iteratis vicibus, quod judicio medici relinquimus, tum unguento borborii univerfum corpus inungendum. Quod fi vigiliæ, ac Phrenitis infeftat, vena frontis recte fecabitur; tum fomnus omni modo conciliandus. Philon. fine Euphorbio; Requie Nicolai, Mithridatio hic confecto recenti, \&c. Sed in periculis, tanquam ad facram anchoram, ad Laudanum nofrum ex Croco confugiendum eft, quod in his regionibus, nunquam fatis laudabitur. Ceteræ, quas dixi, erraticæ $\mathrm{Fe}$ bres curandæ funt eo modo quo illæ, quæ certos paroxifmos habént, \& ad quorum naturam videbuntur proxime accedere: Quæ qnoniam notiffima funt ex aliorum fcriptis, Enchiridii hujus ratio non patitur me longius de iis agere. 


\section{A P. XV. \\ De Febribus quibufdam, quas incole, wocanc Tymorenes, in Indus pecuitiaribus.}

fti, qui navigant in Infulas Solur ac Tymor, cædendarum Santali arborum gratia, corripiuntur febri quadam putrida, quæ fi continua fit, delirium ac Phrenitidem fecum comitem etiam habet, fi vero per intervalla exafperetur (nam remittit fe aliquando hæc Febris: fed intermittitur nunquam ) ea exacerbatio plerumque eft circiter quatuor horarum, qua durante ridiculas admodum actiones ægri edunt; imitantes ea opificia, quæ fani exercuerunt, \& omnia effutientes temere, quæ in vita, tacenda, loquendaque peregerunt, cum maximo aftan-

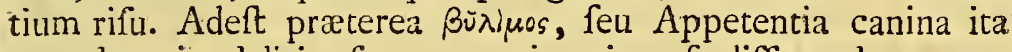
ut, dum in delirio funt, omnia etiam foediffina devorent, quæ ipfis præbentur. Oritur hæc Febris ex diverfis caufis, quarum præcipuæ hæ funt: Odor recentur cæfarum arborum Santali ; quæ ( fatentibus ipfis incolis ) nefcio quid virofum, è cortice maxime, \& cerebro inimicum exfpirant. Santali Hiftor. vid. apud Garc. ab Orta l. I. cap. I7. Ad hæc aëris conftitutio eft hic nebulofa, ac admodum gravis; nam habitacula incolarum funt in fummis montibus; ubi, propter aëris mediam regionem, nebulæ ac pluviofi vapores funt; tum frigus aliquando tam violentum, quam in Hollandia folet effe, quæ omnia non nifi craflos humores ac turbidos fpiritus gignunt. Addita fructus hic nafcentes edendi libertate, qui, cum plerique fint horarii, \& propter humiditatem putredini maxime obnoxii, in corporibus jam ante faftidio maris, laboribus, craffis cibis, tum aëris intemperie immutatis, peffimos fuccos gignunt. Adt de (quod pene omiferam) mutationem fubitam aëris, quam. fubeunt noftri; dum defcendunt ex montibus frigidis ad littus, ac naves, ubi calor fummus corpora urit; Nam infula hæc fita eft verfus meridiem, eirciter decem gradus, à linea æquinoeriali. Et (ut Ovidius ait.)

$$
\text { G.g. } 3 .
$$


Cum modo frigoribus, calido modo ftringimur cefiu, Tempore non certo corpora languor babet:

Præcipue quoque cavendi funt venti ex montibus, poft medium noetis, fpirantes ut \& in Java, \& ceteris circumjacentibus infulis; non fecus ac in quibufdam Gallix Narbonenfis locis, ac Italiæ, præcipue in regno Neapolitano, ac Romæ territorio, ventus frigidus è montibus fpirans (quem Serenas vocant) Pleuritidem, Peripneumoniam, ac reliquos acutos morbos infert: unde Horatius:

\section{Matutina parum cautos jam frigora mordent.}

Cura confiftit in purgatione leni, ac Clyftere præmiffo, in celeri fanguinis miffione, eaque in plethoricis, ac conftantibus viribus, ufque ad animi defectum. Cucurbitæ quoque affigantur cervici, fcapulis, ac, vertice rafo, capiti, incola arterias crotaphos, feu Temporales, lamina candenti, vel fune fclopetario accenfo, urunt, cum ftupendo fructu, quod etiam faciunt in omnibus capitis longis doloribus. Purgatur quoque commode humor vitiofus eled, fratris mei fupra relato. Tum Vomitoria è Croco metallorum, ac fale Vitrioli præcipitato, utiliffima in hoc cafu effe experientia didici. Vigiliæ (quæ funt fomentum phrenitidos ) fi perpetuæ adfint, utamur, præter cetera narcotica, extracto noftro Croci in pilulam formato, vel vino diffoluto. His omnibus generalibus remediis præmiffis; intemperies cordi, hepati, ac cerebro inufta, fudorificis, ac diureticis; Antidotis quoque, ut Bezoar, ac rafura cornu Rhinocerotis, commode difcutitur. Et confervis refrigerantibus, ac fyrupis, fupra fatis ad faftidium nominatis, emendantur. 


\section{$C_{\text {A }} \mathrm{P}$ XVI.}

De Cacitale, ac debilitate vifus, quia mavigantilus Amboynam, ac Moluccas verfus, ac in circumjacentibus fretls accidit.

ui Amboynam, Bandam, ac Moluccas verfus navigant, infeftantur fape debilitate vifus, immo totali cæcitate, $\dot{a}$ craffis lentifque vaporibus caput, ac cerebrum opplentibus, nervofque opticos obftruentibus: qux tamen cacitas non femper pernanet; fed alterius aerris mutatione, vel melioris diætæ, fæpe recedit. Incolæ harum infularum originem trahere dicunt (quod \& experientia, cui contradici vix poteft, comprobatum eft, ex efu Oryzæ calidæ. Hinc Javani, ac Mialaji Oryzam, jam primum coctam, femper prius frigidiori aëri exponent, vel vanno calorem eventilabunt. Tum nautæ noftri fociis fuis navalibus imperant, fub pcena aliqua, ne Oryzam calefactam comedant. Quod fi caufam altius inquirere velimus, ratione eam predicta niti inveniemus: nam Oryza hæc femper plantatur in locis udis, ac paludofis, unde nefcio quid freculenti, ac uliginofi contrahit: quod calidum altius penetrat, quam frigidum: nam etiam ficcæe Oryzæ, crudæque odor caput gravat, ac fomnolentiam quandam introducit. Communis in hoc affectu cura (qua \& ego utor, \& plures ad priftinam fanitatem reduxi) hæc eft; Primum purgandum caput, ac ventriculus à craffis humoribus, qui hos vapores ad cerebrum. mittunt: Quod optime fiet per Pillulas panchymagogas Reiniri Bontii fulpra defcriptas. Dein fternutatoriis è pulvere Tabaci, \&cc. Tum Errhinis, ac Mafticatoriis utendum eft. Vena feeta quoque prodeft. Sed in hoc malo (quod poltremo loco refervavi) fpecificum, ac crebro ufu comprobatum medicamentum eft, Jecur Lamiæ pifcis, crudum cun fale comeftum, quem pifcem een Haye Belgice vocamus, quin \& oleofitas, ex eo in fole inde difilians Traen Belgice, ac oculis inuneta pro prefentaneo eft remedio; quod procul dubio proprietate fub- 
2qú De Cascitate, ac debilitate \&xc:

ftantix fit: Nam tantum abeft, ut aliorum pifcium jecinora hoc præftent, ut potius præfentem noxam inferant. Notandum poftremo eft, quod, quamvis hæc cæcitas fæpe tranfitoria fit, tamen neglecta, ac incommoda diæta, maxime importuno ufu Aracci, fæpe in veram vifus orbitatem degenerat; quorum exempla hic paffim obvia funt.

\section{F I N I S.}

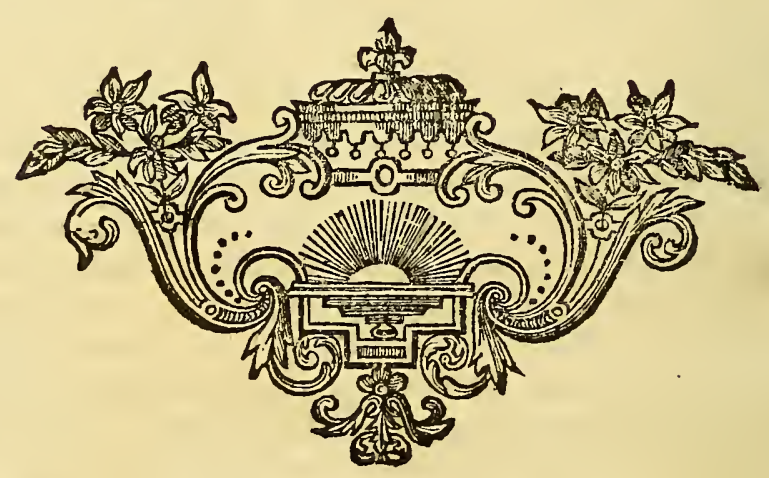




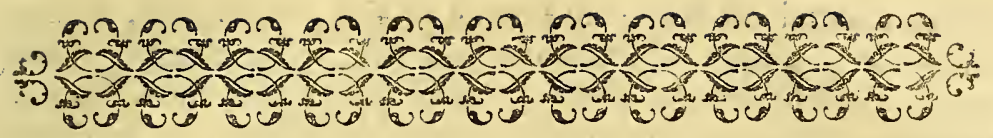 \\ D : E \\ EXTERNIS QUIBUSDAM \\ Corporis Affectibus, in Indiis.}

\section{CA.P. X VII.}

\section{De Herpetis, Jeu Impetiginis Indice Jpecie, incole Courap undigitant.}

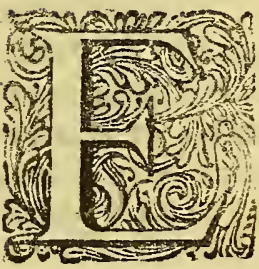

xpofitis morbis internis præcipuis, qui in hifce remotiffimis à noftro colo locis graflantur., omiffis etiam levioribus affectibus, qui hic (ut in patria quoque) quotidiani funt, ad externa quædam corporis vitia, in his regionibus familiaria, devenire conftitui.

- Inter hæc principem locum obtinet Herpes, feu Impetigo quædam moleftiffima, quæ ut plurimum alas, pectus, inguina, faciem, immo aliquando totum corpus occupat, cum pruritu intolerabili, adeo ut ægri à fcalpendo, dies ac noctes manus abftinere nequeant: Sed ftatim iftam vo. luptatem, quam ex unguium attritu homines fentiunt, acerba ponitentia fequitur: ingens nempe dolor, in crudis, \& cuticula nudatis partibus, quas ungues apperuerunt, dum mordicans, ac nitrofus ifte humor peccans, partes affectas vellicat, $\&$ inde interula, ac indufia, fine cruftarum laceratione, avel-

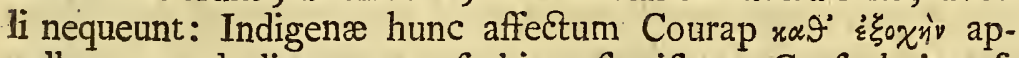
pellant, quod alias omnem fcabiem fignificat: Caufa hujus af- 
$2 f^{2}$ D E H E R E TE, \&C.

tectus cutanei eft falfa, ac nitrofa pituita, mixta bili, ac me. lancholiæ: eftque affectus contagiofus, quia attactu facillime in aliud fubjectum tranfit: ita ut pauci hanc moleftiam effugiant. Quamvis autem hoc malum, Scabram, ac deformen cutem reddat, cum furfuribus: tamen hoc commodum fecum fert, quod quamdiu quis taliter affectus eft, vix alio graviori morbo corripiatur; tum Courap fubito evanefcens, majoris morbi fuperventuri indicium folet effe: humore nimirum peccante, per metaftafin, ad partem nobiliorem aliquam delato. Ideo funt hic qui per aliquot annos hoc malo affecti, non adeo folliciti funt de ejus cura. Sed nos qui novimus fublata caufa, etiam tolli effectum, quod vulgus fanum per fe putat, per accidens fimus evenire; quod hic nempe fit effectus bonus à mala caufa. Non fecus ac in Gonorrhæa: virulenta, ac venerea contingit, Hepate fc. expellente à fe iftud virus ad glandes paraftatas, ac inde ad penem, quo miferi fe confolantur: cum in confeffo fit aliquo modo in re medica expertis, fi ifti malo convenientibus remediis non occurratur, ipfum morbum venereum inde oriri. Sic hoc malum neglectum, præfertim in. fubjectis in melancholicis, ac atrabilariis in Lepram Arabum, vel (quod multo pejus eft) in ipfifimam Elephantiafin tranfit. . Cura hujus mali in principio precipue. conftat in ablatione caufe morbificæ, quod per toties jam dictas purgationes optime fiet: fruftra enim neglectis generalibus, ad particularia ac Topica medicamenta devenitur. Pulvis quoque præftantiffimus ad hunc effectum, ut $\&$ ad reliquos melancholicos à me conficitur hoc modo.

R. Folior. Sennæ mundatorum unc. XIV.

Rhabarbar. optimi.

T'urbith. albi an. unc. viij.

Tartar. albi.

Scammoneæ elect. an. unc. Iv.

M. F. Fulvis fubtiliffimus.

Dofis eft in convenienti liquore $3 \mathrm{j}$. jam ad. Topica deveniamus, inter quæ excellens eft, quod mihi reverendus ac doctiffimus vir Dominus Fuftus Ileurnius communicavit, vir in omni Scien- 
tiarum genere exercitatiffimus.

P. Ferruginis unc. j.

Sulphur. dra. fem.

Subtiliter in marmore fricentur, adde fuccum i folis Baflici hic crefcentis, \& hine fiant paftilli, qui aceto diffoluti \& vefperi Courapo illiti, mane ob deformitatem ablui pofiunt.

Hoc fi minus efficax fit,

P:. Opii for. j. fem.

Calcis vivæ ex conchiliis uftæ fcr. $\ddot{i}$.

Fricentur in marmore, cum fucco Pomorum A.

moris; ufurus abradat cruftam Herpetis, dein abfterfo ichore, illinat.

Ad eadem confert Oleum è gummi Benjuin adjecto nitro, vel fale Prunellæ, vel momento Mercurii fublimati. Commode his quoque mifcetur fuccus Limonum. Cum Tutia præparata, aut Ceruffa, quo folo remedio topico, præmiffa unica purgatione, me ipfum curavi, cum fub alis, ac in pectore hac colluvie infeftarer. Diæta, ut in omnibus cacochymicis affectibus hic moderata, \& boni fucci effe debet. Quod curantis prudentiæ relinquo, ne fruftra actum agam.

\section{A r. XVIII.}

De Papulis rubentibus, feu fudaminibus, que vilgo noftrates het Rootvont vocant, ac obiter de moleftiftmis culicum morfibus.

(7) uas Latinus Hippocrates Cornelius Celfus papulas, Plinius fudamina vocat (noltrates Belgæ Rnotvont) hic ita crebra funt, ut ego adhuc hifce in locis neminem noverim, qui moleftias has effugerit, non magis, quam morfus culicum, quos Lufitani Mofquitas vocant. Sunt autem he papulæ rubentes, ac afperæ aliquantum, per fudorem in cutem ejectæ; plerumque à capite ad calcem ufque, cum fummo pruritu, ac affiduo fcalpendi defiderio erumpentes. Hæc $\mathrm{Hh} 2$ exan- 


\section{4: DE P A P.ULIs, \&c.}

exanthemata magis afficiunt recens advenientes, ut \& Molquitarum puncturæ, quam eos, qui aliquamdiu hic morati funt: ita ut, deridiculi ergo, hic inter noftrates dicterium enatum fit. Fum qui hoc modo affectus fit, effe Orang Barou, quod novitium hominem fignificat, \& propterea culices, ac papulas fibi tributum, è lacte, è butyro, quod eum devoraverint, petere: nam qui hic diutius hæferunt, fe Orang Lamme, id eft veteranos gloriofe nominant. Hæc porro moleftia, cum à natura expellente fiat, inter affectus cutaneos tantum recenfenda venit: fed tamen temere habita, ut \& morfus culicum, unguibus fcilicet cute aperca, ulcera fæpe cacoëthea, ac maligna oriuntur, difficilia fane fanatu.

Sic neglecta folent incendia fumere vires.

Ut itaque pruritui ifti moleftiffimo occurramus, acetum cum aqua mifceri juteo, addito Nitro, feu fale Prunellæ, eoque corpus linteolo immerfo tingi: 'vel, fi acrius defideres, addendus Limonum fuccus recenter expreflus. Q Quæ quamvis primo acrem dolorem inferant, tamen is cito evanefcit, \& multo magis tolerabilis eft, quam pruritus ifte infignis. Hoc denique medicos, ac chirurgos obiter monitos volo, ne in his papulis purgationes, quantumvis leves, inftituant, ne materia acris, ac biliofa, ad inteftina delata Dyfenteriam creet: fed vel potius naturæ hæc fananda relinquant: vel fudorificis excretionem hanc adjuvent: Nam ego, per incuriam, ac impru. dentiam quorundam, hæc infortunia evenire non femel vidi,

\section{A P. X I X.}

De Topbis, gummatis, ac ulcerationibus Endemizs in infula Amboyna, ac Moluccus pracipue; quas noftraies, d'Amboynfe pocken vocant.

F ndemius, feu popularis quidam morbus in Amboyna, ac Moluccis infulis præcipue oritur, qui fymptomátis fuis, ad! modum fimilis eft morbo venerco. Sed in his inter: fe differunt quod 


$$
\text { DE TOPHIS, GUMMATIS, BC. }
$$

quod hic fine congreflu venereo quoque nafi folet. Erumpunt in facie, brachiis, ac cruribus Tophi, feu Tumores, duri primum ac fchirrofi, ac tam crebri per univerfum copus, quam clavi ac verrucæ oriuntur in manibus, ac pedibus in patria; fi vero eos ulcerari contingat, materiam lentam, ac gummofam à fe reddunt, attamen tam acrem, ac mordacem, ut profunda, ac cava ulcera inde oriantur, cum labiis callofis, ac inverfis; fœdum, ac deforme malum, \& cum lue venera conveniens, nifi quod hic tanti dolores non adfint, nec caries in oflibus tam. facile oriatur, nifi per curantis incuriam. Hic affectus originem trahit, primum ex peculiari celi ac foli iftius genio; tum ex aëre, vaporibus falfis , è mari undique afcendentibus infecto; cibis præterea craffis, ac melancholicis \& pituitofis, ut funt pifces marini, quorum hic magna captura eft: quibus incola affiduo vefcuntur, quod reliquæ annonæ fit fatis indiga regio. Magnum etiam momentum huic malo adfert ufus placentarum, quas vice panis, per totum iftum tractum edunt; ac ab incolis Sago vocatur, \& eft è corticibus arborum excuffa farina. Ad: hæc confert potus importunus liquoris cujufdam Saguër vocati, qui ferme eodem modo ex arbore elicitur, quo è palma Indica feu Coquos arbore liquor ifte, quem incolæ Towac; Lufitani Vinho de Palma vocant. Hic immoderate fumptus non fecus, ac vinum, \& cervifia inebriat; caput ac nervos infeftat, hinc etiam in his infulis crebrior eft ifta Paralyfeos fpecies, quam Beriberii fupra diximus appellari. Quantum ad curam attinet, ea, fi recens fit hoc malum, non adnodum difficilis eft. Sin inveteratum, jam moleftior eft curatio. Porro iifdem ferme remediis cedit, quibus lues venerea, obftructiones lienis, Leucophlegmatia, ac ipfe Hydrops, \& ceteri chronici, ac rebelles morbi. Decocta hic itaque parentur è Chinæ radice, Salfa parilla, Guajaco \& corticibuss ejurdem, quibus inco. quantur Anagallidis aquaticæ, feu Becabungæ m. ij. Pof peccans materia vehementioribus catharticis educenda eft: nam levia hic non profunt. Talia funt Extract. guttæ Cambodja, Elaterium: \& fi his non cedit, ad chymica, \& mineralia deveniendum eft: ut funt Mercurius vitæ, fen Butyrum 
Antimonii, Turbith minerale, tum Mercurius præcipitatus albus. Unguenta quoque Mercurialia fecundum artem parata hic externe adhibenda funt: quæ omnia è Crollio, \& aliis doctioribus ac.verfatioribus Chymicis petite.

\section{F I N I S.}

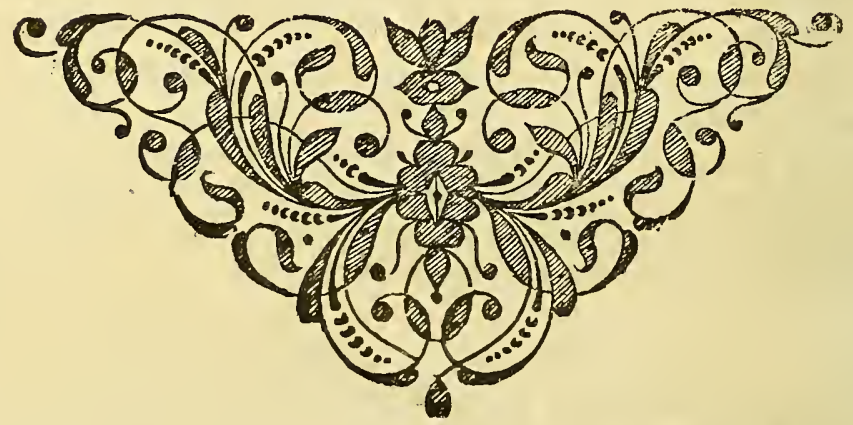




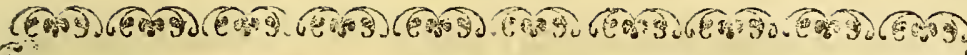

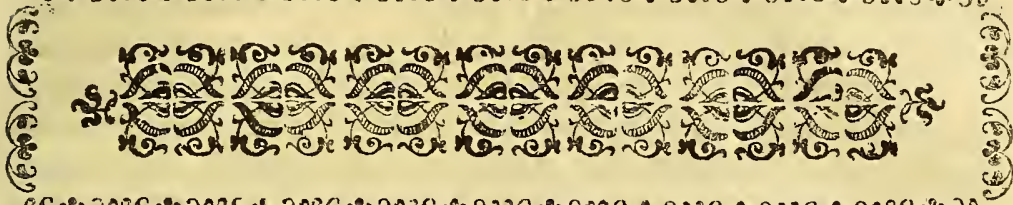

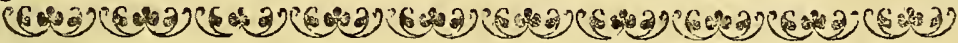

\section{OBSERVATIONES A LIQUOT}

felectx, ex diffectione cadaverum ac.

$$
\text { durofía defumptx: }
$$

Quce precedentıbus jam dictis nom parum

lucis adferunt.

\section{O B'S E R V A.T I O P R I M A:}

\section{De quodam è Spafmo mortuo.}

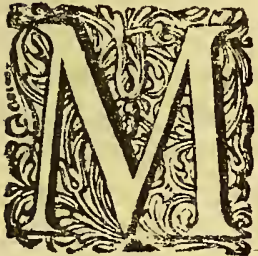

ILEs quidam, cum per integram noctem; ebrius in folo decubuiffet, evigilans tam repente fpafmo correptus eft, flexo in pofteriorem partem corpore, ut omnino rigidus, ac incurvus permaneret. Ipfe in nofocomium delatus noftræ curæ mandatus eft. Nihil deglutire poterat, \& turbide loquebatur, tanquam ex loco fubterraneo vocem emittens, truculenter nos intuebatur; cui cum omnia fruftra adhibuiffemus remedia (quæ fupra in methodo medendi videre eft) ille poft fæviffimos cruciatus, intra quatuor dies interiit. Libuit mihi caufam tam atrocis mali indagare: itaque adhibito Magiftro Andrea Dureo, Nofocomii Batavici Cbirurgo expertiffimo, cadaver aperuimus: Vitalia ut cor, ac pulmones, \& Naturalia membra, ut hepar, ventriculum, ac lienem omnia integra invenimus. Itaque (quod res crat) fufpicati, malum altius hærere. Cerebrum ad 
ventriculos ufque diffecuimus, quos repletos invenimus materia quadam vifcida, ac glutinofa, colore luteo, vitello ovorum per quam fimili: fed fœetida admodum: hæc incumbens principio nervorum, tam fæva fymptomata in fubjectis partibus excitarat. Venæ intercurrentes utramque cerebri menyngem admodum turgidæ erant biliofo fanguine: Obiit anno 1629. menfe Februario. Eodem modo pauco poft tempore affectus fuit fignifer, qui in arce, valli Rubini dicta, præfidium agebat; fed hic præter prædicta fymptomata, fpafmo. Cynico in dextra maxilla, torquebatur, ita ut loqui plane durante ifto paroximo non poffet; \& intra 24 . horas ex vivis exceffit; juve. nis, fi quis alius, fortis, ac robuftus.

O B S E R V A T I O II.

\section{De Pbtifico quodam ac Empyematico.}

Tenricus NN. mercator Danus decumbens in ædibus Am1 brofii vander Keer, hujus urbis fcabini, poft mortem à $M a-$ giftro Andrea diffectus fuit: uterque labus pulmonum, non tantum arete coftis adnatus erat, fed etiam inferius diaphragmati, ut fine laceratione, inde avelli non poffet. In dextro latere, ubi majorem dolorem fenferat, inventa funt fragmenta bronchiorum ab fubftantia pulmonum avulfa, cum fanie copiofa; qualia, dum viveret in magna quantitate excreare confueverat: vox illi erat clangofa, qualis gallorim Africanorum, aut Calecutienfium. Laboraverat longo tempore antea fputo fanguinis; unde hujus miferandi mali principium; quo etiam extreme extenuatus. obiit. 1629. die Augufti 19.

\section{O B S E R V A T I O. III.}

\section{De Dyjenterico.}

Hx mandato Domini Generalis, ego, \& Magifter Adamus Arcis Batavica Chirurgus aperuimus aliquot cadavera ex Dyfenteria mortuorum; inter quæ corpus militis cujufdam è diu- 
diuturna Dyfenteria vita functi, quæ tum temporis cum obfeffi effemus à Javanis hic tanquam morbus epidemicus graffabatur. Et invenimus inteftina vehementer inflata, ac eorum interiorem tunicam plane abrafam; Tum folliculus fellis, quod maxime in eo mirum erat, repletus, ac diftentus, erat humore lento; ac vif́ido, alboque; inftar pultis ex Amylo, quem noftræ mulierculæ Styffel vocant: Bilis autem nequidem veftigium relictum erat. 1624. Nov. I4.

\section{O B S E R V A T IO IV. \\ De quodam Pulmones plenos Pure babente.}

$\Delta$ nno I692. menfe Majo, aperuimus cadaver nautici focii, A ex Phtifi mortui, cujus pulmones fubftantia \& colore externe fani apparebant, quibus tamen diffectis, exiit pus copiofum, viride, ac foetidiffimum; Et dexter pulmonum lobus coftis adnatus erat. Quod obiter notandum in plurimis, quos aperuimus, nunquam finiftrum lobum folum adnatum vidimus; fed vel utrumque, vel dextrum tantum. Ratio (ut ingenue fatear ) me latet, nifi forte, quia in dextro latere tantum vena azygos vel fine pari eft, quæ in pleuritíde, tuffi valida rupta, hanc amurcam á fe rejicit; unde etiam in dextro latere pleuritides exquifitæ magis oriuntur.

\section{O B S E R V A T I O V, \\ De Empyematico fanato.}

Miles quidam, cum potu Arac apprime fe ingurgitaffet, \& ferme fine fenfu, ac motu in arcem ferretur, credebamus ipfum ifta nocta fupervivere non poffe: ille tamen, partim evomita, partim edormita crapula, poftridie in dextro latere Pleuritidie exquifita correptus eft; cui, licet poft fanguinis miffionem, dolor aliquantum fedatus effet: tamen inflammatio in ulcus, \& inde, eo rupto, in Empyema defiit, materia, in dextro latere, fuper diaphragma effufa. Erat adhuc viribus fatis conftantibus, neque febris jam tam vehemens vigebat. 
Itaque inter quartam, ac quintam coftam cauterium potentiale, quod vocant, applicavimus, dein fealpello efcaram porro aperuimus. Indeque effluxit fanies copiofa, cum ramentis, ac particulis aliquot membranæ fuccingentis coftas, jam putrefactæ. Et illæ; adhibitis oportunis Syringationibus, convaluit præter fpem, \&, cum hæc fcribimus, Malaccam verfus navigavit.

\section{O B.SE R V A T I O. VI. \\ De infigni Cranii fractura.}

Taticus quidam focius, dum navem, in ftatione hic ftan: $1 \sqrt{1}$ tem, à fordibus, quas in mari contraxerat, cum ceteris purgaret, \& conto fcapham prohiberet, ne temere navi alliderecur, dum fe inclinat, ut funem, qui feaphæ inferius impactus impedimento erat, auferret, trifti fato, fcapha navi undarum pulfu impegit. \&. caput ipfuus, quod intra fcapham \& navem medium erat ita collifum eft, ut totum cranium comminutum crederetur; ipfe mutus repente, \& fanguinem, per os, aures, ac nares rejiciens, inde delatus eft in Nofocomium. Huic jam, putabamus, defperato, cum Mag. Andraas, \& ego feriam manum præftaremus; Primo à pofteriore capitis parte contufionem ingentem invenimus; quam, poftquam aperuimus, plurimum concreti fanguinis inde extraximus. Poftero die, cum jam mundatiora effent omnia, cranium in multa fragmenta comminutum apparuic: hinc cum aliquot particulas exemiffemus, reliquam curam ( $u$ it in tali cafu decet) aggreffi fumus. Ille porro hæfit inter noftras manus circiter fex menfes; quo tempore totum illid os, quad circumfribitur fintura Lambdoide, per fragmenta exemptum eft, paulo fupra illid foramen, cui inferitur prima cervicis vertebra, dentiformis diEta.. Ille quidem, optime fanus, Novemb. menfe patriam repetiit, appofita pofteriori capitis parti femi-galea argentea,' $\mathrm{ei}_{2}$ in eum finem donata à Domino Generali Coën, ut cerebrum ab. ictibus externis tueretur:- 


\section{OBSERVATIONES. $25 \mathrm{E}$ \\ O B S E R V A T I O VII.}

\section{De Cbronicis ac implicitis morbis in uno fubjeeto.}

$A$ nno 1629 . Septembr. 5. diffecuimus cadaver militis cujuf. A dam Germani, qui ferme per integrum annum languerat, Huxu ventris æruginofo, tuffi ficca, \& infigni refpirandi difficultate, \&c. Mortuo eo, Omentum, ac Mefenterium repertum ferme abfumptum; ita ut inteftina fibi invicem adnata, vel potius nullo ordine inter fe confufa effent, parvulis villis hinc inde enatis. Lien erat contractus in minimam pilæ magnitudinem, \& rotunditatem, ita ut Renes fubjecti longe majores effent. Jecur tam varii erat coloris, luridi, pallidi, flavi ac viridis, ut miraculo fpectantibus nobis effet. Cyftis fellis longe major folito. repleta ac diftenta erat bile æruginofa: Ventriculus, ac inteftina erofa, infignem quoque hujus humoris copiam retinuerant. Præterea è vitalibus dexter lobus pulmonis coftis \& diaphragmati erat adnatus, ut invicem continui viderentur. Videant benigni lectores, nium mirum fit difficiles hic effe curationes, cum tot fimul mala concurrant, quod non in hoc uno, fed plurimis fubjectis reperi. Et hoc nobis præftat nimius potus maledieti Arac ex Oryza \& Holothuris confeeti. Et quoniam dicunt feriptores Phyfici, leporem marinum (qui ut \& Sæpiæ, de Holothuriorum funt genere) venenofa ac peculiari qualitate, pulmonem erodere, lubens in eam fententiam defcendo, omnes iftas immundities eandem tabificam vim habere, \&c.

\section{O BSERVATIOVIII.}

De quodam cui vena cava loco Janguinis, repleta erat adipofa ac medullofa Jubftantia quadam.

Septembris 7: Anni 1629. me præfente, apertum fuit corpus $\int$ cujufdam civis Batavienfis, qui per tres annos languerat miro, ac incognito affectu: Nam fi fuper umbilicum, aut circiter, quis manum impofuiffet; Pulfus, qualis cordis., ac arteria- 


\section{2

rum, tam vehemens fentiebatur, inftar falientis infantis in $\mathrm{ma}$ tris utero, quæ jam partui vicina eft, ita ut manum elevando, repelleret. Eqqualem fuiffe hunc pulfum cum arteriarum \& cordis, hoc modo deprehendi : Siniftram umbilico ægri impofui, dextra arteriam, circa carpum, tetigi ; invenique in fyftoles, \& diaftoles intervallo plane convenire. Unde ego ftatim conjeci arteriam magnam loborare; quod \& poft mortem invenimus. Nam vena cava repleta erat, loco fanguinis adipofa fubftantia, ac medulla fpinali admodum fimili, quæ, pondere fuo, arteriæ vicinæ incumbens, dum illa è contra iftud onus à fe rejicere conaretur, hunc pulfum excitabat. Arteria. magna duplo folito laxior erat, ac repleta fanguine nigro ac ferofo. Cor etiam Magifler Andreas diffecuit; quod etiam folito. majus, ac flaccidius inventum eft, ac fpongiarum modo com-. primebatur; tum uterque ejus ventriculus amplior, ac etiam. fanguine ifto nigro repletus. Quis, rogo, mortalium non obftupefcat, taliter affectum tam diu vitam protrahere potuiffe? lecur erat vividi coloris, ac confiftentia, nifi quod communem menfuram ferme duplo excederet. Cyftis, qua biles continetur, etiam bovinam magnitudine æquabat, eratque intus referta cholera ex nigra viridi, lenta, ac tenaci, craffitudine fyrupi fpiffioris, aut potius extracti. Obiit 7. Septem. I629.

\section{O BSER V A TIO IX. \\ De Apoftemate Hepatis:}

iles Anglus, cum inflammationem primum hepatis paffus 1 effet, \& fruftra tentaffemus ea, quibus opus erat, dolor te remifit quidem: fed defiit malum in fluxum hepaticum; tumore, qui ante erat, in pochondrio plane evanefcente. Cum hoc modo per fex ferme menfes languiffet, tandem ad extremam maciem ita perductus eft, tu ipfiffimam, qualis pingitur, mortem dixiffes, \& fic miferrimam vitam cum morte permutavit: Aperto corpore invenimus loco hepatis, folam membranam ipfum veftientem, fatis craffam, inftar facci, cui adhuc portio faniei, loturæ carnium fimilis inerat, qualem tam longo tempore excreverat. Obiit 1629. Aprili. menf.

$\mathrm{O}$. 
O B S E R V A TIO N E S. 253

O BS E R V A T IO $\mathrm{X}$.

De Vulnere capitus, ubi perperarn fiffum cranium credebatur.

( enfe Majo I 629. vocatus fui à Chirurgo quodam ut vife rem militem in fuprema frontis parte vulneratum; vulnufque, ferme ante tres feptimanas, laxius inciderat, ferramento fuo credens, quod Provettam vocamus, dum afperitatem in cranio, \& offe frontis fentiret, fifluram fubeffe judicavit, \& etiamnum erat in ea opinione; Sed, dum ego oculos propius: admovi, inveni, quam ille fifluram putabat, effe excurrentiam futuræ fagittalis ( $u t$ in iis folet natura ludere) ufque ad nares. Itaque corripiens Chirurgum, oftendi ei errorem fuum. Interea ab aëre os jam alteratum erat; itaque curavi ægrum in Nofocomium deferri ad Magiftrum Andraam, \& jam fextus menfis eft, quo fub cura noftra egit. Exemimus ipfi à futura coronali partem offis ufque ad os temporale, feu petrofum, \& ab altera parte non contemnendum fragmentum; Tum offis frontis duas partes: quæ futura excurrente diftinctæ apud Magiftrum And. Durcum etiamnum refervantur: \& jam, dum hæc fcribo, die Io. Novemb. I 629 , totum vulnus cofolidatum ac cicatrifatum eft, \& ille, hac vefpera, iturus ad navem bene fanus; \& in Patriam, intra tres, aut quatuor dies remeaturus eft.

$$
\text { O B S E R V A T } 1 \text { O XI. }
$$

\section{De Catbarro Suffocanti in Nobilifjmo Domine Foanne} Petri Coën Generali in indius prafecto.

Cum generofus Dominus nofter Foannes Petri Cö̈r aliquandiu Diarahæa laboraffet, \& tamen, ut illi erat fummus animi vigor, nihil de folita diligentia remitteret, dum opera, ac mutationes bellicas ipfe coraminfpicere vult, \& tamen à me aliquoties monitus, ut paulum quieti. fe: daret, ac valetudini fur confuleret, negavit fibi tantum otii effe ut decumberet, quafi diceret præfagiens, Imperatorem ftantem mori oportere. Tandem, decimo nono Septembris 1629 . circa octavam vefI i 3 :

pertio 


\section{4 \\ J A C O B I B O N TII.}

pertinam repente in arcem ad Dominum fum vocatus, quem inveni ægre fpirantem, cum tuffi ficca; externe membra frigebant, fudor aderat frigidus, ac glutinofus. Dejectio per inferiora erat admodum multa, flatulenta, aquofa, ac bullis plena; vomitus præcefferat biliofus. Pulfus arteriæ tam languidus erat, ut vix fentiretur, \& ille quidem vermiculans. His ego omnibus confideratis, adftantibus Ampliflimis Dominis meis Confliariis. Indix $D$. Antonio van Dyemen, $D$. Quirino dे Raemburch ftatim pronuntiavi $D$. Generalem fupremis appropinquare: ipfis re fubita attonitis, ac tantum deliquium animi, ex vomitu, dicentibus, dum paulatim vires, ac- fpiritus redituros putarent, cum pauco ante tempore cum ipfis difcumbens familiariter confabulatus effet: Ideoque dicebant fe mirari, quod tam audacter de tanto viro pronunciarem: Refpondi modefte, mihi in more non effe pofitum, artem meam ludibrio exponere, dum aut jgnorafle, aut fefelliffe viderer: fi fententiam meam non explicuiffem: me tamen in eo optare, ut vaticinium meum fallat. Interea Dominus Generalis inter duodecimam ac primam noctis horam, fuperveniente fpafmo, quem momento temporis ante prædixeram, animam creatori fuo reddidit. Qui Ampliffimi hujus viri ftaturam, ac formam contemplati funt, nihil miri accidiffe fciant. Erat enim longa, ac erecta cervice, alis feu fcapulis prominentibus. Complexione ex melancholica, pituitofa opportunifima ad phtifin \& catharrum fuffocantem, quo etiam mortuus eft. Obiit anno Domini noftri I 629. Septemb. 59.

\section{O BSER V A TI O XII.}

\section{De guodam ex vulnere in pectore mortuo.}

ivis Batavus Foannes Dragon nomine, r 6. Septemb. 1629. in pectore punctim vulneratus eft ictu tranfeunte os fterni, feu fcutiforme, per pulmones in Oefophagum, fuperveniente febre, ac fingultu, octiduo poft vulnus illatum, mortuus eft. Aperuimus præfente magiftratu cadaver, invenimus fecundum conjecturam noftram partes ante dictas læás. Thorax plenus erat fanguine ferofo cum potu, qui ex gula effluxerat mixto. 


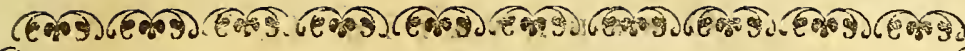

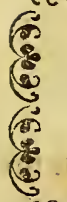

(64) (6)

\section{OBSERVATIONES ALIQUOT}

ex plurimis felectx, de Epidemiis, ac contagiofis, in Indiis, morbis.

\section{O B.SER V A T 1 O P R 1 M A.}

De Dyjenteria Epademica.

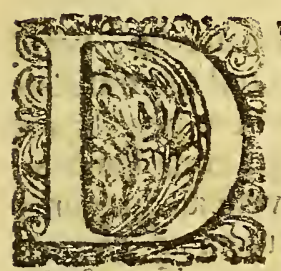

Um anno i 628. á Javanis :Matarenfibus ob-. fidione cingeremur, ampliffmus vir, Feremias de Meefter, Senatus Indici confiliarius, primum in febrem continuam incidit, dein in Dyfenteriam, quæ tum populariter graffabatur; exonerans per alvum cum fæcibus fanguinem nigerrimum, cum fummo cruciatu, ac foetore; tandem cum omnia remedia, qux excogitari ad hujus mali levamen potuiffent, adhibuiffemus; ex vivis exceffit; fupervenientibus, paulo ante mortem, exanthematis nigris, ac lividis, fimilibus is, quæ noftri Peepercoorn vocant, cum fudore frigido, ac male olente.

Similiter Secretarius Domini Generalis, Facobus it Doorefaar,. prædicti Domini de Meefter Gener. paucis diebus poft, Dyfenteria viridi ac genere venenofa mortuus eft, apparentibus co. piofis maculis lividis, in pedibus ac brachiis, ante dictis ref pondentibus. . 
De eadem Dyfenteria Epidemica.

H odem tempore Guilelmus Wyntigs, Fifci advocatus, mihi fraterna amicitia divinctus, incidit in Dyfenteriam veram cum fummis torminibus, quæ perdurans cum/ febre ardentiffima per quinque, aut fex dies, adhibitis omnibus, quæ morbi violentia, \& neceffitas fubita requirebant, cum fummo meo, $\&$ bonorum omnium mœrore, juvenis optimus mortuus eft, apparentibus, tam crebris, ac denfis per univerfum corpus maculis lividis, ut (quod in proverbio eft) locus non effet, cui caput aciculæ imponeres.

\section{O BSERVATIO III.}

\section{De febre ardenti, Dyfenteria, Ulceribus malignis, $\& c$.}

R Everendus, ac Doctiffimus vir Foannes Cavallerius, verbi divini præco, circa idem tempus correptus eft febre ardenti, fuperveniente Dyfenteria atrabiliaria, qua cum per aliquot dies continuaffet, eruperunt fub axillis, in tergo circa lumbos, $\&$ inguinibus, etiam in collo, puftulæ ac veficæ quædam, plenæ ac diftentæ pure viridi, \& fubjectam cutem ad carnem ufque erodente, quæ nobis, prima facie, fpem crifeos faciebant: fed Dyfenteria non ceffante ac febre, cum Phrenitide ingravefcente, probiffimus fimul, ac doctiffimus juvenis, ex hac vita ad coelos raptus eft. Eodem tempore, liberi pulcherrimi C. Adriani Blocq, eadem Dyfenteria maligna obierunt. 


\section{J A COB I BON TII. \\ OBSER VATIO IV.}

Differtatiuncula, utrum morbi Epidemici, ac pefilentiales etzam bic in Indiis Orientalibus grafentur.

T pe paucula, ex fexcentis aliis, exempla ego in medium produxi, ut probarem fruftra eos dixiffé, qui peftilentiales, ac Epidemicos morbos in his locis graflari negaverunt, Quo nomine, alii eos appellent, mea nihil interett. Certe mihi conftat contagiofum hunc, de quo loquor fuiffe, \& qui p'urimos fimul, ac celeriter occuparet. Caufas, quæfo, audite, dein recte judicate. Obfeffi arcte eramus, à triginta quatuor millibus Javanorum Mataranenfium, Duce Tommagom Bauraxa expertiffimo, inter ipfos audaciffimo milite. Quotidie à noftris excurfiones, \& velitationes fiebant, fæpe plurimis ex hofte tum hic, tum in oppugnationibus, quæ ferme fingulis noctibus fiebant, defideratis: quorum cadavera in flumen præcipitabantur, \& fummum foetorem, ac corruptionem aque conciliabant. Tum corpora hominum, \& jumentorum, ex fame, \& vulneribus mortuorum, paffim in campis ac filvis infepulta jacebant, quæ non levem contagionem aëri addiderunt. Præterea flumen inficiebatur radice Serpentáriæ, quam Indi, in profluente, aliquot mille corbibus impofitam, macerabant, ut venenofam qualitatem, ac glutinofam fuam fubftantiam exueret, quam vidimus, fi vitrum aqua plenum reponeremus, per aliquot horas, in fundo tanquam albumen ovi defidere; Qua dein tota vice Oryzæ, cujus in caftris fumma penuria erat, uterentur; dưn unico infultu nos poffe capi fperaffent, \& hinc minus fibi providiffent. Hæc non tam mira videbuntur iis, qui fciunt in Indiis Oecidentalibus radicent $\mathrm{Ca}$ favi, loco panis effe, cujus tamen fuccus expreffus præfentaneum eft venellum. Ad rem venio: Adde his potum aqua fubfalfæ: Nam, dum ventis è mari fpirantibus, ttato tempore aqua marina fluvium impellitur, ejus alveum falfedine inficiebat; \& nos propter obfidentes hoftes, alcius ex flumine pete- 


\section{8 \\ OBSERVATIONES.}

re aquam nor audebamus; Adhæc cadaveribus infectum flumen vermibus featebat. Omnibus iftis adde tempus anni, quod tum calidiffimum fimul ac humidiffimum erat, propter affiduas pluvias tum temporis, utpote à Septembri, ufque ad Februarii initium, tum fole fupra verticem noftrum exiftente in linea rquinoctiali: Quæ umnia me quoque, per quatuor continuos menfes lecto affixerunt, cum fummo vitæ meæ defcrimine. Primo invadente me febre ardenti; fubfequente dein Dyfenteria, \& augefcente, qua jam ante menfem affligi coperam Paralyfeos ifta fpecie, quam Beriberii vocari diximus. Quæ omnia Deo propitio fuperavi, uxore interea, ac utrogue filio meo ijfdem moleftiis vexatis, ac decumbentibus.

\section{Dedit Deus bis quoque finem.}

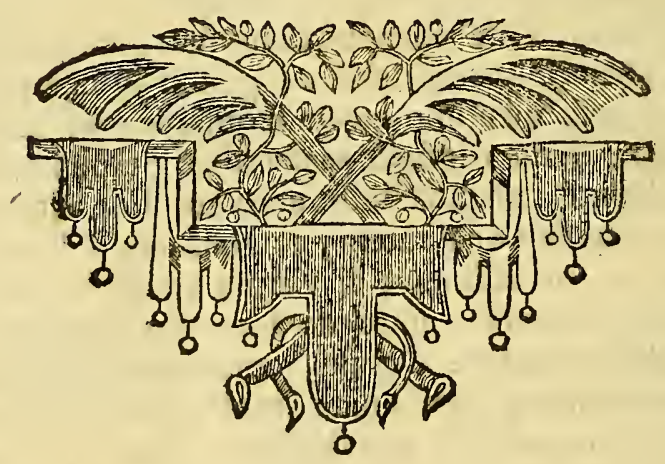




\section{N D E X}

\section{Capitum hujus Methodi medendi in Indiis.}

C. A. I. E Paralyseos quadam Jpecie, quam indigena Beo

II. De Spafmo.

209

21 1

III. De Alvi profluviis, ac primum de dyfenteria.vera. 214

IV. De fluxiu alvi bepatico. 216

V. De Tenefmo.

218

VI. De Ćbolera.

219

VII. De Affectibus Hepatis, Vifceris Nobilis, ac primun de ejus Obftructione, ac Inflammatione.

22 :

VIII. De Apnftemate Hepatis ac de ejus cura unica. 224

IX. De Hydrope, familiariffino in Indiis morbo. 225

$\mathrm{X}$. De IEtero in Indiis. 227

XI. De Arropbia, Seu Extabe Centia quadam, Indicis regionibus familiari, ab obftructione vifcerum, prefertim Mefenterii orta.

230

XII. De quibufdam Pilmonum vitiis, qua hic grafantur; ac primum de Hamoptofi, ac fanguinis Sputo, EO Phtifi, feu Ulcere Pulmonum. $23 \mathbf{I}$

XIII. De Empyemate Eं fultuatione puris fuper feptum tranfverfum.

234

XIV. De Febribus in Indiis.

235

X V. De Febribus quibufdam, quas incole rocant TymorenSes in Indiis peculiaribus.

237

XVI. De Crecitate, ac debilitate vifus, que navigantibus Amboynam, ac Moluccas verfus accidit.

XVII. De Herpetis five impetiginis Indica fpecie, quan incole Courap indigitant.

$24 \pi$

XVIII. De Papulis rubentibus, feu fudaminibus, que vulgo nnflitates het Rootvont vocant, ac obiter de moleftiffimis culicum morfibus. 243

X IX. De-Topbis, gummatis, ac ulcerationibus in infulis Amboyna, ac Moluccis pracipue; quas noftrates, d'Amboynfe pocken vocant. 


\section{N D E X}

Obfervationum Selectarum.

E quodam è Spafmo mortuo.

De Pbtifico quodam, ac Empyematico.

Fol. 247

248

248

De Dyenterico.

De quodam Pulmones plenos Pure babente.

De Empyematico fanato.

De infigni Cranii fractura.

250

De Chronicis, ac implicitis morbis in uno fubjecito. $25 \mathrm{r}$

De quodan cui vena cana loco fanguinis, repleta erat adipofa, E medullofa fubftantia quadain.

25 I

De Apoftemate Hepatis.

252

De Vulnere capitis, ubi perperam filJum cranium credebatur. 253

De Catbarro finfocanti in Nobiliffimo Domino Foanne Petri Coën Generali in Indiis prefecto.

De quodam ex vulnere in pectore mortuo.

253

De morbis Epidemicis obfervationes aliquot è plurimis feleîte. 255

De Dyenteria Epidemica.

255

De eadem Dy Jenteria Epidemica.

256

De febre ardenti, Dysenteria, Ulceribus malignis. Eंc. 256 Differtatiuncula, utrum morbi Epidemici, ac peftilentiales etiam bic in Indiis Orientalibus graßjentur.

\section{F I N I S.}




$i$ 




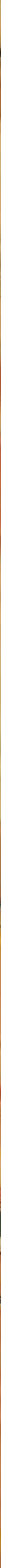




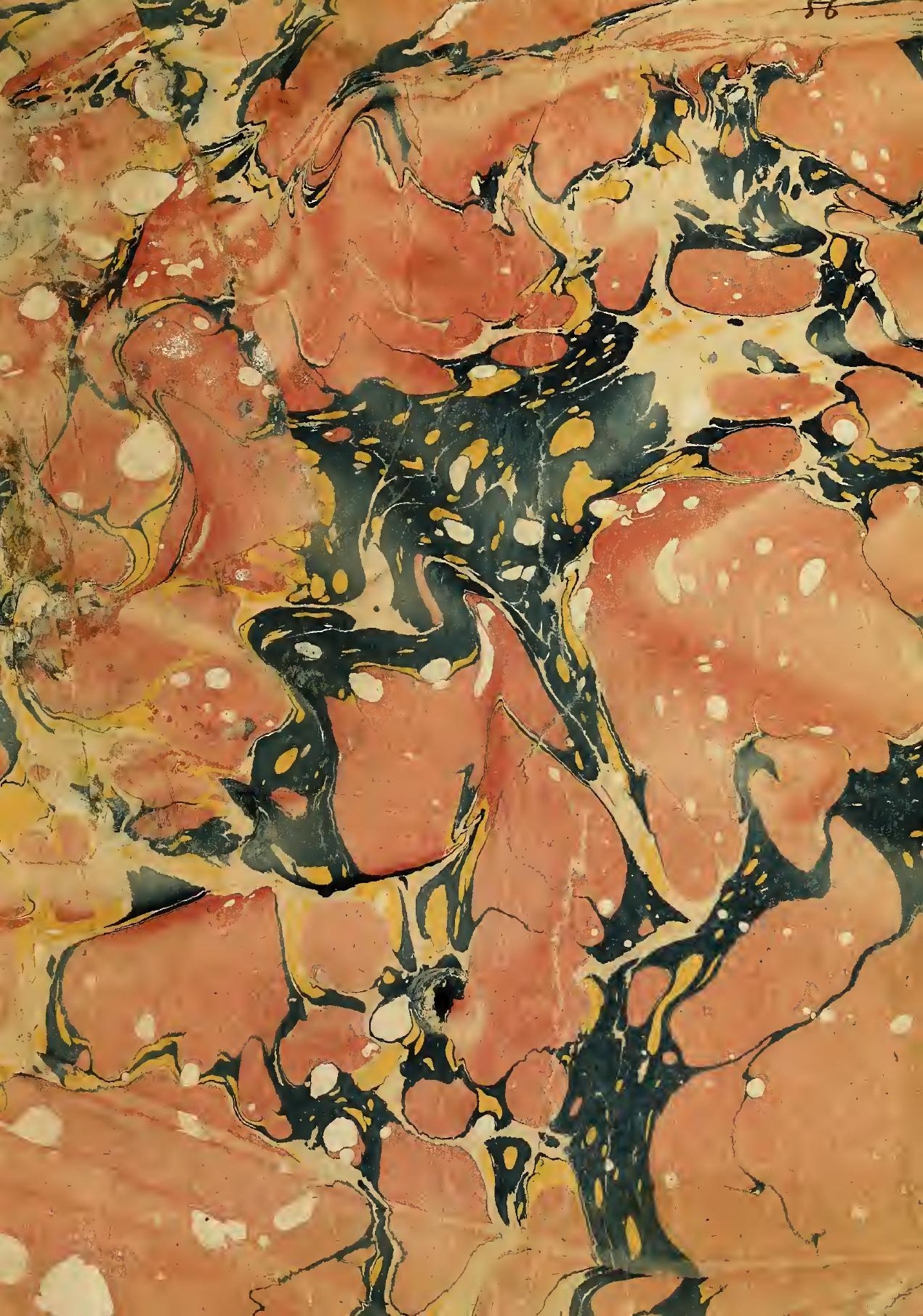




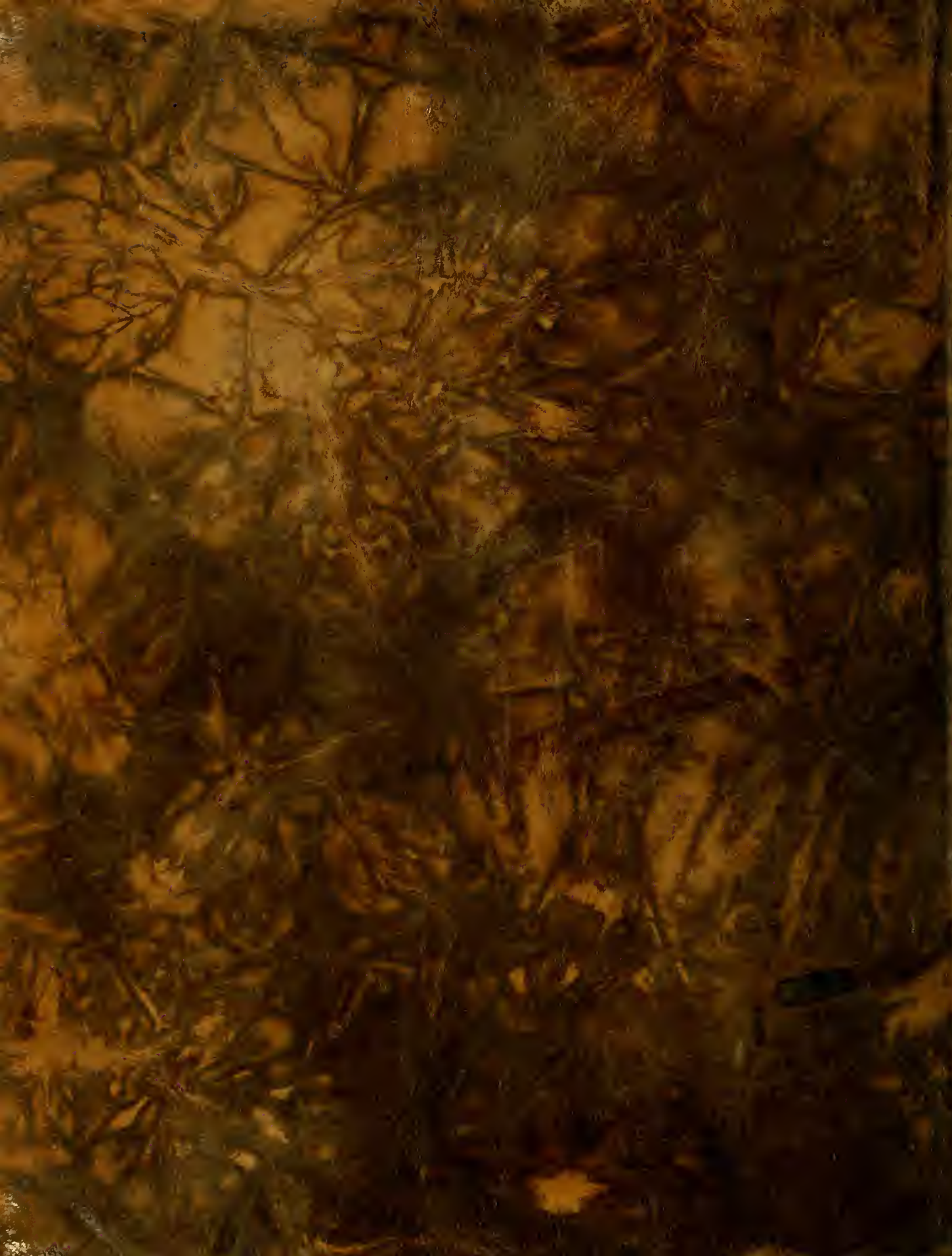

